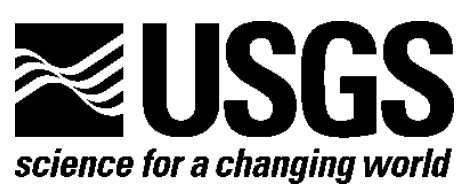

Prepared in cooperation with California Department of Water Resources

\title{
Bivalve Effects on the Food Web Supporting Delta Smelt- A Long-Term Study of Bivalve Recruitment, Biomass, and Grazing Rate Patterns with Varying Freshwater Outflow
}

By Jeff S. Crauder, Janet K. Thompson, Francis Parchaso, Rosa I. Anduaga, Sarah A. Pearson, Karen Gehrts, Heather Fuller, and Elizabeth Wells

Open-File Report 2016-1005

U.S. Department of the Interior U.S. Geological Survey 


\section{U.S. Department of the Interior \\ SALLY JEWELL, Secretary}

\section{U.S. Geological Survey \\ Suzette M. Kimball, Director}

U.S. Geological Survey, Reston, Virginia: 2016

For more information on the USGS—-the Federal source for science about the Earth,

its natural and living resources, natural hazards, and the environment-visit

http://www.usgs.gov/ or call 1-888-ASK-USGS (1-888-275-8747).

For an overview of USGS information products, including maps, imagery, and publications, visit http://www.usgs.gov/pubprod/.

Any use of trade, firm, or product names is for descriptive purposes only and does not imply endorsement by the U.S. Government.

Although this information product, for the most part, is in the public domain, it also may contain copyrighted materials as noted in the text. Permission to reproduce copyrighted items must be secured from the copyright owner.

\section{Suggested citation:}

Crauder, J.S., Thompson, J.K., Parchaso, F., Anduaga, R.I., Pearson, S.A., Gehrts, K., Fuller, H., and Wells, E., 2016, Bivalve effects on the food web supporting delta smelt-A long-term study of bivalve recruitment, biomass, and grazing rate patterns with varying freshwater outflow: U.S. Geological Survey Open-File Report 2016-1005, 216 p., http://dx.doi.org/10.3133/ofr20161005. 


\section{Acknowledgments}

We would like to thank the Interagency Ecological Program (IEP) and Bureau of Reclamation for funding the biomass/grazing rate analyses. A special thanks to California Department of Water Resources Environmental Monitoring Program personnel Scott Waller, Roberta Elkins, Eric Santos, Nick Van Ark, Brianne Sakata, and Dan Riordan and Nick Sakata (Reclamation) for their work in the field collecting the samples and Tiffany Brown, Rachel Pisor, and Melanie LeGro for their time spent in the lab sorting the samples. Thanks to Hydrozoology for sorting and taxonomy and the U.S. Geological Survey personnel who processed the bivalves and compiled data for this report. 


\section{Contents}

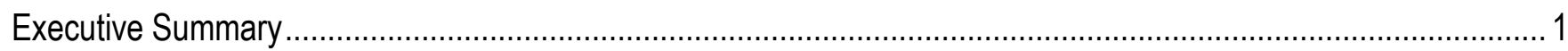

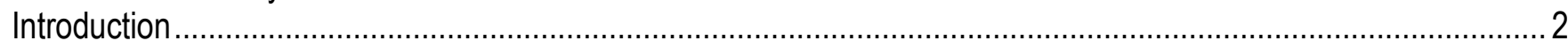

Project Background and the Conceptual Model ......................................................................................

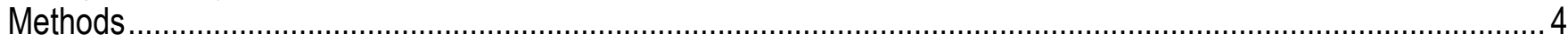

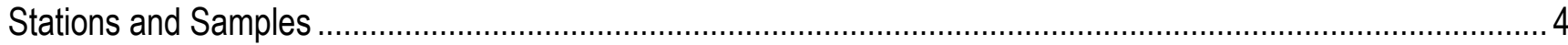

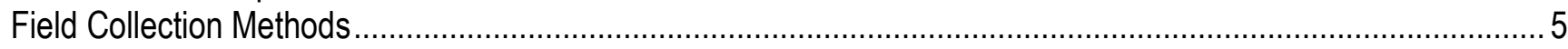

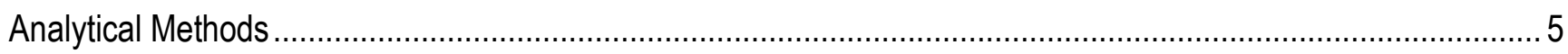

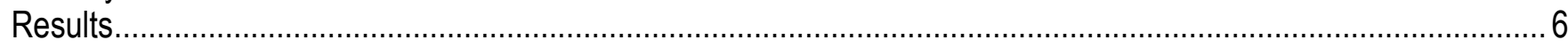

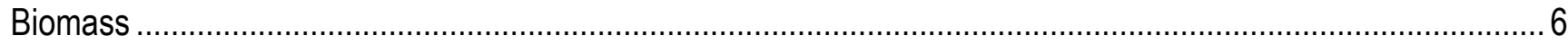

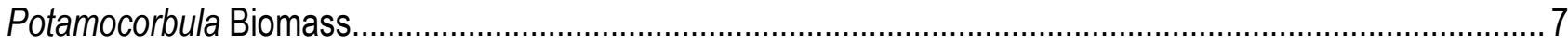

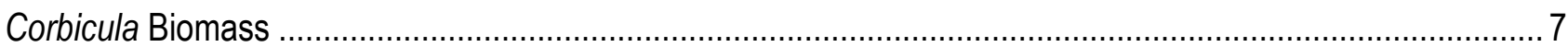

Overlap Biomass (Stations Where Corbicula and Potamocorbula Co-Occur) ................................................

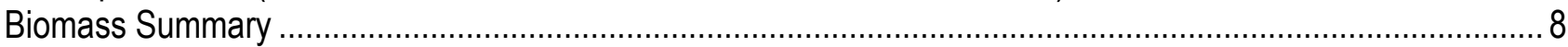

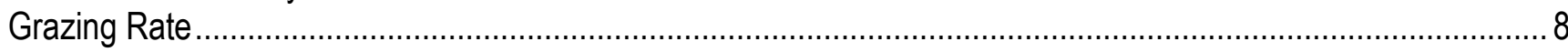

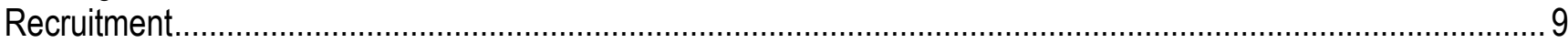

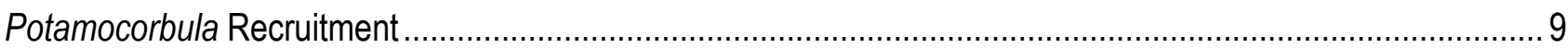

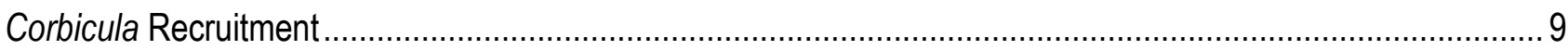

Overlap Recruitment (Stations Where Corbicula and Potamocorbula Co-Occur)............................................ 9

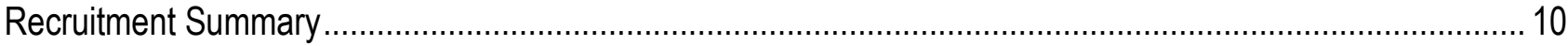

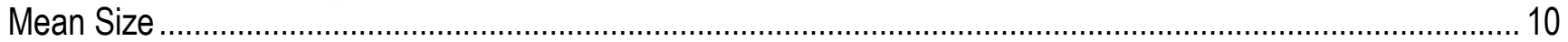

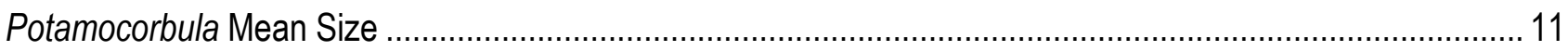

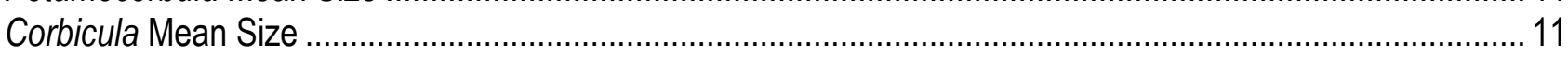

Overlap Mean Size (Stations Where Corbicula and Potamocorbula Co-Occur) ............................................. 11

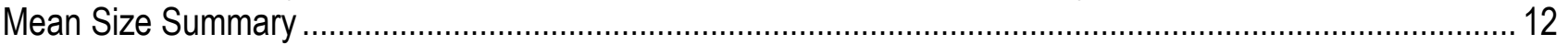

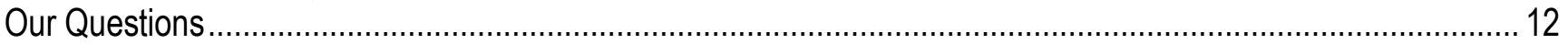

How do Potamocorbula and Corbicula populations at a specific location respond to seasonal and interannual changes in salinity? How does salinity variability influence successful recruitment of these bivalves? ............. 12 Is the magnitude of the grazing rate such that we would expect the feeding of the bivalves to limit seasonally the biomass of phytoplankton, copepods, bacteria, and microzooplankton? ................................................ 13

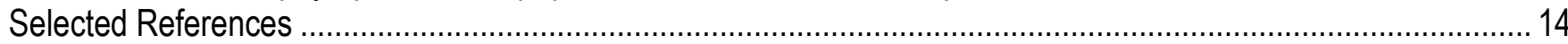

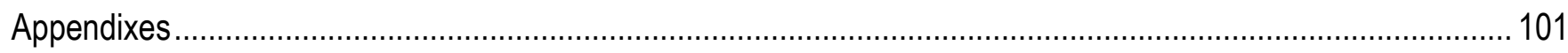

\section{Figures}

1. Map showing location of bivalve sampling stations in San Francisco Bay and the Sacramento-San Joaquin

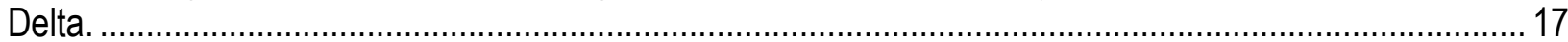

2. Map showing median biomass of Corbicula fluminea in grams per square meter (gm-2) before the arrival of Potamocorbula amurensis to San Francisco Bay and the Sacramento-San Joaquin Delta in 1987............ 18

3. Map showing median bivalve biomass in grams per square meter $\left(\mathrm{gm}^{-2}\right)$ after the arrival of Potamocorbula amurensis to San Francisco Bay and the Sacramento-San Joaquin Delta in 1987.

4. Map showing median grazing rate (GR) of Corbicula fluminea in cubic meters per square meter per day $\left(\mathrm{m}^{3} \mathrm{~m}^{-2} \mathrm{~d}^{-1}\right)$ before the arrival of Potamocorbula amurensis to San Francisco Bay and the Sacramento-San Joaquin Delta in 1987. 
5. Map showing median grazing rate (GR) in cubic meters per square meter per day $\left(\mathrm{m}^{3} \mathrm{~m}^{-2} \mathrm{~d}^{-1}\right)$ after the arrival of Potamocorbula amurensis to San Francisco Bay and the Sacramento-San Joaquin Delta in 1987 ........ 21

6. Map showing median recruitment of Corbicula fluminea in number of recruits per 0.05 meters squared $\left(\# / 0.05 \mathrm{~m}^{2}\right)$ before the arrival of Potamocorbula amurensis to San Francisco Bay and the Sacramento-San Joaquin Delta in 1987. 22

7. Map showing median recruitment of Corbicula fluminea and Potamocorbula amurensis in number of recruits per 0.05 meters squared $\left(\# / 0.05 \mathrm{~m}^{2}\right)$ after the arrival of Potamocorbula amurensis to San Francisco Bay and the Sacramento-San Joaquin Delta in 1987. .................................................................. 23

8. Graph showing Potamocorbula amurensis biomass at station D6 from 2007-2013 ……..........................2

9. Graph showing Potamocorbula amurensis biomass at station D41A from 1987-1996............................. 24

10. Graph showing Potamocorbula amurensis biomass at station D41A from 1996-2003. ........................... 25

11. Graph showing Potamocorbula amurensis biomass at station D41A from 2003-2013 ............................2 25

12. Graph showing Potamocorbula amurensis biomass at station D41C from 1996-2002 ........................... 26

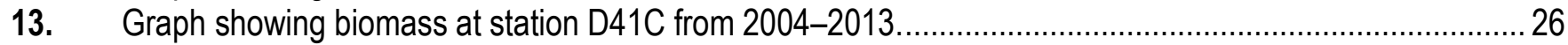

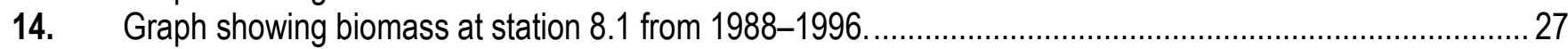

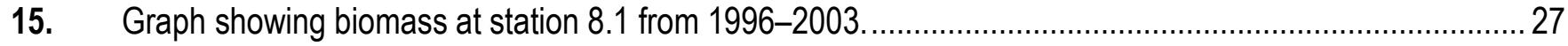

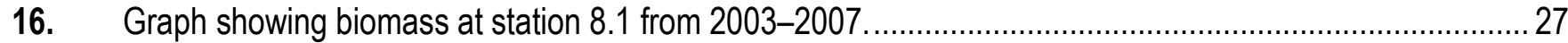

17. Graph showing Corbicula fluminea biomass at station C9 from 1996-2002 ......................................... 28

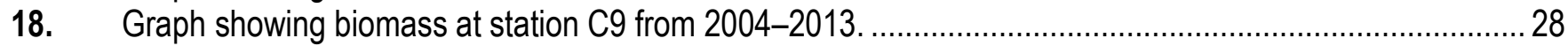

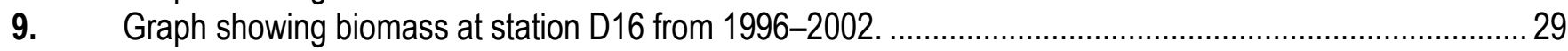

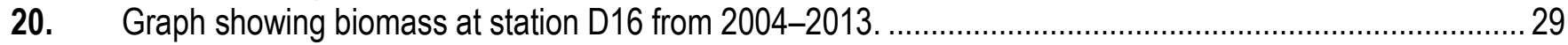

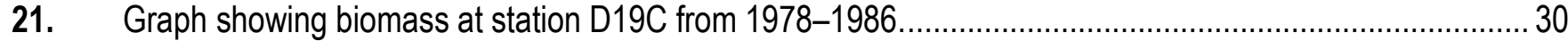

22. Graph showing biomass at station D19C from 1986-1995 .............................................................. 30

23. Graph showing biomass at station D24 from 1996-2002 .............................................................. 31

24. Graph showing biomass at station D24 from 2004-2013 ............................................................. 31

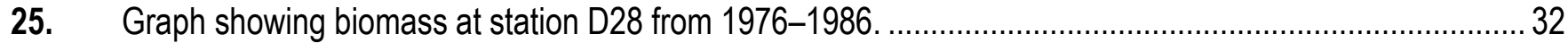

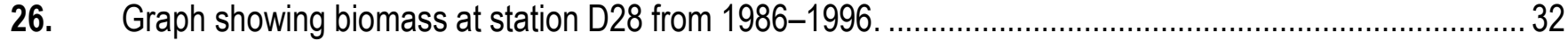

27. Graph showing biomass at station D28 from 1996-2002 …............................................................. 33

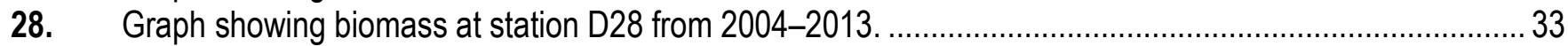

29. Graph showing biomass at station P8 from 1996-2002 ................................................................ 34

30. Graph showing biomass at station P8 from 2004-2013 ............................................................. 34

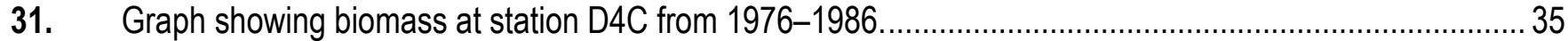

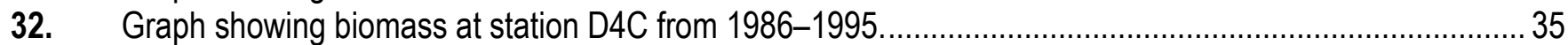

33. Graph showing biomass at station D4L from 1977-1986 ................................................................. 36

34. Graph showing biomass at station D4L from 1986-1996. .............................................................. 36

35. Graph showing biomass at station D4L from 1996-2002 ............................................................. 37

36. Graph showing biomass at station D4L from 2004-2013 ............................................................. 37

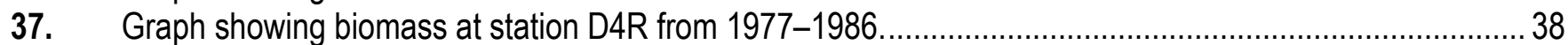

38. Graph showing biomass at station D4R from 1986-1995 .............................................................. 38

39. Graph showing biomass at station D7 from 1981-1986 ............................................................... 39

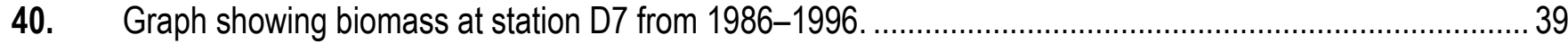

41. Graph showing biomass at station D7 from 1996-2003 ........................................................... 40

42. Graph showing biomass at station D7 from 2003-2013 ............................................................... 40

43. Graph showing biomass at station D11 from 1977-1986 ............................................................ 41

44. Graph showing biomass at station D11 from 1986-1995 ................................................................ 41

45. Graph showing grazing rate at station D41A from 1987-1996 .......................................................... 42

46. Graph showing grazing rate at station D41A from 1996-2003 ........................................................ 42 
47. Graph showing grazing rate at station D41A from 2003-2013......................................................... 42

48. Graph showing grazing rate at station D41C from 1996-2002 ….................................................. 43

49. Graph showing grazing rate at station D41C from 2004-2013...................................................... 43

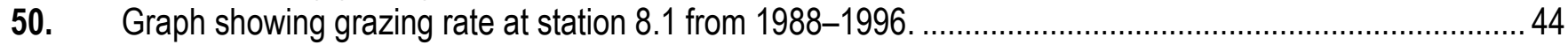

51. Graph showing grazing rate at station 8.1 from 1996-2003.......................................................... 44

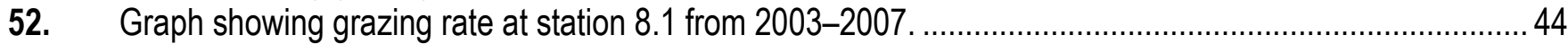

53. Graph showing grazing rate at station C9 from 1996-2002

54. Graph showing grazing rate at station C9 from 2004-2013........................................................... 45

55. Graph showing grazing rate at station D16 from 1996-2002 …....................................................... 46

56. Graph showing grazing rate at station D16 from 2004-2013 ............................................................. 46

57. Graph showing grazing rate at station D19C from 1978-1986 ......................................................... 47

58. Graph showing grazing rate at station D19C from 1986-1995 ......................................................... 47

59. Graph showing grazing rate at station D24 from 1996-2002 ............................................................ 48

60. Graph showing grazing rate at station D24 from 2004-2013 ............................................................ 48

61. Graph showing grazing rate at station D28 from 1976-1986 ......................................................... 49

62. Graph showing grazing rate at station D28 from 1986-1996 .......................................................... 49

63. Graph showing grazing rate at station D28 from 1996-2002 .......................................................50

64. Graph showing grazing rate at station D28 from 2004-2013 ............................................................50

65. Graph showing grazing rate at station P8 from 1996-2002 …....................................................... 51

66. Graph showing grazing rate at station P8 from 2004-2013 ........................................................... 51

67. Graph showing grazing rate at station D4C from 1976-1986 ......................................................... 52

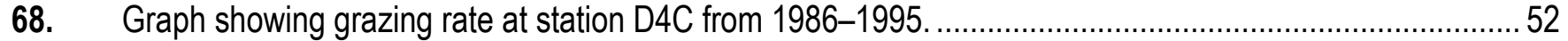

69. Graph showing grazing rate at station D4L from 1977-1986 ............................................................. 53

70. Graph showing grazing rate at station D4L from 1986-1996 ...........................................................53

71. Graph showing grazing rate at station D4L from 1996-2002 …......................................................54

72. Graph showing grazing rate at station D4L from 2004-2013 ...........................................................5

73. Graph showing grazing rate at station D4R from 1977-1986 ........................................................5

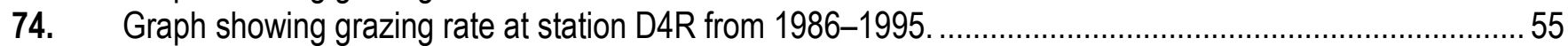

75. Graph showing grazing rate at station D7 from 1981-1986 ...........................................................56

76. Graph showing grazing rate at station D7 from 1986-1996 ..........................................................56

77. Graph showing grazing rate at station D7 from 1996-2003 ........................................................57

78. Graph showing grazing rate at station D7 from 2003-2013 .......................................................... 57

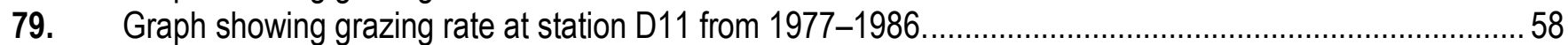

80. Graph showing grazing rate at station D11 from 1986-1995 ............................................................ 58

81. Graph showing grazing rate at station D6 from 2007-2013 ............................................................59

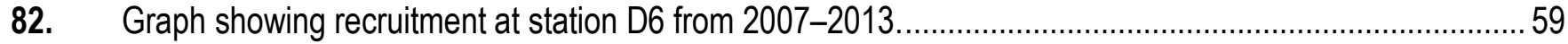

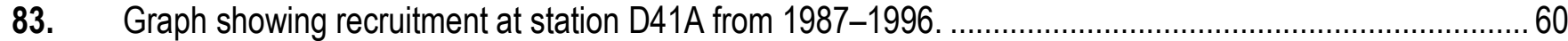

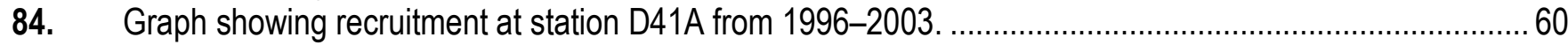

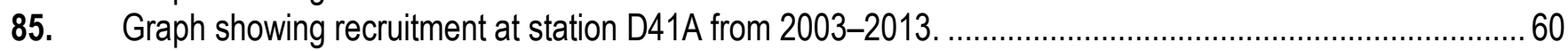

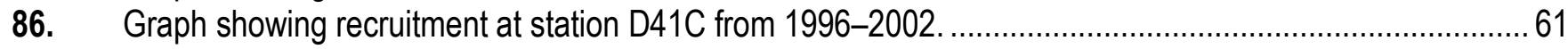

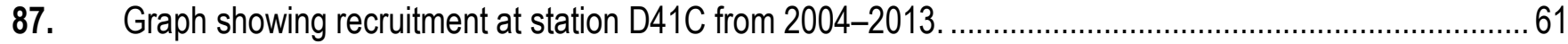

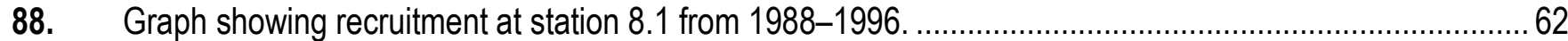

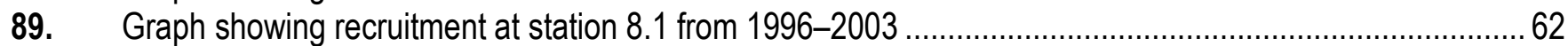

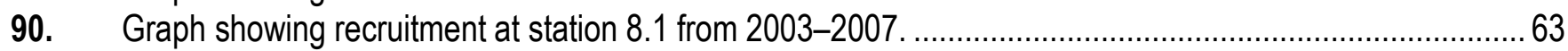

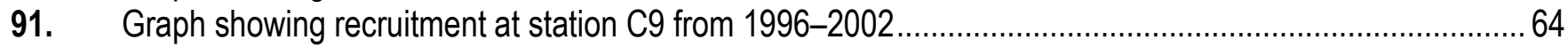

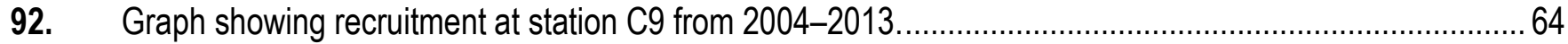

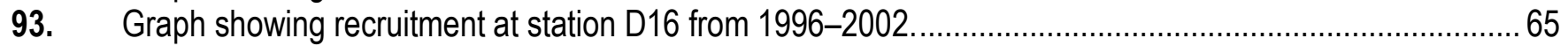




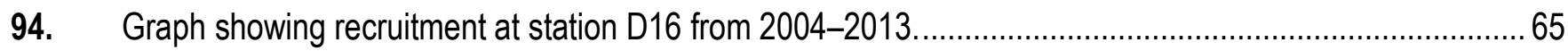

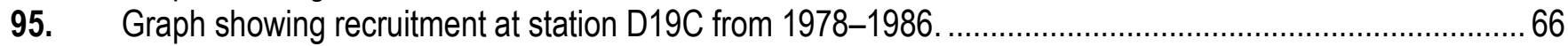

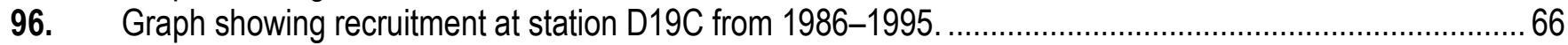

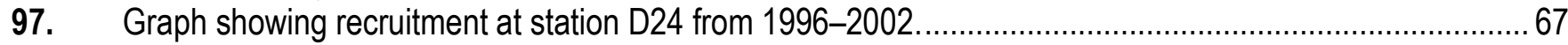

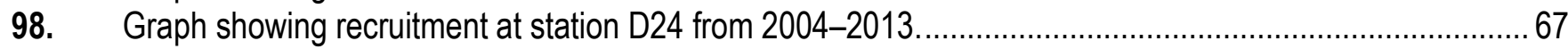

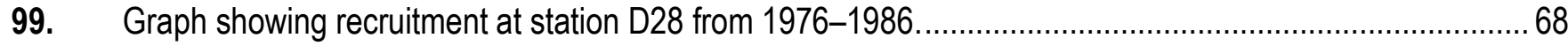

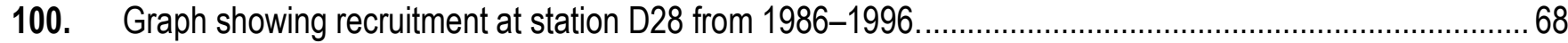

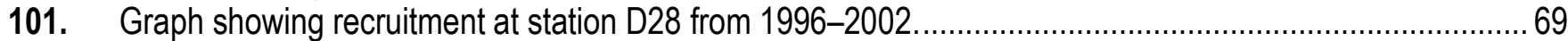

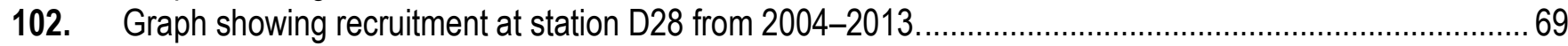

103. Graph showing recruitment at station P8 from 1996-2002 ............................................................. 70

104. Graph showing recruitment at station P8 from 2004-2013 …....................................................... 70

105. Graph showing recruitment at station D4C from 1976-1986 ........................................................... 71

106. Graph showing recruitment at station D4C from 1986-1995....................................................... 71

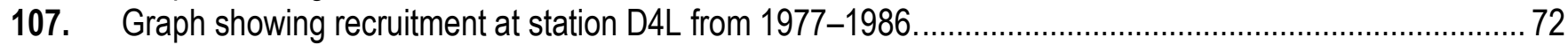

108. Graph showing recruitment at station D4L from 1986-1996 …….................................................... 72

109. Graph showing recruitment at station D4L from 1996-2002 ........................................................... 73

110. Graph showing recruitment at station D4L from 2004-2013 .......................................................... 73

111. Graph showing recruitment at station D4R from 1977-1986 ........................................................ 74

112. Graph showing recruitment at station D4R from 1986-1995 ......................................................... 74

113. Graph showing recruitment at station D7 from 1981-1986 ........................................................... 75

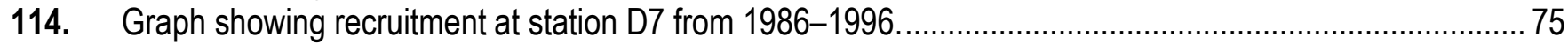

115. Graph showing recruitment at station D7 from 1996-2002 …........................................................ 76

116. Graph showing recruitment at station D7 from 2004-2013 ............................................................. 76

117. Graph showing recruitment at station D11 from 1977-1986 …........................................................ 77

118. Graph showing recruitment at station D11 from 1986-1995 ........................................................... 77

119. Graph showing mean size at station D6 from 2007-2013............................................................. 78

120. Graph showing mean size at station D41A from 1987-1996 .........................................................79

121. Graph showing mean size at station D41A from 1996-2003 ........................................................... 79

122. Graph showing mean size at station D41A from 2003-2013 ............................................................ 79

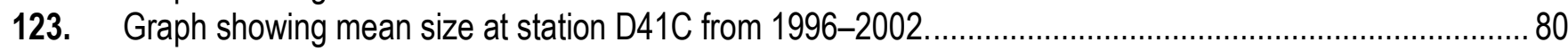

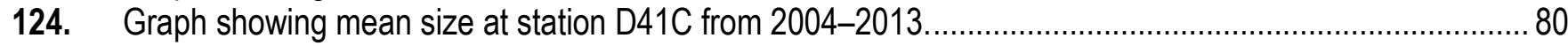

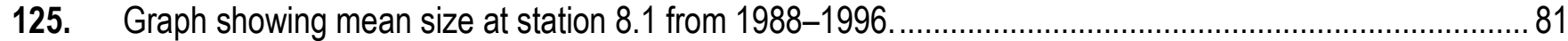

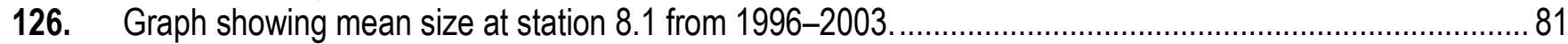

127. Graph showing mean size at station 8.1 from 2003-2007 ............................................................... 81

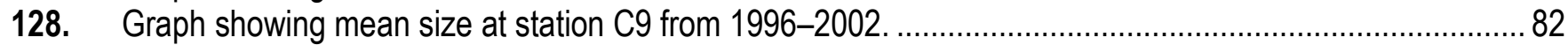

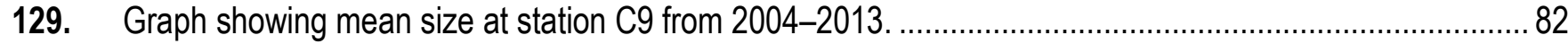

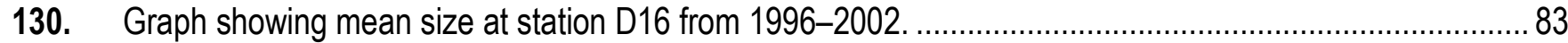

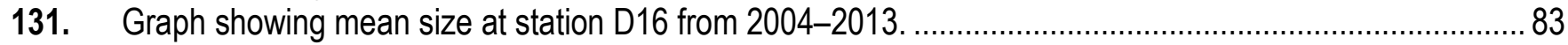

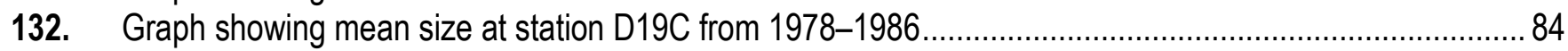

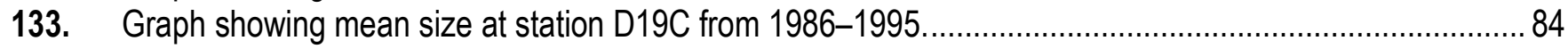

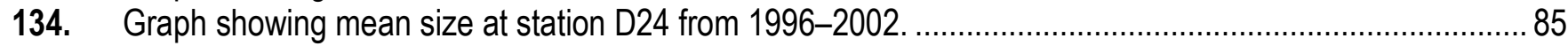

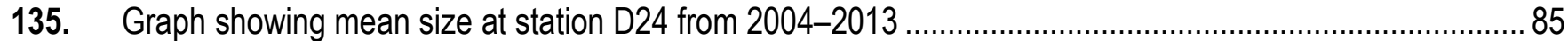

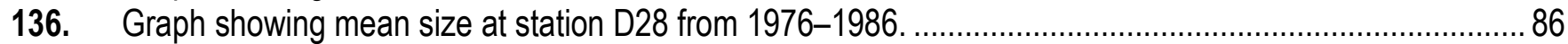

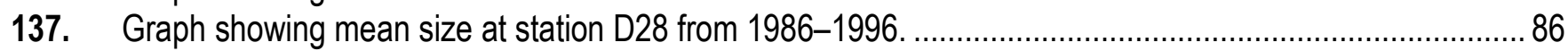

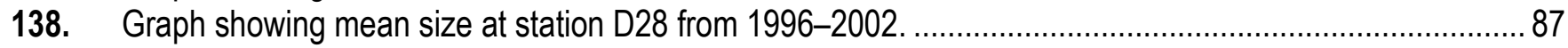

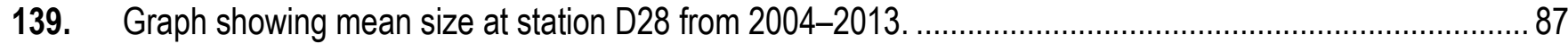

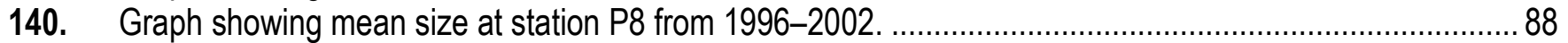




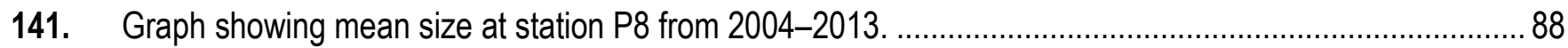

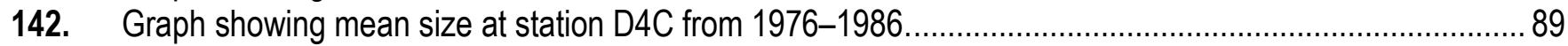

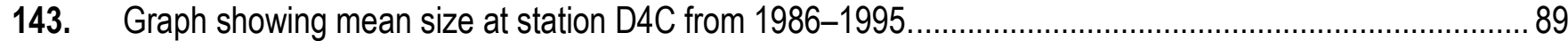

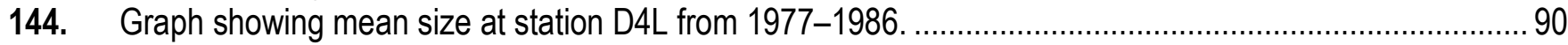

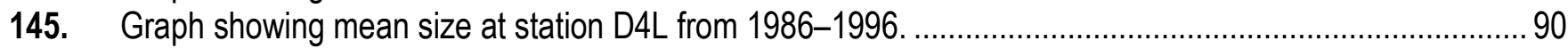

146. Graph showing mean size at station D4L from 1996-2002 …...................................................... 91

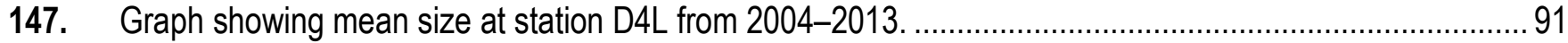

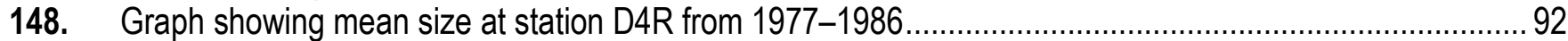

149. Graph showing mean size at station D4R from 1986-1995 .............................................................. 92

150. Graph showing mean size at station D7 from 1981-1986.............................................................. 93

151. Graph showing mean size at station D7 from 1986-1996 ............................................................... 93

152. Graph showing mean size at station D7 from 1996-2002.

153. Graph showing mean size at station D7 from 2004-2013. ......................................................... 94

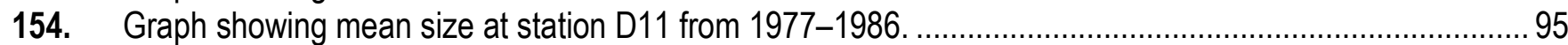

155. Graph showing mean size at station D11 from 1986-1995 .............................................................. 95

156. Graphs plotting X2 in kilometers upstream of the Golden Gate Bridge from 1980 through 1996. Colors represent station locations relative to $\mathrm{X} 2$. The $\mathrm{X} 2$ position is not a precise measurement but represents the distance upstream from the Golden Gate Bridge, where a daily average salinity at 1 meter $(\mathrm{m})$ above of the bottom is 2 (Jassby and others, 1995).

157. Graphs plotting X2 in kilometers upstream of the Golden Gate Bridge from 1996 through 2013. Colors represent station locations relative to $\mathrm{X} 2$. The $\mathrm{X} 2$ position is not a precise measurement but represents the distance upstream from the Golden Gate Bridge, where a daily average salinity at 1 meter $(\mathrm{m})$ above of the bottom is 2 (Jassby and others, 1995).

\section{Tables}

1. The benthic monitoring station locations, names, and latitude and longitude of DWR and Reclamation's Environmental Monitoring Program (EMP).

2. Average grazing rate, biomass, and recruitment of the bivalves Potamocorbula amurensis and Corbicula fluminea at each site at specified depth in meters $(\mathrm{m})$.

3. Table showing the water year type in Sacramento and San Joaquin Rivers from 1975-2014 ................ 100

\section{Appendixes}

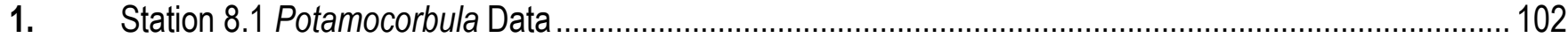

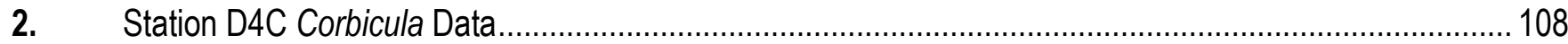

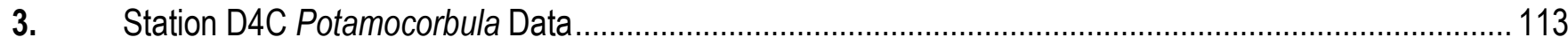

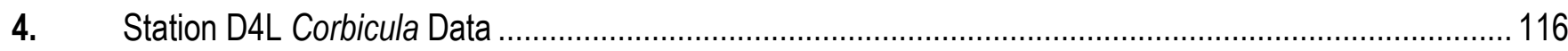

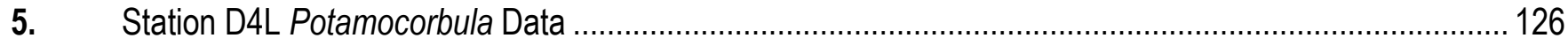

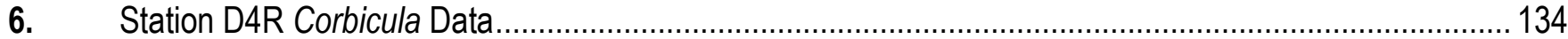

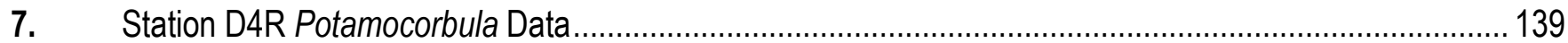

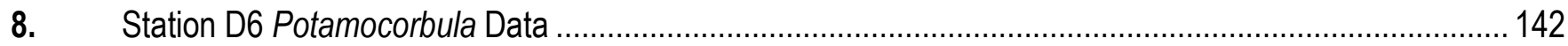

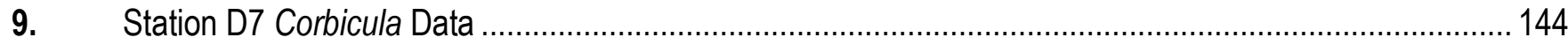

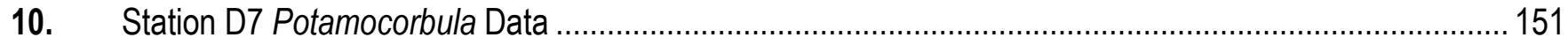

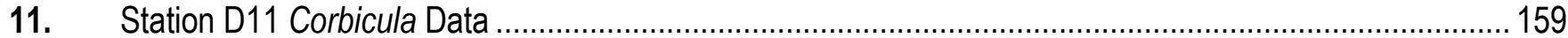

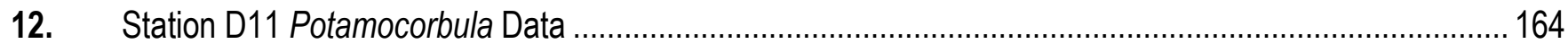

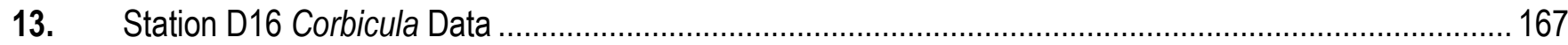

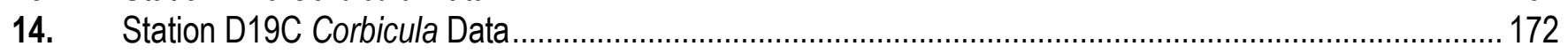




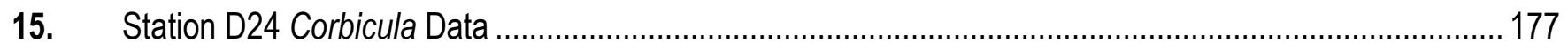

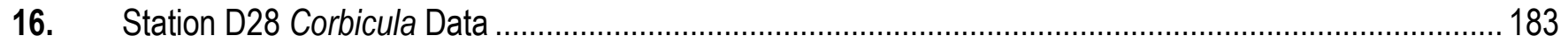

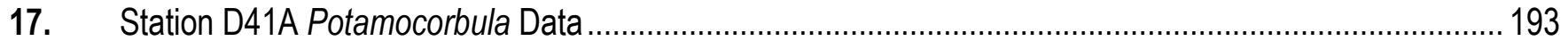

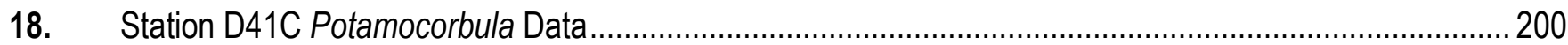

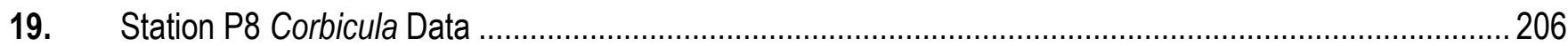

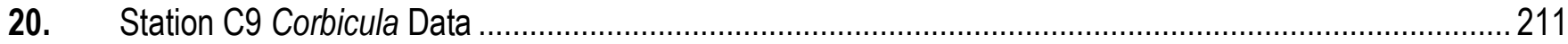




\section{Conversion Factors}

International System of Units to Inch/Pound

\begin{tabular}{|c|c|c|}
\hline Multiply & By & To obtain \\
\hline \multicolumn{3}{|c|}{ Length } \\
\hline millimeter (mm) & 0.03937 & inch (in.) \\
\hline meter (m) & 3.281 & foot $(\mathrm{ft})$ \\
\hline kilometer $(\mathrm{km})$ & 0.6214 & mile (mi) \\
\hline \multicolumn{3}{|c|}{ Area } \\
\hline square meter $\left(\mathrm{m}^{2}\right)$ & 10.76 & square foot $\left(\mathrm{ft}^{2}\right)$ \\
\hline \multicolumn{3}{|c|}{ Volume } \\
\hline liter $(\mathrm{L})$ & 0.2642 & gallon (gal) \\
\hline cubic meter $\left(\mathrm{m}^{3}\right)$ & 264.2 & gallon (gal) \\
\hline \multicolumn{3}{|c|}{ Mass } \\
\hline $\operatorname{gram}(\mathrm{g})$ & 0.03527 & ounce, avoirdupois (oz) \\
\hline
\end{tabular}

Biomass units are grams of ash-free dry mass per square meter ( $g$ ash-free-dry-mass $\left./ \mathrm{m}^{2}\right)$.

Grazing rate is given as cubic meter per meter squared per day $\left(G R=\mathrm{m}^{3} / \mathrm{m}^{2} / \mathrm{d}\right)$.

Recruits are given as the number of bivalves $\leq 2.5$ millimeters in length per meter squared ( $\# / \mathrm{m}^{2}$ of bivalves $\leq 2.5 \mathrm{~mm}$ in length).

The low salinity zone (LSZ)-salinities range from 1 to 6 practical salinity units (psu).

Temperature in degrees Celsius $\left({ }^{\circ} \mathrm{C}\right)$ may be converted to degrees Fahrenheit $\left({ }^{\circ} \mathrm{F}\right)$ as ${ }^{\circ} \mathrm{F}=\left(1.8 \times{ }^{\circ} \mathrm{C}\right)+32$.

Temperature in degrees Fahrenheit $\left({ }^{\circ} \mathrm{F}\right)$ may be converted to degrees Celsius $\left({ }^{\circ} \mathrm{C}\right)$ as ${ }^{\circ} \mathrm{C}=\left({ }^{\circ} \mathrm{F}-32\right) / 1.8$. 


\begin{tabular}{ll} 
Abbreviations \\
AFDM & ash-free dry mass \\
AFDW & ash-free dry weight \\
CBL & concentration boundary layer \\
CF & Corbicula fluminea \\
DWR & California Department of Water Resources \\
EMP & environmental monitoring program \\
GR & grazing rate \\
GRTO & grazing rate turnover rate \\
IEP & Interagency Ecological Program \\
LSZ & low salinity zone \\
PA & Potamocorbula amurensis \\
POD & pelagic organism decline \\
PR & pumping rate \\
Reclamation & Bureau of Reclamation \\
SWRCB & State Water Resources Control Board \\
USGS & U.S. Geological Survey \\
\hline
\end{tabular}




\title{
Bivalve Effects on the Food Web Supporting Delta Smelt- A Long-Term Study of Bivalve Recruitment, Biomass, and Grazing Rate Patterns with Varying Freshwater Outflow
}

\author{
By Jeff S. Crauder ${ }^{1}$, Janet K. Thompson¹, Francis Parchaso¹, Rosa I. Anduaga1, Sarah A. Pearson¹, Karen \\ Gehrts², Heather Fuller2, and Elizabeth Wells² $^{2}$
}

\section{Executive Summary}

Phytoplankton is an important and limiting food source in the Sacramento-San Joaquin Delta (the Delta) and San Francisco Bay; the decline of phytoplankton biomass is one possible factor in the pelagic organism decline and specifically in the decline of the protected delta smelt. The bivalves Corbicula fluminea and Potamocorbula amurensis have been shown to control phytoplankton biomass in several locations throughout the system, and their distribution and population dynamics are therefore of great interest. We were able to describe the distribution and dynamics of bivalve biomass through use of samples collected by the California Department of Water Resources (DWR) as part of a monitoring program from 1977 to 2013. As one element of DWR's and the Bureau of Reclamation's Environmental Monitoring Program (EMP), the DWR benthic monitoring program examines the impact of water project operations on the estuary as prescribed by a series of Water Rights Decisions mandated by the State Water Resources Control Board (SWRCB). The availability of multidecade samples allowed us to examine long-term trends in biomass, recruitment, and size of bivalves at the 15 stations sampled.

Biomass and grazing rate had the same basic trends, and the conclusions that we apply to biomass can be applied to grazing rate data. During winter of most years, Potamocorbula biomass was low at all locations and was near zero in the shallow San Pablo Bay station. The Potamocorbula biomass at shallow stations consistently peaked during summer and fall, but there was no consistent peak season in the deep stations. Corbicula had a much less consistent seasonal biomass pattern than Potamocorbula. However, some interannual patterns were consistent between stations. Corbicula biomass at three stations declined after 2003 (C9, D16, and D28). The Franks Tract (D19) Corbicula biomass had a baseline shift up (that is, all values were $>0$ ) in 1985 until DWR ceased sampling at the station in 1995. Two other stations showed a similar increase in baseline but at different times; D24 shifted up after 2007 and D11 shifted up in 1991.

Potamocorbula recruitment (any bivalve $\leq 2.5$ millimeters [mm] in length) occurred anytime between spring and fall, with bivalves at the most downstream stations in San Pablo Bay recruiting in spring and animals at the most upstream stations recruiting in fall. The bivalves at the stations between these endpoints recruited in (1) spring or (2) summer and fall (Carquinez Strait), or in some combination of two of those three seasons in Grizzly Bay. The few locations where Potamocorbula and Corbicula overlapped showed recruitment abundance opposing each other, with Potamocorbula recruits peaking

\footnotetext{
${ }^{1}$ U.S. Geological Survey

${ }^{2}$ California Department of Water Resources
} 
during the more saline time of year and Corbicula recruits peaking during periods of lower salinities. Corbicula recruits were present throughout most of the year with some peaks in abundance, but the patterns were not seasonally consistent at any station.

Mean size peaked in both bivalves in late summer and early fall and never got above a certain size; maximum size depended on location. The mean size of both bivalves has decreased over the years, with the size distributions throughout the Delta now skewed toward smaller, younger Corbicula $(<10$ $\mathrm{mm}$ ). The mean size of Potamocorbula has also become skewed toward the small, younger bivalves, with sizes in the range of 2-8 $\mathrm{mm}$. The mean size of Potamocorbula increased from spring to fall and decreased in winter. A similar generalization is not possible with Corbicula because seasonal patterns in size varied depending on station location. Station D24 on the Sacramento River was the only location with an increase in Corbicula mean size over the sampling period.

The largest mean sized Potamocorbula were seen in the channel areas, where sizes of $15 \mathrm{~mm}$ were common at stations D41C, 8.1, and D6; sizes in excess of $15 \mathrm{~mm}$ were observed at all three D4 stations during the mid 1990s. The mean size of Potamocorbula in the shoals was $\approx 5-7 \mathrm{~mm}$ in most years in Grizzly Bay (D7) and San Pablo Bay (D41A), with an increase to $>10 \mathrm{~mm}$ at D7 in the wet years.

The largest mean sized Corbicula were in the southern Delta (C9 $25 \mathrm{~mm}$ during 1996-97 and 2012-2013), and the smallest average sizes were in the San Joaquin River (P8 and D16). Corbicula at the upstream Sacramento River station (D24) and in the southern Delta (C9) showed similar interannual patterns in average size although the animals at C9 were consistently larger than those at D24 were. Corbicula in Franks Tract (D19) and the Old River (D28A) south of Franks Tract were also similar in size and in interannual patterns.

At the few stations where Potamocorbula and Corbicula co-occur, it appears that they did not hinder each other's growth. Both bivalves had large animals at D4, where Corbicula size increased coincident with the presence of Potamocorbula in 1987. Corbicula were observed in wet years prior to Potamocorbula's invasion at D7 (Grizzly Bay) and were capable of growing to significant size in wet years (> $20 \mathrm{~mm}$ in 1986).

\section{Introduction}

The State Water Resources Control Board (SWRCB) sets water quality objectives to protect beneficial uses of water in the Sacramento-San Joaquin Delta (the Delta) and Suisun and San Pablo Bays. To meet these objectives, the SWRCB establishes mandated standards in the water rights permits issued to the Department of Water Resources (DWR) and Bureau of Reclamation (Reclamation). Water Rights Decisions (D-1379, D-1485, and D-1641) have established water quality requirements and provided terms and conditions for a comprehensive monitoring program to determine water quality conditions and changes in environmental conditions within the estuary. The benthic monitoring program is one element of DWR and Reclamation's Environmental Monitoring Program (EMP) wherein the impact of water project operations on the estuary are determined. These impacts are determined by changes in benthic fauna presence, abundance and distribution of the benthos associated with physical factors in the estuary, and the detection of newly introduced species in the estuary. This benthic monitoring program is the backbone of this study, and we are using samples collected from 1977 through 2013 to examine how the biomass and grazing rate of the bivalves have changed in time and space.

Large changes that have occurred in San Francisco Bay (hereafter Bay) and the Delta over the past several decades have fueled the interest in bivalve grazing rates and biomass. Four species of fish, many macrozooplankton species, and the native mysid shrimp (Neomysis mercedis) have shown large 
population declines in the San Francisco Bay estuary (Baxter and others, 2008). Although all of these reductions in abundance of species are problematic, the decline of the delta smelt, Hypomesus transpacificus, is of most concern because of its protected status under the Endangered Species Act (ESA). One of the suggested causes for ecological decline - the pelagic organism decline (POD) - is the reduction of phytoplankton in the northern estuary coincident with the introduction of the exotic, filterfeeding bivalve Potamocorbula amurensis (hereafter Potamocorbula) in 1987. Phytoplankton biomass immediately declined when Potamocorbula invaded, and since that time, net phytoplankton growth rates have remained very low (Alpine and Cloern, 1992; MacNally and others, 2010). The phytoplankton biomass in the northern estuary and the western Delta is now chronically low and is considered a contributor to, if not a major cause of, the POD (Baxter and others, 2008; Hammock and others, 2015).

If we consider the northern San Francisco Bay and the Delta as the habitat for the POD species, two large bivalve species inhabit the area - an estuarine bivalve, Potamocorbula, and a freshwater bivalve, Corbicula fluminea (hereafter Corbicula). Both bivalves can limit the availability of phytoplankton biomass to other members of the food web in the estuary (Kimmerer and Thompson, 2014; Lopez and others, 2006; Lucas and others, 2002; Lucas and others, 2009; Thompson and others, 2008). In addition, Potamocorbula can filter zooplankton nauplii and ciliates out of the water column (Kimmerer and others, 1994; Greene and others, 2011), and Corbicula can filter ciliates (Scherwass and others, 2001) and glochidia (Scherwass and Arndt, 2005) from the water column. We therefore hypothesize that both bivalves may reduce the food supply to delta smelt and other fish species on at least two levels of the food web. For example, any direct reduction in zooplankton through filtration by bivalves, or indirect reduction in zooplankton owing to food limitation, can affect delta smelt, which feed mostly on calanoid copepods throughout their lives (Nobriga, 2002).

We are interested in the dynamics of both species of bivalve and specifically want to describe their temporal and spatial distributions to begin exploring possible controls on their distributions. Because Corbicula and Potamocorbula have varying (almost opposite) salinity limits, we expect that the primary limit for both species will be physiological. Other factors that are likely to affect the bivalve's distribution include (1) physical habitat, which is important for reproductive and recruitment success but can also be a stress to adults; (2) food availability, which may limit both species at all ages in this food-limited estuary (Kimmerer and Thompson, 2014); and (3) available predators, which are poorly understood.

In this report, we summarize the temporal variability of Corbicula and Potamocorbula in the north Bay and Delta by examining time series of biomass, grazing rate, recruit density, and average length of bivalves in samples from 15 monitoring stations. These bivalves are from benthic samples collected as part of the monitoring program conducted by the California Department of Water Resources Environmental Monitoring Program (http://www.water.ca.gov/bdma/) between 1977 and 2013. We specifically address the following questions in this paper:

1. How do Potamocorbula and Corbicula populations at a specific location respond to seasonal and interannual changes in salinity? How does salinity variability influence successful recruitment of these bivalves?

2. Is the magnitude of the grazing rate such that we would expect the feeding of the bivalves to limit seasonally the biomass of phytoplankton, copepods, bacteria, and microzooplankton?

\section{Project Background and the Conceptual Model}

All POD models have recognized that food limitation may be contributing to the decline of delta smelt (Baxter and others, 2008). The new, spatially explicit conceptual model for 2011 (as described in 
"Draft Plan: Adaptive Management of Fall Outflow for delta smelt Protection and Water Supply Reliability") highlights the importance of the biotic habitat as well as the abiotic physical habitat as measured by the position of X2 (kilometers [km] upstream of the Golden Gate Bridge) (Jassby and others, 1995). The longitudinal salinity distribution helps determine the available habitat for each bivalve and thus, ultimately, what the potential for limiting grazing rates is along the longitudinal gradient. We will use the position of X2 as our measure of salinity distribution and expect that Corbicula and Potamocorbula will overlap in the region of X2. This overlap is expected because the physiological limit for new recruits of both species is a salinity of 2 . The X2 position is not a precise measurement but represents the distance upstream from the Golden Gate Bridge, where a daily average salinity at 1 meter (m) above of the bottom is 2 (Jassby and others, 1995); therefore, the actual occurrence of a salinity of 2 is within an area upstream and downstream of the calculated X2 values. The X2 position moves up and down the estuary with tides and with seasons. We know that the abiotic habitat increases in complexity, and the potential for local food production increases where delta smelt habitat coincides with the shallow water $(\leq 3 \mathrm{~m})$ of Suisun Bay, Grizzly Bay, Honker Bay, and Suisun Marsh (fig 1). A critical component of food production, the phytoplankton biomass, is controlled by a combination of light and nutrient availability, residence time, and benthic and pelagic grazing losses (Kimmerer and others, 2012). Therefore, the high turbidity of the system limits positive net production to shallow areas, where accelerated vertical mixing rates expose phytoplankton cells to more light than in the channel (Cloern and others, 1985). Grazing losses to bivalves may also be greater in shallow water because increased mixing rates afford the bivalves more access to pelagic food. However, Thompson and others (2008) and Lucas and others (2009) have also shown that clams in the deep water $(\geq 5 \mathrm{~m}$ ) can have very high grazing rates and can depress the phytoplankton biomass that is transported from the shallows to this habitat.

The questions of how food availability for delta smelt has changed during the POD years and what factors are responsible for those changes have not been resolved. We know that the variability in salinity has decreased in late summer and fall during the POD and that delta smelt mostly live in the low salinity zone (LSZ) during this period. Several components of the LSZ food web, including the success and distribution of bivalves, may be affected by this change in salinity.

We analyzed bivalve grazing effects at all monitoring stations with available samples. We also examined bivalve recruitment patterns to understand how increasing freshwater flow can influence the distribution of each species.

\section{Methods}

\section{Stations and Samples}

The California Department of Water Resources Environmental Monitoring Program (http://www.water.ca.gov/bdma/) sampled 15 stations throughout the San Francisco Bay and Sacramento-San Joaquin Delta between 1977 and 2013 (fig. 1). Sampling occurred at various intervals until midway through 1980, when samples were collected at near monthly intervals. During 2004 and 2005, samples were collected quarterly. Station 8.1 is a U.S. Geological Survey (USGS) station that was a precursor to DWR sampling at site D6; it is in close approximation to but not in the same location as DWR site D6. Station 8.1 was sampled from 1988 to 2007, and DWR began sampling at D6 in 1996; the USGS measured bivalves through 2007 from station 8.1 and then finished the time series with samples from D6. From 1977-95, a single sample was archived of the 3-4 collected each month at each station. After 1996, three to four samples were collected and archived at each station (table 1). We measured all available bivalve samples except for those collected in 2003, when all samples were lost 
(2003 appears as holes in the data). Station D4 was collected as an across channel transect, shown as D4C, D4L, and D4R. Samples were collected in the channel (D4C) from 1977 to 1995, in the left shoal (D4L) from 1976 to present, and in the right shoal (D4R) from 1977 to 1995.

\section{Field Collection Methods}

California Department of Water Resources Environmental Monitoring Program uses a 0.052-m ${ }^{2}$ (square meter) ponar dredge to sample the bottom area to a depth that varies with the type of sediment and the ability of the dredge to penetrate it. At all sites, DWR collected an extra sample to determine the monthly length-to-weight (ash-free dry weight, [AFDW]) relation of the bivalve species. Each sample was sieved through a U.S. Standard No. 30 stainless steel mesh screen $(0.595-\mathrm{mm}$ openings) and preserved in a solution of approximately 10-20 percent buffered formaldehyde (depending on the substrate) with rose bengal dye added for laboratory analysis. We received sorted samples from DWR after their routine laboratory analyses were completed.

\section{Analytical Methods}

\section{Measuring Bivalves}

USGS personnel measured the bivalves to the nearest millimeter using a video image analyzer with HLImage++ software (http://www.wvision.com/) and handheld calipers (for the larger animals, $>5$ $\mathrm{mm}$ ). The USGS has used this technique for over 20 years. Bivalves were then returned to DWR for archiving. Biomass estimates were based on relations between shell length and dry tissue weight that were calculated by DWR and the USGS during each field sampling using the standard techniques described in Thompson and others (2008).

\section{Estimating Grazing Rates}

Grazing rates were calculated using the method described in Thompson and others (2008) for Potamocorbula and in Lopez and others (2006) for Corbicula. Pumping rates were adjusted for temperature and are provided as conservative rates (corrected for concentration boundary layer). Community pumping rates $(P R)$ were based on published relations: Potamocorbula, 400 liters (L) per gram (g) of ash free dry weight (AFDW) per day (d) $\left(\mathrm{Lg}^{-1} \mathrm{~d}^{-1}\right)$ (Cole and others, 1992; AFDW=dry weight-ash weight). Community pumping rates were converted to grazing rates $(G R)$ by reducing $P R$ to adjust for the presence of a concentration boundary layer. This adjustment was based on O'Riordan and others' (1995, figure 7b) refiltration relationship, $n_{\max }=2.5 /\left(s\left(d_{0}\right)^{-1}\right)$, where $n_{\max }$ is the maximum refiltration proportion. The refiltration proportion $\left(n_{\max }\right)$ is the proportion of water previously filtered by a square meter of bivalves $\left(G R=P R\left(1-n_{\max }\right)\right)$. The distance between siphon pairs $(s)$ is a measure of animal density, and $d_{0}$ is the average diameter of the excurrent siphon of the animals collected at each site (a measure of animal size). The diameter of the excurrent siphon was changed throughout each year to reflect the change in average size of animals as the year progressed, and the distance between siphon pairs was based on density of animals observed in our benthic sampling assuming equidistant spacing within the $0.05-\mathrm{m}^{2}$ grab. Benthic grazing rates calculated in this manner represent the minimum grazing rates because they assume that the near bottom boundary layer is depleted of phytoplankton, and mixing of the water column is inadequate to replenish that lower layer with biomass. We assumed all bivalves grazed continuously.

Dry weight was used to estimate temperature-corrected pumping rates for Corbicula. Pumping rate, expressed as a unit of weight $\left(P R_{\mathrm{wt}}\right)$, was derived from data published by Foe and Knight (1986) 
for Corbicula fluminea from the Delta: $P R_{\mathrm{wt}}$ milliliters $(\mathrm{mL})$ per milligram $(\mathrm{mg})$ of ash free dry mass $(\mathrm{AFDM})$ per hour $(\mathrm{hr})\left(\mathrm{mL}(\mathrm{mg} \mathrm{AFDM})^{-1} \mathrm{hr}^{-1}\right)=0.4307 e^{0.1113(\mathrm{temp})}$, valid for temperatures between 16 and $30^{\circ} \mathrm{C}$. Pumping rate for each individual is calculated as $P R\left(\mathrm{~L} \mathrm{~d}^{-1}\right)=\left(P R_{\mathrm{wt}}\right)$ (AFDM). Calculated pumping rates were converted to grazing rates assuming a maximum effect of a concentration boundary layer (CBL) by decreasing pumping rate using the refiltration relationship, $n_{\max }=3\left(s\left(d_{0}\right)^{-1}\right)^{-1}$ derived by O'Riordan and others (1995) for a similar bivalve (Venerupis japonica, a bivalve with similar pumping rates $\left[\approx 8 \mathrm{~mL} \mathrm{mg}^{-1} \mathrm{hr}^{-1}\right.$ ] as Corbicula fluminea).

\section{Data Analysis}

Data were analyzed and geographic plots were made using the analysis program Tableau 9.0 (http://www.tableau.com/). Data are shown in graphs (figs. 2-156) as well as listed in appendixes 1-20.

\section{Results}

We begin by showing median biomass, grazing rate, and recruitment for each monitoring station (fig. 1) for the period before and after Potamocorbula invaded, when the bivalve presence greatly changed in the north San Francisco Bay and Delta. Median biomass prior to 1987 was mostly concentrated in the central and southern Delta in Franks Tract and Old River (fig. 2) and consisted entirely of Corbicula. Biomass distribution shifted after Potamocorbula invaded in1987, and after some stations were dropped in 1995 (D19C, D11, and D4C), others were started in 1996 (D41A, D41C, D6, 8.1, D16, D24, C9, and P8). There is much higher biomass in Suisun Bay now, than seen in the decade before (fig. 3), which is a function of Potamocorbula invading and the addition of new stations to northern San Francisco Bay. A new station on the Sacramento River (D24) revealed that Corbicula arefound in large numbers on that section of the river, whereas the two stations added on the San Joaquin River at the same time had much smaller populations of Corbicula than were seen in either the Delta or the Sacramento River stations. Grazing rate is a nonlinear function of biomass, particularly when the biomass is large, but figures 4 and 5 show median grazing rate patterns similar to those displayed by median biomass. We observed no relation between the median number of recruits and biomass for either bivalve (figs. 6-7).

We summarize the temporal variability of Corbicula and Potamocorbula in the Bay and Delta by examining time series of biomass, grazing rate, recruit density, and average length of bivalves in samples from 15 monitoring stations (fig. 1). We will focus on how Potamocorbula and Corbicula biomass and grazing rate at a specific location vary seasonally and interannually. We will also examine variability and trends, if visible, in successful recruitment and growth of these bivalves. We define recruitment for our purposes as any bivalve $\leq 2.5 \mathrm{~mm}$ in length. Data have been broken down into sections where visible breaks in the data can be observed (that is, the introduction of Potamocorbula in 1987, massive floods of water in 1996, and the POD in 2004); this will allow the reader to see the data in more detail. These ecological events or breaks correspond to potential changes in bivalve biomass, grazing rate, and recruitment. We briefly describe what distinguishes the populations at each station and then summarize general patterns that we have observed in the following sections.

\section{Biomass}

We examine how Potamocorbula and Corbicula biomass changed over time as well as seasonally (figs. 8-44). Biomass at most sites in San Francisco Bay and the Sacramento-San Joaquin Delta averaged at least 5 grams per square meter $\left(\mathrm{g} \mathrm{m}^{-2}\right)$, with the highest average Corbicula biomass 
over the entire period being observed north at D24 (Rio Vista) and in the central Delta (table 2). The highest average Potamocorbula biomass was in Suisun Bay.

\section{Potamocorbula Biomass}

D6 (Carquinez Strait, on shelf, fig. 8) - There was no clear seasonal pattern, although most peaks occurred in spring, summer, and (or) fall, and minimum biomass occurred in winter of most years. D41A (San Pablo Bay, shoal, figs. 9-11) - Biomass was seasonal with high biomass in late summer/early fall (August-October) until 2004. Potamocorbula biomass remained low from 2004 2010, when high seasonal biomass returned in the fall of 2010 and continued through 2012 . The biomass plot of 2013 shows the population in decline again with a small peak in biomass and the population disappearing earlier than in the previous three years.

D41C (San Pablo Bay, deep, figs. 12-13) - Seasonal trends in biomass were present, with high biomass in late summer and early fall for the first three years until 1999. Potamocorbula biomass rarely recovered to those high levels seen in the earlier years except in 2006.

USGS 8.1 (Carquinez Strait, deep, figs. 14-16) - Early in the Potamocorbula invasion, this station had extremely high biomass, which leveled out after 1990. Since then, the pattern has been mixed. When biomass peaks occurred, they seemed to do so in late spring and (or) late fall. Minimum biomass values occurred most often in December and January.

\section{Corbicula Biomass}

C9 (southern Delta, figs. 17-18) - Biomass peaks were high the first four years and declined after 1999 with the only exception being one month in 2001. Although the biomass was lower after the first 4 years, the baseline moved upward in 2009 (that is, there were very few zeros and never any zeros for 2 consecutive months). The baseline may have been declining at the end of 2013.

D16 (San Joaquin River near Franks Tract, figs. 19-20) - Biomass patterns differed before and after 2002. Peaks in biomass prior to 2002 were 5-10 times higher than those observed after 2002.

D19 (Franks Tract, figs. 21-22) - Peak Corbicula biomass usually fell between 40 and $60 \mathrm{~g} \mathrm{~m}^{-2}$ with the exception of 1986. The baseline shifted upward during 1986 and stayed elevated through the end of the sampling in 1995.

D24 (Sacramento River upstream of Rio Vista, figs. 23-24) — Corbicula biomass was mostly seasonal, with peaks in late spring or early summer in most years with an additional peak in late fall of some years. The biomass increased after 2002, and both the peaks and the baseline steadily increased between 2006 and 2013.

D28 (Old River, middle Delta, figs. 25-28) — D28 is one of the longest sampled stations, and the biomass was quite variable but mostly peaked at $>50 \mathrm{~g} \mathrm{~m}^{-2}$ until 2002. Prior to that time, any decrease was followed by a bounce back to prior biomass levels. After 2002, the biomass values never returned to their previous levels.

P8 (San Joaquin River near Rough and Ready Island, figs. 29-30)-Biomass was low throughout the entire study period at this station with the exception of 1997, a wet year.

Overlap Biomass (Stations Where Corbicula and Potamocorbula Co-Occur)

D4C (Collinsville, center of channel near the confluence of Sacramento and San Joaquin Rivers, figs. 31-32) - Corbicula biomass peaked between 1985 and 1989. Corbicula biomass then decreased after 1989 and remained relatively low through 1995 when DWR discontinued sampling.

Potamocorbula had a small $\left(<10 \mathrm{~g} \mathrm{~m}^{-2}\right)$ but persistent biomass presence beginning in 1987. 
D4L (Collinsville, left side of channel near the confluence of Sacramento and San Joaquin Rivers, figs. 33-36) - D4L is one of the stations that has been sampled the longest (1977 to present). Corbicula biomass was low through 1996, increased briefly through 2001, and then declined in 2002. From 2005, peak biomass was low, but the baseline shifted upward, a trend that persisted through 2013.

Potamocorbula biomass was low throughout the study period with the exception of 1993-1994, when biomass was elevated for short time periods.

D4R (Collinsville, right side of channel near the confluence of Sacramento and San Joaquin Rivers, figs. 37-38) - Corbicula biomass was low throughout the sampling period. Potamocorbula biomass was low from 1987-1990 then dramatically increased from 1991-1994.

D7 (shoals of Grizzly Bay, figs. 39-42) —Corbicula biomass was high from 1984-1987, and then Corbicula essentially disappeared after Potamocorbula invaded. Potamocorbula biomass showed strong seasonal peaks in fall throughout the study period with biomass minima occurring in late winter/early spring of every year. The regular seasonal pattern did not stabilize until after the 1987-1992 drought. Potamocorbula peak biomass was lower during wet years.

D11 (Sherman Lake, figs. 43-44) - Corbicula biomass was low from 1977-1989 and then showed an upward trend through the end of the sampling period which ended in 1995 for this station. Annual increases occurred in Corbicula biomass in the spring from 1990-1995. Potamocorbula biomass was low throughout the sampling period.

\section{Biomass Summary}

Potamocorbula biomass was low in winter at all locations and near zero in the shallow San Pablo Bay station in winter. The Potamocorbula biomass at shallow stations consistently peaked in summer and fall, but there was no consistent peak season in the deep stations. Corbicula had a much less consistent seasonal biomass pattern than Potamocorbula. However, some interannual patterns were consistent between stations. Corbicula biomass at three stations declined after 2003 (C9, D16, and D28). The Franks Tract (D19) Corbicula biomass had a baseline shift up (that is, all values were $>0$ ) in 1985 until DWR ceased sampling the station in 1995. Two other stations showed a similar increase in baseline but at different times; D24 shifted up after 2007, and D11 shifted up in 1991.

\section{Grazing Rate}

Grazing rates (figs. 45-81) have the same basic patterns as biomass, and the same descriptions and conclusions that we applied to biomass can be applied to grazing rate data. Grazing rate has a nonlinear relationship with biomass; high biomass will have lower grazing rates than might be expected owing to the formation of the concentration boundary, which is stronger with higher bivalve abundance and biomass. The concentration boundary layer, as explained earlier, decreases the effectiveness of the bivalves' feeding and reduces grazing rates. The pumping rate is a function of temperature, so grazing rates tend to be lower in winter months than one would expect if the relationship with biomass were linear. In this case, the lower temperatures slow down the pumping rate, resulting in lower grazing rates.

Potamocorbula's pumping rates are about four times higher than Corbicula's pumping rates. At the stations where the two bivalves overlap, the strength of feeding rate relative to biomass for the two species is affected (see figs. 68, 70, 74, and 76). Potamocorbula biomass can be about 25 percent of Corbicula's biomass and have a similar grazing rate as Corbicula. 


\section{Recruitment}

Potamocorbula's seasonal recruitment changed with station location. Corbicula's recruitment showed less of a seasonal trend; recruitment occurred throughout the year with an occasional peak in the spring. We will define recruitment as any bivalve $\leq 2.5 \mathrm{~mm}$ in length.

\section{Potamocorbula Recruitment}

D6 (fig. 82) - Recruitment peaked in summer/early fall except during the wet year 2011, when recruitment was smaller and delayed to late fall. During dry or critically dry years on the Sacramento River (table 3), recruitment increased by as much as nine times that observed during other water years. D41A (figs. 83-85) - Recruitment occurred in late spring/summer. Recruit abundance was very low in 2004-2009; recruits returned in 2010-2012. Recruitment in the wet year 2011 was seasonally anomalous with the peak occurring in fall.

D41C (figs. 86-87) - Recruitment was annual and peaked in spring/summer until 2001, when the number of recruits declined, and did not recover until 2006, when there was a small peak in spring. 8.1 (figs. 88-90) - This station is in the middle channel of Carquinez Strait, where current velocities are high and recruitment could be strongly influenced by the hydrodynamics. The only year with $>100$ recruits during the initial 10 years of the study was 1992 . There were then major peaks in recruitment in fall 1999 and spring 2000 and again in fall and winter 2006.

\section{Corbicula Recruitment}

C9 (figs. 91-92) - Corbicula recruits were observed in most months. The most frequent season of peak recruitment was spring, followed by fall. The largest numbers of recruits occurred in both a wet year (1996) and a dry year (2002).

D16 (figs. 93-94) - Recruits were present in most samples in this San Joaquin River channel station. Recruits were present through 2002 and peaked at different times of the year. Recruit abundance then declined and did not increase again until 2009, when we saw a small fall peak that reoccurred through 2013.

D19 (figs. 95-96) - Corbicula recruits were present for prolonged periods in many years, particularly before 1986. The number of recruits was lowest at the end of the drought, 1991-1994, and rapidly increased in 1995.

D24 (figs. 97-98) - Corbicula recruitment decreased after 2002, when recruits became less abundant.. No consistent seasonal pattern was evident during any period, with recruits occurring equally in spring, summer, and fall of some years (for example, 2000).

D28 (figs. 99-102, note the change in scale on vertical axes) - Recruit abundance is normal to high relative to other stations. Corbicula recruitment occurred in the spring/summer, with the most abundant recruitment years being 1982, 1989, and 1990. The abundance of recruits was lower in 1984-1988 and 1994-2013 relative to the periods of maximum abundance.

P8 (figs. 103-104) - Recruit abundance peaked in late winter/early spring and fall of most years. The recruit abundance was similar to that observed at $\mathrm{C}$.

Overlap Recruitment (Stations Where Corbicula and Potamocorbula Co-Occur)

D4C (figs. 105-106) - Corbicula recruitment peaked in spring and fall until 1986. Potamocorbula recruits appeared in late summer/fall of 1987 and again in 1991, after which neither bivalve had significant numbers of recruits. 
D4L (figs. 107-110) - D4L is one of the longest-term monitoring stations. Corbicula recruits peaked in spring through 1987. Potamocorbula recruits appeared in summer 1988, and Corbicula recruit abundance declined with small peaks in 1990 and 1996. Corbicula recruit abundance increased from 1996-2013 but never to the sustained levels seen in the 1980s. Potamocorbula recruits were visible in fall of most years but in low abundance; highest Potamocorbula recruit abundance was in their first year of the invasion, 1987.

D4R (figs. 111-112) - Corbicula recruits at D4R, which is on the opposite side of the channel from D4L, had an interannual pattern similar to that seen at D4L but with fewer recruits. Potamocorbula recruit abundance was higher, started at the same time in 1987, but was more consistent than at D4L until 1993, when recruits at both stations declined.

D7 (figs. 113-116) - Corbicula recruitment was low except in 1984. Potamocorbula recruitment occurred in late summer/early fall beginning in 1987. Recruitment greatly increased in the summer of 2006, 2008, and 2009, and again in the spring of 2013.

D11 (figs. 117-118) - Corbicula recruits were present through most months with the exception of 1993 and 1994. Recruit abundance peaked in spring and fall, and the largest recruit abundance occurred in two drought years, 1990 and 1991. No Potamocorbula recruits were present.

\section{Recruitment Summary}

Potamocorbula recruitment occurs anytime between spring and fall, with bivalves at the most downstream stations in San Pablo Bay recruiting in spring and animals at the most upstream stations recruiting in fall. The bivalves at the stations between these endpoints recruit in (1)spring or (2) summer and fall (Carquinez Strait), or in some combination of two of those three seasons in Grizzly Bay. The shallow station in San Pablo Bay (D41A) had the highest peak recruit abundance $\left(2,000\right.$ recruits $/ 0.05 \mathrm{~m}^{2}$ in the year 2000). The smallest recruit abundance, at a location where adults were found, was in Sherman Lake, where we found no recruits. San Pablo Bay shallow water Potamocorbula recruitment stopped after 2002 and did not restart until 2010, reflecting the declining and absent Potamocorbula biomass during those years at that station. The few locations where Potamocorbula and Corbicula overlapped show recruit abundance opposing each other, with Potamocorbula recruits peaking during the more saline time of year and the Corbicula recruits peaking during the periods with lower salinities.

Corbicula were mostly present throughout the year with some peaks in abundance, but the patterns were not seasonally consistent at any station. The highest recruit abundance occurred at D28 on Old River (1,200 recruits $/ 0.05 \mathrm{~m}^{2}$ ), and the lowest recruit abundances were at C9 in the south Delta at Clifton Court and at P8 on the San Joaquin River upstream of Stockton. Many stations showed a reduction in the volatility of recruit abundance; the high peaks were absent at D28 after 1993, after 1985 at D4C, and after 1987 at D4L and D4R.

\section{Mean Size}

The final parameter we examined was the mean size of the clams at each station over time. The mean size can change with an influx of juveniles, the mortality of an older year class, or the lack of recruitment but continual growth of the previous year classes. We therefore expect the size to be dynamic. Potamocorbula also live for at most 3 years, whereas Corbicula can live 5 years, which makes the average size range of Potamocorbula potentially more dynamic. 


\section{Potamocorbula Mean Size}

D6 (fig. 155) - Average size declined coincident with recruitment. The 2011 data reflect a mean size of a population not diluted by spring recruits in that year. Prior to the recruitment in September 2011, the mean size of the population was about $9 \mathrm{~mm}$.

D41A (figs. 120-122) - Unlike D6, this San Pablo Bay station had a distinct 1-month recruitment period, and this resulted in a regular pattern in mean size. Peaks were seen in fall in the 6-8 $\mathrm{mm}$ range in years when recruits were observed. Mean size varied greatly in years with low population abundance (1994-1995, 2002-2009).

D41C (figs. 123-124) - Individuals were very large at this deep-water station, with animals exceeding $10-12 \mathrm{~mm}$ some years.

8.1 (figs. 125-127) - Recruitment at this deep-water station was very low and uneven between years; the average size reflects that variability. The mean size in some years fluctuated around the 4-6 $\mathrm{mm}$ range (1999-2003) and was $>10 \mathrm{~mm}$ in other years.

\section{Corbicula Mean Size}

C9 (figs. 128-129) - Maximum mean size of Corbicula was $>25 \mathrm{~mm}$ in 1996-1997 but declined thereafter until the mean size was $<10 \mathrm{~mm}$ from 1999-2007. The mean size then began to increase in 2008 and was over $20 \mathrm{~mm}$ by 2012 .

D16 (figs. 130-131) - Mean size peaked in the $>10 \mathrm{~mm}$ range through 2010. The sizes declined from 2011-2013, when recruitment (fig. 94) began to appear every year.

D19 (figs. 132-133) - Mean size steadily increased from the 4-6 $\mathrm{mm}$ range from 1981 through 1983 to a peak of $>16 \mathrm{~mm}$ in 1986 and 1987. The mean size declined after 1987 but never returned to the smaller sizes that observed at the beginning of the record in the early 1980s.

D24 (figs. 134-135) - Mean size decreased after 1998 from $>10 \mathrm{~mm}$ to a 4-6 mm range until 2006, when the average size began to increase and then maintained an annual mean peak size of $>12 \mathrm{~mm}$ after 2006.

D28 (figs. 136-139) - In a pattern similar to D19 before 1996, individual mean size increased from 10 $\mathrm{mm}$ in 1981 to $15-20 \mathrm{~mm}$ in 1984 through 1987 . Thereafter, the maximum mean size was mostly $\approx 10$ $15 \mathrm{~mm}$ until 2002-2013, when it declined to $<10 \mathrm{~mm}$.

P8 (figs. 140-141) - Animals were small at this station, with most annual maxima $<5 \mathrm{~mm}$ except for brief eruptions in 1997-1998, 2009, and 2012.

\section{Overlap Mean Size (Stations Where Corbicula and Potamocorbula Co-Occur)}

D4C (figs. 142-143) - The maximum mean size of Corbicula increased from 10-15 mm before 1985 to $>20$ from 1985 through 1995. Potamocorbula was quite large in most years at this station $(>10 \mathrm{~mm})$ except in 1990.

D4L (figs. 144-147) - As in the mid-channel station, the mean size of Corbicula was small $(<5 \mathrm{~mm})$ until 1986, after which they were at least $10 \mathrm{~mm}$. A strong seasonal pattern seen in most years disappeared in 2006 and continues through the present at this station. Potamocorbula mean size was very dynamic with large animals (15 mm and larger) in 1994 and 1996-1997. Potamocorbula showed the seasonal pattern we have seen downstream since 2007, with peak sizes occurring in summer and fall and minimum sizes in winter and spring.

D4R (figs. 148-149) - Corbicula mean size was small $(<10 \mathrm{~mm})$ until 1987, when the population size became more dynamic, with maximum mean size exceeding $20 \mathrm{~mm}$ in several years. Potamocorbula mean size was also large ( $>10 \mathrm{~mm})$ at this station except in 1991-1992, when it was $<10 \mathrm{~mm}$. 
D7 (figs. 150-153) — Corbicula was present until Potamocorbula came into Grizzly Bay in 1987. During that time, the mean size steadily increased from 1984 to 1987, where it reached a maximum of $25 \mathrm{~mm}$. Potamocorbula was less variable, and the mean size stayed under $10 \mathrm{~mm}$ with few exceptions. D11 (figs. 154-155) - Corbicula mean size was consistently $<5 \mathrm{~mm}$ until 1992, when the individuals increased in size (>15 mm). Corbicula stayed large until 1995, when they declined to about $10 \mathrm{~mm}$. Potamocorbula was variable and had no consistent pattern.

\section{Mean Size Summary}

Both clams reached a peak size in late summer/early fall and never got above a certain size depending on location. The data show that the mean size has decreased over the years, and the size distributions throughout the Delta are now skewed toward small or young Corbicula $(<10 \mathrm{~mm})$. The mean size of Potamocorbula was skewed toward the small, or young, with sizes in the range of 2-8 $\mathrm{mm}$. The mean size of Potamocorbula increased from spring to fall and decreased in winter. A similar generalization is not possible with Corbicula because seasonal patterns in size varied depending on station location. Station D24 on the Sacramento River was the only location with an increase in Corbicula mean size over the sampling period.

The largest mean sized Potamocorbula were in the channel areas, where sizes of $15 \mathrm{~mm}$ were common at stations D41C, 8.1, and D6. Sizes in excess of $15 \mathrm{~mm}$ occurred at all three D4 stations in the mid-1990s. The average size of Potamocorbula in the shoals was $\approx 5-7 \mathrm{~mm}$ in most years in Grizzly Bay (D7) and San Pablo Bay (D41A), with an increase to $>10 \mathrm{~mm}$ at D7 in the wet years.

The largest mean sized Corbicula occurred in the southern Delta (C9 $25 \mathrm{~mm}$ in 1996-1997 and 2012-2013), and the smallest average sizes were observed in the San Joaquin River (P8 and D16). The bivalves at the upriver Sacramento River station (D24) and in the southern Delta (C9) showed similar interannual patterns in average size, although the animals at C9 were consistently larger than those at D24 were. Bivalves were largest in 1996-1997. The bivalves in Franks Tract (D19) and those in the Old River (D28A) south of Franks Tract were also similar in size and in interannual patterns.

At the few stations where Potamocorbula and Corbicula overlap, it appears that they do not hinder each other's growth. Both bivalves have large animals at D4, where Corbicula size increased coincident with the presence of Potamocorbula in 1987. Corbicula were observed in wet years prior to Potamocorbula's invasion at D7 and were capable of growing to significant size in wet years $(>20 \mathrm{~mm}$ in 1986).

\section{Our Questions}

\section{How do Potamocorbula and Corbicula populations at a specific location respond to seasonal and interannual changes in salinity? How does salinity variability influence successful recruitment of these bivalves?}

The conceptual model for the distribution of Corbicula and Potamocorbula is based on the physiological salinity limits of the recruits (Potamocorbula $\geq 2$, Corbicula $\leq 2$ ) and the adults (Potamocorbula $>0$, Corbicula $<10$ ) of each species. We use X2 to demonstrate where a salinity of 2 is most likely to occur during the study period with the stations designated on the figure to show their position in X2 space (fig. 156). Because X2 is not a specific location but rather a representation of a range of locations over a tidal cycle, we expect the relationship between X2 position and clam distribution to be approximate. Starting at the most down bay station, we see that Potamocorbula in San Pablo Bay appear to have not been limited by salinity since their arrival (fig. 156), and it is doubtful that Corbicula could live in this saline environment. Similarly, adult Potamocorbula were not likely to be 
limited by salinity at the Carquinez Strait stations (8.1 and D6), although there were short periods in 1995 and 2006 when the water may have been too fresh for the recruits. The salinity was sufficiently low in the 1980s at the Grizzly Bay station (D7) to support Corbicula, but despite the low salinities in 1995, 1996, 2006, and 2011, we did not see Corbicula settle at this station, so something other than salinity may be limiting their success. The salinities were likely in the range that Potamocorbula adults could adjust after the species invaded in 1986. Recruits, however, were limited to the fall during the nondrought years (figs. 40-42); salinities were frequently $<2$ in spring in nondrought years. The stations at Collinsville (D4R, D4C, and D4L) were at the border of the distribution of the two species for most of the study. Corbicula and Potamocorbula adults and recruits appeared and disappeared with changing freshwater flow and therefore with the position of X2. Corbicula was consistently present prior to Potamocorbula's arrival and had not regained its dominance by 1996, despite the low salinity years 1995-1996, when two of the stations were discontinued. Potamocorbula settled and grew during the 1987-1992 drought in the shoals (D4R and D4L) adjacent to the channel but had a limited appearance at the mid-channel station (D4C). Sampling at D4L was continued and, despite many low flow years after 1998 (fig. 156) that moved X2 up stream, Potamocorbula never regained the biomass seen in the 1980s. Corbicula, however, developed a more consistent and persistent biomass presence (figs. 32-38). Salinity did not control distribution at the remaining stations in the Delta because the water at these stations was mostly fresh throughout the study.

\section{Is the magnitude of the grazing rate such that we would expect the feeding of the bivalves to limit seasonally the biomass of phytoplankton, copepods, bacteria, and microzooplankton?}

Limits on phytoplankton and zooplankton biomass by bivalve grazers is a function of a number of factors that control bivalve grazing rates, such as biomass, density of bivalves, and temperature, which can change pumping rate. Limits on phytoplankton growth rate include bivalve grazing rate, water depth, turbidity, residence time of the water column, and nutrients (Lucas and Thompson, 2012). Water depth determines the availability of pelagic food sources to bottom feeders because water column mixing and turnover is more frequent in shallow water. Residence time of the water column establishes how long the phytoplankton have to grow and be grazed before they are transported elsewhere; residence times in the channels or on the edge of channels in this tidal system are likely to be the shortest. Therefore, the locations where we would expect the bivalves to have the most influence are in shallow areas with relatively long residence times. We use the grazing rate turnover rate (GRTO/day, table 2), which is the ratio of grazing rate to water depth, to examine this dynamic. A phytoplankton doubling time of 3.5 days is reasonable for the northern estuary (Jassby, 2008), and thus any grazing rate that exceeds that rate, which is equivalent to a coupling rate of $\approx 0.2 /$ day, has the potential to reduce the phytoplankton biomass given sufficient light and long enough residence time. The channel areas rarely meet the light requirements for phytoplankton growth because of high turbidity and low light, conditions which result in high respiration rates (Cloern and others, 1985). The channel location depths in this dataset are all greater than about $5 \mathrm{~m}$ (stations 8.1, D24, D4C, and D41C), and we will assume that factors other than bivalve grazing are first order controls on phytoplankton growth at these locations. The two stations on either side of D4C (D4R and D4L) are on the channel edge and unlikely to have a long enough residence time to be effective plankton growth areas, although they could reduce zooplankton to some unknown degree. Of the remaining stations, those with average water column turnover rates equal to or greater than the phytoplankton doubling rate include C9, D16, D19, D28, and D11 (locations with Corbicula), and also D41A, D6, and D7 (locations with Potamocorbula). Grazing rates that will result in no net phytoplankton growth given the water depths of each station (table 1) range from $>0.3$ to $>0.9 \mathrm{~m}^{3} \mathrm{~m}^{-2} \mathrm{~d}^{-1}$. If we look at the grazing rate graphs in figures $47-81$ and 
conservatively estimate that a grazing rate $>1 \mathrm{~m}^{3} \mathrm{~m}^{-2} \mathrm{~d}^{-1}$ is likely to limit phytoplankton biomass, we see that there are periods when this is true at all stations. The two stations (D41A and D7) that are likely to have the most favorable conditions for phytoplankton growth (long residence time, shallow water, and good light) also had high grazing rates most of the time from Potamocorbula. The San Pablo Bay shallow station (D41A) has high bivalve grazing rates during the summer and fall periods through 2002, with the Potamocorbula population essentially disappearing each winter and spring. A very similar pattern occurred in Grizzly Bay (D7), but the winter/spring low grazing rate periods are shorter, and in most cases grazing rates were greater than zero. In both of these bays, we would expect to see phytoplankton biomass accumulate most frequently in the winter/spring period. Corbicula and Potamocorbula are concurrently present at D4L and D4R, which are on the edges of the main channel. Although neither site is likely to have high enough residence time to support phytoplankton growth, the bivalves on the right side of the channel (D4R) in particular had very high grazing rates in the 1990s and may have been significantly grazing some zooplankton biomass. The bivalves on the left side of the channel (D4L) have been variable, with Corbicula having sufficient grazing rates to reduce pelagic food resources from the mid-1990s until present. The grazing rates at D4 are certainly sufficient to reduce microzooplankton from the water column. The other two embayments with potential for phytoplankton growth were Franks Tract (figs. 57-58), where grazing rates $>1 \mathrm{~m}^{3} \mathrm{~m}^{-2} \mathrm{~d}^{-1}$ for several months of every year until sampling at this station was discontinued in 1995, and Sherman Lake, where the smallest bivalve populations found in an embayment occurred. In Sherman Lake, Potamocorbula and Corbicula were both present, but grazing rates for both were too low most of the time. The remaining stations are likely to have low residence times because of their location in channels. We have chosen to comment on these stations because (1) they are shallow enough that benthic grazing could affect the pelagic system and, in particular, microzooplankton and (2) all of these stations have shown a shift in grazing magnitude at the same time. The San Joaquin River station near Jersey Point (D16) had quite high grazing rates in 1996-2002, and the rates were usually well above the $1 \mathrm{~m}^{3} \mathrm{~m}^{-2} \mathrm{~d}^{-1}$ threshold. However, sometime between the 2003 period, when we do not have samples, and 2005, the grazing rate dropped to near zero. At this grazing rate, the bivalves at this station are unlikely to affect any portion of the food web with their filter feeding. We saw a similar change in grazing rate at D28 on the Old River and at C9 near Clifton Court. Corbicula grazing rates were well in excess of the threshold at both of these locations until 2005, and the grazing rate has exceeded the threshold only a few periods since 2005 . The station near Stockton (P8) on the San Joaquin River had a similar but less dramatic shift in grazing rates in 2002.

\section{Selected References}

Alpine, A.E., Cloern, J.E.,1992, Tropic innteractions and direct physical effects control phytoplankton biomass and production in an estuary: Limnology and Oceanography, v. 37, no. 5, p. 946-955.

Baxter, R., Breuer, R., Brown, L., Chotkowski, M., Feyrer, F., Gingras, M., Herbold, B., MuellerSolger, A., Nobriga, M., Sommer, T., and Souza, K., 2008, Pelagic organism decline progress report; 2007 synthesis of results: Interagency Ecological Program for the San Francisco Estuary, 78 p.

Bouley, P., and Kimmerer, W.J., 2006, Ecology of a highly abundant, introduced cyclopoid copepod in a temperate estuary: Marine Ecology Progress Series, v. 324, p. 219-228.

Canuel, E.A., Cloern, J.E., Ringelberg, D.B., Guckert, J.B., and Rau, G.H., 1995, Molecular and isotopic traces used to examine sources of organic matter and its incorporation into the food webs of San Francisco Bay: Limnology and Oceanography, v. 40, no. 1, p. 67-81.

Cloern, J.E., Cole, B.E., Wong, R.L.J., and Alpine, A.E., 1985, Temporal dynamics of estuarine phytoplankton — a case study of San Francisco Bay: Hydrobiologia, v. 129, no. 1, p.153-176. 
Cole, B.E., and Cloern, J.E., 1984, Significance of biomass and light availability to phytoplankton productivity in San Francisco Bay: Marine Ecology Progress Series, v. 17, p. 15-24.

Crimaldi, J.P., Thompson, J.K., Rosman, J.H., Lowe, R.J., and Koseff, J.R., 2002, Hydrodynamics of larval settlement; The influence of turbulent stress events at potential recruitment sites: Limnology and Oceanography, v. 47, no. 4, p. 1137-1151.

Foe, C., and Knight, A., 1986, Growth of Corbicula fluminea (bivalvia) fed artificial and algal diets: Hydrobiologica, v. 133, no. 2, p. 155-164.

Greene, V.E., Sullivan, L.J., Thompson, J.K., and Kimmerer, W., 2011, Grazing impact of the invasive clam Corbula amurensis on the microplankton assemblage of the northern San Francisco Estuary: Marine Ecology Progress Series, v. 431, p. 183-193.

Hammock, B.G., Hobbs, J.A., Slater, S.B., Acuña, S., and Teh, S.J., 2015, Contaminant and food limitation stress in an endangered estuarine fish: Science of the Total Environment, v. 532, p. 316 326.

Jassby, A.D., Kimmerer, W.J., Monismith, S.G., Armor, C., Cloern, J.E., Powell, T.M., Schubel, J.R., and Vendlinski, T.J., 1995, Isohaline position as a habitat indicator for estuarine populations:

Ecological Applications, v. 5, no. 1, p. 272-289.

Jassby, A.D., 2008, Phytoplankton in the upper San Francisco Estuary-recent biomass trends, their causes, and their trophic significance: San Francisco Estuary and Watershed Science, v. 6, no. 1, article 2.

Kimmerer, W.J., Gartside, E., and Orsi, J.J., 1994, Predation by an introduced clam as the likely cause of substantial declines in zooplankton of San Francisco Bay: Marine Ecology Progress Series, v. 324, p. 207-218.

Kimmerer, W.J., Parker, A.E., Lidström, U.E., and Carpenter, E.J., 2012, Short-term and interannual variability in primary production in the low-salinity zone of the San Francisco Estuary: Estuaries and Coasts, v. 35, no. 4, p. 913-929.

Kraemer, L.R., and Galloway, M.L., 1986, Larval development of Corbicula fluminea (Müller) (Bivalvia: Corbiculacea); an appraisal of its heterochrony: American Malacological Bulletin, v. 4, no. 1, p. 61-79.

Lopez, C.B., Cloern, J.E., Schraga, T.S., Little, A.J., Lucas, L.V., Thompson, J.K., and Burau, J.R., 2006, Ecological values of shallow-water habitats - implications for restoration of disturbed ecosystems: Ecosystems, v. 9, p. 422-440.

Lucas, L.V., Cloern, J.E., Thompson, J.K., and Monsen, N.E., 2002, Functional variability of habitats in the Sacramento-San Joaquin Delta—restoration implications: Ecological Applications, v.12, no. 5, p. $1528-1547$.

Lucas, L.V., Thompson, J.K., and Brown, L.R., 2009, Why are diverse relationships observed between phytoplankton biomass and transport time?: Limnology and Oceanography, v. 54, no. 1, p. 381-390.

Lucas, L.V., and Thompson, J.K., 2012, Changing restoration rules; Exotic bivalves interact with residence time and depth to control phytoplankton productivity: Ecosphere, v. 3, no. 12, article 117.

MacNally, R., Thomson, J.R., Kimmerer, W.J., Feyrer, F., Newman, K.B., Sih, A., Bennett, W.A., Brown, L., Fleishman, E., Culberson, S.D., and Castillo, G., 2010, Analysis of pelagic species decline in the upper San Francisco Estuary using multivariate autoregressive modeling (MAR): Ecological Applications, v. 20, no. 5, p.1417-1430.

McManus, G.B., York, J.K., and Kimmerer, W.J., 2008, Microzooplankton dynamics in the low salinity zone of the San Francisco Estuary: Verhandlungen des Internationalen Verein Limnologie, v. 30, p. 196-202. 
Nobriga, M.L., 2002, Larval delta smelt diet composition and feeding incidence-environmental and ontogenetic influences: California Fish and Game, v. 88, p. 149-164.

O'Riordan, C.A., Monismith, S.G., and Koseff, J.R., 1995, The effect of bivalve excurrent jet dynamics on mass transfer in a benthic boundary layer: Limnology and Oceanography, v. 40, no. 2, p. 330-344.

Parchaso, F., and Thompson, J.K., 2002, The influence of hydrologic processes on reproduction of the introduced bivalve Potamocorbula amurensis in northern San Francisco Bay, California: Pacific Science, v. 56, no. 3, p. 329-345.

Scherwass, A., Eimer, A., and Arndt, H., 2001, Selective influence of filter-feeding benthic bivalves $(C$. fluminea sp., Mytilus sp.) on planktonic ciliates: Verhandlungen der Internationalen Vereinigung für

Theoretische und Angewandte Limnologie, v. 27, p. 3315-3318.

Scherwass, A., and Arndt, H., 2005, Structure, dynamics and control of the ciliate fauna in the potamoplankton of the river Rhine: Archiv für Hydrobiologie, v. 164, no. 3, p. 287-307.

Schlekat, D.W., Lee, B.G., and Luoma, S.N., 2002, Assimilation of selenium from phytoplankton by three benthic invertebrates - effect of phytoplankton species: Marine Ecology Progress Series, v. 237, p. 79-85.

Stevens, D.L., Jr., and Olsen, A.R., 2004, Spatially-balanced sampling of natural resources in the presence of frame imperfections: Journal of American Statistical Association, v. 99, p. 262-278.

Thompson, J.K., Koseff, J.R., Monismith, S.G., and Lucas, L.V., 2008, Shallow water processes govern system-wide phytoplankton bloom dynamics - A field study: Journal of Marine Systems, v. 74, nos. 1-2, p. 153-166.

Werner, I., and Hollibaugh, J.T., 1993, Potamocorbula amurensis-comparison of clearance rates and assimilation efficiencies for phytoplankton and bacterioplankton: Limnology and Oceanography, $\mathrm{v}$. 38, no. 5, p. 949-964. 


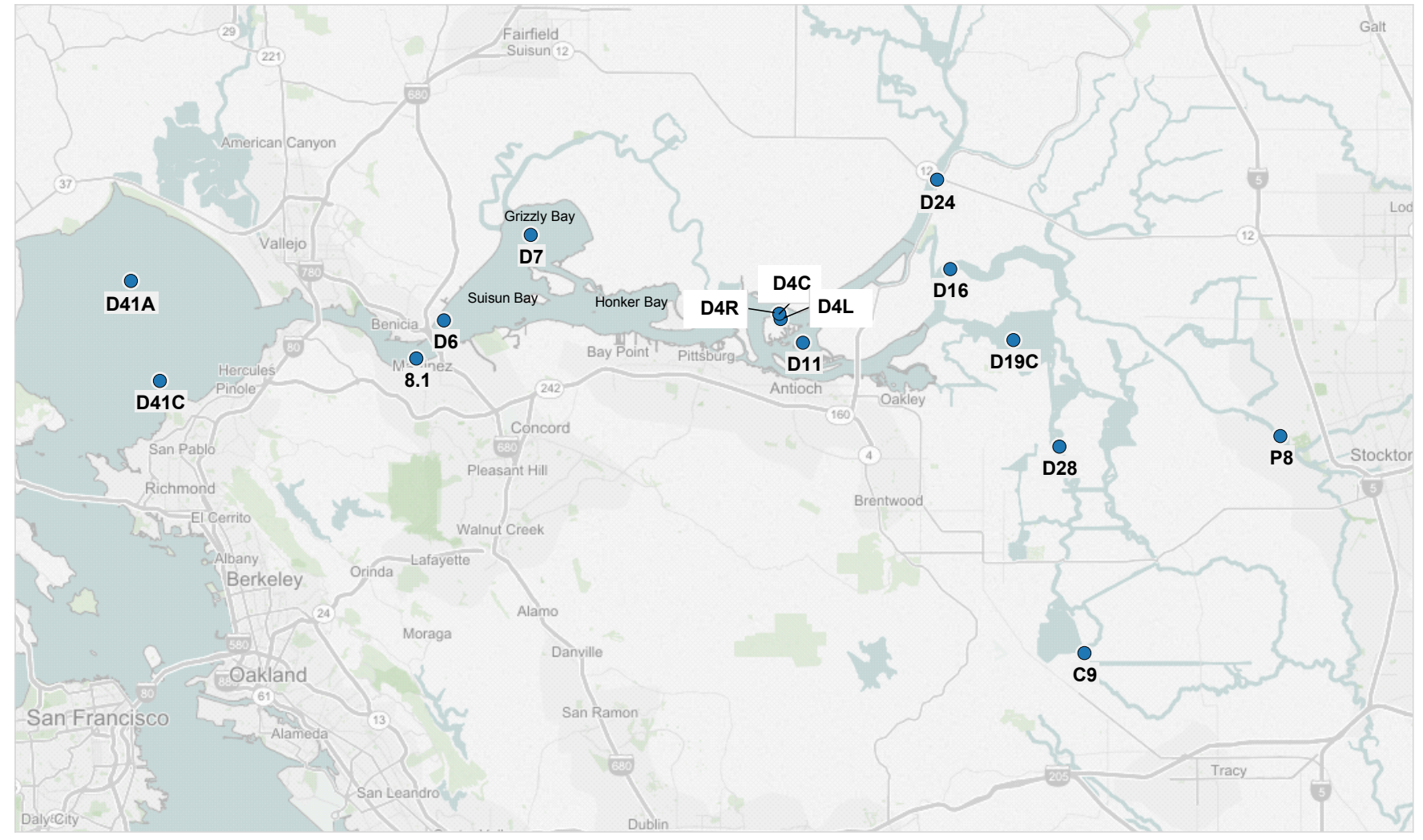

Figure 1. Map showing location of bivalve sampling stations in San Francisco Bay and the Sacramento-San Joaquin Delta. 


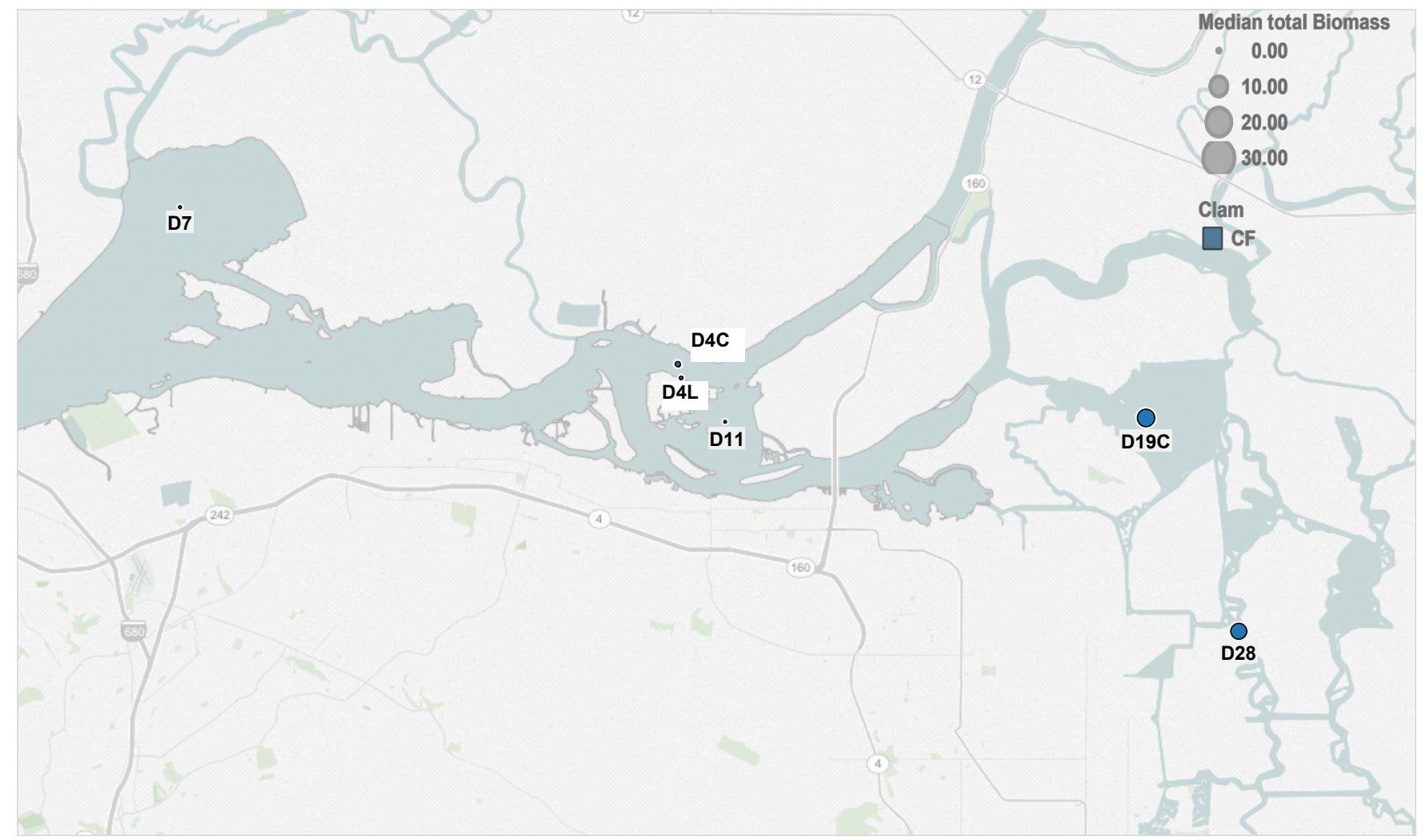

Figure 2. Map showing median biomass of Corbicula fluminea (CF) in grams per square meter ( $\mathrm{gm}^{-2}$ ) before the arrival of Potamocorbula amurensis to San Francisco Bay and the Sacramento-San Joaquin Delta in 1987. 


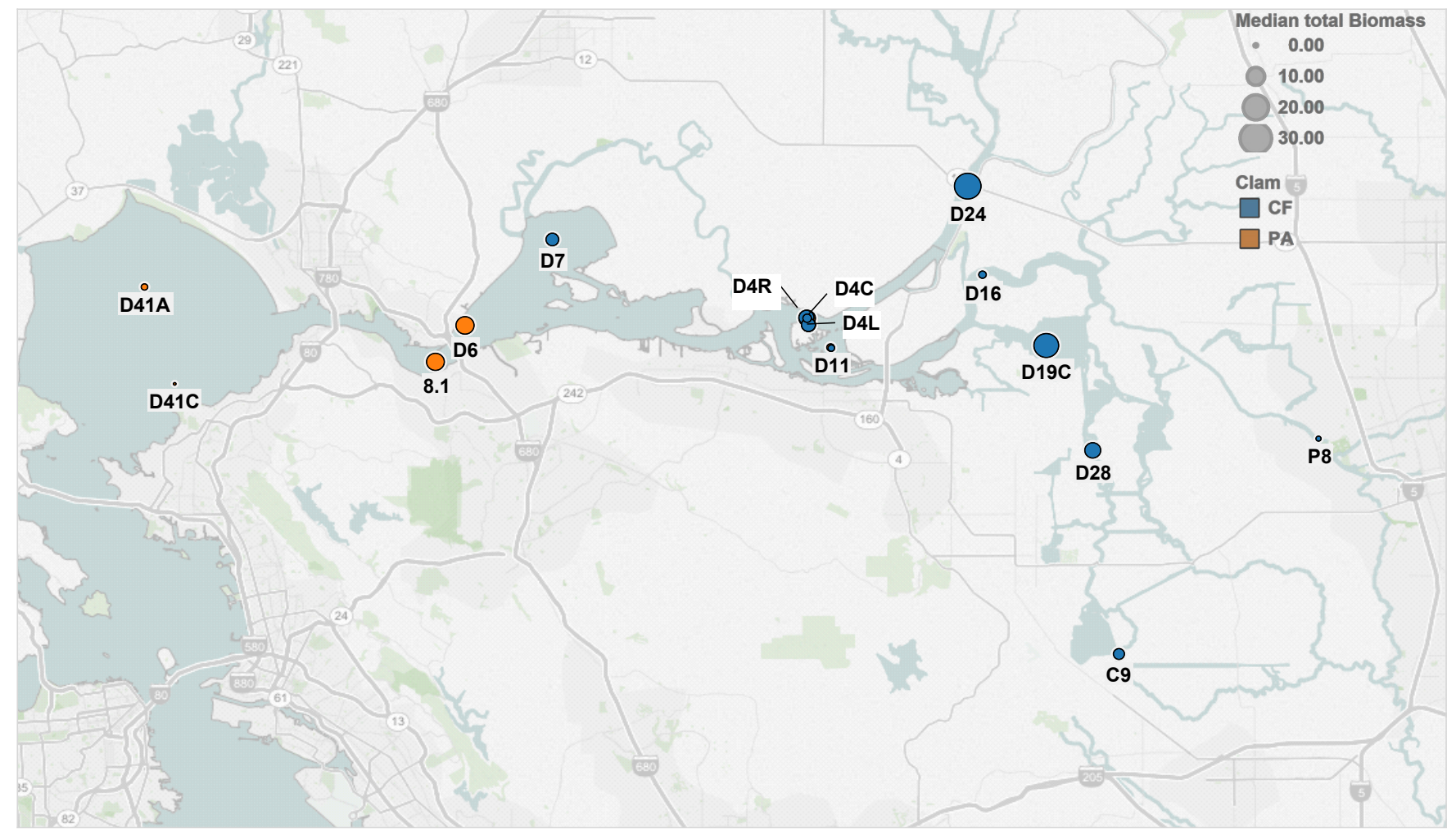

Figure 3. Map showing median bivalve biomass in grams per square meter $\left(\mathrm{gm}^{-2}\right)$ after the arrival of Potamocorbula amurensis to San Francisco Bay and the Sacramento-San Joaquin Delta in 1987. CF, Corbicula fluminea; PA, Potamocorbula amurensis. 


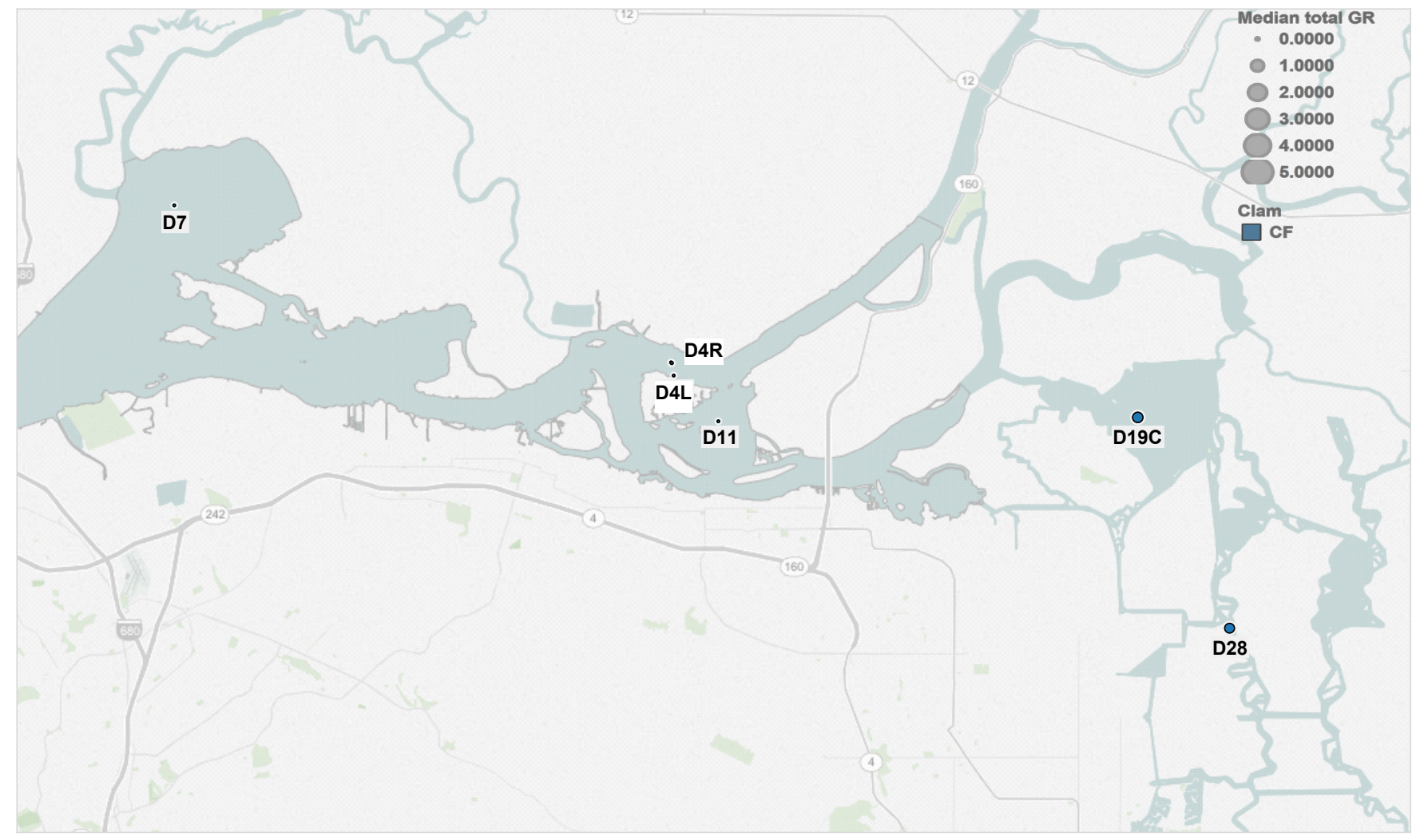

Figure 4. Map showing median grazing rate (GR) of Corbicula fluminea (CF) in cubic meters per square meter per day $\left(\mathrm{m}^{3} \mathrm{~m}^{-2} \mathrm{~d}^{-1}\right)$ before the arrival of Potamocorbula amurensis to San Francisco Bay and the Sacramento-San Joaquin Delta in 1987. CF= Corbicula fluminea. 


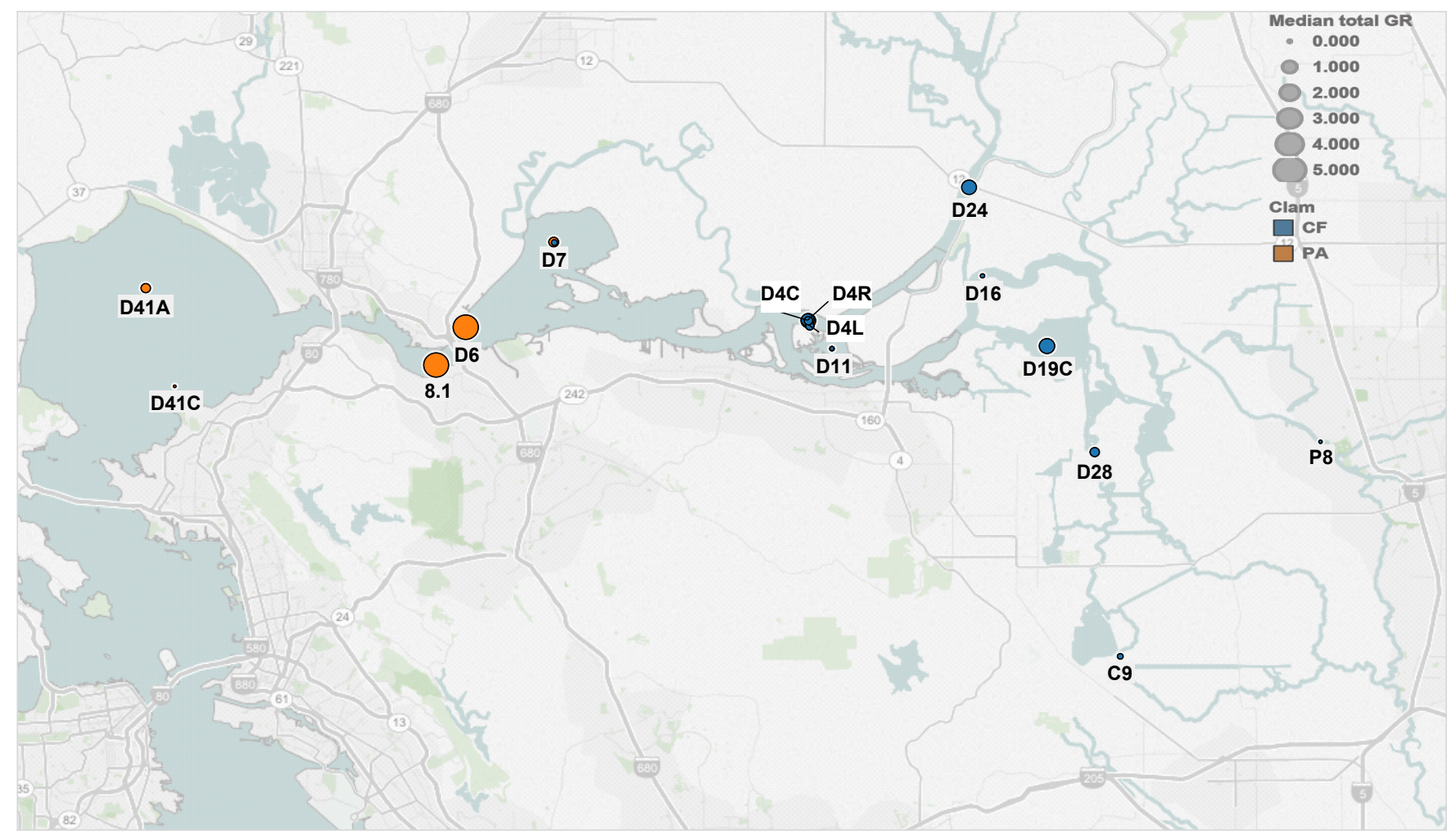

Figure 5. Map showing median grazing rate (GR) in cubic meters per square meter per day $\left(\mathrm{m}^{3} \mathrm{~m}^{-2} \mathrm{~d}^{-1}\right)$ after the arrival of Potamocorbula amurensis to San Francisco Bay and the Sacramento-San Joaquin Delta in 1987. CF= Corbicula. $\mathrm{PA}=$ Potamocorbula. 


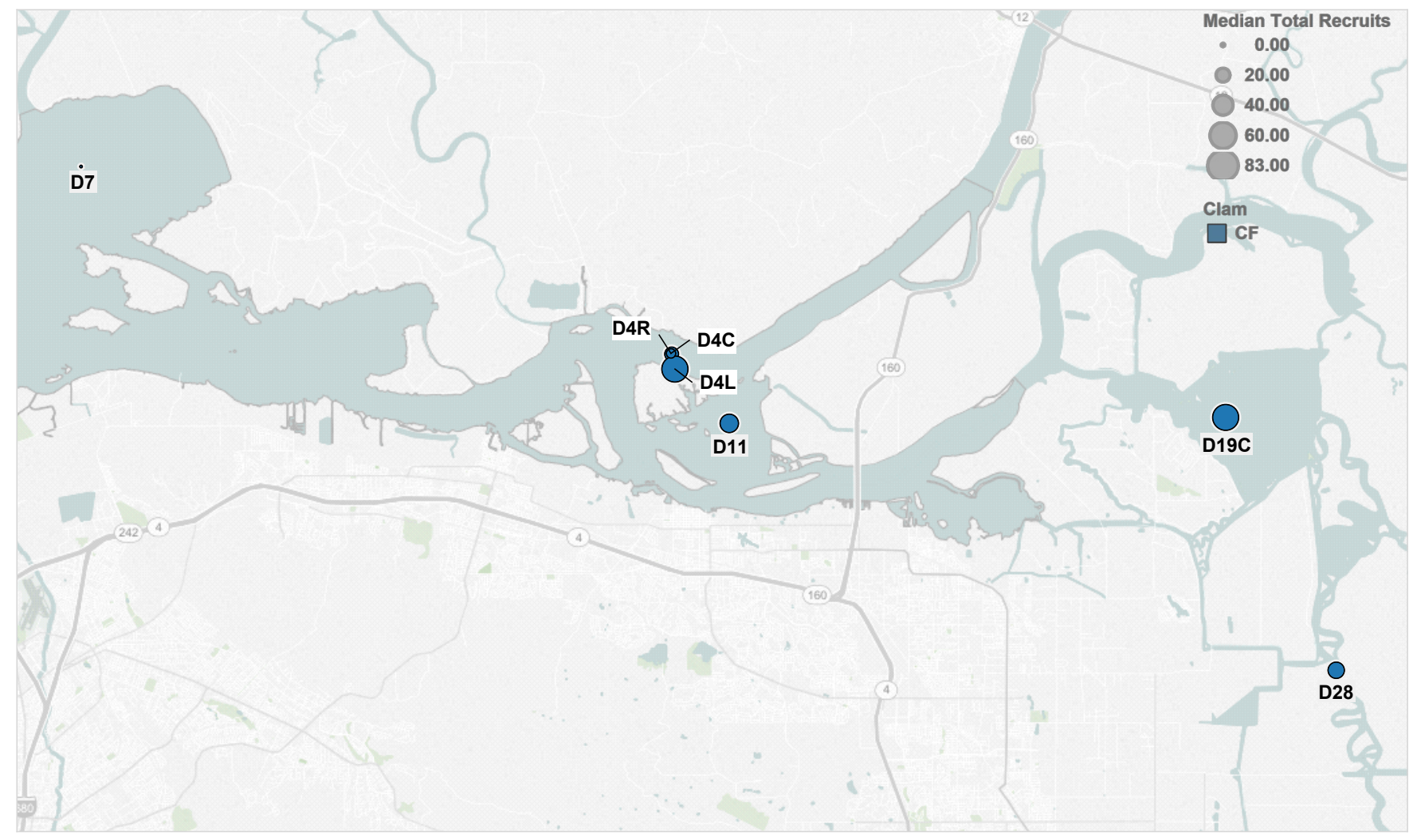

Figure 6. Map showing median recruitment of Corbicula fluminea (CF) in number of recruits per 0.05 meters squared $\left(\# / 0.05 \mathrm{~m}^{2}\right)$ before the arrival of Potamocorbula amurensis to San Francisco Bay and the Sacramento-San Joaquin Delta in 1987. CF= Corbicula. 


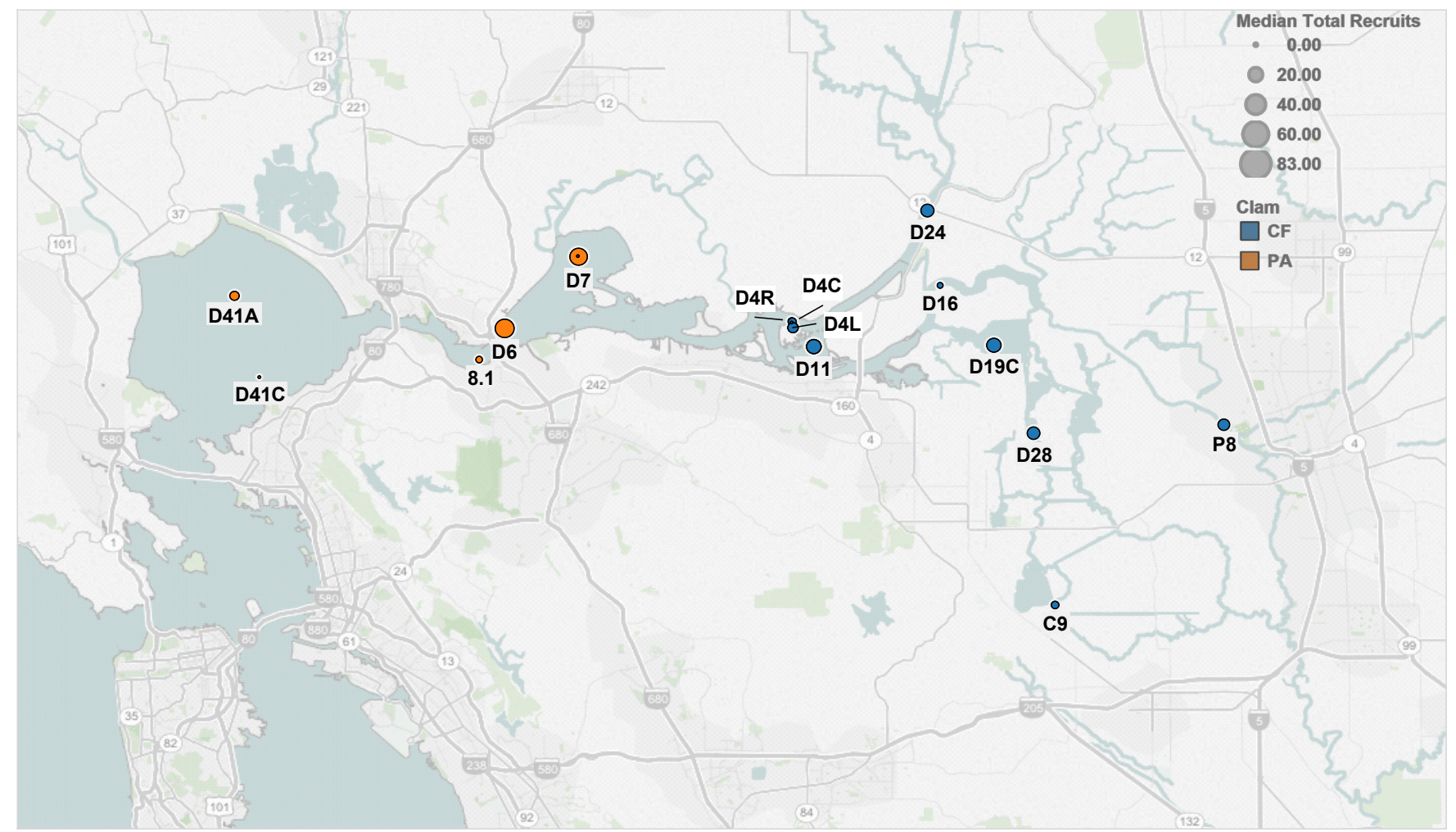

Figure 7. Map showing median recruitment of Corbicula fluminea (CF) and Potamocorbula amurensis (PA) in number of recruits per 0.05 meters squared $\left(\# / 0.05 \mathrm{~m}^{2}\right)$ after the arrival of Potamocorbula amurensis to San Francisco Bay and the Sacramento-San Joaquin Delta in 1987. CF= Corbicula. PA= Potamocorbula. 


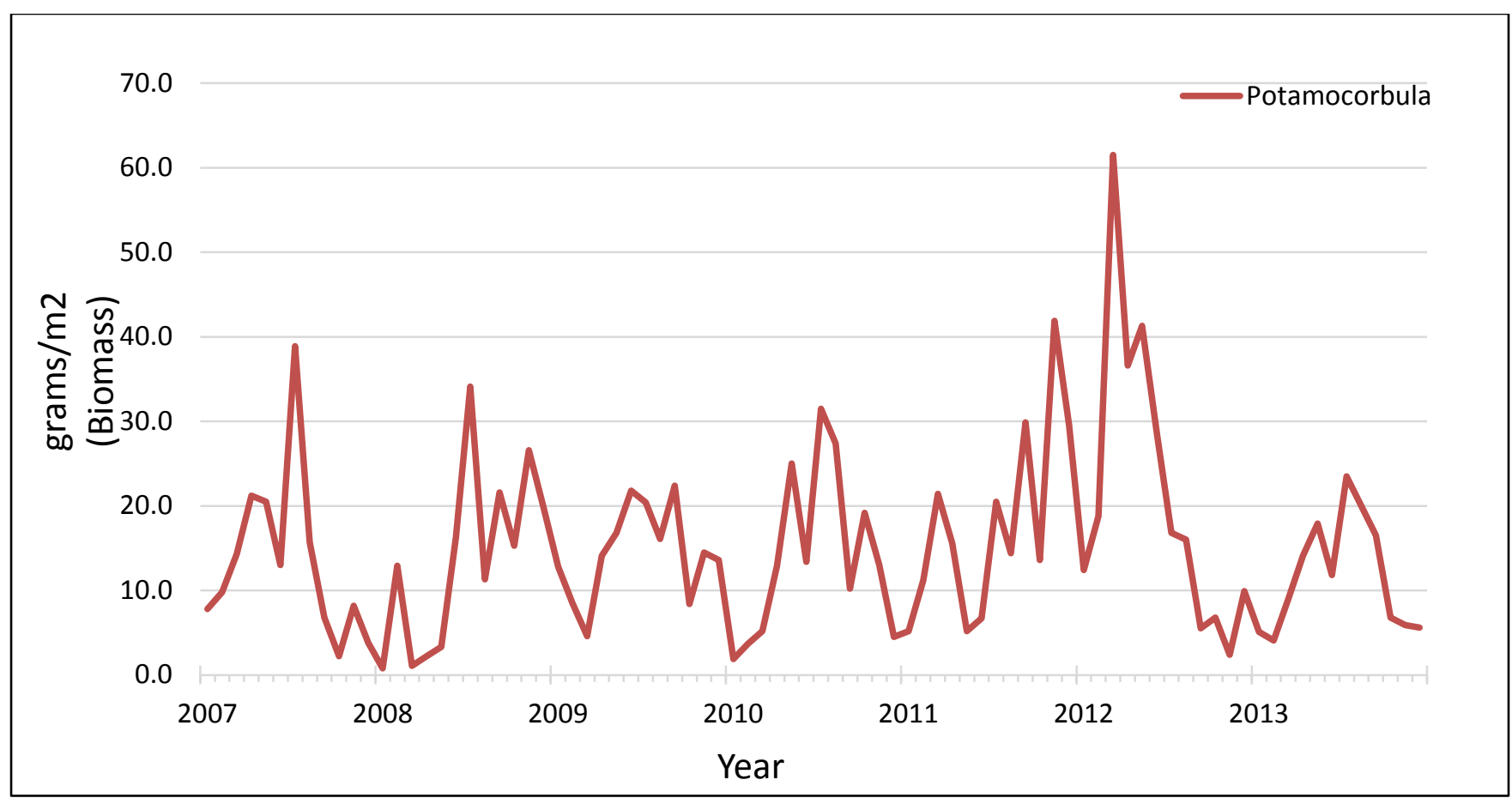

Figure 8. Graph showing Potamocorbula amurensis biomass at station D6 from 2007-2013. For station locations refer to table 1.

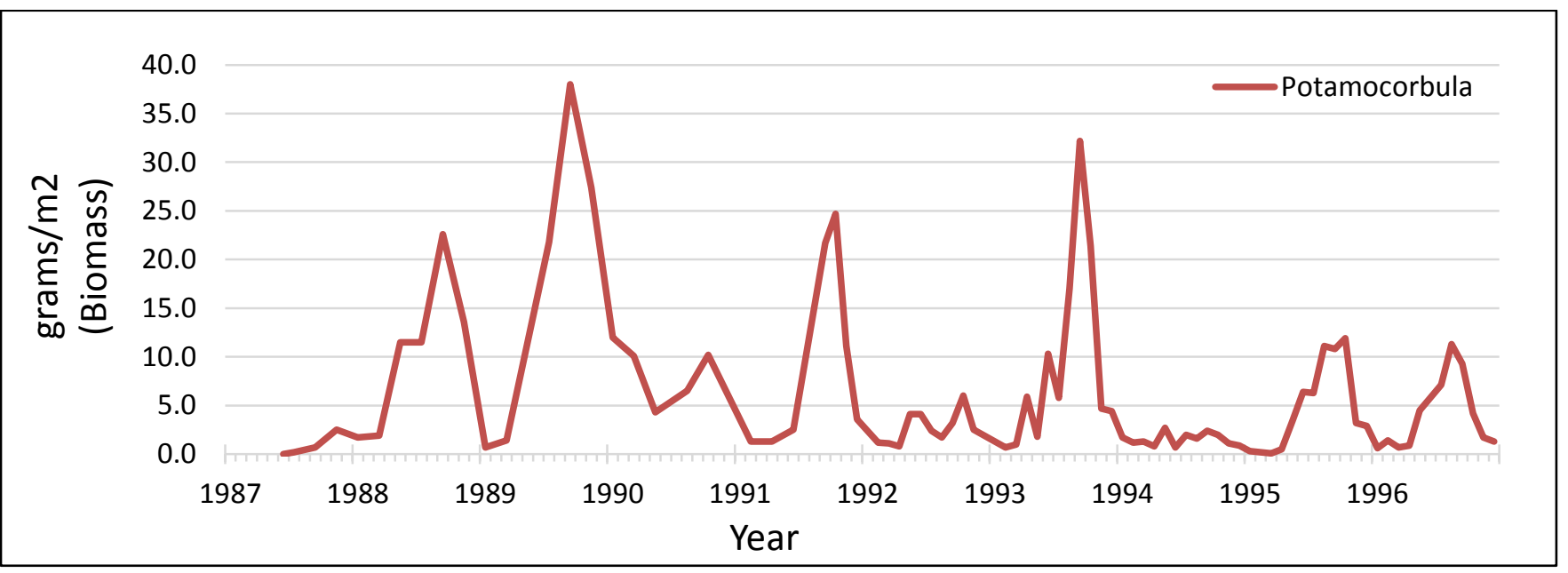

Figure 9. Graph showing Potamocorbula amurensis biomass at station D41A from 1987-1996. For station locations refer to table 1. 


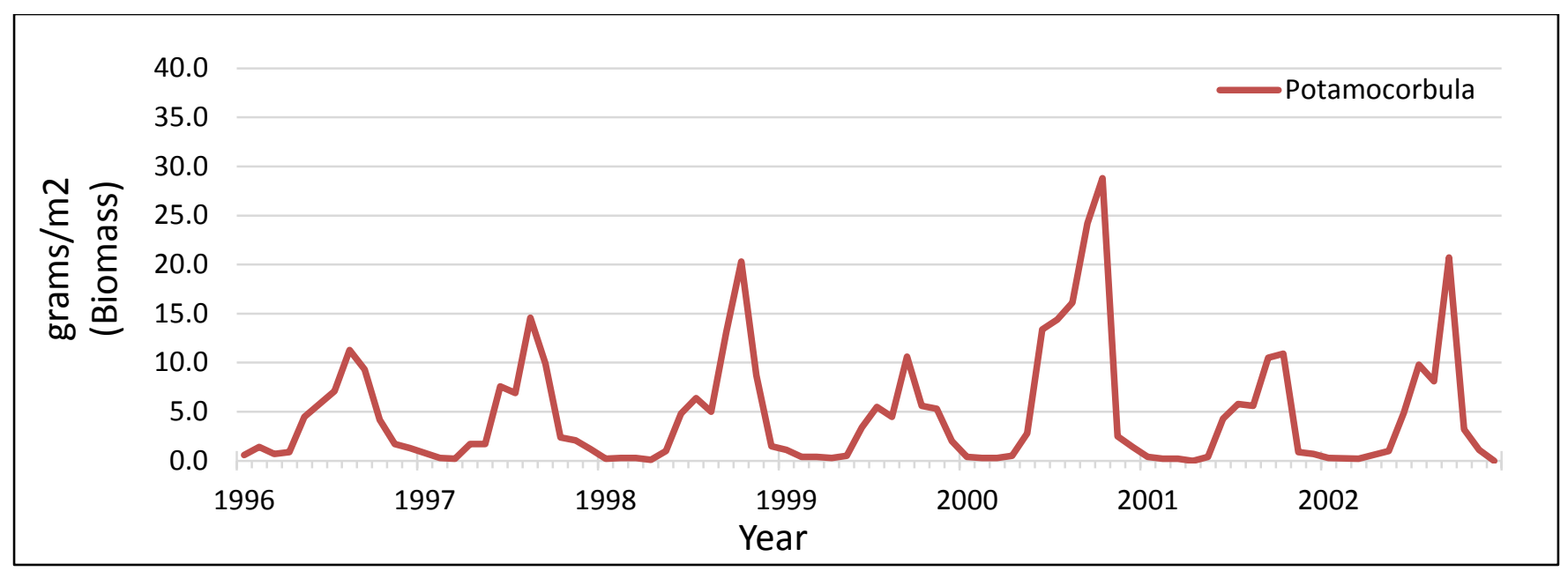

Figure 10. Graph showing Potamocorbula amurensis biomass at station D41A from 1996-2003. For station locations refer to table 1.

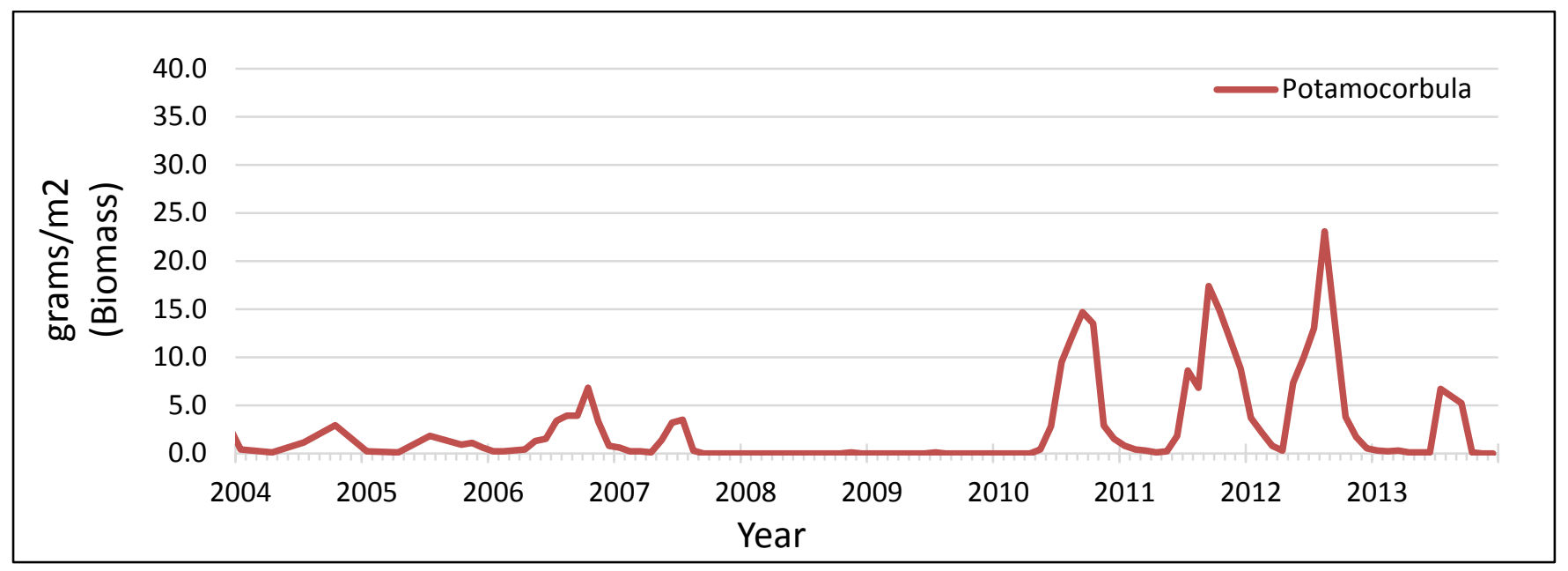

Figure 11. Graph showing Potamocorbula amurensis biomass at station D41A from 2003-2013. For station locations refer to table 1. 


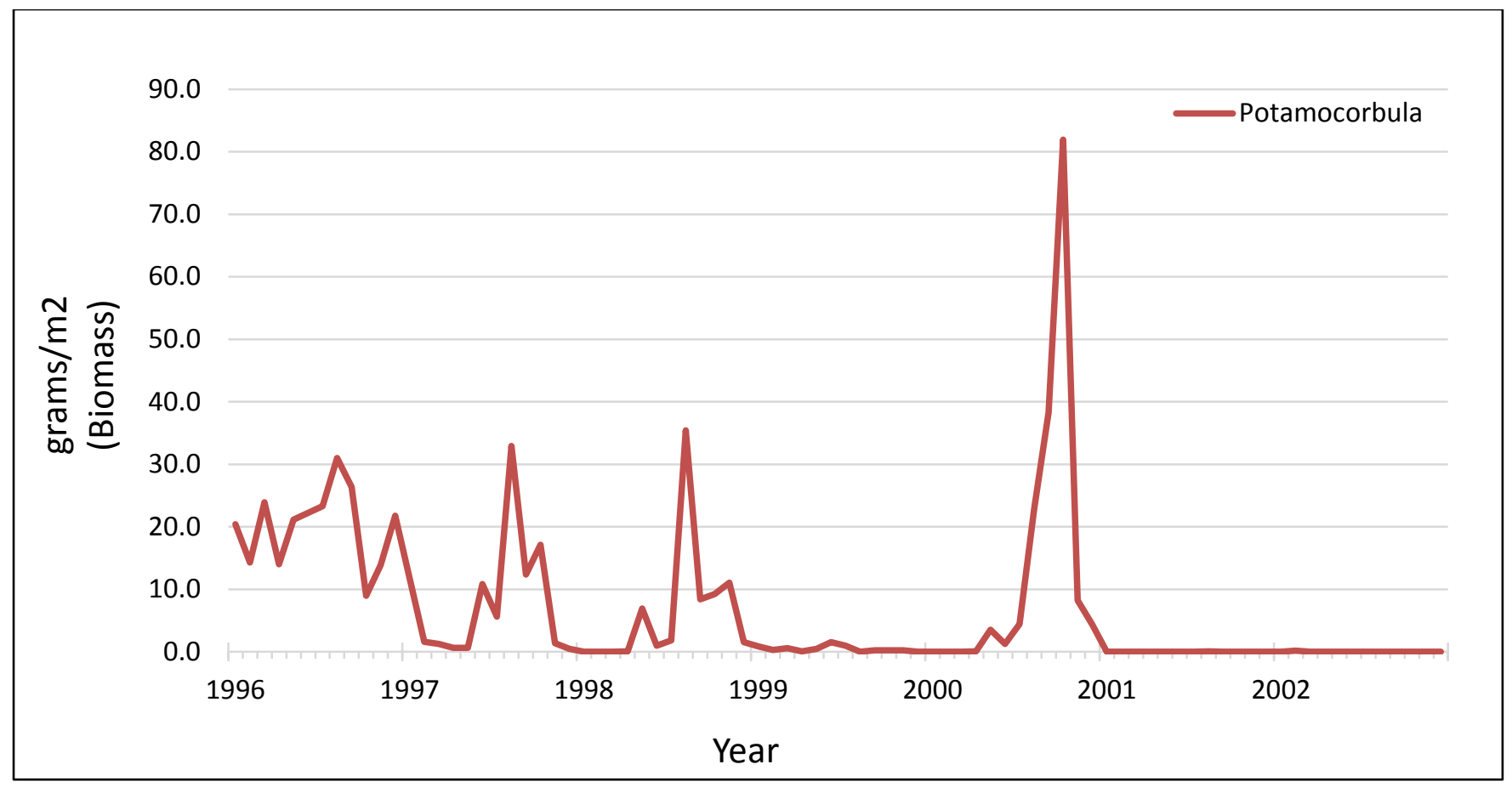

Figure 12. Graph showing Potamocorbula amurensis biomass at station D41C from 1996-2002. For station locations refer to table 1.

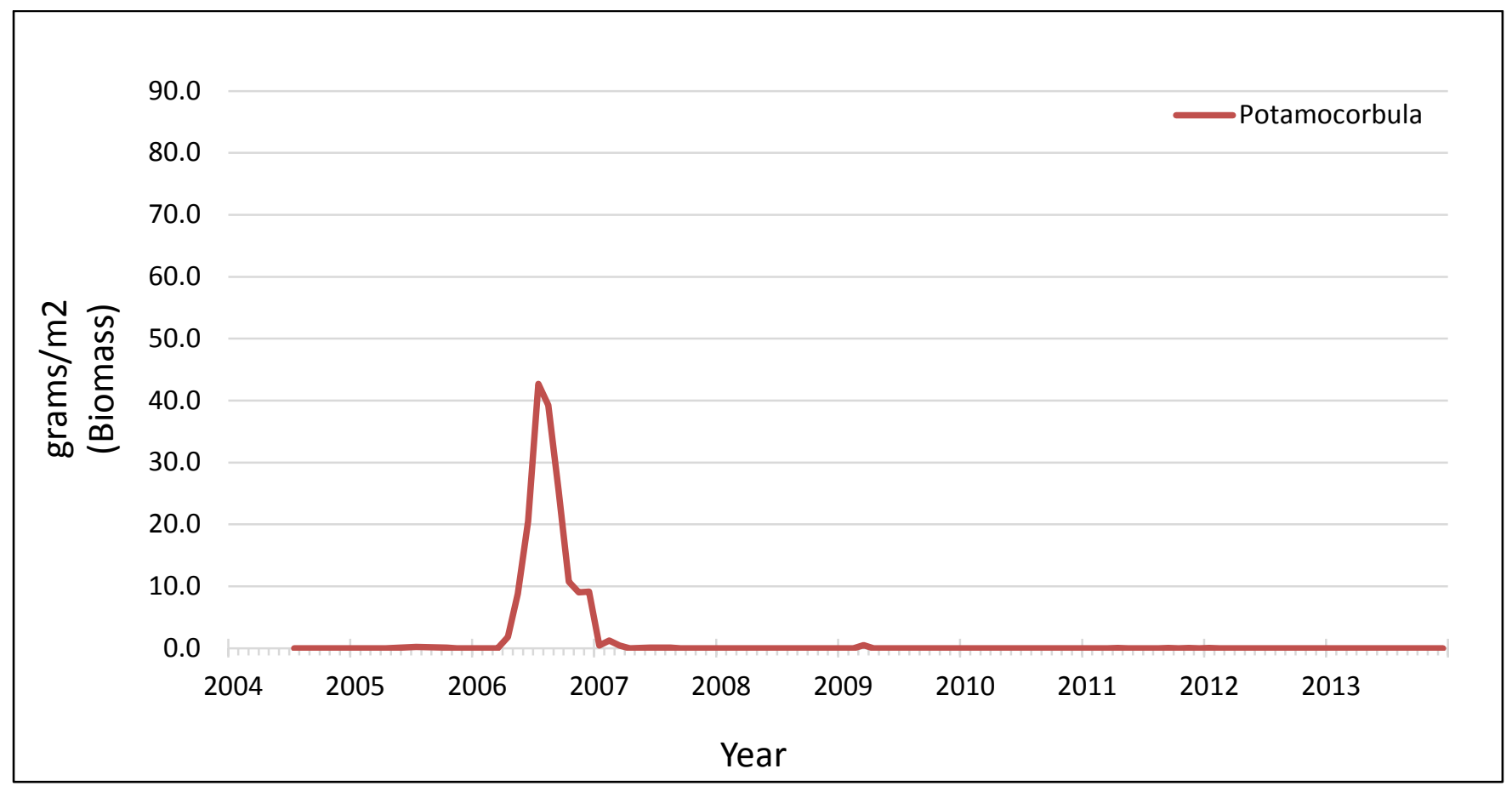

Figure 13. Graph showing biomass at station D41C from 2004-2013. For station locations refer to table 1. 


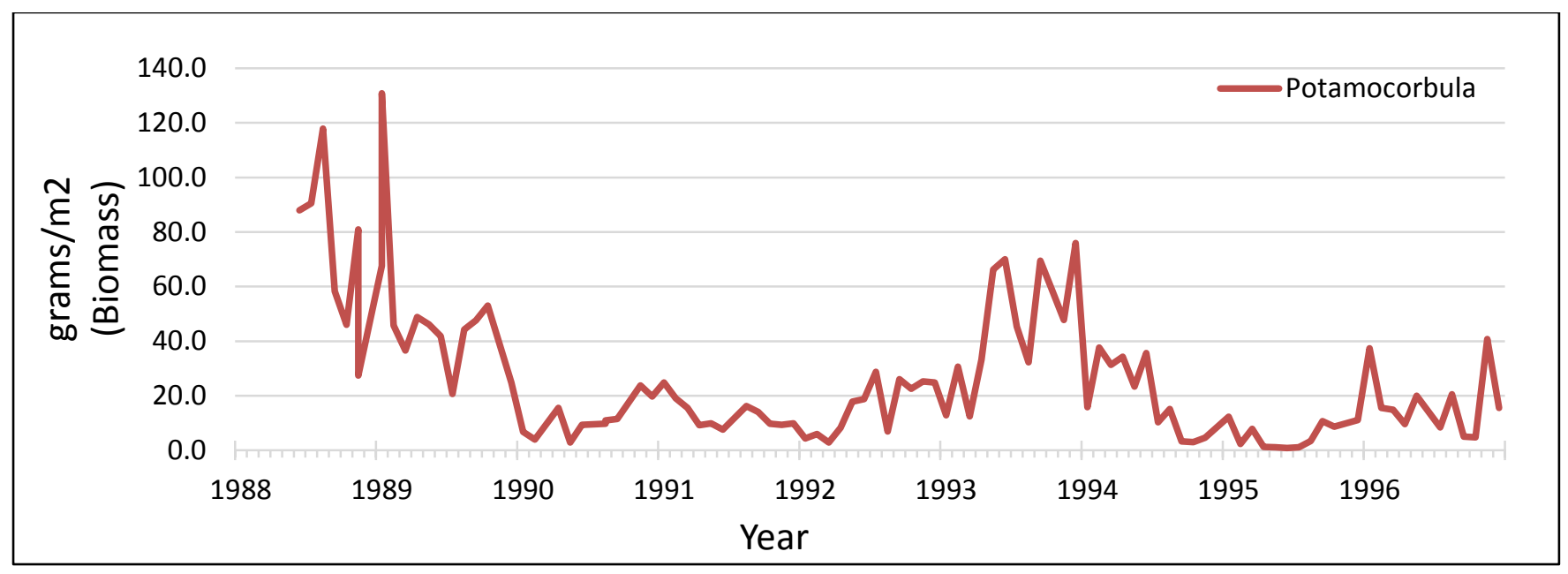

Figure 14. Graph showing biomass at station 8.1 from 1988-1996. For station locations refer to table 1.

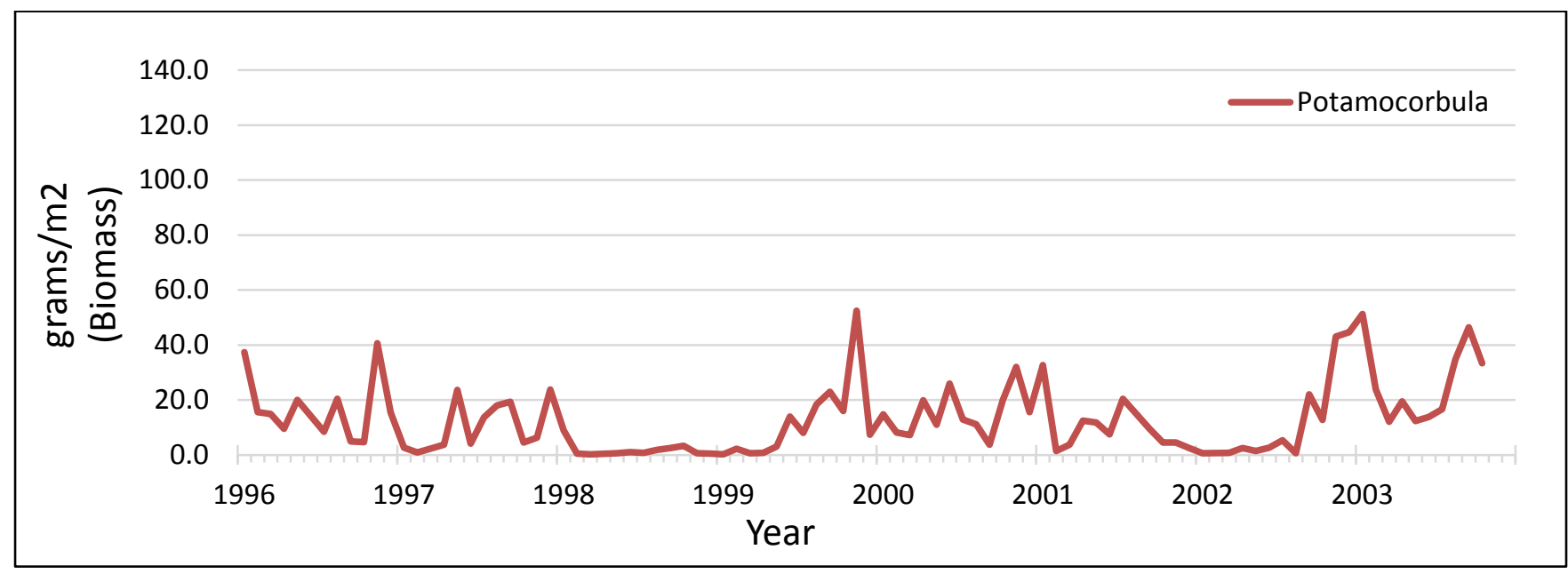

Figure 15. Graph showing biomass at station 8.1 from 1996-2003. For station locations refer to table 1.

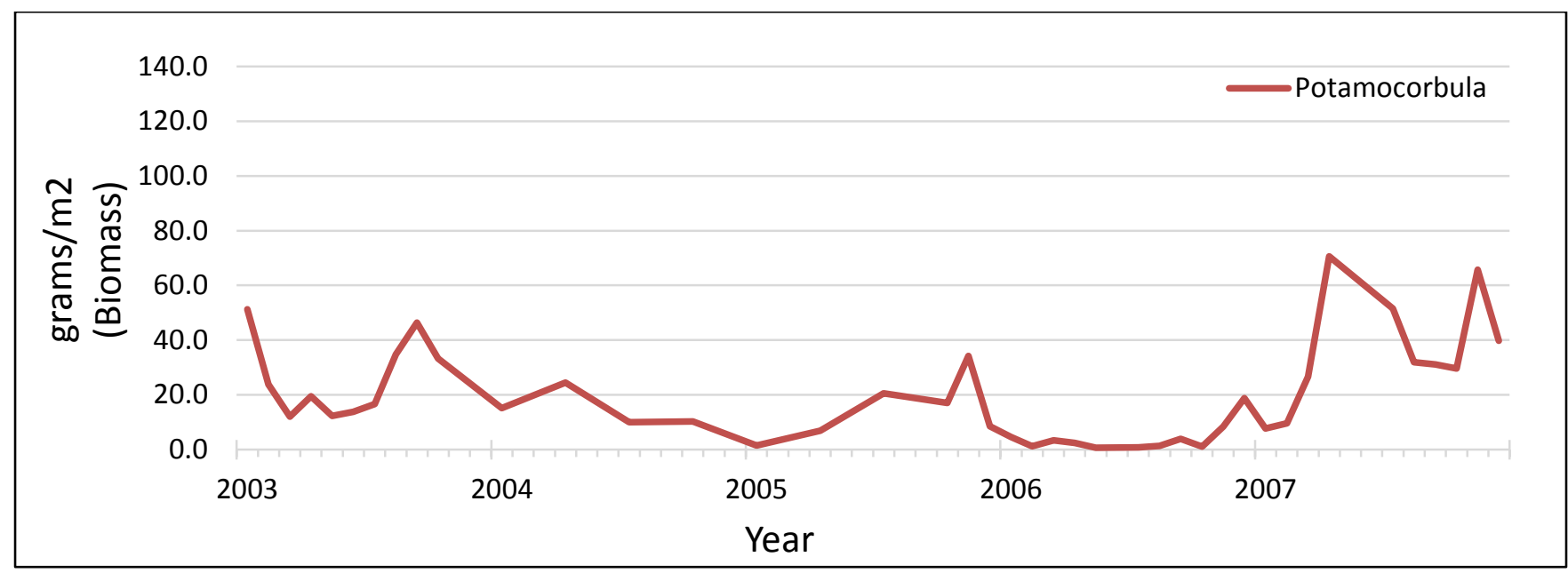

Figure 16. Graph showing biomass at station 8.1 from 2003-2007. For station locations refer to table 1. 


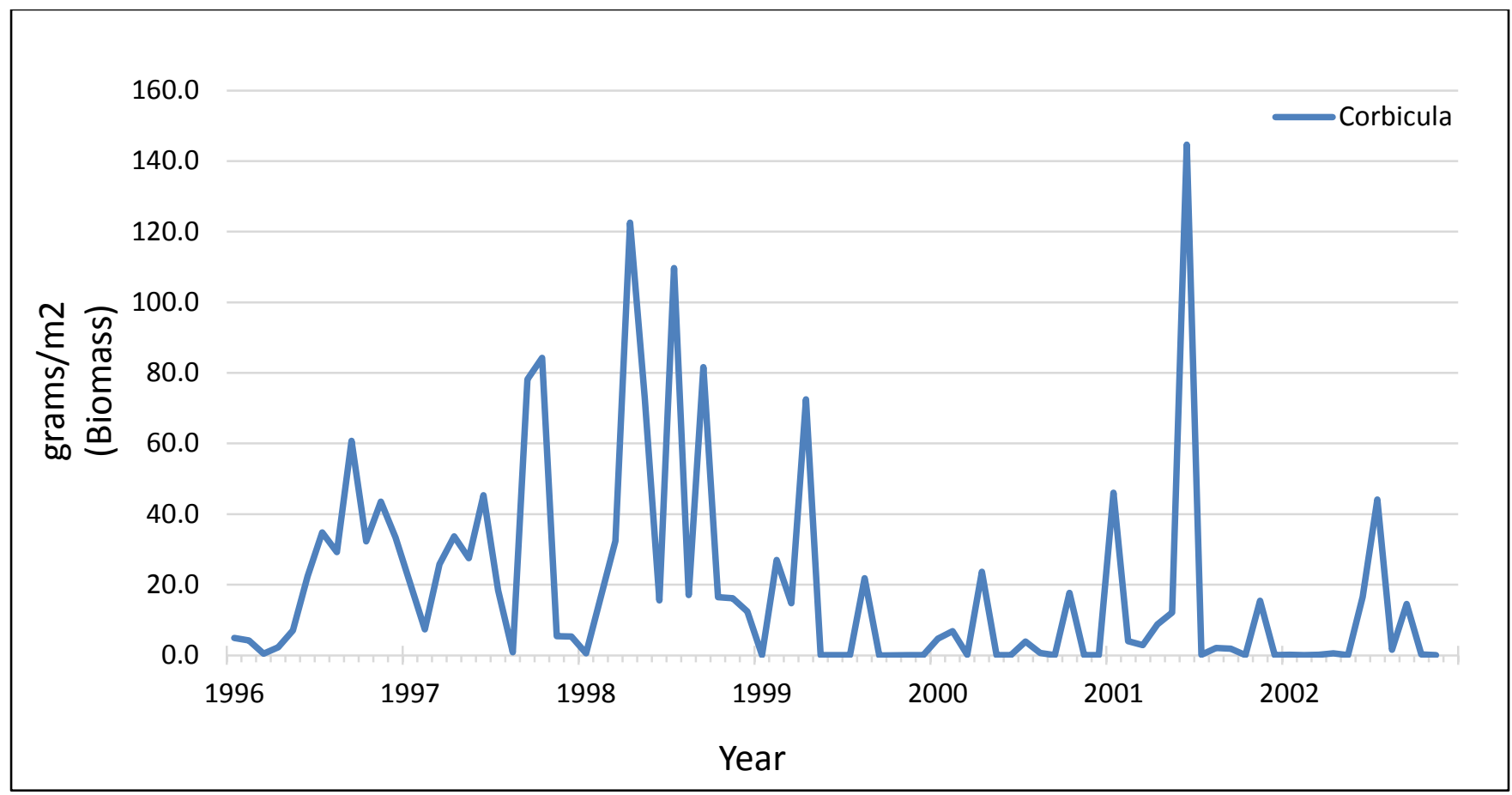

Figure 17. Graph showing Corbicula fluminea biomass at station C9 from 1996-2002. For station locations refer to table 1.

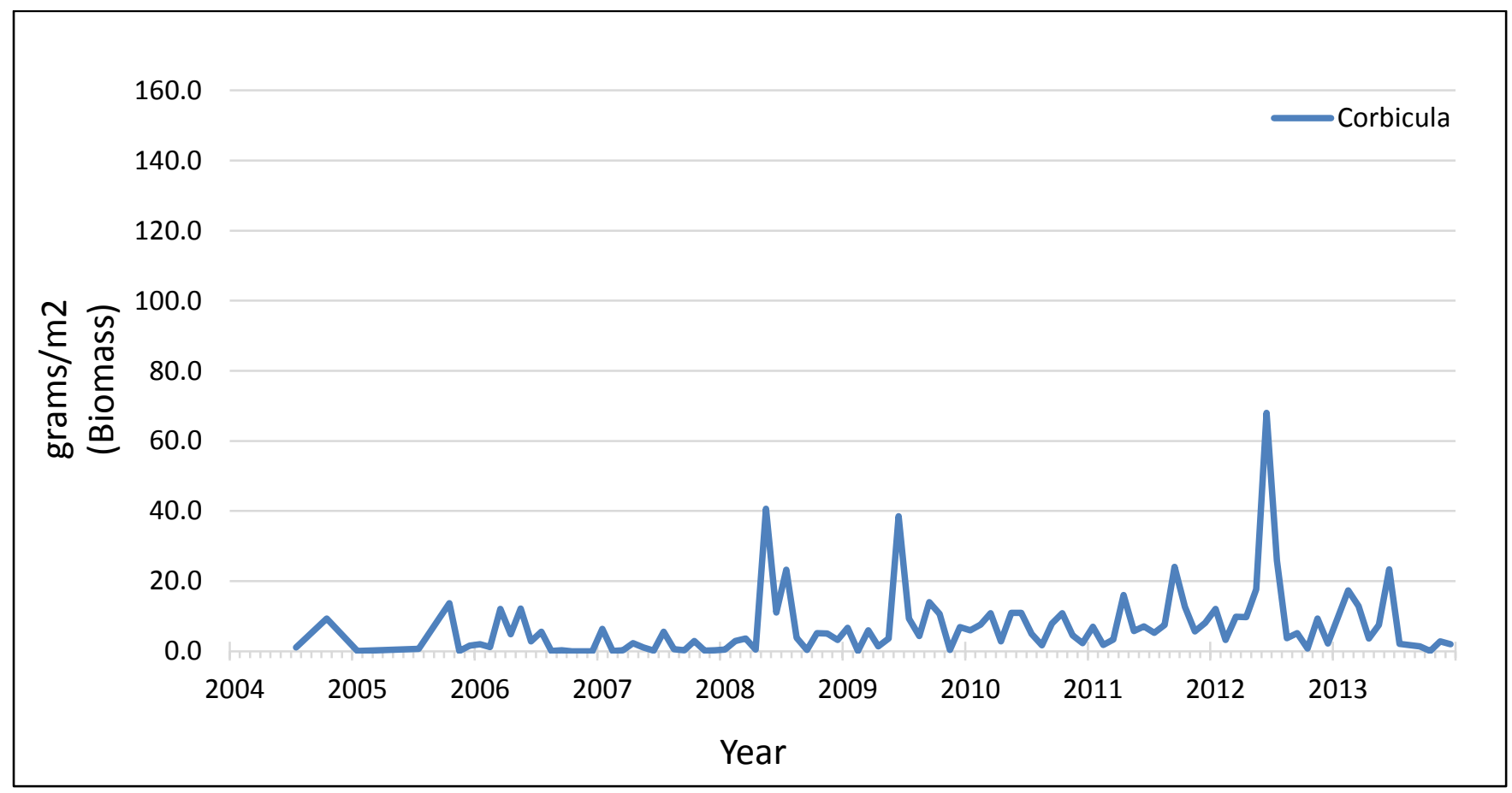

Figure 18. Graph showing biomass at station C9 from 2004-2013. For station locations refer to table 1. 


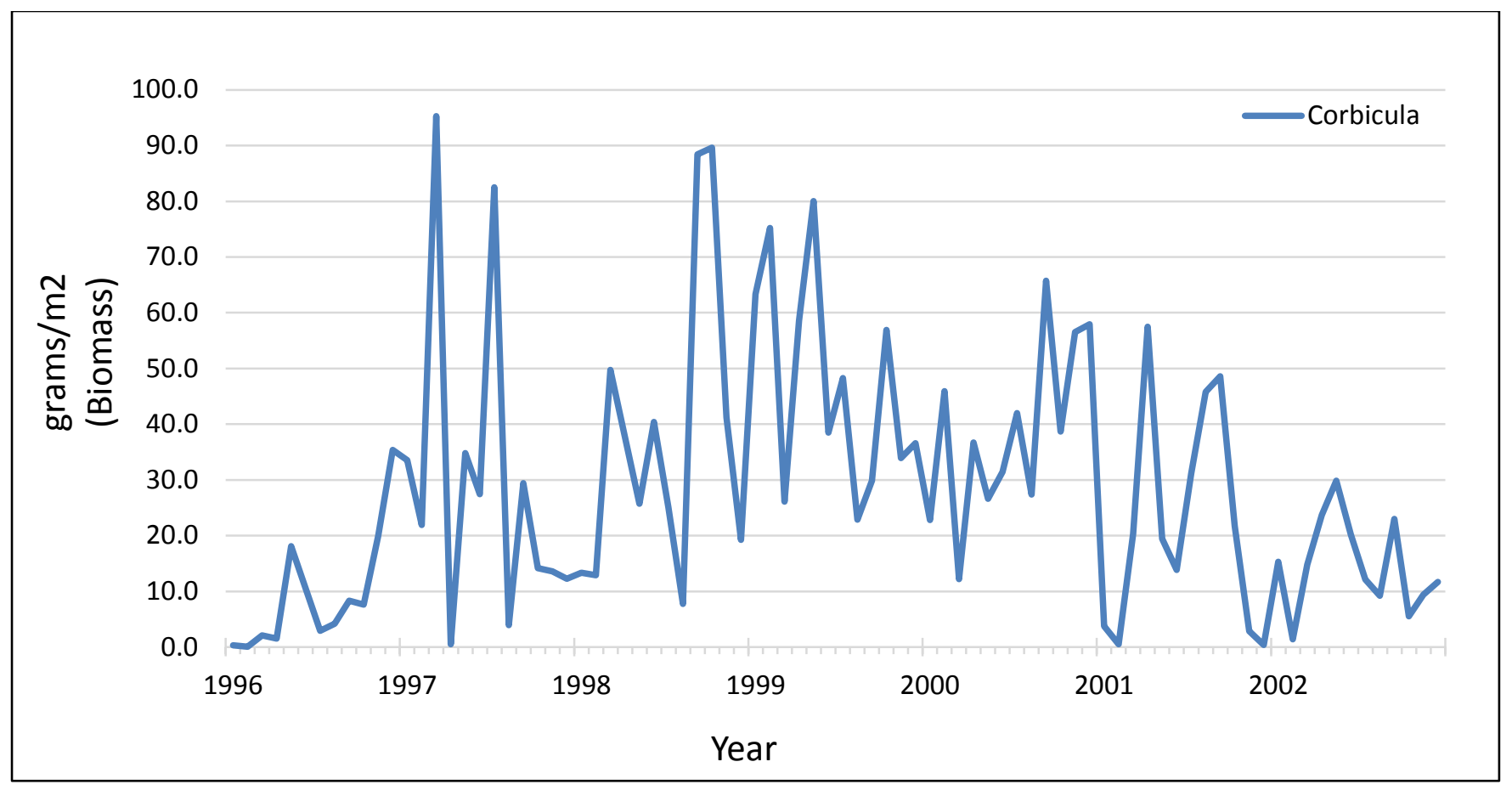

Figure 19. Graph showing biomass at station D16 from 1996-2002. For station locations refer to table 1.

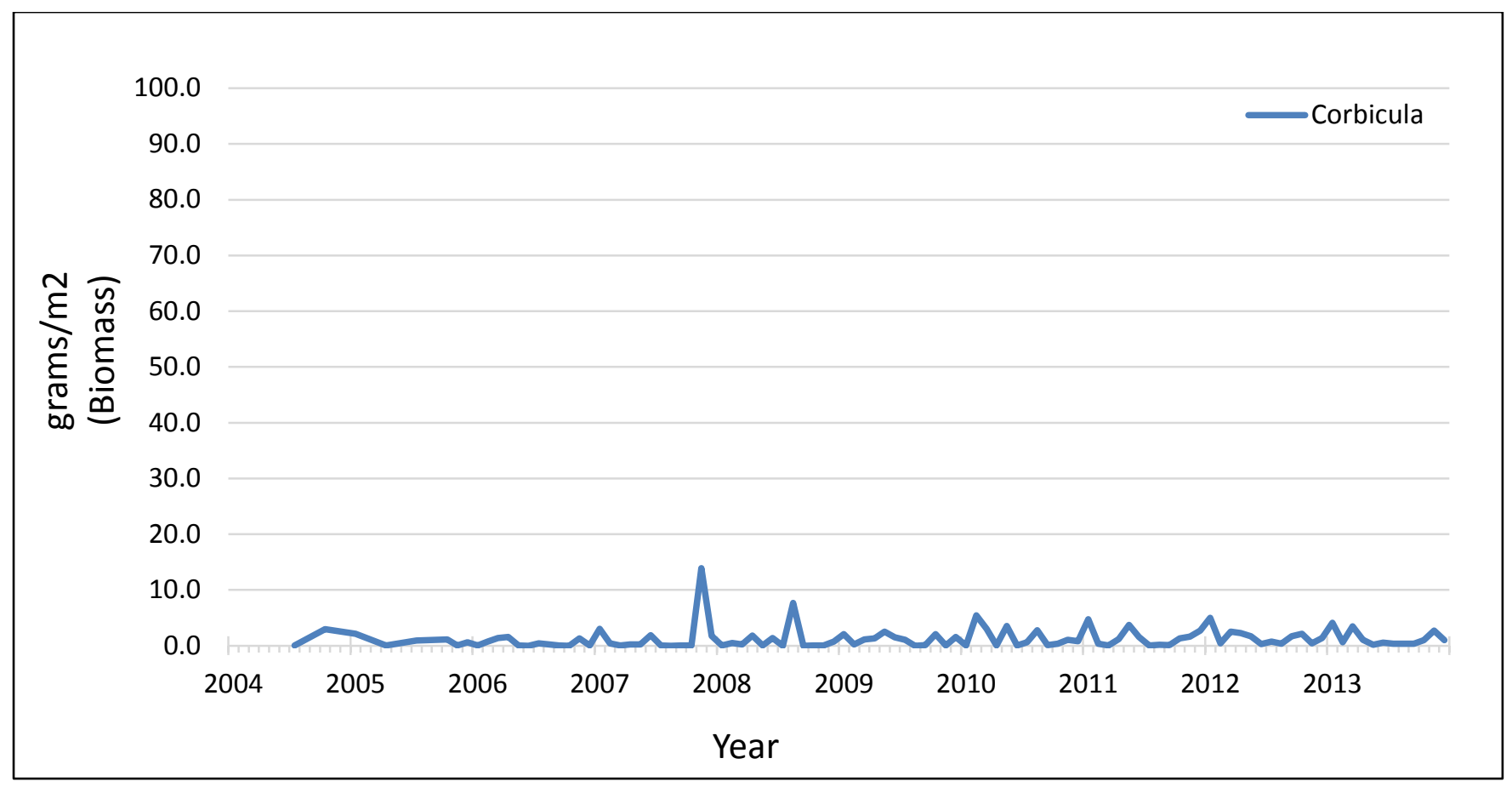

Figure 20. Graph showing biomass at station D16 from 2004-2013 For station locations refer to table 1. 


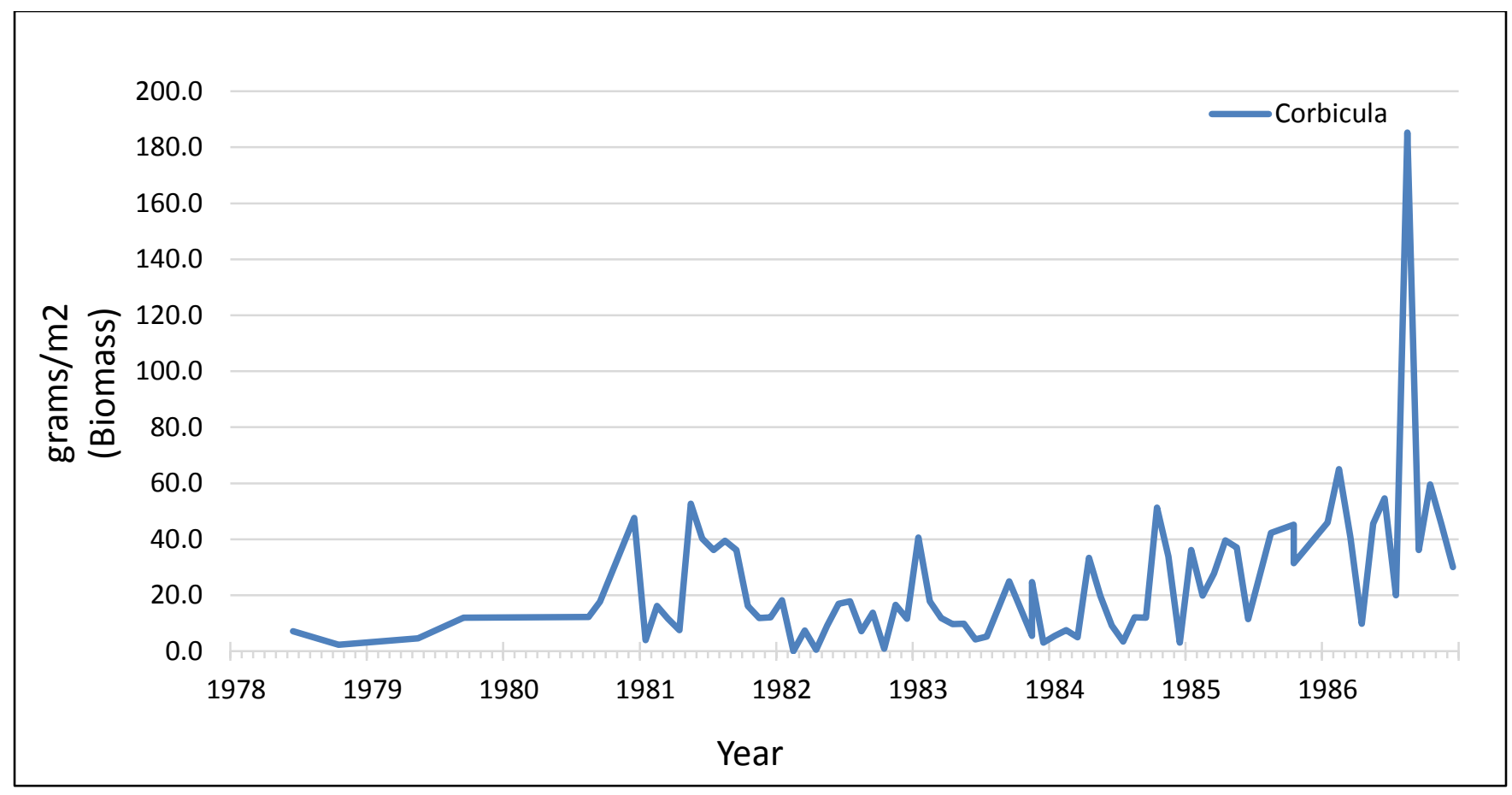

Figure 21. Graph showing biomass at station D19C from 1978-1986. For station locations refer to table 1.

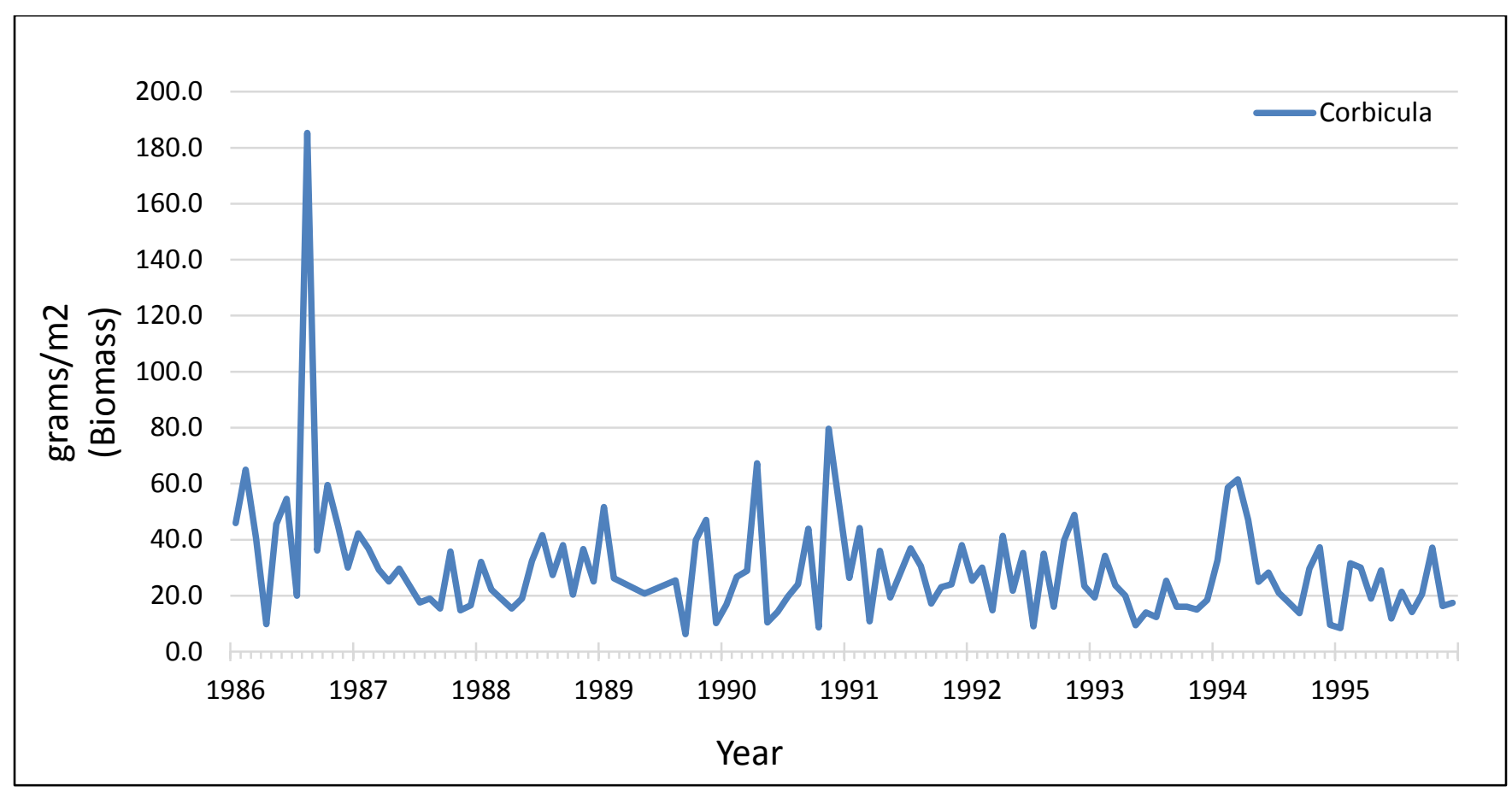

Figure 22. Graph showing biomass at station D19C from 1986-1995. For station locations refer to table 1. 


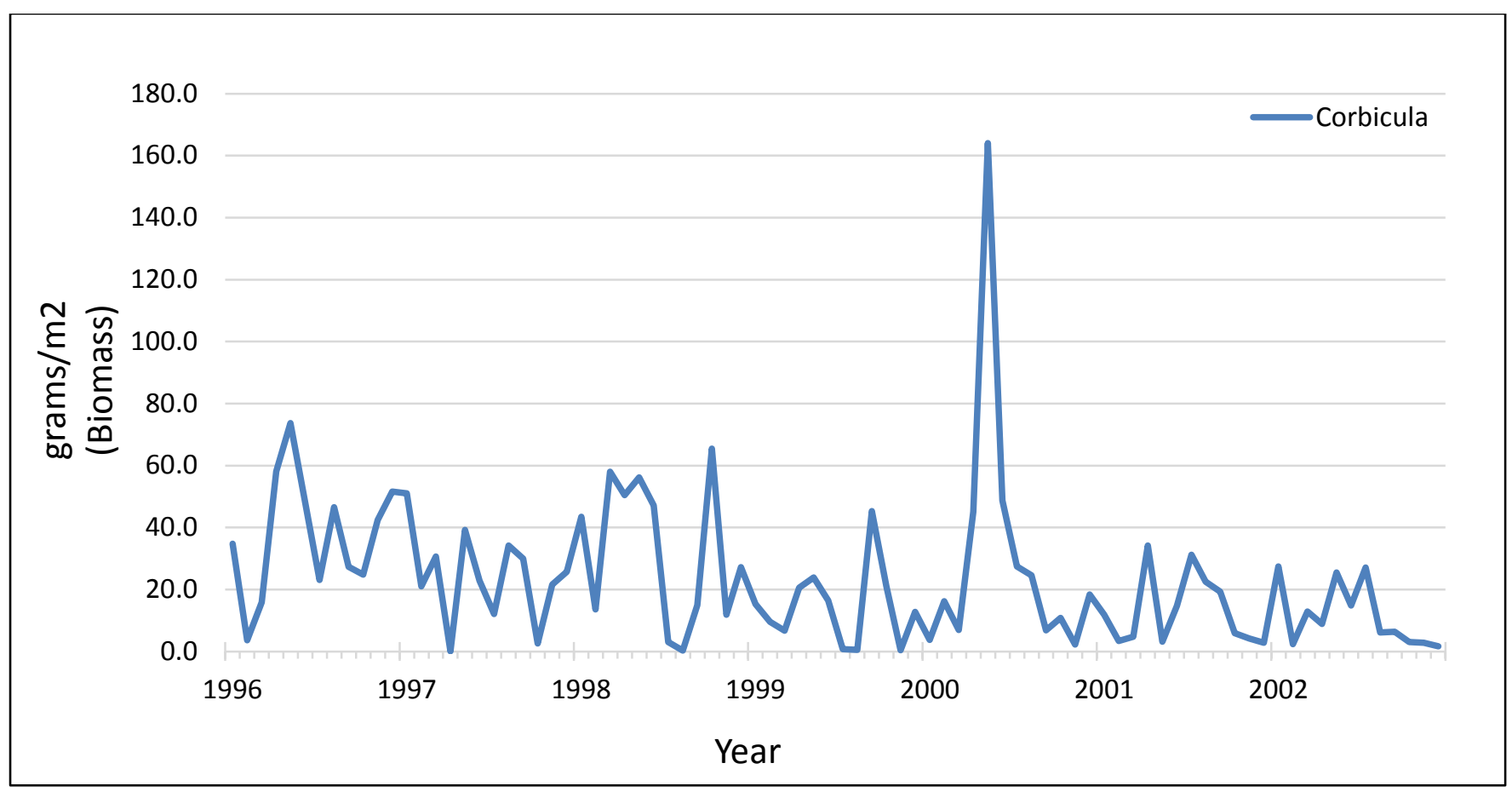

Figure 23. Graph showing biomass at station D24 from 1996-2002. For station locations refer to table 1.

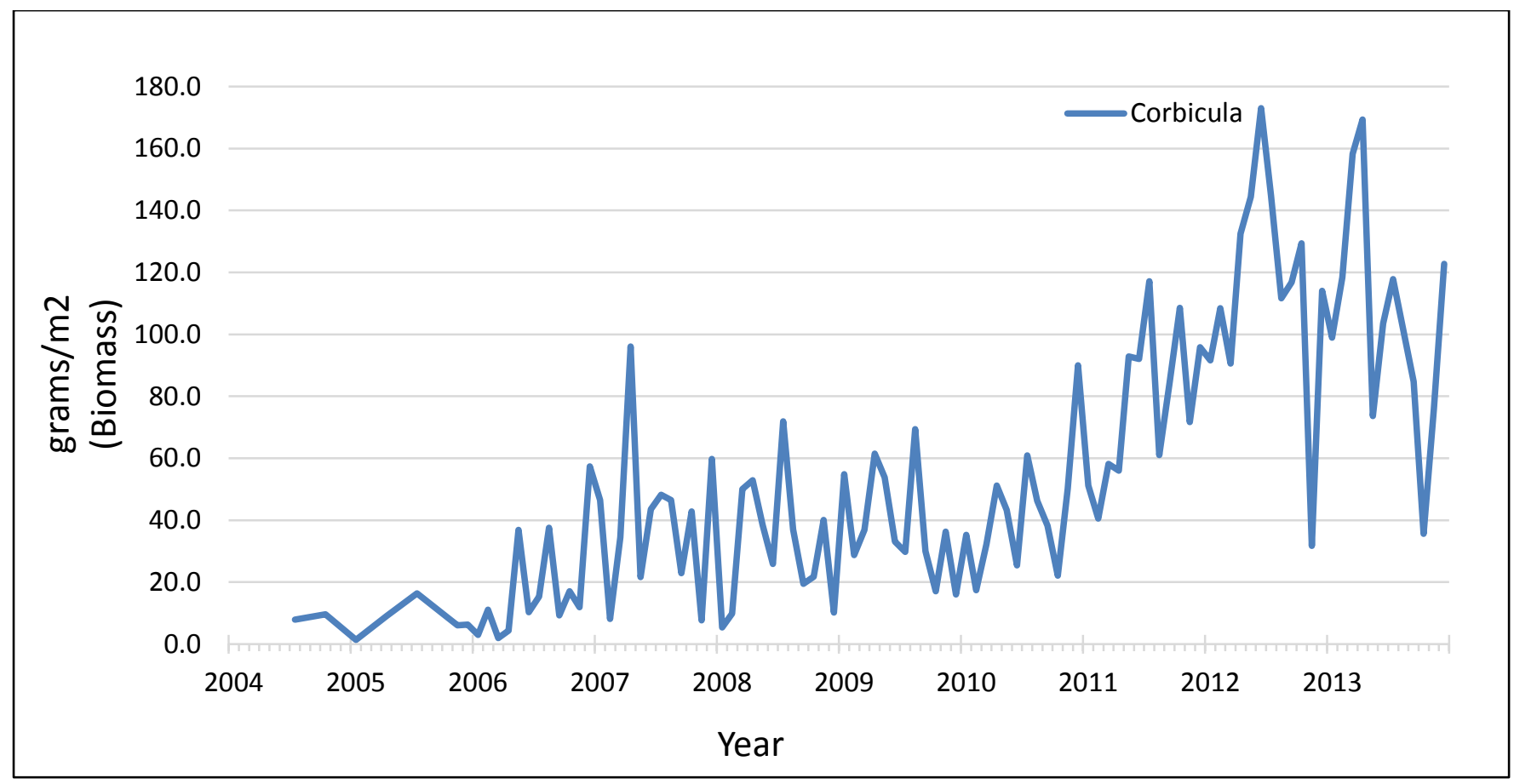

Figure 24. Graph showing biomass at station D24 from 2004-2013. For station locations refer to table 1. 


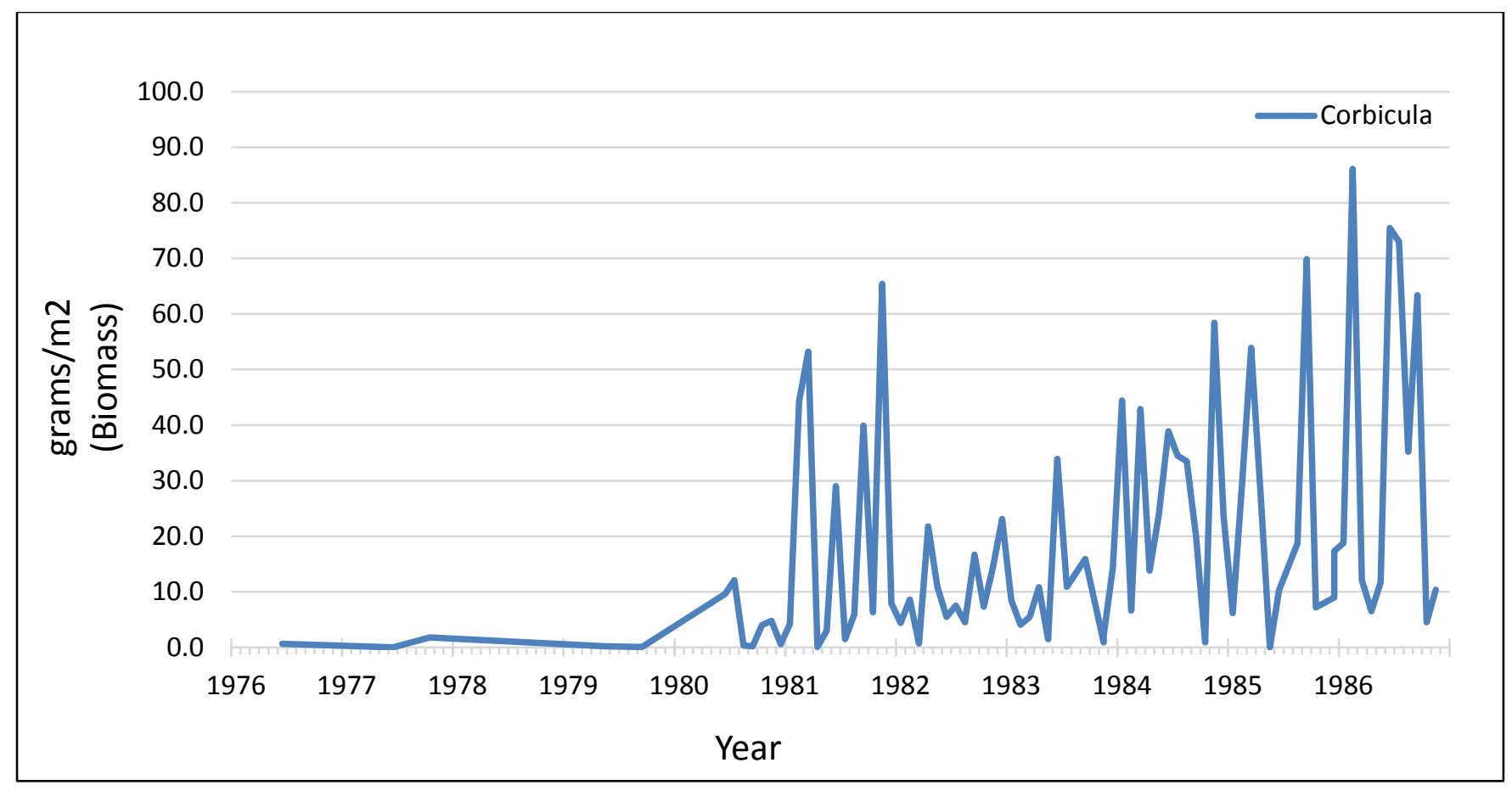

Figure 25. Graph showing biomass at station D28 from 1976-1986. For station locations refer to table 1.

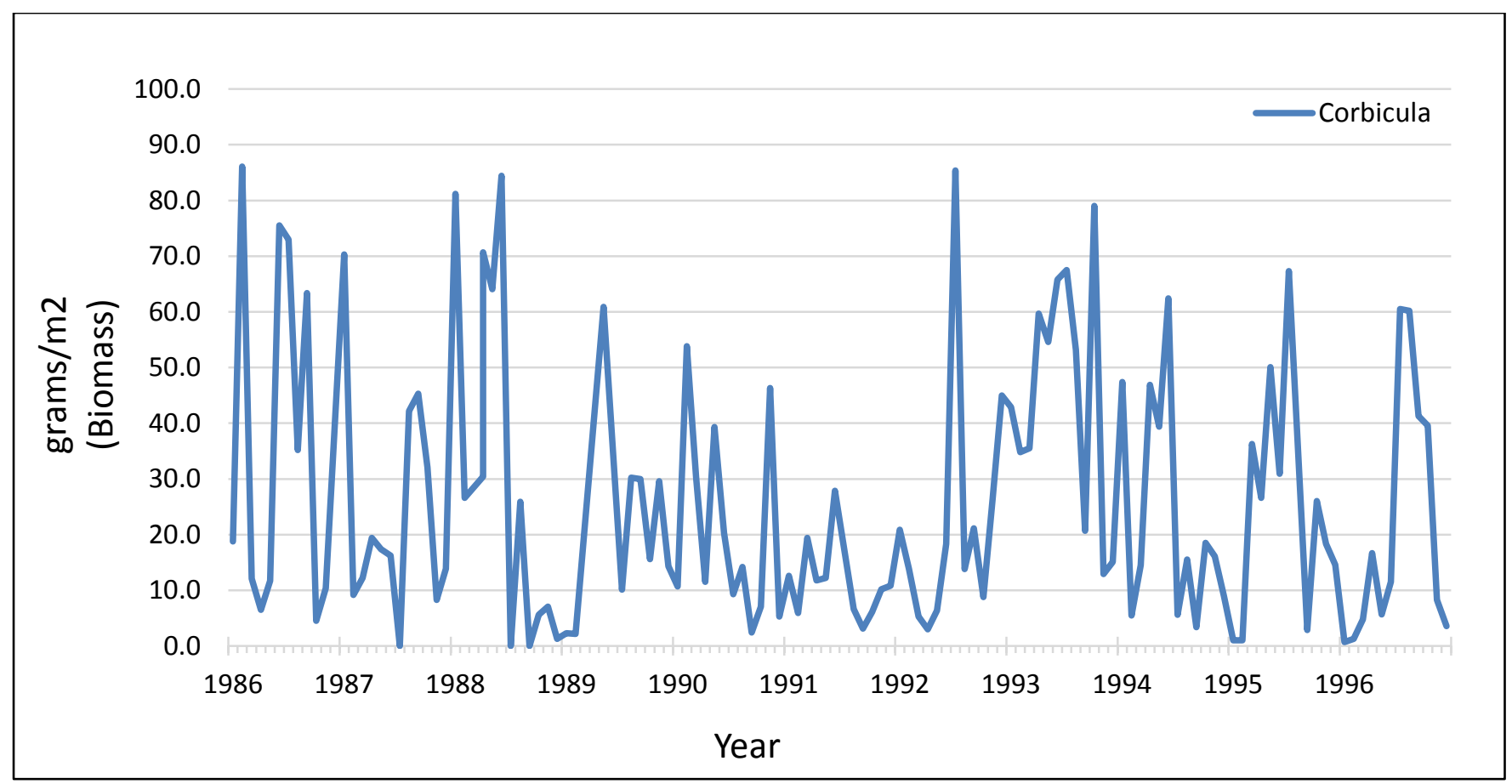

Figure 26. Graph showing biomass at station D28 from 1986-1996. For station locations refer to table 1. 


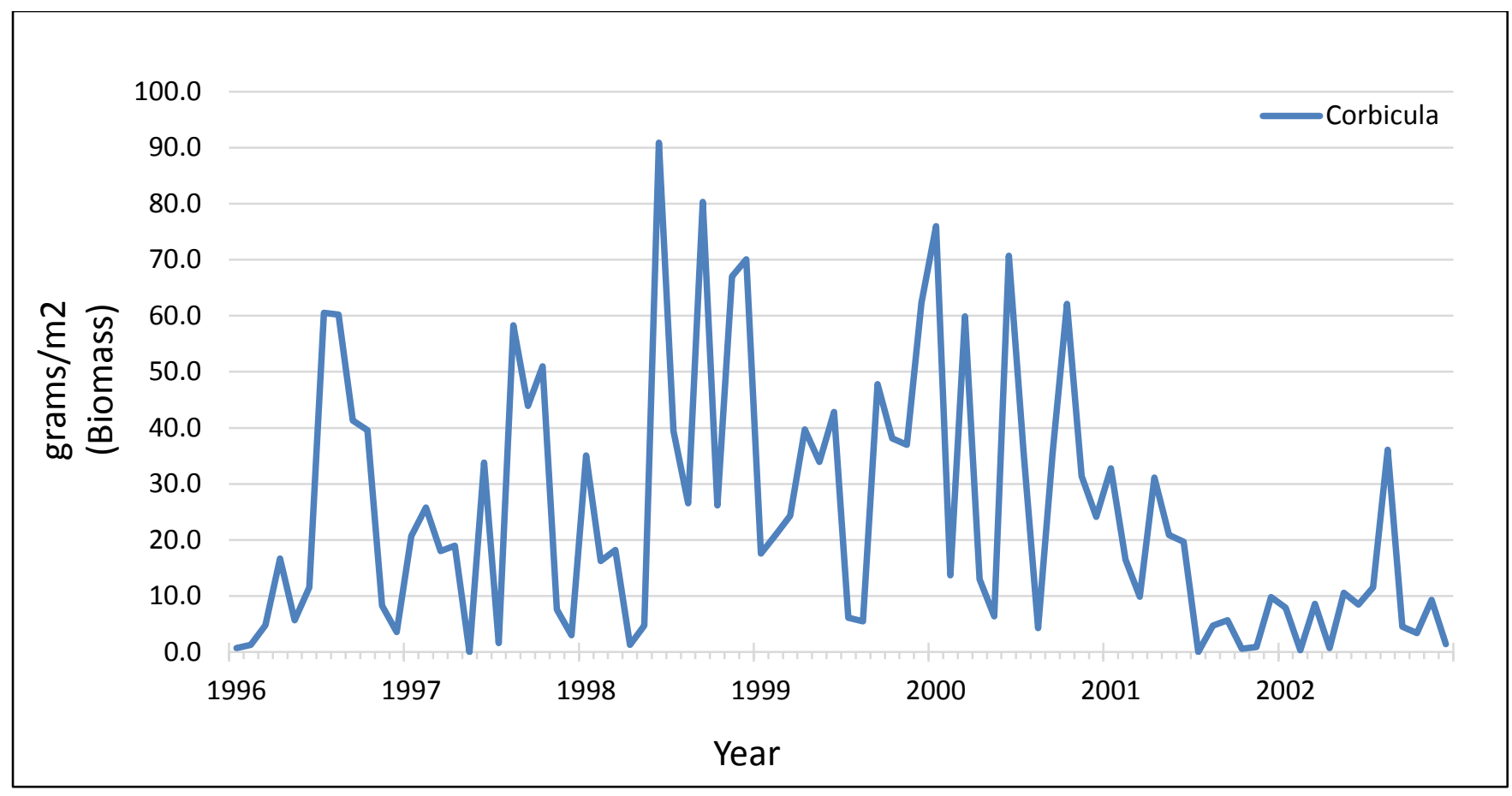

Figure 27. Graph showing biomass at station D28 from 1996-2002. For station locations refer to table 1.

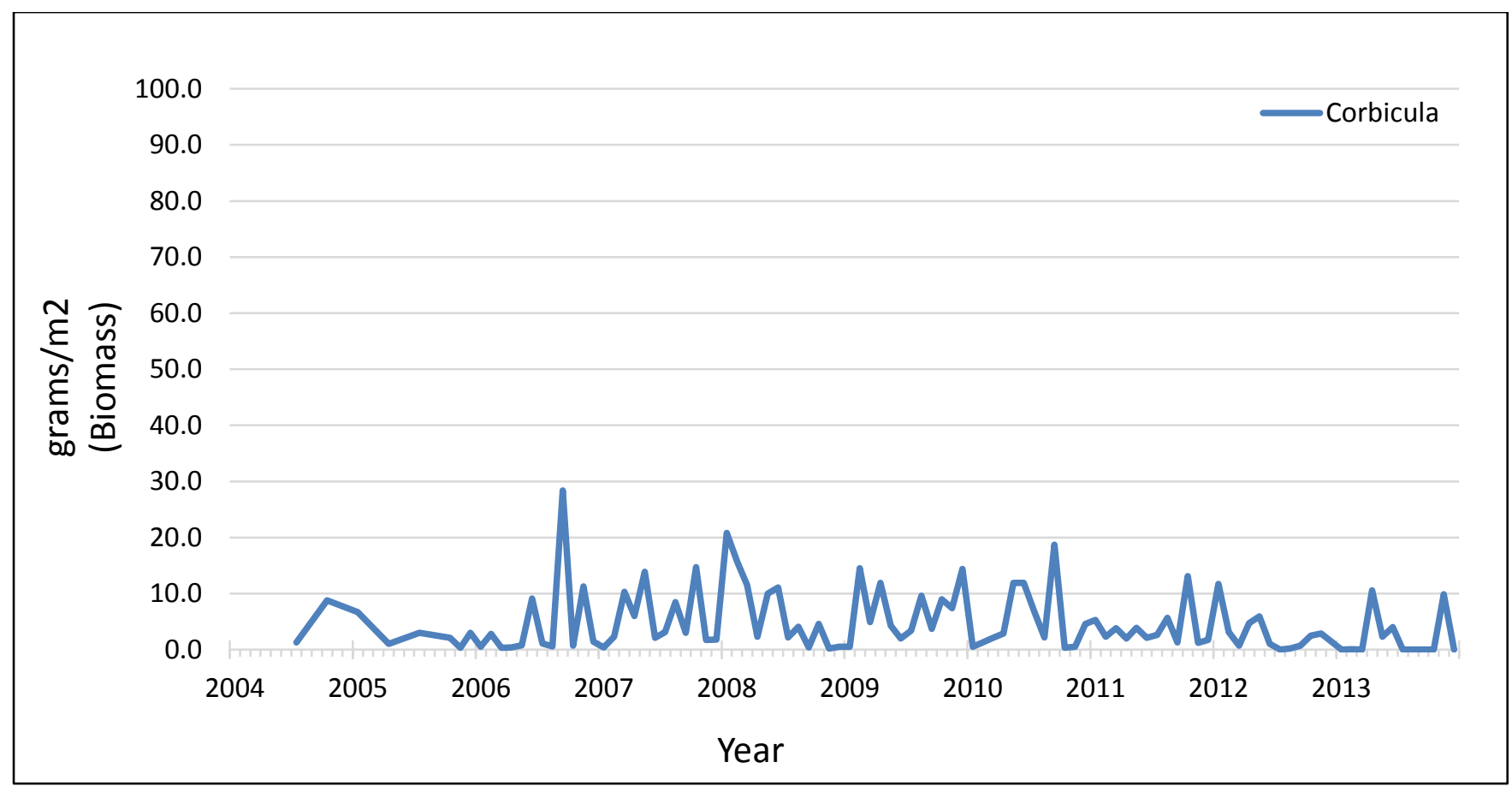

Figure 28. Graph showing biomass at station D28 from 2004-2013. For station locations refer to table 1. 


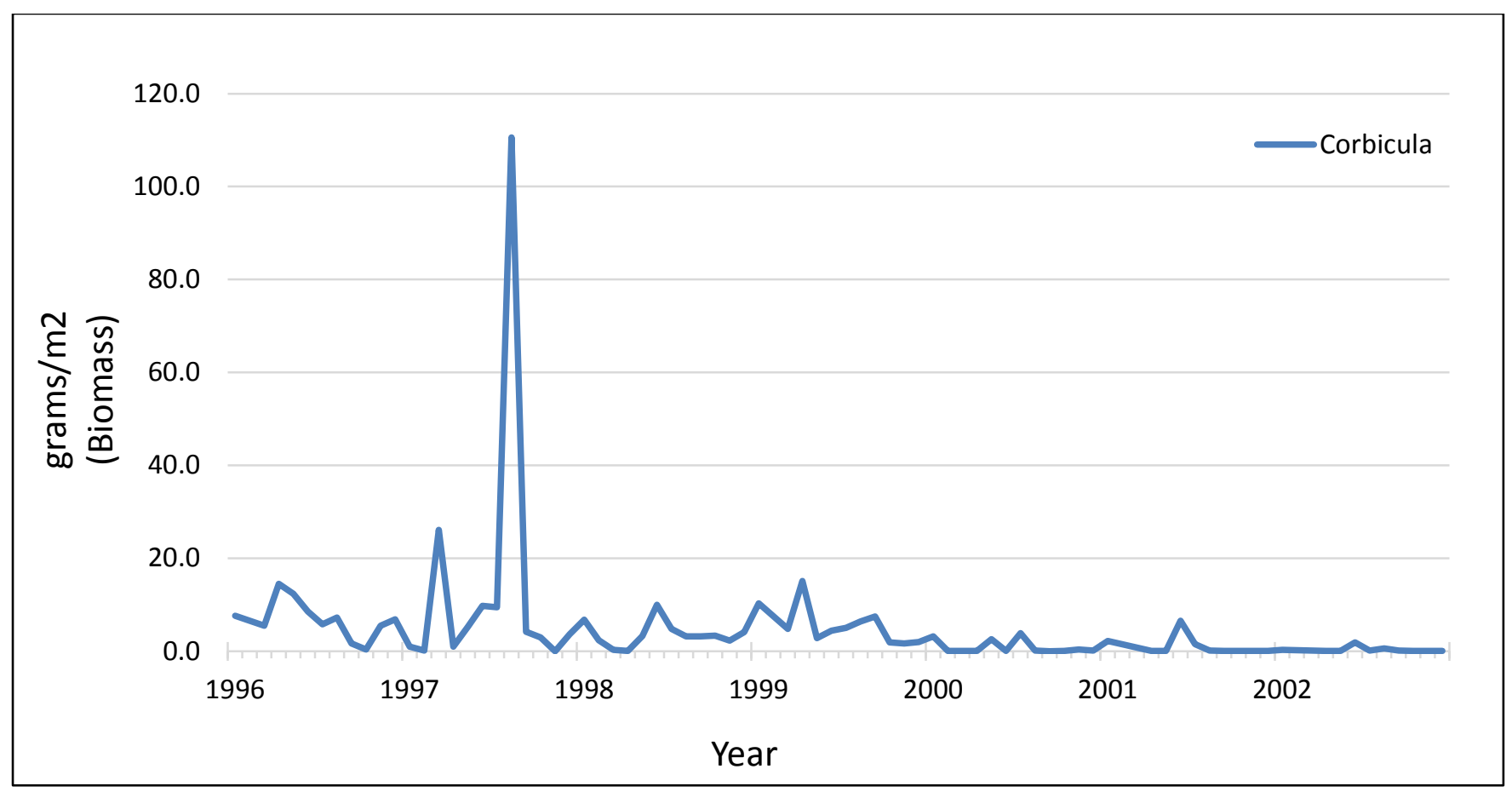

Figure 29. Graph showing biomass at station P8 from 1996-2002. For station locations refer to table 1.

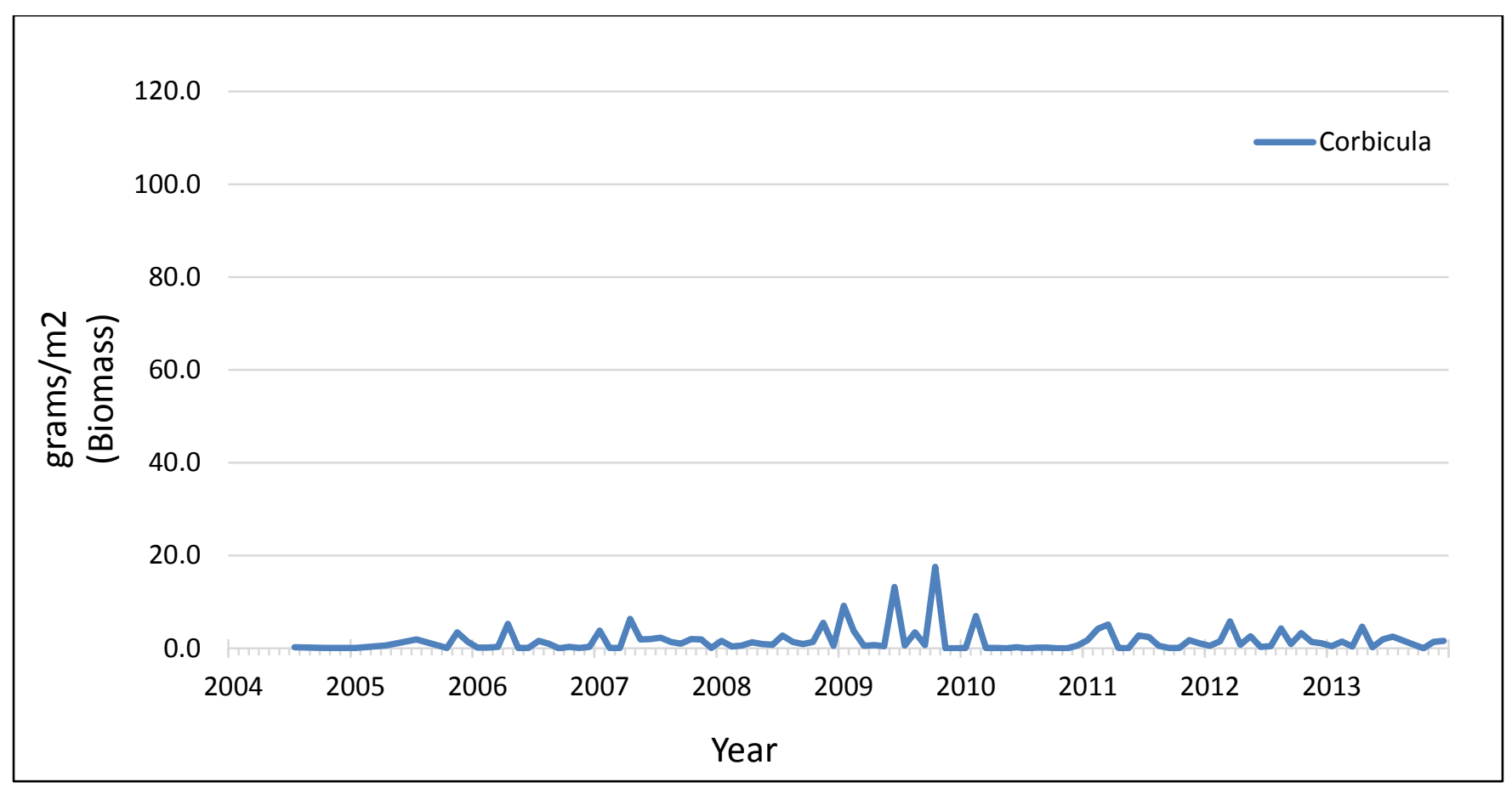

Figure 30. Graph showing biomass at station P8 from 2004-2013. For station locations refer to table 1. 


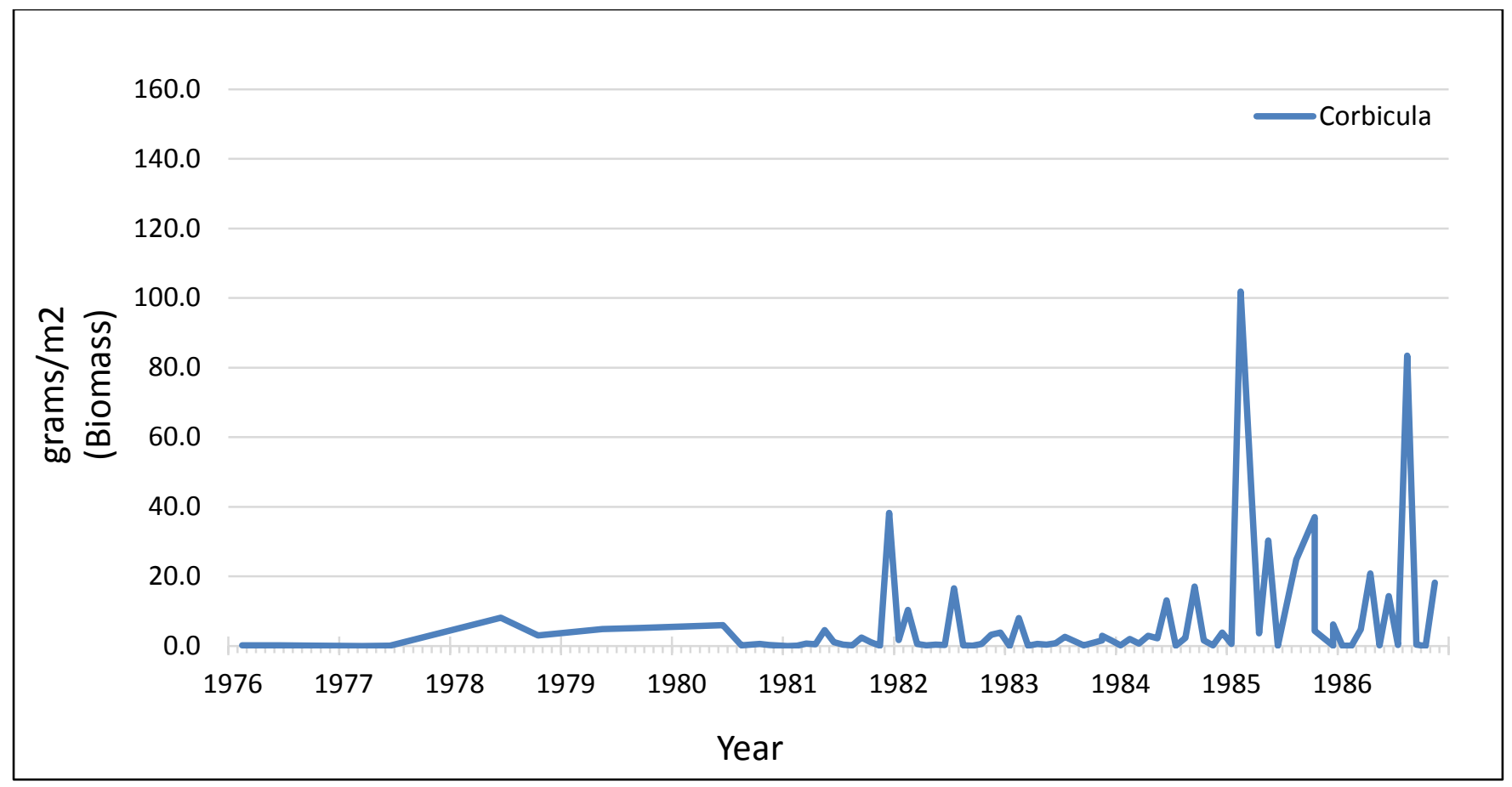

Figure 31. Graph showing biomass at station D4C from 1976-1986. For station locations refer to table 1.

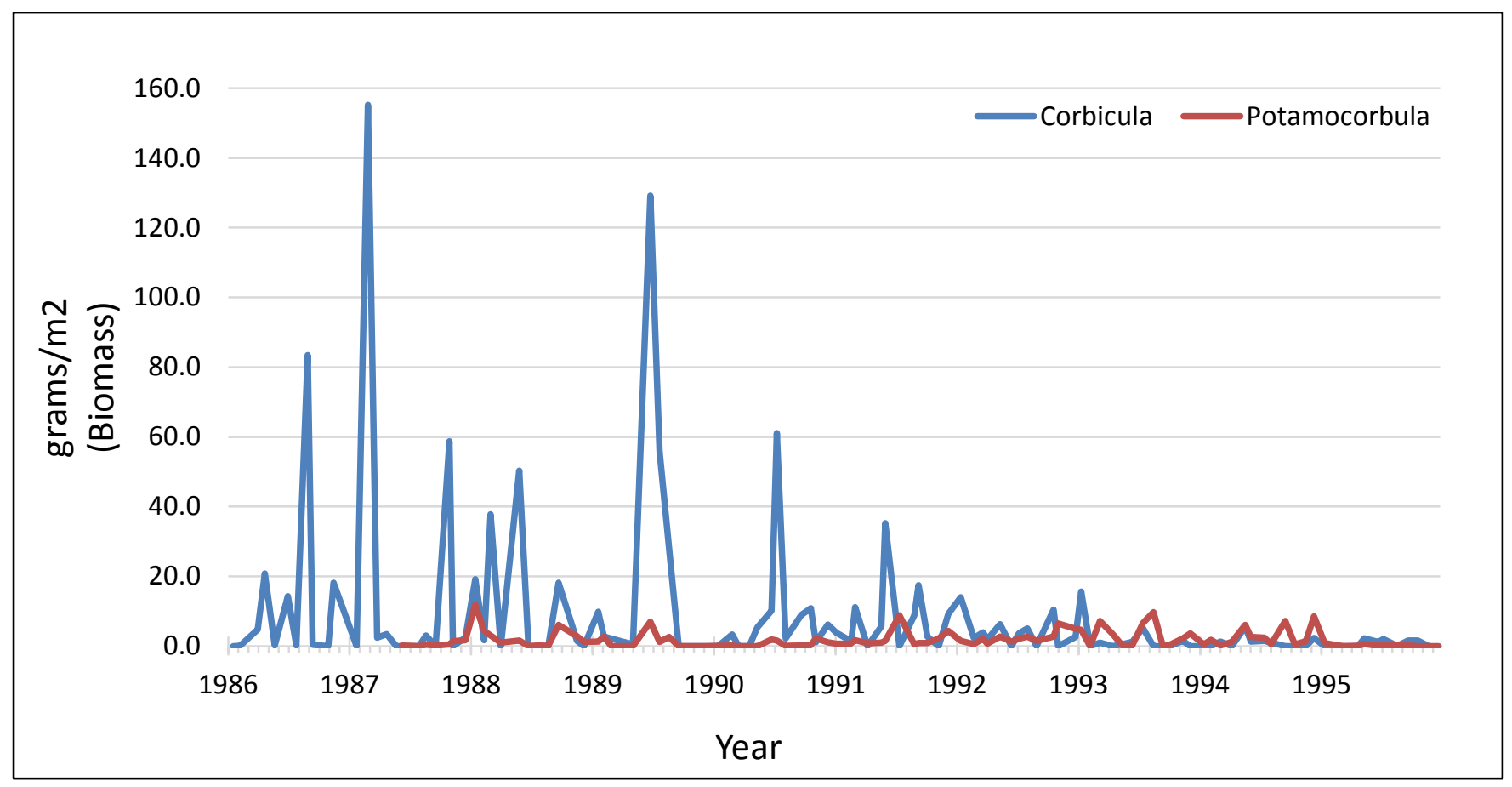

Figure 32. Graph showing biomass at station D4C from 1986-1995. For station locations refer to table 1. 


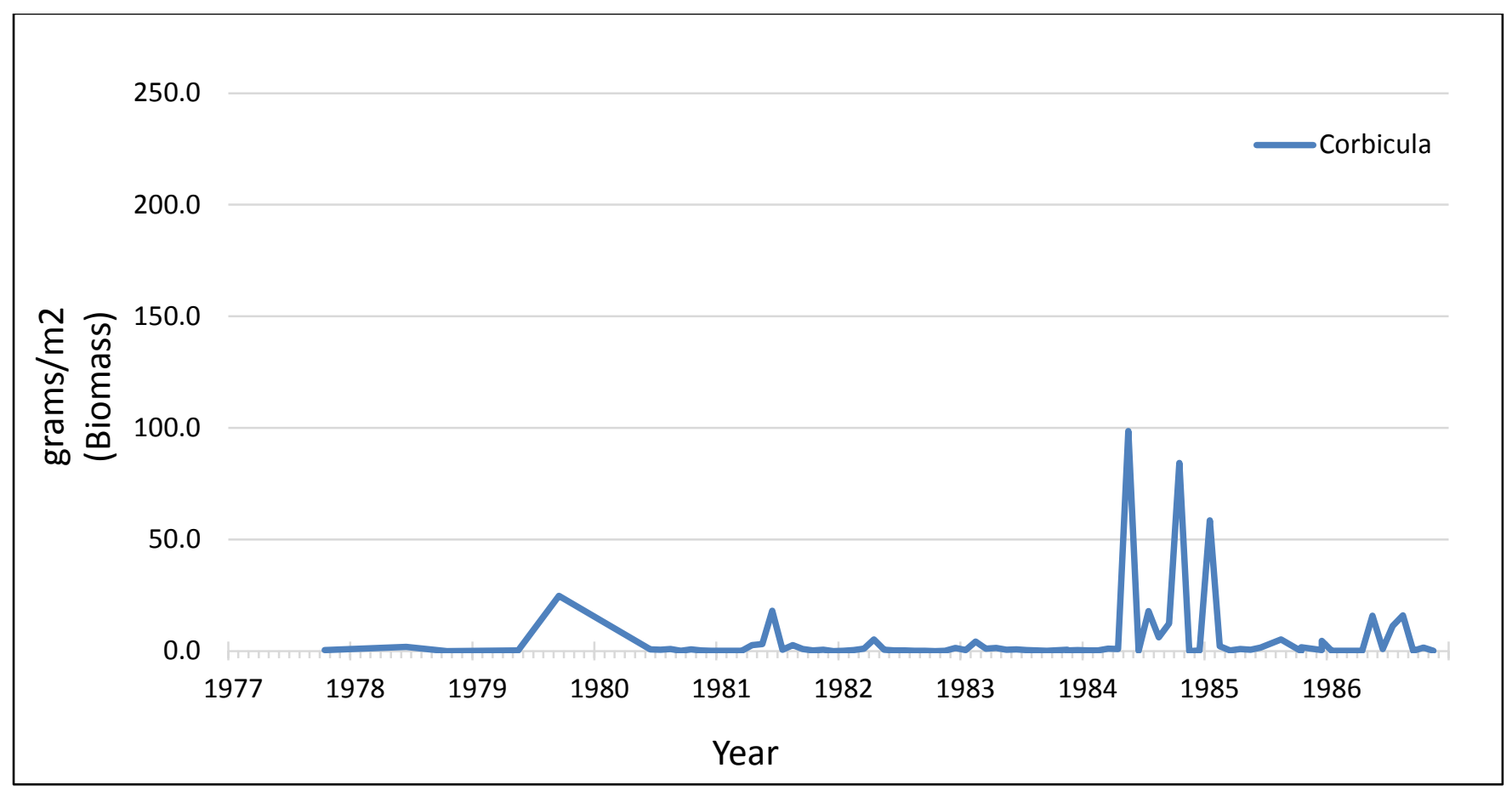

Figure 33. Graph showing biomass at station D4L from 1977-1986. For station locations refer to table 1.

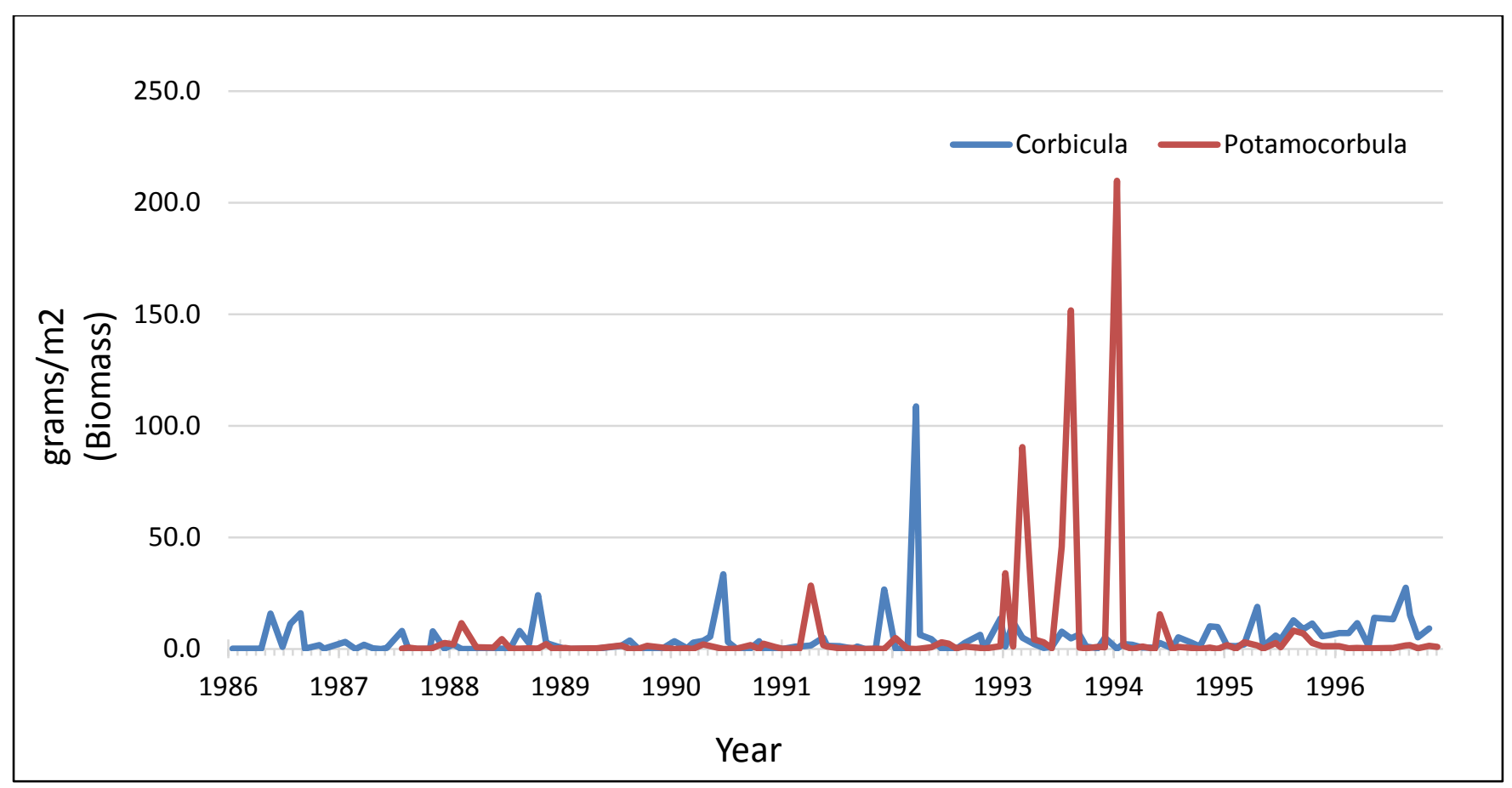

Figure 34. Graph showing biomass at station D4L from 1986-1996. For station locations refer to table 1. 


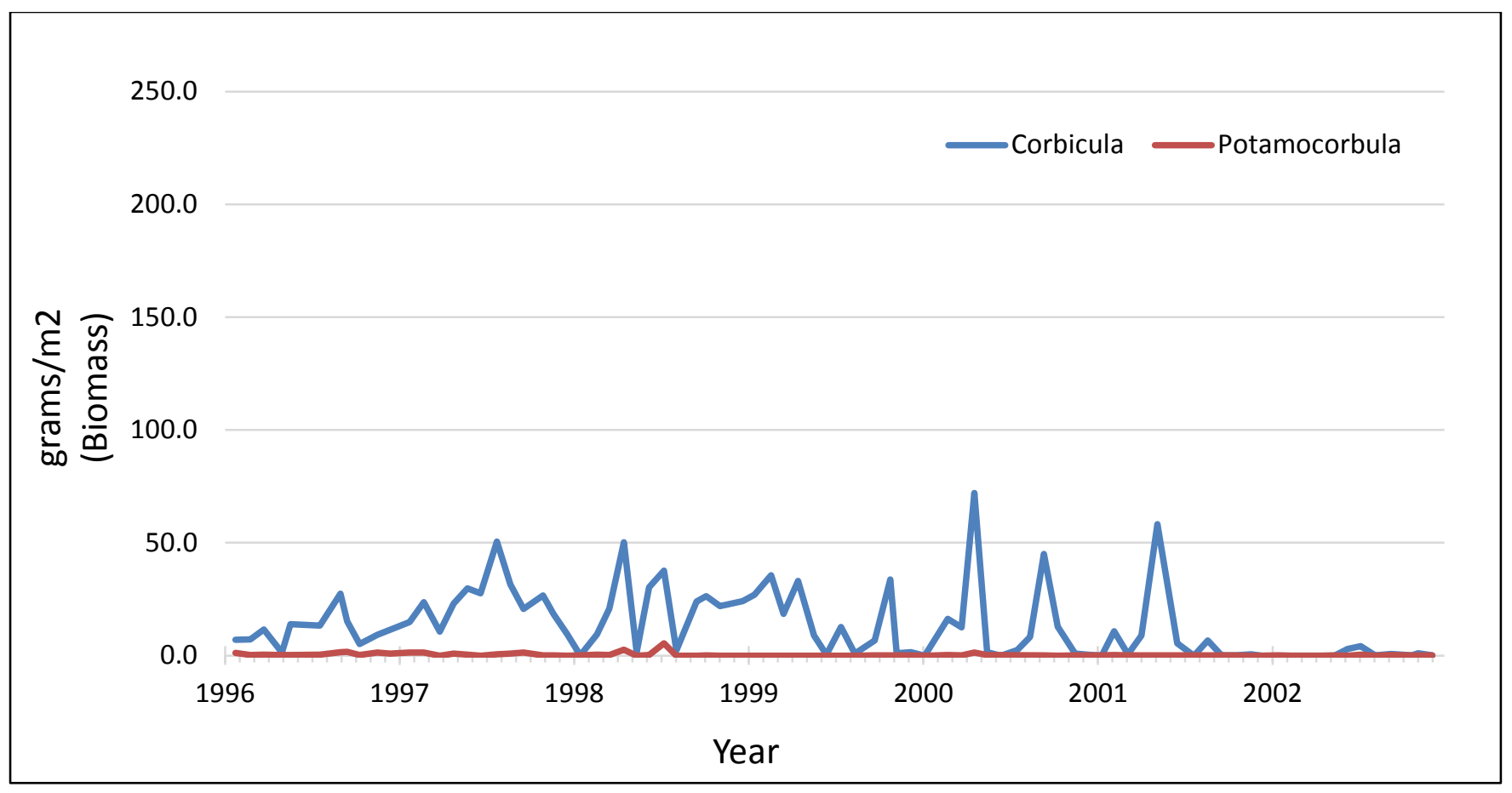

Figure 35. Graph showing biomass at station D4L from 1996-2002. For station locations refer to table 1.

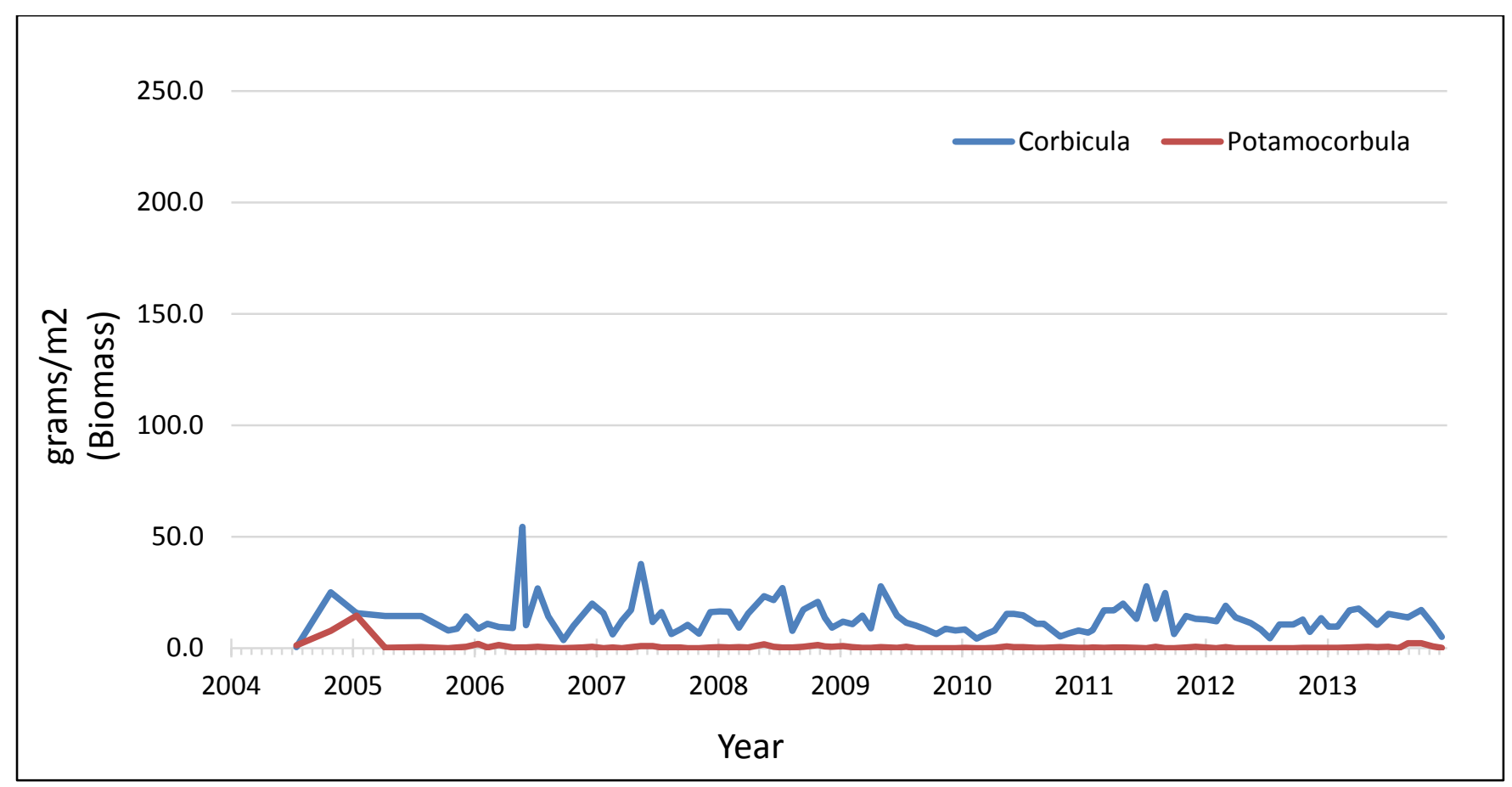

Figure 36. Graph showing biomass at station D4L from 2004-2013. For station locations refer to table 1. 


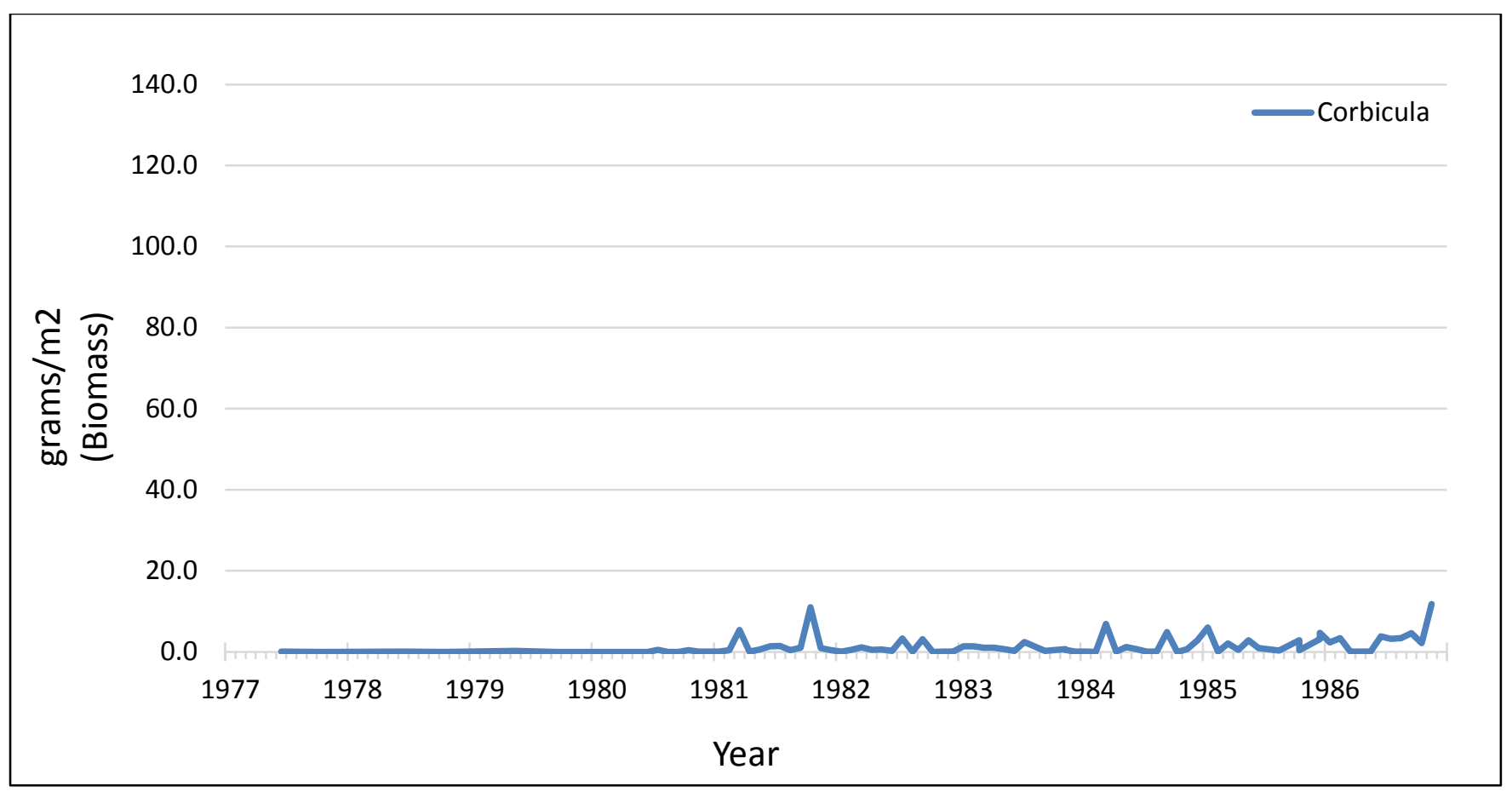

Figure 37. Graph showing biomass at station D4R from 1977-1986. For station locations refer to table 1.

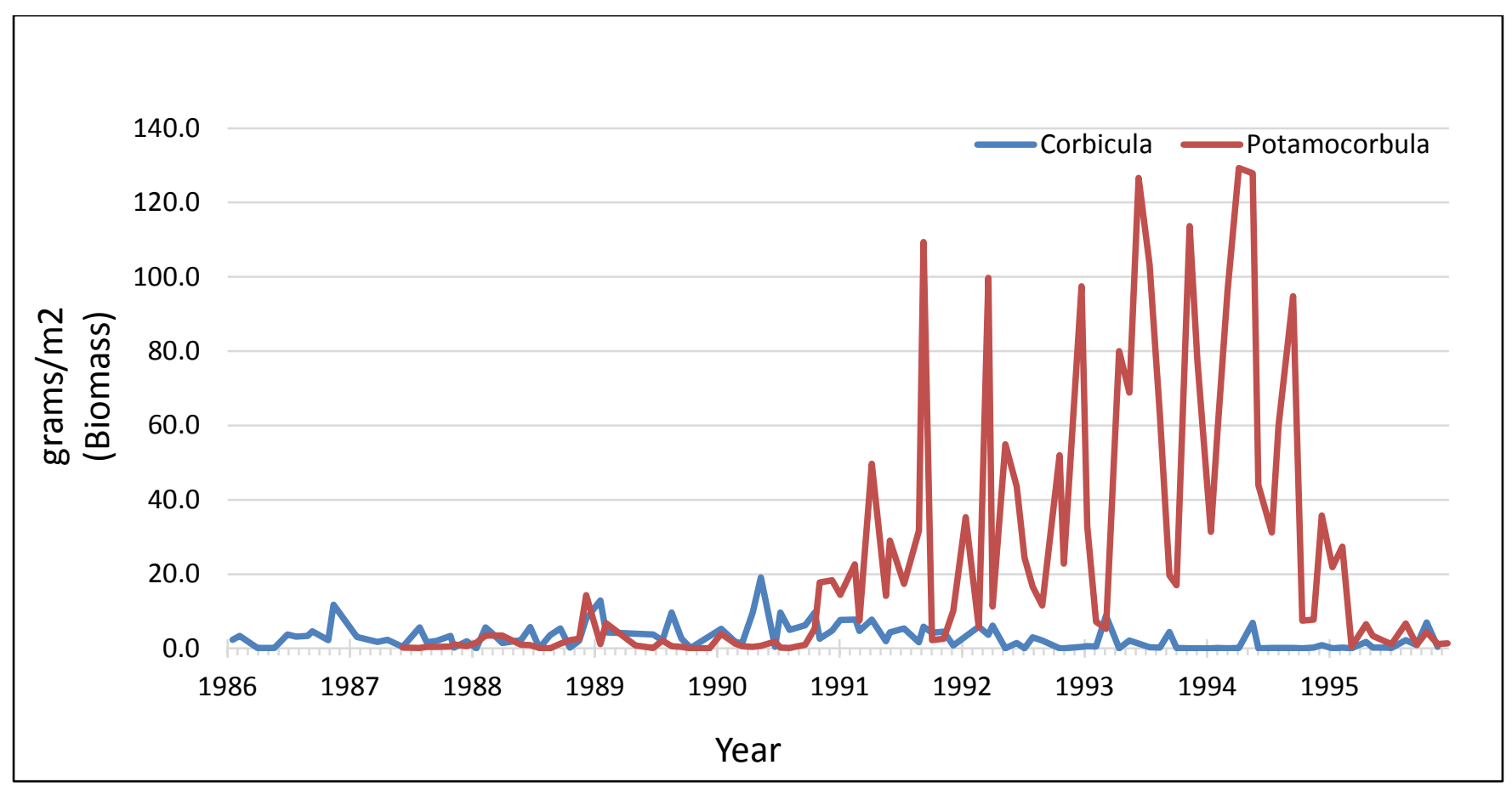

Figure 38. Graph showing biomass at station D4R from 1986-1995. For station locations refer to table 1. 


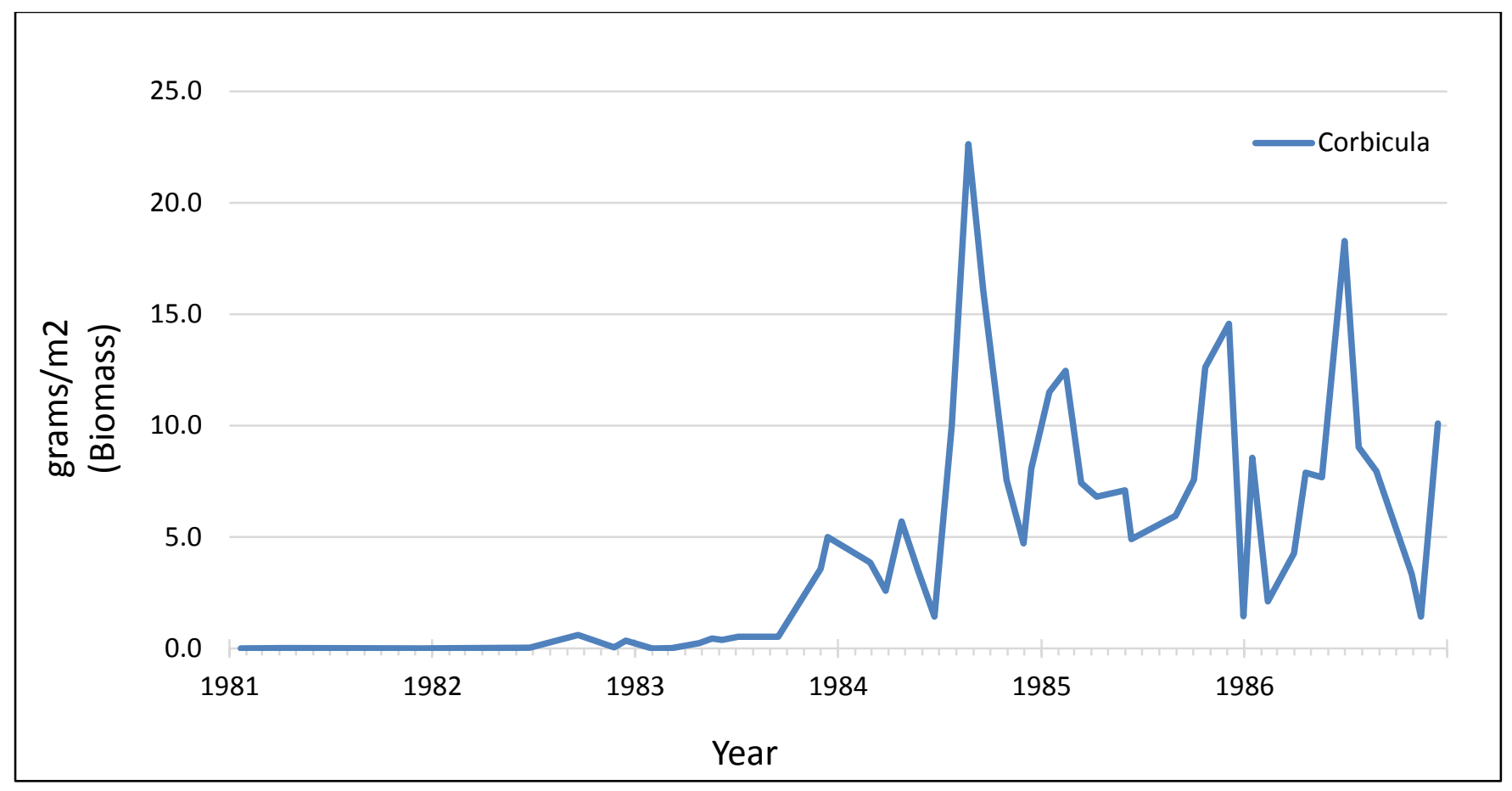

Figure 39. Graph showing biomass at station D7 from 1981-1986. For station locations refer to table 1.

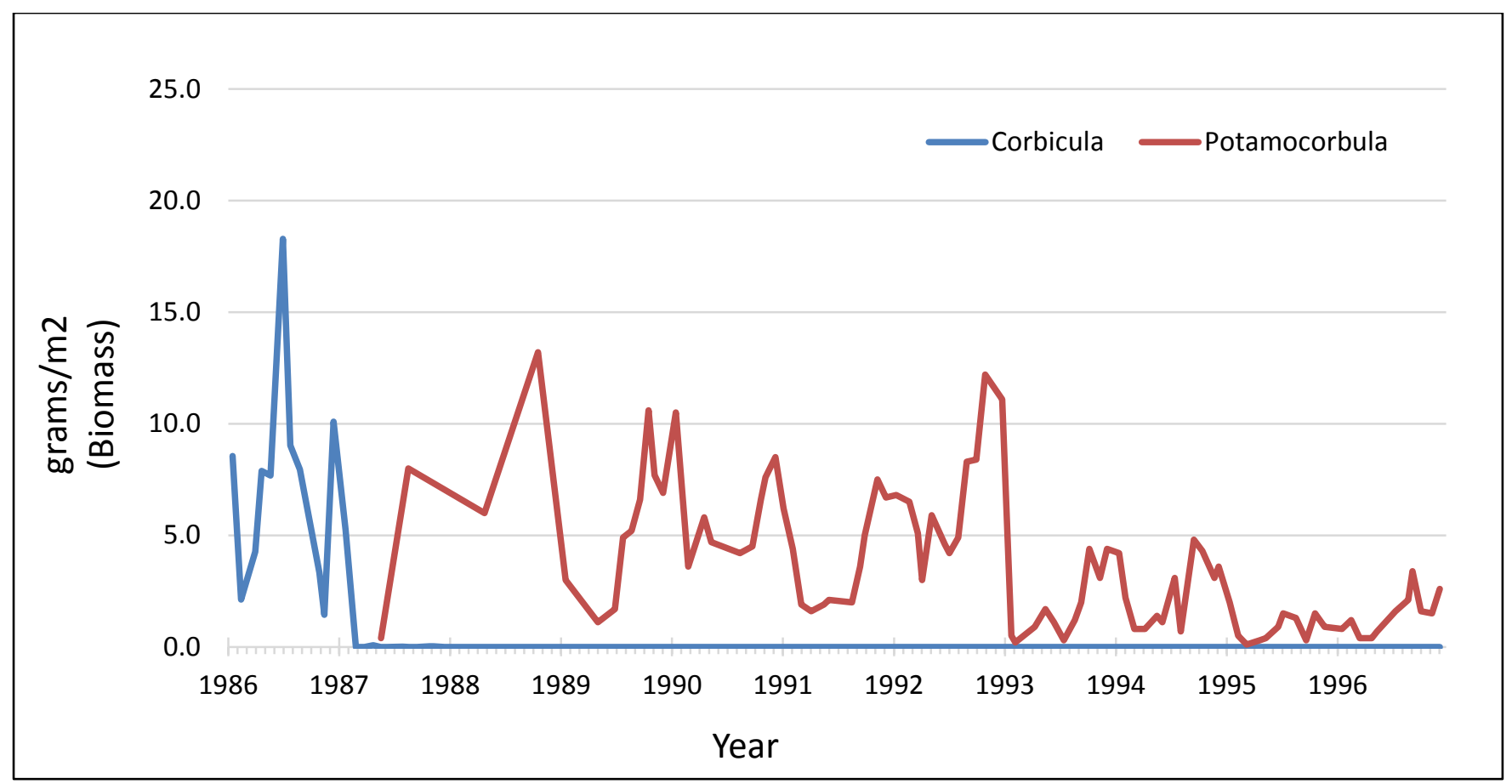

Figure 40. Graph showing biomass at station D7 from 1986-1996. For station locations refer to table 1. 


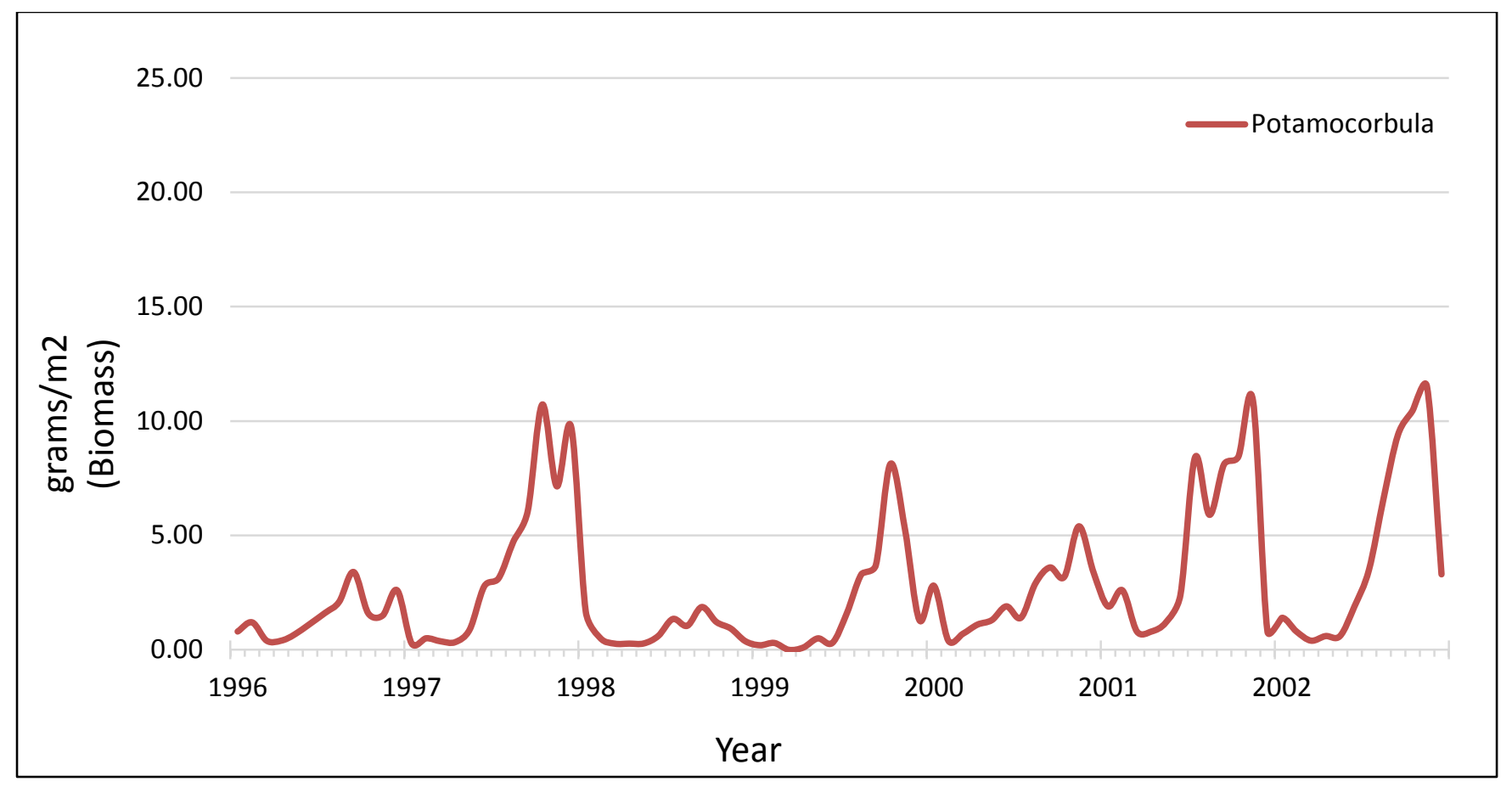

Figure 41. Graph showing biomass at station D7 from 1996-2003. For station locations refer to table 1.

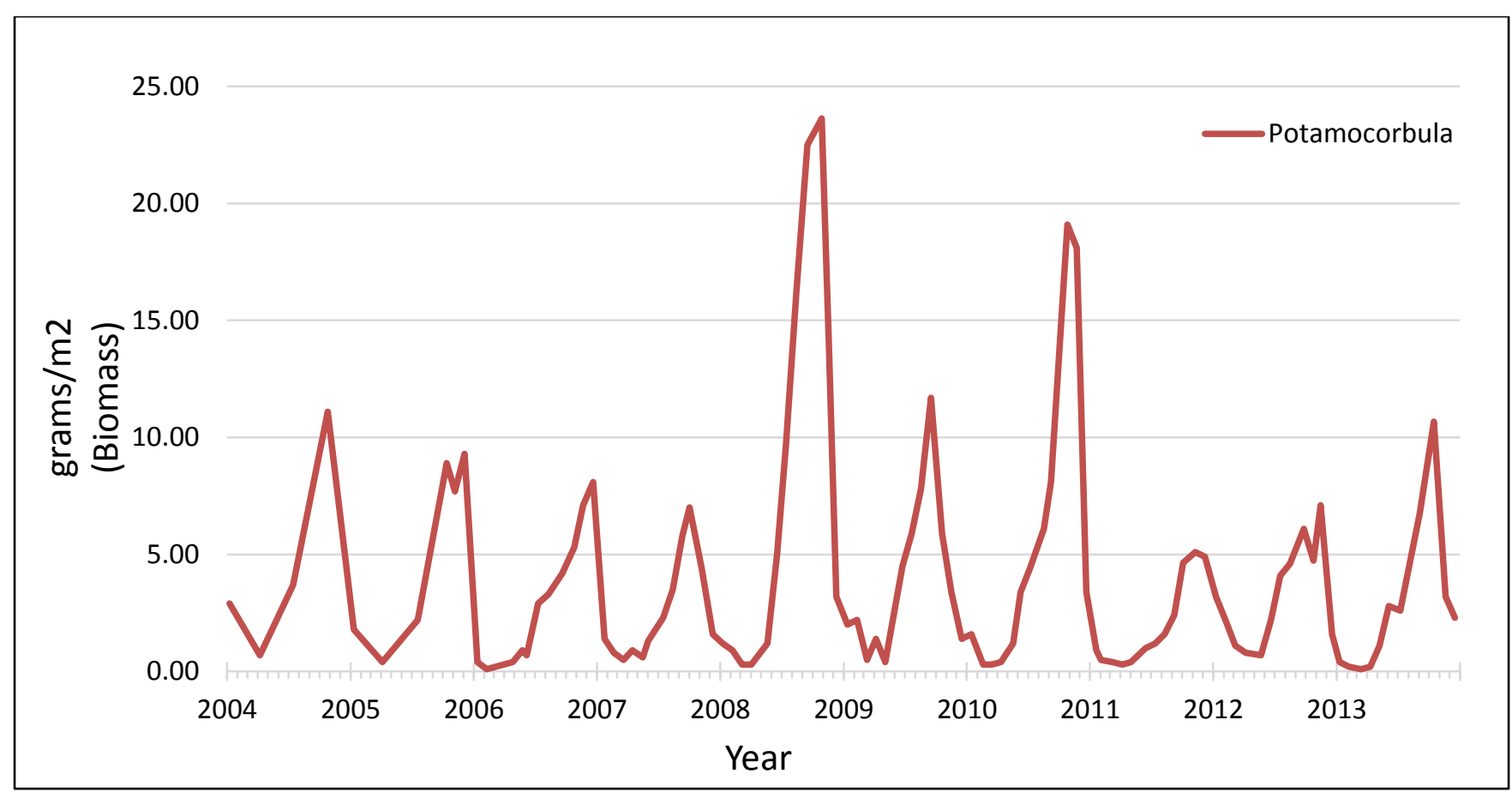

Figure 42. Graph showing biomass at station D7 from 2003-2013. For station locations refer to table 1. 


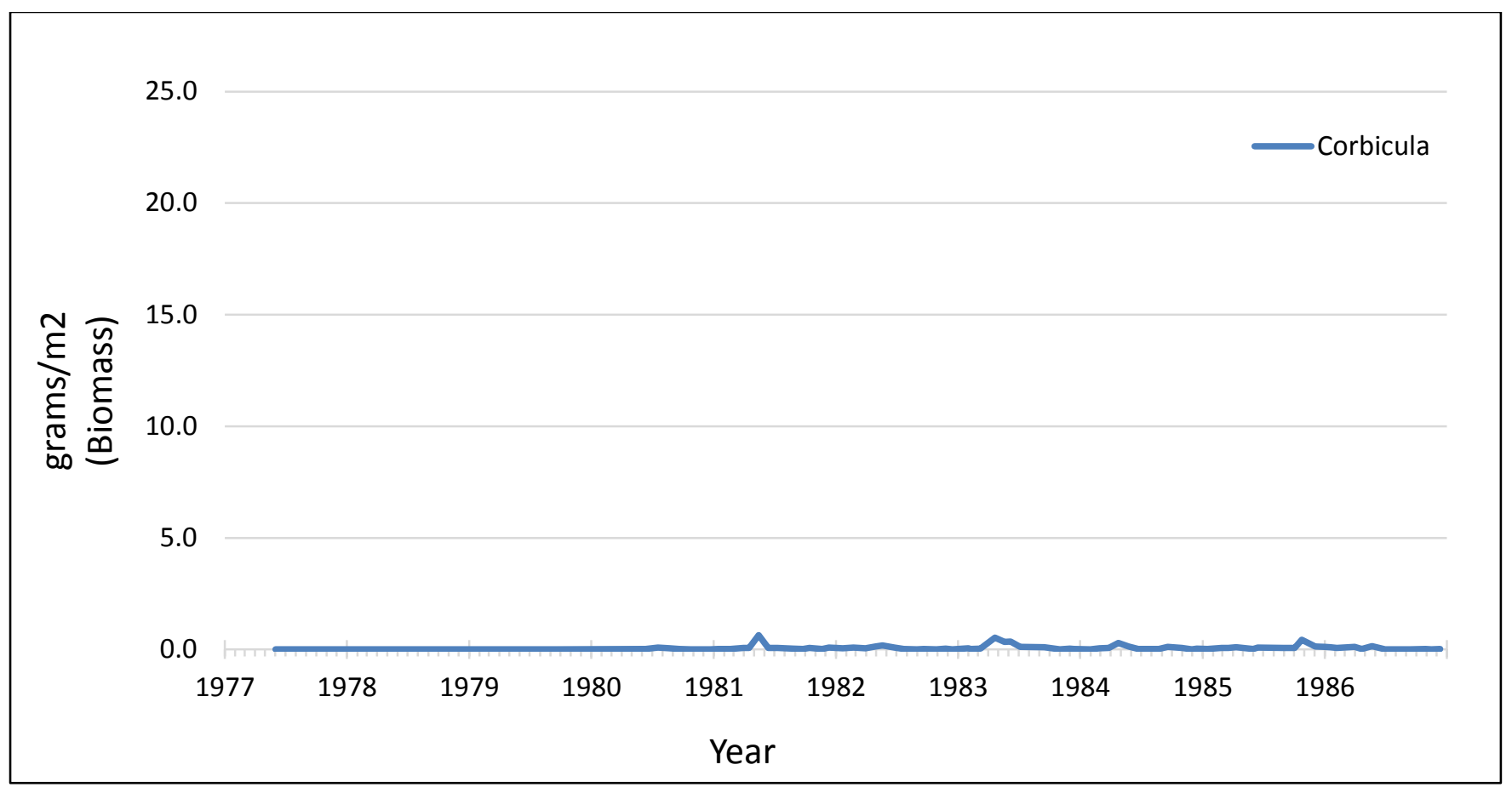

Figure 43. Graph showing biomass at station D11 from 1977-1986. For station locations refer to table 1.

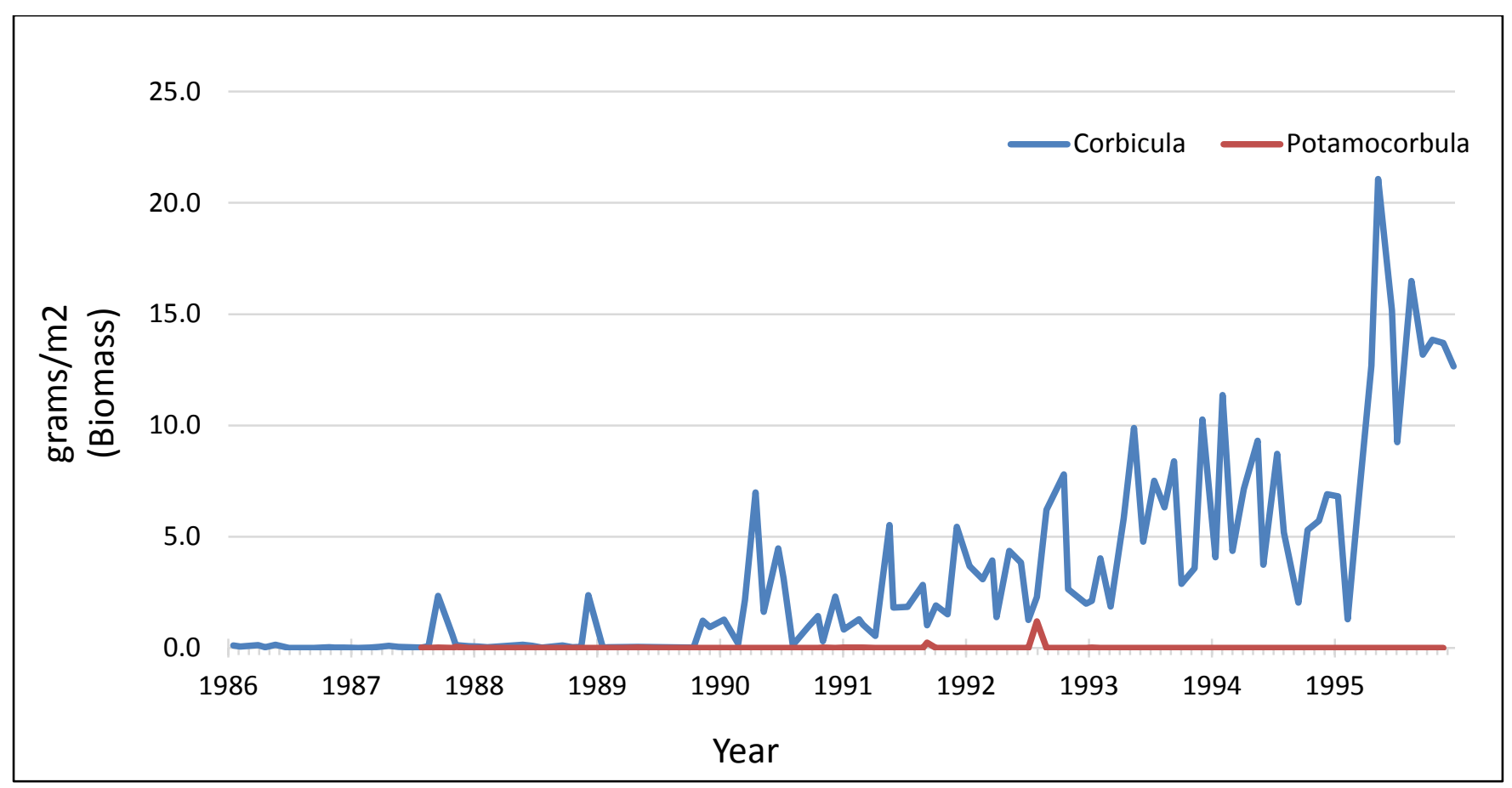

Figure 44. Graph showing biomass at station D11 from 1986-1995. For station locations refer to table 1. 


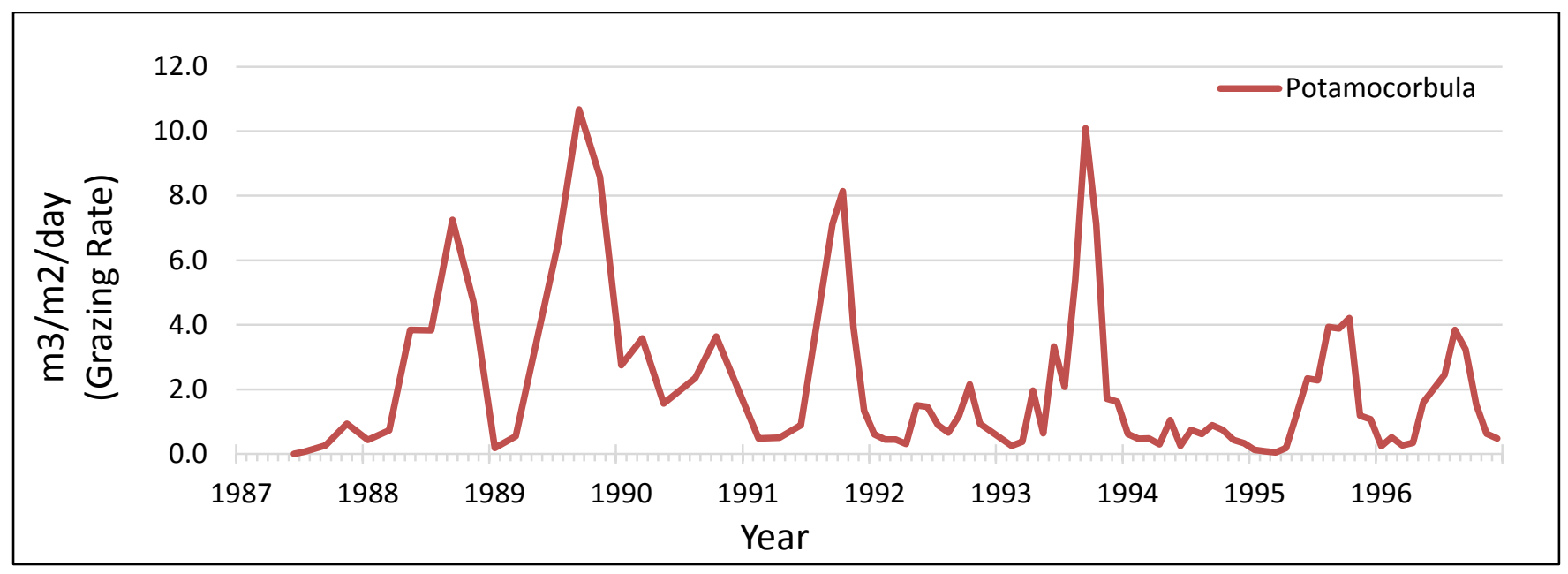

Figure 45. Graph showing grazing rate at station D41A from 1987-1996. For station locations refer to table 1.

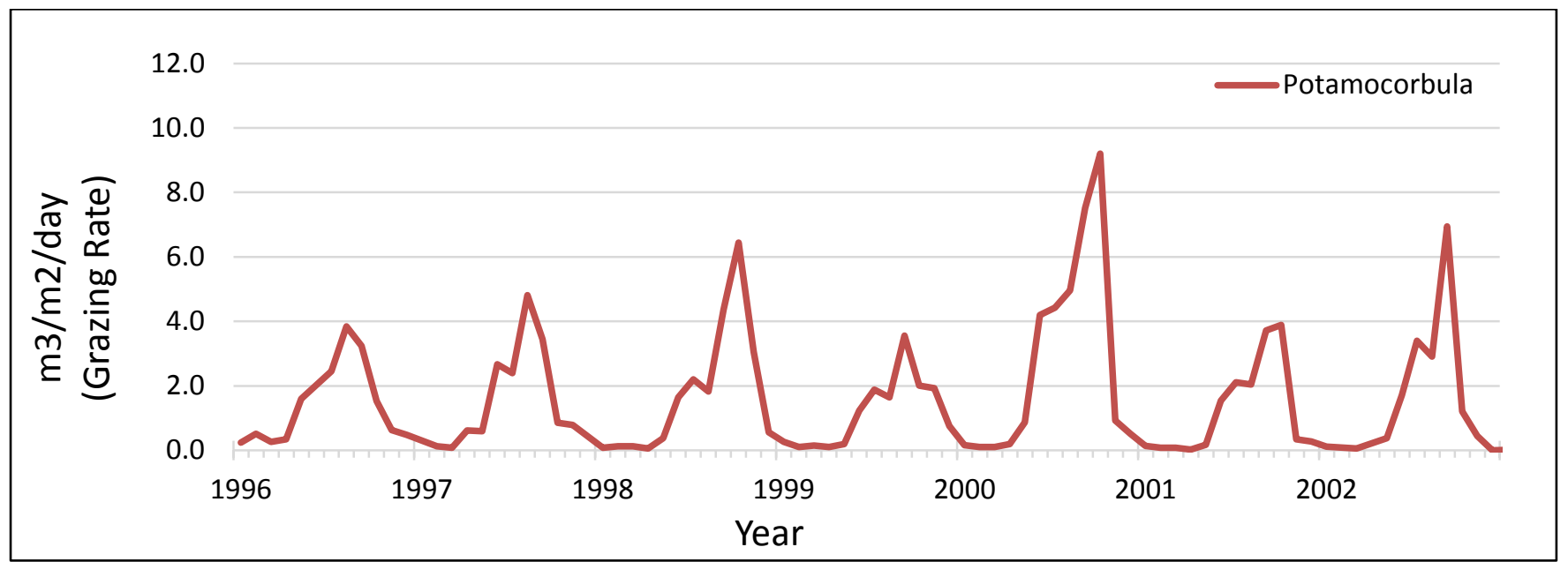

Figure 46. Graph showing grazing rate at station D41A from 1996-2003. For station locations refer to table 1.

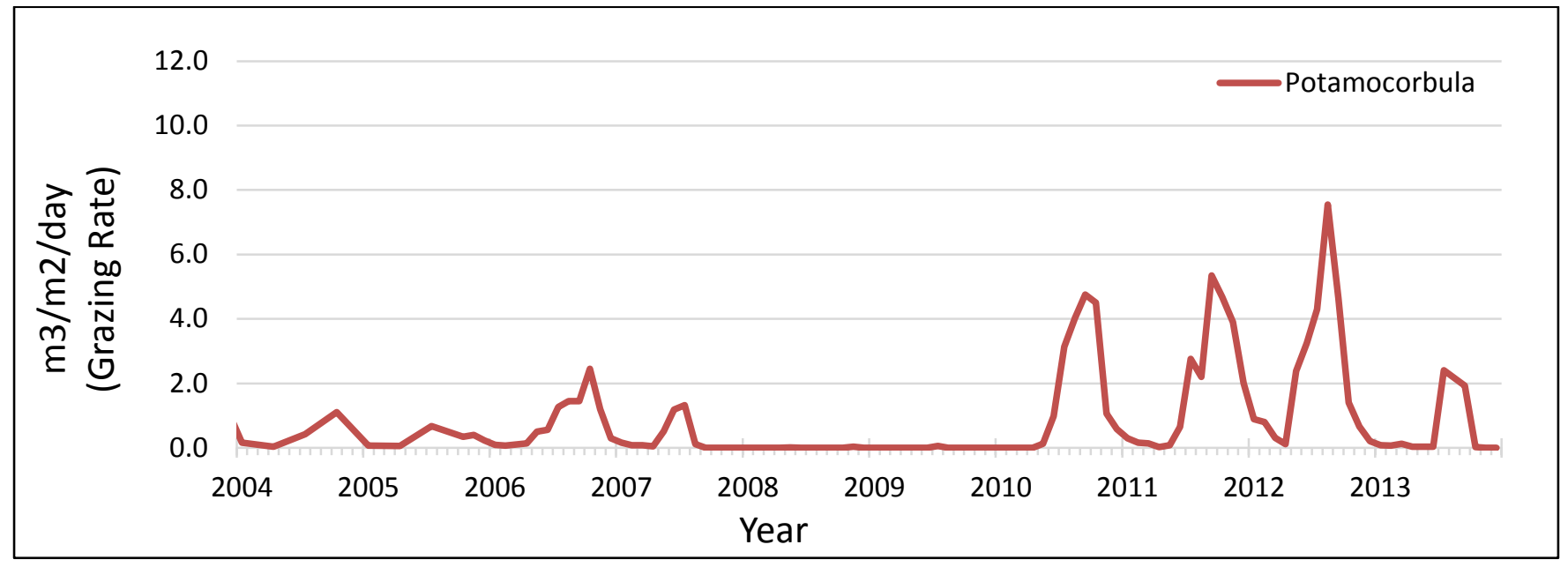

Figure 47. Graph showing grazing rate at station D41A from 2003-2013. For station locations refer to table 1. 


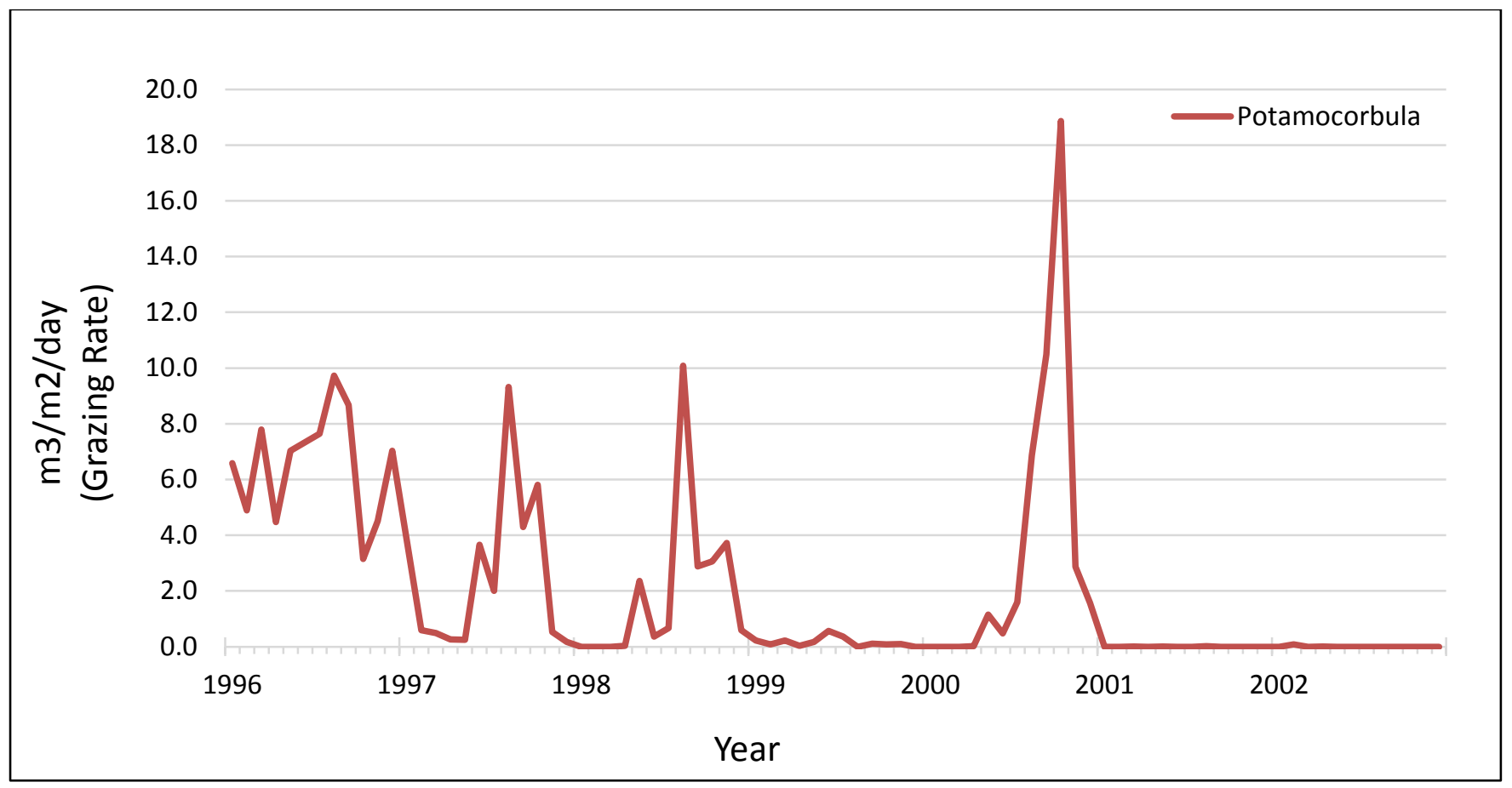

Figure 48. Graph showing grazing rate at station D41C from 1996-2002. For station locations refer to table 1.

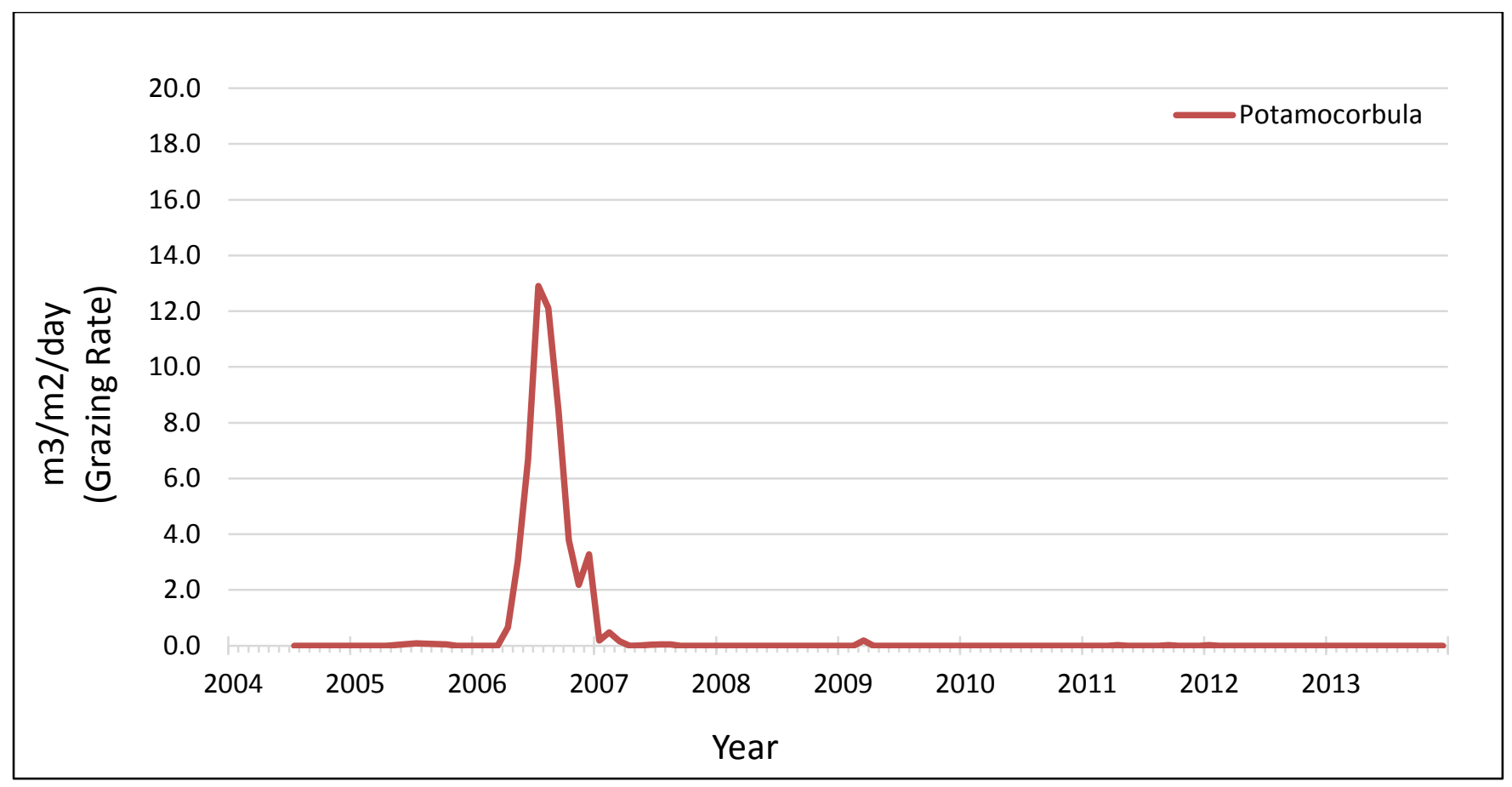

Figure 49. Graph showing grazing rate at station D41C from 2004-2013. For station locations refer to table 1. 


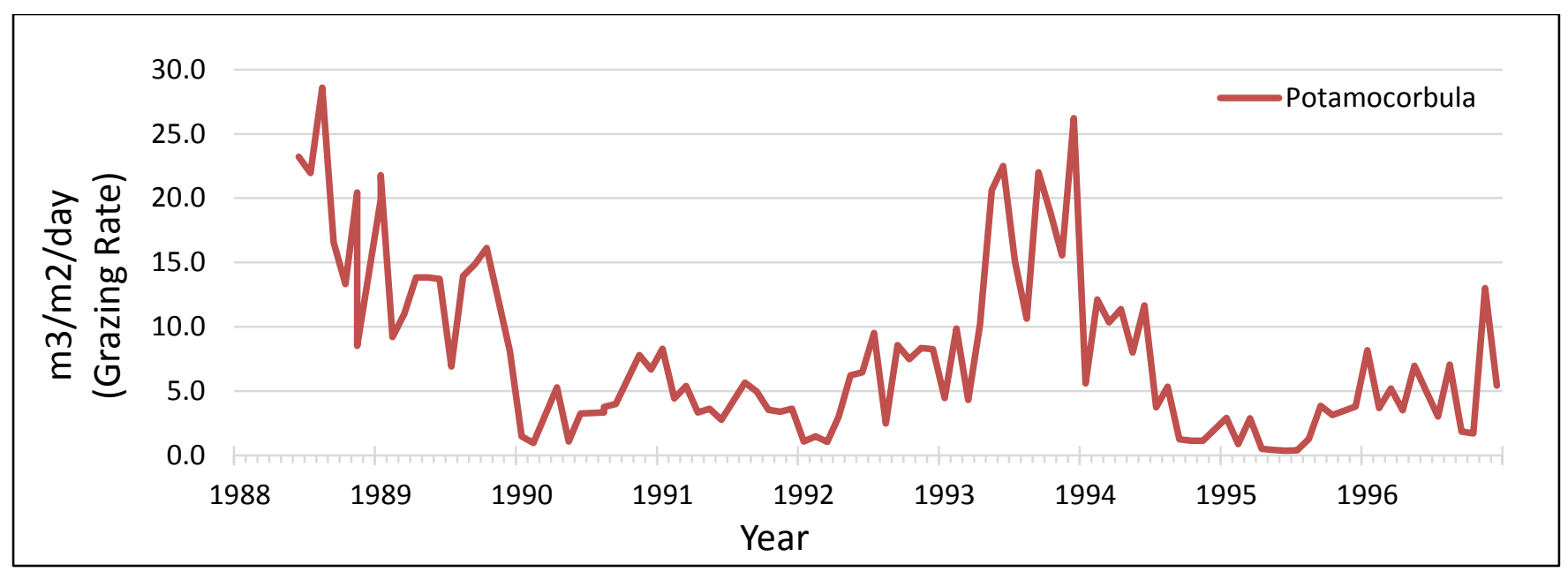

Figure 50. Graph showing grazing rate at station 8.1 from 1988-1996. For station locations refer to table 1.

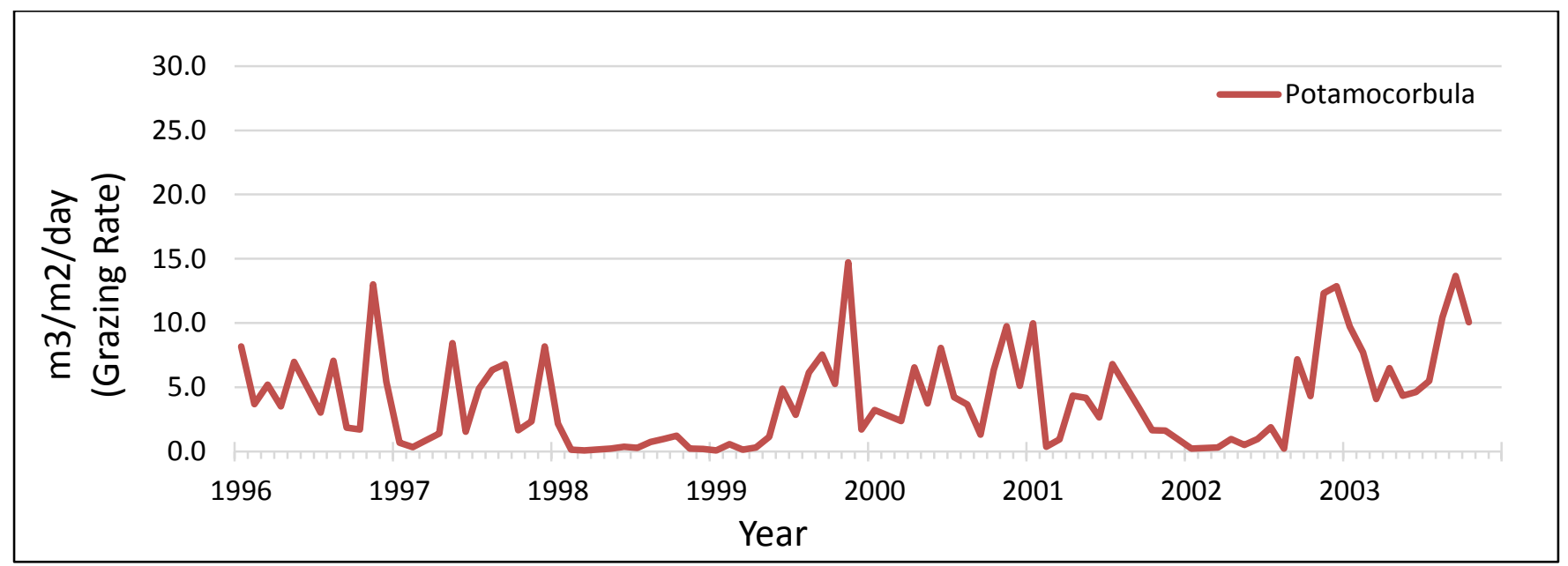

Figure 51. Graph showing grazing rate at station 8.1 from 1996-2003. For station locations refer to table 1.

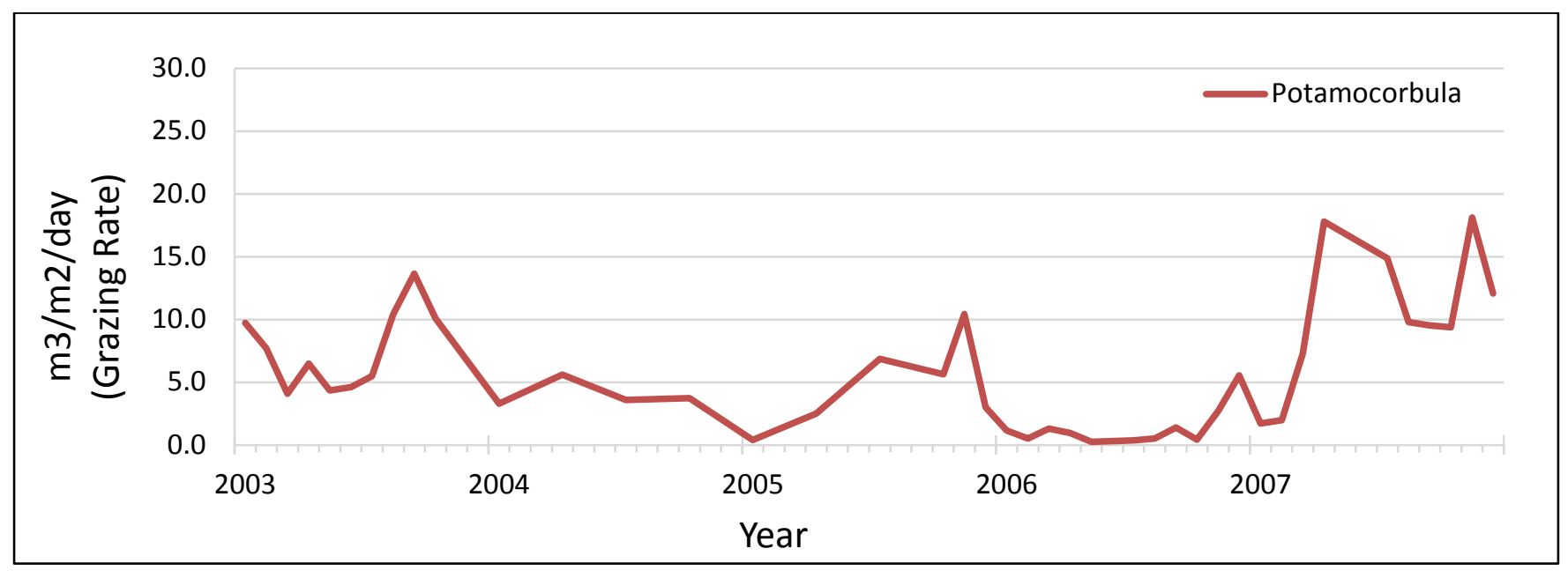

Figure 52. Graph showing grazing rate at station 8.1 from 2003-2007. For station locations refer to table 1. 


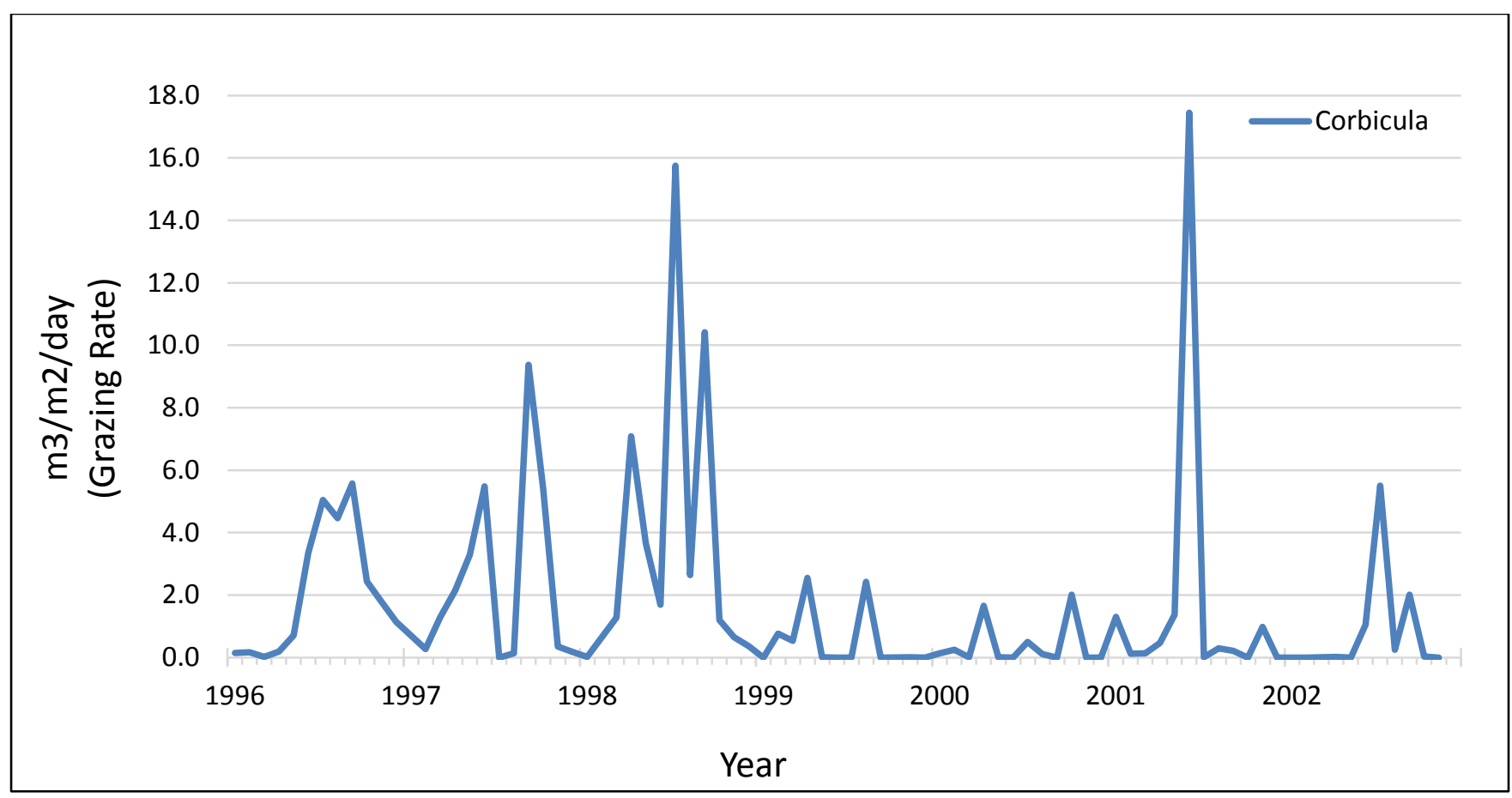

Figure 53. Graph showing grazing rate at station C9 from 1996-2002. For station locations refer to table 1.

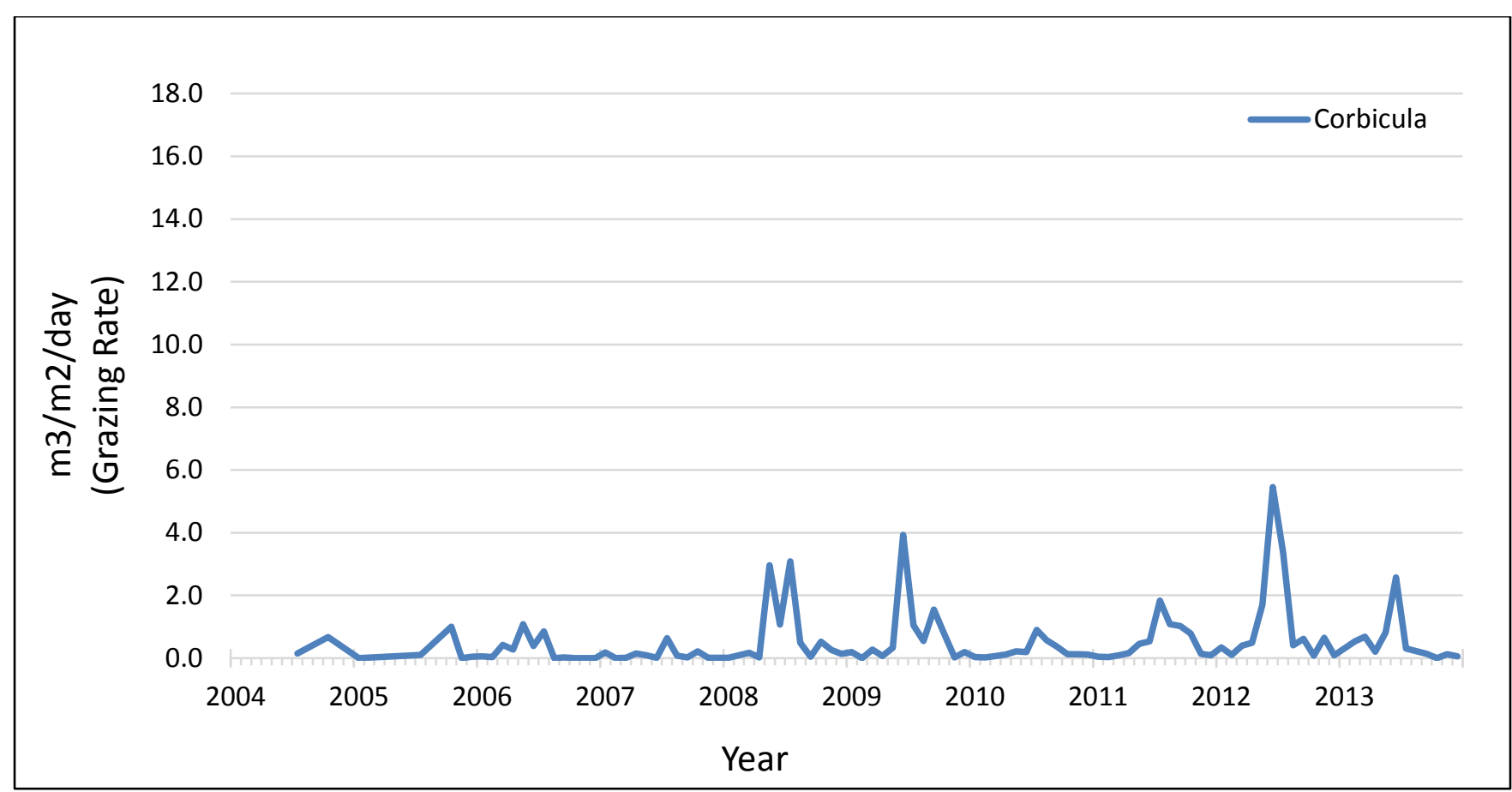

Figure 54. Graph showing grazing rate at station C9 from 2004-2013. For station locations refer to table 1. 


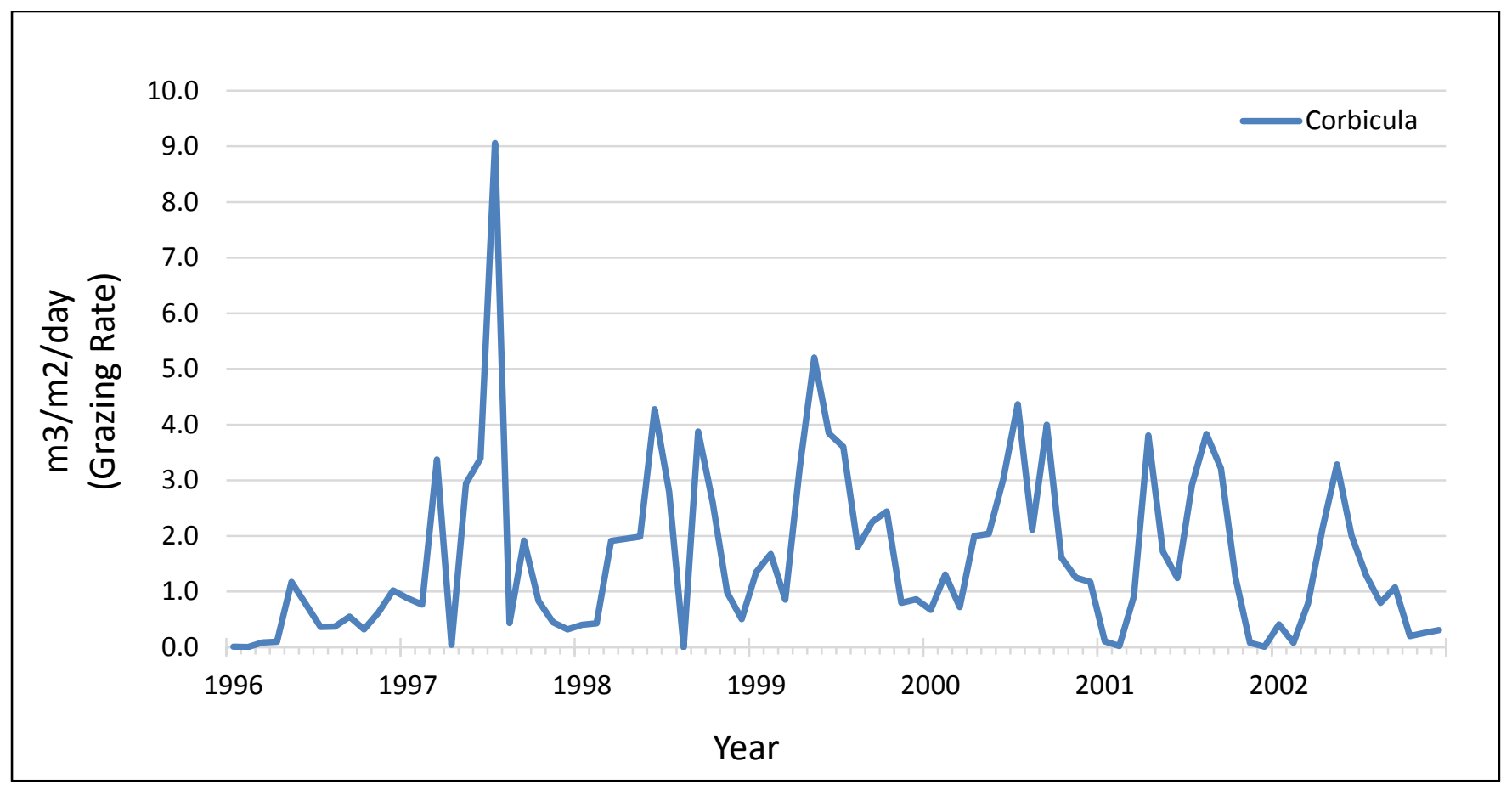

Figure 55. Graph showing grazing rate at station D16 from 1996-2002. For station locations refer to table 1.

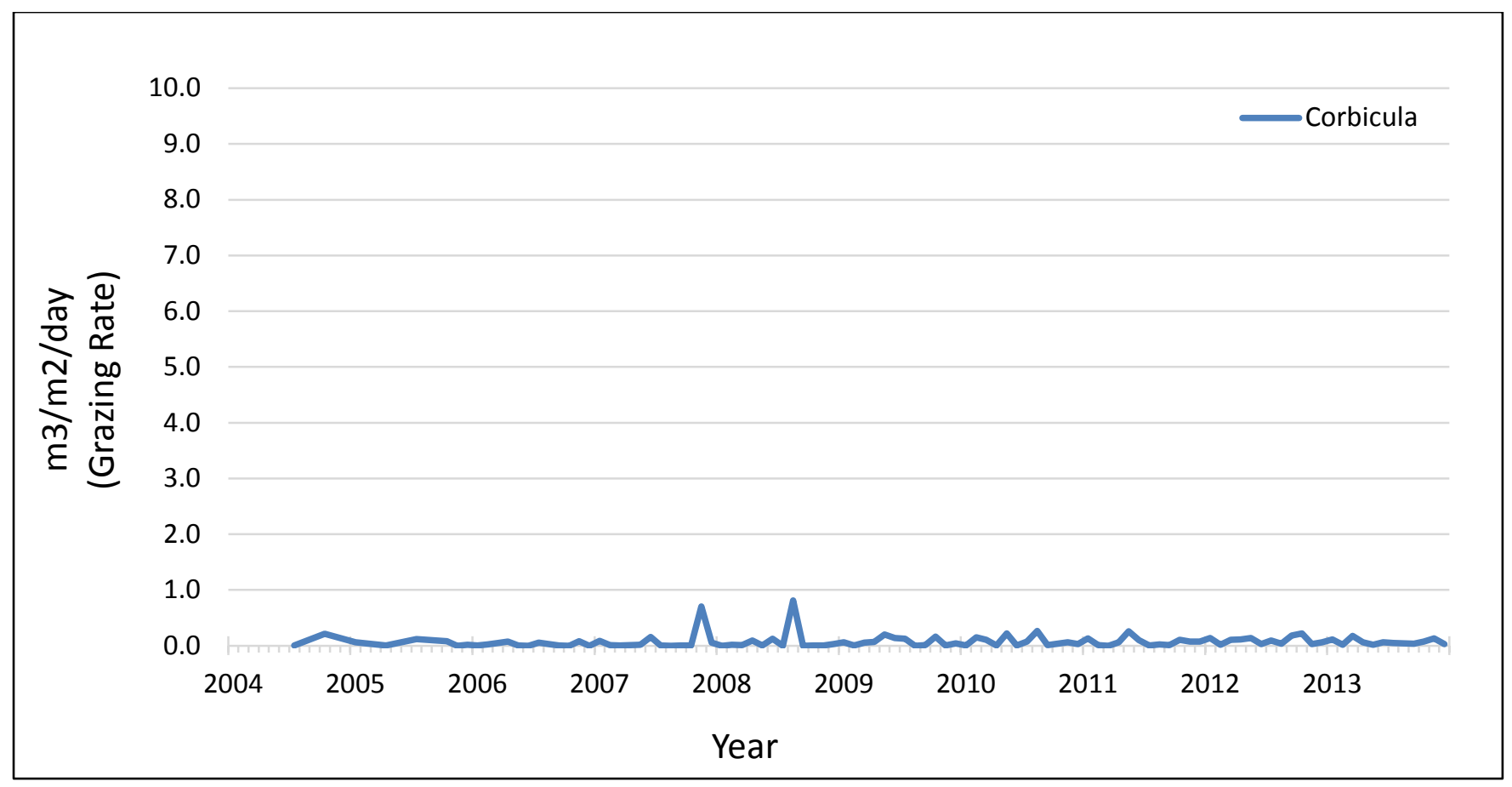

Figure 56. Graph showing grazing rate at station D16 from 2004-2013. For station locations refer to table 1. 


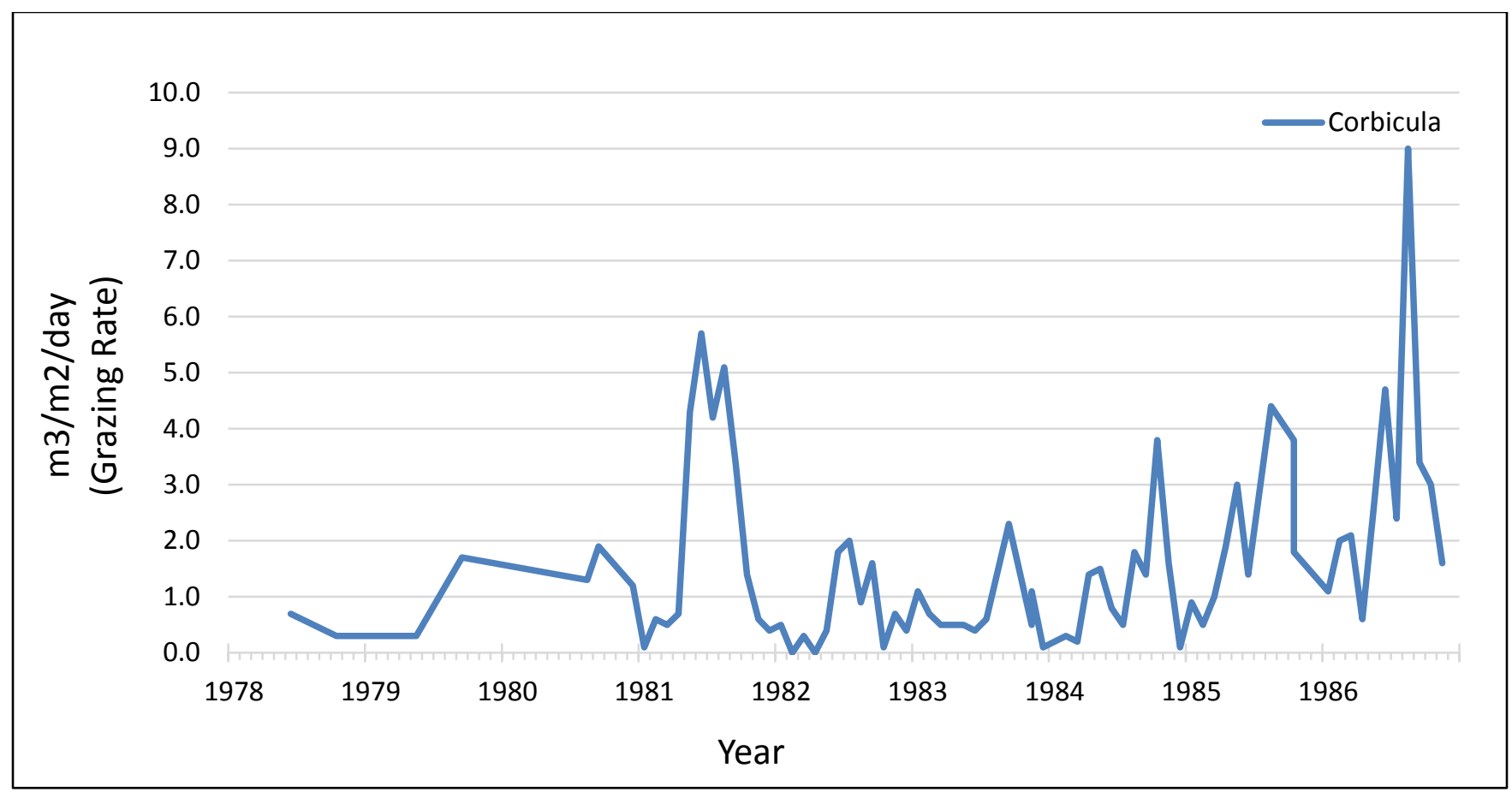

Figure 57. Graph showing grazing rate at station D19C from 1978-1986. For station locations refer to table 1.

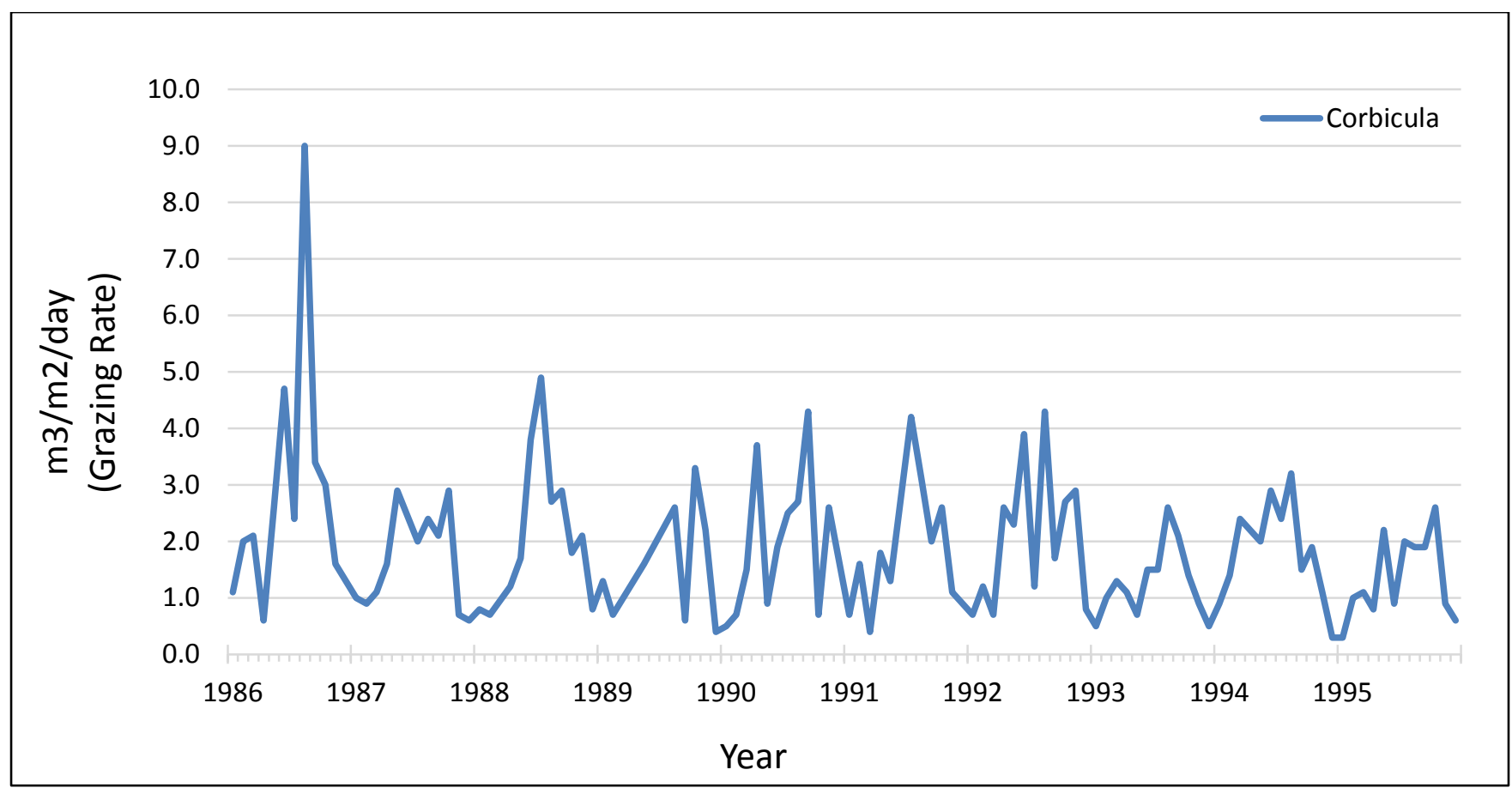

Figure 58. Graph showing grazing rate at station D19C from 1986-1995. For station locations refer to table 1. 


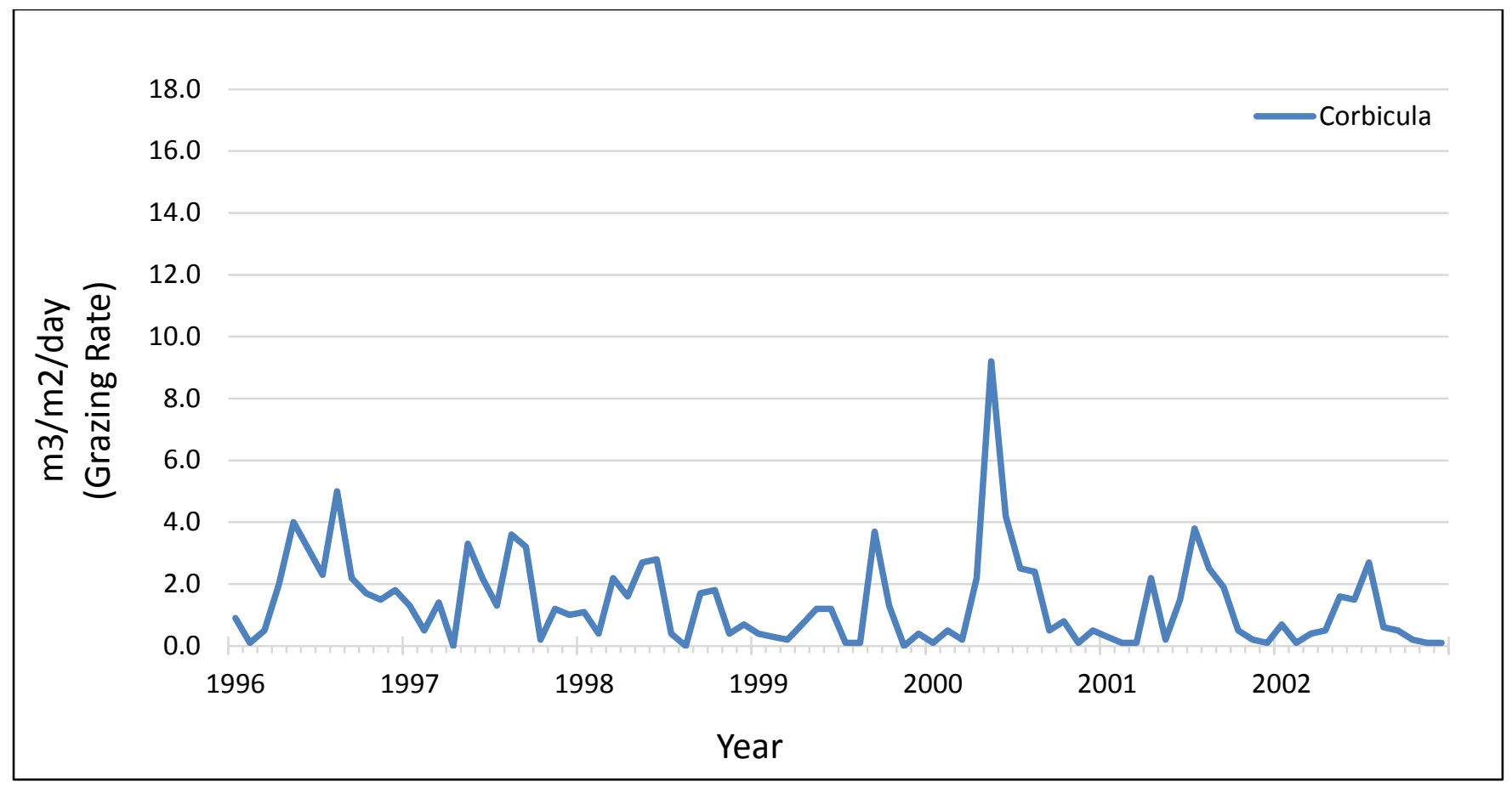

Figure 59. Graph showing grazing rate at station D24 from 1996-2002. For station locations refer to table 1.

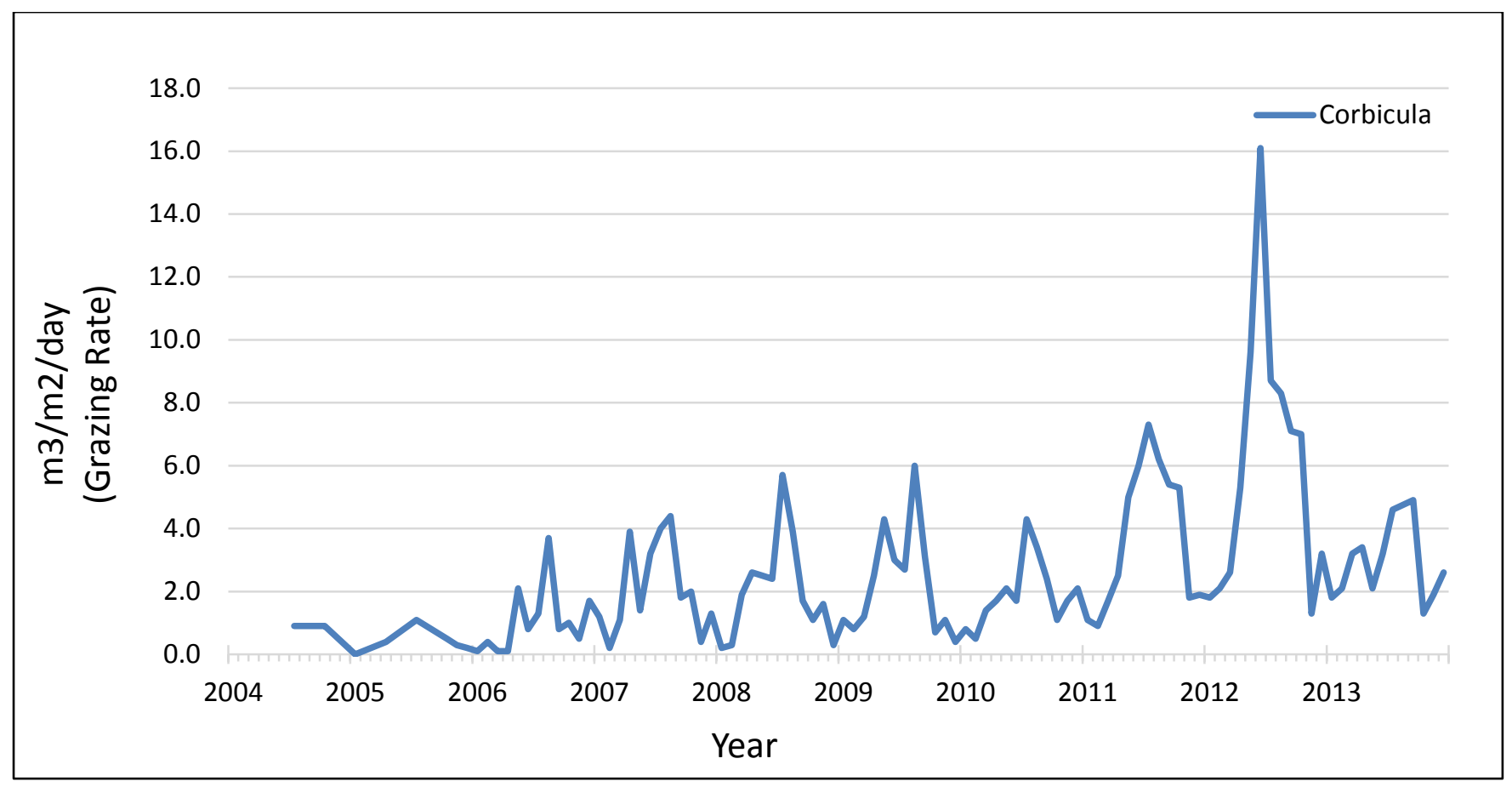

Figure 60. Graph showing grazing rate at station D24 from 2004-2013. For station locations refer to table 1. 


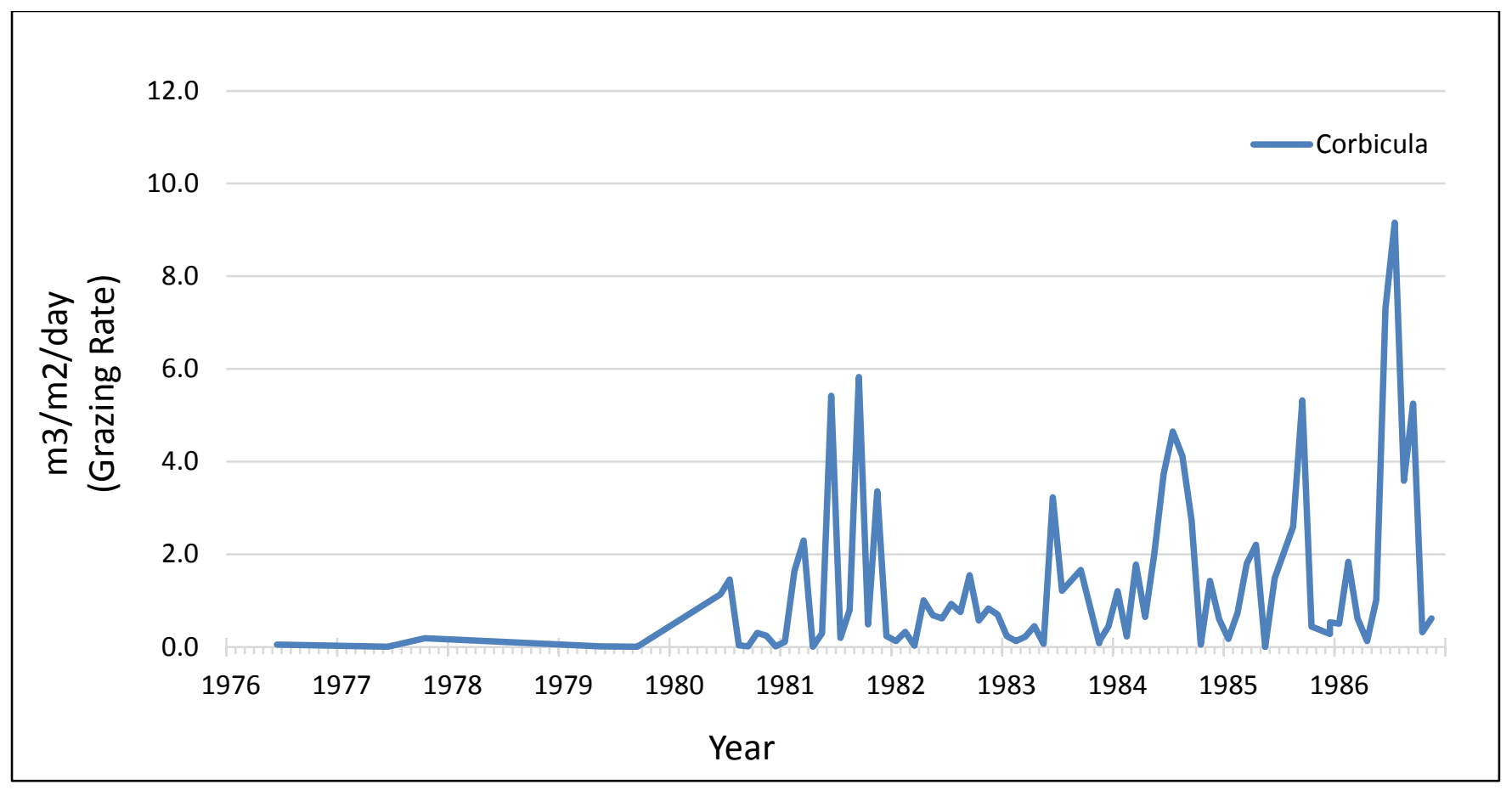

Figure 61. Graph showing grazing rate at station D28 from 1976-1986. For station locations refer to table 1.

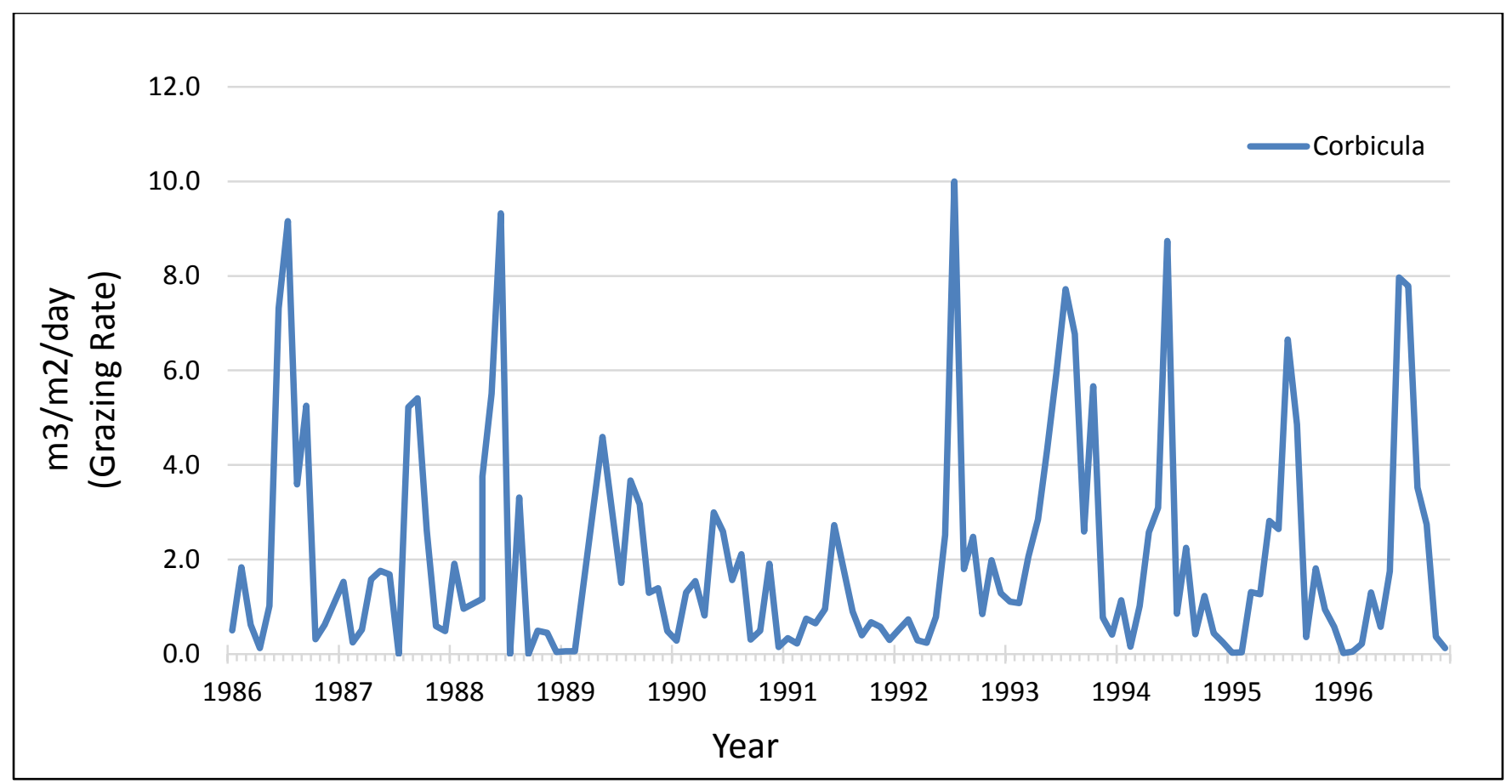

Figure 62. Graph showing grazing rate at station D28 from 1986-1996. For station locations refer to table 1. 


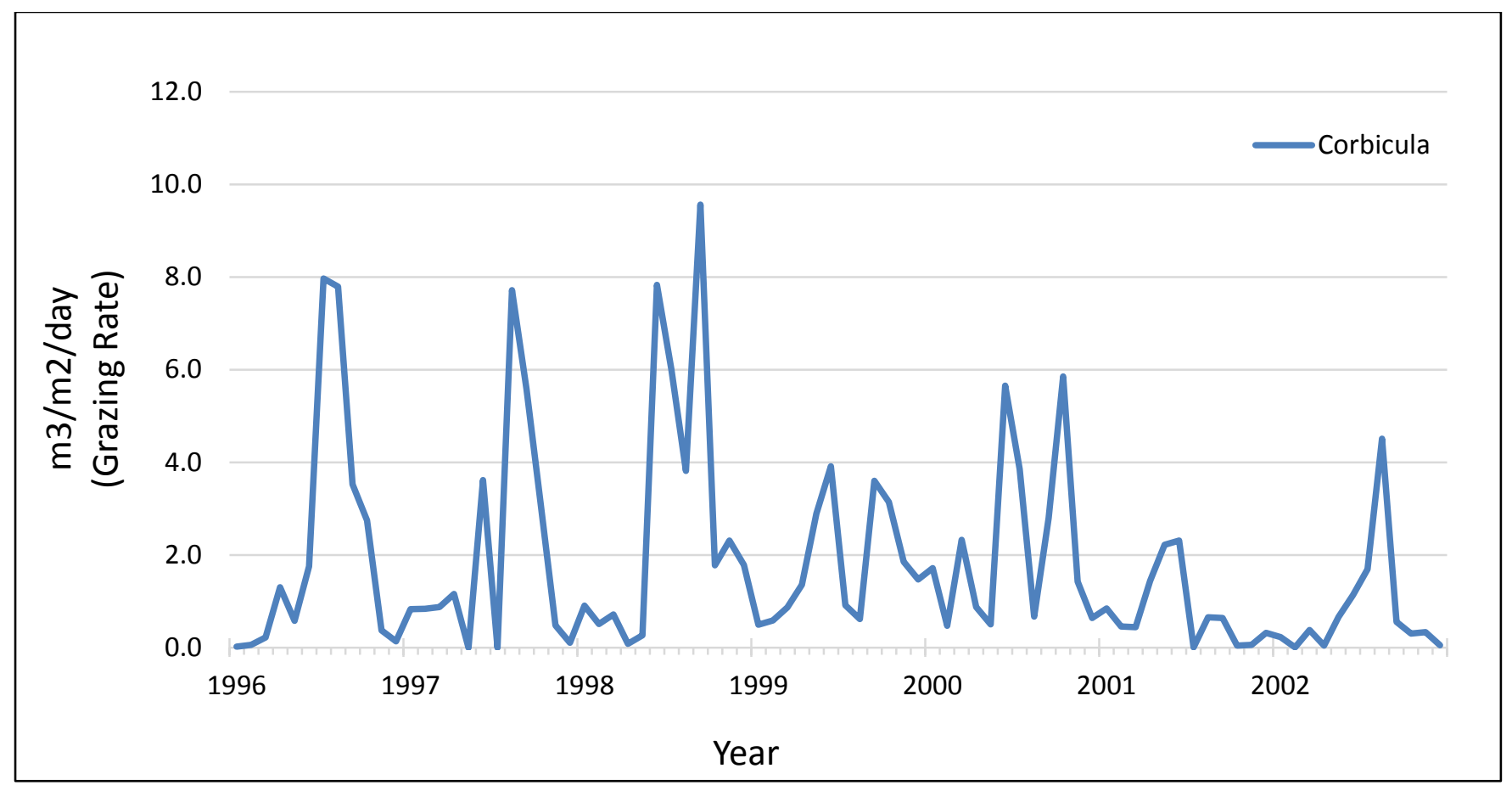

Figure 63. Graph showing grazing rate at station D28 from 1996-2002. For station locations refer to table 1.

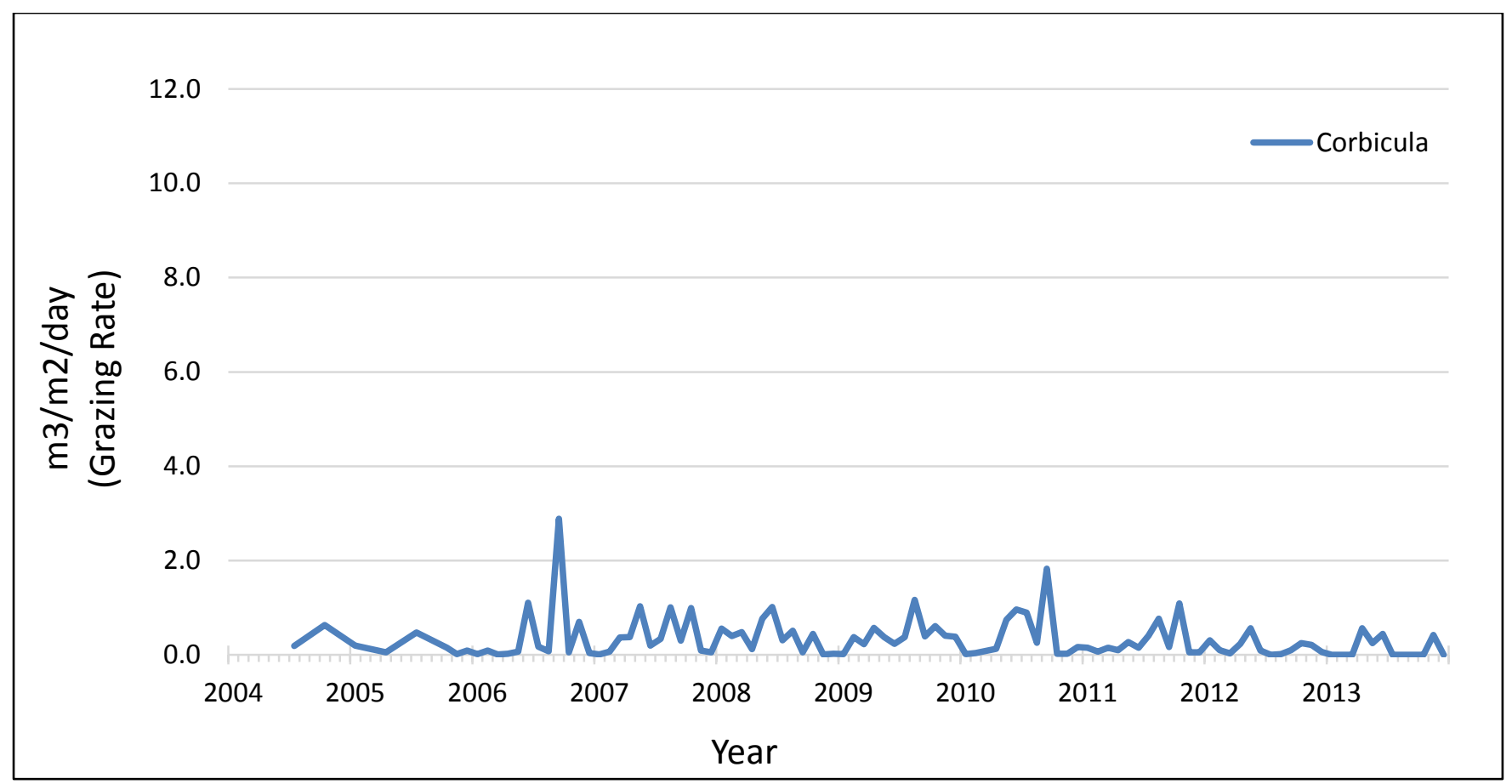

Figure 64. Graph showing grazing rate at station D28 from 2004-2013. For station locations refer to table 1. 


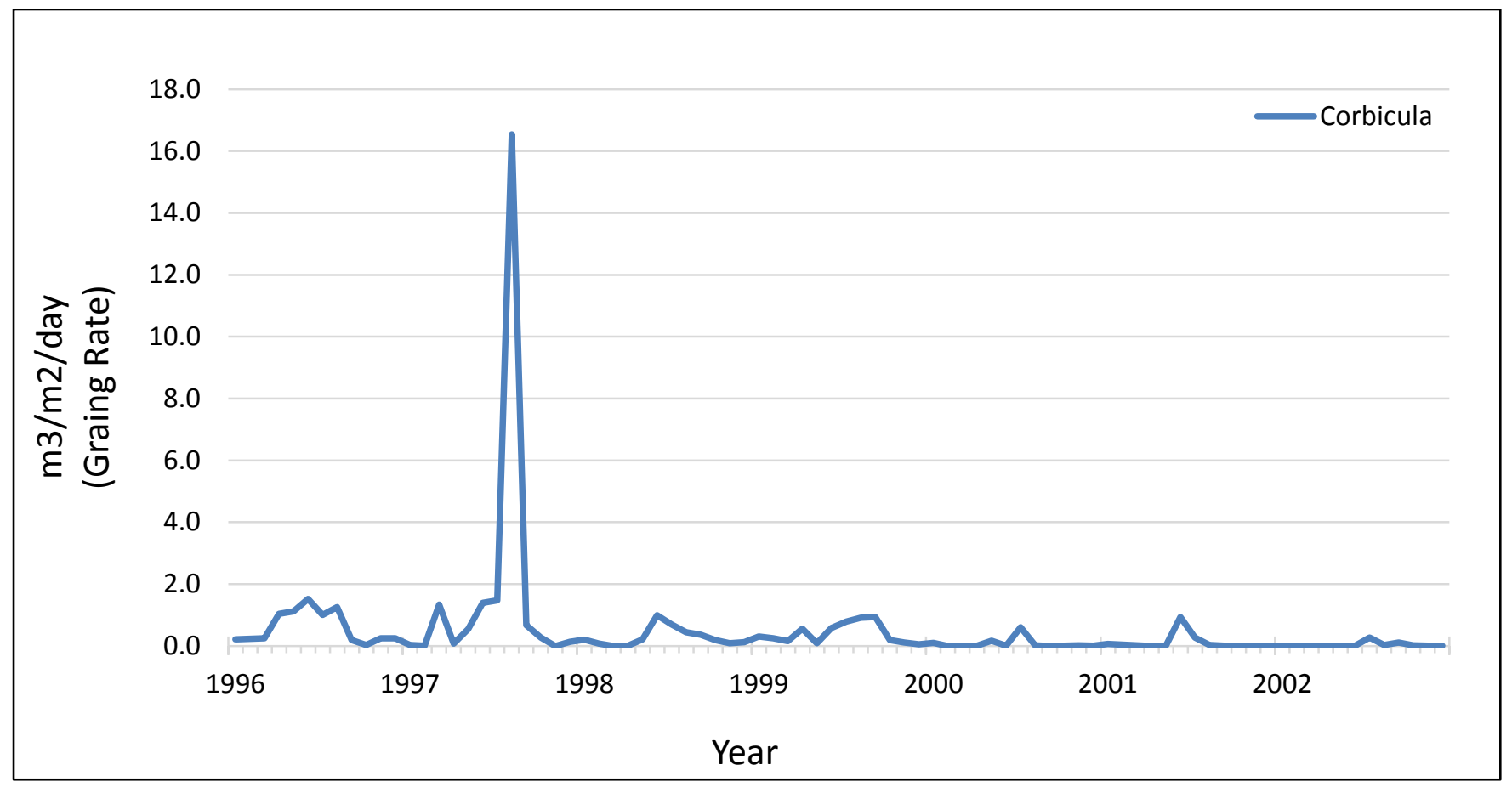

Figure 65. Graph showing grazing rate at station P8 from 1996-2002. For station locations refer to table 1.

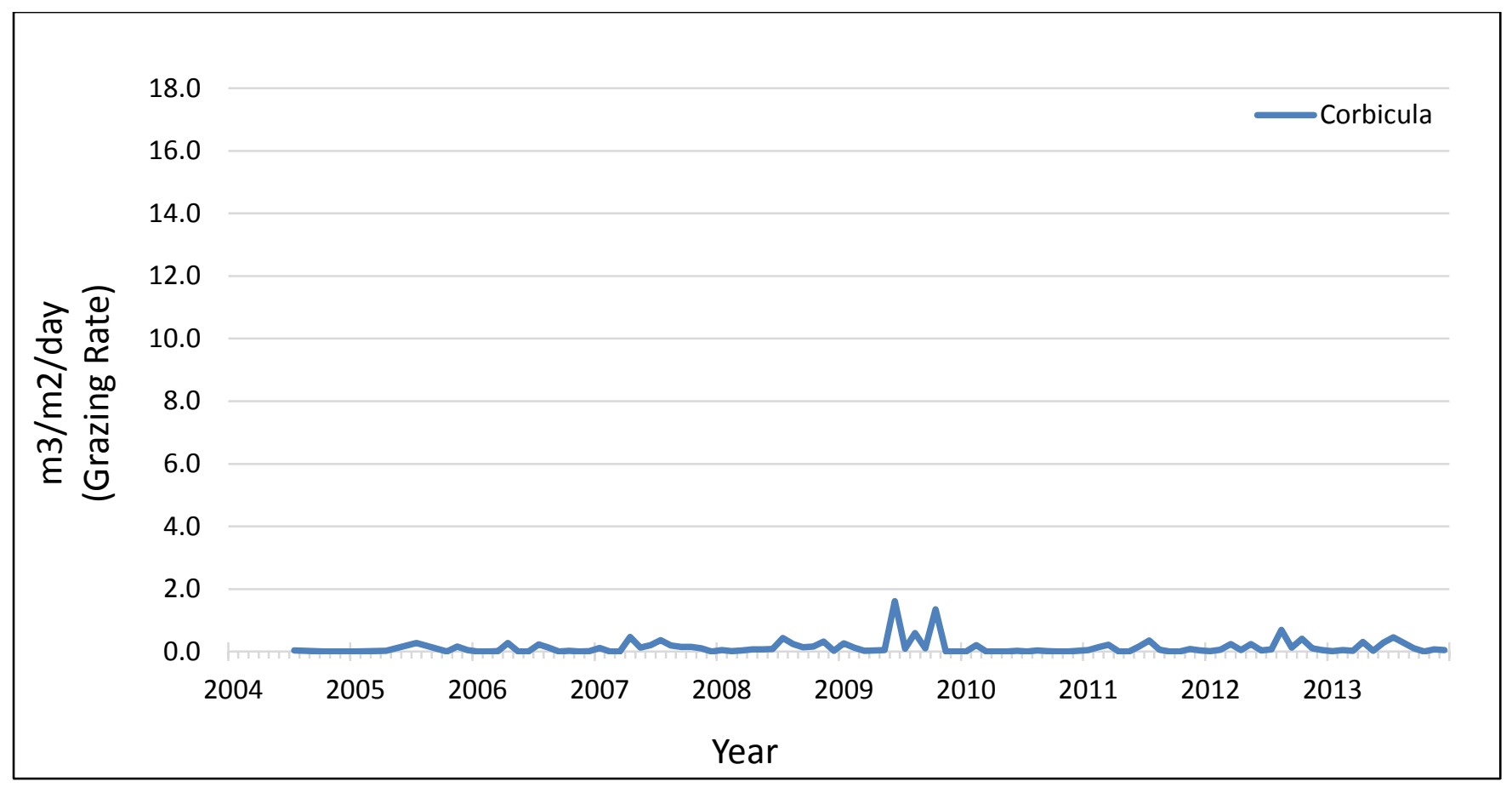

Figure 66. Graph showing grazing rate at station P8 from 2004-2013. For station locations refer to table 1. 


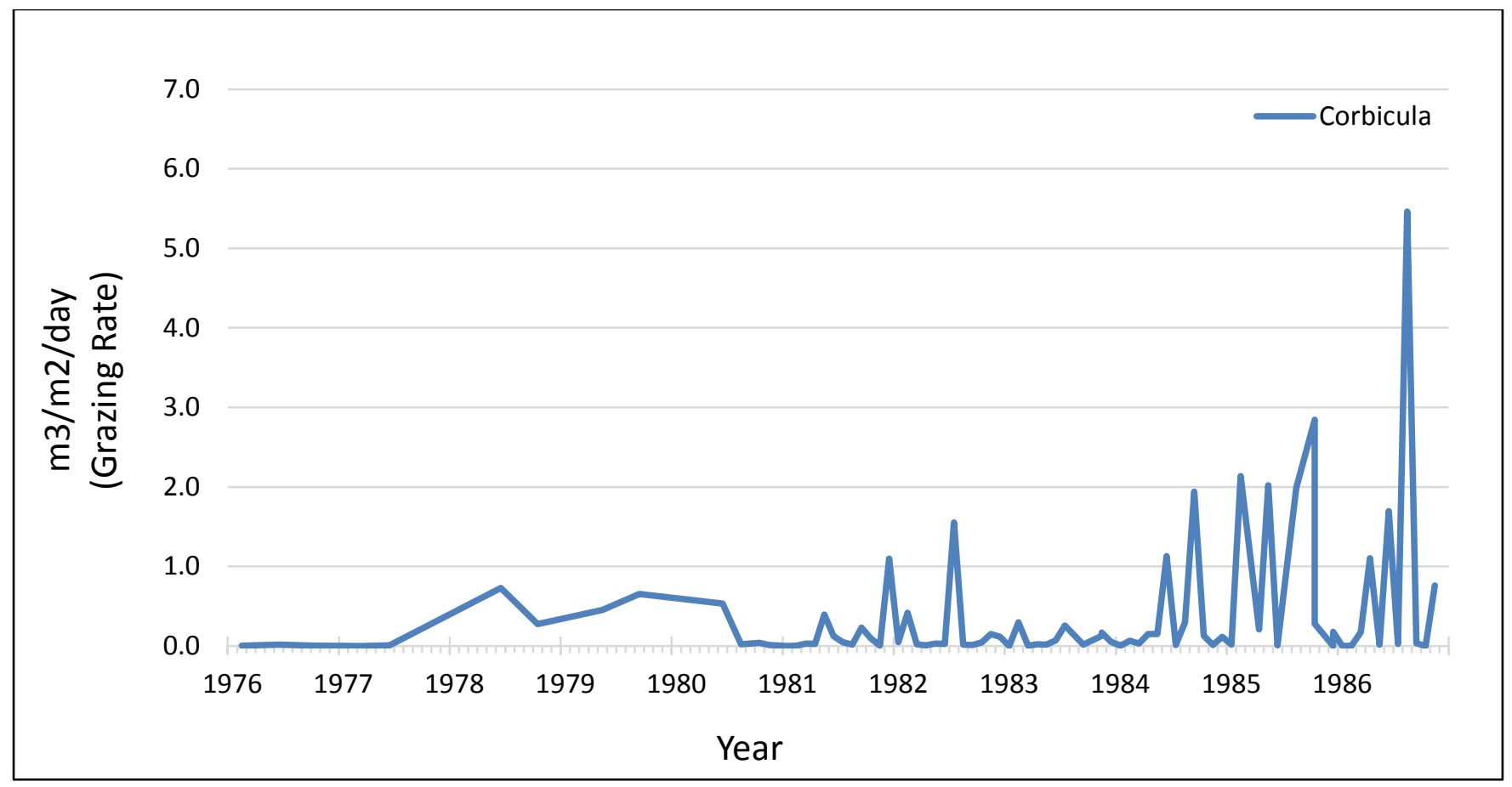

Figure 67. Graph showing grazing rate at station D4C from 1976-1986. For station locations refer to table 1.

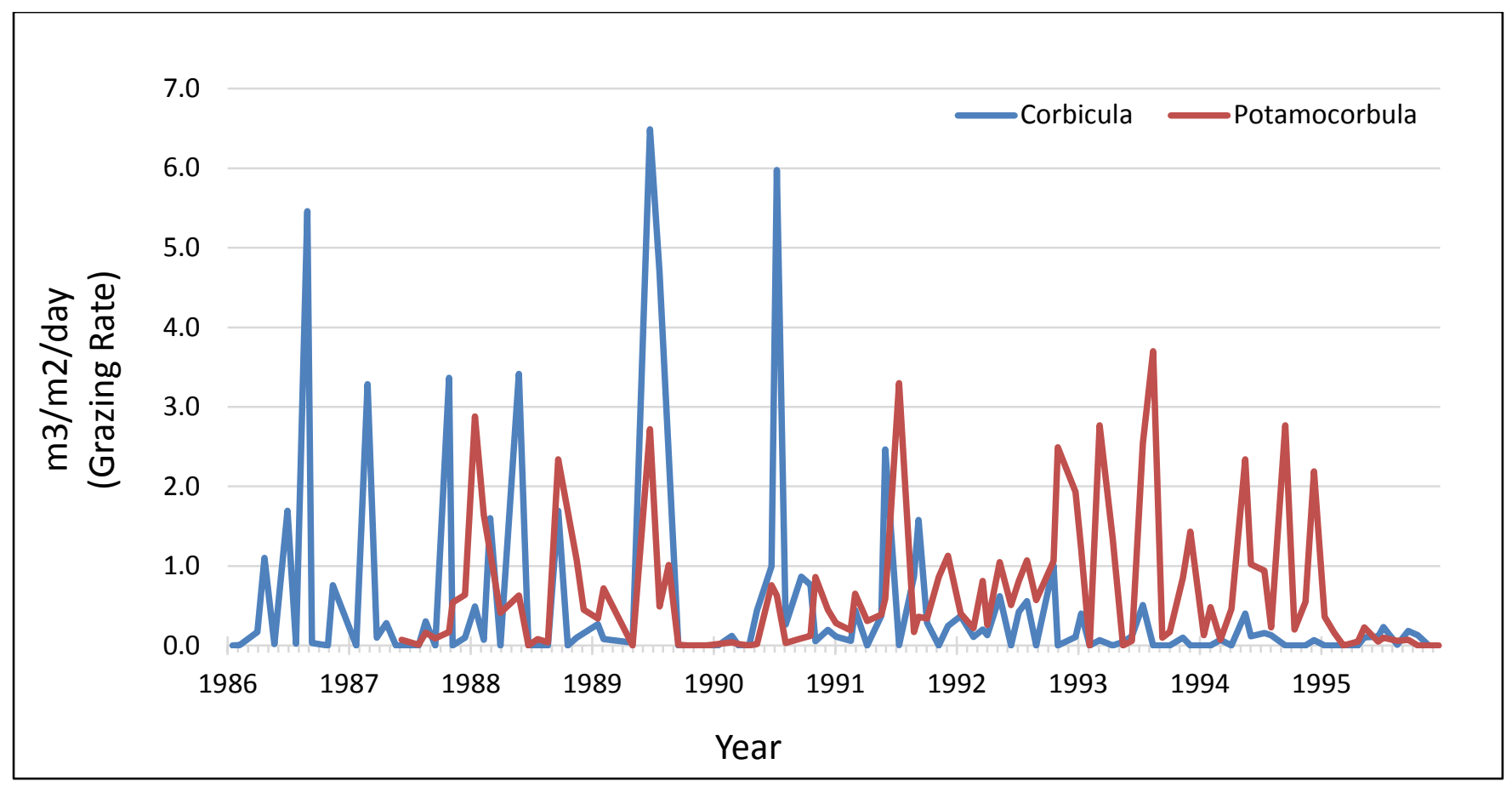

Figure 68. Graph showing grazing rate at station D4C from 1986-1995. For station locations refer to table 1. 


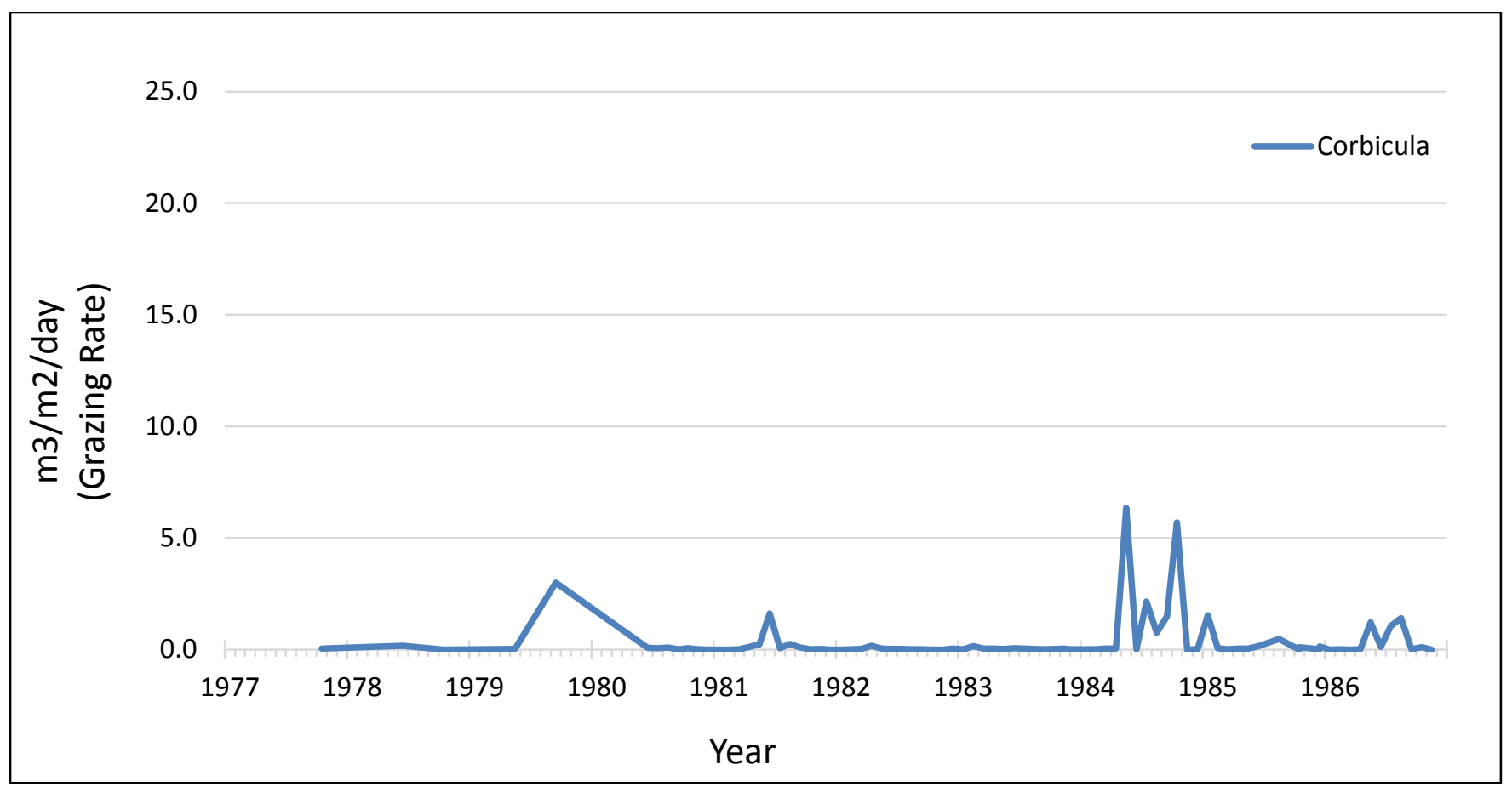

Figure 69. Graph showing grazing rate at station D4L from 1977-1986. For station locations refer to table 1.

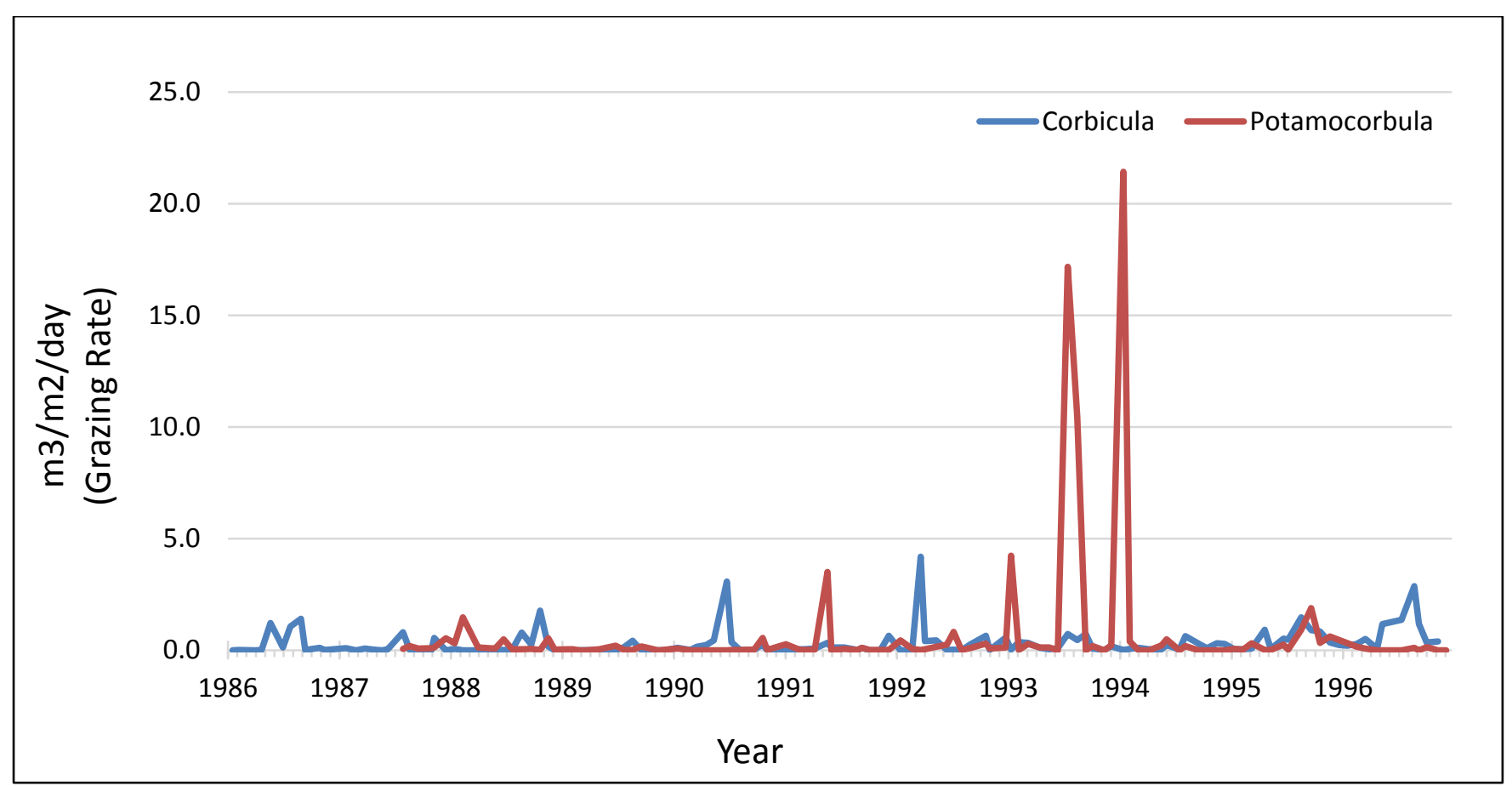

Figure 70. Graph showing grazing rate at station D4L from 1986-1996. For station locations refer to table 1. 


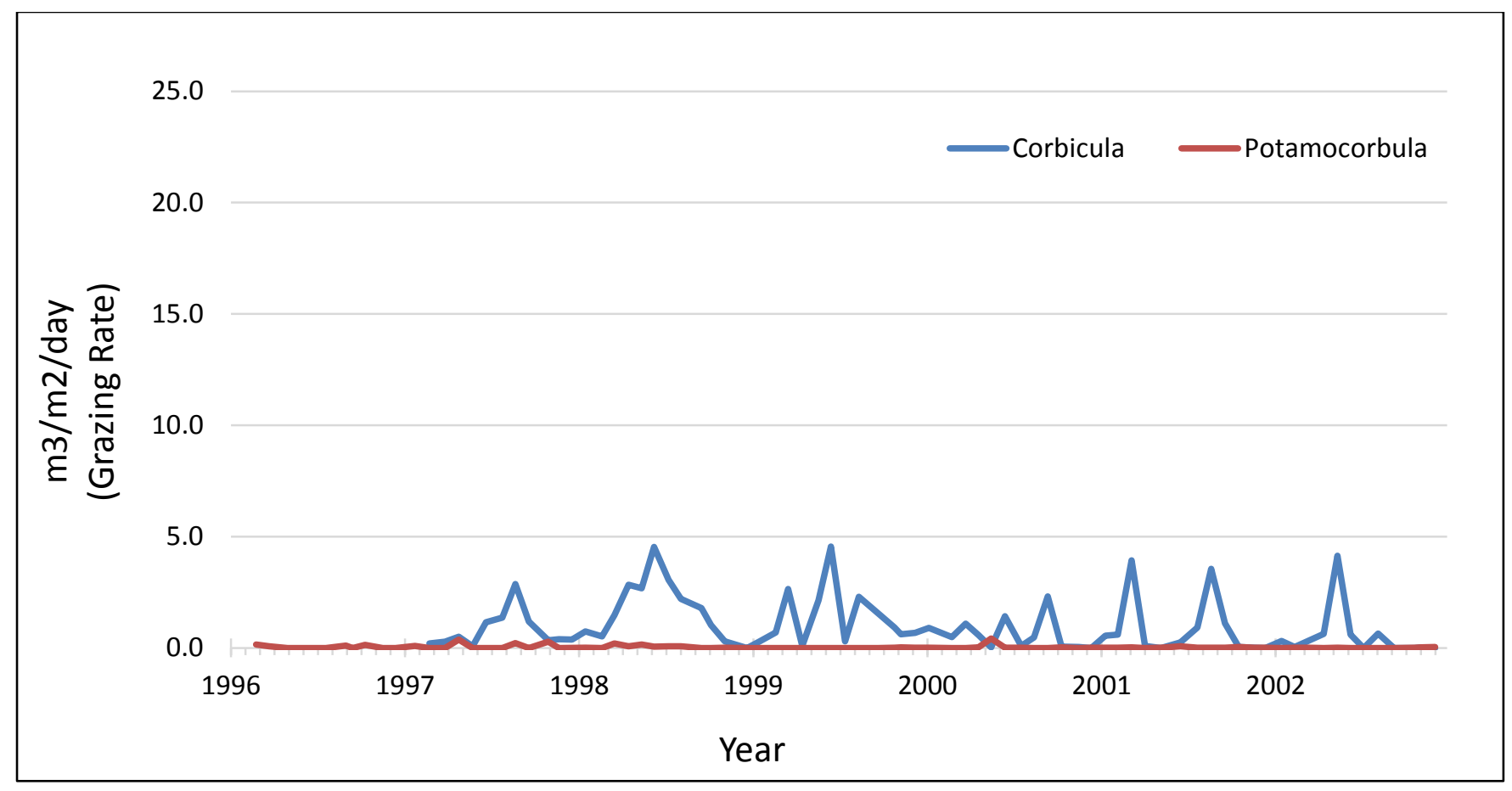

Figure 71. Graph showing grazing rate at station D4L from 1996-2002. For station locations refer to table 1.

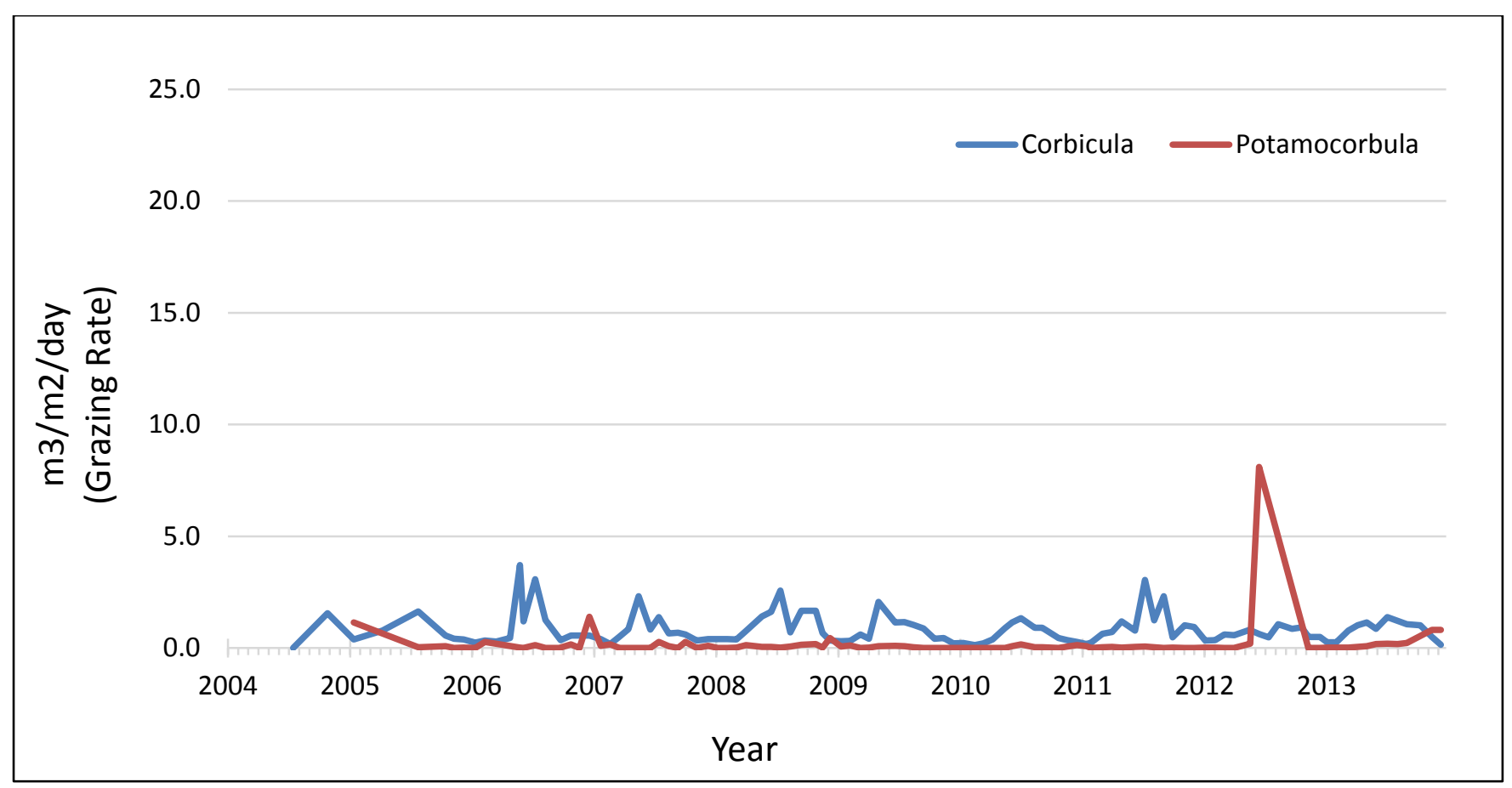

Figure 72. Graph showing grazing rate at station D4L from 2004-2013. For station locations refer to table 1. 


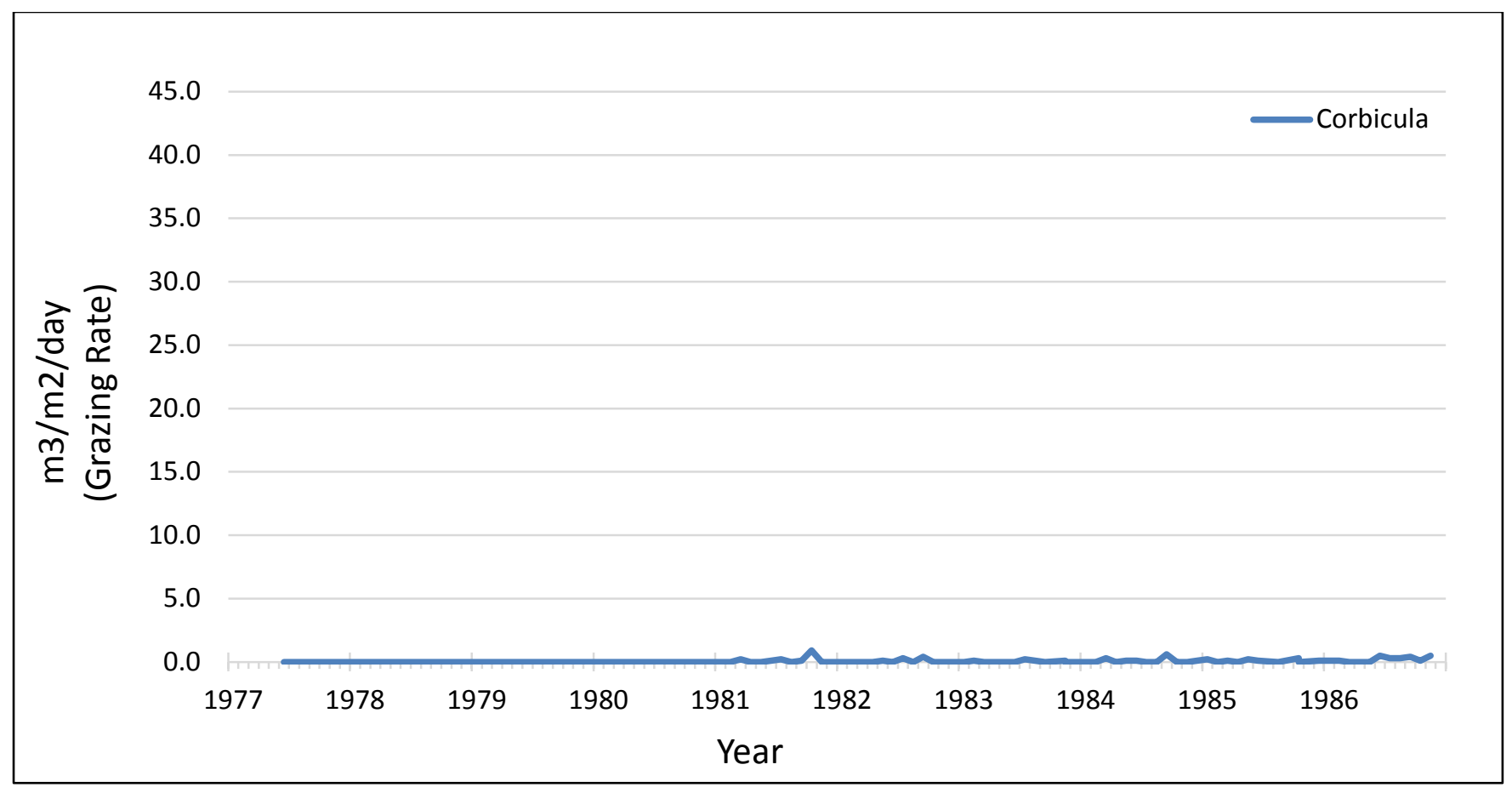

Figure 73. Graph showing grazing rate at station D4R from 1977-1986. For station locations refer to table 1.

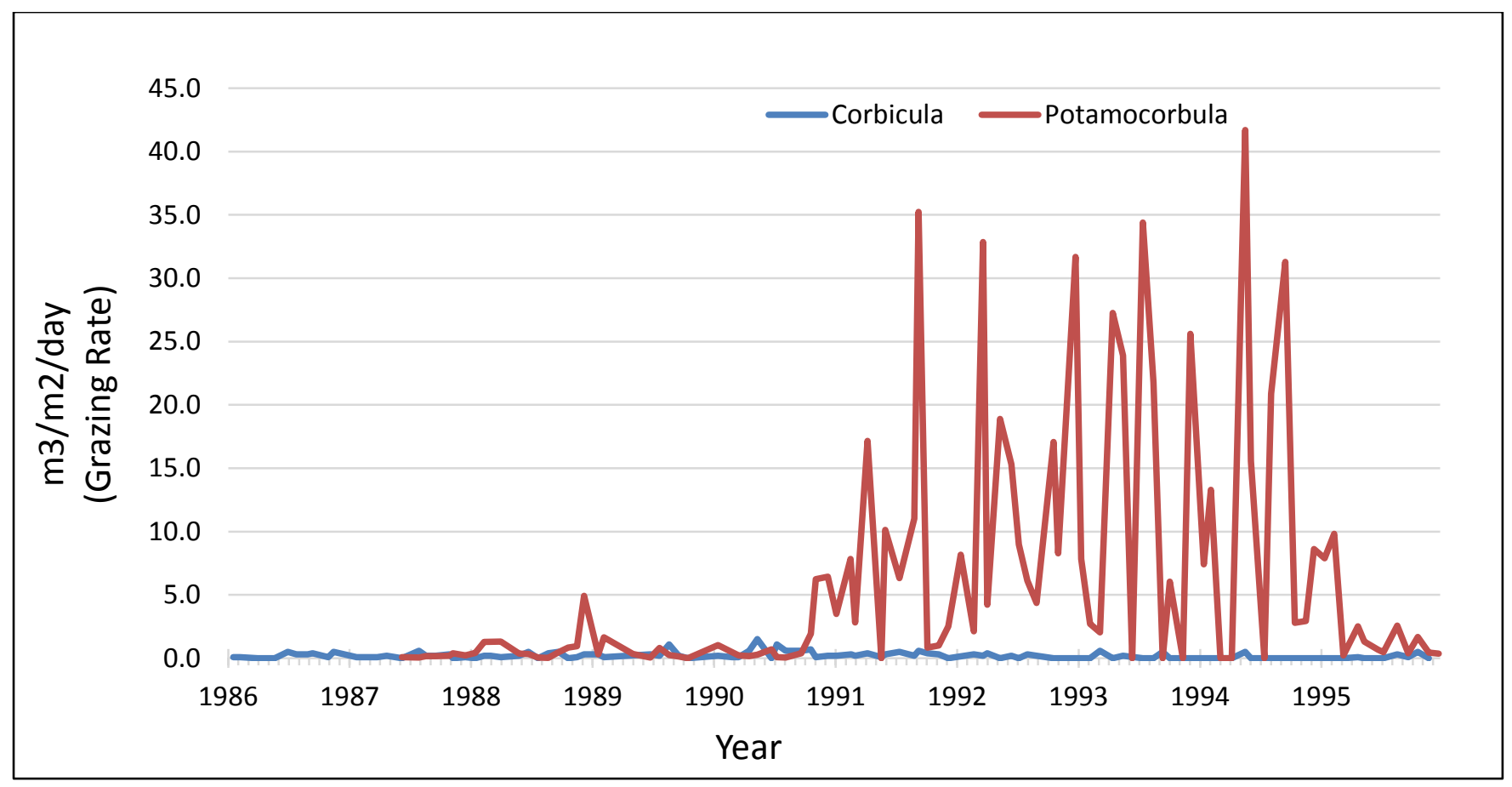

Figure 74. Graph showing grazing rate at station D4R from 1986-1995. For station locations refer to table 1. 


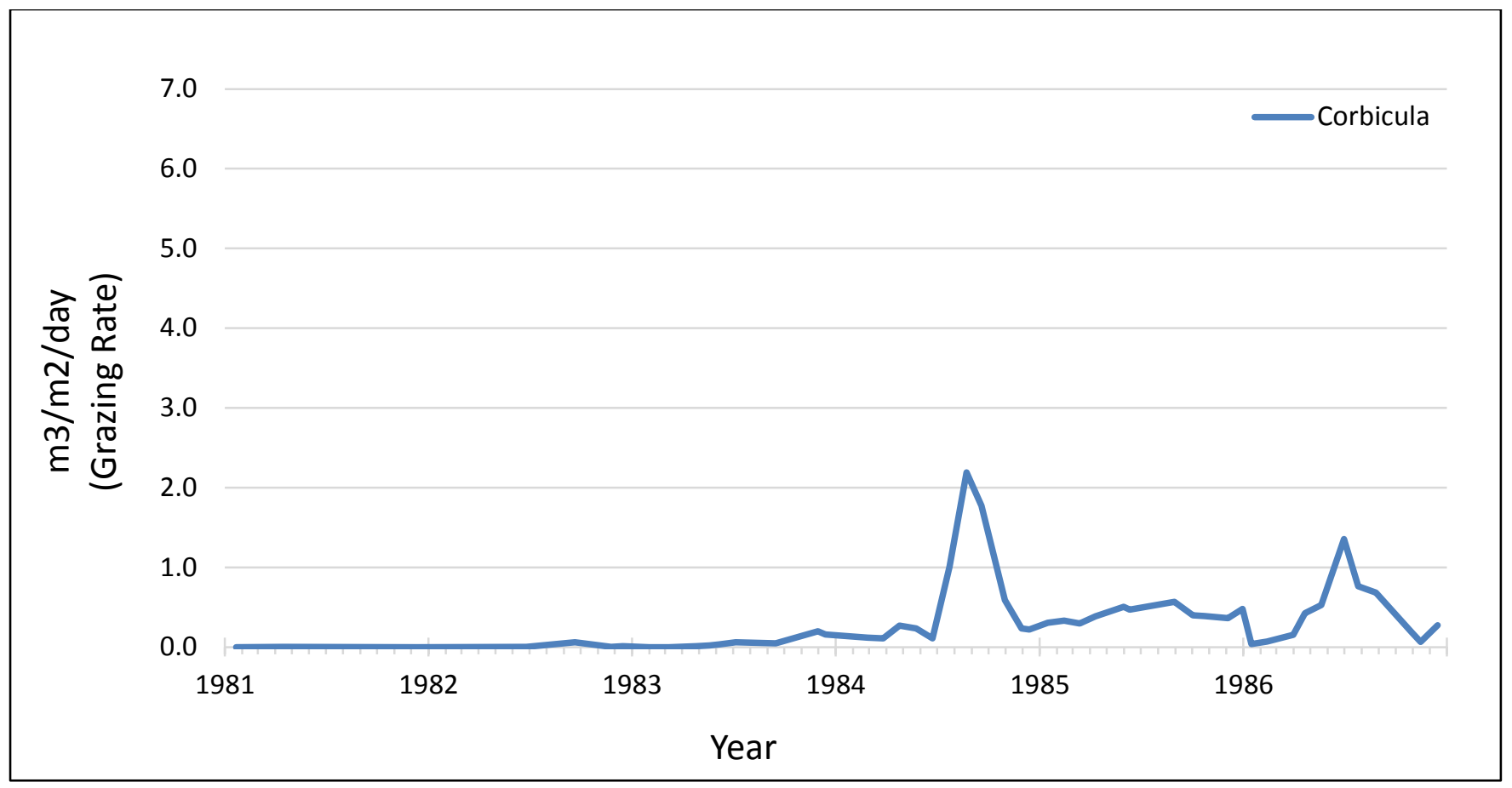

Figure 75. Graph showing grazing rate at station D7 from 1981-1986. For station locations refer to table 1.

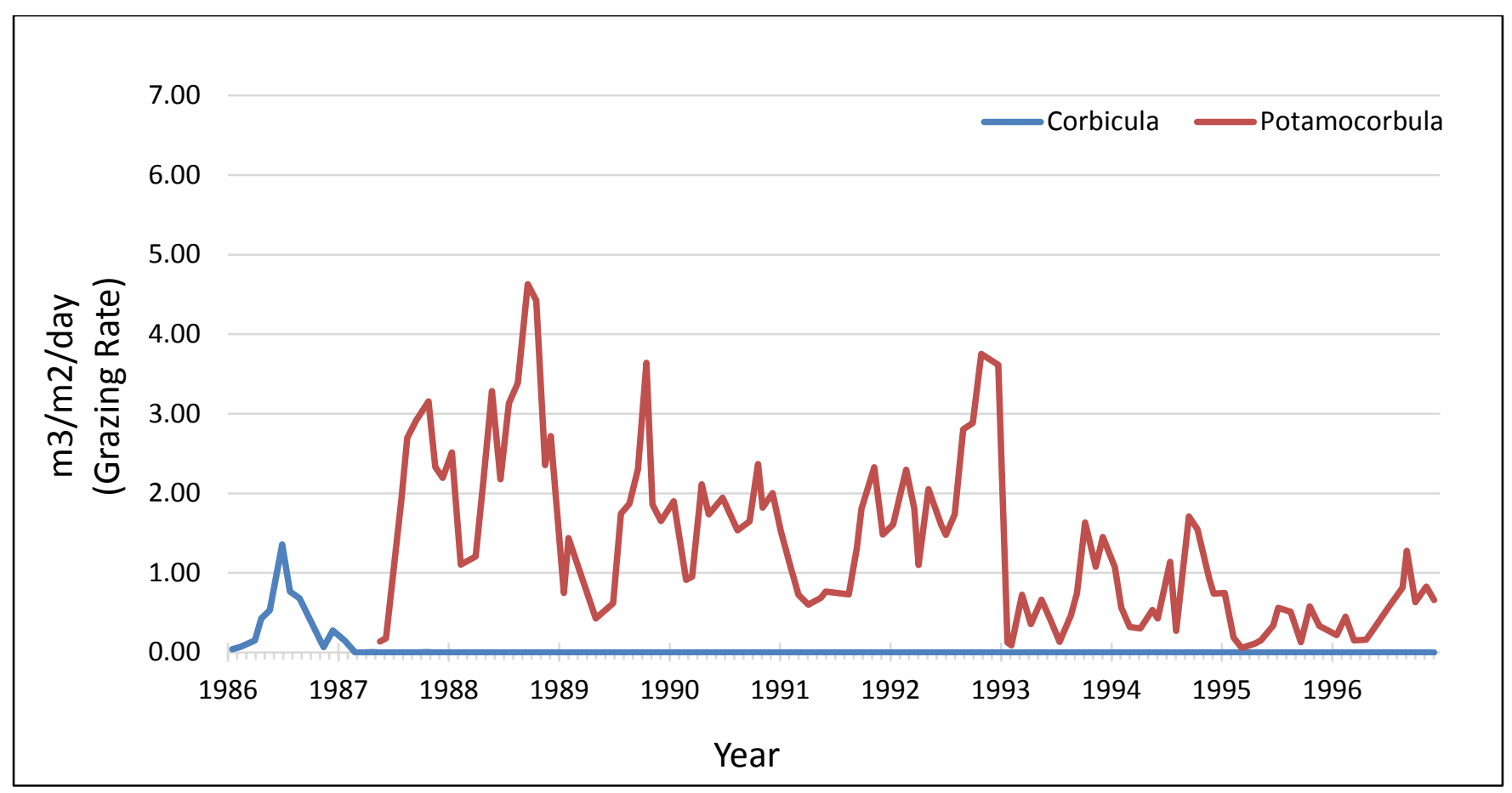

Figure 76. Graph showing grazing rate at station D7 from 1986-1996. For station locations refer to table 1. 


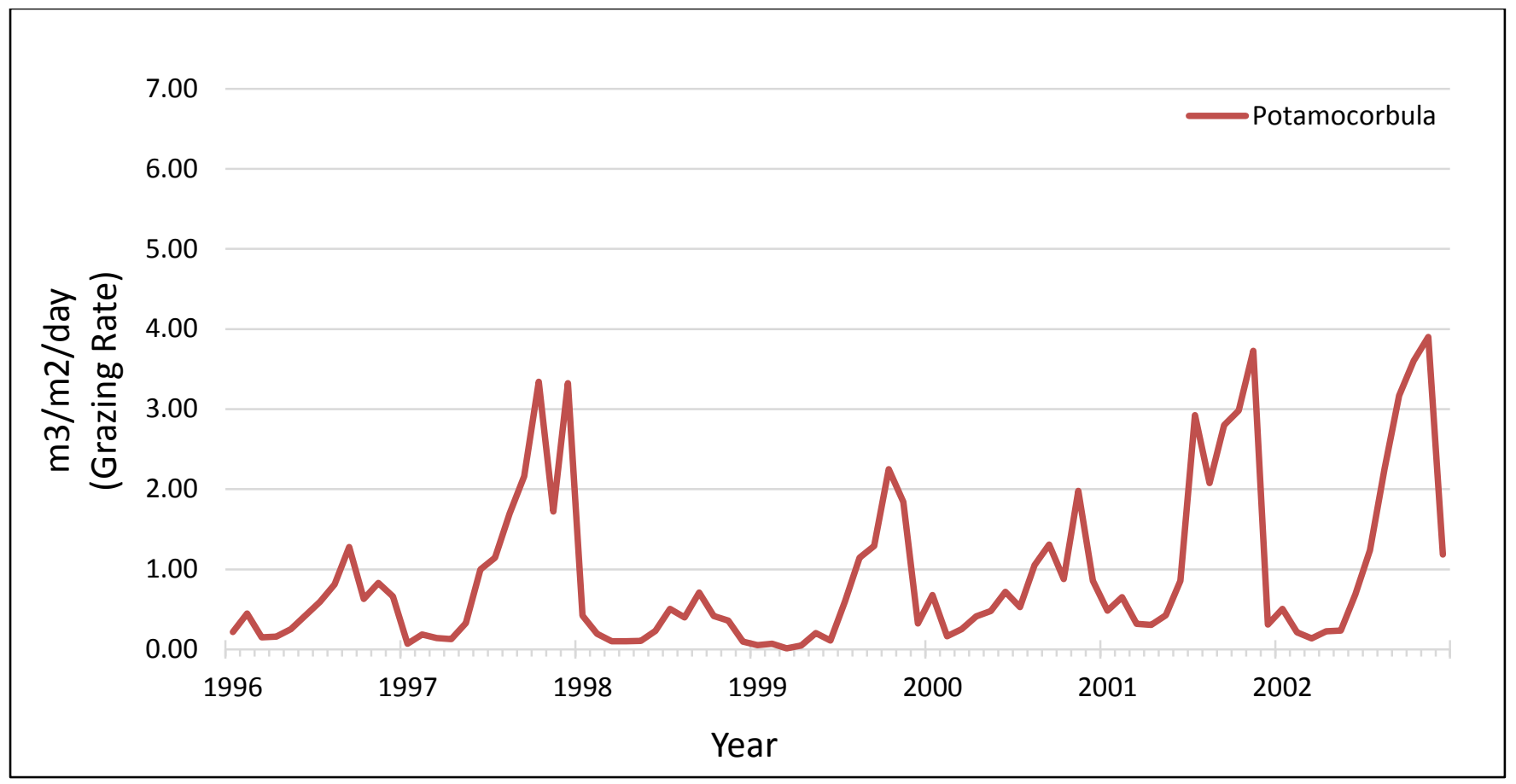

Figure 77. Graph showing grazing rate at station D7 from 1996-2003. For station locations refer to table 1.

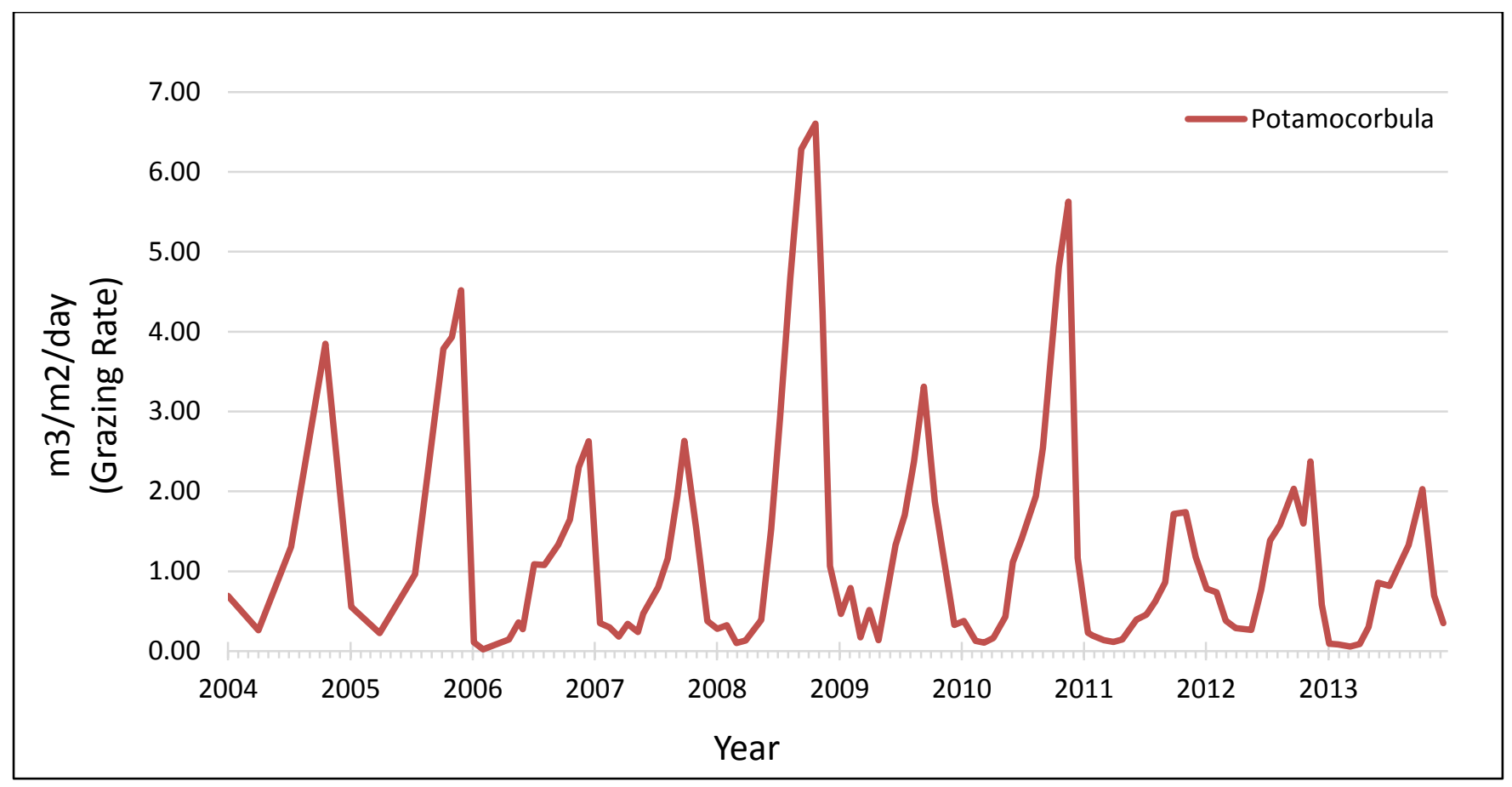

Figure 78. Graph showing grazing rate at station D7 from 2003-2013. For station locations refer to table 1. 


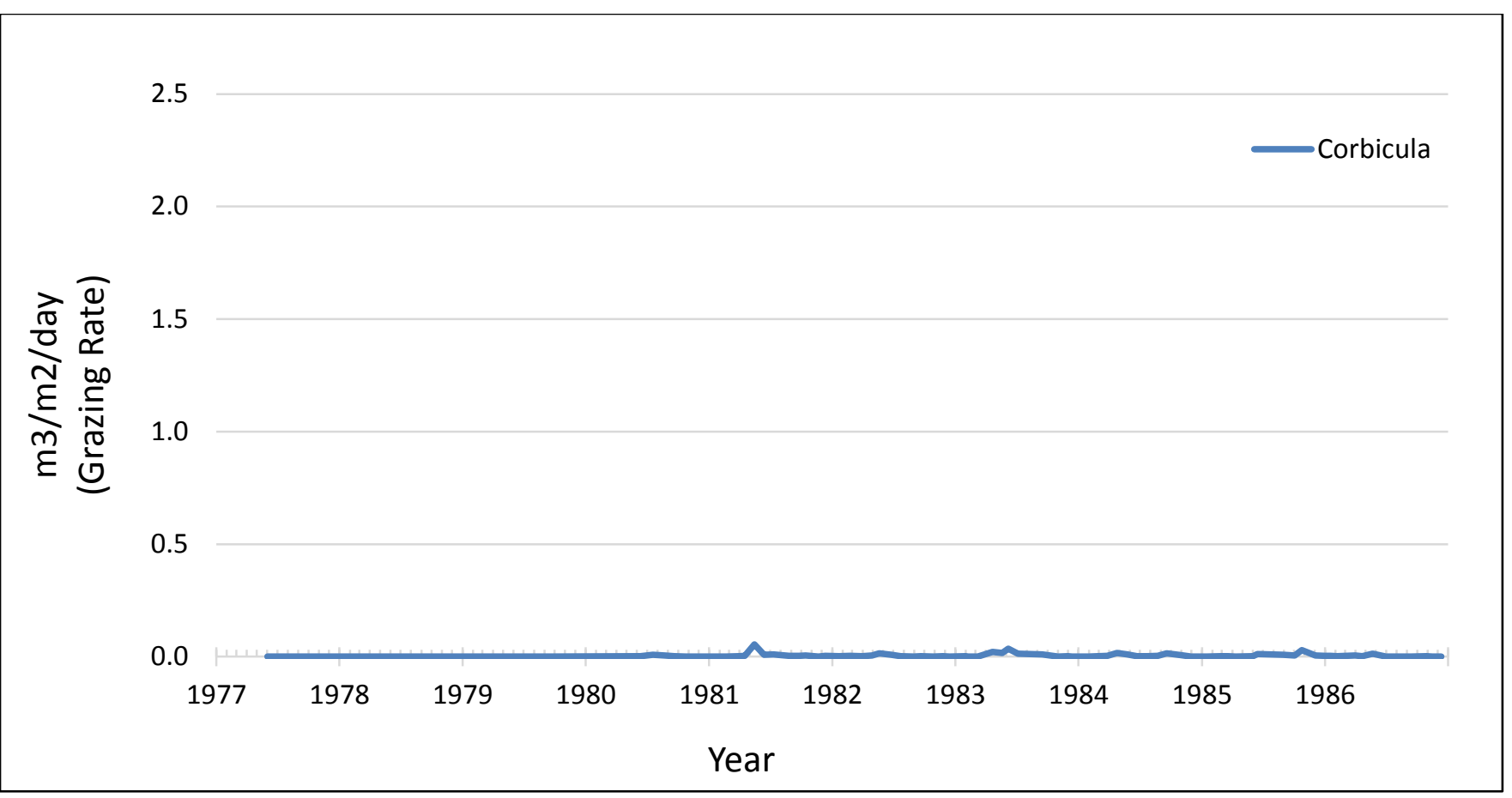

Figure 79. Graph showing grazing rate at station D11 from 1977-1986. For station locations refer to table 1.

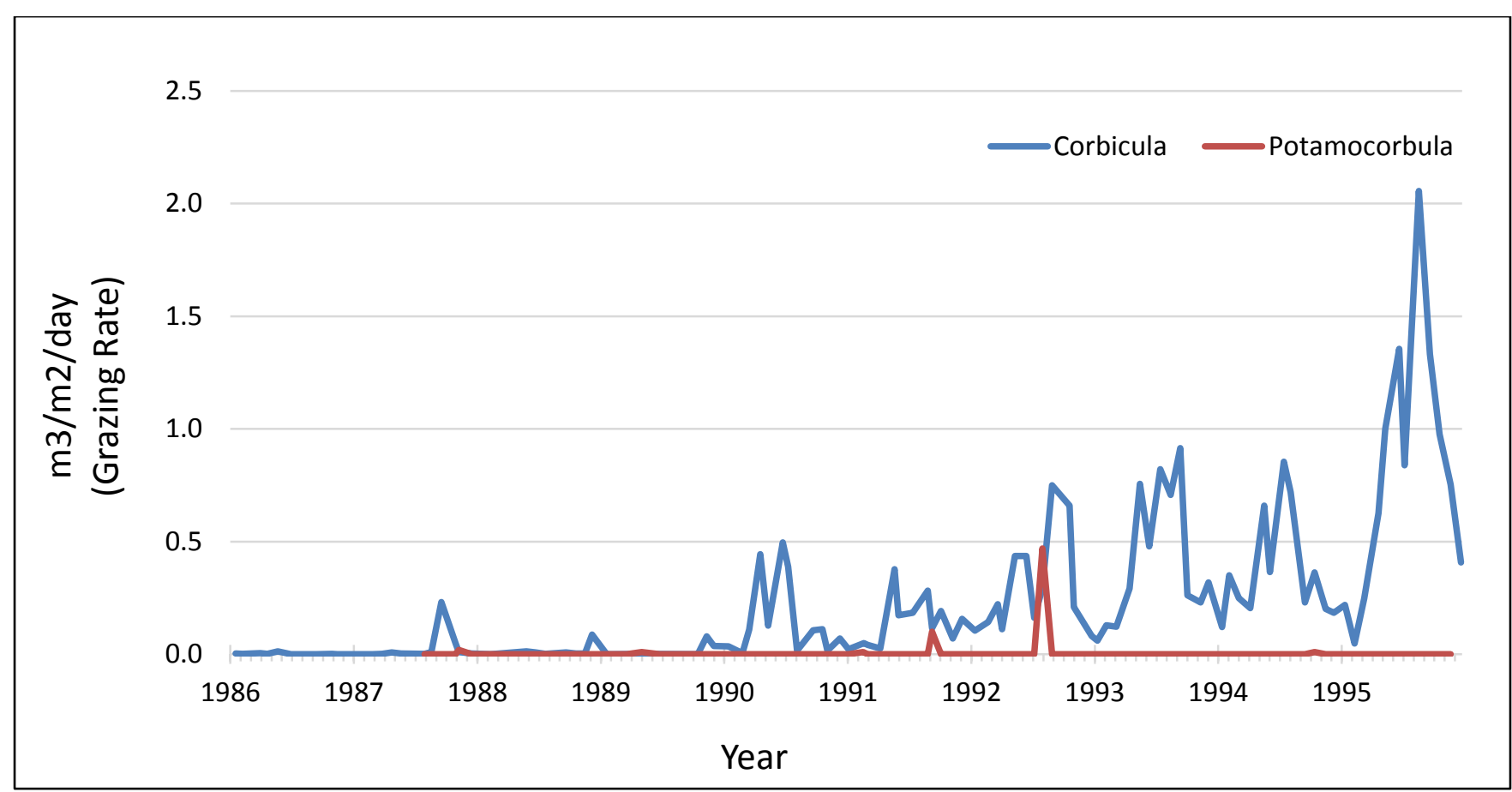

Figure 80. Graph showing grazing rate at station D11 from 1986-1995. For station locations refer to table 1. 


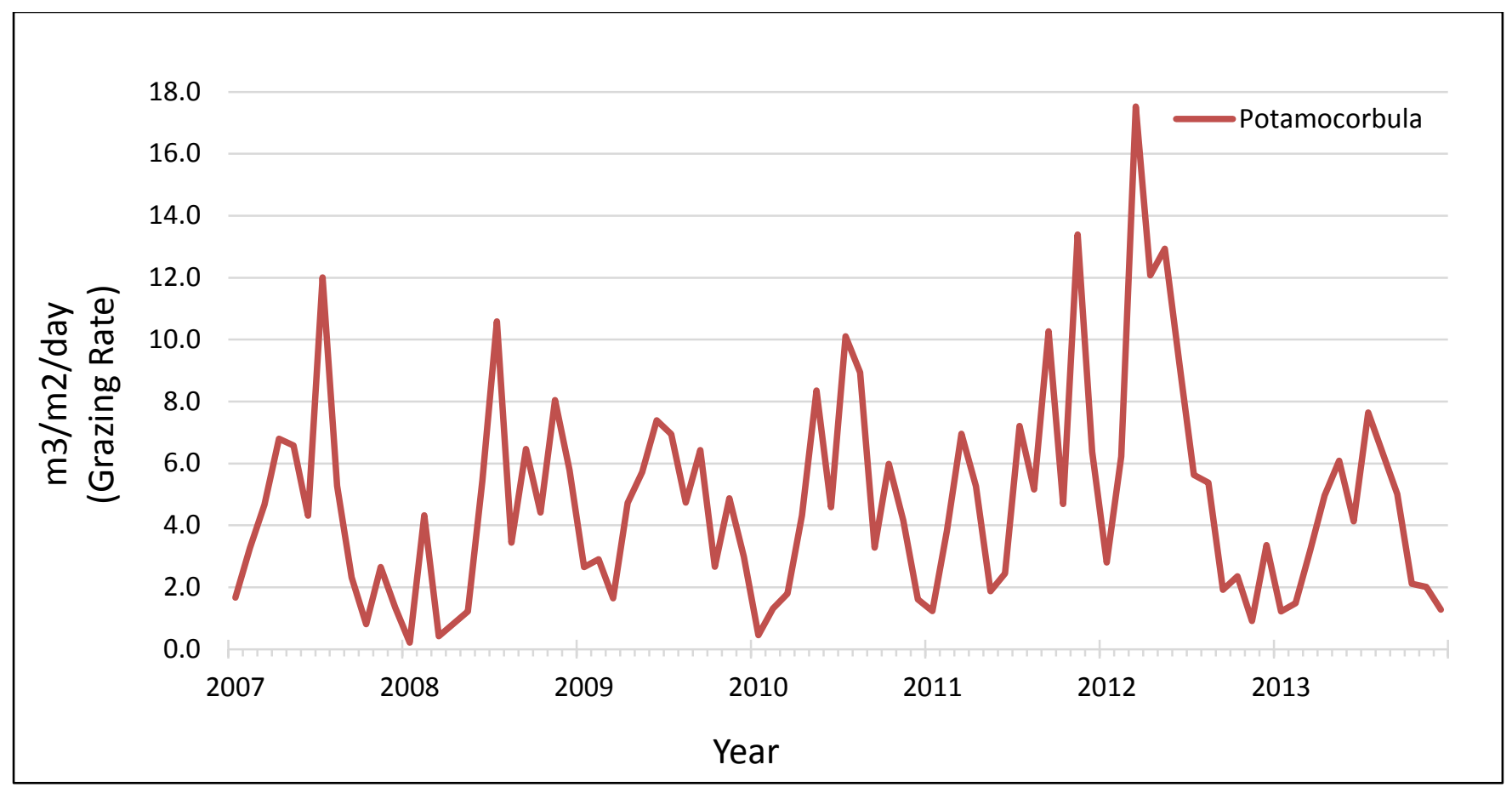

Figure 81. Graph showing grazing rate at station D6 from 2007-2013. For station locations refer to table 1.

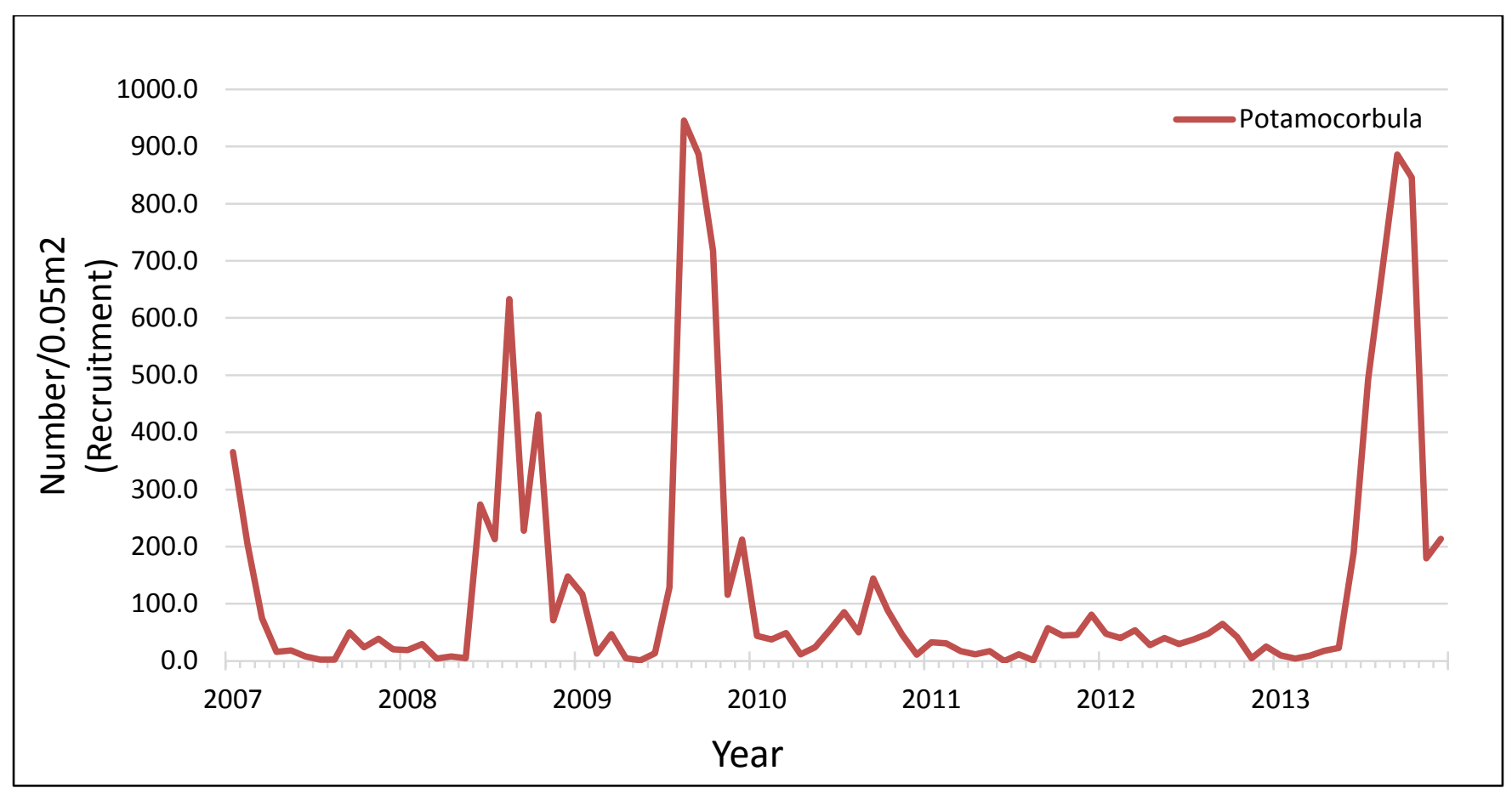

Figure 82. Graph showing recruitment at station D6 from 2007-2013. For station locations refer to table 1. 


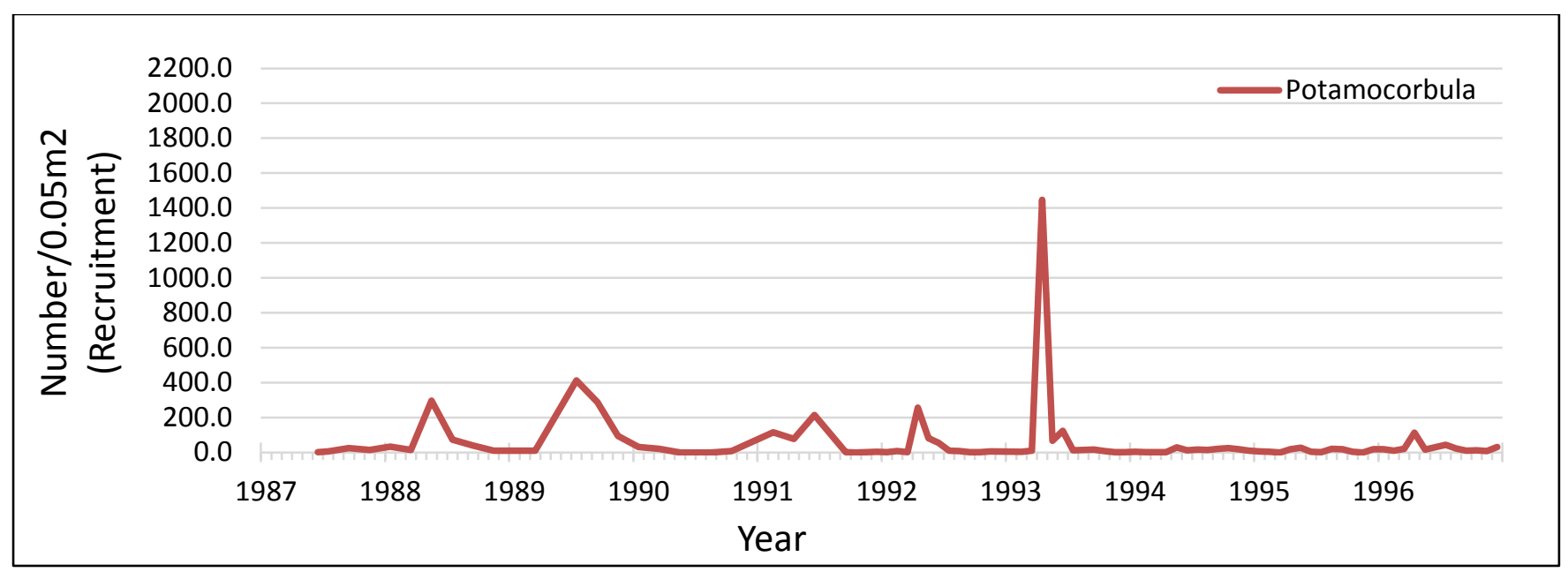

Figure 83. Graph showing recruitment at station D41A from 1987-1996. For station locations refer to table 1.

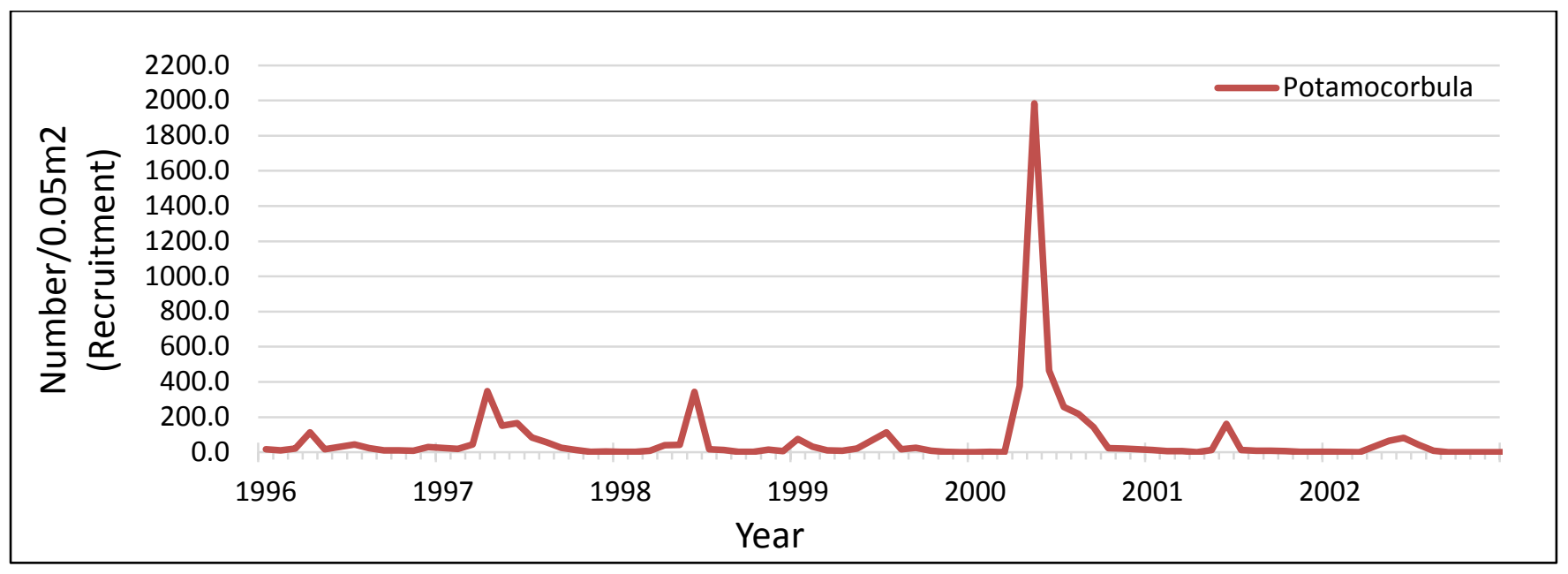

Figure 84. Graph showing recruitment at station D41A from 1996-2003. For station locations refer to table 1.

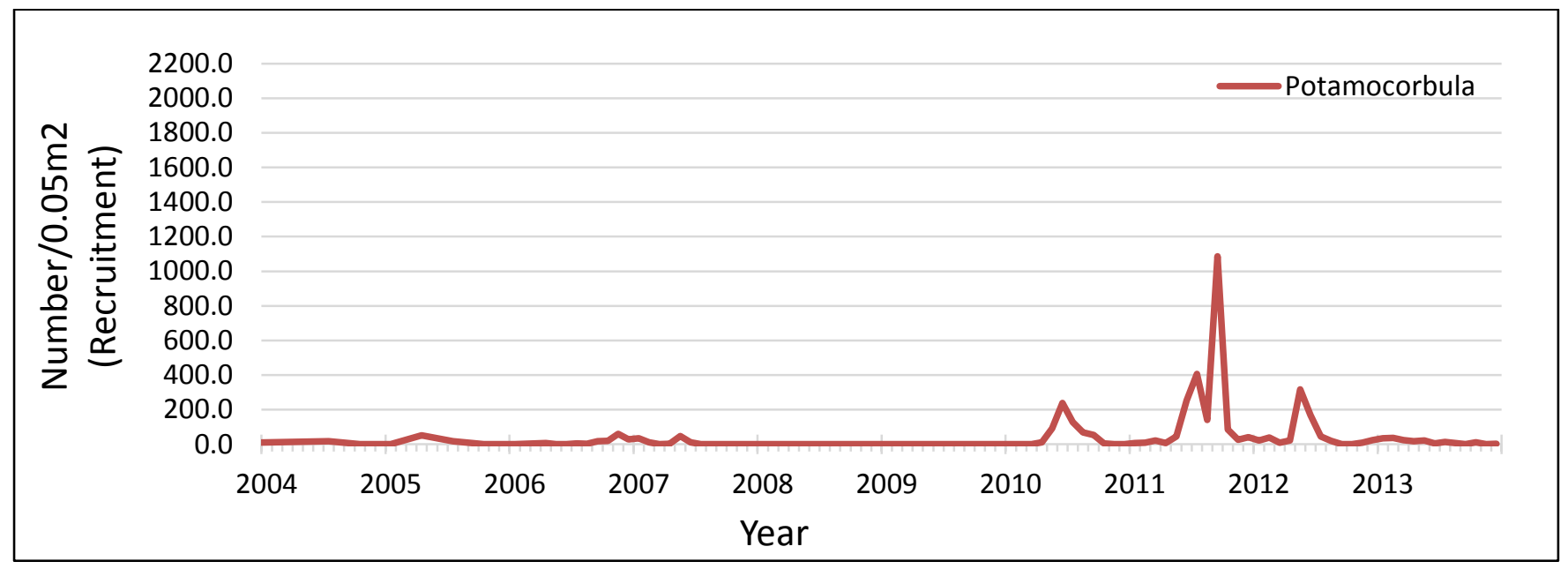

Figure 85. Graph showing recruitment at station D41A from 2003-2013. For station locations refer to table 1. 


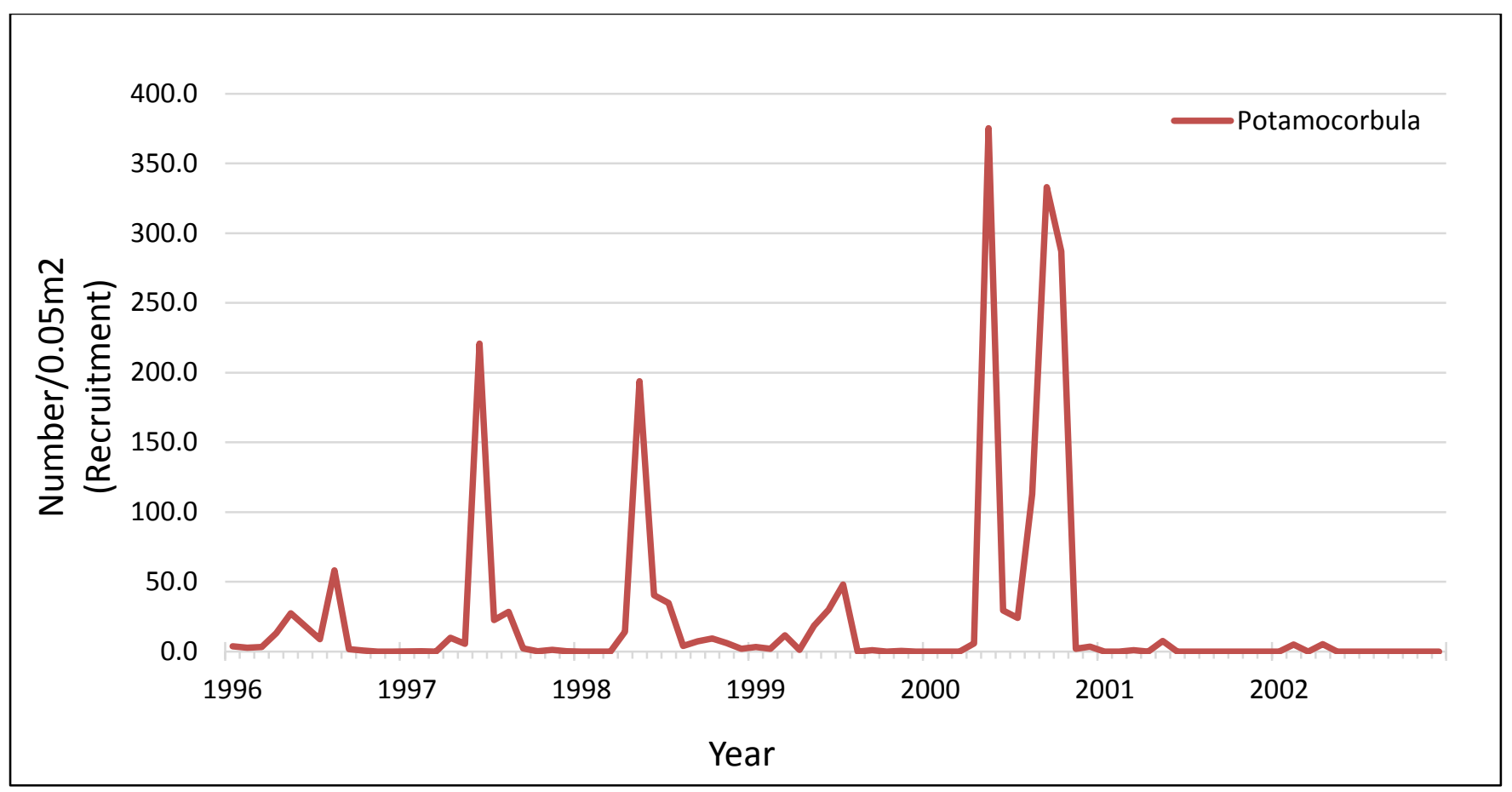

Figure 86. Graph showing recruitment at station D41C from 1996-2002. For station locations refer to table 1.

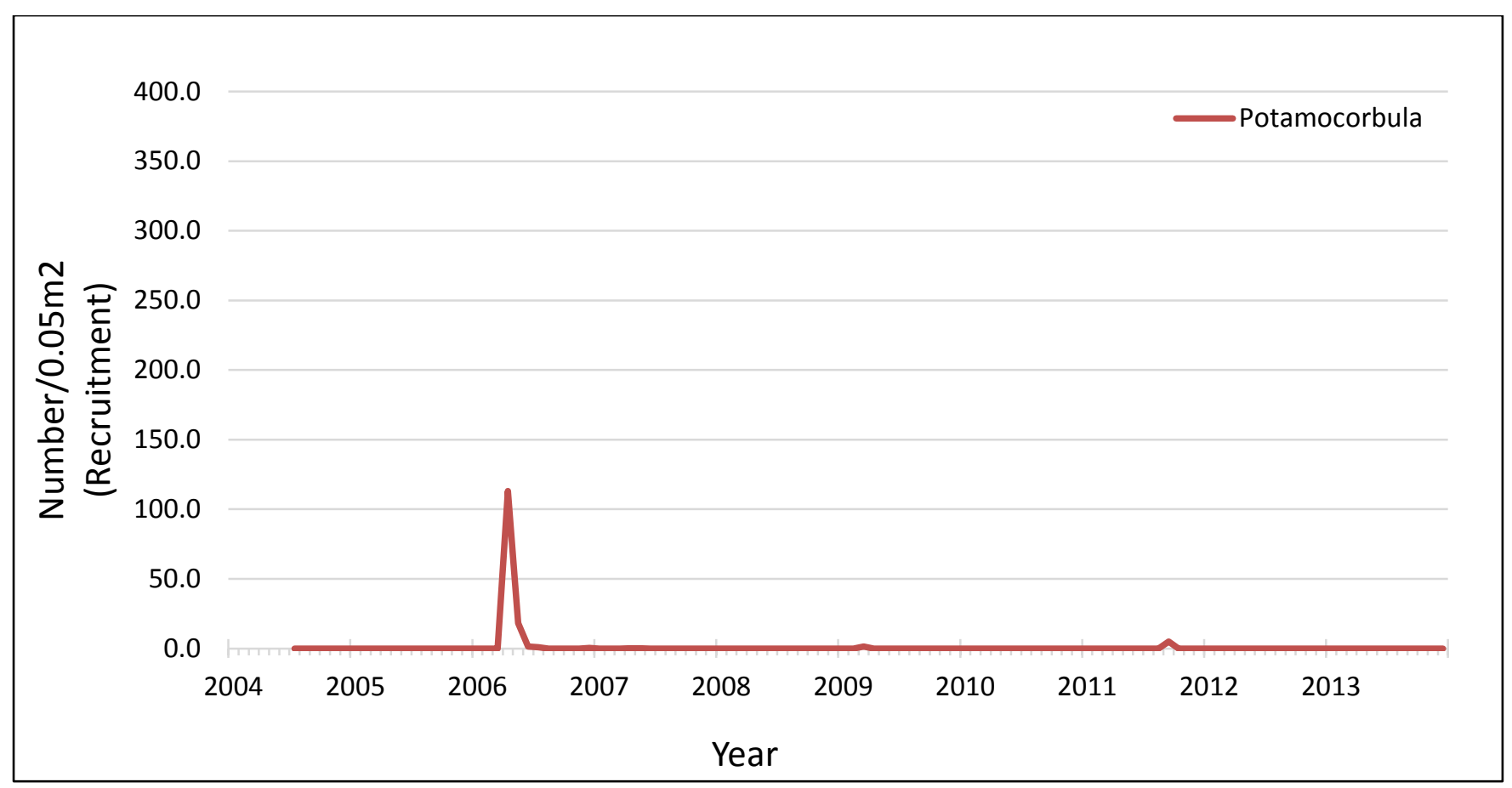

Figure 87. Graph showing recruitment at station D41C from 2004-2013. For station locations refer to table 1. 


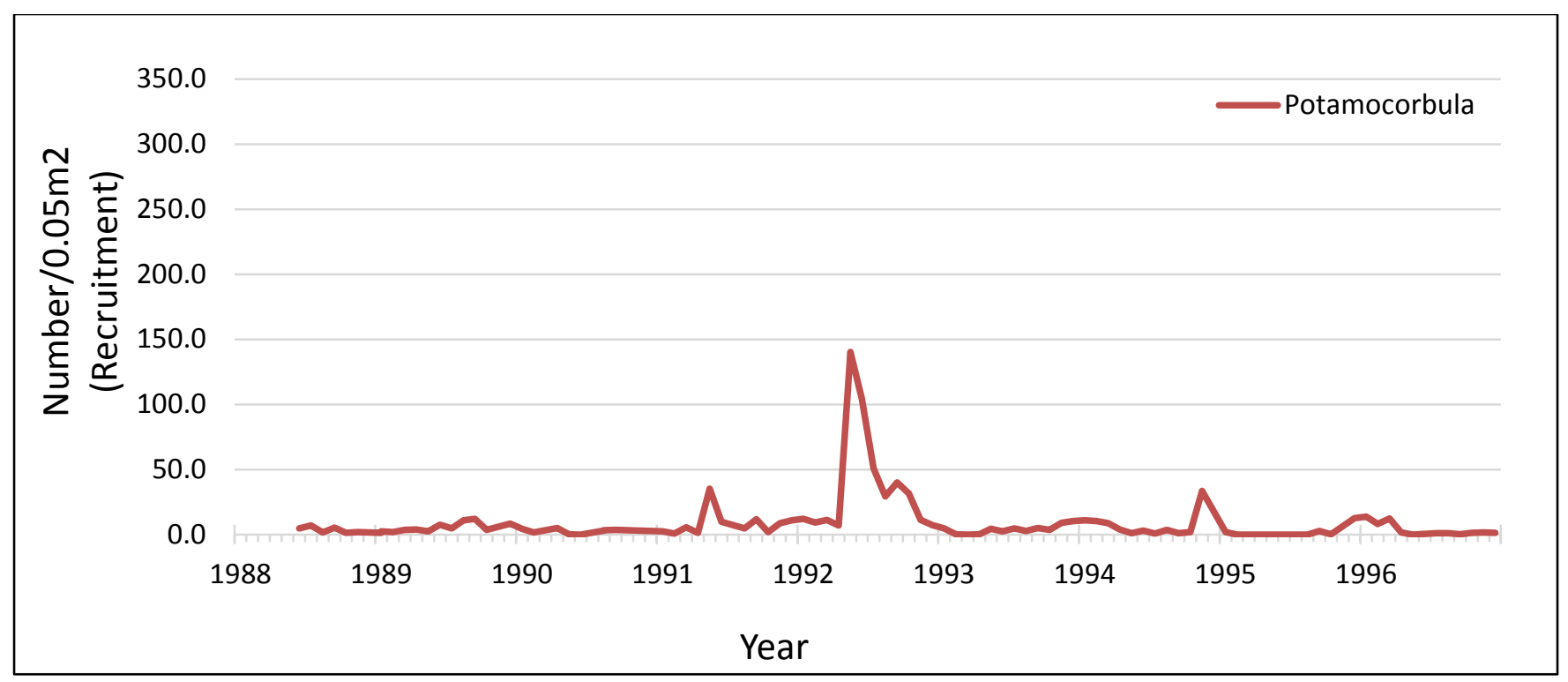

Figure 88. Graph showing recruitment at station 8.1 from 1988-1996. For station locations refer to table 1.

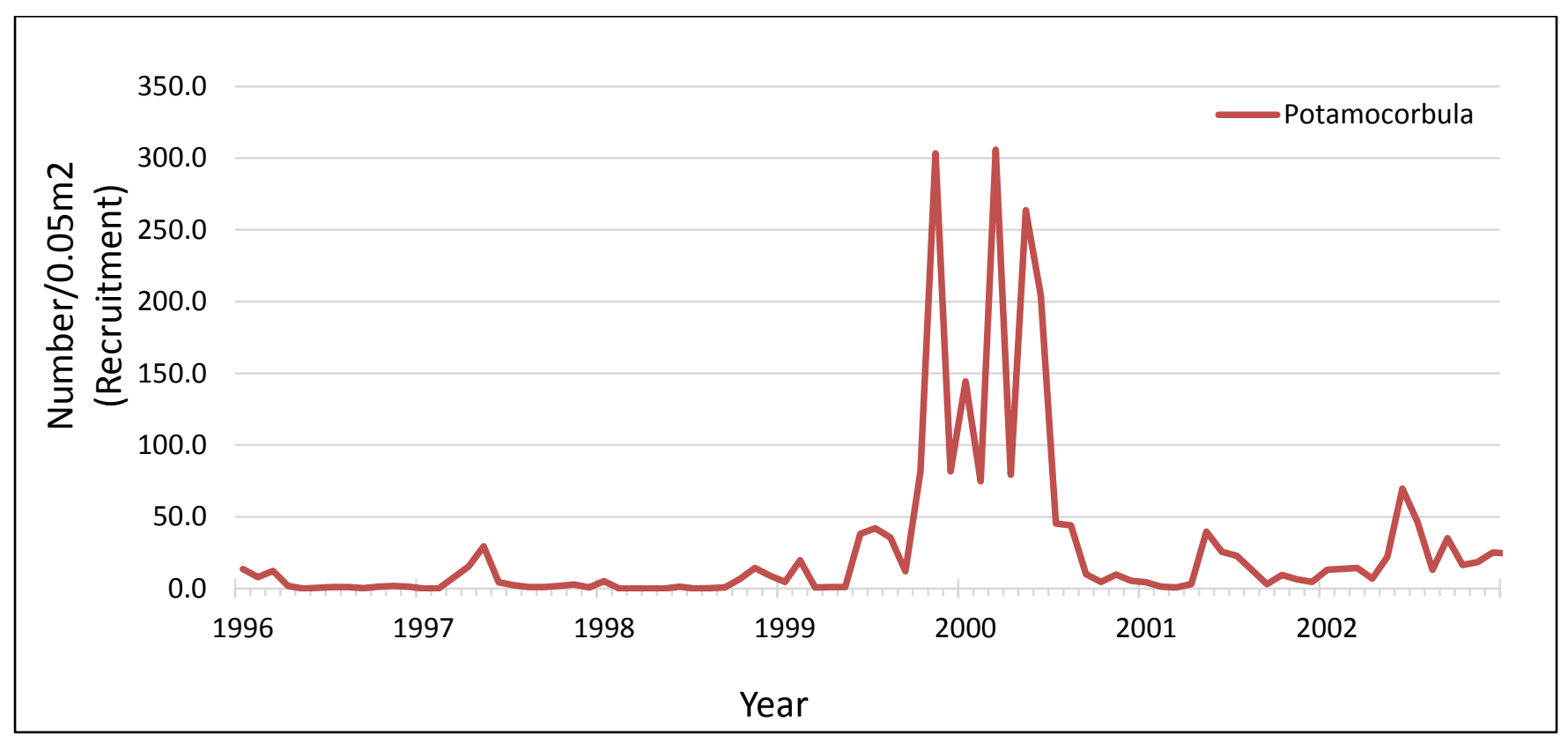

Figure 89. Graph showing recruitment at station 8.1 from 1996-2003 For station locations refer to table 1. 


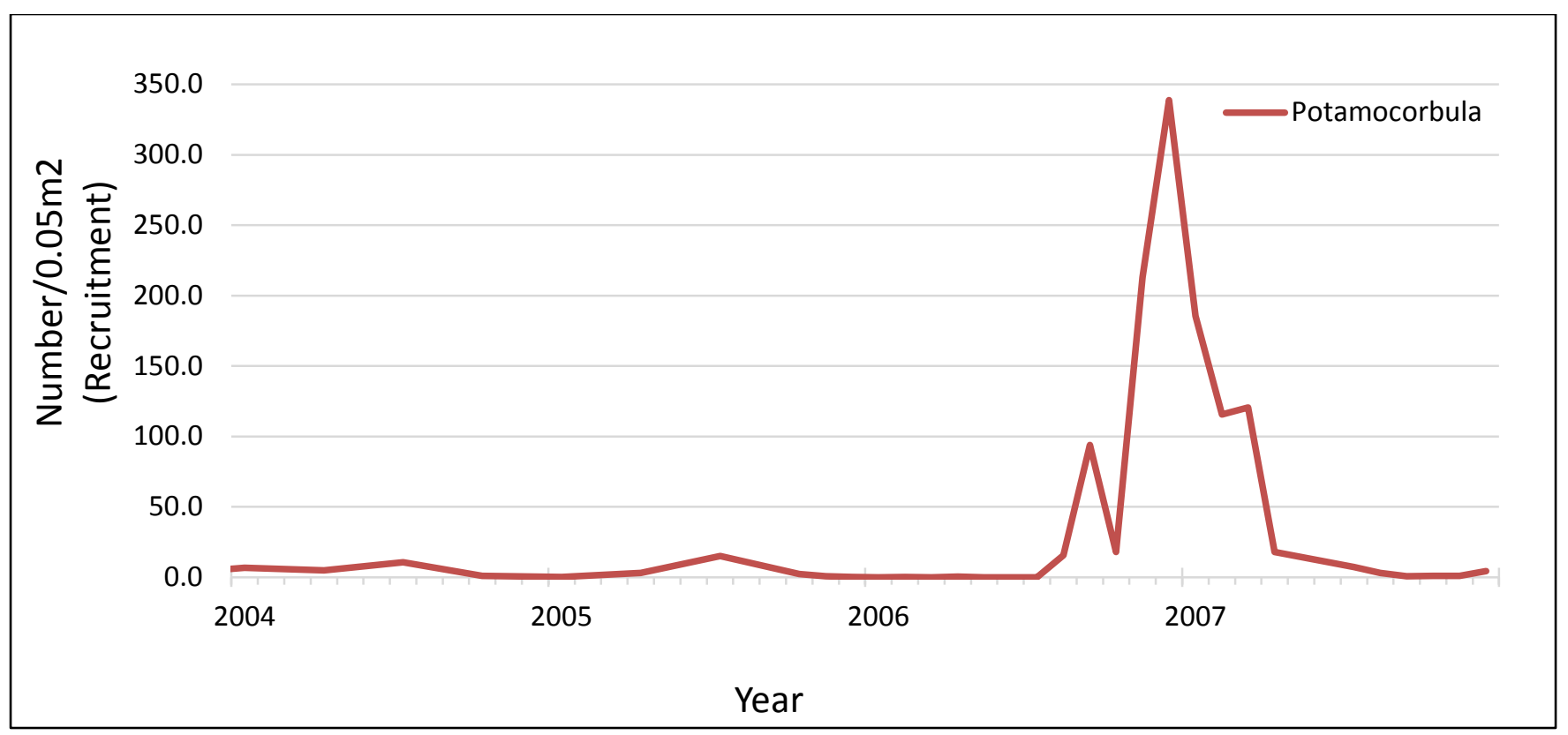

Figure 90. Graph showing recruitment at station 8.1 from 2003-2007. For station locations refer to table 1. 


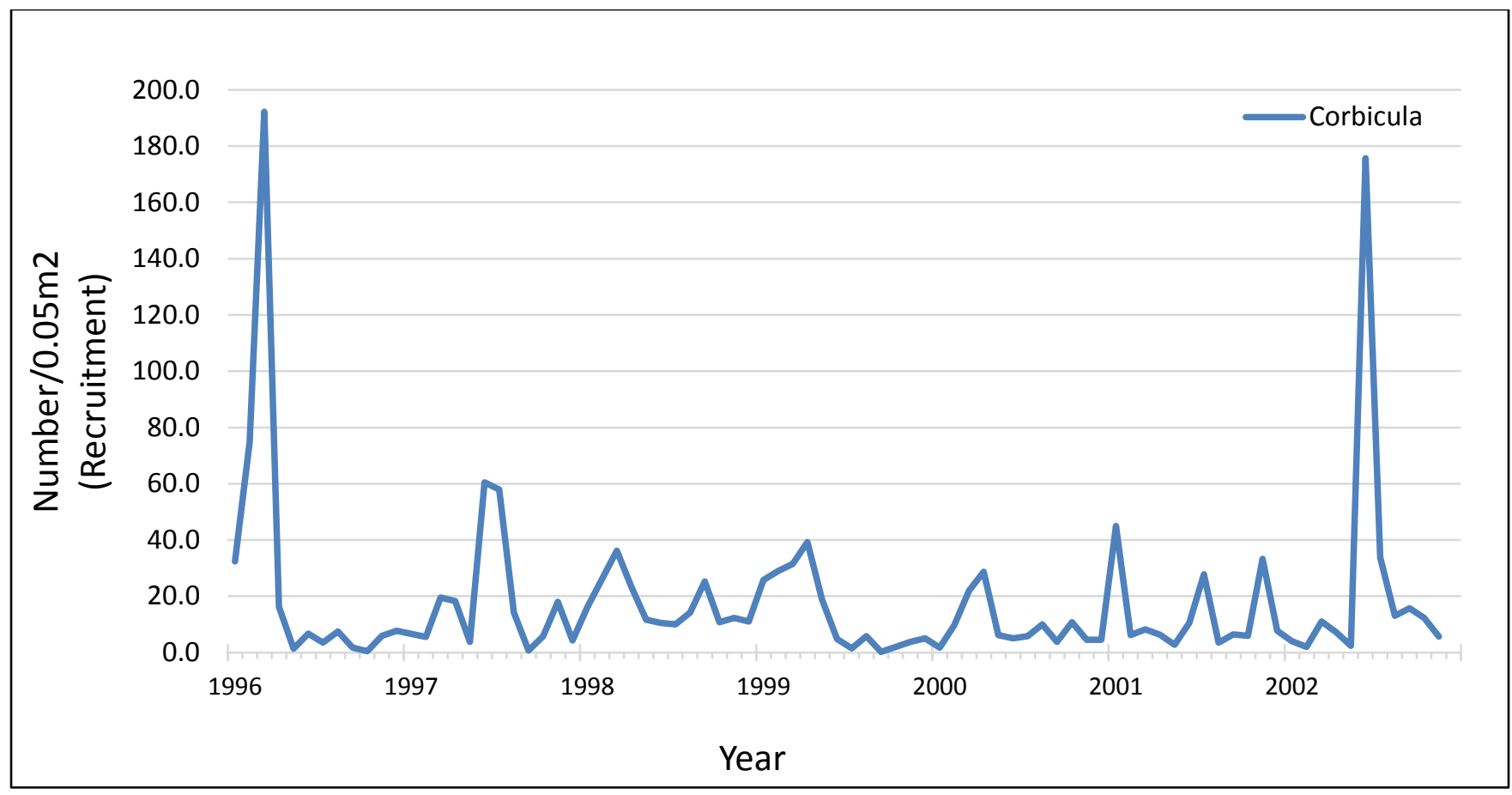

Figure 91. Graph showing recruitment at station C9 from 1996-2002. For station locations refer to table 1.

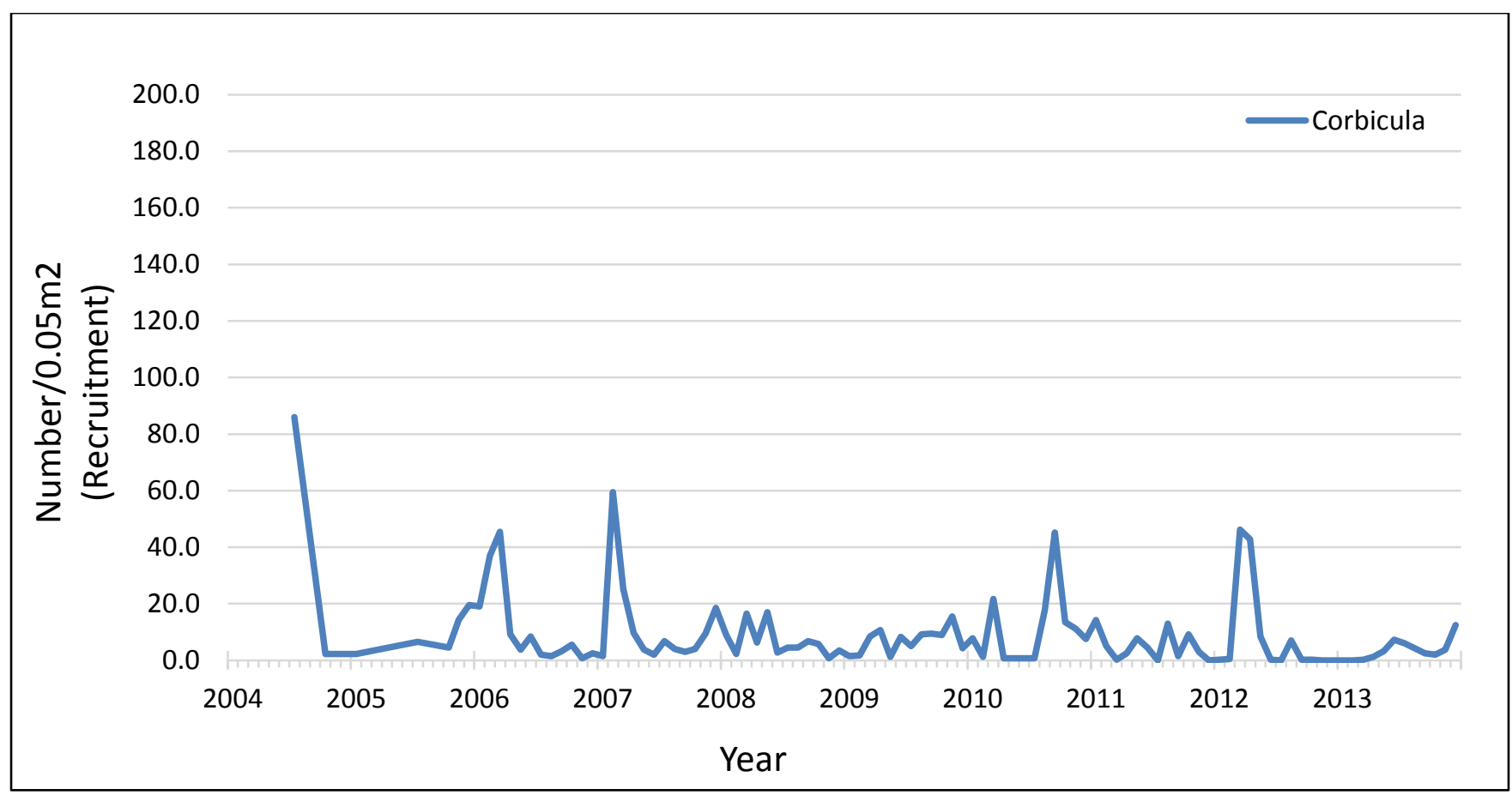

Figure 92. Graph showing recruitment at station C9 from 2004-2013. For station locations refer to table 1. 


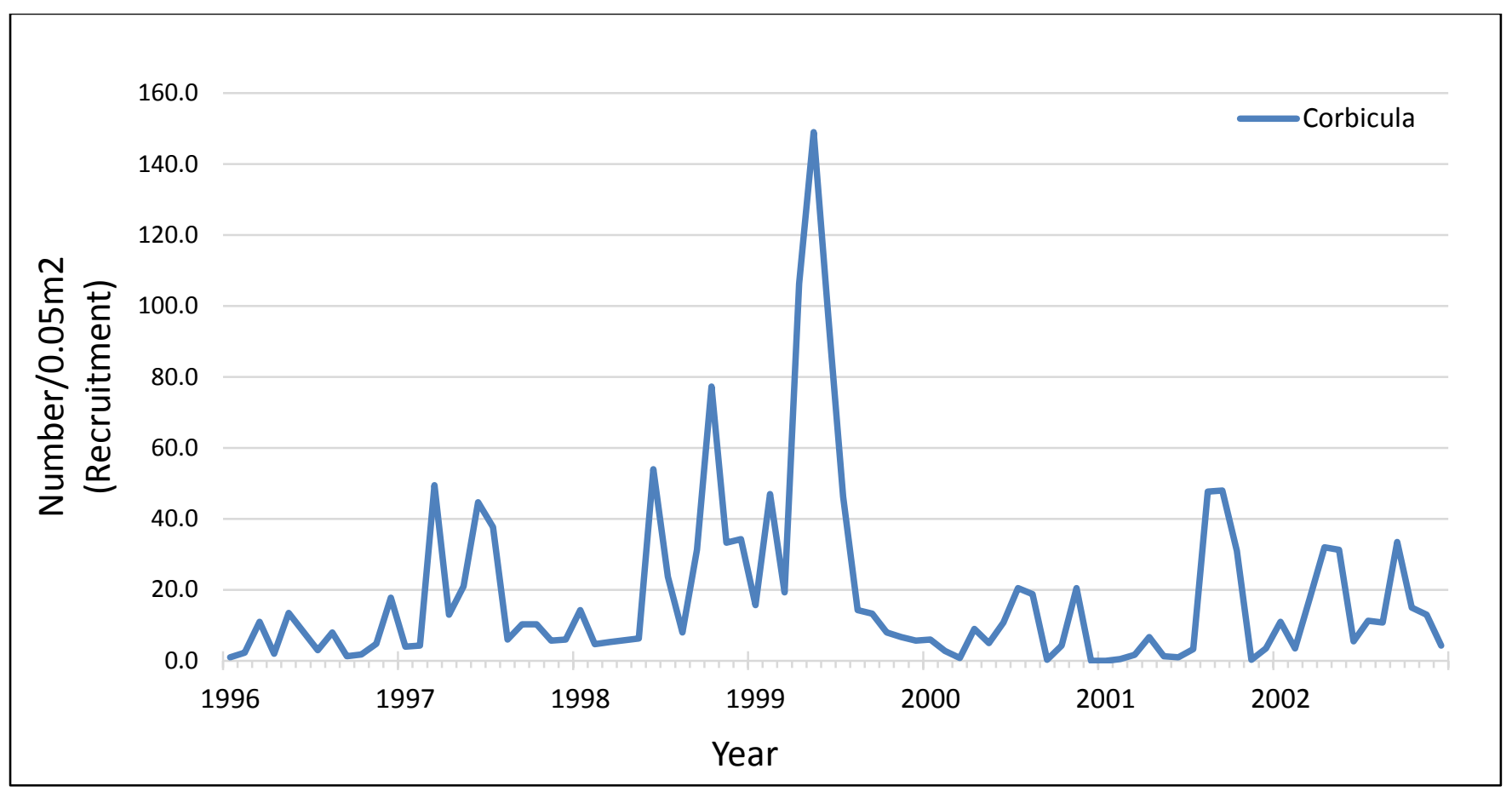

Figure 93. Graph showing recruitment at station D16 from 1996-2002. For station locations refer to table 1.

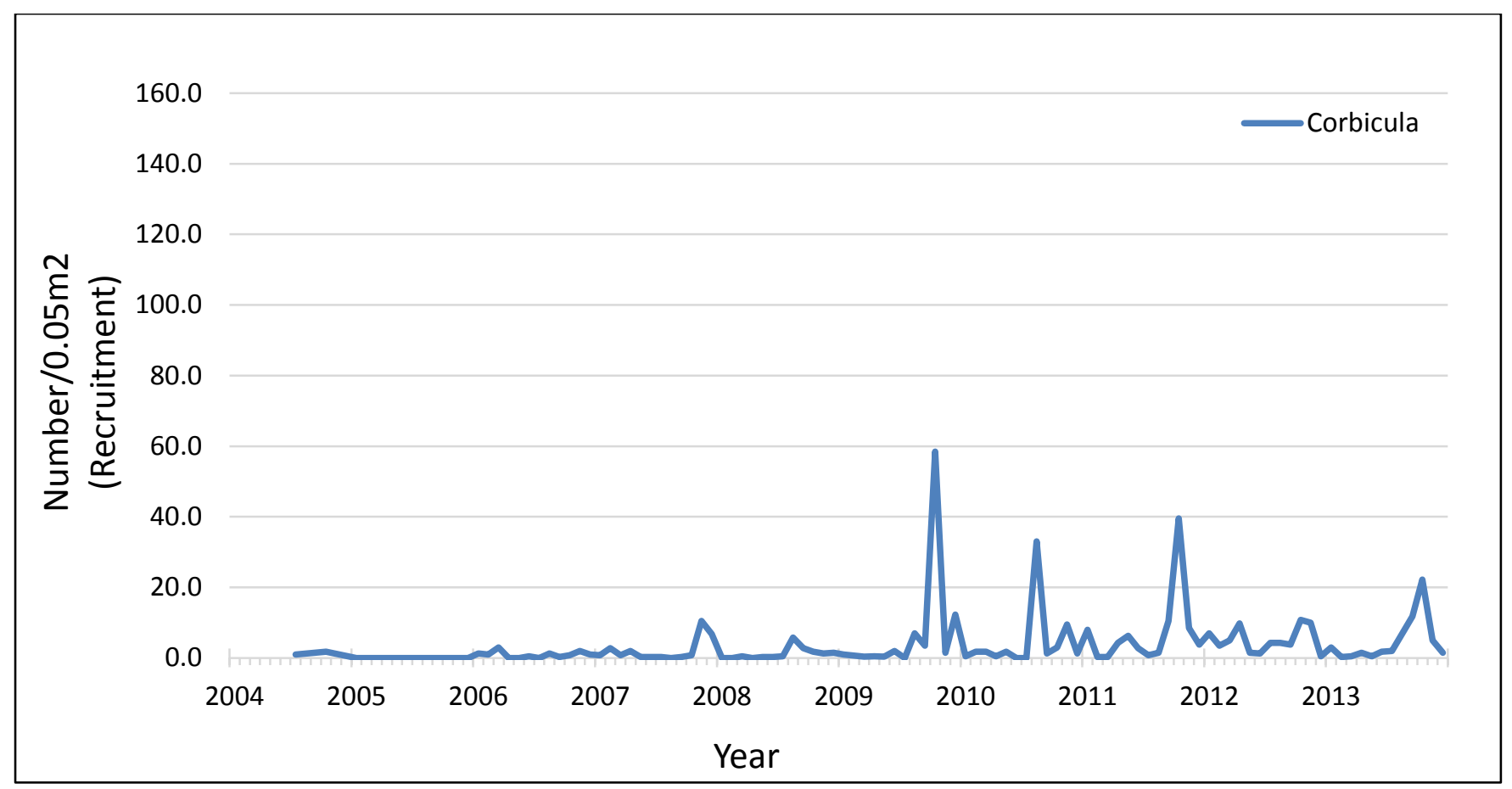

Figure 94. Graph showing recruitment at station D16 from 2004-2013. For station locations refer to table 1. 


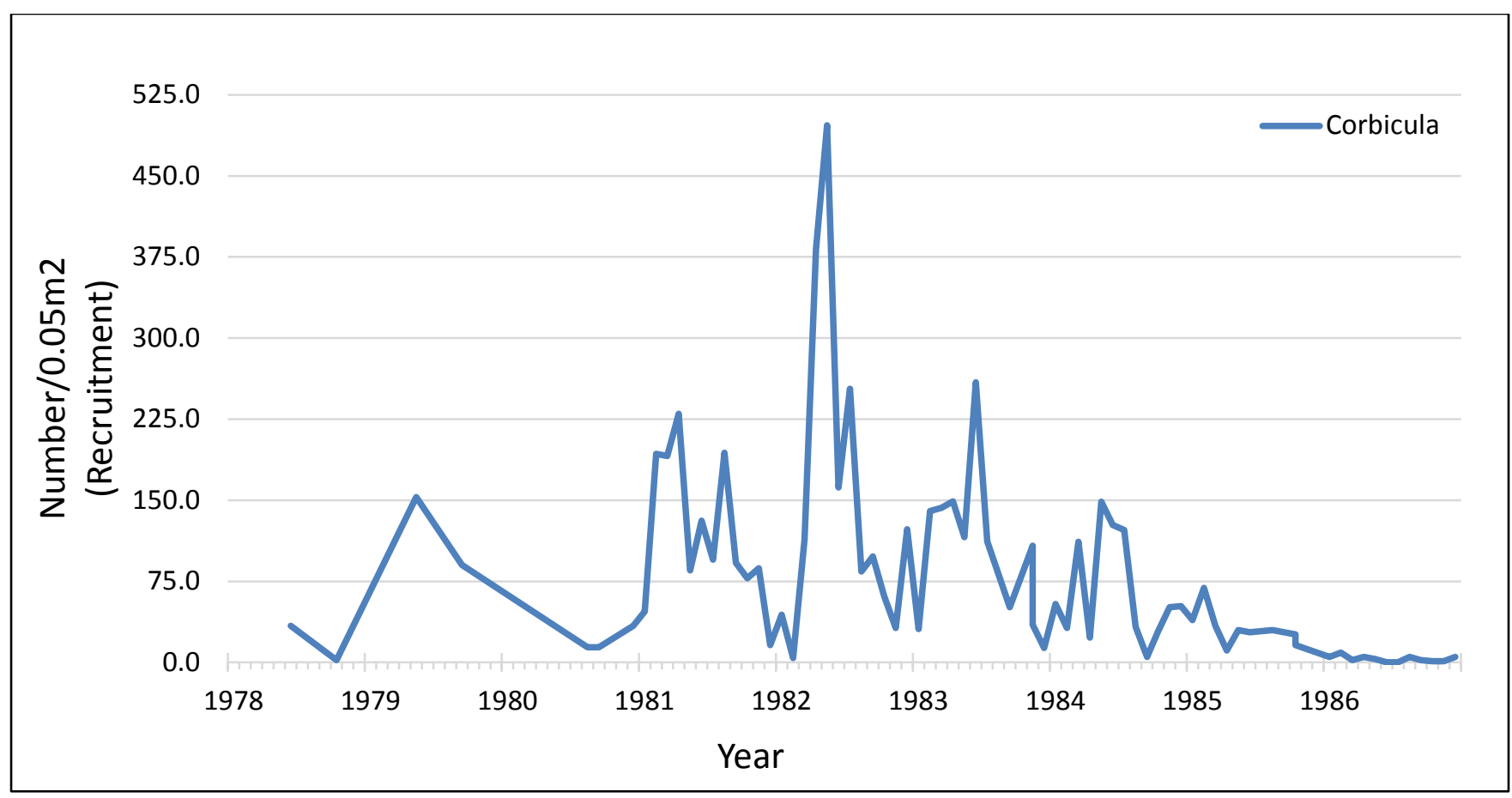

Figure 95. Graph showing recruitment at station D19C from 1978-1986. For station locations refer to table 1.

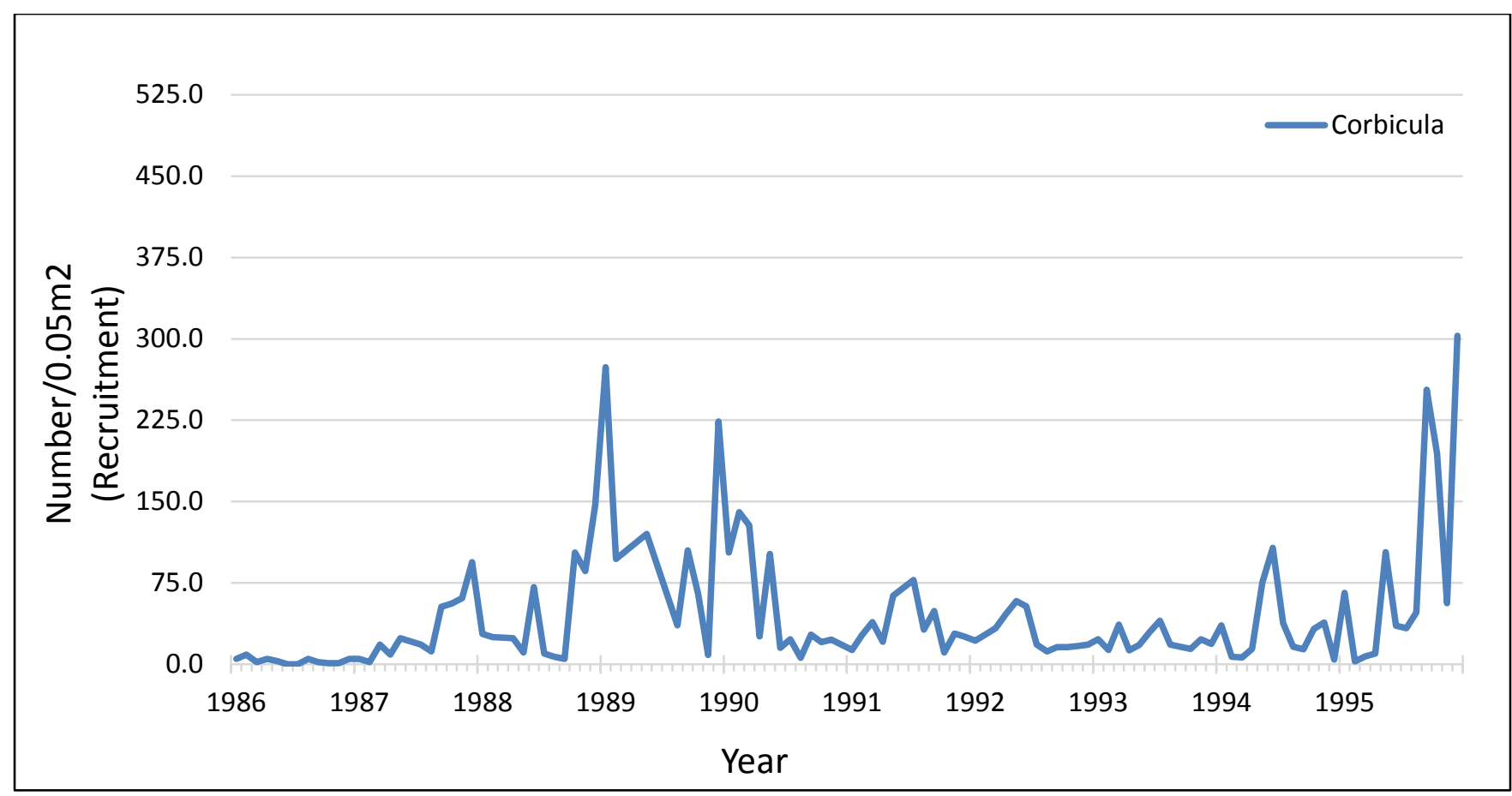

Figure 96. Graph showing recruitment at station D19C from 1986-1995. For station locations refer to table 1. 


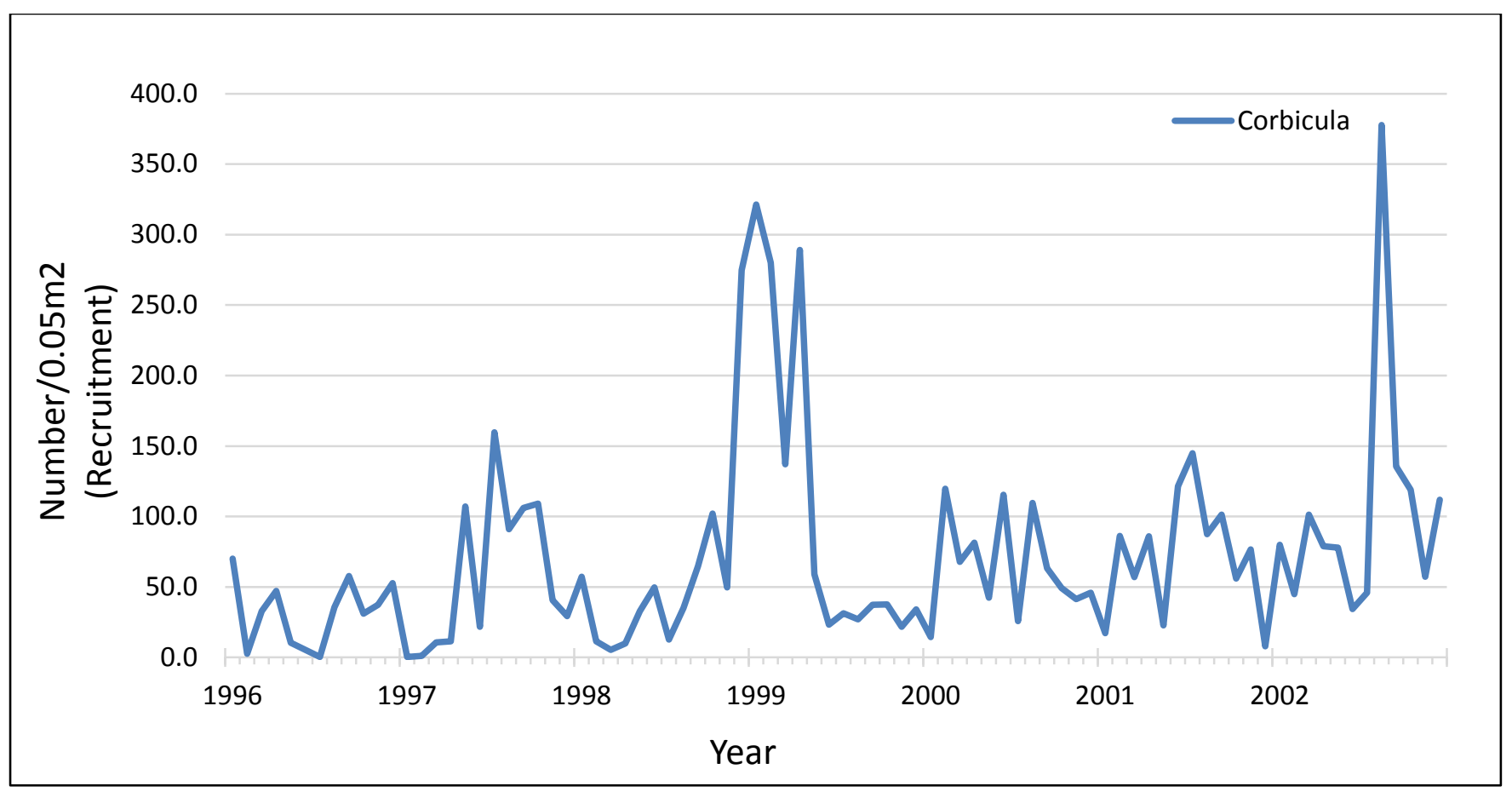

Figure 97. Graph showing recruitment at station D24 from 1996-2002. For station locations refer to table 1.

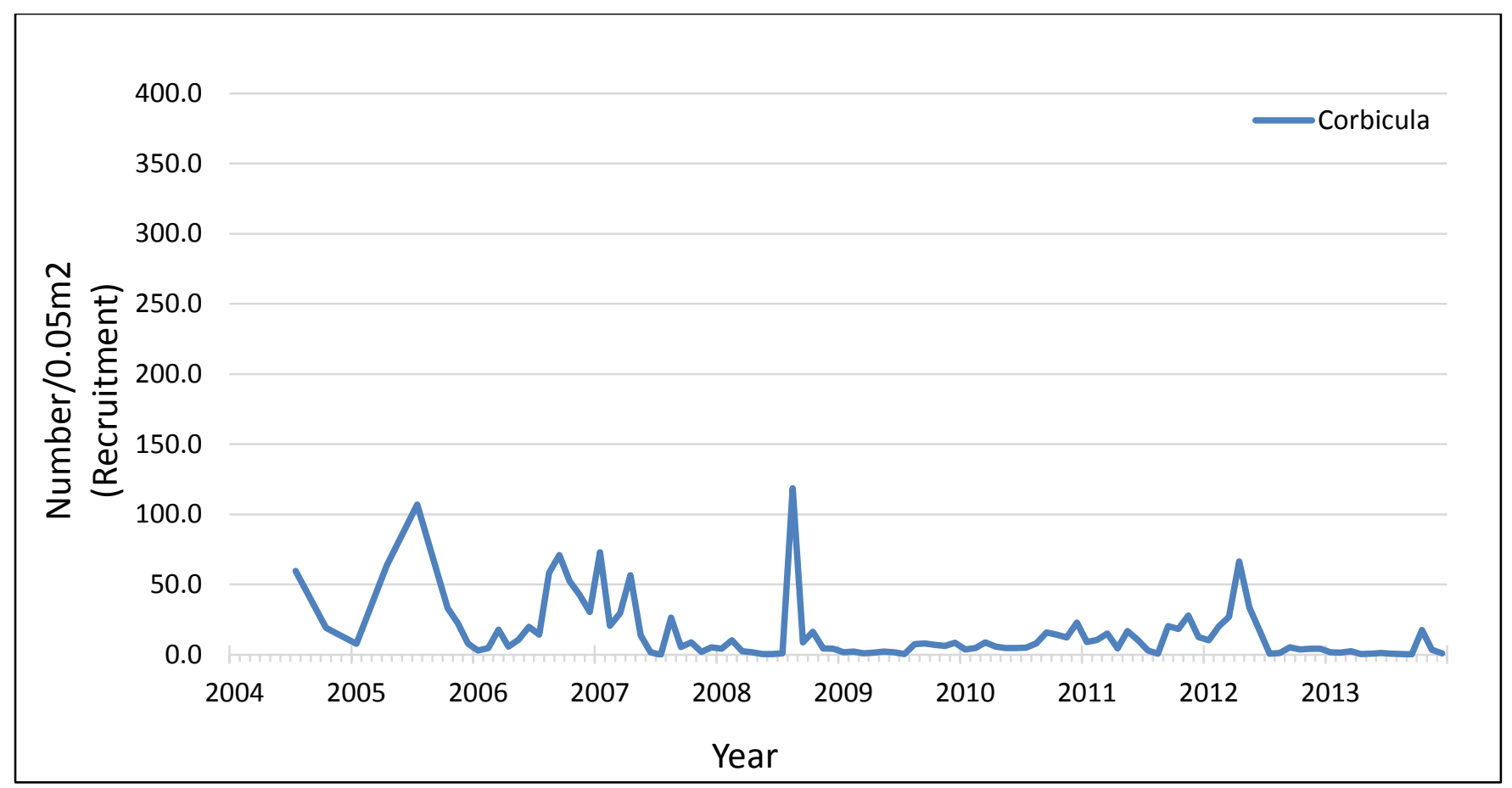

Figure 98. Graph showing recruitment at station D24 from 2004-2013. For station locations refer to table 1. 


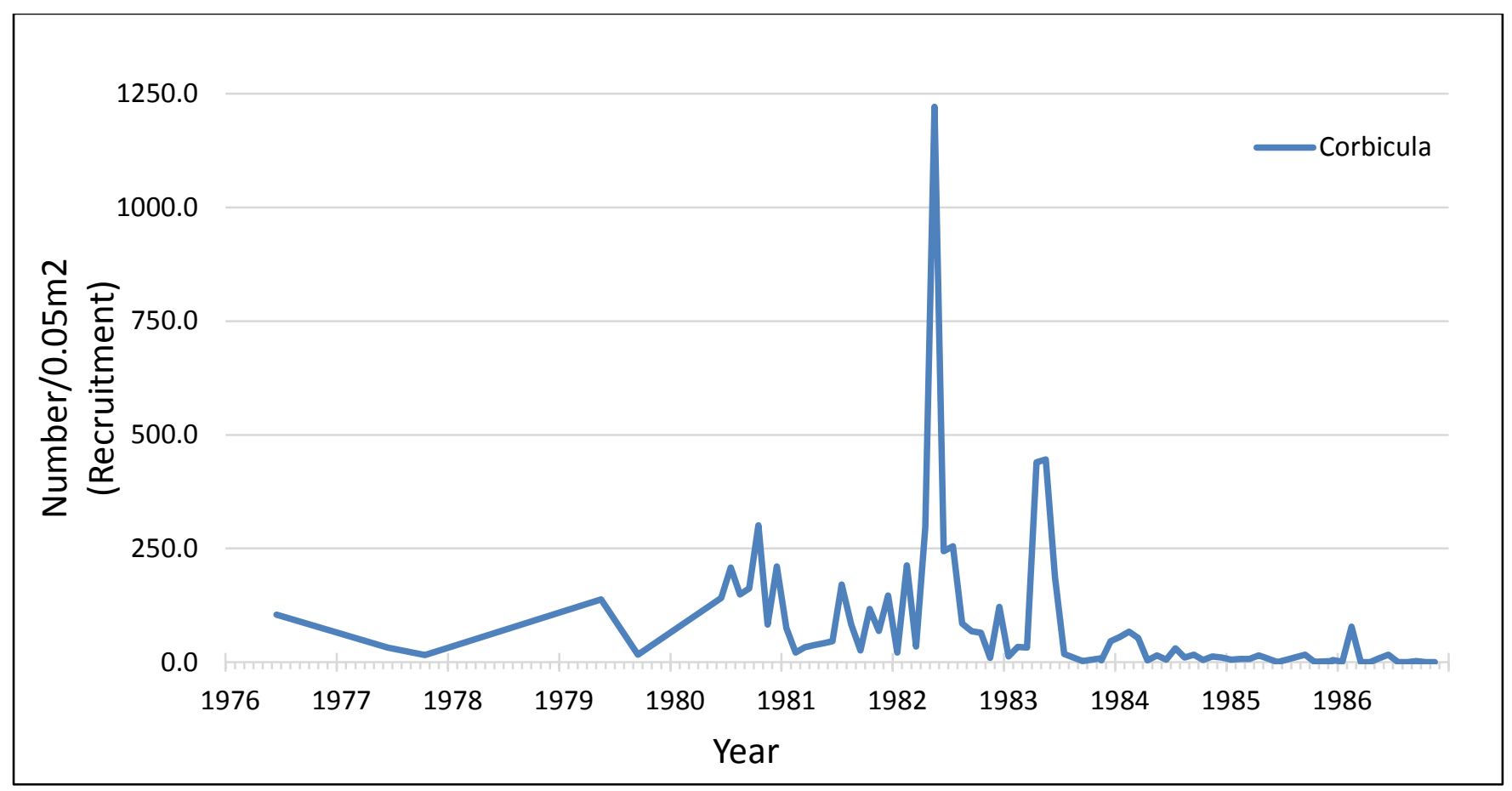

Figure 99. Graph showing recruitment at station D28 from 1976-1986. For station locations refer to table 1.

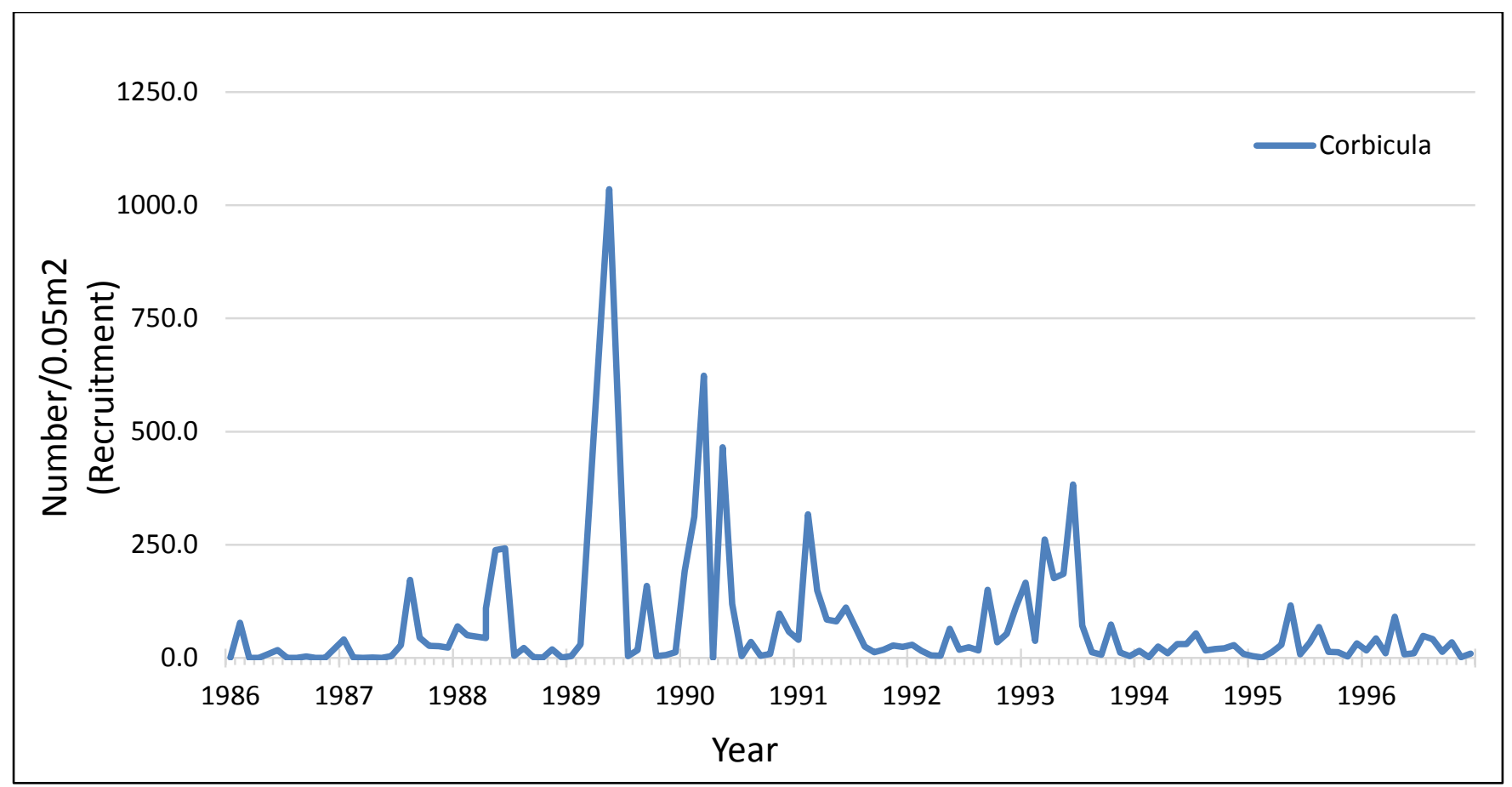

Figure 100. Graph showing recruitment at station D28 from 1986-1996. For station locations refer to table 1. 


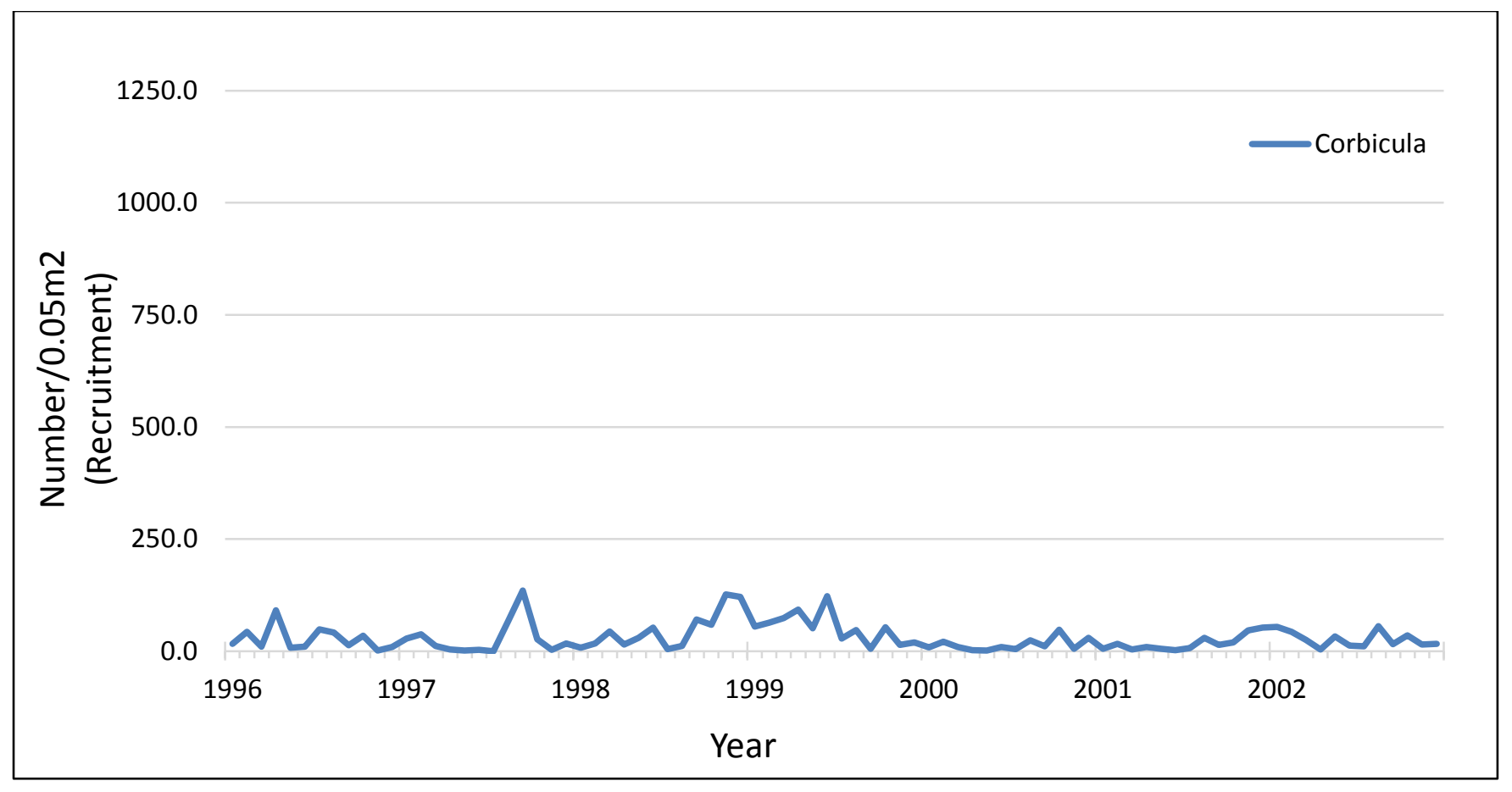

Figure 101. Graph showing recruitment at station D28 from 1996-2002. For station locations refer to table 1.

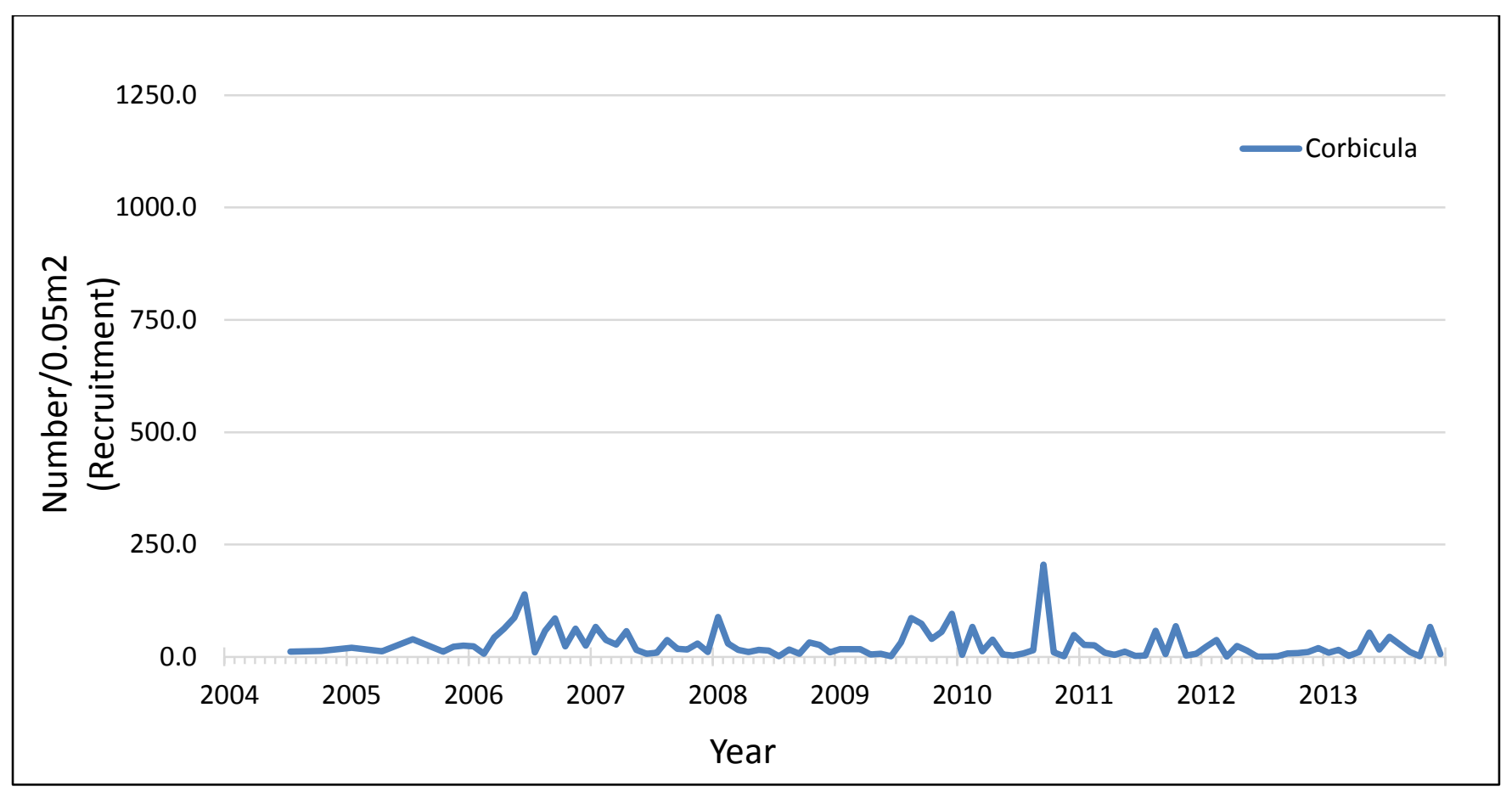

Figure 102. Graph showing recruitment at station D28 from 2004-2013. For station locations refer to table 1. 


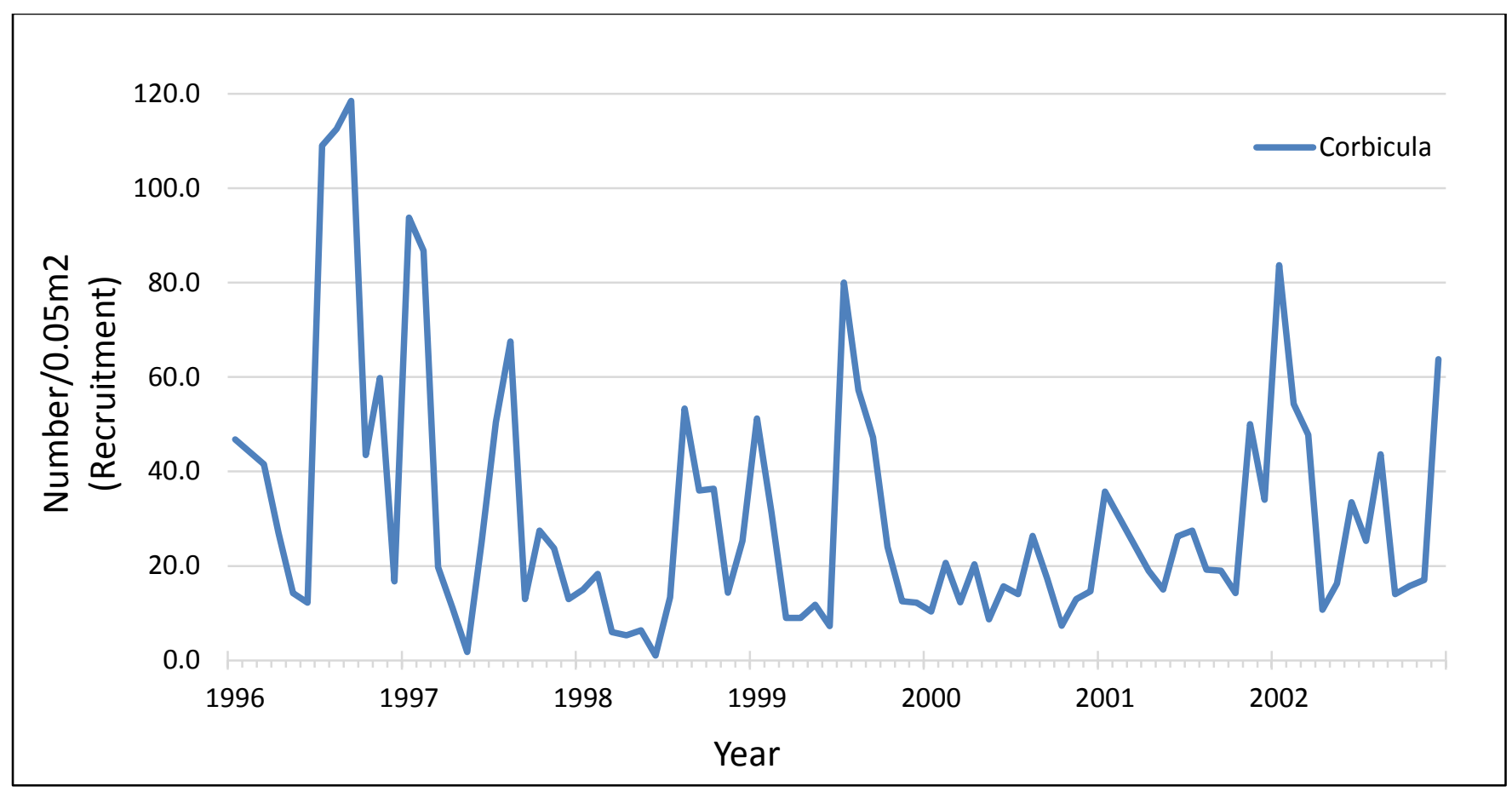

Figure 103. Graph showing recruitment at station P8 from 1996-2002. For station locations refer to table 1.

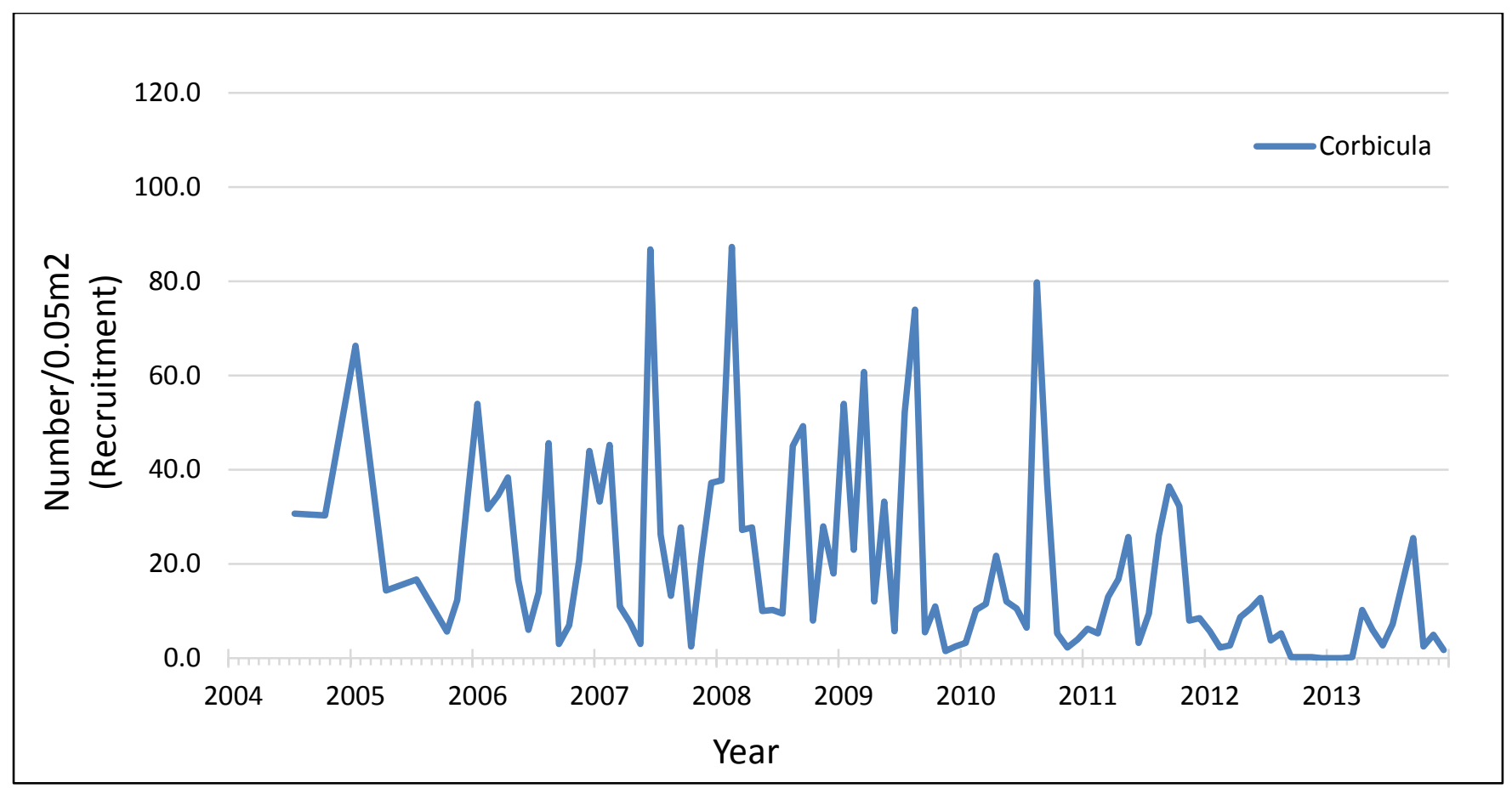

Figure 104. Graph showing recruitment at station P8 from 2004-2013. For station locations refer to table 1. 


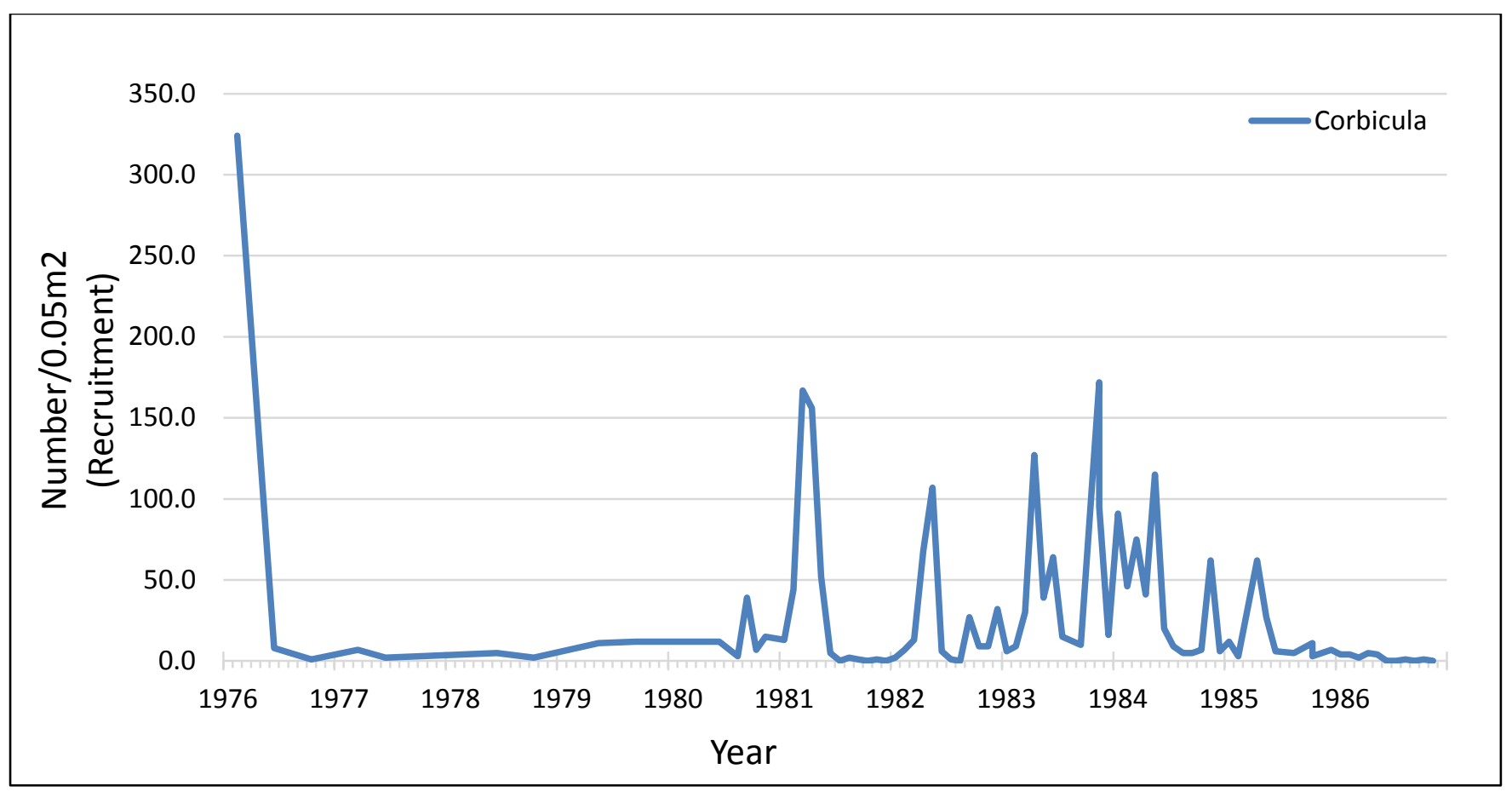

Figure 105. Graph showing recruitment at station D4C from 1976-1986 For station locations refer to table 1.

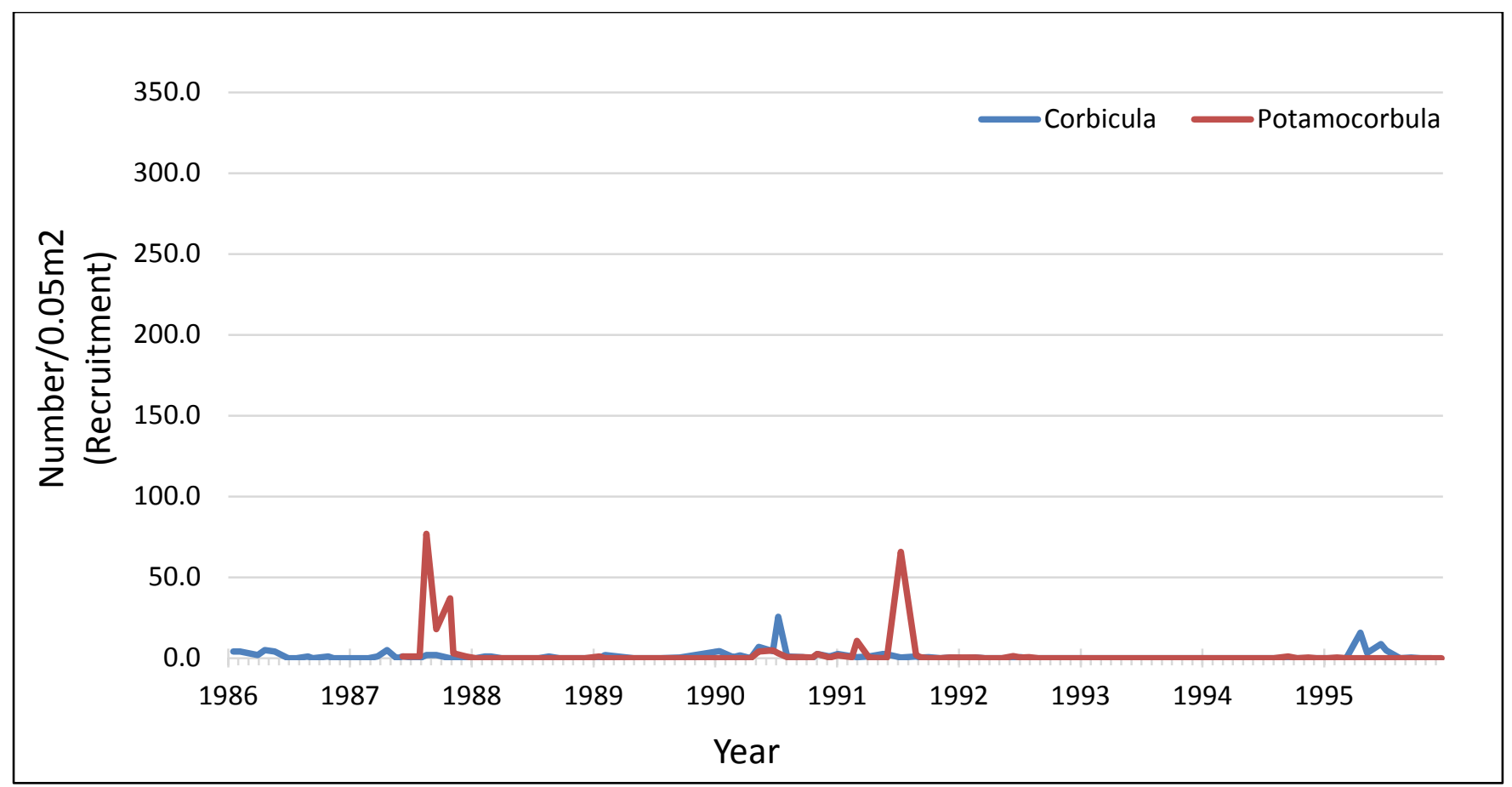

Figure 106. Graph showing recruitment at station D4C from 1986-1995. For station locations refer to table 1. 


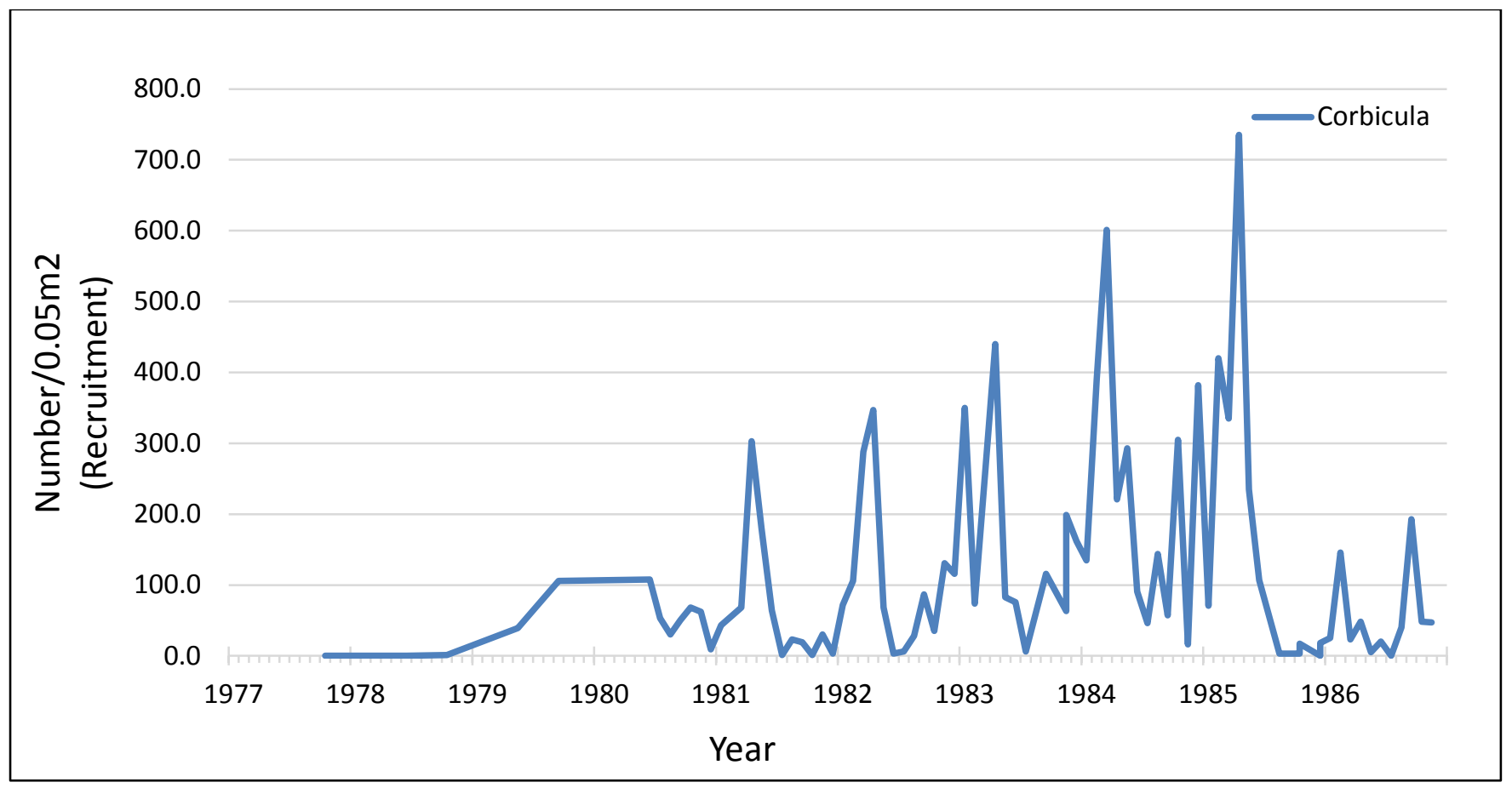

Figure 107. Graph showing recruitment at station D4L from 1977-1986. For station locations refer to table 1.

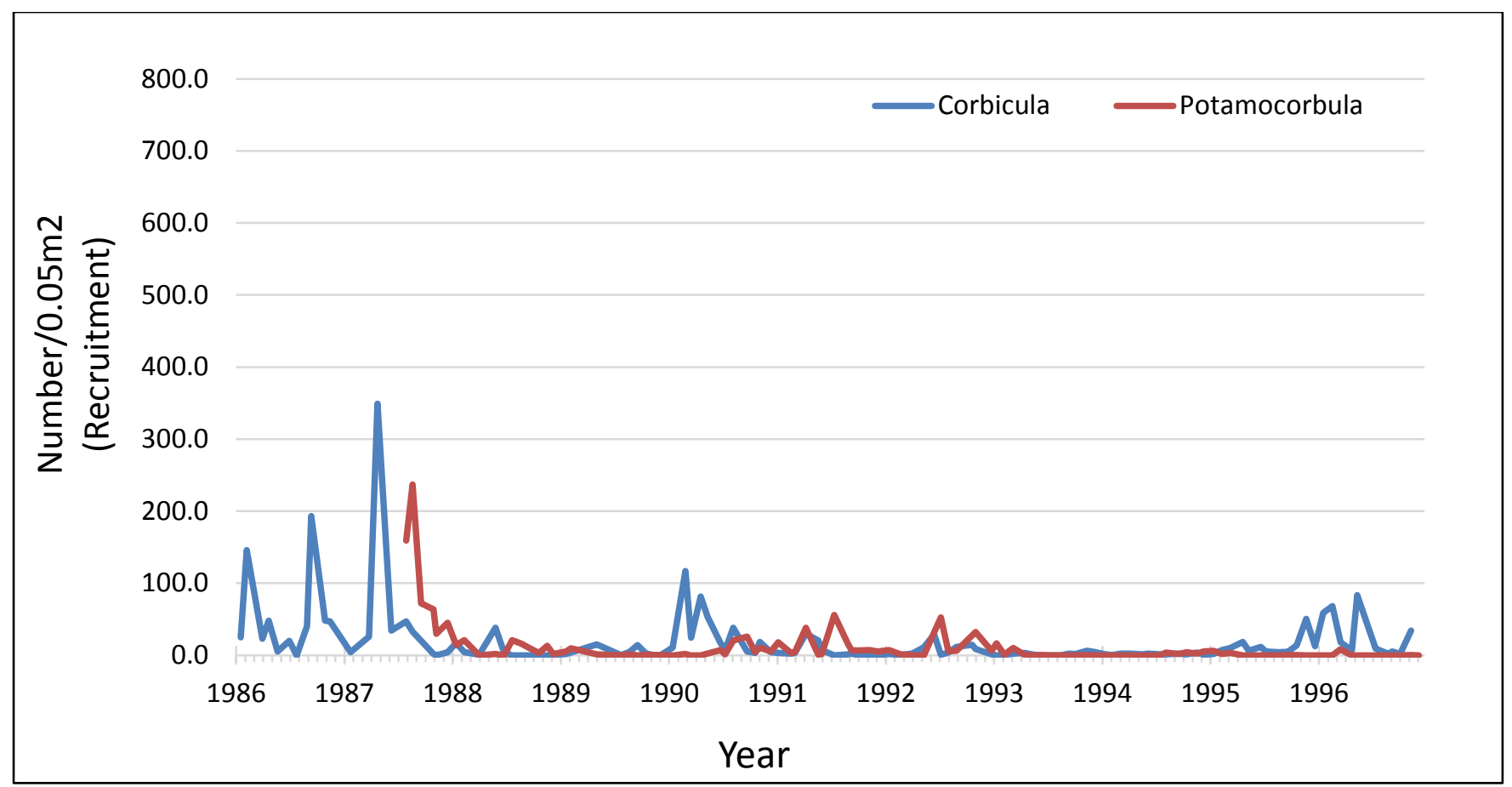

Figure 108. Graph showing recruitment at station D4L from 1986-1996. For station locations refer to table 1. 


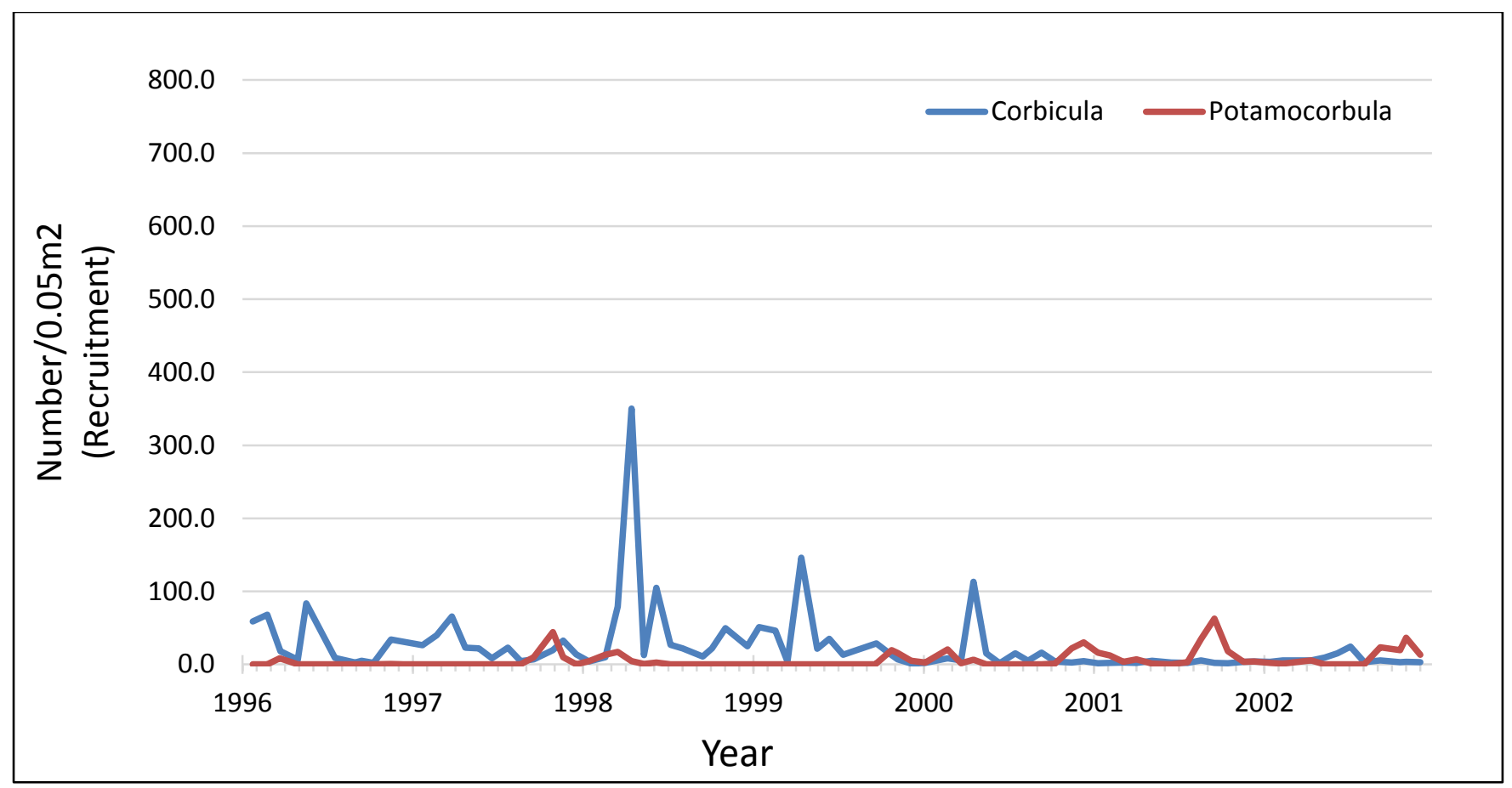

Figure 109. Graph showing recruitment at station D4L from 1996-2002. For station locations refer to table 1.

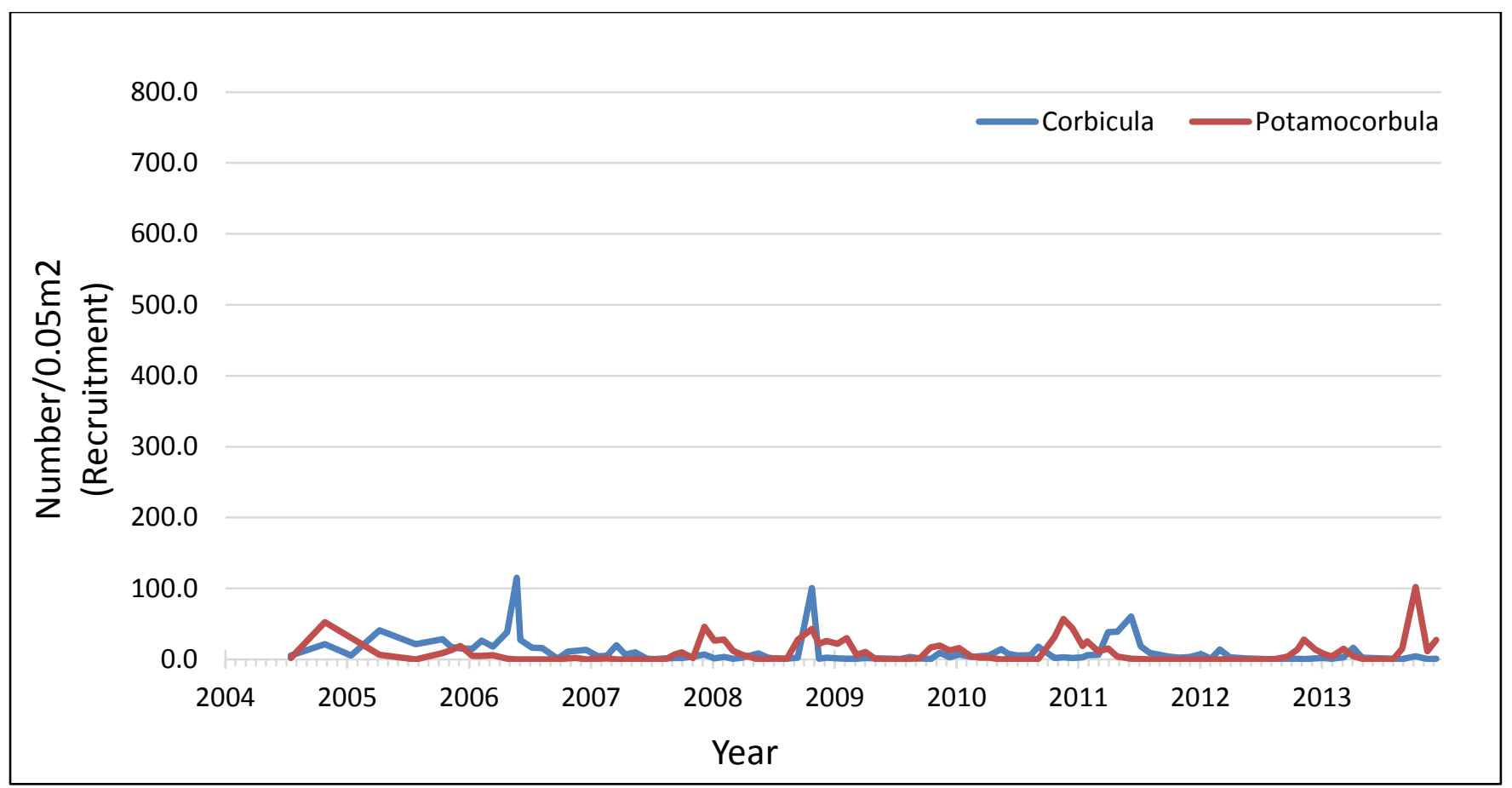

Figure 110. Graph showing recruitment at station D4L from 2004-2013. For station locations refer to table 1. 


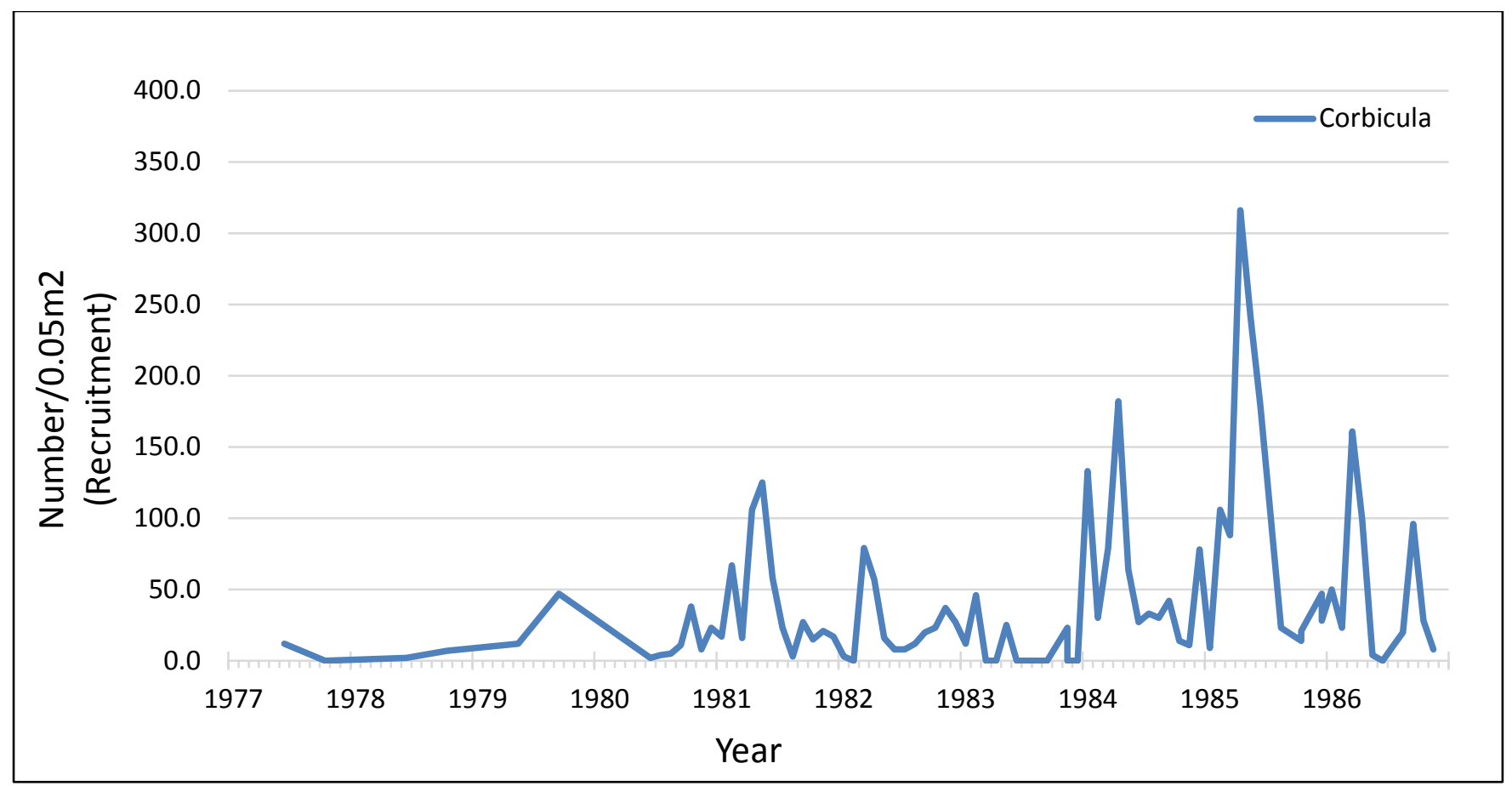

Figure 111. Graph showing recruitment at station D4R from 1977-1986. For station locations refer to table 1.

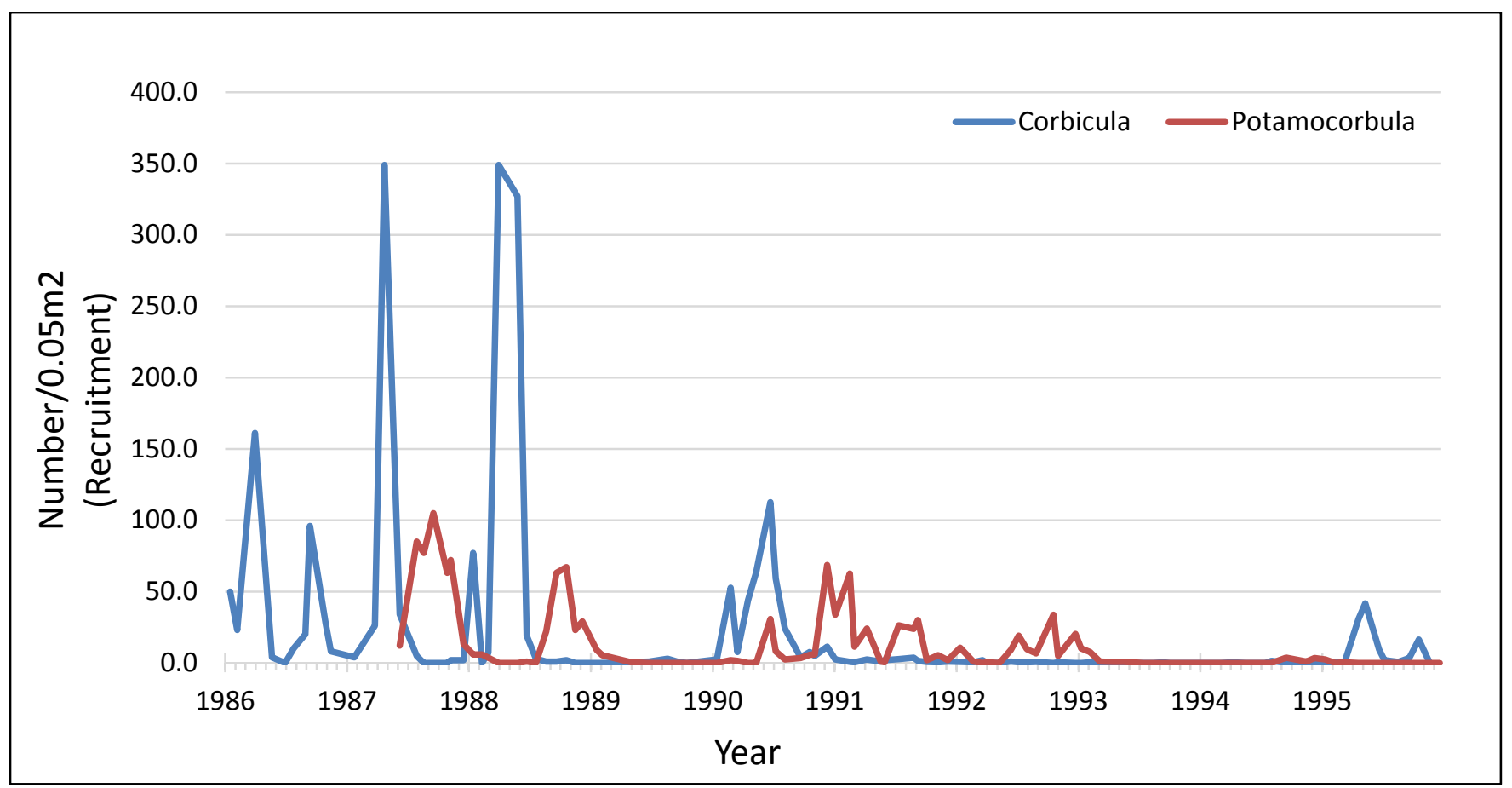

Figure 112. Graph showing recruitment at station D4R from 1986-1995. For station locations refer to table 1. 


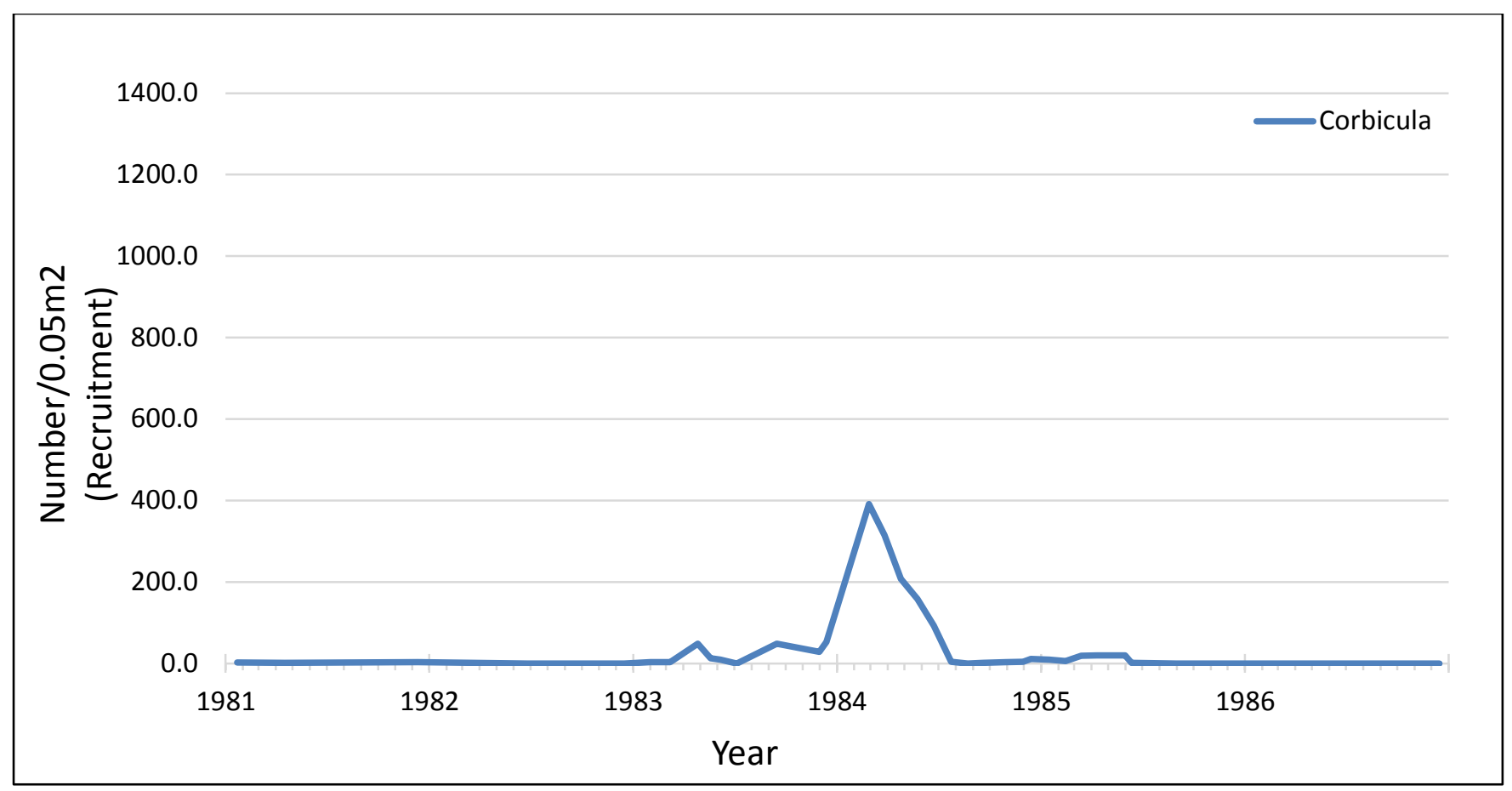

Figure 113. Graph showing recruitment at station D7 from 1981-1986. For station locations refer to table 1.

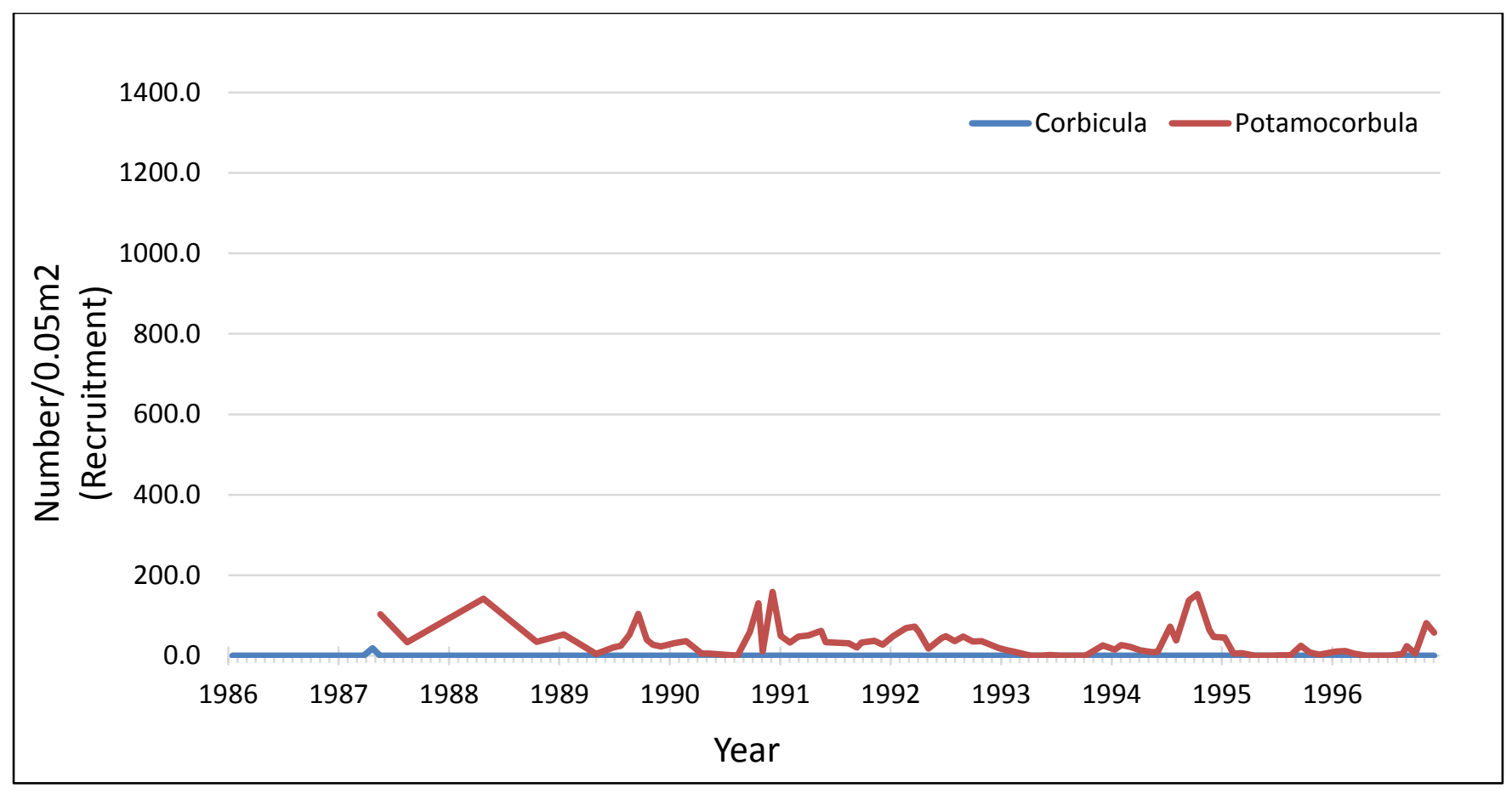

Figure 114. Graph showing recruitment at station D7 from 1986-1996. For station locations refer to table 1. 


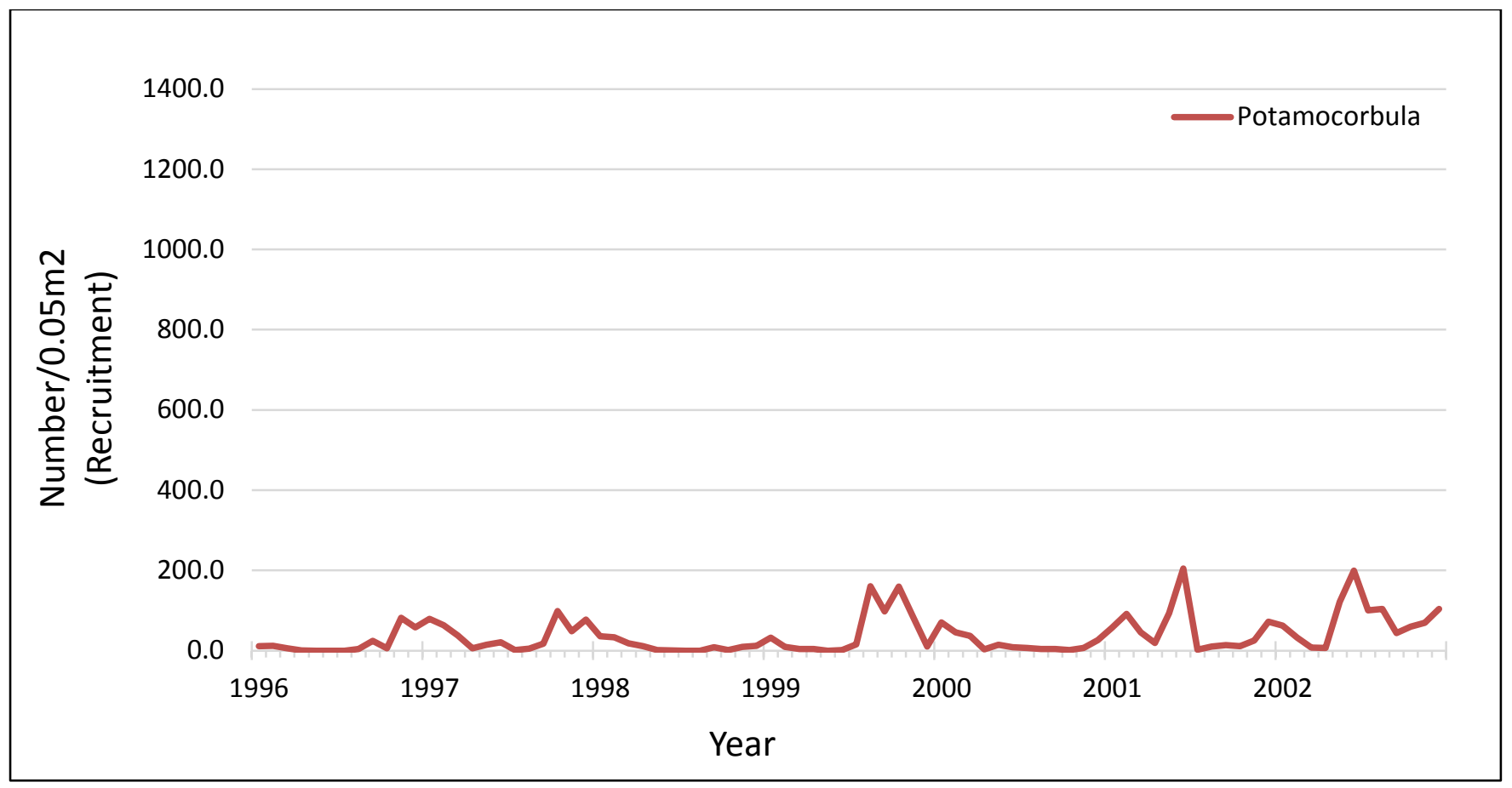

Figure 115. Graph showing recruitment at station D7 from 1996-2002. For station locations refer to table 1.

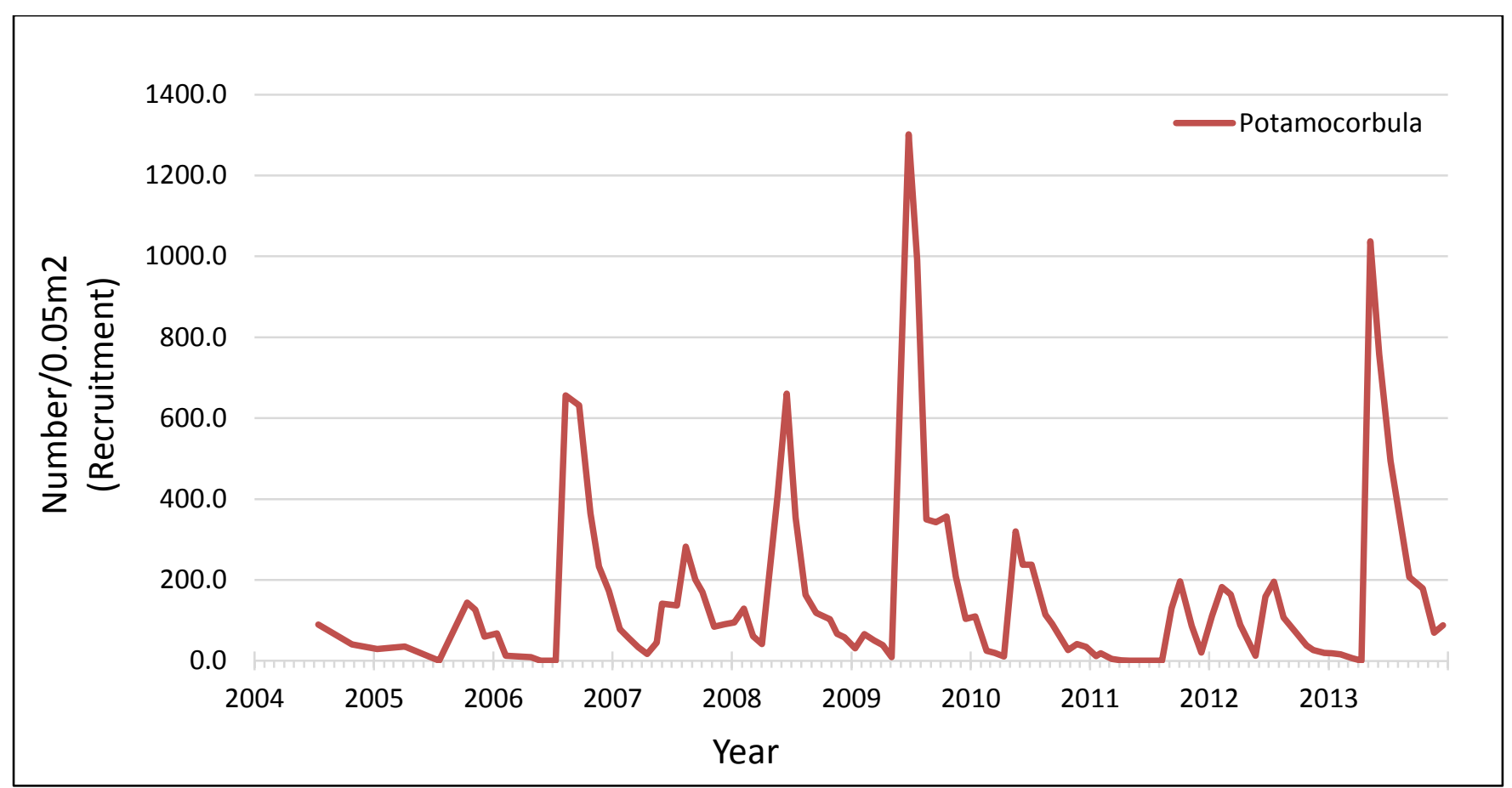

Figure 116. Graph showing recruitment at station D7 from 2004-2013. For station locations refer to table 1. 


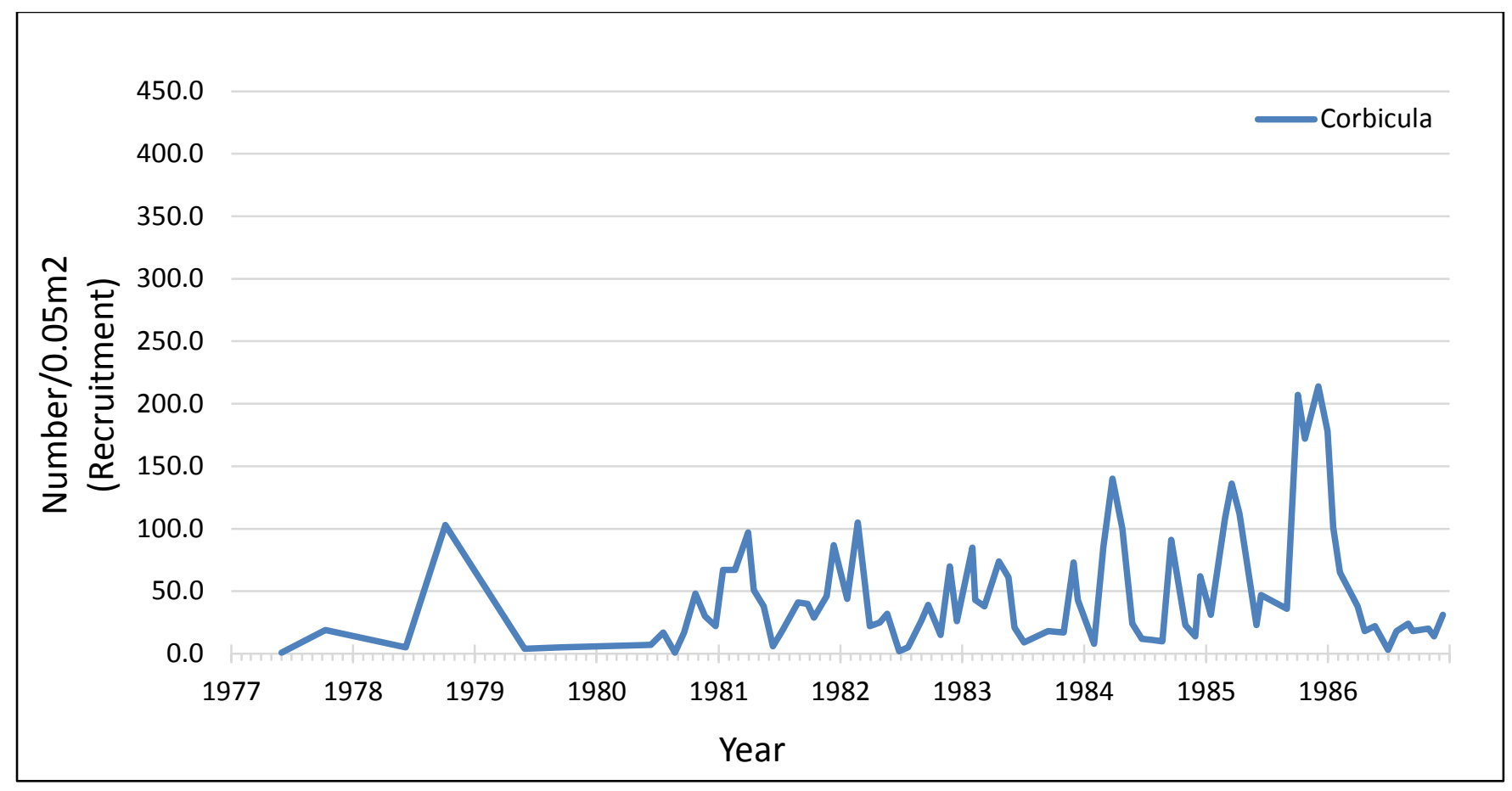

Figure 117. Graph showing recruitment at station D11 from 1977-1986. For station locations refer to table 1.

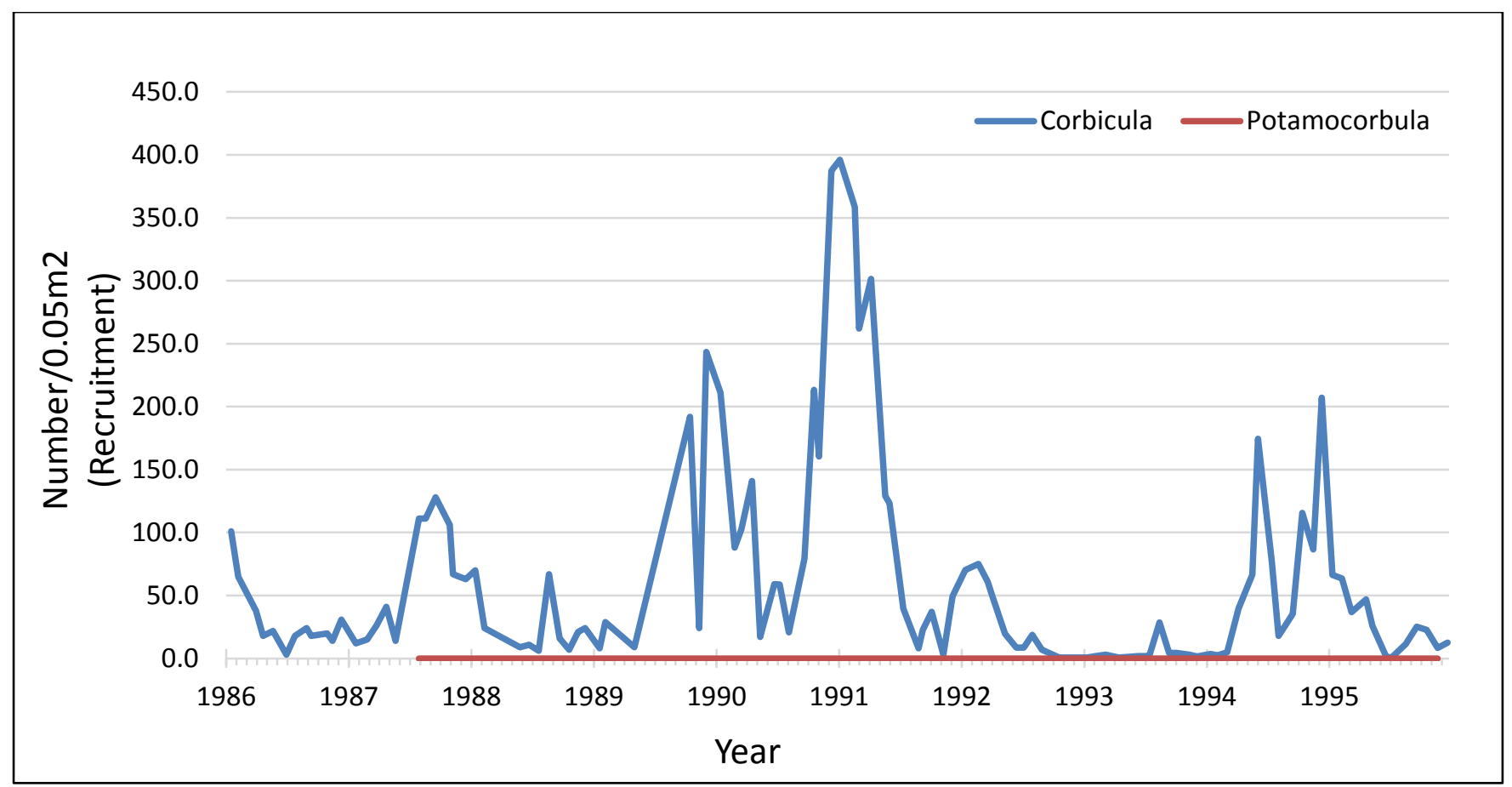

Figure 118. Graph showing recruitment at station D11 from 1986-1995. For station locations refer to table 1. 


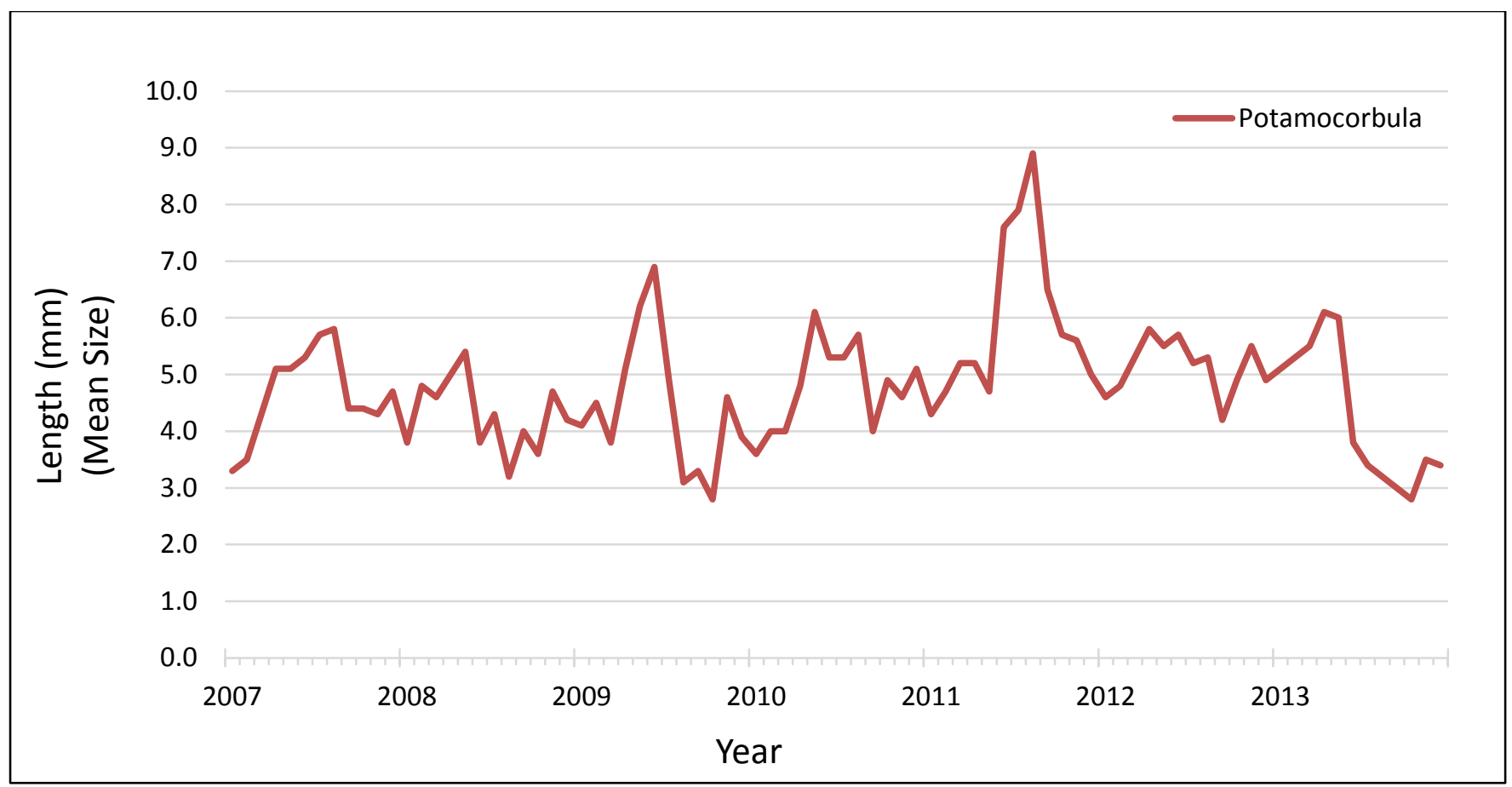

Figure 119. Graph showing mean size at station D6 from 2007-2013. For station locations refer to table 1. 


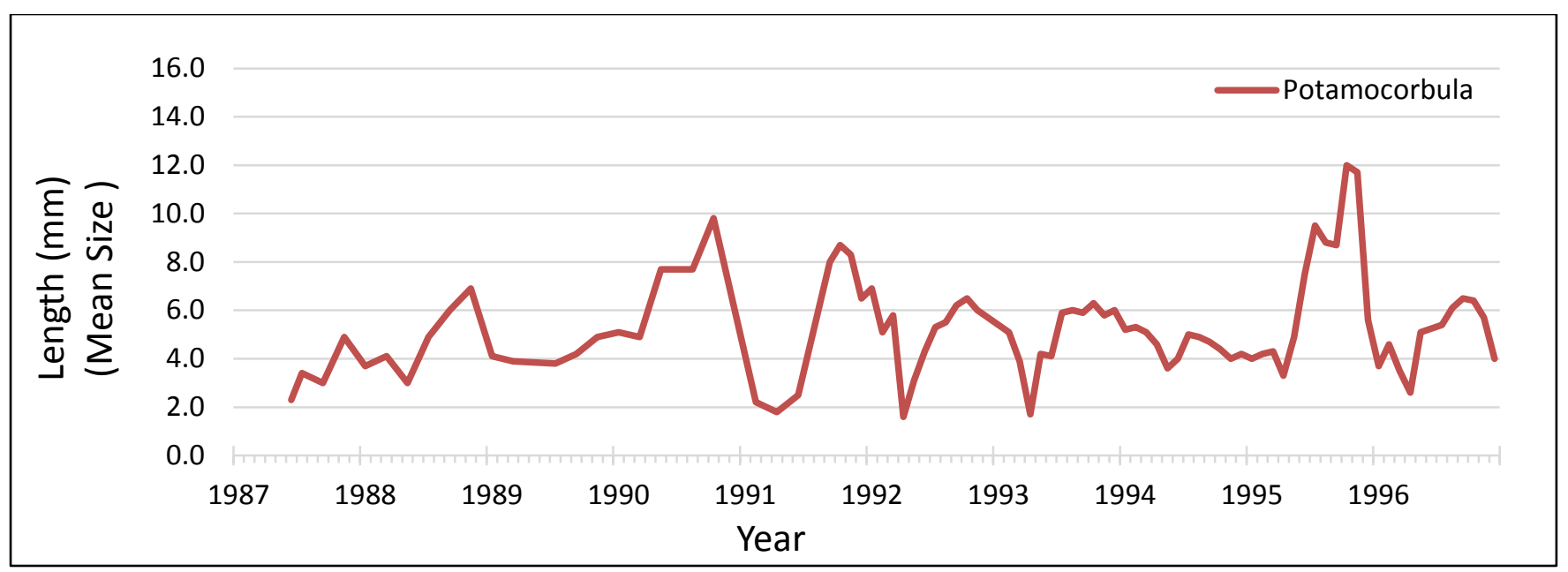

Figure 120. Graph showing mean size at station D41A from 1987-1996. For station locations refer to table 1.

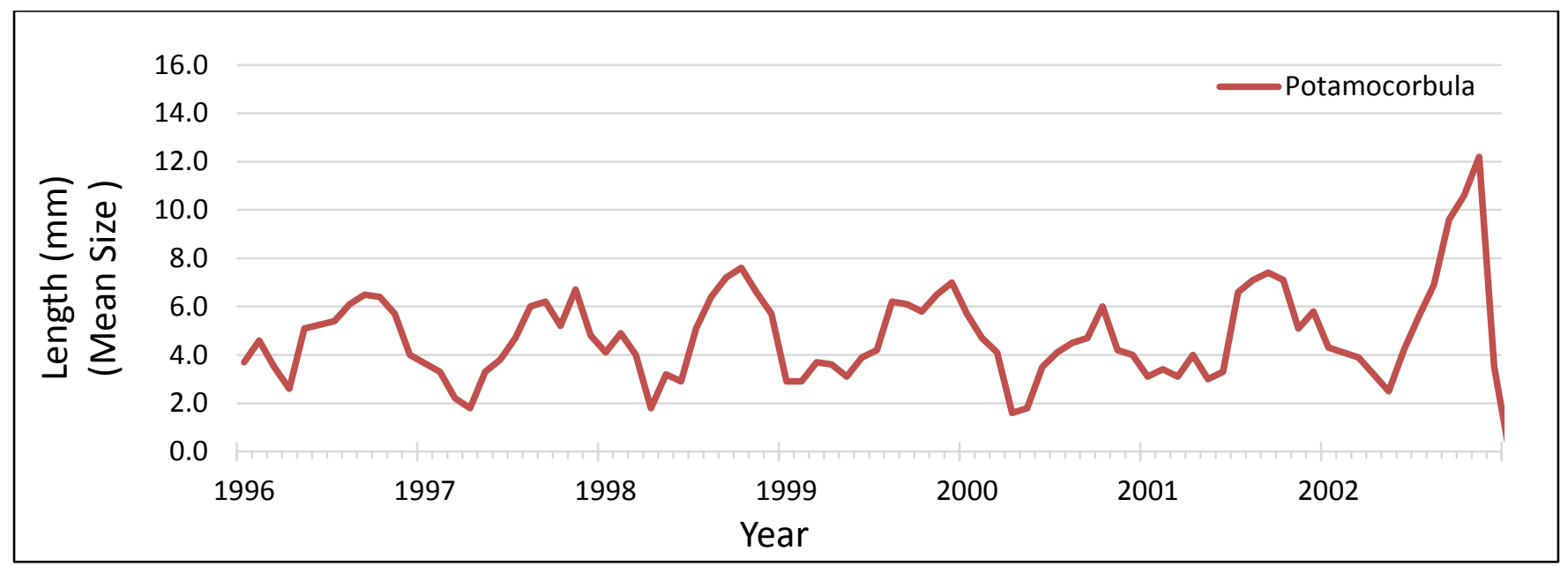

Figure 121. Graph showing mean size at station D41A from 1996-2003. For station locations refer to table 1.

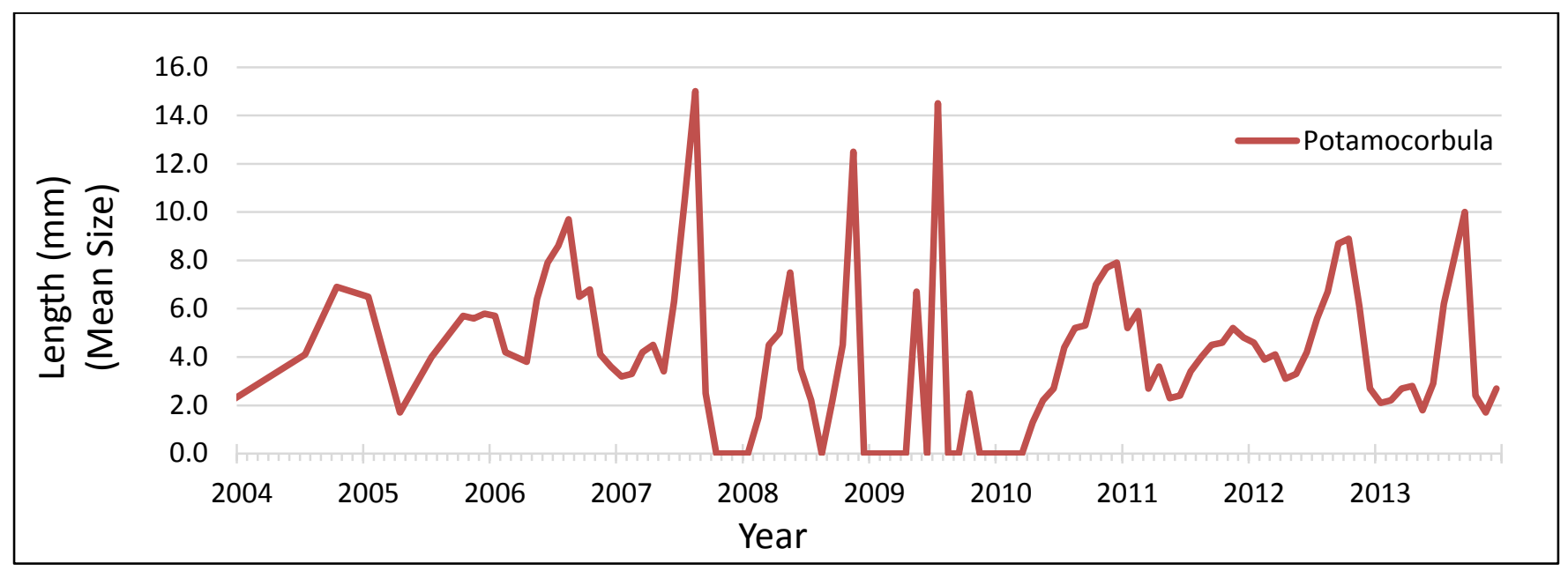

Figure 122. Graph showing mean size at station D41A from 2003-2013. For station locations refer to table 1. 


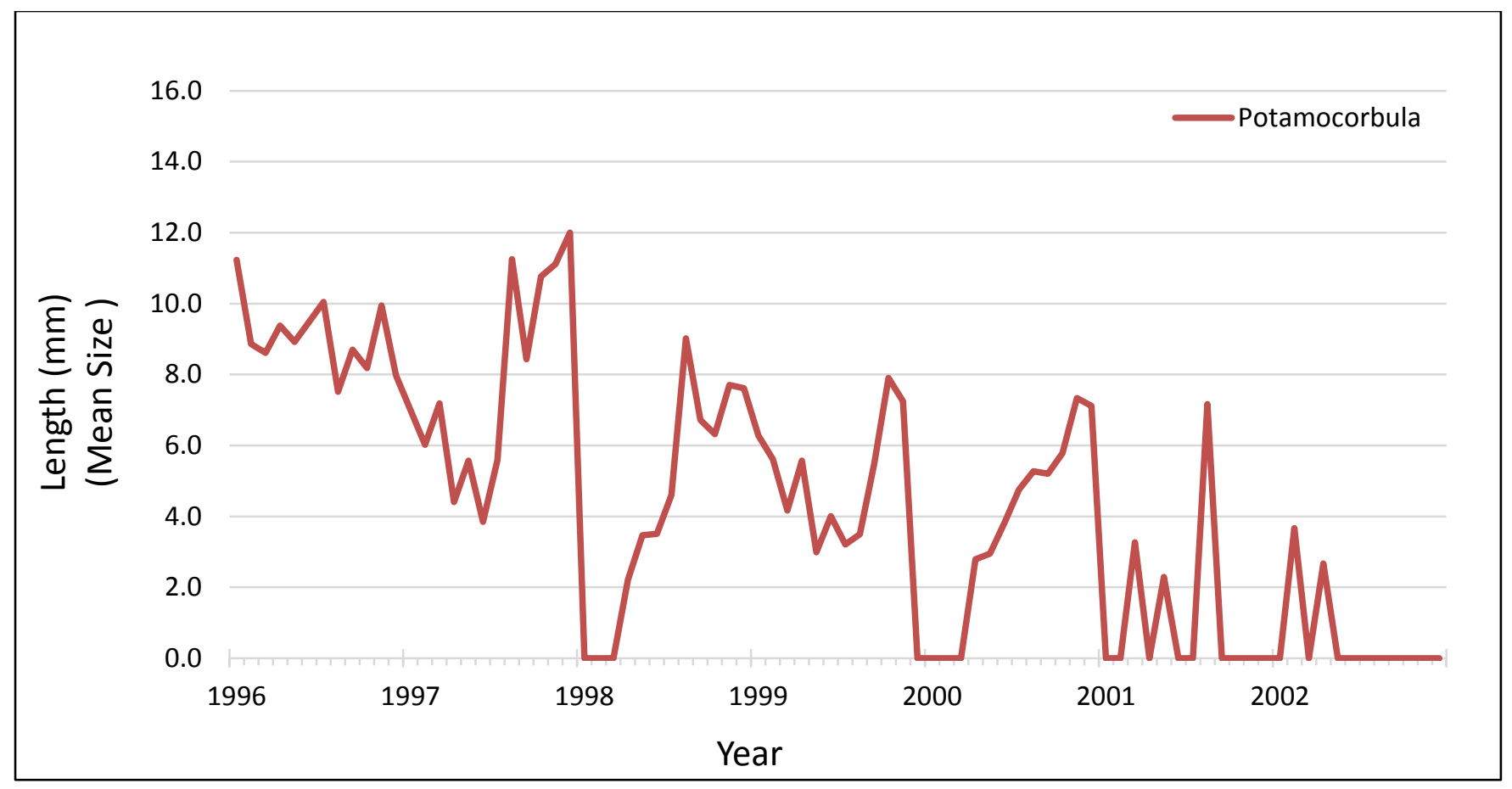

Figure 123. Graph showing mean size at station D41C from 1996-2002. For station locations refer to table 1.

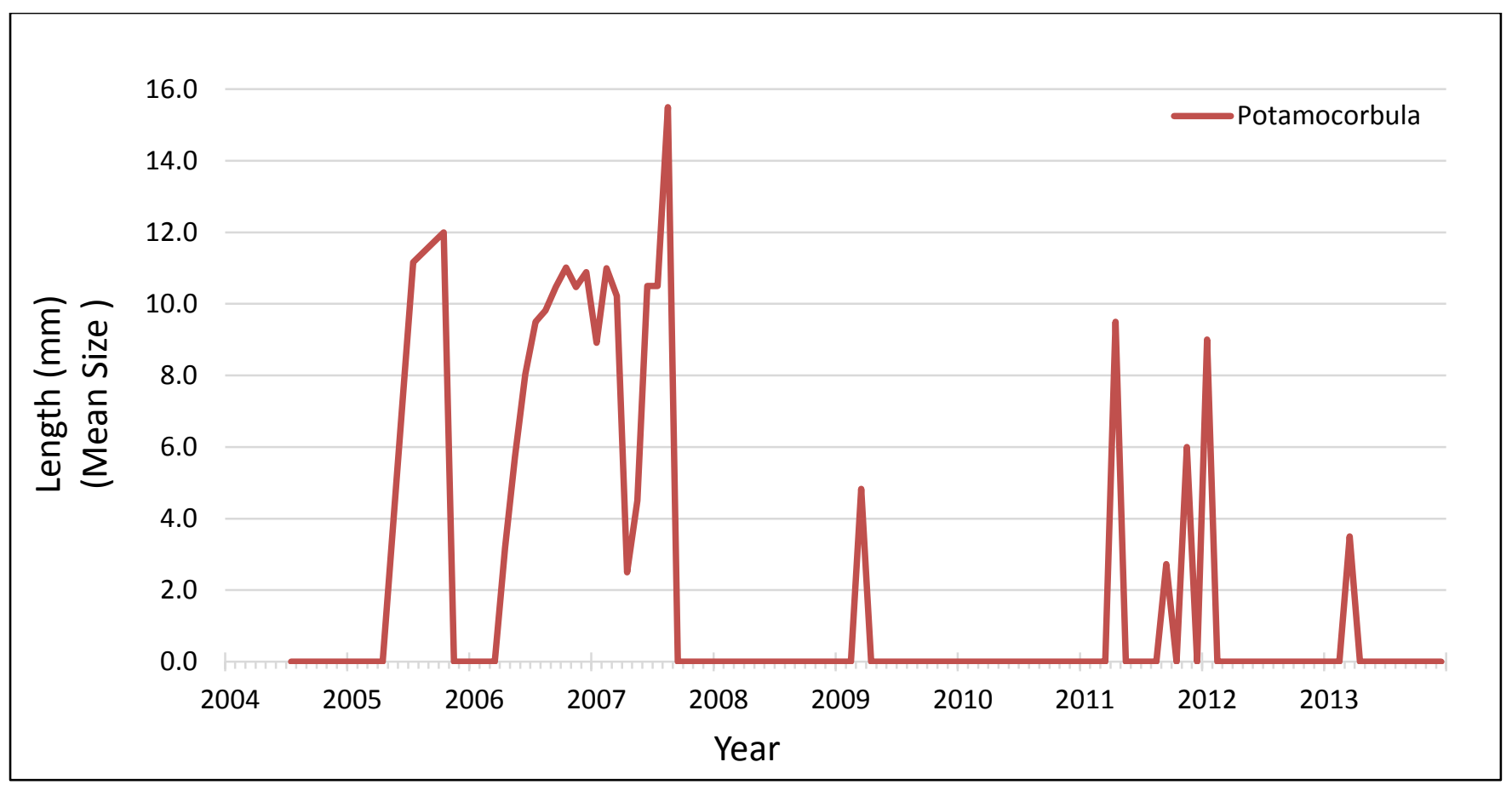

Figure 124. Graph showing mean size at station D41C from 2004-2013. For station locations refer to table 1. 


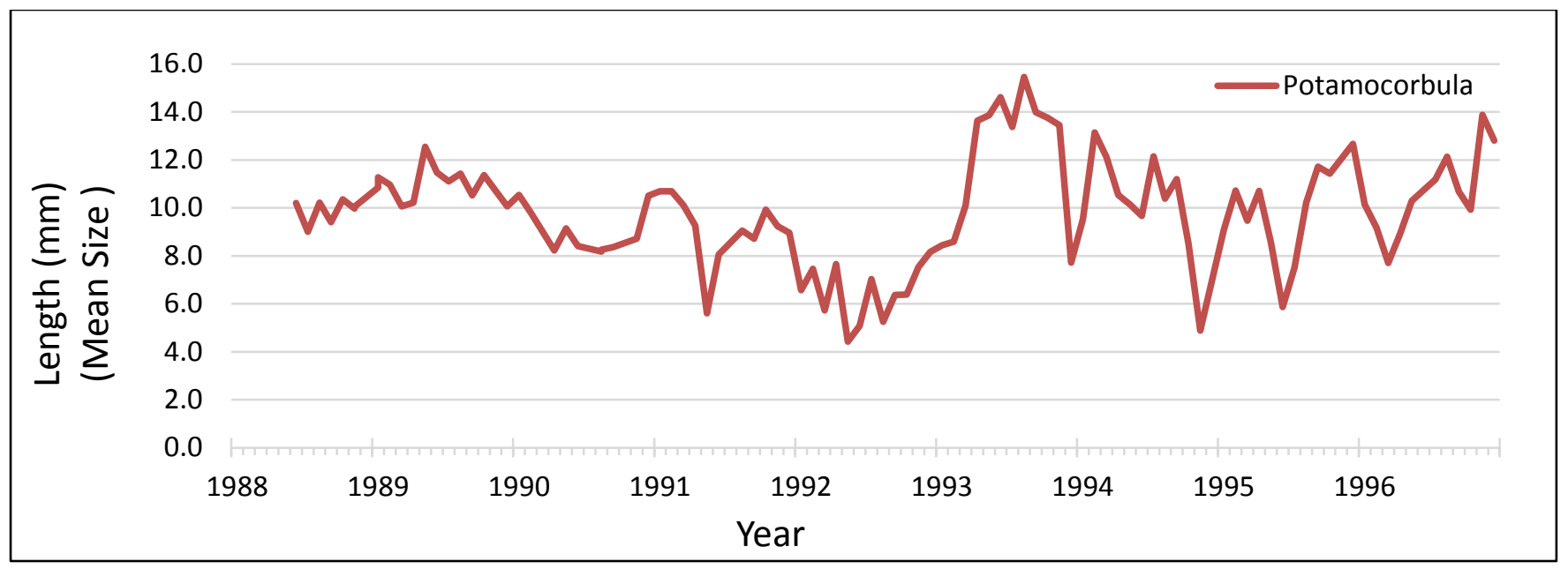

Figure 125. Graph showing mean size at station 8.1 from 1988-1996. For station locations refer to table 1.

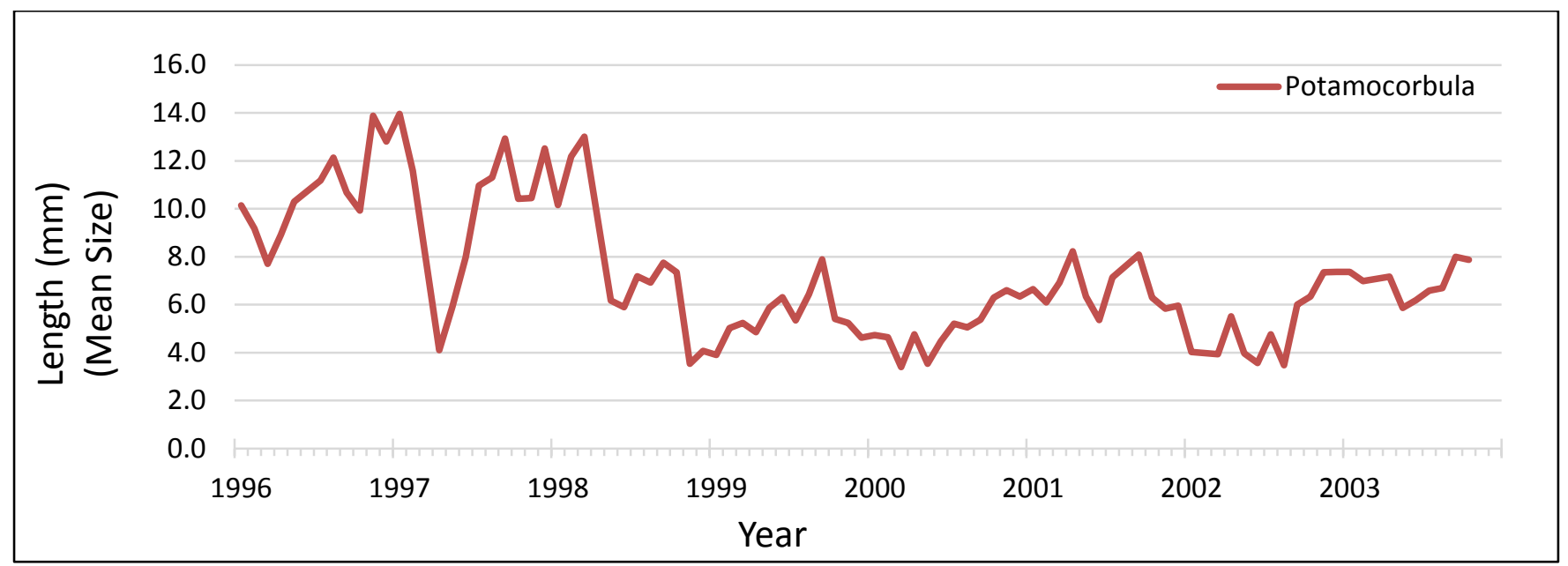

Figure 126. Graph showing mean size at station 8.1 from 1996-2003. For station locations refer to table 1.

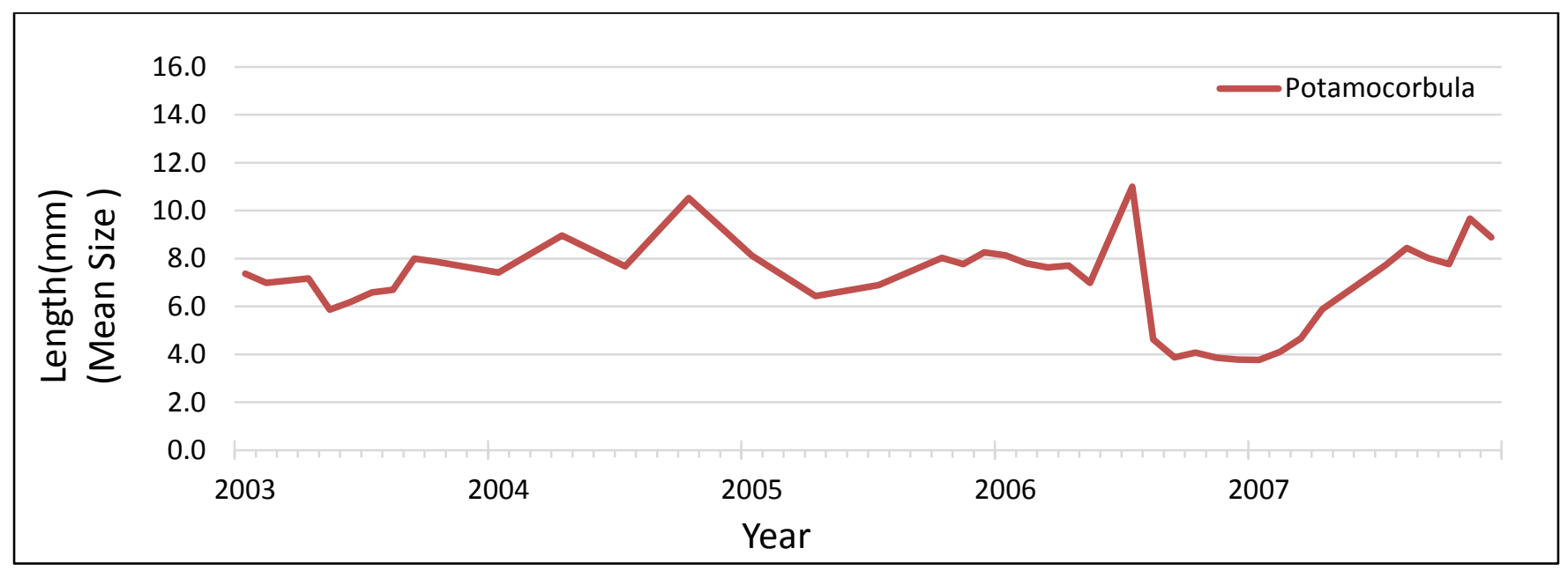

Figure 127. Graph showing mean size at station 8.1 from 2003-2007. For station locations refer to table 1. 


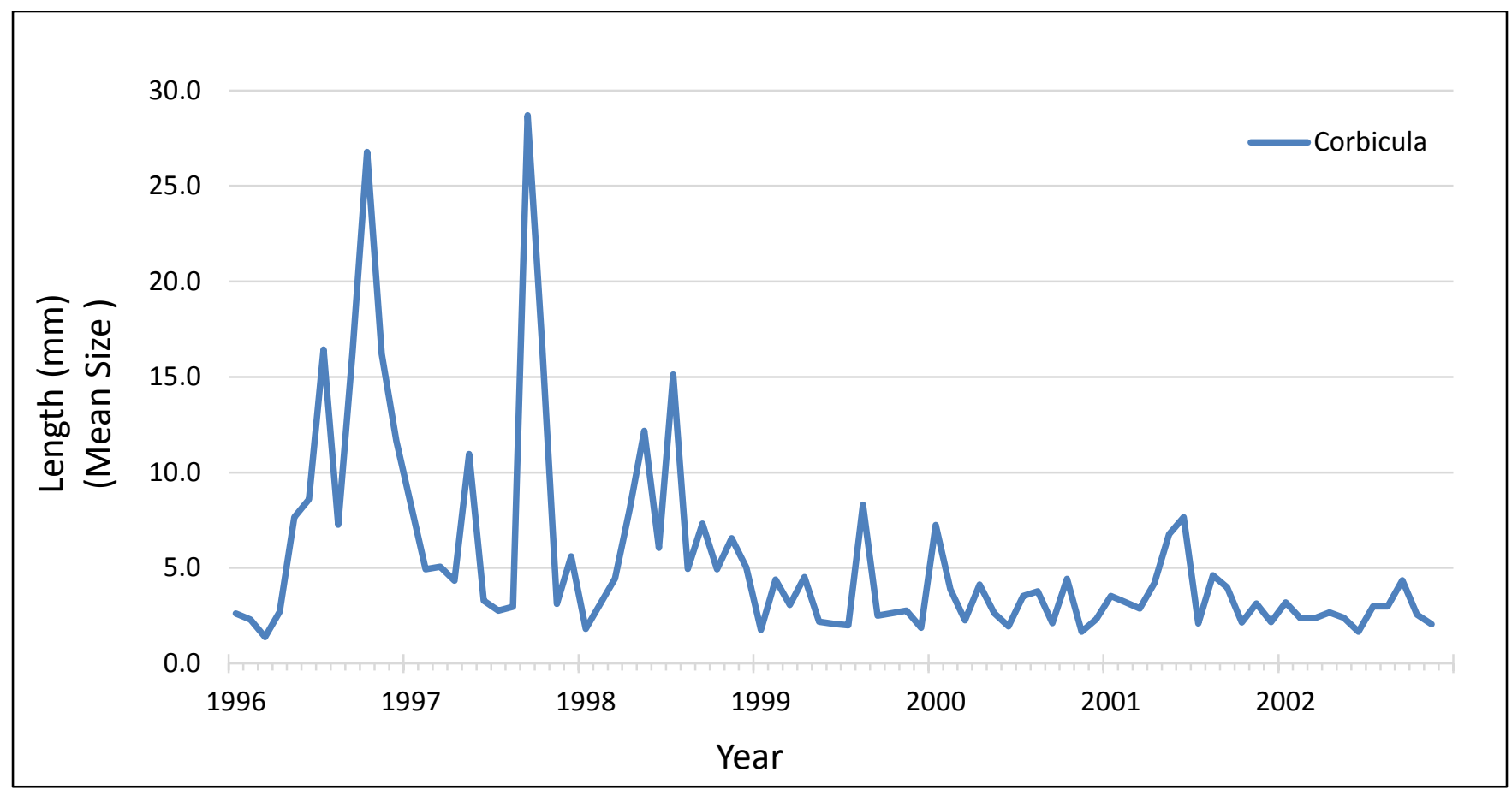

Figure 128. Graph showing mean size at station C9 from 1996-2002. For station locations refer to table 1.

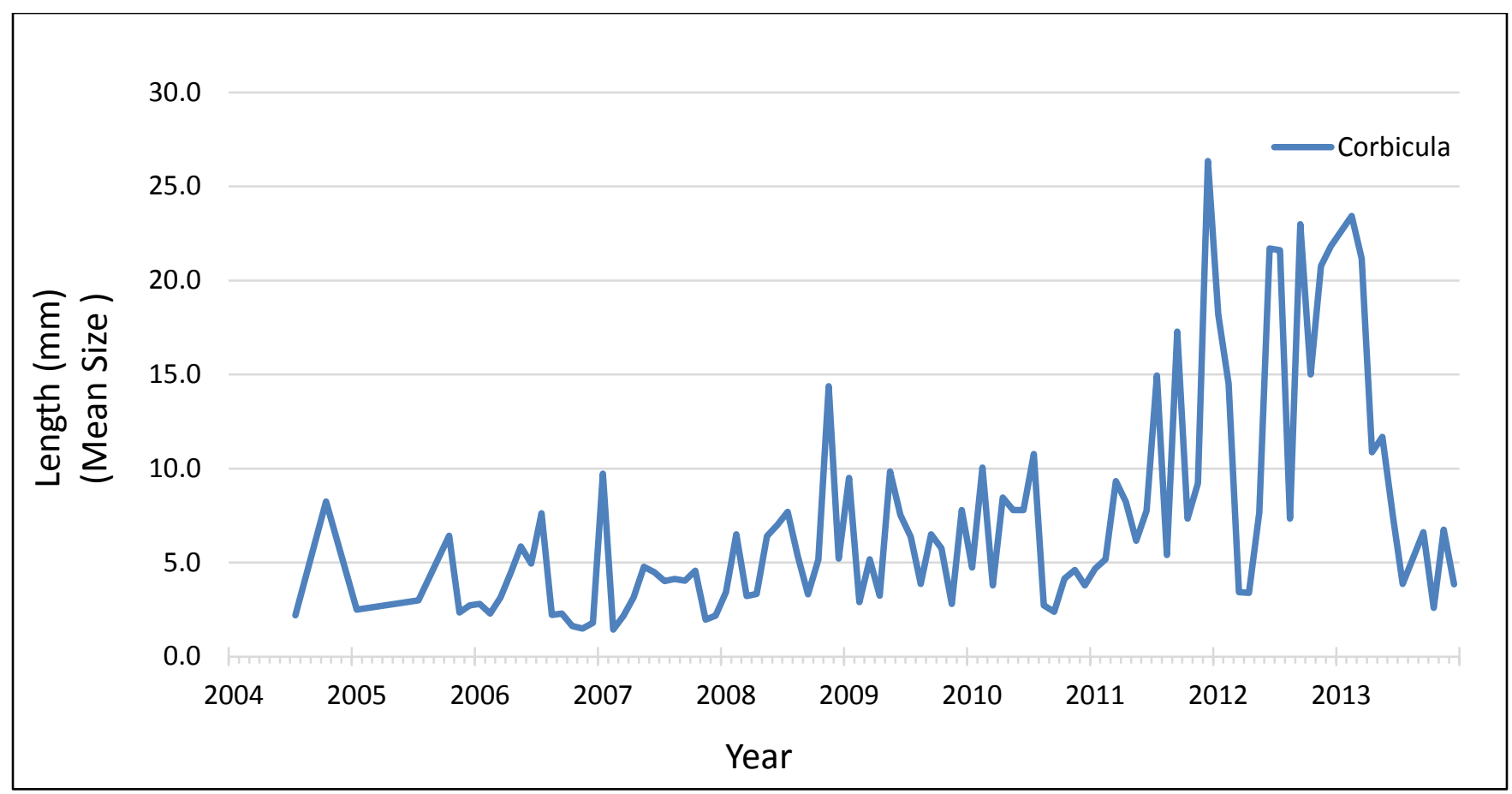

Figure 129. Graph showing mean size at station C9 from 2004-2013. For station locations refer to table 1. 


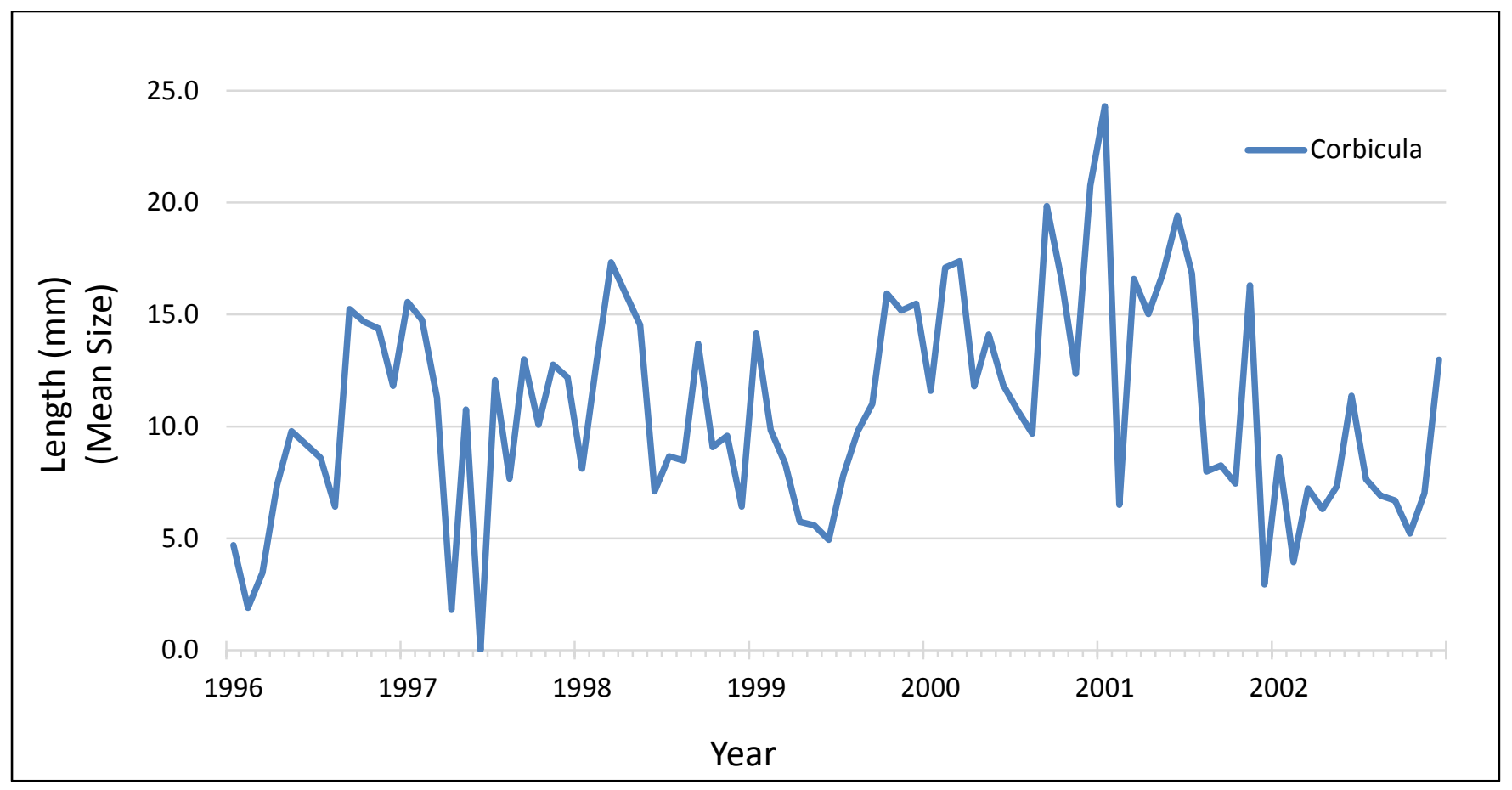

Figure 130. Graph showing mean size at station D16 from 1996-2002. For station locations refer to table 1.

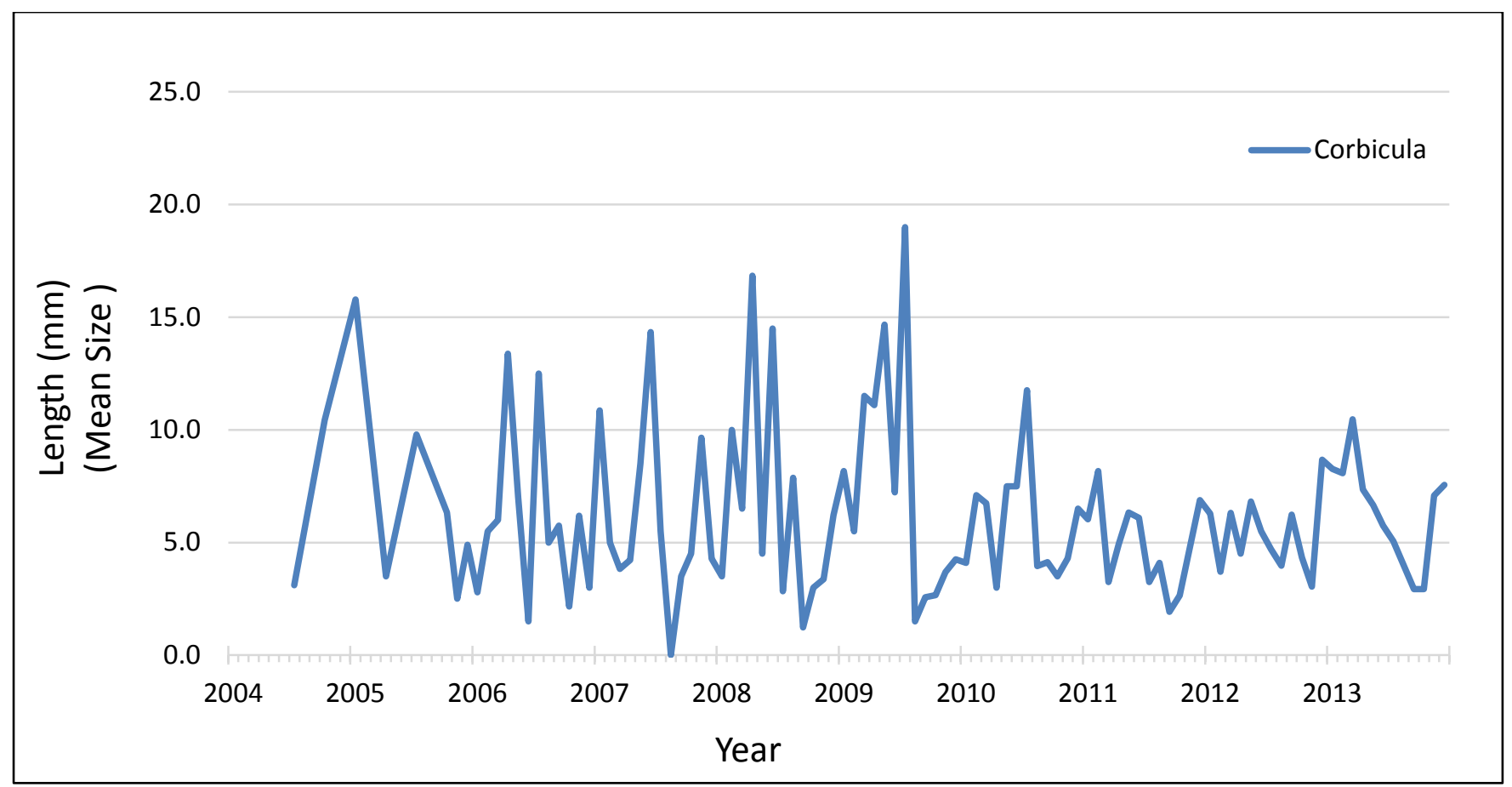

Figure 131. Graph showing mean size at station D16 from 2004-2013. For station locations refer to table 1. 


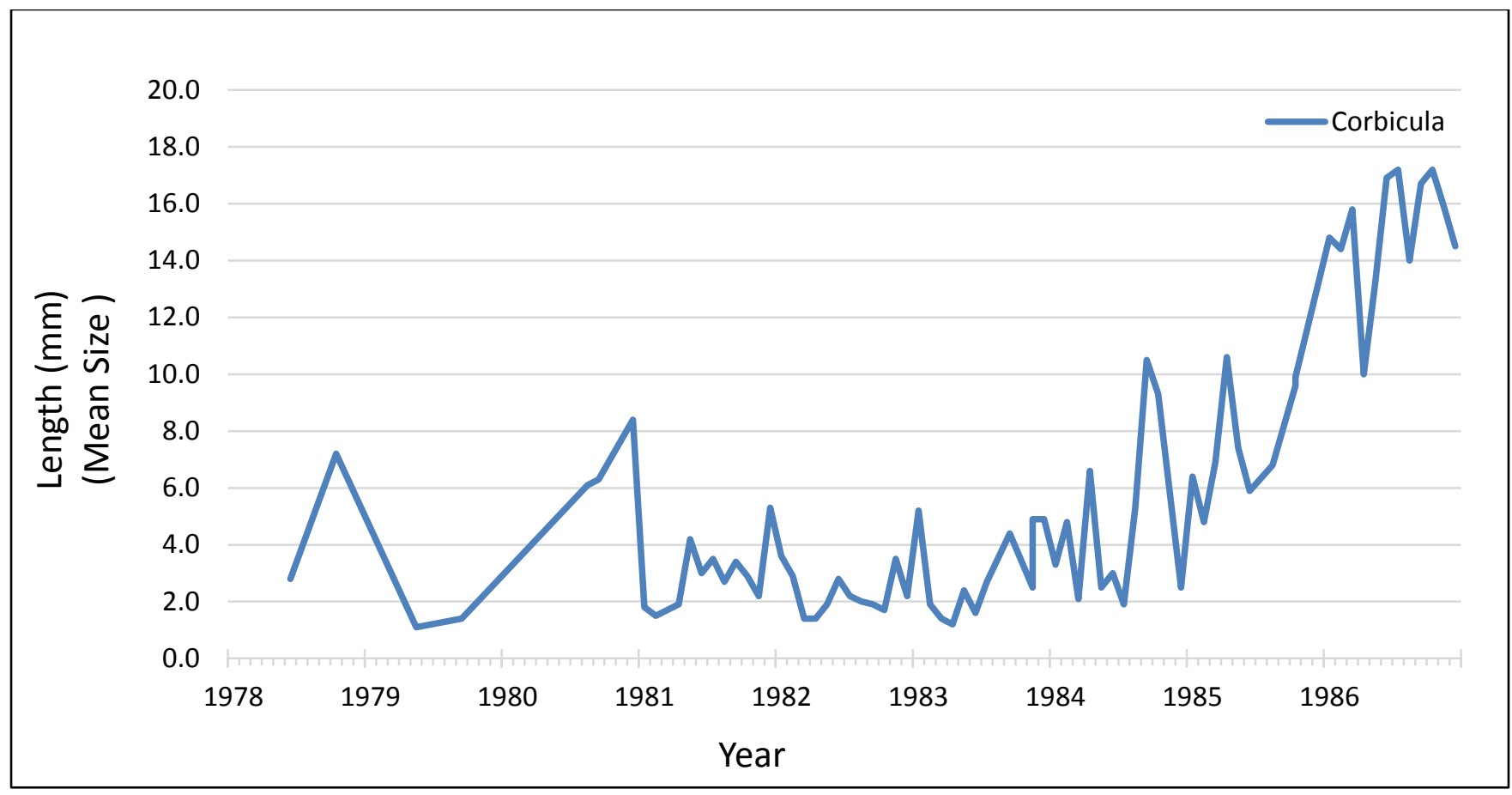

Figure 132. Graph showing mean size at station D19C from 1978-1986. For station locations refer to table 1.

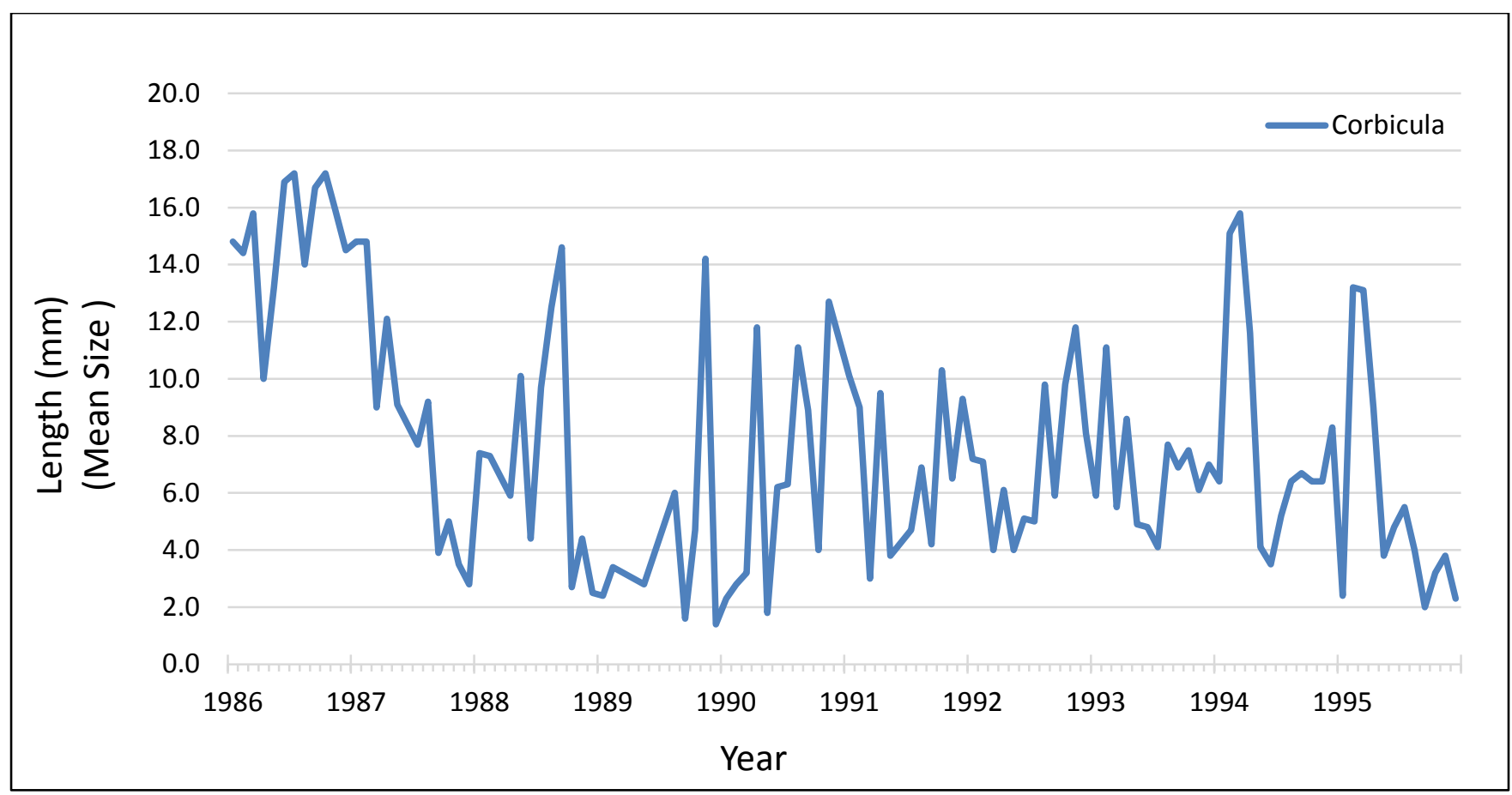

Figure 133. Graph showing mean size at station D19C from 1986-1995. For station locations refer to table 1. 


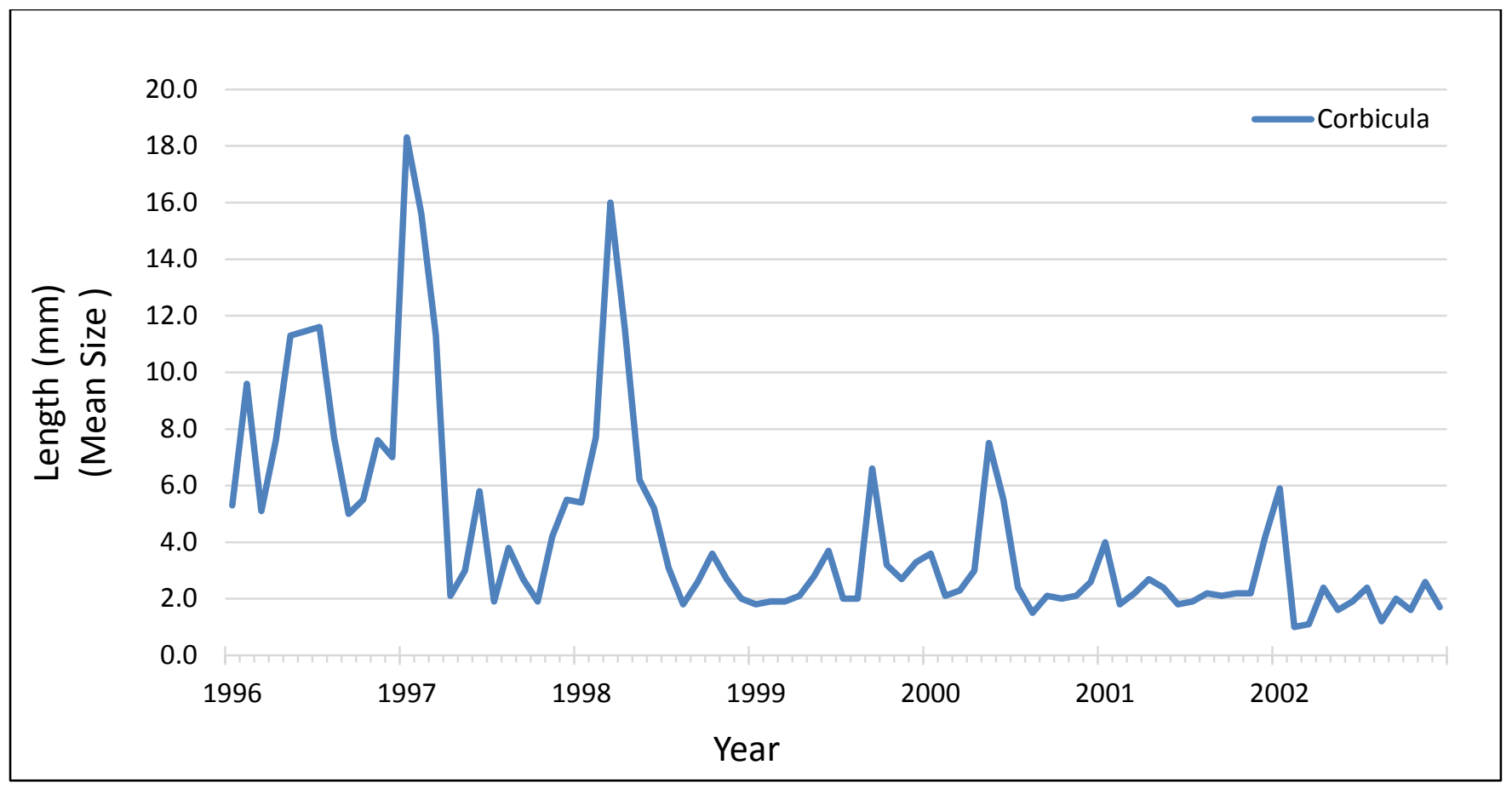

Figure 134. Graph showing mean size at station D24 from 1996-2002. For station locations refer to table 1.

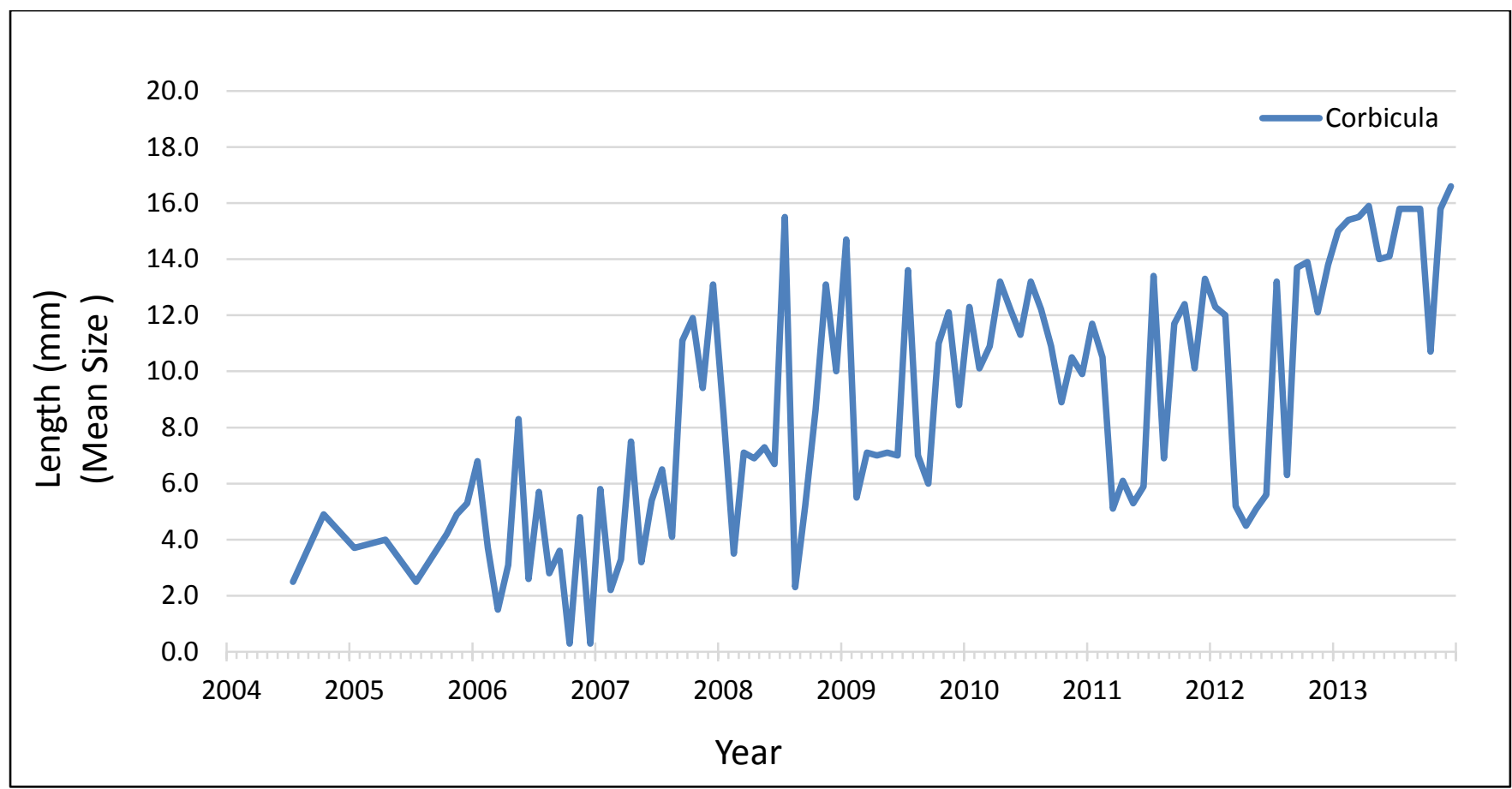

Figure 135. Graph showing mean size at station D24 from 2004-2013 For station locations refer to table 1. 


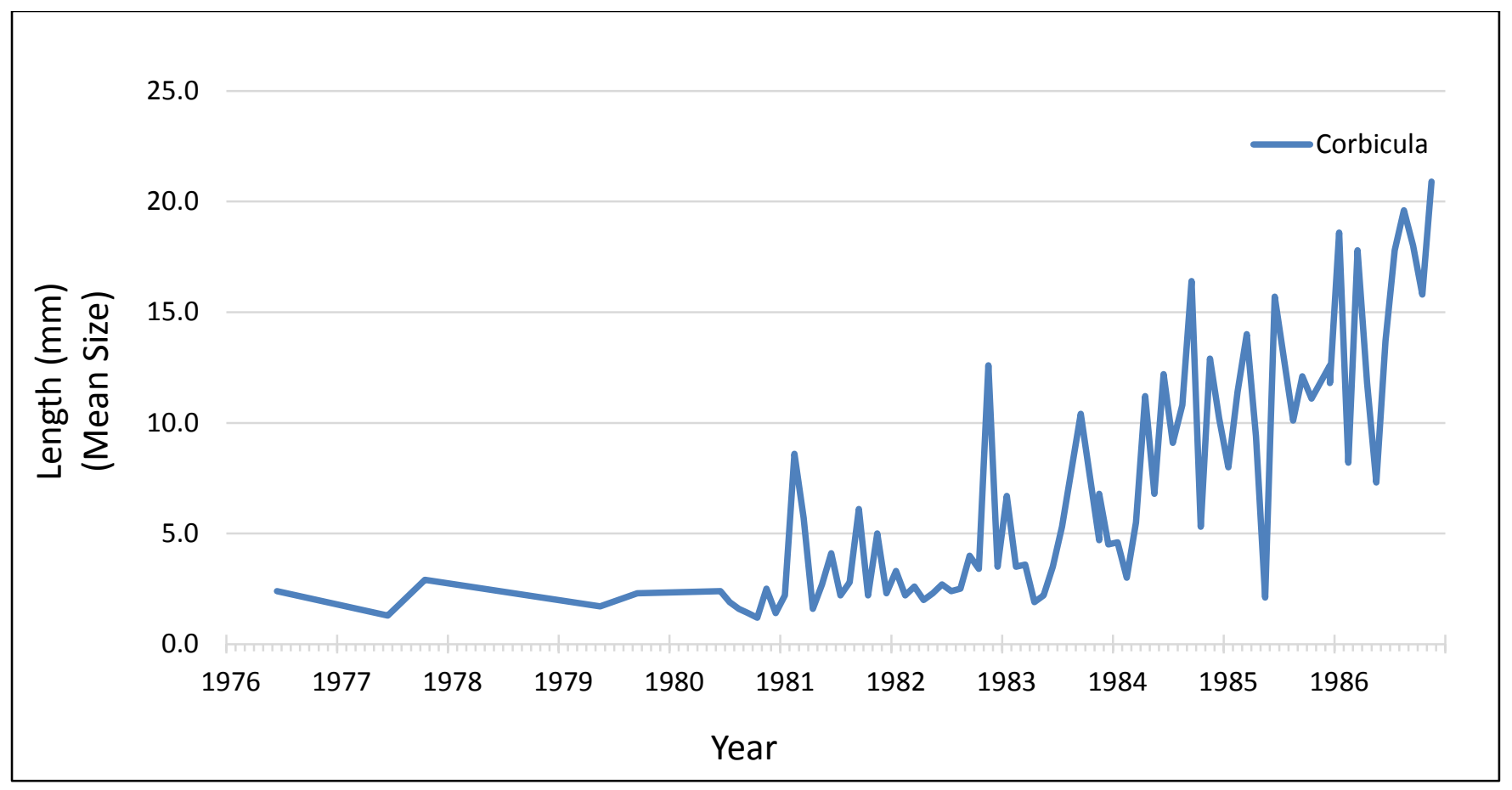

Figure 136. Graph showing mean size at station D28 from 1976-1986. For station locations refer to table 1.

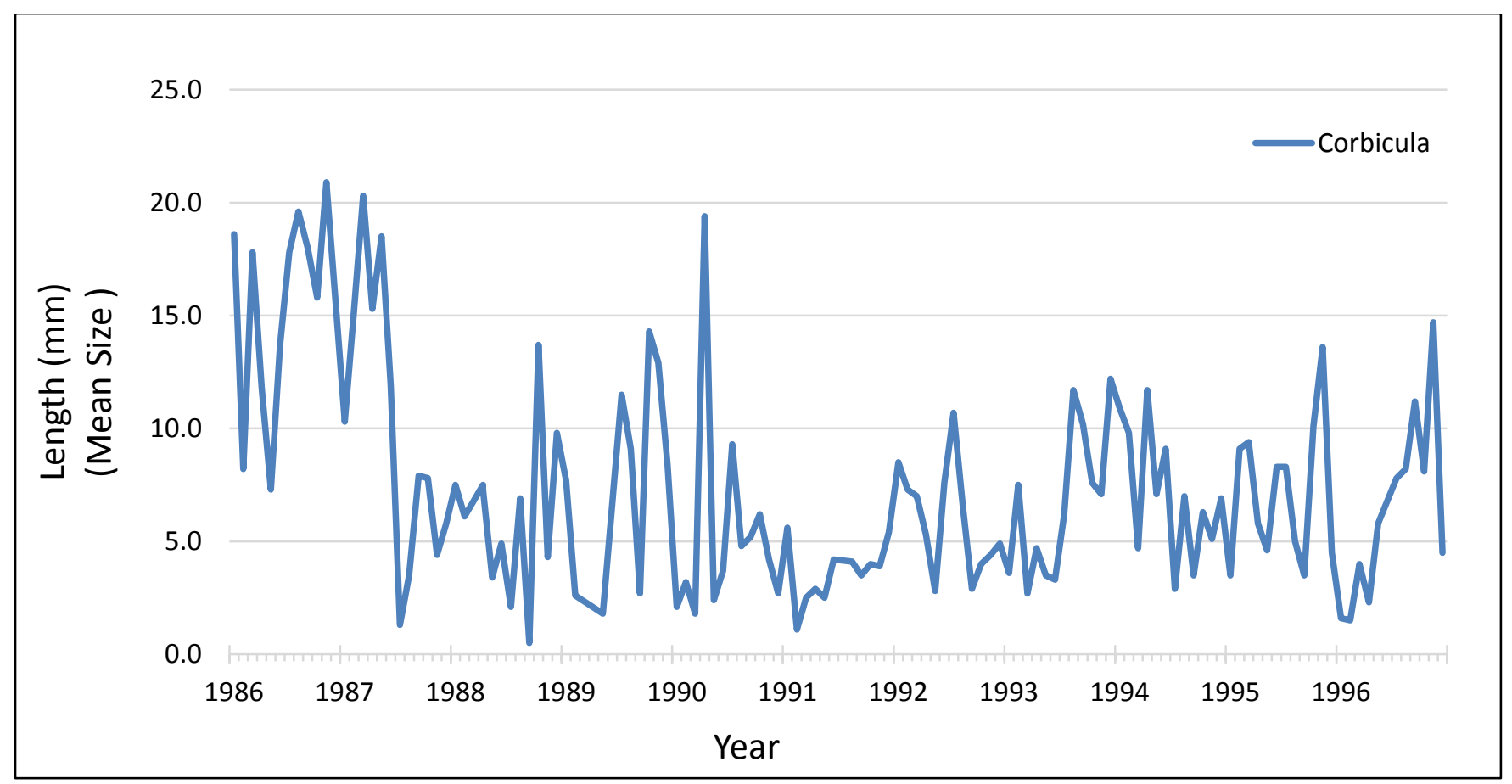

Figure 137. Graph showing mean size at station D28 from 1986-1996. For station locations refer to table 1. 


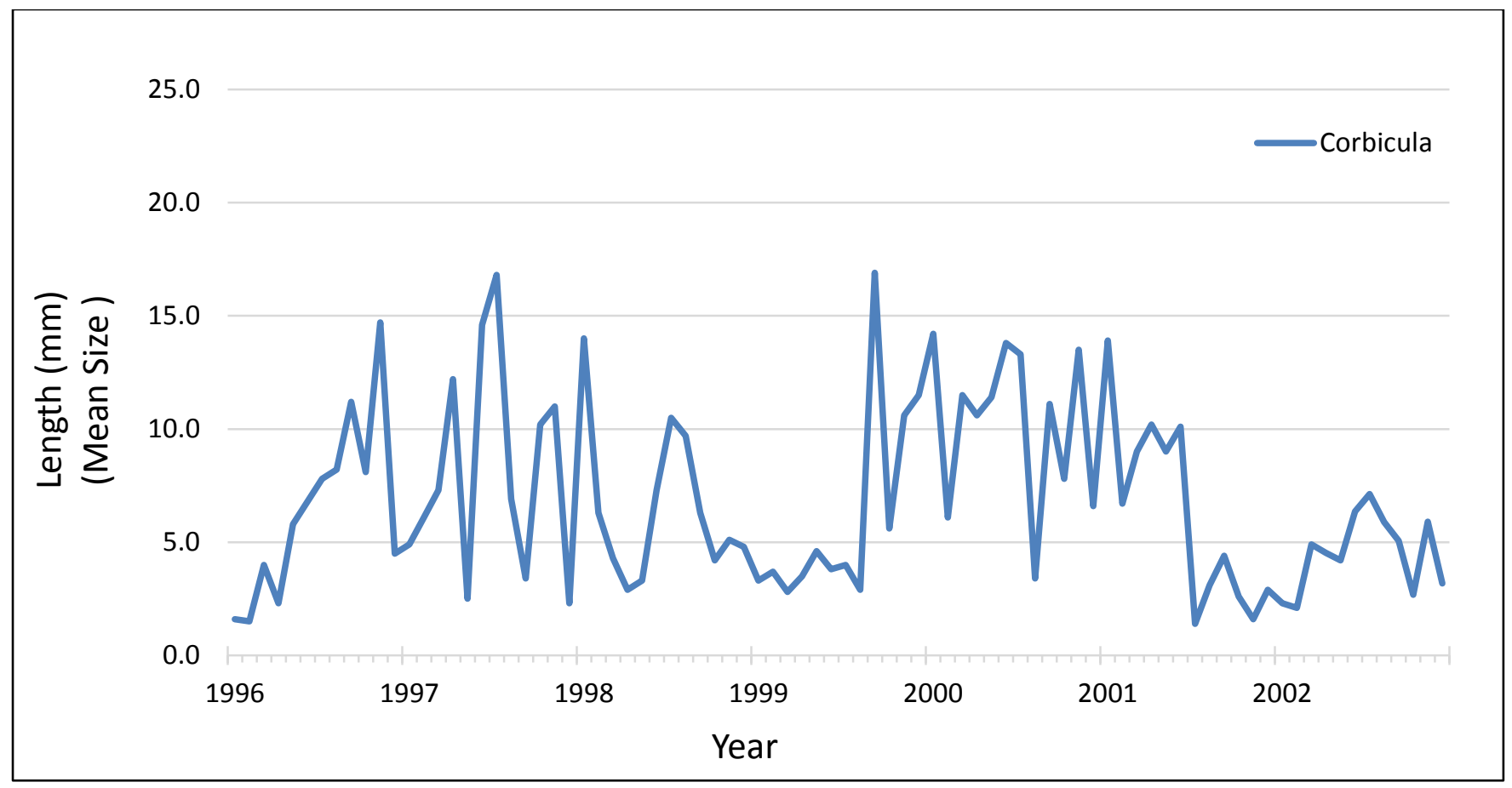

Figure 138. Graph showing mean size at station D28 from 1996-2002. For station locations refer to table 1.

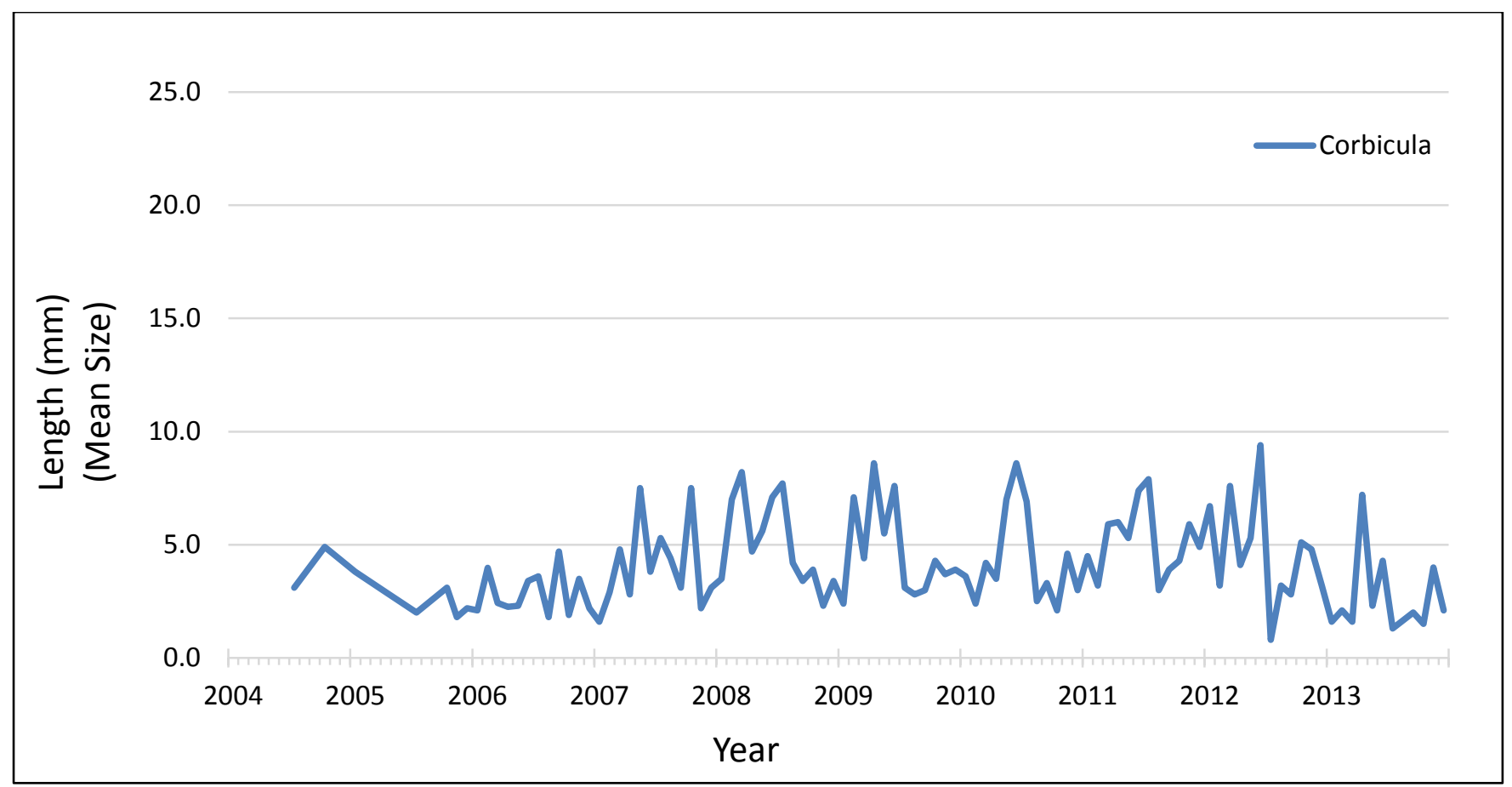

Figure 139. Graph showing mean size at station D28 from 2004-2013. For station locations refer to table 1. 


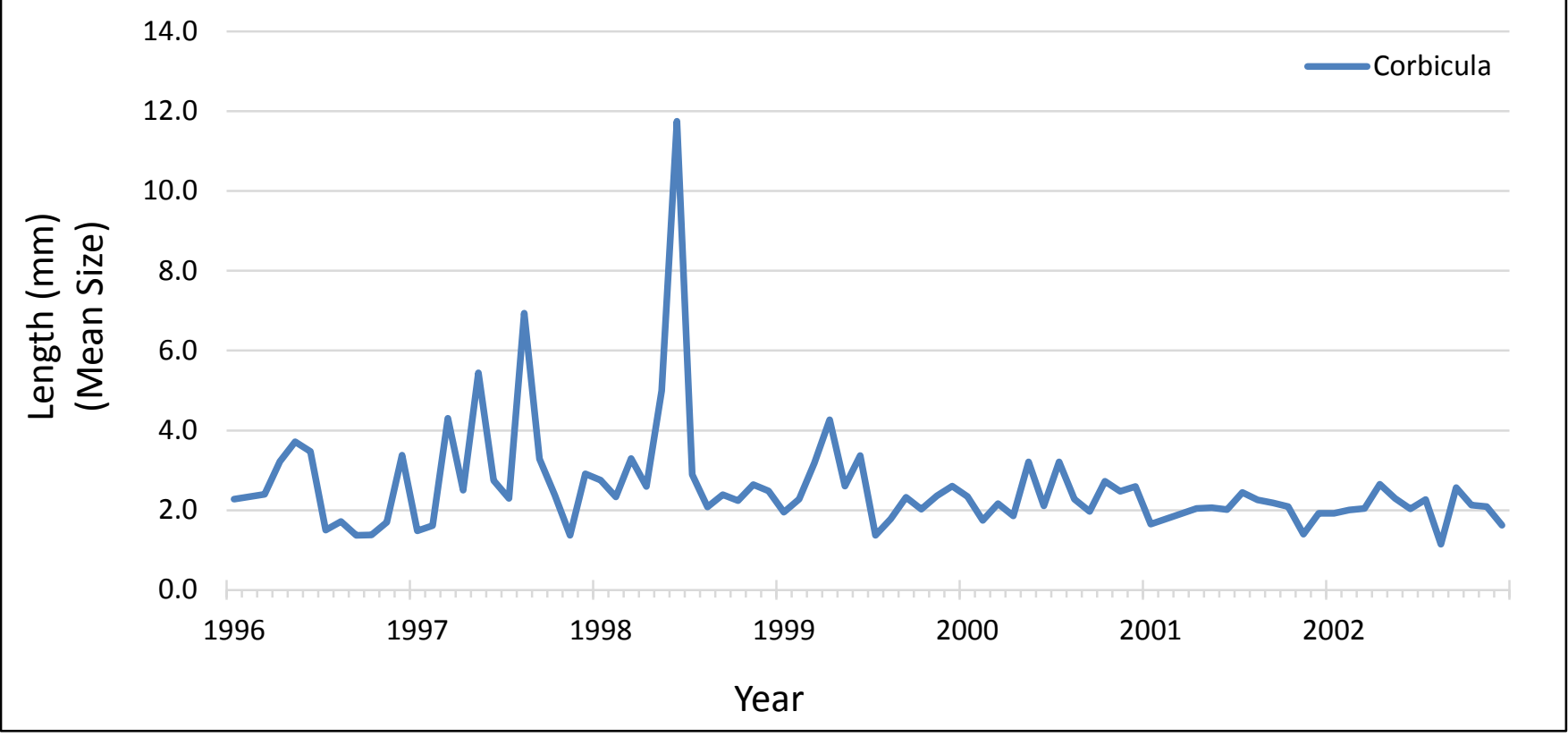

Figure 140. Graph showing mean size at station P8 from 1996-2002. For station locations refer to table 1.

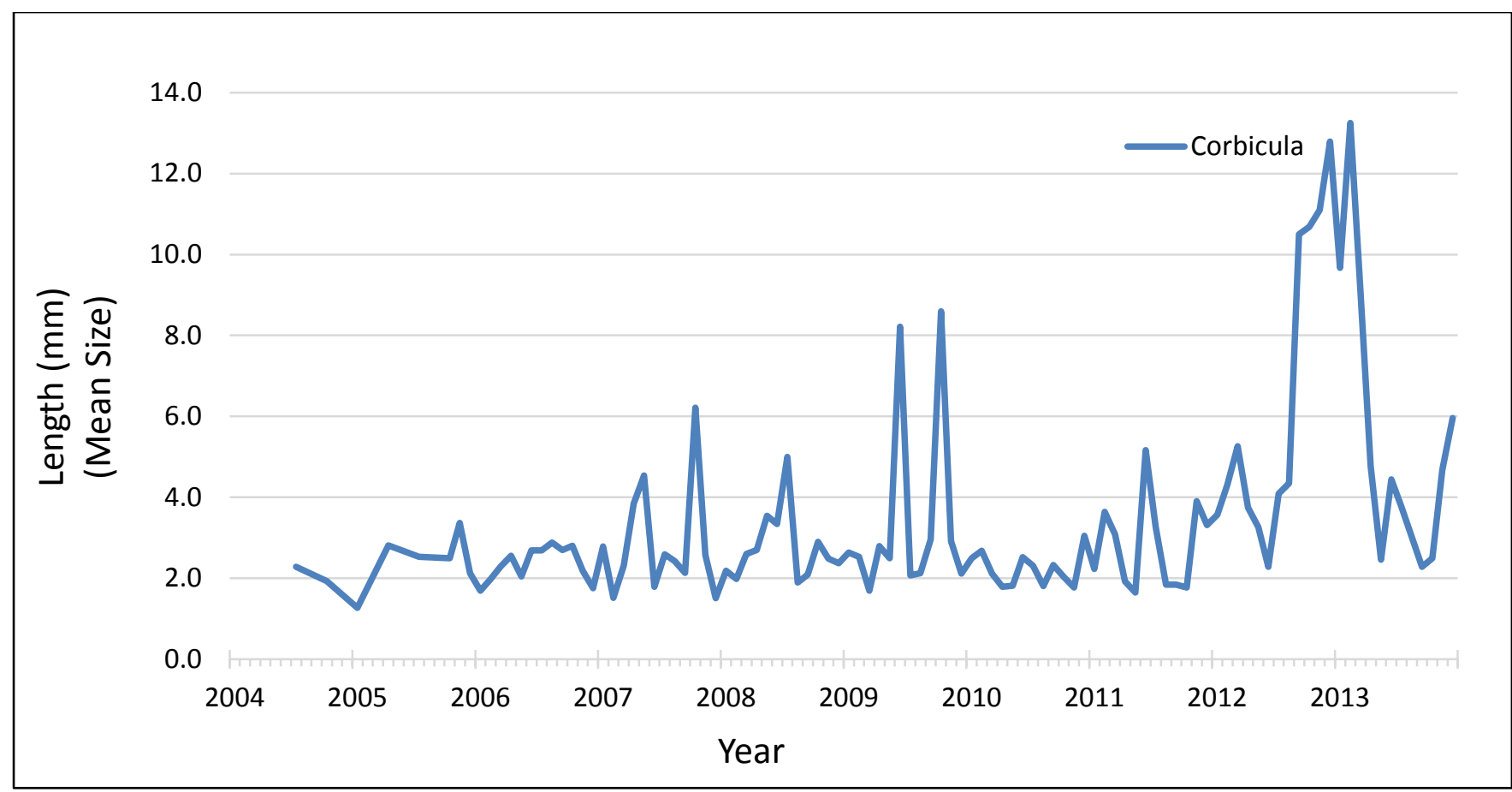

Figure 141. Graph showing mean size at station P8 from 2004-2013. For station locations refer to table 1. 


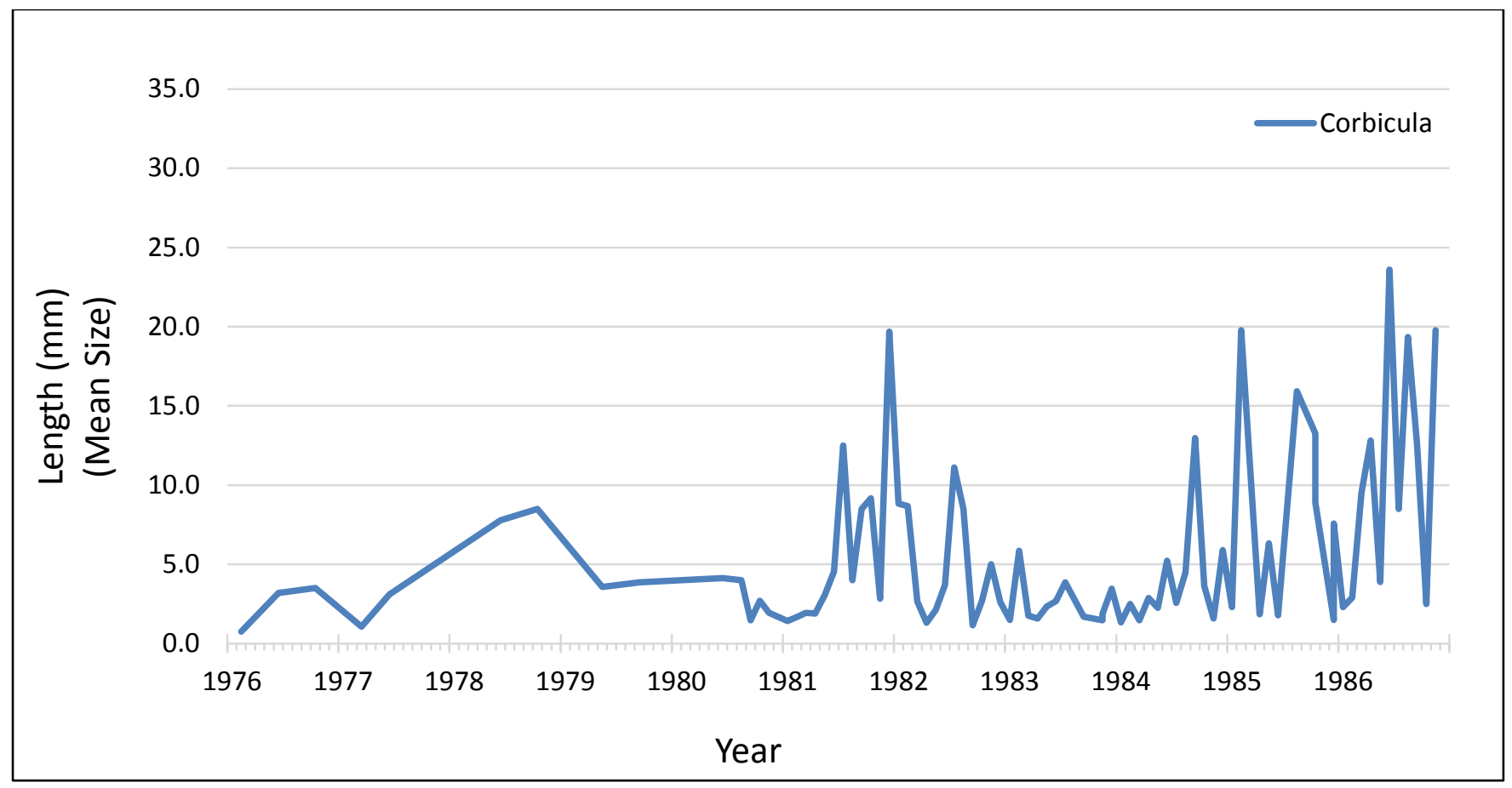

Figure 142. Graph showing mean size at station D4C from 1976-1986. For station locations refer to table 1.

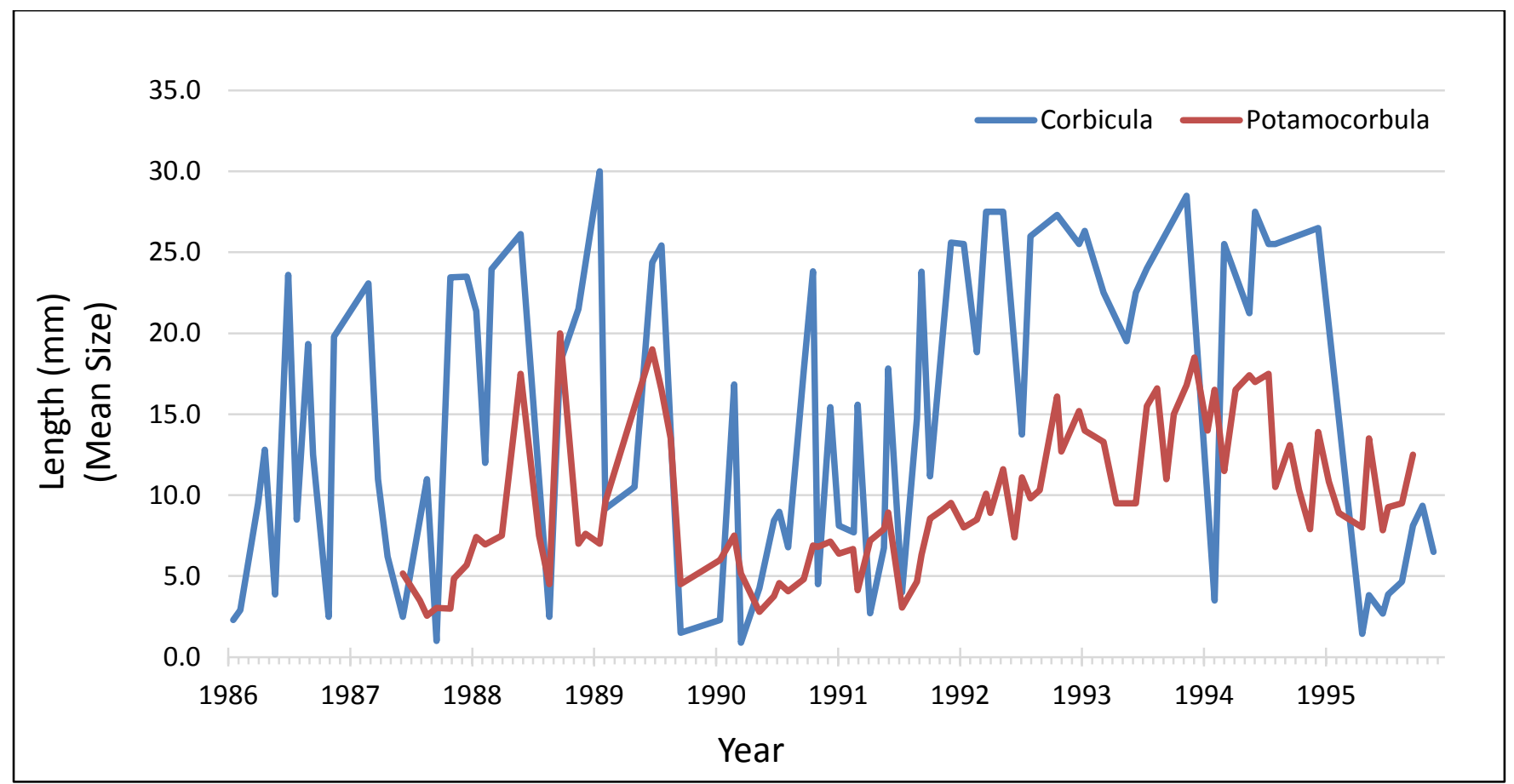

Figure 143. Graph showing mean size at station D4C from 1986-1995. For station locations refer to table 1. 


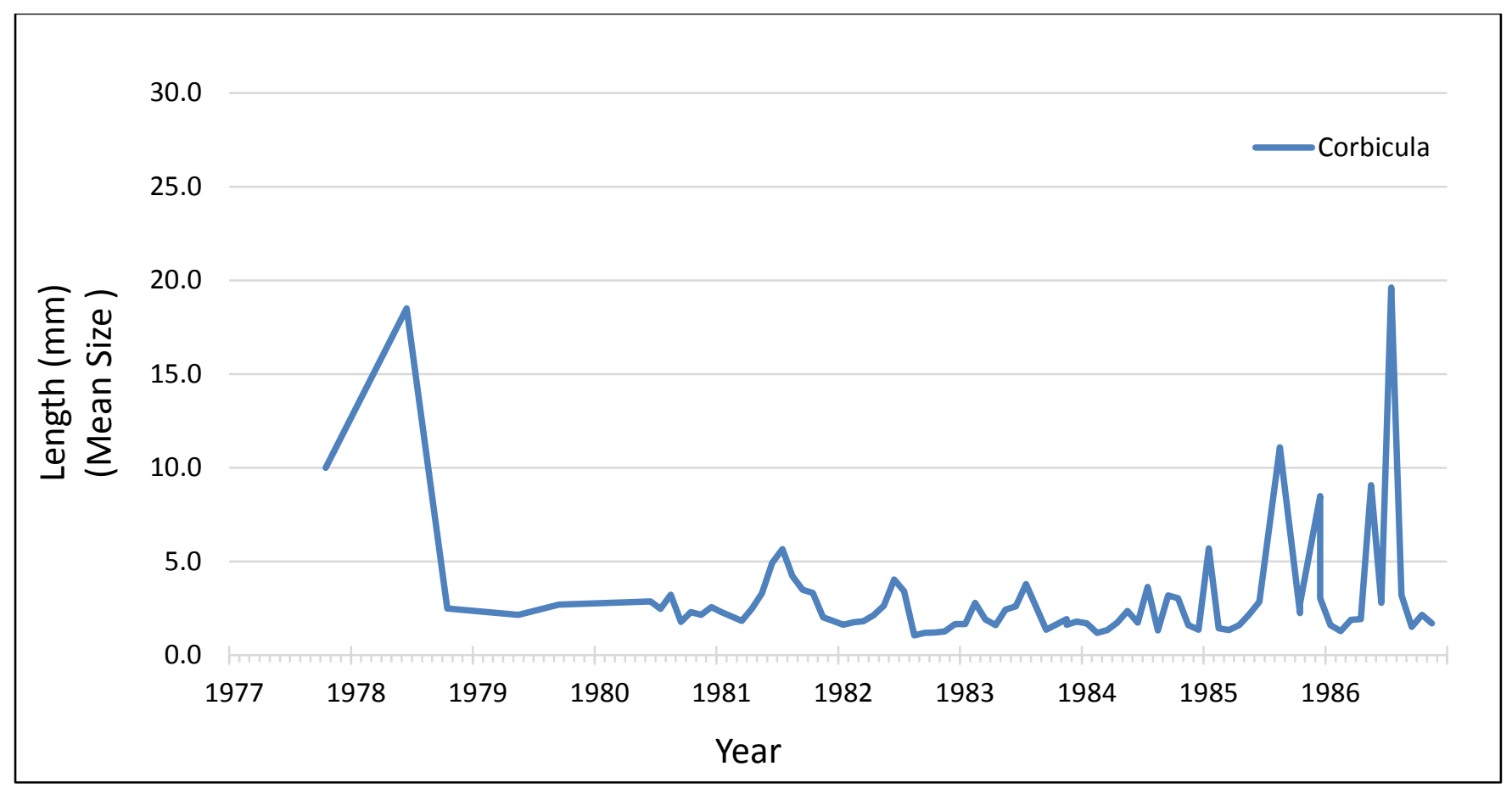

Figure 144. Graph showing mean size at station D4L from 1977-1986. For station locations refer to table 1.

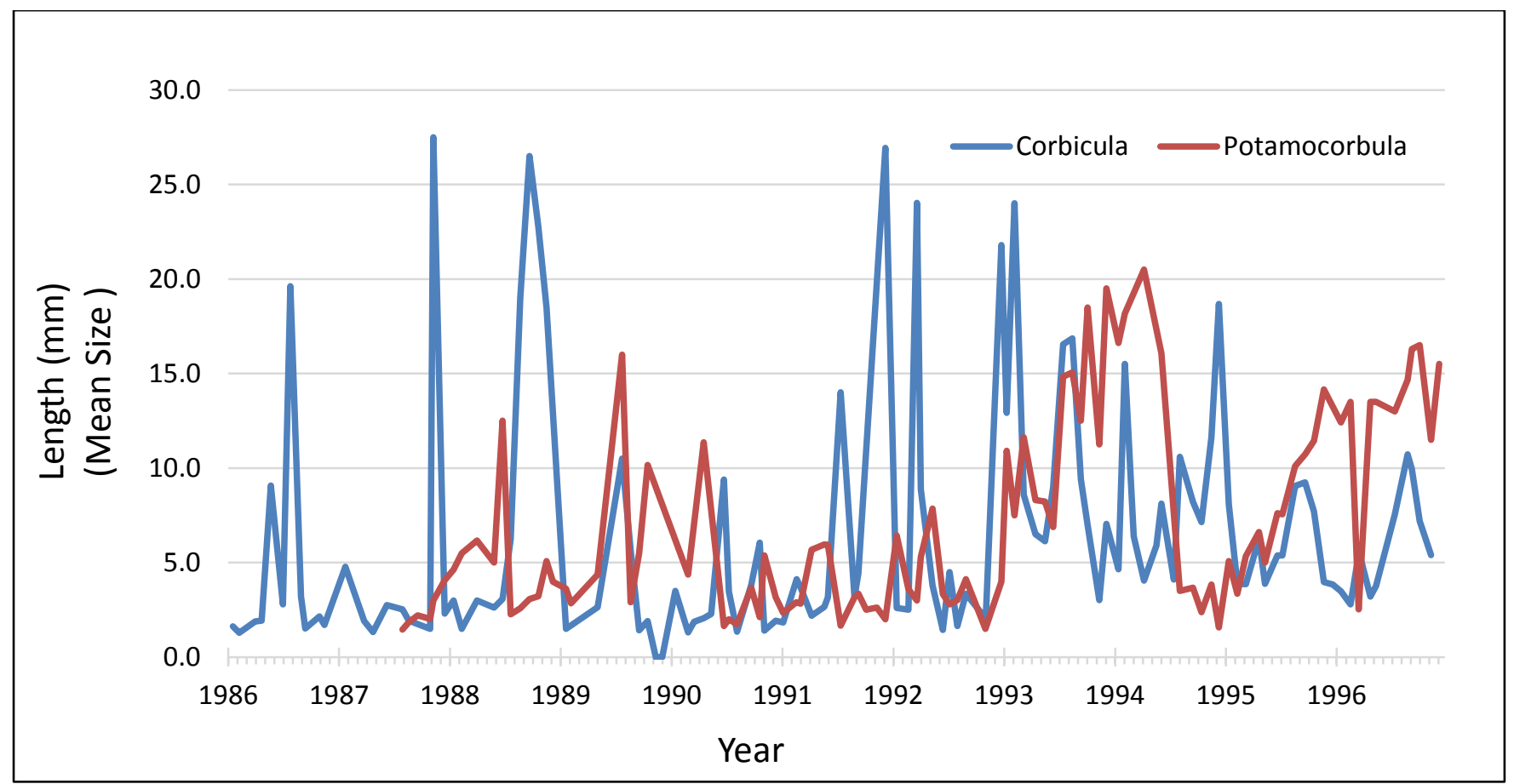

Figure 145. Graph showing mean size at station D4L from 1986-1996. For station locations refer to table 1. 


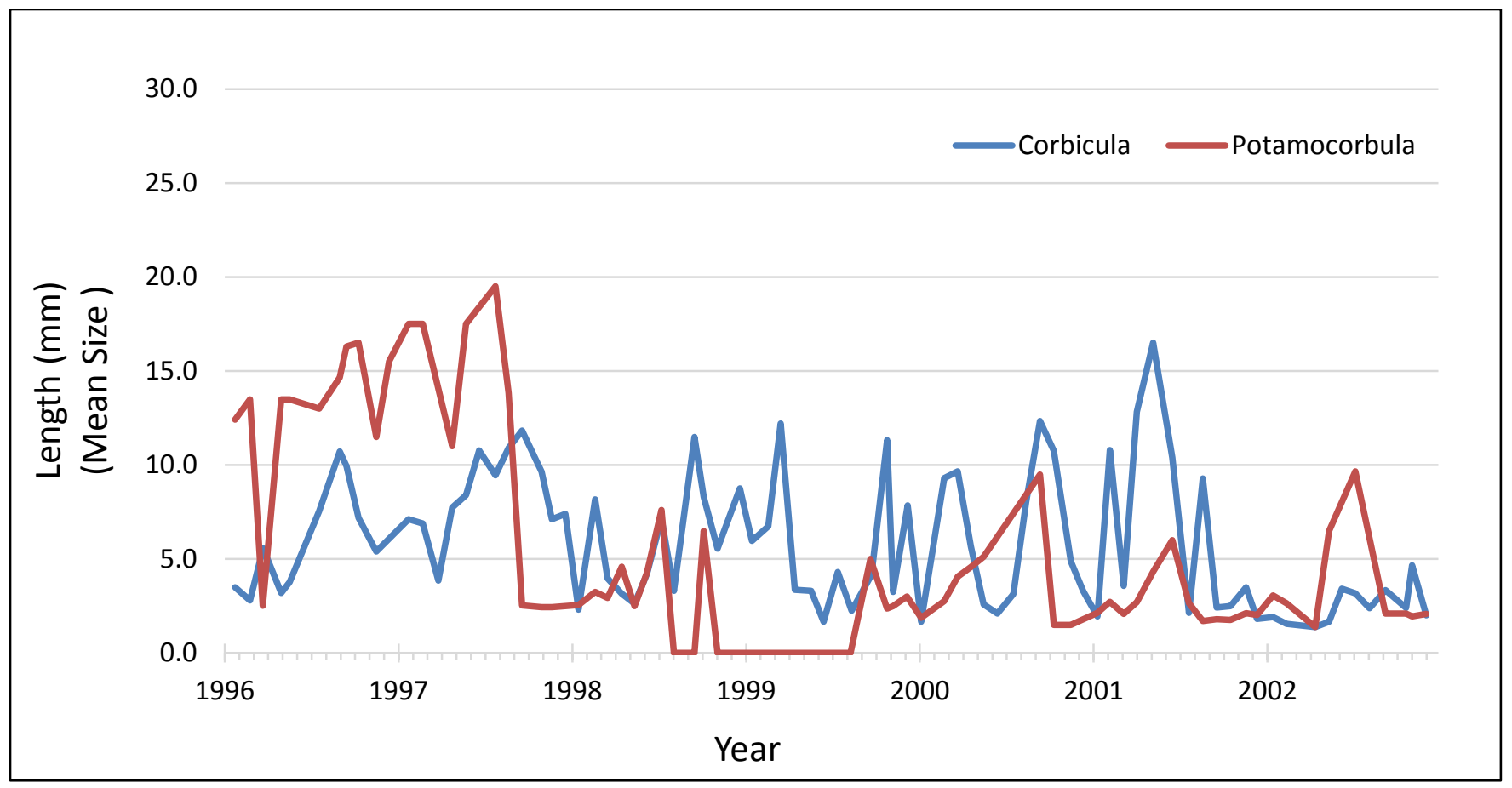

Figure 146. Graph showing mean size at station D4L from 1996-2002. For station locations refer to table 1.

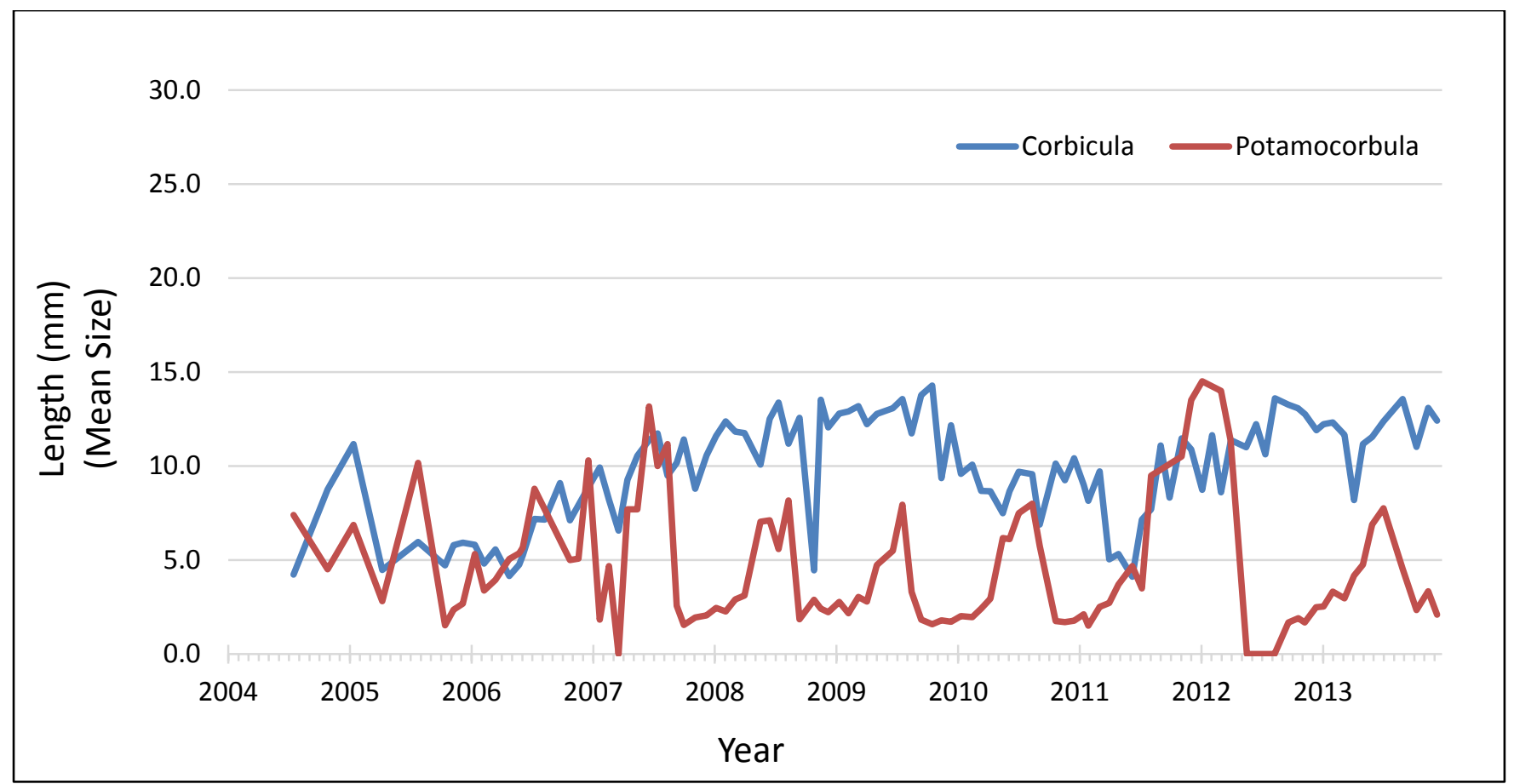

Figure 147. Graph showing mean size at station D4L from 2004-2013. For station locations refer to table 1. 


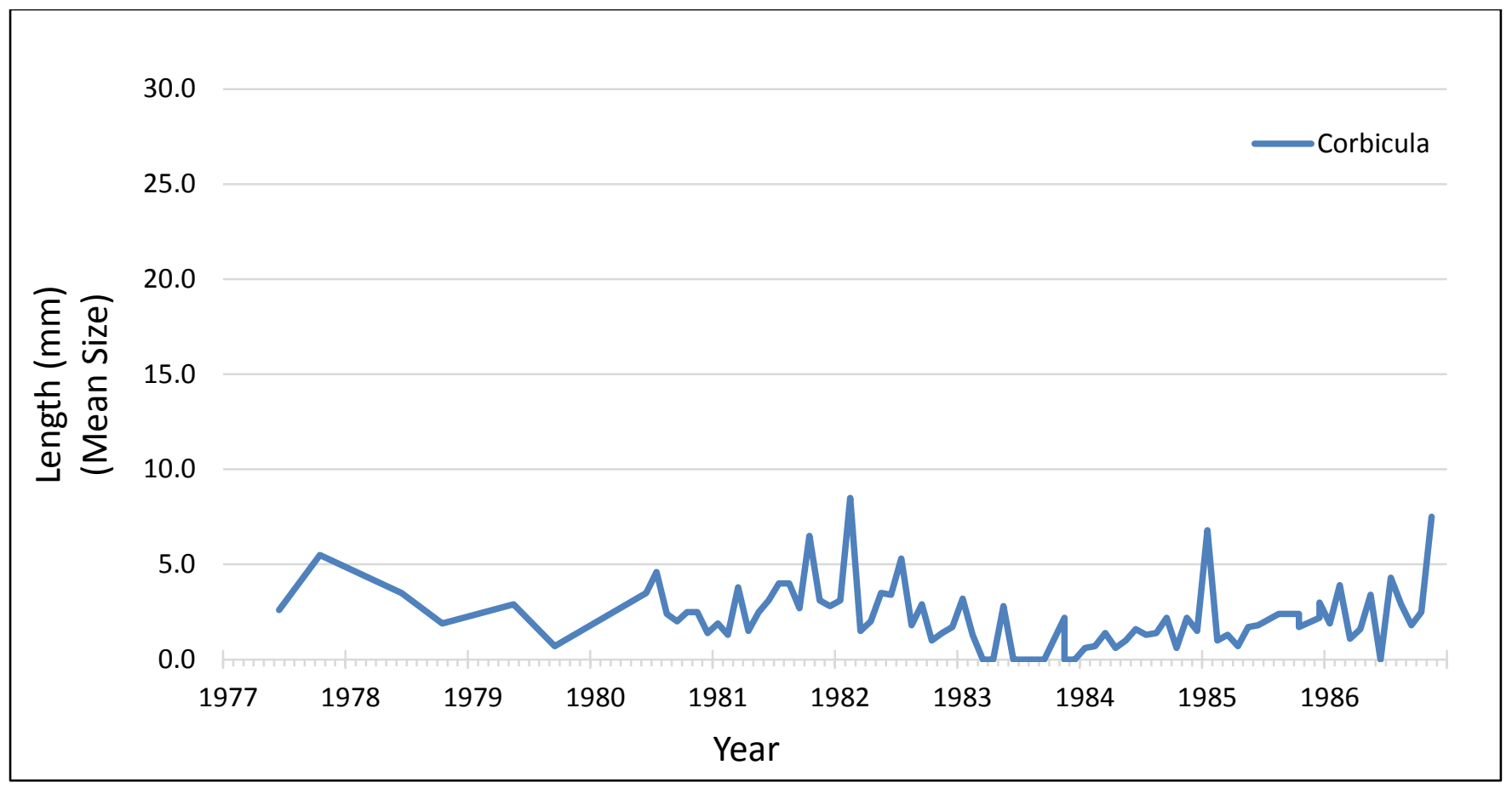

Figure 148. Graph showing mean size at station D4R from 1977-1986. For station locations refer to table 1.

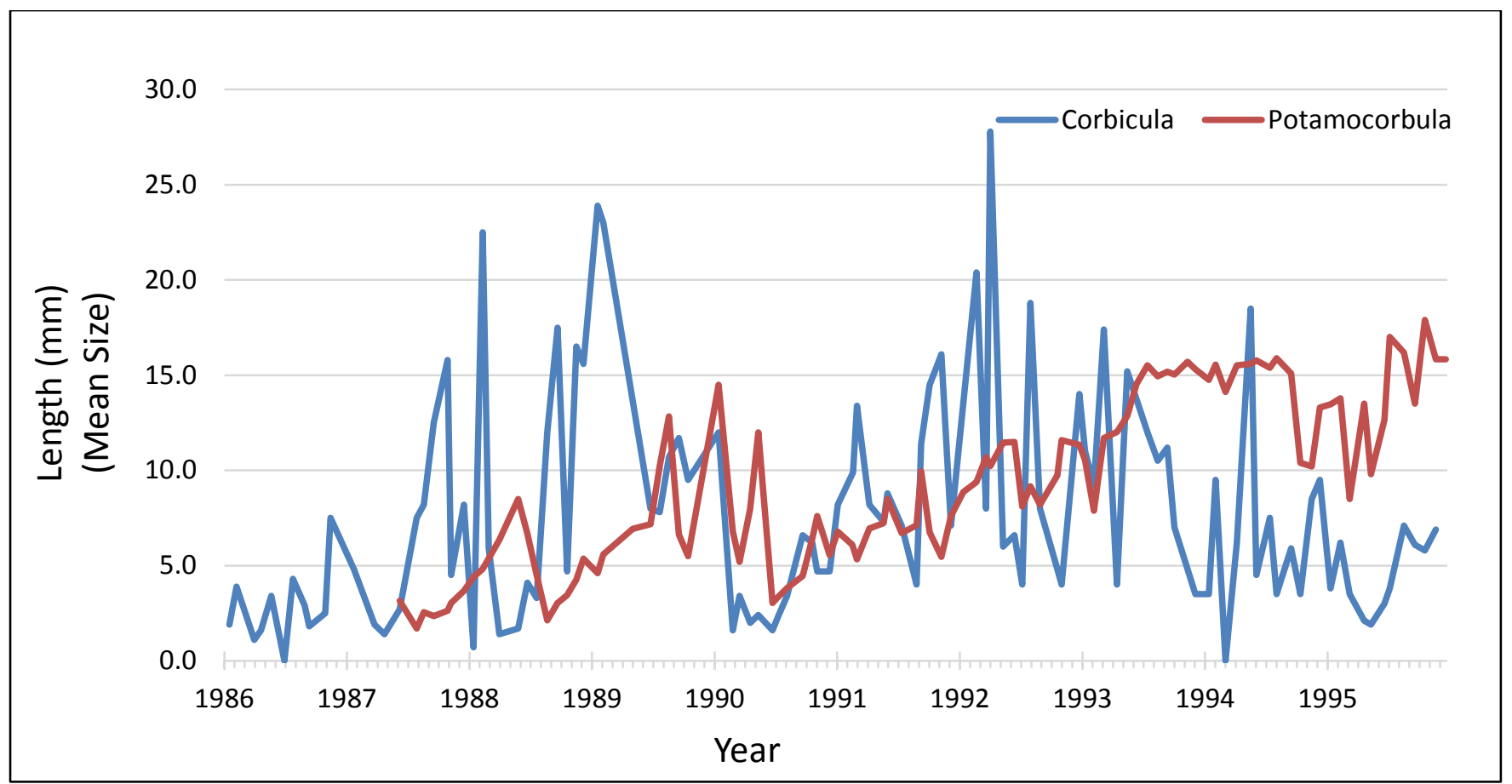

Figure 149. Graph showing mean size at station D4R from 1986-1995. For station locations refer to table 1. 


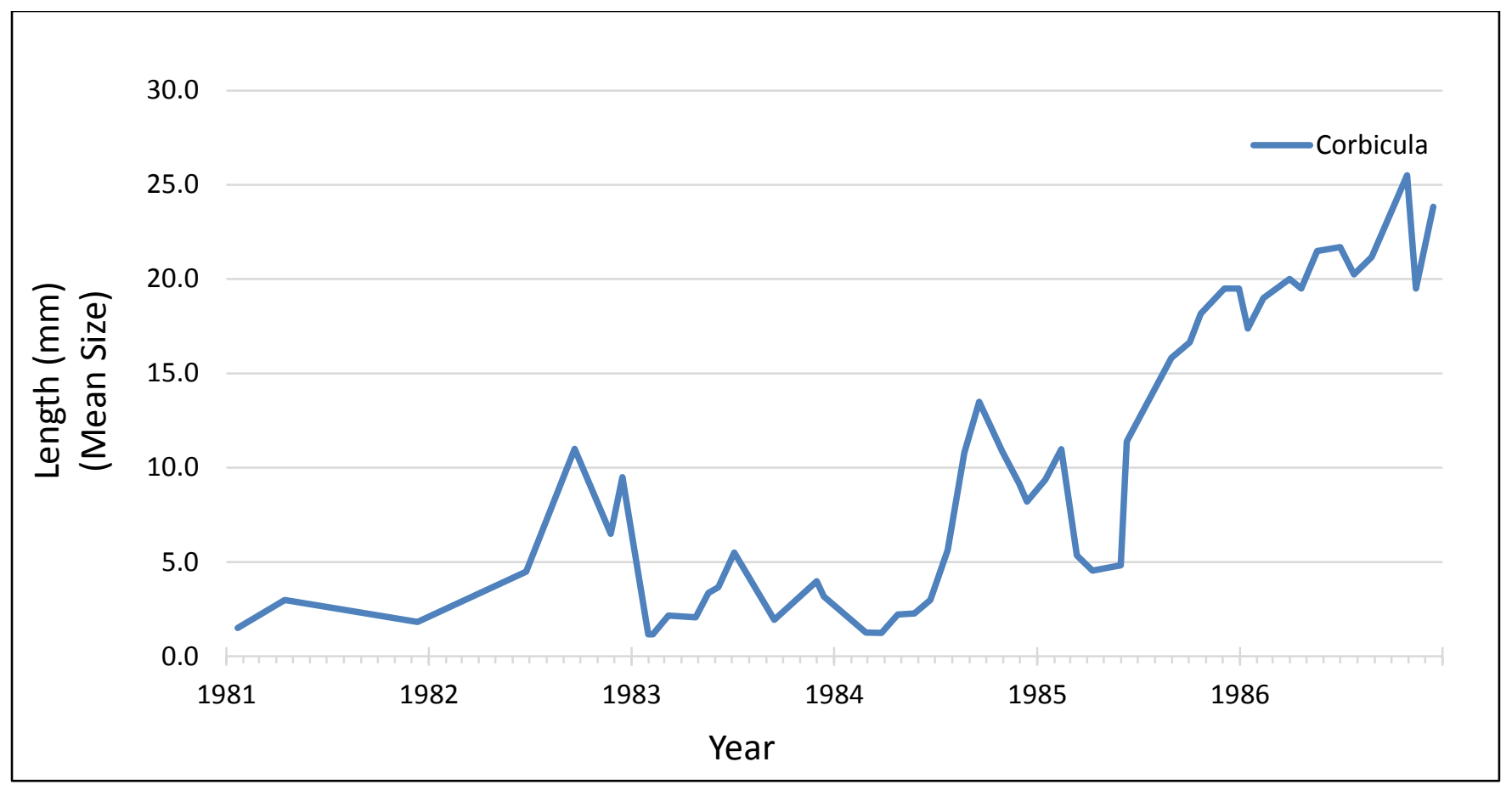

Figure 150. Graph showing mean size at station D7 from 1981-1986. For station locations refer to table 1.

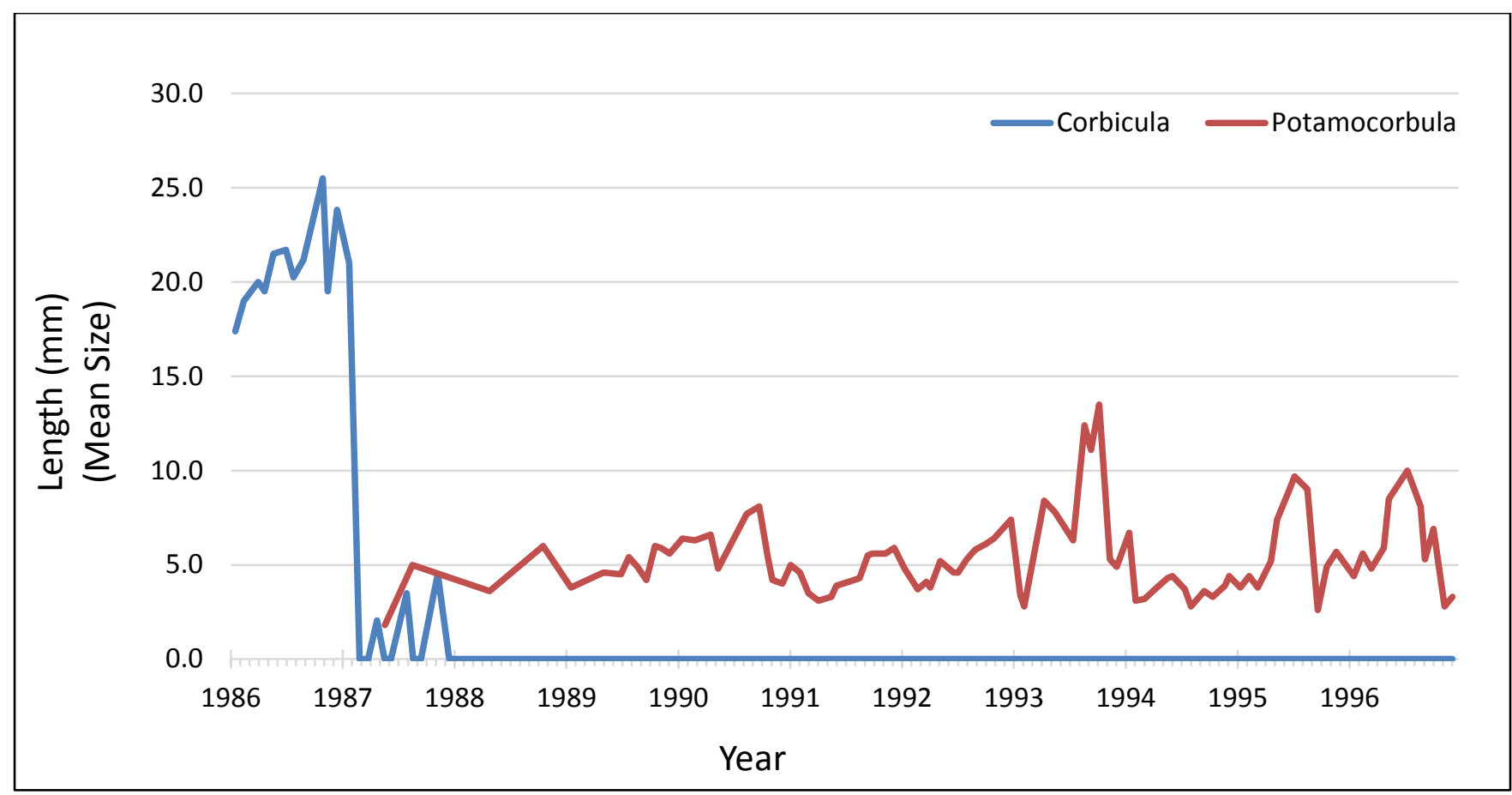

Figure 151. Graph showing mean size at station D7 from 1986-1996. For station locations refer to table 1. 


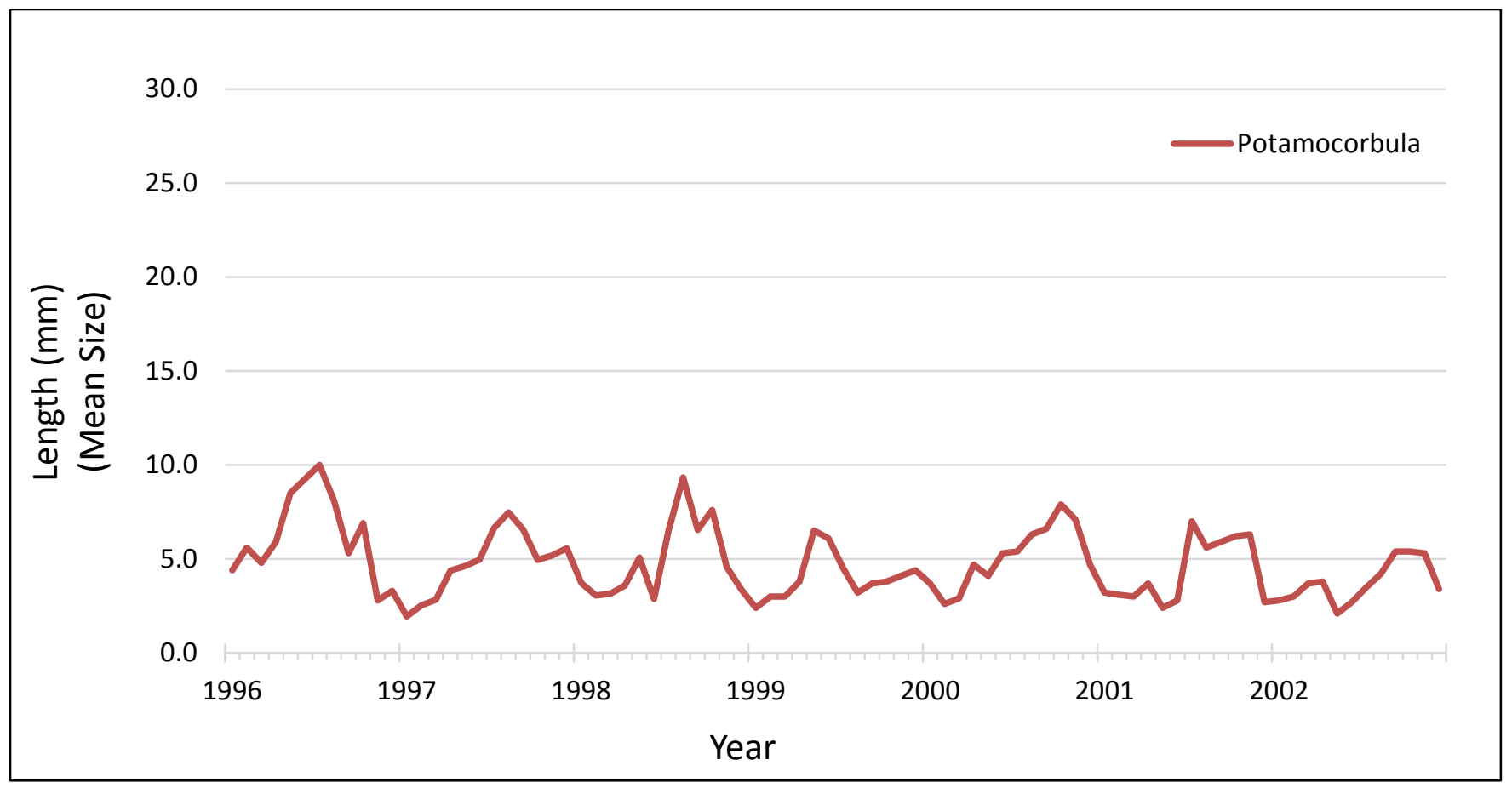

Figure 152. Graph showing mean size at station D7 from 1996-2002. For station locations refer to table 1.

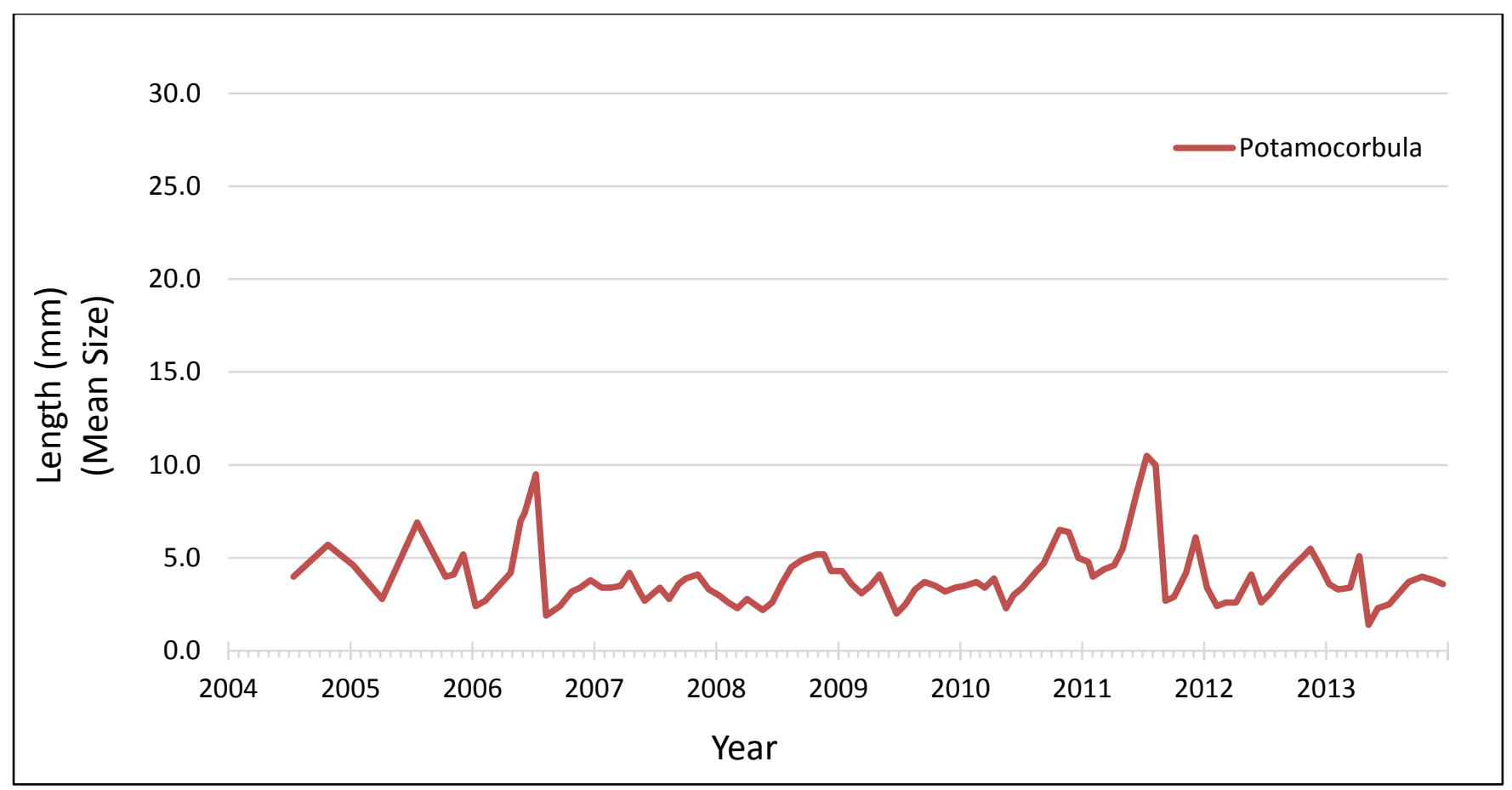

Figure 153. Graph showing mean size at station D7 from 2004-2013. For station locations refer to table 1. 


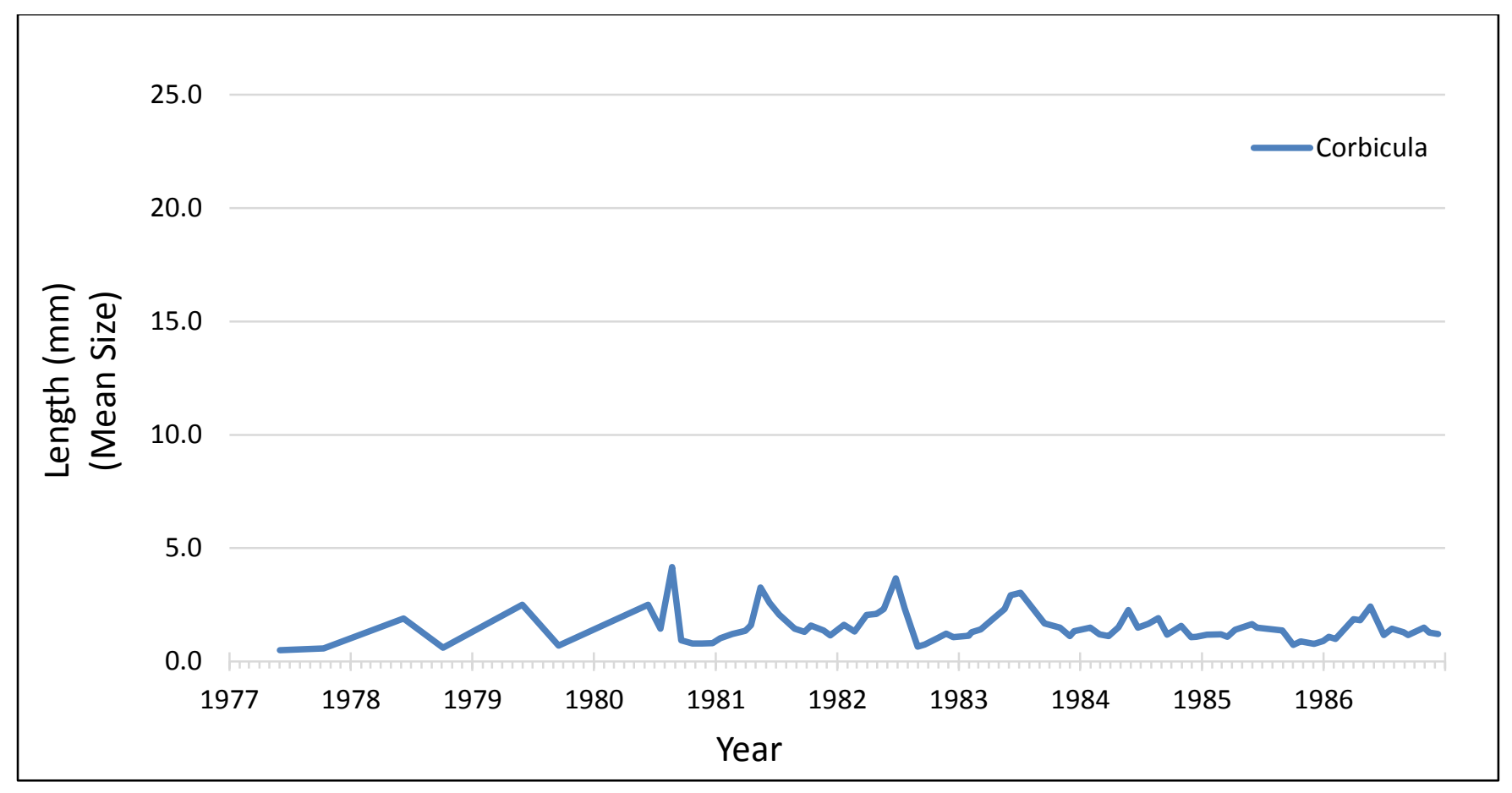

Figure 154. Graph showing mean size at station D11 from 1977-1986. For station locations refer to table 1.

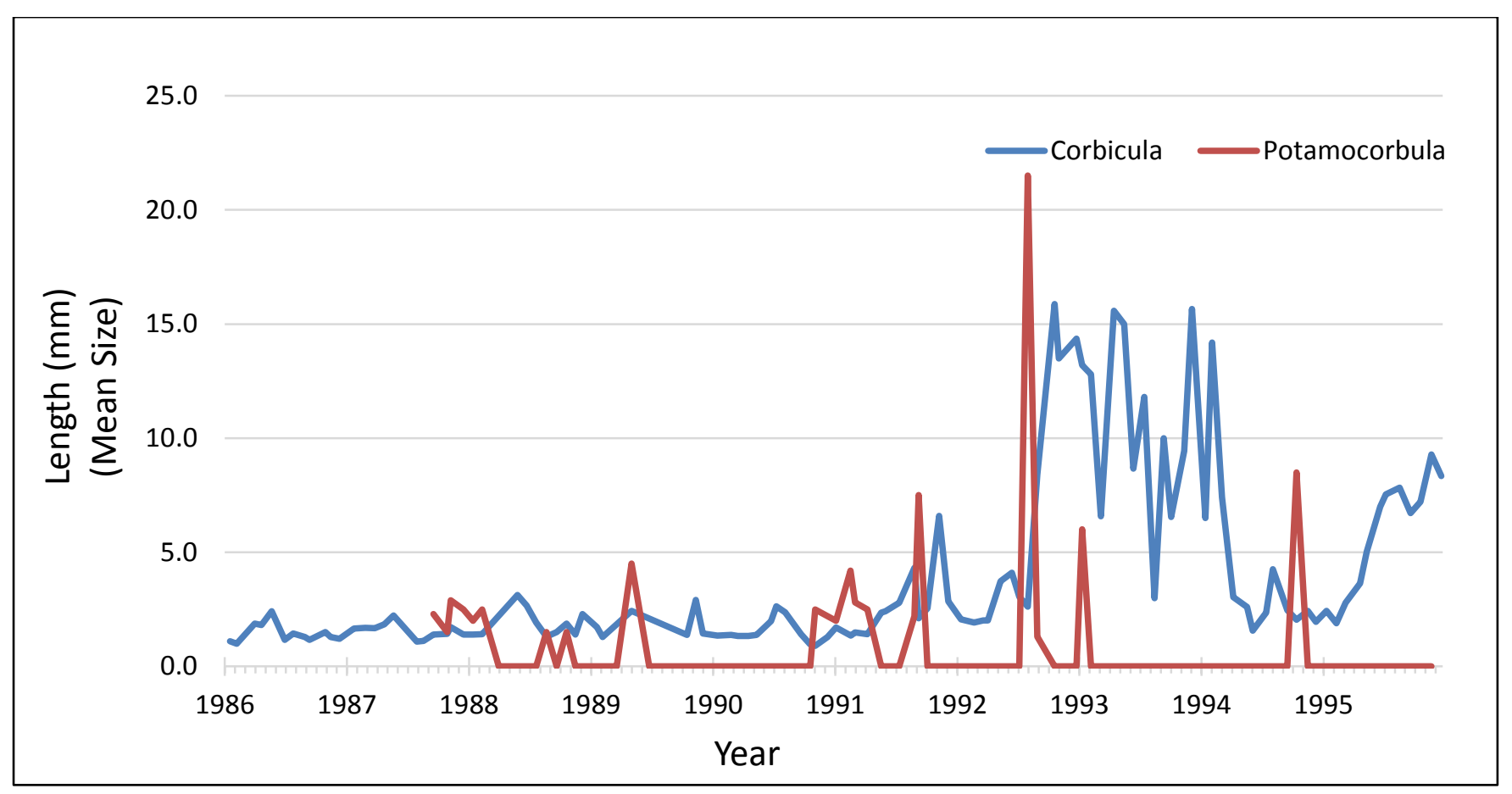

Figure 155. Graph showing mean size at station D11 from 1986-1995. For station locations refer to table 1. 

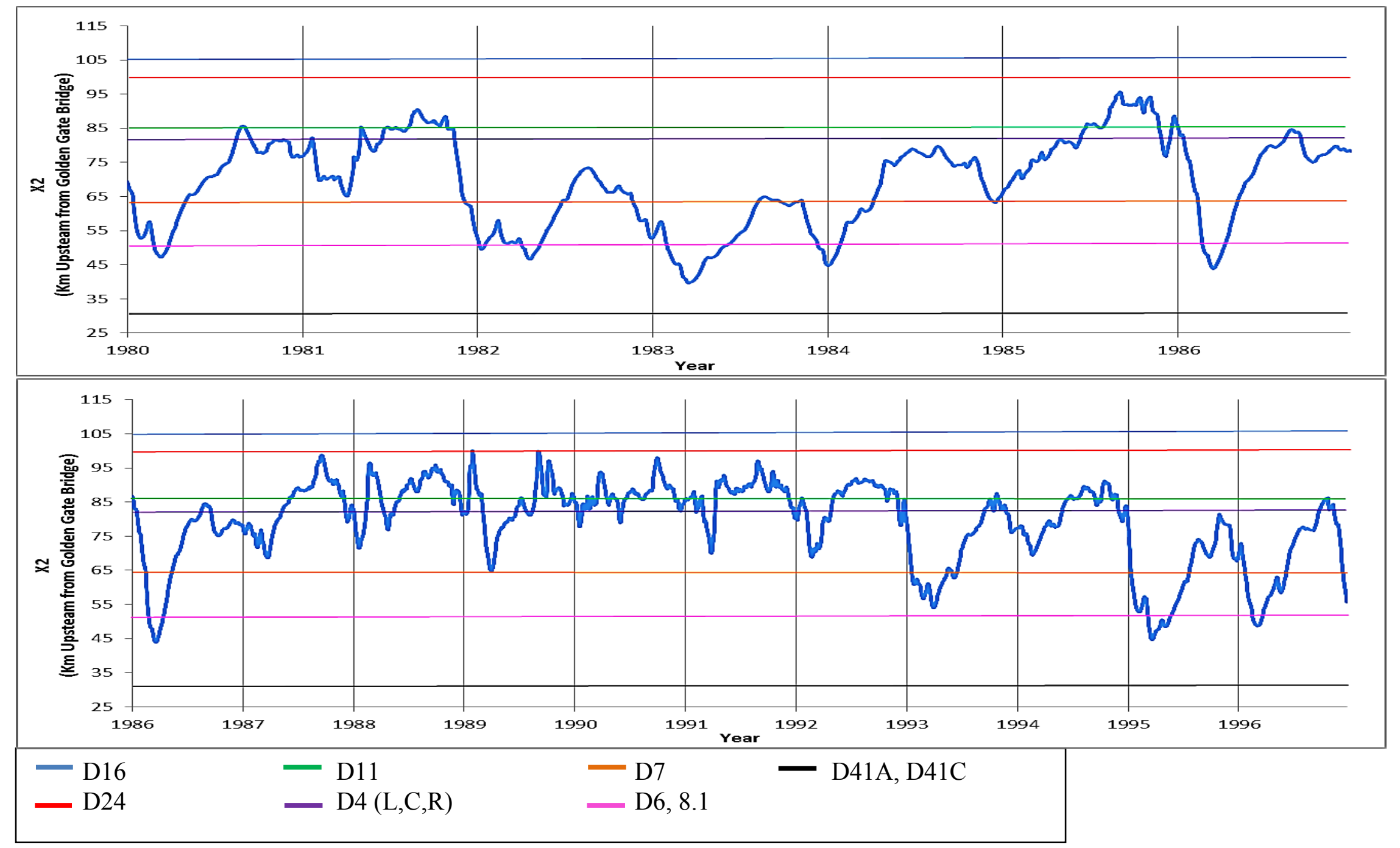

Figure 156. Graphs plotting X2 in kilometers upstream of the Golden Gate Bridge from 1980 through 1996. Colors represent station locations relative to X2. The X2 position is not a precise measurement but represents the distance upstream from the Golden Gate Bridge, where a daily average salinity at 1 meter ( $\mathrm{m}$ ) above of the bottom is 2 (Jassby and others, 1995). 


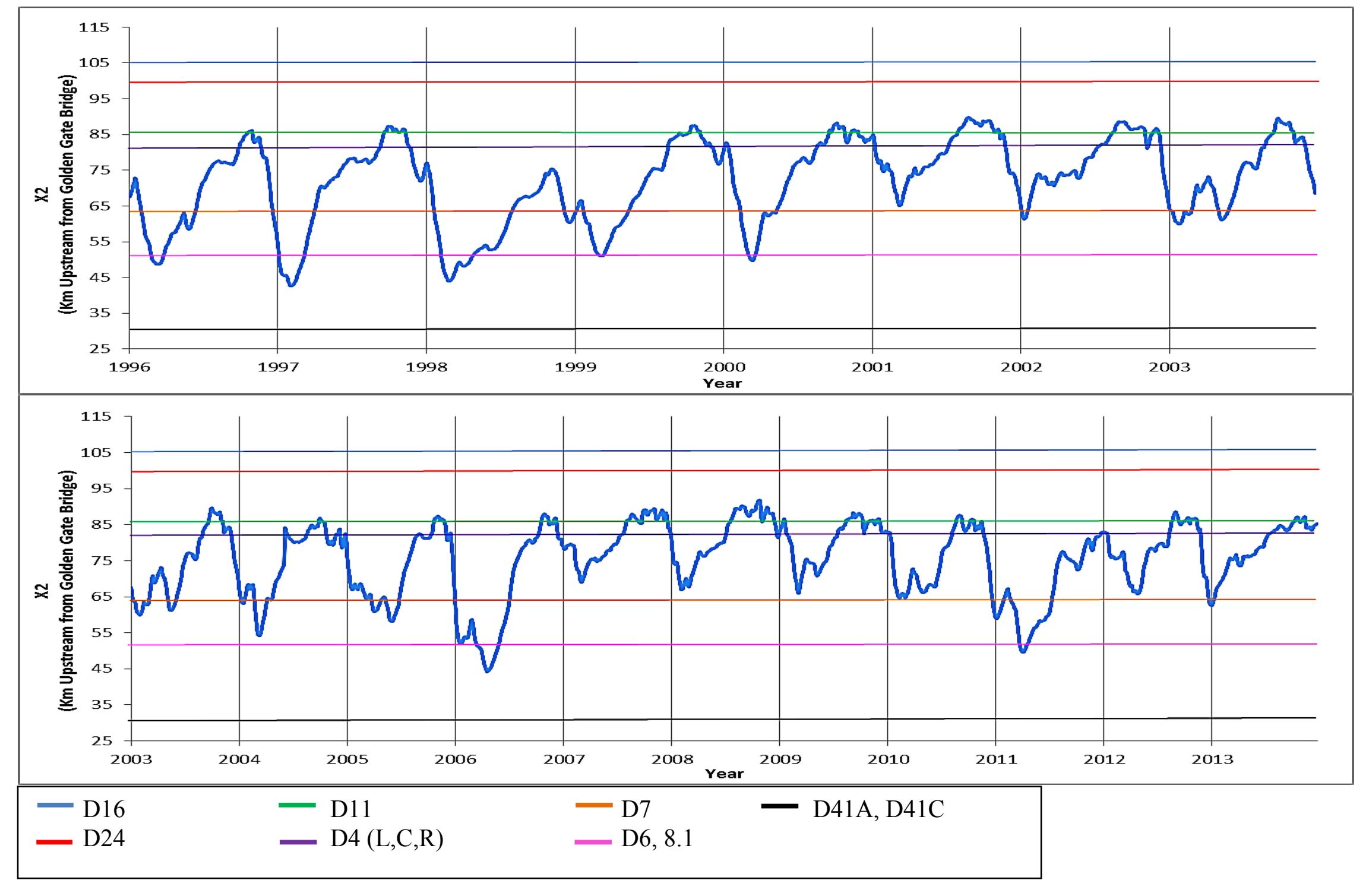

Figure 157. Graphs plotting X2 in kilometers upstream of the Golden Gate Bridge from 1996 through 2013. Colors represent station locations relative to X2. The X2 position is not a precise measurement but represents the distance upstream from the Golden Gate Bridge, where a daily average salinity at 1 meter $(\mathrm{m})$ above of the bottom is 2 (Jassby and others, 1995). 
Table 1. The benthic monitoring station locations, names, and latitude and longitude of DWR and Reclamation's Environmental Monitoring Program (EMP).

[Samples were taken and sorted for the bivalves Potamocorbula amurensis and Corbicula fluminea. All depths are in meters (m), left and right are in reference to which side of the shipping channel (looking downstream) samples were taken]

\begin{tabular}{|c|c|c|c|c|}
\hline $\begin{array}{l}\text { Station } \\
\text { code }\end{array}$ & Location & Latitude & Longitude & $\begin{array}{l}\text { Depth } \\
\text { (m) }\end{array}$ \\
\hline 8.1 & Sacramento River downstream of I-680 bridge & 38.0316 & 122.1403 & 15.0 \\
\hline C9 & $\begin{array}{l}\text { Old River upstream of Clifton Court Forebay Intake } \\
\text { (left) }\end{array}$ & 37.8271 & 121.5522 & 1.7 \\
\hline D11 & Sherman Lake (center) & 38.0422 & 121.7995 & 3.0 \\
\hline D16 & San Joaquin River at Bradford Island (left) & 38.0930 & 121.6697 & 3.0 \\
\hline D19 & Franks Tract (center) & 38.0438 & 121.6148 & 3.0 \\
\hline D24 & $\begin{array}{l}\text { Sacramento River downstream of Rio Vista bridge } \\
\text { (left) }\end{array}$ & 38.1547 & 121.6814 & 8.0 \\
\hline D28A & Old River upstream of Rock Slough (left) & 37.9701 & 121.5741 & 4.5 \\
\hline D4C & $\begin{array}{l}\text { Sacramento River at Sherman Island upstream of } \\
\text { Point Sacramento (center) }\end{array}$ & 38.0581 & 121.8193 & 10.0 \\
\hline D4L & $\begin{array}{l}\text { Sacramento River at Sherman Island upstream of } \\
\text { Point Sacramento (left) }\end{array}$ & 38.0581 & 121.8193 & 4.9 \\
\hline D4R & $\begin{array}{l}\text { Sacramento River at Sherman Island upstream of } \\
\text { Point Sacramento (right) }\end{array}$ & 38.0581 & 121.8193 & 4.5 \\
\hline D41A & San Pablo Bay-north central (shallow) & 38.0847 & 122.3906 & 2.5 \\
\hline D41C & San Pablo Bay near Pinole Point (deep) & 38.0160 & 122.3647 & 4.9 \\
\hline D6 & Suisun Bay upstream of I-680 bridge (right) & 38.0577 & 122.1149 & 3.5 \\
\hline D7 & Grizzly Bay at Dolphin near Suisun Slough (center) & 38.1171 & 122.0395 & 3.0 \\
\hline P8 & San Joaquin River at Buckley Cove (right) & 37.9778 & 121.3799 & 3.0 \\
\hline
\end{tabular}


Table 2. Average grazing rate, biomass, and recruitment of the bivalves Potamocorbula amurensis and Corbicula fluminea at each site at specified depth in meters $(\mathrm{m})$.

[Grazing rate (GR) is given in units of meters cubed per meter squared per day $\left(\mathrm{m}^{3} / \mathrm{m}^{2} / \mathrm{d}\right)$. Grazing rate turnover rate (GRTO) is the amount of time in days (d) it takes the clams to completely graze the water column. Biomass is given in units of grams per meter squared $\left(\mathrm{g} / \mathrm{m}^{2}\right)$. Recruitment is the number of each bivalve less than $2.5 \mathrm{~mm}$ in length per 0.05 meter squared $\left(\# / 0.05 \mathrm{~m}^{2}\right)$. Years sampled represent the time period in years in which each station was actively sampled]

\begin{tabular}{|c|c|c|c|c|c|c|}
\hline Station & $\begin{array}{l}\text { Depth } \\
\text { (m) }\end{array}$ & $\begin{array}{c}\text { AVG GR } \\
\left(\mathrm{m}^{3} / \mathrm{m}^{2} / \mathrm{d}\right)\end{array}$ & $\begin{array}{c}\text { AVG GRTO } \\
(/ d)\end{array}$ & $\begin{array}{c}\text { AVG } \\
\text { biomass } \\
\left(\mathrm{g} / \mathrm{m}^{2}\right)\end{array}$ & $\begin{array}{c}\text { AVG } \\
\text { recruitment } \\
(\# / 0.05)\end{array}$ & $\begin{array}{c}\text { Years } \\
\text { sampled }\end{array}$ \\
\hline 8.1 $1^{1}$ Potamocorbula & 15.0 & 5.88 & 0.39 & 20.07 & 4.67 & 1988-2007 \\
\hline C9 Corbicula & 3.0 & 1.06 & 0.35 & 12.88 & 6.5 & 1996-present \\
\hline D11 Potamocorbula & 3.0 & 0.28 & 0.09 & 0.02 & 36.00 & 1987-1995 \\
\hline D11 Corbicula & 3.0 & 0.24 & 0.08 & 2.30 & 26.00 & 1987-1995 \\
\hline D16 Corbicula & 3.0 & 0.76 & 0.25 & 13.46 & 3.50 & 1996-present \\
\hline D19 Corbicula & 3.0 & 1.87 & 0.62 & 26.10 & 23.5 & 1977-1995 \\
\hline D24 Corbicula & 8.0 & 2.03 & 0.25 & 40.50 & 19.38 & 1996-present \\
\hline D28 Corbicula & 3.5 & 1.39 & 0.40 & 18.63 & 17.88 & 1976-present \\
\hline D41A Potamocorbula & 2.5 & 1.48 & 0.49 & 4.42 & 9.75 & 1987-present \\
\hline D41C Potamocorbula & 4.9 & 1.20 & 0.26 & 3.88 & 0.02 & 1996-present \\
\hline D4L Potamocorbula & 4.9 & 0.34 & 0.07 & 2.77 & 12.29 & 1987-present \\
\hline D4L Corbicula & 4.9 & 0.60 & 0.12 & 9.00 & 11.00 & 1987-present \\
\hline D4C Potamocorbula & 10.0 & 0.67 & 0.13 & 1.82 & 2.40 & 1976-1995 \\
\hline D4C Corbicula & 10.0 & 0.10 & 0.02 & 8.10 & 12.30 & 1976-1995 \\
\hline D4R Potamocorbula & 4.5 & 6.28 & 1.28 & 24.02 & 5.58 & 1976-1995 \\
\hline D4R Corbicula & 4.5 & 0.10 & 0.02 & 2.50 & 12.50 & 1976-1995 \\
\hline D6 Potamocorbula & 7.0 & 4.76 & 0.68 & 15.01 & 40.88 & 2007-present \\
\hline D7 Potamocorbula & 1.7 & 1.20 & 0.70 & 3.90 & 34.50 & 1987-present \\
\hline D7 Corbicula & 1.7 & 0.32 & 0.18 & 5.02 & 0.00 & 1987-present \\
\hline P8 Corbicula & 3.0 & 0.29 & 0.10 & 3.01 & 15.33 & 1996-present \\
\hline
\end{tabular}

${ }^{1}$ Station 8.1 is a U.S. Geological Survey station that was a precursor to Department of Water Resources sampling at site D6. 
Table 3. Table showing the water year type in Sacramento and San Joaquin Rivers from 1975-2014.

[WY, water year (October 1-September 30); W, wet year type; AN, above normal year type; BN, below normal year type; D, dry year type; $\mathbf{C}$, critical year type]

\begin{tabular}{|c|c|c|c|c|c|}
\hline Water year & $\begin{array}{c}\text { Sacramento } \\
\text { River }\end{array}$ & $\begin{array}{l}\text { San Joaquin } \\
\text { River }\end{array}$ & Water year & $\begin{array}{c}\text { Sacramento } \\
\text { River }\end{array}$ & $\begin{array}{c}\text { San Joaquin } \\
\text { River }\end{array}$ \\
\hline 1975 & W & W & 1995 & W & W \\
\hline 1976 & C & C & 1996 & w & w \\
\hline 1977 & C & C & 1997 & w & w \\
\hline 1978 & AN & w & 1998 & w & W \\
\hline 1979 & BN & AN & 1999 & w & AN \\
\hline 1980 & AN & W & 2000 & AN & AN \\
\hline 1981 & D & D & 2001 & D & D \\
\hline 1982 & w & W & 2002 & D & D \\
\hline 1983 & w & W & 2003 & AN & $\mathrm{BN}$ \\
\hline 1984 & $w$ & AN & 2004 & $\mathrm{BN}$ & D \\
\hline 1985 & D & D & 2005 & AN & w \\
\hline 1986 & w & W & 2006 & w & w \\
\hline 1987 & D & C & 2007 & D & C \\
\hline 1988 & C & C & 2008 & C & C \\
\hline 1989 & D & C & 2009 & D & $\mathrm{BN}$ \\
\hline 1990 & C & C & 2010 & $\mathrm{BN}$ & AN \\
\hline 1991 & C & C & 2011 & w & w \\
\hline 1992 & C & C & 2012 & BN & D \\
\hline 1993 & AN & w & 2013 & D & C \\
\hline 1994 & C & C & 2014 & C & C \\
\hline
\end{tabular}




\section{Appendixes}

Potamocorbula amurensis and Corbicula fluminea data are shown in the following units:

Biomass - grams ash-free dry mass/square meter $\left(\mathrm{g} / \mathrm{m}^{2}\right)$, a biomass of $\geq 5 \mathrm{~g} / \mathrm{m}^{2}$ is considered high Grazing rate (GR) — cubic meter per square meter per day $\left(\mathrm{m}^{3} / \mathrm{m}^{2} / \mathrm{d}\right)$

Recruitment—number of bivalves $\leq 2.5$ millimeters in length per square meter $\left(\# / \mathrm{m}^{2}\right)$

Mean size - mean length of bivalve in millimeters ( $\mathrm{mm}$ )

Number of grabs per sample - number of archived samples used in data analysis

N/D means no data was found. 
Appendix 1. Station 8.1 Potamocorbula Data

\begin{tabular}{|c|c|c|c|c|c|c|c|}
\hline Date & $\begin{array}{l}\text { Total \# of } \\
\text { clams in } \\
\text { sample } \\
\left(\# / \mathrm{m}^{2}\right)\end{array}$ & $\begin{array}{c}\text { Biomass } \\
\left(\mathrm{g} / \mathrm{m}^{2}\right)\end{array}$ & $\mathrm{rec} / 0.05 \mathrm{~m}^{2}$ & $\begin{array}{l}\text { Mean size } \\
(\mathrm{mm})\end{array}$ & $\begin{array}{c}\text { GR } \\
\left(\mathrm{m}^{3} / \mathrm{m}^{2} / \mathrm{d}\right)\end{array}$ & $\begin{array}{l}\text { Depth } \\
\text { (m) }\end{array}$ & \# grabs \\
\hline $6 / 23 / 1988$ & 10753.00 & 87.90 & 4.67 & 10.20 & 23.22 & 15 & 3 \\
\hline $7 / 21 / 1988$ & 16000.00 & 90.50 & 7.00 & 9.00 & 21.95 & 15 & 3 \\
\hline $8 / 17 / 1988$ & 14453.00 & 117.90 & 1.67 & 10.21 & 28.59 & 15 & 3 \\
\hline 9/13/1988 & 8693.00 & 58.30 & 5.33 & 9.41 & 16.56 & 15 & 3 \\
\hline $10 / 5 / 1988$ & 7140.00 & 46.00 & 1.33 & 10.35 & 13.31 & 15 & 3 \\
\hline $11 / 2 / 1988$ & 14130.00 & 81.00 & 2.00 & 9.97 & 20.43 & 15 & 3 \\
\hline $11 / 30 / 1988$ & 4627.00 & 27.40 & 2.00 & 10.05 & 8.52 & 15 & 3 \\
\hline 1/4/1989 & 6480.00 & 67.60 & 1.33 & 10.84 & 19.91 & 15 & 3 \\
\hline 1/31/1989 & 11333.00 & 130.80 & 2.33 & 11.27 & 21.78 & 15 & 3 \\
\hline 2/28/1989 & 5967.00 & 45.70 & 2.00 & 10.96 & 9.22 & 15 & 3 \\
\hline $3 / 21 / 1989$ & 5773.00 & 36.60 & 3.67 & 10.07 & 11.00 & 15 & 3 \\
\hline 4/12/1989 & 7987.00 & 48.90 & 4.00 & 10.21 & 13.83 & 15 & 3 \\
\hline $5 / 10 / 1989$ & 4393.00 & 46.10 & 2.33 & 12.54 & 13.83 & 15 & 3 \\
\hline $6 / 14 / 1989$ & 2487.00 & 41.80 & 7.67 & 11.48 & 13.73 & 15 & 3 \\
\hline $7 / 12 / 1989$ & 2120.00 & 20.70 & 4.67 & 11.11 & 6.92 & 15 & 3 \\
\hline 8/9/1989 & 3540.00 & 44.30 & 11.00 & 11.42 & 13.94 & 15 & 3 \\
\hline 9/6/1989 & 4460.00 & 47.60 & 12.00 & 10.52 & 14.88 & 15 & 3 \\
\hline 10/4/1989 & 4407.00 & 53.00 & 3.67 & 11.37 & 16.13 & 15 & 3 \\
\hline $11 / 9 / 1989$ & N/D & N/D & N/D & $\mathrm{N} / \mathrm{D}$ & $N / D$ & N/D & $\mathrm{N} / \mathrm{D}$ \\
\hline 12/12/1989 & 3187.00 & 24.90 & 8.33 & 10.07 & 8.13 & 15 & 3 \\
\hline $1 / 17 / 1990$ & 3113.30 & 6.80 & 4.33 & 10.54 & 1.50 & 15 & 3 \\
\hline 2/26/1990 & 526.70 & 3.90 & 1.67 & 9.80 & 0.98 & 15 & 3 \\
\hline $3 / 18 / 1990$ & $N / D$ & $\mathrm{~N} / \mathrm{D}$ & $N / D$ & $N / D$ & $N / D$ & $\mathrm{~N} / \mathrm{D}$ & $\mathrm{N} / \mathrm{D}$ \\
\hline 4/18/1990 & 2993.30 & 15.60 & 5.00 & 8.22 & 5.29 & 15 & 3 \\
\hline $5 / 30 / 1990$ & 413.30 & 2.90 & 0.33 & 9.15 & 1.08 & 15 & 3 \\
\hline $6 / 28 / 1990$ & 1910.00 & 9.30 & 0.00 & 8.41 & 3.26 & 15 & 3 \\
\hline $8 / 2 / 1990$ & 2190.00 & 9.70 & 3.00 & 8.18 & 3.36 & 15 & 3 \\
\hline $8 / 22 / 1990$ & 2353.30 & 10.90 & 3.33 & 8.25 & 3.77 & 15 & 3 \\
\hline 9/27/1990 & 2360.00 & 11.50 & 3.67 & 8.37 & 3.99 & 15 & 3 \\
\hline $10 / 25 / 1990$ & $\mathrm{~N} / \mathrm{D}$ & $\mathrm{N} / \mathrm{D}$ & $N / D$ & $N / D$ & $N / D$ & $\mathrm{~N} / \mathrm{D}$ & $N / D$ \\
\hline $11 / 8 / 1990$ & 4220.00 & 23.80 & 3.00 & 8.71 & 7.80 & 15 & 3 \\
\hline 12/6/1990 & 2153.30 & 19.70 & 2.67 & 10.51 & 6.68 & 15 & 3 \\
\hline 1/7/1991 & 2527.00 & 24.80 & 2.33 & 10.69 & 8.28 & 15 & 3 \\
\hline 2/6/1991 & 1860.00 & 19.10 & 0.67 & 10.69 & 4.44 & 15 & 3 \\
\hline $3 / 6 / 1991$ & 1467.00 & 15.50 & 5.67 & 10.11 & 5.41 & 15 & 3 \\
\hline 4/8/1991 & 820.00 & 9.20 & 1.33 & 9.27 & 3.36 & 15 & 3 \\
\hline $5 / 20 / 1991$ & 1540.00 & 9.90 & 35.33 & 5.60 & 3.63 & 15 & 3 \\
\hline $6 / 5 / 1991$ & 1020.00 & 7.60 & 9.67 & 8.05 & 2.78 & 15 & 3 \\
\hline
\end{tabular}


Appendix 1. Station 8.1 Potamocorbula Data

\begin{tabular}{|c|c|c|c|c|c|c|c|}
\hline Date & $\begin{array}{c}\text { Total \# of } \\
\text { clams in } \\
\text { sample } \\
\left(\# / \mathrm{m}^{2}\right)\end{array}$ & $\begin{array}{c}\text { Biomass } \\
\left(\mathrm{g} / \mathrm{m}^{2}\right)\end{array}$ & $\mathrm{rec} / 0.05 \mathrm{~m}^{2}$ & $\begin{array}{l}\text { Mean size } \\
(\mathrm{mm})\end{array}$ & $\begin{array}{c}\text { GR } \\
\left(\mathrm{m}^{3} / \mathrm{m}^{2} / \mathrm{d}\right)\end{array}$ & $\begin{array}{l}\text { Depth } \\
\text { (m) }\end{array}$ & \# grabs \\
\hline $8 / 20 / 1991$ & 1633.00 & 16.20 & 4.67 & 9.05 & 5.65 & 15 & 3 \\
\hline 9/16/1991 & 1593.00 & 14.00 & 11.67 & 8.71 & 4.99 & 15 & 3 \\
\hline 10/1/1991 & 860.00 & 9.80 & 2.00 & 9.92 & 3.56 & 15 & 3 \\
\hline 11/13/1991 & 800.00 & 9.30 & 8.67 & 9.24 & 3.39 & 15 & 3 \\
\hline 12/11/1991 & 933.00 & 9.90 & 11.00 & 8.96 & 3.62 & 15 & 3 \\
\hline 1/14/1992 & 593.00 & 4.30 & 12.00 & 6.57 & 1.09 & 15 & 3 \\
\hline $2 / 26 / 1992$ & 940.00 & 6.00 & 9.33 & 7.46 & 1.50 & 15 & 3 \\
\hline $3 / 25 / 1992$ & 620.00 & 2.80 & 11.33 & 5.73 & 1.05 & 15 & 3 \\
\hline 4/8/1992 & 1173.00 & 8.30 & 7.00 & 7.66 & 3.02 & 15 & 3 \\
\hline $5 / 10 / 1992$ & 4247.00 & 17.90 & 140.33 & 4.43 & 6.24 & 15 & 3 \\
\hline $6 / 22 / 1992$ & 4380.00 & 18.80 & 104.33 & 5.08 & 6.45 & 15 & 3 \\
\hline 7/7/1992 & 4413.00 & 28.80 & 50.67 & 7.03 & 9.51 & 15 & 3 \\
\hline $8 / 5 / 1992$ & 2273.00 & 6.90 & 29.33 & 5.25 & 2.50 & 15 & 3 \\
\hline 9/2/1992 & 6020.00 & 26.10 & 40.00 & 6.37 & 8.59 & 15 & 3 \\
\hline 10/4/1992 & 5220.00 & 22.50 & 31.67 & 6.38 & 7.50 & 15 & 3 \\
\hline $11 / 2 / 1992$ & 4320.00 & 25.20 & 11.33 & 7.54 & 8.34 & 15 & 3 \\
\hline $12 / 28 / 1992$ & 3680.00 & 24.90 & 7.33 & 8.17 & 8.27 & 15 & 3 \\
\hline $1 / 27 / 1993$ & 2280.00 & 12.90 & 4.67 & 8.44 & 4.46 & 15 & 3 \\
\hline 2/9/1993 & 4913.30 & 30.60 & 0.33 & 8.60 & 9.85 & 15 & 3 \\
\hline $3 / 17 / 1993$ & 1486.70 & 12.40 & 0.00 & 10.10 & 4.33 & 15 & 3 \\
\hline 4/15/1993 & 3240.00 & 33.20 & 0.33 & 13.63 & 10.19 & 15 & 3 \\
\hline $5 / 20 / 1993$ & 2920.00 & 66.20 & 4.33 & 13.87 & 20.61 & 15 & 3 \\
\hline $6 / 17 / 1993$ & 2113.30 & 70.00 & 2.33 & 14.62 & 22.51 & 15 & 3 \\
\hline $7 / 19 / 1993$ & 1673.30 & 45.30 & 4.67 & 13.38 & 15.09 & 15 & 3 \\
\hline $8 / 25 / 1993$ & 1486.70 & 32.30 & 2.67 & 15.45 & 10.65 & 15 & 3 \\
\hline 9/15/1993 & 2580.00 & 69.50 & 5.00 & 13.98 & 22.02 & 15 & 3 \\
\hline $10 / 12 / 1993$ & 2233.30 & 58.70 & 3.67 & 13.76 & 18.94 & 15 & 3 \\
\hline $11 / 16 / 1993$ & 2066.70 & 47.80 & 9.00 & 13.45 & 15.56 & 15 & 3 \\
\hline 12/9/1993 & 2726.70 & 75.90 & 10.33 & 7.72 & 26.21 & 15 & 3 \\
\hline 1/18/1994 & 1407.00 & 15.80 & 11.00 & 9.53 & 5.60 & 15 & 3 \\
\hline 2/8/1994 & 2327.00 & 37.70 & 10.33 & 13.15 & 12.12 & 15 & 3 \\
\hline 3/9/1994 & 2120.00 & 31.30 & 8.67 & 12.12 & 10.36 & 15 & 3 \\
\hline 4/13/1994 & 2680.00 & 34.30 & 4.00 & 10.54 & 11.38 & 15 & 3 \\
\hline $5 / 23 / 1994$ & 1907.00 & 23.40 & 1.00 & 10.14 & 8.02 & 15 & 3 \\
\hline 6/9/1994 & 3367.00 & 35.60 & 3.00 & 9.66 & 11.66 & 15 & 3 \\
\hline $7 / 20 / 1994$ & 567.00 & 10.30 & 0.67 & 12.15 & 3.74 & 15 & 3 \\
\hline 8/9/1994 & 1207.00 & 15.10 & 3.67 & 10.38 & 5.35 & 15 & 3 \\
\hline 9/21/1994 & 247.00 & 3.30 & 1.00 & 11.20 & 1.26 & 15 & 3 \\
\hline
\end{tabular}


Appendix 1. Station 8.1 Potamocorbula Data

\begin{tabular}{|c|c|c|c|c|c|c|c|}
\hline Date & $\begin{array}{c}\text { Total \# of } \\
\text { clams in } \\
\text { sample } \\
\left(\# / \mathrm{m}^{2}\right)\end{array}$ & $\begin{array}{c}\text { Biomass } \\
\left(\mathrm{g} / \mathrm{m}^{2}\right)\end{array}$ & $\mathrm{rec} / 0.05 \mathrm{~m}^{2}$ & $\begin{array}{l}\text { Mean size } \\
(\mathrm{mm})\end{array}$ & $\begin{array}{c}\text { GR } \\
\left(\mathrm{m}^{3} / \mathrm{m}^{2} / \mathrm{d}\right)\end{array}$ & $\begin{array}{l}\text { Depth } \\
\text { (m) }\end{array}$ & \# grabs \\
\hline $10 / 19 / 1994$ & 433.33 & 3.04 & 2.00 & 8.50 & 1.15 & 15 & 3 \\
\hline $11 / 28 / 1994$ & 1247.00 & 4.60 & 33.67 & 4.88 & 1.15 & 15 & 3 \\
\hline $12 / 12 / 1994$ & $N / D$ & $\mathrm{~N} / \mathrm{D}$ & $N / D$ & N/D & $N / D$ & $\mathrm{~N} / \mathrm{D}$ & N/D \\
\hline 1/17/1995 & 1480.00 & 12.30 & 2.00 & 9.08 & 2.93 & 15 & 3 \\
\hline 2/15/1995 & 180.00 & 2.30 & 0.00 & 10.72 & 0.88 & 15 & 3 \\
\hline 3/15/1995 & 747.00 & 7.90 & 0.00 & 9.46 & 2.90 & 15 & 3 \\
\hline 4/27/1995 & 93.00 & 1.30 & 0.00 & 10.71 & 0.51 & 15 & 3 \\
\hline 5/17/1995 & 120.00 & 1.10 & 0.00 & 8.56 & 0.42 & 15 & 3 \\
\hline $6 / 27 / 1995$ & 167.00 & 0.90 & 0.00 & 5.86 & 0.36 & 15 & 3 \\
\hline $7 / 13 / 1995$ & 260.00 & 1.10 & 0.00 & 7.50 & 0.41 & 15 & 3 \\
\hline $8 / 24 / 1995$ & 347.00 & 3.40 & 0.00 & 10.21 & 1.28 & 15 & 3 \\
\hline 9/27/1995 & 773.00 & 10.70 & 2.67 & 11.72 & 3.85 & 15 & 3 \\
\hline $10 / 26 / 1995$ & 533.00 & 8.60 & 0.33 & 11.43 & 3.14 & 15 & 3 \\
\hline $11 / 27 / 1995$ & $\mathrm{~N} / \mathrm{D}$ & $\mathrm{N} / \mathrm{D}$ & $N / D$ & $N / D$ & $N / D$ & $\mathrm{~N} / \mathrm{D}$ & $N / D$ \\
\hline $12 / 15 / 1995$ & 1453.00 & 11.10 & 12.67 & 12.67 & 3.79 & 15 & 3 \\
\hline 1/23/1996 & 3327.00 & 37.40 & 13.67 & 10.14 & 8.19 & 15 & 3 \\
\hline 2/22/1996 & 1627.00 & 15.60 & 8.00 & 9.17 & 3.69 & 15 & 3 \\
\hline 3/21/1996 & 2240.00 & 14.90 & 12.33 & 7.70 & 5.21 & 15 & 3 \\
\hline $4 / 30 / 1996$ & 1007.00 & 9.60 & 1.67 & 8.91 & 3.51 & 15 & 3 \\
\hline 5/17/1996 & 1533.00 & 20.00 & 0.00 & 10.29 & 6.98 & 15 & 3 \\
\hline 7/17/1996 & 687.00 & 8.40 & 1.00 & 11.18 & 3.03 & 15 & 3 \\
\hline $8 / 29 / 1996$ & 1347.00 & 20.50 & 1.00 & 12.13 & 7.06 & 15 & 3 \\
\hline 9/12/1996 & 500.00 & 5.00 & 0.33 & 10.67 & 1.85 & 15 & 3 \\
\hline 10/10/1996 & 587.00 & 4.70 & 1.33 & 9.93 & 1.73 & 15 & 3 \\
\hline $11 / 15 / 1996$ & 2407.00 & 40.70 & 1.67 & 13.88 & 13.02 & 15 & 3 \\
\hline 12/11/1996 & 1093.00 & 15.50 & 1.33 & 12.80 & 5.43 & 15 & 3 \\
\hline 1/21/1997 & 147.00 & 2.70 & 0.00 & 13.95 & 0.69 & 15 & 3 \\
\hline 2/23/1997 & 80.00 & 0.90 & 0.00 & 11.58 & 0.35 & 15 & 3 \\
\hline $3 / 25 / 1997$ & $N / D$ & N/D & $N / D$ & N/D & $N / D$ & $N / D$ & N/D \\
\hline $4 / 22 / 1997$ & 460.00 & 3.70 & 15.33 & 4.11 & 1.40 & 15 & 3 \\
\hline $5 / 21 / 1997$ & 2760.00 & 23.70 & 29.33 & 5.92 & 8.43 & 15 & 3 \\
\hline 6/18/1997 & 693.00 & 4.20 & 4.33 & 7.98 & 1.55 & 15 & 3 \\
\hline $7 / 22 / 1997$ & 1080.00 & 13.70 & 2.33 & 10.97 & 4.89 & 15 & 3 \\
\hline 8/19/1997 & 1047.00 & 18.00 & 1.00 & 11.31 & 6.34 & 15 & 3 \\
\hline 9/16/1997 & 1060.00 & 19.40 & 1.00 & 12.93 & 6.80 & 15 & 3 \\
\hline $10 / 28 / 1997$ & 393.00 & 4.50 & 1.67 & 10.42 & 1.67 & 15 & 3 \\
\hline $11 / 18 / 1997$ & 493.00 & 6.30 & 2.67 & 10.45 & 2.34 & 15 & 3 \\
\hline 12/14/1997 & 1440.00 & 23.80 & 0.67 & 12.51 & 8.17 & 15 & 3 \\
\hline
\end{tabular}


Appendix 1. Station 8.1 Potamocorbula Data

\begin{tabular}{|c|c|c|c|c|c|c|c|}
\hline Date & $\begin{array}{l}\text { Total \# of } \\
\text { clams in } \\
\text { sample } \\
\left(\# / \mathrm{m}^{2}\right)\end{array}$ & $\begin{array}{c}\text { Biomass } \\
\left(\mathrm{g} / \mathrm{m}^{2}\right)\end{array}$ & $\mathrm{rec} / 0.05 \mathrm{~m}^{2}$ & $\begin{array}{c}\text { Mean size } \\
(\mathrm{mm})\end{array}$ & $\begin{array}{c}\text { GR } \\
\left(\mathrm{m}^{3} / \mathrm{m}^{2} / \mathrm{d}\right)\end{array}$ & $\begin{array}{l}\text { Depth } \\
\text { (m) }\end{array}$ & \# grabs \\
\hline 1/12/1998 & 1027.00 & 9.00 & 5.00 & 10.16 & 2.17 & 15 & 3 \\
\hline 2/17/1998 & 40.00 & 0.50 & 0.00 & 12.17 & 0.14 & 15 & 3 \\
\hline $3 / 16 / 1998$ & 13.00 & 0.20 & 0.00 & 13.00 & 0.08 & 15 & 3 \\
\hline 4/13/1998 & $\mathrm{N} / \mathrm{D}$ & $\mathrm{N} / \mathrm{D}$ & N/D & $\mathrm{N} / \mathrm{D}$ & $\mathrm{N} / \mathrm{D}$ & $\mathrm{N} / \mathrm{D}$ & N/D \\
\hline $5 / 12 / 1998$ & 120.00 & 0.60 & 0.00 & 6.17 & 0.22 & 15 & 3 \\
\hline 6/8/1998 & 367.00 & 1.00 & 1.33 & 5.90 & 0.37 & 15 & 3 \\
\hline $7 / 8 / 1998$ & 207.00 & 0.80 & 0.00 & 7.18 & 0.30 & 15 & 3 \\
\hline 8/3/1998 & 560.00 & 1.90 & 0.33 & 6.92 & 0.74 & 15 & 3 \\
\hline 9/16/1998 & 613.00 & 2.60 & 0.67 & 7.75 & 0.97 & 15 & 3 \\
\hline $10 / 6 / 1998$ & 800.00 & 3.30 & 6.67 & 7.35 & 1.23 & 15 & 3 \\
\hline $11 / 3 / 1998$ & 447.00 & 0.60 & 14.33 & 3.53 & 0.23 & 15 & 3 \\
\hline $12 / 21 / 1998$ & 333.00 & 0.50 & 9.00 & 4.08 & 0.20 & 15 & 3 \\
\hline 1/13/1999 & 260.00 & 0.20 & 4.67 & 3.91 & 0.08 & 15 & 3 \\
\hline 2/17/1999 & 973.00 & 2.30 & 19.67 & 5.03 & 0.57 & 15 & 3 \\
\hline 3/16/1999 & 273.00 & 0.60 & 0.67 & 5.23 & 0.15 & 15 & 3 \\
\hline 4/14/1999 & 560.00 & 0.80 & 1.00 & 4.85 & 0.32 & 15 & 3 \\
\hline 5/18/1999 & 1107.00 & 3.10 & 1.00 & 5.87 & 1.15 & 15 & 3 \\
\hline 6/14/1999 & 2940.00 & 14.00 & 38.00 & 6.31 & 4.90 & 15 & 3 \\
\hline 7/13/1999 & 3120.00 & 8.10 & 42.00 & 5.35 & 2.85 & 15 & 3 \\
\hline 8/11/1999 & 5187.00 & 18.40 & 35.67 & 6.43 & 6.15 & 15 & 3 \\
\hline 9/22/1999 & 4647.00 & 23.00 & 12.00 & 7.89 & 7.56 & 15 & 3 \\
\hline 10/27/1999 & 6927.00 & 16.00 & 81.67 & 5.40 & 5.25 & 15 & 3 \\
\hline 11/9/1999 & 19827.00 & 52.50 & 303.33 & 5.24 & 14.71 & 15 & 3 \\
\hline 12/8/1999 & 4947.00 & 7.40 & 81.67 & 4.62 & 1.72 & 15 & 3 \\
\hline $1 / 5 / 2000$ & 9440.00 & 14.85 & 144.33 & 4.73 & 3.24 & 15 & 3 \\
\hline $2 / 23 / 2000$ & 5840.00 & 8.20 & 74.67 & 4.64 & 2.79 & 15 & 3 \\
\hline $3 / 22 / 2000$ & 11733.00 & 7.24 & 306.00 & 3.40 & 2.38 & 15 & 3 \\
\hline $4 / 19 / 2000$ & 8287.00 & 19.91 & 79.33 & 4.77 & 6.54 & 15 & 3 \\
\hline $5 / 16 / 2000$ & 8927.00 & 11.08 & 263.67 & 3.54 & 3.75 & 15 & 3 \\
\hline $6 / 14 / 2000$ & 12793.00 & 25.94 & 204.00 & 4.47 & 8.07 & 15 & 3 \\
\hline $7 / 17 / 2000$ & 7293.00 & 12.92 & 45.33 & 5.21 & 4.23 & 15 & 3 \\
\hline $8 / 16 / 2000$ & 6980.00 & 11.12 & 44.00 & 5.06 & 3.66 & 15 & 3 \\
\hline $9 / 13 / 2000$ & 2567.00 & 3.69 & 10.00 & 5.37 & 1.32 & 15 & 3 \\
\hline $10 / 10 / 2000$ & 8493.00 & 20.10 & 4.67 & 6.30 & 6.34 & 15 & 3 \\
\hline $11 / 15 / 2000$ & 10667.00 & 31.97 & 9.67 & 6.60 & 9.76 & 15 & 3 \\
\hline $12 / 13 / 2000$ & 6280.00 & 15.60 & 5.33 & 6.35 & 5.11 & 15 & 3 \\
\hline $1 / 11 / 2001$ & 10833.00 & 32.70 & 4.33 & 6.64 & 9.97 & 15 & 3 \\
\hline $2 / 7 / 2001$ & 867.00 & 1.50 & 1.33 & 6.09 & 0.37 & 15 & 3 \\
\hline
\end{tabular}


Appendix 1. Station 8.1 Potamocorbula Data

\begin{tabular}{|c|c|c|c|c|c|c|c|}
\hline Date & $\begin{array}{c}\text { Total \# of } \\
\text { clams in } \\
\text { sample } \\
\left(\# / \mathrm{m}^{2}\right)\end{array}$ & $\begin{array}{c}\text { Biomass } \\
\left(\mathrm{g} / \mathrm{m}^{2}\right)\end{array}$ & $\mathrm{rec} / 0.05 \mathrm{~m}^{2}$ & $\begin{array}{l}\text { Mean size } \\
(\mathrm{mm})\end{array}$ & $\begin{array}{c}\text { GR } \\
\left(\mathrm{m}^{3} / \mathrm{m}^{2} / \mathrm{d}\right)\end{array}$ & $\begin{array}{l}\text { Depth } \\
\text { (m) }\end{array}$ & \# grabs \\
\hline $3 / 7 / 2001$ & 1140.00 & 3.80 & 0.67 & 6.92 & 0.94 & 15 & 3 \\
\hline $4 / 4 / 2001$ & 2260.00 & 12.50 & 3.00 & 8.22 & 4.35 & 15 & 3 \\
\hline $5 / 9 / 2001$ & 2493.00 & 11.80 & 39.67 & 6.34 & 4.18 & 15 & 3 \\
\hline $6 / 5 / 2001$ & 2987.00 & 7.50 & 25.67 & 5.36 & 2.65 & 15 & 3 \\
\hline $7 / 24 / 2001$ & 4020.00 & 20.40 & 22.67 & 7.13 & 6.80 & 15 & 3 \\
\hline $8 / 22 / 2001$ & $\mathrm{~N} / \mathrm{D}$ & N/D & $N / D$ & $N / D$ & $N / D$ & $N / D$ & $N / D$ \\
\hline $9 / 18 / 2001$ & 1553.00 & 9.50 & 3.00 & 8.08 & 3.39 & 15 & 3 \\
\hline $10 / 16 / 2001$ & 1407.00 & 4.60 & 9.33 & 6.30 & 1.67 & 15 & 3 \\
\hline $11 / 19 / 2001$ & 2007.00 & 4.50 & 6.33 & 5.84 & 1.64 & 15 & 3 \\
\hline $12 / 11 / 2001$ & 1153.00 & 2.50 & 4.67 & 5.95 & 0.94 & 15 & 3 \\
\hline $1 / 15 / 2002$ & 820.00 & 0.60 & 13.00 & 4.02 & 0.24 & 15 & 3 \\
\hline $2 / 14 / 2002$ & $\mathrm{~N} / \mathrm{D}$ & N/D & $N / D$ & $\mathrm{~N} / \mathrm{D}$ & N/D & N/D & $N / D$ \\
\hline $3 / 12 / 2002$ & 713.00 & 0.80 & 14.33 & 3.93 & 0.31 & 15 & 3 \\
\hline $4 / 15 / 2002$ & 993.00 & 2.60 & 7.00 & 5.51 & 0.96 & 15 & 3 \\
\hline $5 / 13 / 2002$ & 1133.00 & 1.40 & 22.00 & 3.96 & 0.51 & 15 & 3 \\
\hline $6 / 10 / 2002$ & 2887.00 & 2.70 & 69.67 & 3.56 & 0.97 & 15 & 3 \\
\hline $7 / 7 / 2002$ & 4160.00 & 5.40 & 46.67 & 4.76 & 1.90 & 15 & 3 \\
\hline $8 / 8 / 2002$ & 387.00 & 0.60 & 13.00 & 3.48 & 0.23 & 15 & 3 \\
\hline $9 / 9 / 2002$ & 6460.00 & 22.00 & 35.00 & 6.01 & 7.17 & 15 & 3 \\
\hline $10 / 23 / 2002$ & 4573.00 & 12.80 & 16.33 & 6.34 & 4.32 & 15 & 3 \\
\hline $11 / 5 / 2002$ & 11927.00 & 43.10 & 18.33 & 7.35 & 12.32 & 15 & 3 \\
\hline $12 / 4 / 2002$ & 11460.00 & 44.70 & 25.00 & 7.37 & 12.88 & 15 & 3 \\
\hline $1 / 21 / 2003$ & 13030.00 & 51.30 & 41.50 & 7.36 & 9.72 & 15 & 3 \\
\hline $2 / 18 / 2003$ & 6847.00 & 23.80 & 23.67 & 6.98 & 7.72 & 15 & 3 \\
\hline $3 / 18 / 2003$ & 3313.00 & 12.10 & 3.33 & 7.08 & 4.10 & 15 & 3 \\
\hline $4 / 16 / 2003$ & 4160.00 & 19.50 & 14.67 & 7.17 & 6.49 & 15 & 3 \\
\hline $5 / 14 / 2003$ & 3553.00 & 12.40 & 40.67 & 5.87 & 4.34 & 15 & 3 \\
\hline $6 / 1 / 2003$ & 4847.00 & 13.80 & 14.00 & 6.19 & 4.63 & 15 & 3 \\
\hline $7 / 14 / 2003$ & 5847.00 & 16.70 & 9.67 & 6.58 & 5.50 & 15 & 3 \\
\hline $8 / 13 / 2003$ & 11947.00 & 34.80 & 30.33 & 6.69 & 10.43 & 15 & 3 \\
\hline $9 / 18 / 2003$ & 10140.00 & 46.40 & 7.33 & 7.99 & 13.66 & 15 & 3 \\
\hline $10 / 23 / 2003$ & 8687.00 & 33.30 & 2.33 & 7.87 & 10.07 & 15 & 3 \\
\hline $1 / 8 / 2004$ & 5620.00 & 15.20 & 6.67 & 7.41 & 3.29 & 15 & 3 \\
\hline $4 / 7 / 2004$ & 2900.00 & 24.50 & 5.00 & 8.96 & 5.62 & 15 & 3 \\
\hline $7 / 15 / 2004$ & 1533.00 & 10.00 & 10.67 & 7.67 & 3.58 & 15 & 3 \\
\hline $10 / 26 / 2004$ & 973.00 & 10.40 & 1.00 & 10.53 & 3.73 & 15 & 3 \\
\hline $1 / 11 / 2005$ & 293.00 & 1.60 & 0.33 & 8.11 & 0.41 & 15 & 3 \\
\hline $4 / 6 / 2005$ & 1793.00 & 7.00 & 3.00 & 6.43 & 2.51 & 15 & 3 \\
\hline
\end{tabular}




\begin{tabular}{|c|c|c|c|c|c|c|c|}
\hline \multicolumn{8}{|c|}{ Appendix 1. Station 8.1 Potamocorbula Data } \\
\hline Date & $\begin{array}{c}\text { Total \# of } \\
\text { clams in } \\
\text { sample } \\
\left(\# / \mathrm{m}^{2}\right)\end{array}$ & $\begin{array}{c}\text { Biomass } \\
\left(\mathrm{g} / \mathrm{m}^{2}\right)\end{array}$ & $\mathrm{rec} / 0.05 \mathrm{~m}^{2}$ & $\begin{array}{l}\text { Mean size } \\
(\mathrm{mm})\end{array}$ & $\begin{array}{c}\text { GR } \\
\left(\mathrm{m}^{3} / \mathrm{m}^{2} / \mathrm{d}\right)\end{array}$ & $\begin{array}{l}\text { Depth } \\
\text { (m) }\end{array}$ & \# grabs \\
\hline $7 / 20 / 2005$ & 5167.00 & 20.60 & 15.00 & 6.89 & 6.87 & 15 & 3 \\
\hline 10/13/2005 & 3973.00 & 17.10 & 2.33 & 8.03 & 5.65 & 15 & 3 \\
\hline $11 / 7 / 2005$ & 8320.00 & 34.20 & 0.67 & 7.76 & 10.42 & 15 & 3 \\
\hline $12 / 5 / 2005$ & 1953.00 & 8.60 & 0.33 & 8.26 & 3.02 & 15 & 3 \\
\hline $1 / 12 / 2006$ & 1100.00 & 4.70 & 0.00 & 8.14 & 1.16 & 15 & 3 \\
\hline $2 / 8 / 2006$ & 247.00 & 1.30 & 0.33 & 7.80 & 0.51 & 15 & 3 \\
\hline $3 / 15 / 2006$ & 667.00 & 3.50 & 0.00 & 7.63 & 1.31 & 15 & 3 \\
\hline $4 / 26 / 2006$ & 580.00 & 2.50 & 0.50 & 7.71 & 0.95 & 15 & 3 \\
\hline $5 / 25 / 2006$ & 153.00 & 0.70 & 0.00 & 6.98 & 0.27 & 15 & 3 \\
\hline $6 / 6 / 2006$ & $\mathrm{~N} / \mathrm{D}$ & $N / D$ & $N / D$ & $\mathrm{~N} / \mathrm{D}$ & $N / D$ & $\mathrm{~N} / \mathrm{D}$ & $\mathrm{N} / \mathrm{D}$ \\
\hline $7 / 10 / 2006$ & 67.00 & 0.90 & 0.00 & 11.00 & 0.37 & 15 & 3 \\
\hline $8 / 10 / 2006$ & 1227.00 & 1.40 & 15.67 & 4.63 & 0.51 & 15 & 3 \\
\hline $9 / 20 / 2006$ & 5850.00 & 4.00 & 94.00 & 3.88 & 1.41 & 15 & 3 \\
\hline $10 / 25 / 2006$ & 1613.00 & 1.20 & 18.00 & 4.08 & 0.44 & 15 & 3 \\
\hline $11 / 20 / 2006$ & 15167.00 & 8.50 & 213.00 & 3.86 & 2.71 & 15 & 3 \\
\hline $12 / 20 / 2006$ & 25580.00 & 18.80 & 338.67 & 3.78 & 5.54 & 15 & 3 \\
\hline $1 / 23 / 2007$ & 12013.00 & 7.80 & 185.67 & 3.76 & 1.73 & 15 & 3 \\
\hline $2 / 20 / 2007$ & 14267.00 & 9.60 & 115.67 & 4.10 & 1.98 & 15 & 3 \\
\hline $3 / 20 / 2007$ & 26140.00 & 26.70 & 120.67 & 4.67 & 7.29 & 15 & 3 \\
\hline $4 / 16 / 2007$ & 30087.00 & 70.60 & 18.00 & 5.88 & 17.81 & 15 & 3 \\
\hline $5 / 16 / 2007$ & N/D & N/D & $N / D$ & $\mathrm{~N} / \mathrm{D}$ & $\mathrm{N} / \mathrm{D}$ & $\mathrm{N} / \mathrm{D}$ & $\mathrm{N} / \mathrm{D}$ \\
\hline $6 / 20 / 2007$ & $\mathrm{~N} / \mathrm{D}$ & $\mathrm{N} / \mathrm{D}$ & $N / D$ & $\mathrm{~N} / \mathrm{D}$ & $N / D$ & $\mathrm{~N} / \mathrm{D}$ & $\mathrm{N} / \mathrm{D}$ \\
\hline $7 / 16 / 2007$ & 11307.00 & 51.50 & 7.33 & 7.72 & 14.87 & 15 & 3 \\
\hline $8 / 13 / 2007$ & 6967.00 & 31.90 & 3.00 & 8.44 & 9.80 & 15 & 3 \\
\hline $9 / 11 / 2007$ & 7033.00 & 31.10 & 0.67 & 8.02 & 9.53 & 15 & 3 \\
\hline $10 / 2 / 2007$ & 6420.00 & 29.60 & 1.00 & 7.76 & 9.37 & 15 & 3 \\
\hline $11 / 7 / 2007$ & 9993.00 & 65.80 & 1.00 & 9.67 & 18.13 & 15 & 3 \\
\hline $12 / 10 / 2007$ & 7567.00 & 39.80 & 4.33 & 8.88 & 12.07 & 15 & 3 \\
\hline
\end{tabular}




\begin{tabular}{|c|c|c|c|c|c|c|c|}
\hline \multicolumn{8}{|c|}{ Appendix 2. Station D4C Corbicula Data } \\
\hline Date & $\begin{array}{l}\text { Total \# of } \\
\text { clams in } \\
\text { sample } \\
\left(\# / \mathrm{m}^{2}\right)\end{array}$ & $\begin{array}{c}\text { biomass } \\
\left(\mathrm{g} / \mathrm{m}^{2}\right)\end{array}$ & $\begin{array}{c}\text { recruit/0.05 } \\
\mathrm{m}^{2}\end{array}$ & $\begin{array}{l}\text { mean size } \\
(\mathrm{mm})\end{array}$ & $\begin{array}{c}\text { GR } \\
\left(\mathrm{m}^{3} / \mathrm{m}^{2} / \mathrm{d}\right)\end{array}$ & Depth(M) & \# Grabs \\
\hline 2/18/1976 & 6194.0 & 0.2 & 324 & 0.7 & 0.0 & 10.0 & 1 \\
\hline 6/11/1976 & 361.0 & 0.2 & 8 & 3.2 & 0.0 & 10.0 & 1 \\
\hline 10/7/1976 & 95.0 & 0.0 & 1 & 3.5 & 0.0 & 10.0 & 1 \\
\hline 3/4/1977 & 133.0 & 0.0 & 7 & 1.1 & 0.0 & 10.0 & 1 \\
\hline 6/1/1977 & 95.0 & 0.1 & 2.0 & 3.1 & 0.0 & 10.0 & 1 \\
\hline 10/13/1977 & 13.0 & $\mathrm{~N} / \mathrm{A}$ & N/A & $\mathrm{N} / \mathrm{A}$ & $\mathrm{N} / \mathrm{A}$ & 10.0 & 1 \\
\hline 6/8/1978 & 133.0 & 8.1 & 5.0 & 7.8 & 0.7 & 10.0 & 1 \\
\hline $10 / 4 / 1978$ & 76.0 & 3.0 & 2.0 & 8.5 & 0.3 & 10.0 & 1 \\
\hline $5 / 30 / 1979$ & 247.0 & 4.9 & 11.0 & 3.6 & 0.5 & 10.0 & 1 \\
\hline 9/17/1979 & 411.7 & 5.1 & 12.0 & 3.9 & 0.7 & 10.0 & 1 \\
\hline $6 / 11 / 1980$ & 418.0 & 6.0 & 12.0 & 4.1 & 0.5 & 10.0 & 1 \\
\hline $7 / 18 / 1980$ & 76.0 & $\mathrm{~N} / \mathrm{A}$ & N/A & $\mathrm{N} / \mathrm{A}$ & $\mathrm{N} / \mathrm{A}$ & 10.0 & 1 \\
\hline $8 / 22 / 1980$ & 76.0 & 0.2 & 3.0 & 4.0 & 0.0 & 10.0 & 1 \\
\hline 9/19/1980 & 798.0 & 0.3 & 39.0 & 1.5 & 0.0 & 10.0 & 1 \\
\hline $10 / 23 / 1980$ & 190.0 & 0.6 & 7.0 & 2.7 & 0.0 & 10.0 & 1 \\
\hline $11 / 20 / 1980$ & 342.0 & 0.3 & 15.0 & 1.9 & 0.0 & 10.0 & 1 \\
\hline $12 / 22 / 1980$ & 513.0 & N/A & N/A & N/A & N/A & 10.0 & 1 \\
\hline 1/14/1981 & 266.0 & 0.0 & 13.0 & 1.4 & 0.0 & 10.0 & 1 \\
\hline 2/19/1981 & 988.0 & 0.1 & 44.0 & 1.7 & 0.0 & 10.0 & 1 \\
\hline 3/30/1981 & 3686.0 & 0.7 & 167.0 & 1.9 & 0.0 & 10.0 & 1 \\
\hline $4 / 16 / 1981$ & 3420.0 & 0.5 & 156.0 & 1.9 & 0.0 & 10.0 & 1 \\
\hline $5 / 15 / 1981$ & 1330.0 & 4.6 & 52.0 & 3.1 & 0.4 & 10.0 & 1 \\
\hline $6 / 12 / 1981$ & 418.0 & 1.1 & 5.0 & 4.5 & 0.1 & 10.0 & 1 \\
\hline $7 / 10 / 1981$ & 19.0 & 0.4 & 0.0 & 12.5 & 0.0 & 10.0 & 1 \\
\hline $8 / 26 / 1981$ & 114.0 & 0.2 & 2.0 & 4.0 & 0.0 & 10.0 & 1 \\
\hline 9/24/1981 & 209.0 & 2.4 & 1.0 & 8.5 & 0.2 & 10.0 & 1 \\
\hline 10/13/1981 & 57.0 & 1.1 & 0.0 & 9.2 & 0.1 & 10.0 & 1 \\
\hline 11/20/1981 & 57.0 & 0.0 & 1.0 & 2.8 & 0.0 & 10.0 & 1 \\
\hline 12/11/1981 & 418.0 & 38.2 & 0.0 & 19.7 & 1.1 & 10.0 & 1 \\
\hline $1 / 21 / 1982$ & 114.0 & 1.7 & 2.0 & 8.8 & 0.0 & 10.0 & 1 \\
\hline $2 / 22 / 1982$ & 228.0 & 10.4 & 7.0 & 8.7 & 0.4 & 10.0 & 1 \\
\hline $3 / 30 / 1982$ & 361.0 & 0.6 & 13.0 & 2.7 & 0.0 & 10.0 & 1 \\
\hline 4/28/1982 & 1330.0 & 0.1 & 68.0 & 1.3 & 0.0 & 10.0 & 1 \\
\hline $6 / 25 / 1982$ & 285.0 & 0.3 & 6.0 & 3.7 & 0.0 & 10.0 & 1 \\
\hline $7 / 22 / 1982$ & 247.0 & 16.5 & 1.0 & 11.1 & 1.6 & 10.0 & 1 \\
\hline $8 / 30 / 1982$ & 19.0 & 0.1 & 0.0 & 8.5 & 0.0 & 10.0 & 1 \\
\hline 9/20/1982 & 551.0 & 0.1 & 27.0 & 1.2 & 0.0 & 10.0 & 1 \\
\hline 10/28/1982 & 228.0 & 0.6 & 9.0 & 2.7 & 0.0 & 10.0 & 1 \\
\hline
\end{tabular}




\begin{tabular}{|c|c|c|c|c|c|c|c|}
\hline \multicolumn{8}{|c|}{ Appendix 2. Station D4C Corbicula Data } \\
\hline Date & $\begin{array}{l}\text { Total \# of } \\
\text { clams in } \\
\text { sample } \\
\left(\# / \mathrm{m}^{2}\right)\end{array}$ & $\begin{array}{c}\text { biomass } \\
\left(\mathrm{g} / \mathrm{m}^{2}\right)\end{array}$ & $\begin{array}{l}\text { recruit/0.05 } \\
\mathrm{m}^{2}\end{array}$ & $\begin{array}{l}\text { mean size } \\
(\mathrm{mm})\end{array}$ & $\begin{array}{c}\text { GR } \\
\left(\mathrm{m}^{3} / \mathrm{m}^{2} / \mathrm{d}\right)\end{array}$ & Depth(M) & \# Grabs \\
\hline 11/24/1982 & 228.0 & 3.2 & 9.0 & 5.0 & 0.1 & 10.0 & 1 \\
\hline 12/15/1982 & 665.0 & 3.9 & 32.0 & 2.6 & 0.1 & 10.0 & 1 \\
\hline $1 / 31 / 1983$ & 114.0 & 0.0 & 6.0 & 1.5 & 0.0 & 10.0 & 1 \\
\hline 2/8/1983 & 209.0 & 8.0 & 9.0 & 5.9 & 0.3 & 10.0 & 1 \\
\hline $3 / 8 / 1983$ & 608.0 & 0.1 & 30.0 & 1.8 & 0.0 & 10.0 & 1 \\
\hline $4 / 21 / 1983$ & 2603.0 & 0.6 & 127.0 & 1.6 & 0.0 & 10.0 & 1 \\
\hline $5 / 19 / 1983$ & 1007.0 & 0.4 & 39.0 & 2.3 & 0.0 & 10.0 & 1 \\
\hline 6/6/1983 & 1786.0 & 0.8 & 64.0 & 2.7 & 0.1 & 10.0 & 1 \\
\hline 7/5/1983 & 741.0 & 2.6 & 15.0 & 3.9 & 0.3 & 10.0 & 1 \\
\hline 9/15/1983 & 209.0 & 0.2 & 10.0 & 1.7 & 0.0 & 10.0 & 1 \\
\hline $11 / 1 / 1983$ & 3420.0 & 1.6 & 172.0 & 1.5 & 0.1 & 10.0 & 1 \\
\hline $11 / 30 / 1983$ & 1995.0 & 2.9 & 95.0 & 1.9 & 0.2 & 10.0 & 1 \\
\hline 12/13/1983 & 399.0 & 1.6 & 16.0 & 3.5 & 0.1 & 10.0 & 1 \\
\hline 1/31/1984 & 1824.0 & 0.1 & 91.0 & 1.3 & 0.0 & 10.0 & 1 \\
\hline 2/27/1984 & 988.0 & 2.1 & 46.0 & 2.5 & 0.1 & 10.0 & 1 \\
\hline $3 / 26 / 1984$ & 1558.0 & 0.7 & 75.0 & 1.5 & 0.0 & 10.0 & 1 \\
\hline $4 / 24 / 1984$ & 988.0 & 2.9 & 41.0 & 2.9 & 0.1 & 10.0 & 1 \\
\hline $5 / 24 / 1984$ & 2907.0 & 2.2 & 115.0 & 2.2 & 0.1 & 10.0 & 1 \\
\hline $6 / 22 / 1984$ & 684.0 & 13.1 & 20.0 & 5.2 & 1.1 & 10.0 & 1 \\
\hline $7 / 23 / 1984$ & 266.0 & 0.1 & 9.0 & 2.6 & 0.0 & 10.0 & 1 \\
\hline $8 / 22 / 1984$ & 266.0 & 2.3 & 5.0 & 4.5 & 0.3 & 10.0 & 1 \\
\hline $9 / 18 / 1984$ & 285.0 & 17.1 & 5.0 & 13.0 & 1.9 & 10.0 & 1 \\
\hline $10 / 30 / 1984$ & 152.0 & 1.6 & 7.0 & 3.6 & 0.1 & 10.0 & 1 \\
\hline $11 / 29 / 1984$ & 1235.0 & 0.2 & 62.0 & 1.6 & 0.0 & 10.0 & 1 \\
\hline $12 / 14 / 1984$ & 190.0 & 3.9 & 6.0 & 5.9 & 0.1 & 10.0 & 1 \\
\hline 1/15/1985 & 285.0 & 0.5 & 12.0 & 2.3 & 0.0 & 10.0 & 1 \\
\hline $2 / 26 / 1985$ & 627.0 & 101.8 & 3.0 & 19.8 & 2.1 & 10.0 & 1 \\
\hline 3/18/1985 & 389.5 & N/A & N/A & $\mathrm{N} / \mathrm{A}$ & $\mathrm{N} / \mathrm{A}$ & 10.0 & 1 \\
\hline 4/10/1985 & 1273.0 & 3.6 & 62.0 & 1.9 & 0.2 & 10.0 & 1 \\
\hline $5 / 31 / 1985$ & 779.0 & 30.3 & 27.0 & 6.3 & 2.0 & 10.0 & 1 \\
\hline $6 / 14 / 1985$ & 133.0 & 0.0 & 6.0 & 1.8 & 0.0 & 10.0 & 1 \\
\hline $8 / 30 / 1985$ & 266.0 & 24.8 & 5.0 & 15.9 & 2.0 & 10.0 & 1 \\
\hline 10/2/1985 & 494.0 & 37.0 & 11.0 & 13.3 & 2.8 & 10.0 & 1 \\
\hline 10/24/1985 & 190.0 & 4.4 & 3.0 & 8.9 & 0.3 & 10.0 & 1 \\
\hline $12 / 30 / 1985$ & 247.0 & 6.2 & 7.0 & 7.6 & 0.2 & 10.0 & 1 \\
\hline 1/16/1986 & 95.0 & 0.0 & 4.0 & 2.3 & 0.0 & 10.0 & 1 \\
\hline 2/6/1986 & 95.0 & 0.1 & 4.0 & 2.9 & 0.0 & 10.0 & 1 \\
\hline 3/31/1986 & 114.0 & 4.7 & 2.0 & 9.5 & 0.2 & 10.0 & 1 \\
\hline
\end{tabular}




\begin{tabular}{|c|c|c|c|c|c|c|c|}
\hline \multicolumn{8}{|c|}{ Appendix 2. Station D4C Corbicula Data } \\
\hline Date & $\begin{array}{l}\text { Total \# of } \\
\text { clams in } \\
\text { sample } \\
\left(\# / \mathrm{m}^{2}\right)\end{array}$ & $\begin{array}{c}\text { biomass } \\
\left(\mathrm{g} / \mathrm{m}^{2}\right)\end{array}$ & $\begin{array}{l}\text { recruit/0.05 } \\
\mathrm{m}^{2}\end{array}$ & $\begin{array}{l}\text { mean size } \\
(\mathrm{mm})\end{array}$ & $\begin{array}{c}G R \\
\left(\mathrm{~m}^{3} / \mathrm{m}^{2} / \mathrm{d}\right)\end{array}$ & Depth(M) & \# Grabs \\
\hline 4/21/1986 & 247.0 & 20.8 & 5.0 & 12.8 & 1.1 & 10.0 & 1 \\
\hline 5/21/1986 & 152.0 & 0.2 & 4.0 & 3.9 & 0.0 & 10.0 & 1 \\
\hline $6 / 30 / 1986$ & 57.0 & 14.3 & 0.0 & 23.6 & 1.7 & 10.0 & 1 \\
\hline 7/25/1986 & 38.0 & 0.2 & 0.0 & 8.5 & 0.0 & 10.0 & 1 \\
\hline $8 / 29 / 1986$ & 608.0 & 83.4 & 1.0 & 19.3 & 5.5 & 10.0 & 1 \\
\hline 9/12/1986 & 19.0 & 0.4 & 0.0 & 12.5 & 0.0 & 10.0 & 1 \\
\hline 10/29/1986 & 19.0 & 0.0 & 1.0 & 2.5 & 0.0 & 10.0 & 1 \\
\hline 11/14/1986 & 133.0 & 18.2 & 0.0 & 19.8 & 0.8 & 10.0 & 1 \\
\hline 1/23/1987 & 0.0 & 0.0 & 0.0 & N/A & 0.0 & 10.0 & 1 \\
\hline $2 / 26 / 1987$ & 893.0 & 155.3 & 0.0 & 23.1 & 3.3 & 10.0 & 1 \\
\hline $3 / 26 / 1987$ & 38.0 & 2.4 & 1.0 & 11.0 & 0.1 & 10.0 & 1 \\
\hline $4 / 24 / 1987$ & 133.0 & 3.4 & 5.0 & 6.2 & 0.3 & 10.0 & 1 \\
\hline $5 / 22 / 1987$ & 0.0 & 0.0 & 0.0 & N/A & 0.0 & 10.0 & 1 \\
\hline 6/9/1987 & 19.0 & 0.0 & 1.0 & 2.5 & 0.0 & 10.0 & 1 \\
\hline $7 / 30 / 1987$ & 0.0 & 0.0 & 0.0 & N/A & 0.0 & 10.0 & 1 \\
\hline $8 / 20 / 1987$ & 76.0 & 3.0 & 2.0 & 11.0 & 0.3 & 10.0 & 1 \\
\hline 9/18/1987 & 38.0 & 0.0 & 2.0 & 1.0 & 0.0 & 10.0 & 1 \\
\hline 10/30/1987 & 475.0 & 58.7 & 0.0 & 23.5 & 3.4 & 10.0 & 1 \\
\hline $11 / 9 / 1987$ & 0.0 & 0.0 & 0.0 & $\mathrm{~N} / \mathrm{A}$ & 0.0 & 10.0 & 1 \\
\hline 12/17/1987 & 19.0 & 2.4 & 0.0 & 23.5 & 0.1 & 10.0 & 1 \\
\hline 1/15/1988 & 152.0 & 19.2 & 0.0 & 21.4 & 0.5 & 10.0 & 1 \\
\hline 2/11/1988 & 38.0 & 1.8 & 1.0 & 12.0 & 0.1 & 10.0 & 1 \\
\hline $3 / 1 / 1988$ & 209.0 & 37.8 & 1.0 & 24.0 & 1.6 & 10.0 & 1 \\
\hline 4/1/1988 & 0.0 & 0.0 & 0.0 & $\mathrm{~N} / \mathrm{A}$ & 0.0 & 10.0 & 1 \\
\hline $5 / 27 / 1988$ & 152.0 & 50.3 & 0.0 & 26.1 & 3.4 & 10.0 & 1 \\
\hline $6 / 24 / 1988$ & 0.0 & 0.0 & 0.0 & $\mathrm{~N} / \mathrm{A}$ & 0.0 & 10.0 & 1 \\
\hline $7 / 22 / 1988$ & 0.0 & 0.0 & 0.0 & $\mathrm{~N} / \mathrm{A}$ & 0.0 & 10.0 & 1 \\
\hline $8 / 22 / 1988$ & 19.0 & 0.0 & 1.0 & 2.5 & 0.0 & 10.0 & 1 \\
\hline $9 / 22 / 1988$ & 114.0 & 18.2 & 0.0 & 18.2 & 1.7 & 10.0 & 1 \\
\hline 10/21/1988 & 0.0 & N/A & N/A & $\mathrm{N} / \mathrm{A}$ & 0.0 & 10.0 & 1 \\
\hline $11 / 17 / 1988$ & 19.0 & 1.6 & 0.0 & 21.5 & 0.1 & 10.0 & 1 \\
\hline $12 / 8 / 1988$ & 5.7 & 0.0 & 0.0 & $\mathrm{~N} / \mathrm{A}$ & N/A & 10.0 & 1 \\
\hline 1/20/1989 & 38.0 & 9.9 & 0.0 & 30.0 & 0.3 & 10.0 & 1 \\
\hline 2/6/1989 & 57.0 & 2.8 & 2.0 & 9.2 & 0.1 & 10.0 & 1 \\
\hline 5/4/1989 & 28.5 & 0.5 & 0.0 & 10.5 & 0.0 & 10.0 & 1 \\
\hline 7/24/1989 & 171.0 & 55.9 & 0.0 & 25.4 & 4.7 & 10.0 & 1 \\
\hline $8 / 21 / 1989$ & 24.7 & $\mathrm{~N} / \mathrm{A}$ & N/A & N/A & N/A & 10.0 & 1 \\
\hline 9/19/1989 & 6.3 & 0.0 & 0.3 & 1.5 & 0.0 & 10.0 & 1 \\
\hline
\end{tabular}




\begin{tabular}{|c|c|c|c|c|c|c|c|}
\hline \multicolumn{8}{|c|}{ Appendix 2. Station D4C Corbicula Data } \\
\hline Date & $\begin{array}{l}\text { Total \# of } \\
\text { clams in } \\
\text { sample } \\
\left(\# / \mathrm{m}^{2}\right)\end{array}$ & $\begin{array}{c}\text { biomass } \\
\left(\mathrm{g} / \mathrm{m}^{2}\right)\end{array}$ & $\begin{array}{c}\text { recruit/0.05 } \\
\mathrm{m}^{2}\end{array}$ & $\begin{array}{l}\text { mean size } \\
(\mathrm{mm})\end{array}$ & $\begin{array}{c}G R \\
\left(\mathrm{~m}^{3} / \mathrm{m}^{2} / \mathrm{d}\right)\end{array}$ & Depth(M) & \# Grabs \\
\hline 10/17/1989 & 43.7 & N/A & N/A & N/A & N/A & 10.0 & 1 \\
\hline 11/13/1989 & 38.0 & $\mathrm{~N} / \mathrm{A}$ & N/A & $\mathrm{N} / \mathrm{A}$ & $\mathrm{N} / \mathrm{A}$ & 10.0 & 1 \\
\hline 12/4/1989 & 24.7 & $\mathrm{~N} / \mathrm{A}$ & N/A & N/A & $\mathrm{N} / \mathrm{A}$ & 10.0 & 1 \\
\hline $1 / 16 / 1990$ & 95.0 & 0.0 & 4.3 & 2.3 & 0.0 & 10.0 & 3 \\
\hline 2/27/1990 & 38.0 & 3.4 & 0.7 & 16.8 & 0.1 & 10.0 & 3 \\
\hline 3/19/1990 & 31.7 & 0.0 & 1.7 & 0.9 & 0.0 & 10.0 & 3 \\
\hline $4 / 20 / 1990$ & 0.0 & 0.0 & 0.0 & N/A & 0.0 & 10.0 & 3 \\
\hline $5 / 14 / 1990$ & 158.3 & 5.3 & 7.0 & 4.3 & 0.4 & 10.0 & 3 \\
\hline $6 / 26 / 1990$ & 183.7 & 10.1 & 4.3 & 8.4 & 1.0 & 10.0 & 3 \\
\hline $7 / 12 / 1990$ & 779.0 & 61.0 & 25.7 & 9.0 & 6.0 & 10.0 & 3 \\
\hline 8/8/1990 & 44.3 & 2.3 & 1.0 & 6.8 & 0.3 & 10.0 & 3 \\
\hline 9/24/1990 & 69.7 & 8.9 & 0.7 & 17.7 & 0.9 & 10.0 & 3 \\
\hline 10/22/1990 & 38.0 & 10.9 & 0.0 & 23.8 & 0.8 & 10.0 & 3 \\
\hline $11 / 6 / 1990$ & 101.3 & 1.1 & 2.7 & 4.5 & 0.1 & 10.0 & 3 \\
\hline 12/13/1990 & 95.0 & 6.2 & 1.0 & 15.4 & 0.2 & 10.0 & 3 \\
\hline 1/7/1991 & 82.3 & 3.8 & 2.7 & 8.1 & 0.1 & 10.0 & 3 \\
\hline 2/21/1991 & 31.7 & 1.4 & 1.0 & 7.7 & 0.1 & 10.0 & 3 \\
\hline 3/5/1991 & 76.0 & 11.2 & 0.7 & 15.6 & 0.4 & 10.0 & 3 \\
\hline 4/11/1991 & 31.7 & 0.0 & 1.0 & 2.7 & 0.0 & 10.0 & 3 \\
\hline 5/23/1991 & 76.0 & 5.6 & 2.7 & 6.8 & 0.4 & 10.0 & 3 \\
\hline 6/4/1991 & 272.3 & 35.3 & 2.3 & 17.8 & 2.5 & 10.0 & 3 \\
\hline $7 / 16 / 1991$ & 50.7 & 0.0 & 0.3 & 4.0 & 0.0 & 10.0 & 3 \\
\hline $8 / 30 / 1991$ & 82.3 & 8.9 & 1.0 & 14.7 & 0.9 & 10.0 & 3 \\
\hline 9/12/1991 & 101.3 & 17.5 & 0.3 & 23.8 & 1.6 & 10.0 & 3 \\
\hline 10/8/1991 & 19.0 & 2.7 & 0.7 & 11.2 & 0.3 & 10.0 & 3 \\
\hline 11/12/1991 & 0.0 & 0.0 & 0.0 & $\mathrm{~N} / \mathrm{A}$ & 0.0 & 10.0 & 3 \\
\hline 12/10/1991 & 69.7 & 9.3 & 0.3 & 25.6 & 0.2 & 10.0 & 3 \\
\hline 1/17/1992 & 76.0 & 14.0 & 0.0 & 25.5 & 0.4 & 10.0 & 3 \\
\hline 2/25/1992 & 19.0 & 2.4 & 0.3 & 18.8 & 0.1 & 10.0 & 3 \\
\hline 3/24/1992 & 12.7 & 3.9 & 0.0 & 27.5 & 0.2 & 10.0 & 3 \\
\hline 4/6/1992 & 6.3 & 2.0 & 0.0 & 27.5 & 0.1 & 10.0 & 3 \\
\hline $5 / 14 / 1992$ & 19.0 & 6.3 & 0.0 & 27.5 & 0.6 & 10.0 & 3 \\
\hline 6/17/1992 & 0.0 & 0.0 & 0.0 & N/A & 0.0 & 10.0 & 3 \\
\hline $7 / 10 / 1992$ & 25.3 & 3.7 & 0.7 & 13.8 & 0.4 & 10.0 & 3 \\
\hline 8/4/1992 & 25.3 & 5.1 & 0.0 & 26.0 & 0.6 & 10.0 & 3 \\
\hline 9/1/1992 & 0.0 & 0.0 & 0.0 & $\mathrm{~N} / \mathrm{A}$ & 0.0 & 10.0 & 3 \\
\hline 11/5/1992 & 0.0 & 0.0 & 0.0 & N/A & 0.0 & 10.0 & 3 \\
\hline 12/28/1992 & 19.0 & 2.6 & 0.0 & 25.5 & 0.1 & 10.0 & 3 \\
\hline
\end{tabular}




\begin{tabular}{|c|c|c|c|c|c|c|c|}
\hline \multicolumn{8}{|c|}{ Appendix 2. Station D4C Corbicula Data } \\
\hline Date & $\begin{array}{l}\text { Total \# of } \\
\text { clams in } \\
\text { sample } \\
\left(\# / \mathrm{m}^{2}\right)\end{array}$ & $\begin{array}{c}\text { biomass } \\
\left(\mathrm{g} / \mathrm{m}^{2}\right)\end{array}$ & $\begin{array}{l}\text { recruit/0.05 } \\
\mathrm{m}^{2}\end{array}$ & $\begin{array}{l}\text { mean size } \\
(\mathrm{mm})\end{array}$ & $\begin{array}{c}\text { GR } \\
\left(\mathrm{m}^{3} / \mathrm{m}^{2} / \mathrm{d}\right)\end{array}$ & Depth(M) & \# Grabs \\
\hline 1/14/1993 & 101.3 & 15.7 & 0.0 & 26.3 & 0.4 & 10.0 & 3 \\
\hline 2/9/1993 & 0.0 & 0.0 & 0.0 & N/A & 0.0 & 10.0 & 3 \\
\hline 3/11/1993 & 6.3 & 1.0 & 0.0 & 22.5 & 0.1 & 10.0 & 3 \\
\hline $4 / 19 / 1993$ & 0.0 & 0.0 & 0.0 & N/A & 0.0 & 10.0 & 3 \\
\hline $5 / 20 / 1993$ & 6.3 & 0.6 & 0.0 & 19.5 & 0.0 & 10.0 & 3 \\
\hline $6 / 16 / 1993$ & 6.3 & 1.2 & 0.0 & 22.5 & 0.1 & 10.0 & 3 \\
\hline $7 / 19 / 1993$ & 25.3 & 5.1 & 0.0 & 24.0 & 0.5 & 10.0 & 3 \\
\hline $8 / 19 / 1993$ & 0.0 & 0.0 & 0.0 & N/A & 0.0 & 10.0 & 3 \\
\hline 9/16/1993 & 0.0 & 0.0 & 0.0 & N/A & 0.0 & 10.0 & 3 \\
\hline 10/8/1993 & 0.0 & 0.0 & 0.0 & N/A & 0.0 & 10.0 & 3 \\
\hline 11/16/1993 & 6.3 & 1.5 & 0.0 & 28.5 & 0.1 & 10.0 & 3 \\
\hline 12/9/1993 & 0.0 & 0.0 & 0.0 & N/A & 0.0 & 10.0 & 3 \\
\hline 1/18/1994 & 0.0 & 0.0 & 0.0 & N/A & 0.0 & 10.0 & 3 \\
\hline 2/8/1994 & 6.3 & 0.0 & 0.0 & 3.5 & 0.0 & 10.0 & 3 \\
\hline 3/9/1994 & 6.3 & 1.4 & 0.0 & 25.5 & 0.1 & 10.0 & 3 \\
\hline 4/12/1994 & 0.0 & 0.0 & 0.0 & N/A & 0.0 & 10.0 & 3 \\
\hline $5 / 23 / 1994$ & 25.3 & 5.6 & 0.0 & 21.3 & 0.4 & 10.0 & 3 \\
\hline $6 / 9 / 1994$ & 6.3 & 1.3 & 0.0 & 27.5 & 0.1 & 10.0 & 3 \\
\hline $7 / 20 / 1994$ & 6.3 & 1.5 & 0.0 & 25.5 & 0.2 & 10.0 & 3 \\
\hline $8 / 9 / 1994$ & 6.3 & 1.0 & 0.0 & 25.5 & 0.1 & 10.0 & 3 \\
\hline $9 / 21 / 1994$ & 0.0 & 0.0 & 0.0 & N/A & 0.0 & 10.0 & 3 \\
\hline 10/19/1994 & 0.0 & 0.0 & 0.0 & N/A & 0.0 & 10.0 & 3 \\
\hline $11 / 21 / 1994$ & 0.0 & 0.0 & 0.0 & N/A & 0.0 & 10.0 & 3 \\
\hline 12/16/1994 & 12.7 & 2.3 & 0.0 & 26.5 & 0.1 & 10.0 & 3 \\
\hline $1 / 17 / 1995$ & 0.0 & 0.0 & 0.0 & N/A & 0.0 & 10.0 & 3 \\
\hline 2/15/1995 & 0.0 & 0.0 & 0.0 & N/A & 0.0 & 10.0 & 3 \\
\hline 3/15/1995 & 0.0 & 0.0 & 0.0 & N/A & 0.0 & 10.0 & 3 \\
\hline 4/27/1995 & 304.0 & 0.0 & 15.7 & 1.4 & 0.0 & 10.0 & 3 \\
\hline 5/17/1995 & 76.0 & 2.2 & 3.3 & 3.8 & 0.1 & 10.0 & 3 \\
\hline $6 / 27 / 1995$ & 196.3 & 1.2 & 8.7 & 2.7 & 0.1 & 10.0 & 3 \\
\hline $7 / 13 / 1995$ & 139.3 & 2.0 & 4.7 & 3.9 & 0.2 & 10.0 & 3 \\
\hline 8/24/1995 & 38.0 & 0.1 & 0.0 & 4.7 & 0.0 & 10.0 & 3 \\
\hline 9/26/1995 & 50.7 & 1.6 & 0.3 & 8.1 & 0.2 & 10.0 & 3 \\
\hline 10/25/1995 & 44.3 & 1.6 & 0.0 & 9.4 & 0.1 & 10.0 & 3 \\
\hline 11/27/1995 & 6.3 & 0.0 & 0.0 & 6.5 & 0.0 & 10.0 & 3 \\
\hline
\end{tabular}




\begin{tabular}{|c|c|c|c|c|c|c|c|}
\hline \multicolumn{8}{|c|}{ Appendix 3. Station D4C Potamocorbula Data } \\
\hline Date & $\begin{array}{l}\text { Total \# of } \\
\text { clams in } \\
\text { sample } \\
\left(\# / \mathrm{m}^{2}\right)\end{array}$ & $\begin{array}{c}\text { Biomass } \\
\left(\mathrm{g} / \mathrm{m}^{2}\right)\end{array}$ & $\mathrm{rec} / 0.05 \mathrm{~m}^{2}$ & $\begin{array}{c}\text { mean size } \\
(\mathrm{mm})\end{array}$ & $\begin{array}{c}\text { GR } \\
\left(\mathrm{m}^{3} / \mathrm{m}^{2} / \mathrm{d}\right)\end{array}$ & Depth(M) & \# Grabs \\
\hline 6/9/1987 & 57.00 & 0.17 & 1.00 & 5.17 & 0.07 & 10.0 & 1 \\
\hline $7 / 30 / 1987$ & 38.00 & 0.03 & 1.00 & 3.50 & 0.01 & 10.0 & 1 \\
\hline $8 / 20 / 1987$ & 1767.00 & 0.44 & 77.00 & 2.56 & 0.16 & 10.0 & 1 \\
\hline 9/18/1987 & 684.00 & 0.24 & 18.00 & 3.03 & 0.09 & 10.0 & 1 \\
\hline 10/30/1987 & 1349.00 & 0.45 & 37.00 & 2.99 & 0.17 & 10.0 & 1 \\
\hline 11/9/1987 & 950.00 & 1.43 & 3.00 & 4.86 & 0.54 & 10.0 & 1 \\
\hline 12/17/1987 & 684.00 & 1.70 & 1.00 & 5.69 & 0.64 & 10.0 & 1 \\
\hline $1 / 15 / 1988$ & 1558.00 & 11.91 & 0.00 & 7.41 & 2.88 & 10.0 & 1 \\
\hline 2/11/1988 & 646.00 & 4.36 & 0.00 & 6.97 & 1.64 & 10.0 & 1 \\
\hline 4/1/1988 & 133.00 & 1.05 & 0.00 & 7.50 & 0.41 & 10.0 & 1 \\
\hline $5 / 27 / 1988$ & 19.00 & 1.61 & 0.00 & 17.50 & 0.63 & 10.0 & 1 \\
\hline $6 / 24 / 1988$ & 0.00 & 0.00 & 0.00 & $\mathrm{~N} / \mathrm{D}$ & 0 & 10.0 & 1 \\
\hline $7 / 22 / 1988$ & 38.00 & 0.20 & 0.00 & 7.50 & 0.08 & 10.0 & 1 \\
\hline $8 / 22 / 1988$ & 95.00 & 0.09 & 0.00 & 4.50 & 0.04 & 10.0 & 1 \\
\hline $9 / 22 / 1988$ & 38.00 & 6.07 & 0.00 & 20.00 & 2.34 & 10.0 & 1 \\
\hline 10/21/1988 & $N / D$ & $N / D$ & $\mathrm{~N} / \mathrm{D}$ & $\mathrm{N} / \mathrm{D}$ & $N / D$ & 10.0 & 1 \\
\hline 11/17/1988 & 190.00 & 2.81 & 0.00 & 7.00 & 1.08 & 10.0 & 1 \\
\hline $12 / 8 / 1988$ & 171.00 & 1.17 & 0.00 & 7.61 & 0.45 & 10.0 & 1 \\
\hline 1/20/1989 & 209.00 & 1.32 & 1.00 & 7.00 & 0.34 & 10.0 & 1 \\
\hline 2/6/1989 & 180.50 & 2.77 & 0.00 & 9.60 & 0.72 & 10.0 & 1 \\
\hline 2/28/1989 & 0.00 & 0.00 & 0.00 & N/D & $\mathrm{N} / \mathrm{D}$ & 10.0 & 1 \\
\hline 3/21/1989 & 0.00 & 0.00 & 0.00 & $\mathrm{~N} / \mathrm{D}$ & $\mathrm{N} / \mathrm{D}$ & 10.0 & 1 \\
\hline 5/4/1989 & 0.00 & 0.00 & 0.00 & $\mathrm{~N} / \mathrm{D}$ & 0 & 10.0 & 1 \\
\hline $6 / 26 / 1989$ & 38.00 & 7.04 & 0.00 & 19.00 & 2.72 & 10.0 & 1 \\
\hline 7/24/1989 & 12.67 & 1.24 & 0.00 & 16.50 & 0.49 & 10.0 & 1 \\
\hline 8/21/1989 & 47.50 & 2.60 & 0.00 & 13.50 & 1.01 & 10.0 & 1 \\
\hline 9/19/1989 & 19.00 & 0.02 & 0.00 & 4.50 & 0.01 & 10.0 & 1 \\
\hline 10/17/1989 & 0.00 & 0.00 & 0.00 & $\mathrm{~N} / \mathrm{D}$ & 0 & 10.0 & 1 \\
\hline 11/13/1989 & 0.00 & 0.00 & 0.00 & $\mathrm{~N} / \mathrm{D}$ & 0 & 10.0 & 1 \\
\hline 12/12/1989 & 0.00 & 0.00 & 0.00 & $\mathrm{~N} / \mathrm{D}$ & 0 & 10.0 & 1 \\
\hline $1 / 16 / 1990$ & 25.33 & 0.06 & 0.00 & 6.00 & 0.02 & 10.0 & 3 \\
\hline $2 / 27 / 1990$ & 19.00 & 0.17 & 0.00 & 7.50 & 0.04 & 10.0 & 3 \\
\hline 3/19/1990 & 19.00 & 0.04 & 0.00 & 5.17 & 0.02 & 10.0 & 3 \\
\hline $4 / 20 / 1990$ & 0.00 & 0.00 & 0.00 & $\mathrm{~N} / \mathrm{D}$ & 0 & 10.0 & 3 \\
\hline $5 / 14 / 1990$ & 133.00 & 0.04 & 4.00 & 2.79 & 0.02 & 10.0 & 3 \\
\hline $6 / 26 / 1990$ & 164.67 & 1.94 & 4.67 & 3.77 & 0.76 & 10.0 & 3 \\
\hline $7 / 12 / 1990$ & 228.00 & 1.61 & 3.00 & 4.58 & 0.63 & 10.0 & 3 \\
\hline 8/8/1990 & 44.33 & 0.09 & 0.67 & 4.07 & 0.03 & 10.0 & 3 \\
\hline
\end{tabular}




\begin{tabular}{|c|c|c|c|c|c|c|c|}
\hline \multicolumn{8}{|c|}{ Appendix 3. Station D4C Potamocorbula Data } \\
\hline Date & $\begin{array}{l}\text { Total \# of } \\
\text { clams in } \\
\text { sample } \\
\left(\# / \mathrm{m}^{2}\right)\end{array}$ & $\begin{array}{c}\text { Biomass } \\
\left(\mathrm{g} / \mathrm{m}^{2}\right)\end{array}$ & $\mathrm{rec} / 0.05 \mathrm{~m}^{2}$ & $\begin{array}{c}\text { mean size } \\
(\mathrm{mm})\end{array}$ & $\begin{array}{c}\text { GR } \\
\left(\mathrm{m}^{3} / \mathrm{m}^{2} / \mathrm{d}\right)\end{array}$ & Depth(M) & \# Grabs \\
\hline 9/24/1990 & 101.33 & 0.22 & 0.67 & 4.81 & 0.09 & 10.0 & 3 \\
\hline 10/22/1990 & 88.67 & 0.32 & 0.33 & 6.90 & 0.12 & 10.0 & 3 \\
\hline 11/6/1990 & 297.67 & 2.24 & 2.67 & 6.80 & 0.86 & 10.0 & 3 \\
\hline 12/13/1990 & 69.67 & 1.15 & 0.33 & 7.14 & 0.45 & 10.0 & 3 \\
\hline 1/7/1991 & 126.67 & 0.73 & 1.67 & 6.40 & 0.28 & 10.0 & 3 \\
\hline 2/19/1991 & 76.00 & 0.71 & 0.67 & 6.67 & 0.19 & 10.0 & 3 \\
\hline 3/5/1991 & 589.00 & 1.71 & 10.67 & 4.13 & 0.65 & 10.0 & 3 \\
\hline 4/11/1991 & 82.33 & 0.79 & 0.33 & 7.19 & 0.31 & 10.0 & 3 \\
\hline 5/23/1991 & 95.00 & 1.01 & 0.00 & 7.90 & 0.39 & 10.0 & 3 \\
\hline 6/4/1991 & 88.67 & 1.51 & 0.33 & 8.93 & 0.59 & 10.0 & 3 \\
\hline $7 / 16 / 1991$ & 1868.33 & 8.87 & 65.67 & 3.05 & 3.3 & 10.0 & 3 \\
\hline $8 / 30 / 1991$ & 291.33 & 0.45 & 2.00 & 4.67 & 0.17 & 10.0 & 3 \\
\hline 9/12/1991 & 177.33 & 0.93 & 0.67 & 6.32 & 0.36 & 10.0 & 3 \\
\hline 10/8/1991 & 114.00 & 0.87 & 0.00 & 8.56 & 0.34 & 10.0 & 3 \\
\hline 11/12/1991 & 158.33 & 2.23 & 0.00 & 9.06 & 0.86 & 10.0 & 3 \\
\hline 12/10/1991 & 221.67 & 4.38 & 0.33 & 9.53 & 1.13 & 10.0 & 3 \\
\hline 1/17/1992 & 158.33 & 1.53 & 0.33 & 8.00 & 0.40 & 10.0 & 3 \\
\hline 2/25/1992 & 63.33 & 0.56 & 0.33 & 8.50 & 0.22 & 10.0 & 3 \\
\hline $3 / 24 / 1992$ & 107.67 & 2.11 & 0.00 & 10.10 & 0.81 & 10.0 & 3 \\
\hline 4/6/1992 & 44.33 & 0.67 & 0.00 & 8.90 & 0.26 & 10.0 & 3 \\
\hline $5 / 14 / 1992$ & 57.00 & 2.70 & 0.00 & 11.60 & 1.05 & 10.0 & 3 \\
\hline $6 / 17 / 1992$ & 76.00 & 1.29 & 1.33 & 7.40 & 0.51 & 10.0 & 3 \\
\hline $7 / 10 / 1992$ & 57.00 & 2.08 & 0.33 & 11.10 & 0.81 & 10.0 & 3 \\
\hline 8/4/1992 & 101.33 & 2.76 & 0.67 & 9.80 & 1.07 & 10.0 & 3 \\
\hline 9/1/1992 & 50.67 & 1.47 & 0.00 & 10.30 & 0.57 & 10.0 & 3 \\
\hline 10/23/1992 & 69.67 & 2.76 & 0.00 & 16.10 & 1.06 & 10.0 & 3 \\
\hline $11 / 5 / 1992$ & 120.33 & 6.50 & 0.00 & 12.70 & 2.49 & 10.0 & 3 \\
\hline 12/28/1992 & 63.33 & 5.01 & 0.00 & 15.20 & 1.93 & 10.0 & 3 \\
\hline $1 / 14 / 1993$ & 82.33 & 4.67 & 0.00 & 14.00 & 1.21 & 10.0 & 3 \\
\hline 2/9/1993 & 0.00 & 0.00 & 0.00 & $\mathrm{~N} / \mathrm{D}$ & 0.00 & 10.0 & 3 \\
\hline 3/11/1993 & 101.33 & 7.22 & 0.00 & 13.30 & 2.77 & 10.0 & 3 \\
\hline 4/19/1993 & 120.33 & 3.48 & 0.00 & 9.50 & 1.34 & 10.0 & 3 \\
\hline $5 / 20 / 1993$ & 0.00 & 0.00 & 0.00 & $\mathrm{~N} / \mathrm{D}$ & 0.00 & 10.0 & 3 \\
\hline $6 / 16 / 1993$ & 12.67 & 0.15 & 0.00 & 9.50 & 0.06 & 10.0 & 3 \\
\hline 7/19/1993 & 69.67 & 6.59 & 0.00 & 15.50 & 2.54 & 10.0 & 3 \\
\hline 8/19/1993 & 107.67 & 9.73 & 0.00 & 16.60 & 3.70 & 10.0 & 3 \\
\hline $9 / 16 / 1993$ & 12.67 & 0.24 & 0.00 & 11.00 & 0.10 & 10.0 & 3 \\
\hline 10/8/1993 & 12.67 & 0.43 & 0.00 & 15.00 & 0.17 & 10.0 & 3 \\
\hline
\end{tabular}




\begin{tabular}{|c|c|c|c|c|c|c|c|}
\hline \multicolumn{8}{|c|}{ Appendix 3. Station D4C Potamocorbula Data } \\
\hline Date & $\begin{array}{l}\text { Total \# of } \\
\text { clams in } \\
\text { sample } \\
\left(\# / \mathrm{m}^{2}\right)\end{array}$ & $\begin{array}{c}\text { Biomass } \\
\left(\mathrm{g} / \mathrm{m}^{2}\right)\end{array}$ & $\mathrm{rec} / 0.05 \mathrm{~m}^{2}$ & $\begin{array}{c}\text { mean size } \\
(\mathrm{mm})\end{array}$ & $\begin{array}{c}\text { GR } \\
\left(\mathrm{m}^{3} / \mathrm{m}^{2} / \mathrm{d}\right)\end{array}$ & $\operatorname{Depth}(\mathrm{M})$ & \# Grabs \\
\hline $11 / 16 / 1993$ & 25.33 & 2.18 & 0.00 & 16.80 & 0.85 & 10.0 & 3 \\
\hline 12/9/1993 & 31.67 & 3.69 & 0.00 & 18.50 & 1.43 & 10.0 & 3 \\
\hline $1 / 18 / 1994$ & 12.67 & 0.49 & 0.00 & 14.00 & 0.13 & 10.0 & 3 \\
\hline 2/8/1994 & 31.67 & 1.81 & 0.00 & 16.50 & 0.48 & 10.0 & 3 \\
\hline 3/9/1994 & 6.33 & 0.17 & 0.00 & 11.50 & 0.07 & 10.0 & 3 \\
\hline 4/12/1994 & 12.67 & 1.16 & 0.00 & 16.50 & 0.46 & 10.0 & 3 \\
\hline $5 / 23 / 1994$ & 50.67 & 6.06 & 0.00 & 17.40 & 2.34 & 10.0 & 3 \\
\hline 6/9/1994 & 25.33 & 2.62 & 0.00 & 17.00 & 1.02 & 10.0 & 3 \\
\hline $7 / 20 / 1994$ & 19.00 & 2.41 & 0.00 & 17.50 & 0.94 & 10.0 & 3 \\
\hline 8/9/1994 & 19.00 & 0.58 & 0.00 & 10.50 & 0.23 & 10.0 & 3 \\
\hline 9/21/1994 & 95.00 & 7.21 & 1.00 & 13.10 & 2.77 & 10.0 & 3 \\
\hline $10 / 19 / 1994$ & 31.67 & 0.52 & 0.00 & 10.30 & 0.20 & 10.0 & 3 \\
\hline $11 / 21 / 1994$ & 63.33 & 1.40 & 0.33 & 7.90 & 0.55 & 10.0 & 3 \\
\hline $12 / 16 / 1994$ & 120.33 & 8.49 & 0.00 & 13.90 & 2.19 & 10.0 & 3 \\
\hline 1/17/1995 & 38.00 & 0.91 & 0.00 & 10.83 & 0.36 & 10.0 & 3 \\
\hline 2/15/1995 & 31.67 & 0.41 & 0.33 & 8.90 & 0.16 & 10.0 & 3 \\
\hline 3/15/1995 & 0.00 & 0.00 & 0.00 & $\mathrm{~N} / \mathrm{D}$ & .000 & 10.0 & 3 \\
\hline 4/27/1995 & 12.67 & 0.12 & 0.00 & 8.00 & 0.05 & 10.0 & 3 \\
\hline 5/17/1995 & 12.67 & 0.58 & 0.00 & 13.50 & 0.23 & 10.0 & 3 \\
\hline 6/27/1995 & 19.00 & 0.13 & 0.00 & 7.83 & 0.05 & 10.0 & 3 \\
\hline 7/13/1995 & 25.33 & 0.25 & 0.00 & 9.25 & 0.10 & 10.0 & 3 \\
\hline $8 / 24 / 1995$ & 12.67 & 0.15 & 0.00 & 9.50 & 0.06 & 10.0 & 3 \\
\hline 9/26/1995 & 6.33 & 0.19 & 0.00 & 12.50 & 0.07 & 10.0 & 3 \\
\hline 10/25/1995 & 0.00 & 0.00 & 0.00 & $N / D$ & 0.00 & 10.0 & 3 \\
\hline $11 / 27 / 1995$ & 0.00 & 0.00 & 0.00 & $\mathrm{~N} / \mathrm{D}$ & 0.00 & 10.0 & 3 \\
\hline 12/27/1995 & 0.00 & 0.00 & 0.00 & $N / D$ & 0.00 & 10.0 & 3 \\
\hline
\end{tabular}




\begin{tabular}{|c|c|c|c|c|c|c|c|}
\hline \multicolumn{8}{|c|}{ Appendix 4. Station D4L Corbicula Data } \\
\hline Date & $\begin{array}{l}\text { Total \# of } \\
\text { clams in } \\
\text { sample } \\
\left(\# / \mathrm{m}^{2}\right)\end{array}$ & $\begin{array}{c}\text { Biomass } \\
\left(\mathrm{g} / \mathrm{m}^{2}\right)\end{array}$ & $\begin{array}{c}\text { recruit/0.05 } \\
\mathrm{m}^{2}\end{array}$ & $\begin{array}{c}\text { mean } \\
\text { size } \\
(\mathrm{mm})\end{array}$ & $\begin{array}{c}\text { GR } \\
\left(\mathrm{m}^{3} / \mathrm{m}^{2} / \mathrm{d}\right)\end{array}$ & $\begin{array}{l}\text { Depth } \\
\text { (m) }\end{array}$ & \# Grabs \\
\hline $6 / 1 / 1977$ & N/D & N/D & $\mathrm{N} / \mathrm{D}$ & $\mathrm{N} / \mathrm{D}$ & $\mathrm{N} / \mathrm{D}$ & $\mathrm{N} / \mathrm{D}$ & $\mathrm{N} / \mathrm{D}$ \\
\hline 10/13/1977 & 38.00 & 0.4 & 0.00 & 10.0 & 0.0 & 4.9 & 1 \\
\hline $6 / 8 / 1978$ & 19.00 & 1.9 & 0.00 & 18.5 & 0.2 & 4.9 & 1 \\
\hline $10 / 4 / 1978$ & 19.00 & 0.0 & 1.00 & 2.5 & 0.0 & 4.9 & 1 \\
\hline $5 / 30 / 1979$ & 931.00 & 0.3 & 39.00 & 2.2 & 0.0 & 4.9 & 1 \\
\hline 9/17/1979 & 2178.67 & 24.8 & 106.00 & 2.7 & 3.0 & 4.9 & 1 \\
\hline $6 / 11 / 1980$ & 3268.00 & 0.8 & 108.00 & 2.9 & 0.1 & 4.9 & 1 \\
\hline $7 / 18 / 1980$ & 1463.00 & 0.6 & 53.00 & 2.5 & 0.1 & 4.9 & 1 \\
\hline $8 / 22 / 1980$ & 912.00 & 0.9 & 30.00 & 3.2 & 0.1 & 4.9 & 1 \\
\hline 9/19/1980 & 1007.00 & 0.0 & 50.00 & 1.8 & 0.0 & 4.9 & 1 \\
\hline $10 / 23 / 1980$ & 1520.00 & 0.8 & 68.00 & 2.3 & 0.1 & 4.9 & 1 \\
\hline $11 / 20 / 1980$ & 1444.00 & 0.3 & 62.00 & 2.2 & 0.0 & 4.9 & 1 \\
\hline $12 / 22 / 1980$ & 247.00 & 0.1 & 9.00 & 2.6 & 0.0 & 4.9 & 1 \\
\hline 1/14/1981 & 950.00 & 0.1 & 43.00 & 2.3 & 0.0 & 4.9 & 1 \\
\hline 2/19/1981 & N/D & N/D & N/D & $\mathrm{N} / \mathrm{D}$ & 0.0 & 4.9 & $\mathrm{~N} / \mathrm{D}$ \\
\hline $3 / 30 / 1981$ & 1406.00 & 0.1 & 68.00 & 1.8 & 0.0 & 4.9 & 1 \\
\hline 4/16/1981 & 7220.00 & 2.6 & 303.00 & 2.5 & 0.1 & 4.9 & 1 \\
\hline 5/15/1981 & 8056.00 & 3.2 & 180.00 & 3.3 & 0.2 & 4.9 & 1 \\
\hline $6 / 12 / 1981$ & 6023.00 & 18.0 & 64.00 & 4.9 & 1.6 & 4.9 & 1 \\
\hline $7 / 10 / 1981$ & 228.00 & 0.6 & 1.00 & 5.7 & 0.1 & 4.9 & 1 \\
\hline $8 / 26 / 1981$ & 931.00 & 2.6 & 23.00 & 4.2 & 0.3 & 4.9 & 1 \\
\hline 9/24/1981 & 570.00 & 0.9 & 19.00 & 3.5 & 0.1 & 4.9 & 1 \\
\hline $10 / 13 / 1981$ & 114.00 & 0.2 & 1.00 & 3.3 & 0.0 & 4.9 & 1 \\
\hline $11 / 20 / 1981$ & 646.00 & 0.5 & 30.00 & 2.0 & 0.0 & 4.9 & 1 \\
\hline $12 / 11 / 1981$ & 57.00 & 0.0 & 3.00 & 1.8 & 0.0 & 4.9 & 1 \\
\hline 1/21/1982 & 1368.00 & 0.1 & 72.00 & 1.6 & 0.0 & 4.9 & 1 \\
\hline $2 / 22 / 1982$ & 2166.00 & 0.4 & 106.00 & 1.8 & 0.0 & 4.9 & 1 \\
\hline $3 / 30 / 1982$ & 5681.00 & 1.0 & 288.00 & 1.8 & 0.0 & 4.9 & 1 \\
\hline $4 / 28 / 1982$ & 7695.00 & 5.2 & 347.00 & 2.1 & 0.2 & 4.9 & 1 \\
\hline $5 / 20 / 1982$ & 1767.00 & 0.5 & 68.00 & 2.6 & 0.0 & 4.9 & 1 \\
\hline $6 / 25 / 1982$ & 247.00 & 0.3 & 3.00 & 4.0 & 0.0 & 4.9 & 1 \\
\hline $7 / 22 / 1982$ & 247.00 & 0.3 & 6.00 & 3.4 & 0.0 & 4.9 & 1 \\
\hline $8 / 30 / 1982$ & 570.00 & 0.1 & 28.00 & 1.1 & 0.0 & 4.9 & 1 \\
\hline 9/20/1982 & 1672.00 & 0.1 & 87.00 & 1.2 & 0.0 & 4.9 & 1 \\
\hline $10 / 28 / 1982$ & 665.00 & 0.0 & 35.00 & 1.2 & 0.0 & 4.9 & 1 \\
\hline $11 / 24 / 1982$ & 2489.00 & 0.1 & 131.00 & 1.3 & 0.0 & 4.9 & 1 \\
\hline $12 / 15 / 1982$ & 2261.00 & 1.4 & 116.00 & 1.7 & 0.0 & 4.9 & 1 \\
\hline 1/31/1983 & 6745.00 & 0.5 & 350.00 & 1.7 & 0.0 & 4.9 & 1 \\
\hline
\end{tabular}




\begin{tabular}{|c|c|c|c|c|c|c|c|}
\hline \multicolumn{8}{|c|}{ Appendix 4. Station D4L Corbicula Data } \\
\hline Date & $\begin{array}{l}\text { Total \# of } \\
\text { clams in } \\
\text { sample } \\
\left(\# / \mathrm{m}^{2}\right)\end{array}$ & $\begin{array}{c}\text { Biomass } \\
\left(\mathrm{g} / \mathrm{m}^{2}\right)\end{array}$ & $\begin{array}{c}\text { recruit/0.05 } \\
\mathrm{m}^{2}\end{array}$ & $\begin{array}{c}\text { mean } \\
\text { size } \\
(\mathrm{mm})\end{array}$ & $\begin{array}{c}\text { GR } \\
\left(\mathrm{m}^{3} / \mathrm{m}^{2} / \mathrm{d}\right)\end{array}$ & $\begin{array}{l}\text { Depth } \\
\text { (m) }\end{array}$ & \# Grabs \\
\hline $2 / 8 / 1983$ & 1482.00 & 4.2 & 74.00 & 2.8 & 0.2 & 4.9 & 1 \\
\hline $3 / 8 / 1983$ & 5149.00 & 1.1 & 256.00 & 1.9 & 0.0 & 4.9 & 1 \\
\hline $4 / 21 / 1983$ & 8797.00 & 1.5 & 440.00 & 1.6 & 0.0 & 4.9 & 1 \\
\hline $5 / 19 / 1983$ & 2033.00 & 0.5 & 83.00 & 2.4 & 0.0 & 4.9 & 1 \\
\hline $6 / 6 / 1983$ & 1976.00 & 0.8 & 76.00 & 2.6 & 0.1 & 4.9 & 1 \\
\hline $7 / 5 / 1983$ & 323.00 & 0.4 & 6.00 & 3.8 & 0.0 & 4.9 & 1 \\
\hline 9/15/1983 & 2204.00 & 0.2 & 116.00 & 1.4 & 0.0 & 4.9 & 1 \\
\hline $11 / 1 / 1983$ & 1273.00 & 0.5 & 63.00 & 1.9 & 0.0 & 4.9 & 1 \\
\hline $11 / 30 / 1983$ & 3933.00 & 0.3 & 199.00 & 1.6 & 0.0 & 4.9 & 1 \\
\hline $12 / 13 / 1983$ & 3249.00 & 0.4 & 162.00 & 1.8 & 0.0 & 4.9 & 1 \\
\hline $1 / 31 / 1984$ & 2698.00 & 0.3 & 135.00 & 1.7 & 0.0 & 4.9 & 1 \\
\hline $2 / 27 / 1984$ & 7524.00 & 0.3 & 391.00 & 1.2 & 0.0 & 4.9 & 1 \\
\hline $3 / 26 / 1984$ & 11609.00 & 1.0 & 601.00 & 1.3 & 0.0 & 4.9 & 1 \\
\hline $4 / 24 / 1984$ & 4503.00 & 0.9 & 221.00 & 1.7 & 0.0 & 4.9 & 1 \\
\hline $5 / 24 / 1984$ & 6099.00 & 98.5 & 293.00 & 2.4 & 6.3 & 4.9 & 1 \\
\hline $6 / 22 / 1984$ & 1786.00 & 0.2 & 91.00 & 1.7 & 0.0 & 4.9 & 1 \\
\hline $7 / 23 / 1984$ & 1254.00 & 17.8 & 46.00 & 3.7 & 2.2 & 4.9 & 1 \\
\hline $8 / 22 / 1984$ & 2831.00 & 6.1 & 144.00 & 1.3 & 0.8 & 4.9 & 1 \\
\hline 9/18/1984 & 1235.00 & 12.3 & 57.00 & 3.2 & 1.5 & 4.9 & 1 \\
\hline $10 / 30 / 1984$ & 6308.00 & 84.4 & 305.00 & 3.0 & 5.7 & 4.9 & 1 \\
\hline $11 / 29 / 1984$ & 323.00 & 0.0 & 16.00 & 1.6 & 0.0 & 4.9 & 1 \\
\hline $12 / 14 / 1984$ & 7296.00 & 0.3 & 382.00 & 1.4 & 0.0 & 4.9 & 1 \\
\hline $1 / 15 / 1985$ & 1615.00 & 58.6 & 71.00 & 5.7 & 1.5 & 4.9 & 1 \\
\hline $2 / 26 / 1985$ & 7999.00 & 2.2 & 420.00 & 1.4 & 0.1 & 4.9 & 1 \\
\hline $3 / 18 / 1985$ & 6384.00 & 0.2 & 335.00 & 1.4 & 0.0 & 4.9 & 1 \\
\hline $4 / 10 / 1985$ & 14383.00 & 0.9 & 735.00 & 1.6 & 0.0 & 4.9 & 1 \\
\hline $5 / 31 / 1985$ & 5092.00 & 0.6 & 235.00 & 2.2 & 0.0 & 4.9 & 1 \\
\hline $6 / 14 / 1985$ & 3040.00 & 1.5 & 107.00 & 2.9 & 0.2 & 4.9 & 1 \\
\hline $8 / 30 / 1985$ & 95.00 & 5.3 & 3.00 & 11.1 & 0.5 & 4.9 & 1 \\
\hline $10 / 2 / 1985$ & 76.00 & 0.0 & 3.00 & 2.3 & 0.0 & 4.9 & 1 \\
\hline $10 / 24 / 1985$ & 361.00 & 1.7 & 17.00 & 2.8 & 0.1 & 4.9 & 1 \\
\hline $12 / 3 / 1985$ & 57.00 & 0.4 & 0.00 & 8.5 & 0.0 & 4.9 & 1 \\
\hline $12 / 30 / 1985$ & 380.00 & 4.5 & 18.00 & 3.1 & 0.1 & 4.9 & 1 \\
\hline $1 / 16 / 1986$ & 475.00 & 0.0 & 25.00 & 1.6 & 0.0 & 4.9 & 1 \\
\hline 2/6/1986 & 2812.00 & 0.2 & 146.00 & 1.3 & 0.0 & 4.9 & 1 \\
\hline $3 / 31 / 1986$ & 494.00 & 0.0 & 23.00 & 1.9 & 0.0 & 4.9 & 1 \\
\hline $4 / 21 / 1986$ & 988.00 & 0.1 & 48.00 & 1.9 & 0.0 & 4.9 & 1 \\
\hline $5 / 21 / 1986$ & 266.00 & 15.9 & 5.00 & 9.1 & 1.2 & 4.9 & 1 \\
\hline
\end{tabular}




\begin{tabular}{|c|c|c|c|c|c|c|c|}
\hline \multicolumn{8}{|c|}{ Appendix 4. Station D4L Corbicula Data } \\
\hline Date & $\begin{array}{l}\text { Total \# of } \\
\text { clams in } \\
\text { sample } \\
\left(\# / \mathrm{m}^{2}\right)\end{array}$ & $\begin{array}{c}\text { Biomass } \\
\left(\mathrm{g} / \mathrm{m}^{2}\right)\end{array}$ & $\begin{array}{c}\text { recruit/0.05 } \\
\mathrm{m}^{2}\end{array}$ & $\begin{array}{c}\text { mean } \\
\text { size } \\
(\mathrm{mm})\end{array}$ & $\begin{array}{c}\text { GR } \\
\left(\mathrm{m}^{3} / \mathrm{m}^{2} / \mathrm{d}\right)\end{array}$ & $\begin{array}{l}\text { Depth } \\
\text { (m) }\end{array}$ & \# Grabs \\
\hline $6 / 30 / 1986$ & 513.00 & 0.9 & 20.00 & 2.8 & 0.1 & 4.9 & 1 \\
\hline $7 / 25 / 1986$ & 76.00 & 11.2 & 0.00 & 19.6 & 1.1 & 4.9 & 1 \\
\hline $8 / 29 / 1986$ & 836.00 & 16.0 & 40.00 & 3.2 & 1.4 & 4.9 & 1 \\
\hline 9/12/1986 & 3686.00 & 0.1 & 193.00 & 1.5 & 0.0 & 4.9 & 1 \\
\hline $10 / 29 / 1986$ & 931.00 & 1.6 & 48.00 & 2.2 & 0.1 & 4.9 & 1 \\
\hline $11 / 14 / 1986$ & 912.00 & 0.1 & 47.00 & 1.7 & 0.0 & 4.9 & 1 \\
\hline $1 / 23 / 1987$ & 38.00 & 3.1 & 4.00 & 4.8 & 0.1 & 4.9 & 1 \\
\hline $2 / 26 / 1987$ & 0.00 & 0.0 & $\mathrm{~N} / \mathrm{D}$ & $N / D$ & 0.0 & 4.9 & 1 \\
\hline $3 / 26 / 1987$ & 513.00 & 1.8 & 26.00 & 1.9 & 0.1 & 4.9 & 1 \\
\hline $4 / 24 / 1987$ & 6726.00 & 0.3 & 349.00 & 1.3 & 0.0 & 4.9 & 1 \\
\hline $5 / 22 / 1987$ & 0.00 & 0.0 & $\mathrm{~N} / \mathrm{D}$ & N/D & 0.0 & 4.9 & 1 \\
\hline 6/9/1987 & 931.00 & 0.4 & 34.00 & 2.7 & 0.0 & 4.9 & 1 \\
\hline $7 / 30 / 1987$ & 969.00 & 8.0 & 47.00 & 2.5 & 0.8 & 4.9 & 1 \\
\hline $8 / 20 / 1987$ & 703.00 & 0.1 & 33.00 & 1.9 & 0.0 & 4.9 & 1 \\
\hline 9/18/1987 & 0.00 & 0.0 & $\mathrm{~N} / \mathrm{D}$ & N/D & 0.0 & 4.9 & 1 \\
\hline $10 / 30 / 1987$ & 38.00 & 0.0 & 2.00 & 1.5 & 0.0 & 4.9 & 1 \\
\hline $11 / 9 / 1987$ & 38.00 & 7.9 & 0.00 & 27.5 & 0.6 & 4.9 & 1 \\
\hline $12 / 17 / 1987$ & 95.00 & 0.0 & 4.00 & 2.3 & 0.0 & 4.9 & 1 \\
\hline $1 / 15 / 1988$ & 380.00 & 2.0 & 17.00 & 3.0 & 0.1 & 4.9 & 1 \\
\hline $2 / 11 / 1988$ & 76.00 & 0.0 & 4.00 & 1.5 & 0.0 & 4.9 & 1 \\
\hline 4/1/1988 & 38.00 & 0.0 & 1.00 & 3.0 & 0.0 & 4.9 & 1 \\
\hline $5 / 27 / 1988$ & 988.00 & 0.2 & 38.00 & 2.6 & 0.0 & 4.9 & 1 \\
\hline $6 / 24 / 1988$ & 133.00 & 0.1 & 4.00 & 3.1 & 0.0 & 4.9 & 1 \\
\hline $7 / 22 / 1988$ & 76.00 & 0.2 & 0.00 & 6.3 & 0.0 & 4.9 & 1 \\
\hline $8 / 22 / 1988$ & 38.00 & 8.0 & 0.00 & 19.0 & 0.8 & 4.9 & 1 \\
\hline $9 / 22 / 1988$ & 19.00 & 2.5 & 0.00 & 26.5 & 0.3 & 4.9 & 1 \\
\hline $10 / 21 / 1988$ & 95.00 & 24.0 & 0.00 & 22.8 & 1.8 & 4.9 & 1 \\
\hline $11 / 17 / 1988$ & 38.00 & 2.7 & 0.00 & 18.5 & 0.2 & 4.9 & 1 \\
\hline $12 / 8 / 1988$ & N/D & N/D & N/D & N/D & 0.0 & 4.9 & 1 \\
\hline $1 / 20 / 1989$ & 38.00 & 0.0 & 2.00 & 1.5 & 0.0 & 4.9 & 1 \\
\hline 2/6/1989 & $N / D$ & $\mathrm{~N} / \mathrm{D}$ & $\mathrm{N} / \mathrm{D}$ & $\mathrm{N} / \mathrm{D}$ & 0.0 & 4.9 & 1 \\
\hline 5/4/1989 & 399.00 & 0.1 & 15.00 & 2.6 & 0.0 & 4.9 & 1 \\
\hline 6/26/1989 & $N / D$ & $\mathrm{~N} / \mathrm{D}$ & $\mathrm{N} / \mathrm{D}$ & N/D & 0.0 & 4.9 & 1 \\
\hline $7 / 24 / 1989$ & 31.67 & 1.4 & 0.33 & 10.5 & 0.1 & 4.9 & 1 \\
\hline $8 / 21 / 1989$ & 101.33 & 3.7 & 4.00 & 5.7 & 0.4 & 4.9 & 1 \\
\hline 9/19/1989 & 266.00 & 0.0 & 14.00 & 1.4 & 0.0 & 4.9 & 1 \\
\hline $10 / 17 / 1989$ & 63.33 & 0.0 & 2.67 & 1.9 & 0.0 & 4.9 & 1 \\
\hline 11/13/1989 & 0.00 & 0.0 & 0.00 & 0.0 & 0.0 & 4.9 & 1 \\
\hline
\end{tabular}




\begin{tabular}{|c|c|c|c|c|c|c|c|}
\hline \multicolumn{8}{|c|}{ Appendix 4. Station D4L Corbicula Data } \\
\hline Date & $\begin{array}{l}\text { Total \# of } \\
\text { clams in } \\
\text { sample } \\
\left(\# / \mathrm{m}^{2}\right)\end{array}$ & $\begin{array}{l}\text { Biomass } \\
\left(\mathrm{g} / \mathrm{m}^{2}\right)\end{array}$ & $\begin{array}{l}\text { recruit/0.05 } \\
\mathrm{m}^{2}\end{array}$ & $\begin{array}{c}\text { mean } \\
\text { size } \\
(\mathrm{mm})\end{array}$ & $\begin{array}{c}\text { GR } \\
\left(\mathrm{m}^{3} / \mathrm{m}^{2} / \mathrm{d}\right)\end{array}$ & $\begin{array}{l}\text { Depth } \\
\text { (m) }\end{array}$ & \# Grabs \\
\hline 12/4/1989 & 0.00 & 0.0 & 0.00 & 0.0 & 0.0 & 4.9 & 1 \\
\hline $1 / 16 / 1990$ & 253.33 & 3.4 & 10.67 & 3.5 & 0.1 & 4.9 & 3 \\
\hline $2 / 27 / 1990$ & 2305.33 & 0.3 & 117.00 & 1.3 & 0.0 & 4.9 & 3 \\
\hline $3 / 19 / 1990$ & 468.67 & 2.7 & 24.33 & 1.9 & 0.1 & 4.9 & 3 \\
\hline $4 / 20 / 1990$ & 1798.67 & 3.6 & 81.33 & 2.1 & 0.2 & 4.9 & 3 \\
\hline $5 / 14 / 1990$ & 1140.00 & 5.4 & 53.00 & 2.3 & 0.4 & 4.9 & 3 \\
\hline $6 / 26 / 1990$ & 456.00 & 33.4 & 17.00 & 9.4 & 3.1 & 4.9 & 3 \\
\hline 7/12/1990 & 152.00 & 3.1 & 7.00 & 3.5 & 0.4 & 4.9 & 3 \\
\hline $8 / 8 / 1990$ & 867.67 & 0.1 & 38.33 & 1.3 & 0.0 & 4.9 & 3 \\
\hline 9/24/1990 & 234.33 & 0.3 & 5.33 & 3.8 & 0.0 & 4.9 & 3 \\
\hline $10 / 22 / 1990$ & 69.67 & 3.4 & 3.00 & 6.0 & 0.3 & 4.9 & 3 \\
\hline $11 / 6 / 1990$ & 411.67 & 0.0 & 18.67 & 1.4 & 0.0 & 4.9 & 3 \\
\hline $12 / 13 / 1990$ & 88.67 & 0.0 & 4.33 & 1.9 & 0.0 & 4.9 & 3 \\
\hline 1/7/1991 & 76.00 & 0.0 & 3.33 & 1.8 & 0.0 & 4.9 & 3 \\
\hline 2/21/1991 & 50.67 & 1.0 & 2.33 & 4.1 & 0.0 & 4.9 & 3 \\
\hline 3/5/1991 & 63.33 & 1.0 & 3.00 & 3.7 & 0.0 & 4.9 & 3 \\
\hline 4/11/1991 & 715.67 & 1.5 & 30.00 & 2.2 & 0.1 & 4.9 & 3 \\
\hline $5 / 23 / 1991$ & 418.00 & 5.0 & 20.67 & 2.7 & 0.3 & 4.9 & 3 \\
\hline 6/4/1991 & 152.00 & 1.4 & 7.00 & 3.2 & 0.1 & 4.9 & 3 \\
\hline 7/16/1991 & 12.67 & 1.2 & 0.00 & 14.0 & 0.1 & 4.9 & 3 \\
\hline $8 / 30 / 1991$ & 76.00 & 0.0 & 1.33 & 3.2 & 0.0 & 4.9 & 3 \\
\hline 9/12/1991 & 95.00 & 1.1 & 2.33 & 4.4 & 0.1 & 4.9 & 3 \\
\hline 10/8/1991 & 0.00 & 0 & 0.00 & N/D & 0 & 4.9 & 3 \\
\hline 11/12/1991 & 0.00 & 0 & 0.00 & N/D & 0 & 4.9 & 3 \\
\hline $12 / 10 / 1991$ & 190.00 & 26.7 & 0.33 & 26.9 & 0.7 & 4.9 & 3 \\
\hline 1/17/1992 & 57.00 & 0.0 & 1.67 & 2.6 & 0.0 & 4.9 & 3 \\
\hline $2 / 25 / 1992$ & 6.33 & 0.0 & 0.33 & 2.5 & 0.0 & 4.9 & 3 \\
\hline $3 / 24 / 1992$ & 386.33 & 108.7 & 2.00 & 24.0 & 4.2 & 4.9 & 3 \\
\hline 4/6/1992 & 69.67 & 6.3 & 2.67 & 8.9 & 0.4 & 4.9 & 3 \\
\hline $5 / 14 / 1992$ & 266.00 & 4.4 & 11.00 & 3.8 & 0.4 & 4.9 & 3 \\
\hline $6 / 17 / 1992$ & 614.33 & 0.1 & 29.00 & 1.4 & 0.0 & 4.9 & 3 \\
\hline $7 / 10 / 1992$ & 95.00 & 0.2 & 1.00 & 4.5 & 0.0 & 4.9 & 3 \\
\hline $8 / 4 / 1992$ & 88.67 & 0.0 & 3.67 & 1.6 & 0.0 & 4.9 & 3 \\
\hline 9/1/1992 & 316.67 & 2.7 & 11.67 & 3.4 & 0.2 & 4.9 & 3 \\
\hline $10 / 23 / 1992$ & 291.33 & 6.3 & 14.33 & 2.3 & 0.6 & 4.9 & 3 \\
\hline 11/5/1992 & 190.00 & 0.1 & 8.67 & 1.6 & 0.0 & 4.9 & 3 \\
\hline $12 / 28 / 1992$ & 120.33 & 13.6 & 1.33 & 21.8 & 0.6 & 4.9 & 3 \\
\hline 1/14/1993 & 44.33 & 1.1 & 0.00 & 12.9 & 0.0 & 4.9 & 3 \\
\hline
\end{tabular}




\begin{tabular}{|c|c|c|c|c|c|c|c|}
\hline \multicolumn{8}{|c|}{ Appendix 4. Station D4L Corbicula Data } \\
\hline Date & $\begin{array}{l}\text { Total \# of } \\
\text { clams in } \\
\text { sample } \\
\left(\# / \mathrm{m}^{2}\right)\end{array}$ & $\begin{array}{c}\text { Biomass } \\
\left(\mathrm{g} / \mathrm{m}^{2}\right)\end{array}$ & $\begin{array}{c}\text { recruit/0.05 } \\
\mathrm{m}^{2}\end{array}$ & $\begin{array}{c}\text { mean } \\
\text { size } \\
(\mathrm{mm})\end{array}$ & $\begin{array}{c}\text { GR } \\
\left(\mathrm{m}^{3} / \mathrm{m}^{2} / \mathrm{d}\right)\end{array}$ & $\begin{array}{l}\text { Depth } \\
\text { (m) }\end{array}$ & \# Grabs \\
\hline 2/9/1993 & 75.99 & 12.0 & 0.33 & 24.0 & 0.4 & 4.9 & 3 \\
\hline 3/11/1993 & 69.67 & 5.0 & 2.33 & 8.6 & 0.3 & 4.9 & 3 \\
\hline 4/19/1993 & 158.33 & 2.1 & 3.00 & 6.5 & 0.1 & 4.9 & 3 \\
\hline $5 / 20 / 1993$ & 69.67 & 0.5 & 0.67 & 6.1 & 0.0 & 4.9 & 3 \\
\hline $6 / 16 / 1993$ & 63.33 & 1.0 & 0.00 & 9.0 & 0.1 & 4.9 & 3 \\
\hline 7/19/1993 & 126.67 & 7.8 & 0.00 & 16.6 & 0.7 & 4.9 & 3 \\
\hline $8 / 19 / 1993$ & 69.67 & 4.7 & 0.00 & 16.9 & 0.5 & 4.9 & 3 \\
\hline 9/16/1993 & 69.67 & 6.5 & 2.33 & 9.4 & 0.7 & 4.9 & 3 \\
\hline $10 / 8 / 1993$ & 50.67 & 1.0 & 1.67 & 7.0 & 0.1 & 4.9 & 3 \\
\hline $11 / 16 / 1993$ & 145.67 & 0.2 & 6.00 & 3.0 & 0.0 & 4.9 & 3 \\
\hline $12 / 9 / 1993$ & 139.33 & 5.0 & 4.67 & 7.0 & 0.2 & 4.9 & 3 \\
\hline 1/18/1994 & 44.33 & 0.1 & 1.33 & 4.6 & 0.0 & 4.9 & 3 \\
\hline 2/8/1994 & 12.67 & 2.2 & 0.33 & 15.5 & 0.1 & 4.9 & 3 \\
\hline 3/9/1994 & 114.00 & 1.9 & 2.33 & 6.4 & 0.1 & 4.9 & 3 \\
\hline 4/12/1994 & 57.00 & 0.6 & 2.33 & 4.1 & 0.0 & 4.9 & 3 \\
\hline $5 / 23 / 1994$ & 31.67 & 0.6 & 1.33 & 5.9 & 0.0 & 4.9 & 3 \\
\hline 6/9/1994 & 152.00 & 2.6 & 2.33 & 8.1 & 0.2 & 4.9 & 3 \\
\hline $7 / 20 / 1994$ & 31.67 & 0.3 & 1.33 & 4.1 & 0.0 & 4.9 & 3 \\
\hline 8/9/1994 & 126.67 & 5.2 & 1.33 & 10.6 & 0.6 & 4.9 & 3 \\
\hline 9/21/1994 & 88.67 & 2.9 & 2.33 & 8.2 & 0.3 & 4.9 & 3 \\
\hline $10 / 19 / 1994$ & 69.67 & 1.1 & 1.33 & 7.1 & 0.1 & 4.9 & 3 \\
\hline $11 / 21 / 1994$ & 158.33 & 10.1 & 3.67 & 11.6 & 0.3 & 4.9 & 3 \\
\hline $12 / 16 / 1994$ & 69.67 & 9.8 & 1.00 & 18.7 & 0.3 & 4.9 & 3 \\
\hline 1/17/1995 & 88.67 & 1.3 & 1.67 & 8.1 & 0.0 & 4.9 & 3 \\
\hline 2/15/1995 & 196.33 & 1.2 & 7.33 & 3.9 & 0.0 & 4.9 & 3 \\
\hline 3/15/1995 & 304.00 & 2.0 & 10.00 & 3.9 & 0.1 & 4.9 & 3 \\
\hline 4/27/1995 & 671.33 & 18.9 & 18.67 & 6.3 & 0.9 & 4.9 & 3 \\
\hline 5/17/1995 & 215.33 & 1.2 & 6.00 & 3.9 & 0.1 & 4.9 & 3 \\
\hline 6/27/1995 & 589.00 & 6.0 & 11.67 & 5.4 & 0.5 & 4.9 & 3 \\
\hline 7/13/1995 & 513.00 & 4.2 & 5.33 & 5.4 & 0.5 & 4.9 & 3 \\
\hline $8 / 24 / 1995$ & 475.00 & 12.8 & 4.00 & 9.0 & 1.5 & 4.9 & 3 \\
\hline 9/26/1995 & 582.67 & 8.9 & 4.67 & 9.3 & 0.9 & 4.9 & 3 \\
\hline $10 / 25 / 1995$ & 665.00 & 11.4 & 13.33 & 7.7 & 0.8 & 4.9 & 3 \\
\hline $11 / 27 / 1995$ & 1368.00 & 5.6 & 50.33 & 4.0 & 0.3 & 4.9 & 3 \\
\hline $12 / 27 / 1995$ & 285.00 & 6.4 & 12.67 & 3.8 & 0.2 & 4.9 & 3 \\
\hline 1/23/1996 & 1567.50 & 7.0 & 59.00 & 3.5 & 0.2 & 4.9 & 4 \\
\hline 2/23/1996 & 1596.00 & 7.1 & 68.00 & 2.8 & 0.3 & 4.9 & 4 \\
\hline 3/22/1996 & 905.67 & 11.6 & 18.00 & 5.6 & 0.5 & 4.9 & 4 \\
\hline
\end{tabular}




\begin{tabular}{|c|c|c|c|c|c|c|c|}
\hline \multicolumn{8}{|c|}{ Appendix 4. Station D4L Corbicula Data } \\
\hline Date & $\begin{array}{l}\text { Total \# of } \\
\text { clams in } \\
\text { sample } \\
\left(\# / \mathrm{m}^{2}\right)\end{array}$ & $\begin{array}{c}\text { Biomass } \\
\left(\mathrm{g} / \mathrm{m}^{2}\right)\end{array}$ & $\begin{array}{c}\text { recruit/0.05 } \\
\mathrm{m}^{2}\end{array}$ & $\begin{array}{c}\text { mean } \\
\text { size } \\
(\mathrm{mm})\end{array}$ & $\begin{array}{c}\text { GR } \\
\left(\mathrm{m}^{3} / \mathrm{m}^{2} / \mathrm{d}\right)\end{array}$ & $\begin{array}{l}\text { Depth } \\
\text { (m) }\end{array}$ & \# Grabs \\
\hline 4/29/1996 & 142.50 & 1.3 & 6.50 & 3.2 & 0.1 & 4.9 & 4 \\
\hline 5/17/1996 & 2337.00 & 13.9 & 83.50 & 3.8 & 1.2 & 4.9 & 4 \\
\hline 7/18/1996 & 726.75 & 13.3 & 9.00 & 7.6 & 1.4 & 4.9 & 4 \\
\hline $8 / 30 / 1996$ & 916.75 & 27.4 & 2.50 & 10.7 & 2.9 & 4.9 & 4 \\
\hline 9/13/1996 & 798.00 & 15.2 & 5.00 & 9.9 & 1.2 & 4.9 & 4 \\
\hline 10/9/1996 & 570.00 & 5.2 & 2.00 & 7.2 & 0.3 & 4.9 & 4 \\
\hline $11 / 15 / 1996$ & 1073.50 & 9.2 & 34.00 & 5.4 & 0.4 & 4.9 & 4 \\
\hline 12/12/1996 & N/D & $N / D$ & $N / D$ & $\mathrm{~N} / \mathrm{D}$ & $N / D$ & 4.9 & $N / D$ \\
\hline 1/22/1997 & 1168.50 & 14.9 & 26.25 & 7.1 & 0.4 & 4.9 & 4 \\
\hline 2/21/1997 & 1515.25 & 23.6 & 40.00 & 6.9 & 0.7 & 4.9 & 4 \\
\hline $3 / 26 / 1997$ & 1676.75 & 10.6 & 65.75 & 3.8 & 0.5 & 4.9 & 4 \\
\hline 4/24/1997 & 994.33 & 23.0 & 23.00 & 7.7 & 1.5 & 4.9 & 4 \\
\hline $5 / 23 / 1997$ & 1178.00 & 29.7 & 22.00 & 8.4 & 2.8 & 4.9 & 4 \\
\hline 6/20/1997 & 698.25 & 27.6 & 8.25 & 10.8 & 2.7 & 4.9 & 4 \\
\hline $7 / 24 / 1997$ & 1453.50 & 50.5 & 22.75 & 9.5 & 4.5 & 4.9 & 4 \\
\hline $8 / 21 / 1997$ & 703.00 & 31.5 & 4.50 & 10.9 & 3.1 & 4.9 & 4 \\
\hline 9/18/1997 & 688.75 & 20.7 & 7.00 & 11.8 & 2.2 & 4.9 & 4 \\
\hline 10/29/1997 & 1087.75 & 26.6 & 19.50 & 9.7 & 1.8 & 4.9 & 4 \\
\hline $11 / 20 / 1997$ & 1102.00 & 18.3 & 32.75 & 7.1 & 1.0 & 4.9 & 4 \\
\hline $12 / 18 / 1997$ & 470.25 & 9.5 & 13.75 & 7.4 & 0.3 & 4.9 & 4 \\
\hline $1 / 15 / 1998$ & 101.33 & 0.0 & 4.00 & 2.3 & 0.0 & 4.9 & 4 \\
\hline 2/19/1998 & 639.67 & 9.3 & 9.67 & 8.2 & 0.3 & 4.9 & 4 \\
\hline $3 / 17 / 1998$ & 1912.67 & 20.8 & 79.33 & 4.0 & 0.7 & 4.9 & 4 \\
\hline 4/16/1998 & 7631.67 & 50.2 & 350.33 & 3.2 & 2.6 & 4.9 & 4 \\
\hline 5/13/1998 & 278.67 & 1.5 & 13.00 & 2.6 & 0.1 & 4.9 & 4 \\
\hline 6/8/1998 & 2869.00 & 30.2 & 105.00 & 4.2 & 2.1 & 4.9 & 4 \\
\hline 7/9/1998 & 1203.33 & 37.6 & 26.67 & 7.2 & 4.6 & 4.9 & 4 \\
\hline 8/4/1998 & 614.33 & 2.3 & 22.00 & 3.3 & 0.3 & 4.9 & 4 \\
\hline 9/16/1998 & 652.33 & 24.0 & 11.00 & 11.5 & 2.3 & 4.9 & 4 \\
\hline $10 / 6 / 1998$ & 779.00 & 26.4 & 22.00 & 8.3 & 1.5 & 4.9 & 4 \\
\hline $11 / 4 / 1998$ & 1298.33 & 21.9 & 49.67 & 5.6 & 0.9 & 4.9 & 4 \\
\hline $12 / 21 / 1998$ & 956.33 & 24.1 & 25.00 & 8.8 & 0.6 & 4.9 & 4 \\
\hline 1/15/1999 & 1420.25 & 26.9 & 51.00 & 6.0 & 0.7 & 4.9 & 4 \\
\hline 2/19/1999 & 1439.25 & 35.6 & 46.25 & 6.7 & 0.9 & 4.9 & 4 \\
\hline 3/17/1999 & 313.50 & 18.4 & 4.00 & 12.2 & 0.5 & 4.9 & 4 \\
\hline 4/16/1999 & 3329.75 & 33.2 & 146.25 & 3.4 & 1.1 & 4.9 & 4 \\
\hline $5 / 20 / 1999$ & 536.75 & 8.9 & 21.50 & 3.3 & 0.6 & 4.9 & 4 \\
\hline 6/15/1999 & 703.00 & 0.4 & 35.25 & 1.7 & 0.0 & 4.9 & 4 \\
\hline
\end{tabular}




\begin{tabular}{|c|c|c|c|c|c|c|c|}
\hline \multicolumn{8}{|c|}{ Appendix 4. Station D4L Corbicula Data } \\
\hline Date & $\begin{array}{l}\text { Total \# of } \\
\text { clams in } \\
\text { sample } \\
\left(\# / \mathrm{m}^{2}\right)\end{array}$ & $\begin{array}{c}\text { Biomass } \\
\left(\mathrm{g} / \mathrm{m}^{2}\right)\end{array}$ & $\begin{array}{c}\text { recruit/0.05 } \\
\mathrm{m}^{2}\end{array}$ & $\begin{array}{c}\text { mean } \\
\text { size } \\
(\mathrm{mm})\end{array}$ & $\begin{array}{c}\text { GR } \\
\left(\mathrm{m}^{3} / \mathrm{m}^{2} / \mathrm{d}\right)\end{array}$ & $\begin{array}{l}\text { Depth } \\
\text { (m) }\end{array}$ & \# Grabs \\
\hline 7/15/1999 & 304.00 & 12.6 & 13.25 & 4.3 & 1.4 & 4.9 & 4 \\
\hline 8/13/1999 & 437.00 & 0.9 & 19.75 & 2.3 & 0.1 & 4.9 & 4 \\
\hline 9/24/1999 & 712.50 & 6.6 & 29.00 & 4.2 & 0.5 & 4.9 & 4 \\
\hline $10 / 27 / 1999$ & 665.00 & 33.7 & 12.75 & 11.3 & 2.3 & 4.9 & 4 \\
\hline 11/9/1999 & 171.00 & 1.1 & 7.00 & 3.3 & 0.1 & 4.9 & 4 \\
\hline 12/9/1999 & 80.75 & 1.6 & 1.25 & 7.9 & 0.0 & 4.9 & 4 \\
\hline $1 / 7 / 2000$ & 38.00 & 0.0 & 2.00 & 1.7 & 0.0 & 4.9 & 4 \\
\hline $2 / 24 / 2000$ & 399.00 & 16.2 & 8.33 & 9.3 & 0.5 & 4.9 & 4 \\
\hline $3 / 24 / 2000$ & 329.33 & 12.5 & 5.67 & 9.7 & 0.6 & 4.9 & 4 \\
\hline $4 / 20 / 2000$ & 2888.00 & 72.1 & 113.00 & 5.7 & 3.9 & 4.9 & 4 \\
\hline $5 / 17 / 2000$ & 405.33 & 1.4 & 15.33 & 2.6 & 0.1 & 4.9 & 4 \\
\hline $6 / 15 / 2000$ & 31.67 & 0.0 & 1.67 & 2.1 & 0.0 & 4.9 & 4 \\
\hline $7 / 19 / 2000$ & 411.67 & 2.5 & 15.33 & 3.1 & 0.3 & 4.9 & 4 \\
\hline $8 / 15 / 2000$ & 196.33 & 8.3 & 5.00 & 8.0 & 0.9 & 4.9 & 4 \\
\hline $9 / 13 / 2000$ & 981.67 & 45.1 & 16.00 & 12.3 & 3.6 & 4.9 & 4 \\
\hline $10 / 12 / 2000$ & 196.33 & 12.8 & 4.00 & 10.8 & 1.1 & 4.9 & 4 \\
\hline $11 / 17 / 2000$ & 69.67 & 0.9 & 2.67 & 4.9 & 0.0 & 4.9 & 4 \\
\hline $12 / 13 / 2000$ & 120.33 & 0.5 & 4.33 & 3.3 & 0.0 & 4.9 & 4 \\
\hline $1 / 12 / 2001$ & 42.75 & 0.0 & 1.75 & 1.9 & 0.0 & 4.9 & 4 \\
\hline $2 / 7 / 2001$ & 147.25 & 10.8 & 2.25 & 10.8 & 0.3 & 4.9 & 4 \\
\hline $3 / 8 / 2001$ & 66.50 & 0.6 & 2.75 & 3.6 & 0.0 & 4.9 & 4 \\
\hline $4 / 5 / 2001$ & 128.25 & 9.0 & 2.00 & 12.8 & 0.6 & 4.9 & 4 \\
\hline $5 / 9 / 2001$ & 579.50 & 58.3 & 5.00 & 16.5 & 4.1 & 4.9 & 4 \\
\hline $6 / 19 / 2001$ & 147.25 & 5.5 & 2.75 & 10.4 & 0.6 & 4.9 & 4 \\
\hline $7 / 24 / 2001$ & 52.25 & 0.0 & 2.25 & 2.1 & 0.0 & 4.9 & 4 \\
\hline $8 / 22 / 2001$ & 202.67 & 6.7 & 5.33 & 9.3 & 0.7 & 4.9 & 4 \\
\hline $9 / 20 / 2001$ & 57.00 & 0.0 & 2.25 & 2.4 & 0.0 & 4.9 & 4 \\
\hline $10 / 19 / 2001$ & 42.75 & 0.0 & 1.50 & 2.5 & 0.0 & 4.9 & 4 \\
\hline $11 / 21 / 2001$ & 85.50 & 0.6 & 3.75 & 3.5 & 0.0 & 4.9 & 4 \\
\hline $12 / 14 / 2001$ & 76.00 & 0.0 & 4.00 & 1.8 & 0.0 & 4.9 & 4 \\
\hline $1 / 17 / 2002$ & 76.00 & 0.0 & 3.67 & 1.9 & 0.0 & 4.9 & 4 \\
\hline $2 / 14 / 2002$ & 99.75 & 0.0 & 5.25 & 1.5 & 0.0 & 4.9 & 4 \\
\hline $4 / 16 / 2002$ & 101.33 & 0.0 & 5.33 & 1.4 & 0.0 & 4.9 & 4 \\
\hline $5 / 15 / 2002$ & 183.67 & 0.0 & 9.33 & 1.7 & 0.0 & 4.9 & 4 \\
\hline $6 / 11 / 2002$ & 337.25 & 3.0 & 15.25 & 3.4 & 0.3 & 4.9 & 4 \\
\hline $7 / 9 / 2002$ & 598.50 & 4.2 & 24.50 & 3.2 & 0.5 & 4.9 & 4 \\
\hline $8 / 8 / 2002$ & 85.50 & 0.0 & 3.25 & 2.4 & 0.0 & 4.9 & 4 \\
\hline 9/11/2002 & 147.25 & 0.8 & 5.25 & 3.3 & 0.1 & 4.9 & 4 \\
\hline
\end{tabular}




\begin{tabular}{|c|c|c|c|c|c|c|c|}
\hline \multicolumn{8}{|c|}{ Appendix 4. Station D4L Corbicula Data } \\
\hline Date & $\begin{array}{l}\text { Total \# of } \\
\text { clams in } \\
\text { sample } \\
\left(\# / \mathrm{m}^{2}\right)\end{array}$ & $\begin{array}{c}\text { Biomass } \\
\left(\mathrm{g} / \mathrm{m}^{2}\right)\end{array}$ & $\begin{array}{c}\text { recruit/0.05 } \\
\mathrm{m}^{2}\end{array}$ & $\begin{array}{c}\text { mean } \\
\text { size } \\
(\mathrm{mm})\end{array}$ & $\begin{array}{c}\text { GR } \\
\left(\mathrm{m}^{3} / \mathrm{m}^{2} / \mathrm{d}\right)\end{array}$ & $\begin{array}{l}\text { Depth } \\
\text { (m) }\end{array}$ & \# Grabs \\
\hline $10 / 24 / 2002$ & 90.25 & 0.0 & 3.25 & 2.4 & 0.0 & 4.9 & 4 \\
\hline $11 / 6 / 2002$ & 114.00 & 1.1 & 3.75 & 4.7 & 0.1 & 4.9 & 4 \\
\hline $12 / 6 / 2002$ & 66.50 & 0.0 & 3.25 & 2.0 & 0.0 & 4.9 & 4 \\
\hline $1 / 21 / 2003$ & N/D & $\mathrm{N} / \mathrm{D}$ & $\mathrm{N} / \mathrm{D}$ & $\mathrm{N} / \mathrm{D}$ & $N / D$ & 4.9 & 4 \\
\hline $2 / 18 / 2003$ & $\mathrm{~N} / \mathrm{D}$ & $N / D$ & $\mathrm{~N} / \mathrm{D}$ & $\mathrm{N} / \mathrm{D}$ & $N / D$ & 4.9 & 4 \\
\hline $3 / 18 / 2003$ & $\mathrm{~N} / \mathrm{D}$ & N/D & $\mathrm{N} / \mathrm{D}$ & $\mathrm{N} / \mathrm{D}$ & $N / D$ & 4.9 & 4 \\
\hline $4 / 16 / 2003$ & N/D & N/D & $\mathrm{N} / \mathrm{D}$ & $N / D$ & N/D & 4.9 & 4 \\
\hline $5 / 14 / 2003$ & $\mathrm{~N} / \mathrm{D}$ & $N / D$ & $\mathrm{~N} / \mathrm{D}$ & $\mathrm{N} / \mathrm{D}$ & $N / D$ & 4.9 & 4 \\
\hline $6 / 1 / 2003$ & N/D & N/D & $\mathrm{N} / \mathrm{D}$ & N/D & N/D & 4.9 & 4 \\
\hline $7 / 14 / 2003$ & $\mathrm{~N} / \mathrm{D}$ & $N / D$ & $\mathrm{~N} / \mathrm{D}$ & $\mathrm{N} / \mathrm{D}$ & $N / D$ & 4.9 & 4 \\
\hline $8 / 13 / 2003$ & $N / D$ & N/D & $\mathrm{N} / \mathrm{D}$ & $N / D$ & N/D & 4.9 & 4 \\
\hline $9 / 18 / 2003$ & $\mathrm{~N} / \mathrm{D}$ & N/D & $\mathrm{N} / \mathrm{D}$ & $\mathrm{N} / \mathrm{D}$ & $N / D$ & 4.9 & 4 \\
\hline $10 / 23 / 2003$ & $\mathrm{~N} / \mathrm{D}$ & N/D & $\mathrm{N} / \mathrm{D}$ & N/D & N/D & 4.9 & 4 \\
\hline $1 / 8 / 2004$ & $\mathrm{~N} / \mathrm{D}$ & N/D & $\mathrm{N} / \mathrm{D}$ & N/D & $N / D$ & 4.9 & 4 \\
\hline $4 / 7 / 2004$ & $\mathrm{~N} / \mathrm{D}$ & $\mathrm{N} / \mathrm{D}$ & N/D & N/D & N/D & 4.9 & 4 \\
\hline $7 / 15 / 2004$ & 278.67 & 0.4 & 5.33 & 4.2 & 0.00 & 4.9 & 4 \\
\hline $10 / 26 / 2004$ & 1000.67 & 25.0 & 21.33 & 8.8 & 1.56 & 4.9 & 4 \\
\hline $1 / 12 / 2005$ & 633.33 & 15.7 & 5.33 & 11.2 & 0.4 & 4.9 & 4 \\
\hline $4 / 8 / 2005$ & 1076.67 & 14.5 & 41.00 & 4.5 & 0.8 & 4.9 & 4 \\
\hline $7 / 25 / 2005$ & 912.00 & 14.3 & 21.67 & 6.0 & 1.6 & 4.9 & 4 \\
\hline $10 / 14 / 2005$ & 861.33 & 7.9 & 28.67 & 4.7 & 0.6 & 4.9 & 4 \\
\hline $11 / 9 / 2005$ & 886.67 & 8.7 & 17.67 & 5.8 & 0.4 & 4.9 & 4 \\
\hline $12 / 7 / 2005$ & 962.67 & 14.3 & 15.67 & 5.9 & 0.4 & 4.9 & 4 \\
\hline $1 / 12 / 2006$ & 969.00 & 8.7 & 15.00 & 5.8 & 0.2 & 4.9 & 4 \\
\hline 2/9/2006 & 1121.00 & 11.0 & 26.67 & 4.8 & 0.3 & 4.9 & 4 \\
\hline $3 / 15 / 2006$ & 905.67 & 9.5 & 18.00 & 5.6 & 0.3 & 4.9 & 4 \\
\hline $4 / 26 / 2006$ & 1171.67 & 9.1 & 38.33 & 4.2 & 0.4 & 4.9 & 4 \\
\hline $5 / 25 / 2006$ & 3996.33 & 54.5 & 115.00 & 4.8 & 3.7 & 4.9 & 4 \\
\hline $6 / 5 / 2006$ & 1355.33 & 10.2 & 27.67 & 5.2 & 1.2 & 4.9 & 4 \\
\hline $7 / 10 / 2006$ & 1811.33 & 26.8 & 16.33 & 7.2 & 3.1 & 4.9 & 4 \\
\hline $8 / 10 / 2006$ & 1064.00 & 14.3 & 16.00 & 7.2 & 1.3 & 4.9 & 4 \\
\hline $9 / 25 / 2006$ & 234.33 & 3.6 & 0.67 & 9.1 & 0.3 & 4.9 & 4 \\
\hline $10 / 25 / 2006$ & 1197.00 & 10.0 & 11.00 & 7.1 & 0.6 & 4.9 & 4 \\
\hline $11 / 20 / 2006$ & N/D & $N / D$ & $\mathrm{~N} / \mathrm{D}$ & N/D & N/D & 4.9 & N/D \\
\hline $12 / 20 / 2006$ & 1070.33 & 20.0 & 13.67 & 8.9 & 0.6 & 4.9 & 4 \\
\hline $1 / 23 / 2007$ & 646.00 & 15.6 & 4.25 & 9.9 & 0.4 & 4.9 & 4 \\
\hline $2 / 20 / 2007$ & 475.00 & 6.1 & 4.75 & 8.2 & 0.2 & 4.9 & 4 \\
\hline $3 / 20 / 2007$ & 864.50 & 12.3 & 20.00 & 6.6 & 0.5 & 4.9 & 4 \\
\hline
\end{tabular}




\begin{tabular}{|c|c|c|c|c|c|c|c|}
\hline \multicolumn{8}{|c|}{ Appendix 4. Station D4L Corbicula Data } \\
\hline Date & $\begin{array}{l}\text { Total \# of } \\
\text { clams in } \\
\text { sample } \\
\left(\# / \mathrm{m}^{2}\right)\end{array}$ & $\begin{array}{c}\text { Biomass } \\
\left(\mathrm{g} / \mathrm{m}^{2}\right)\end{array}$ & $\begin{array}{c}\text { recruit/0.05 } \\
\mathrm{m}^{2}\end{array}$ & $\begin{array}{c}\text { mean } \\
\text { size } \\
(\mathrm{mm})\end{array}$ & $\begin{array}{c}\text { GR } \\
\left(\mathrm{m}^{3} / \mathrm{m}^{2} / \mathrm{d}\right)\end{array}$ & $\begin{array}{l}\text { Depth } \\
\text { (m) }\end{array}$ & \# Grabs \\
\hline $4 / 16 / 2007$ & 893.00 & 17.1 & 6.75 & 9.3 & 0.8 & 4.9 & 4 \\
\hline $5 / 16 / 2007$ & 1572.25 & 37.7 & 9.75 & 10.6 & 2.3 & 4.9 & 4 \\
\hline $6 / 20 / 2007$ & 517.75 & 11.7 & 1.00 & 11.4 & 0.8 & 4.9 & 4 \\
\hline $7 / 16 / 2007$ & 646.00 & 16.1 & 0.50 & 11.7 & 1.4 & 4.9 & 4 \\
\hline $8 / 15 / 2007$ & 451.25 & 6.3 & 1.50 & 9.5 & 0.7 & 4.9 & 4 \\
\hline 9/11/2007 & 422.75 & 8.3 & 2.00 & 10.2 & 0.7 & 4.9 & 4 \\
\hline $10 / 3 / 2007$ & 460.75 & 10.5 & 1.75 & 11.4 & 0.6 & 4.9 & 4 \\
\hline $11 / 6 / 2007$ & 555.75 & 6.4 & 3.75 & 8.8 & 0.3 & 4.9 & 4 \\
\hline $12 / 10 / 2007$ & 712.50 & 16.2 & 6.75 & 10.6 & 0.4 & 4.9 & 4 \\
\hline $1 / 8 / 2008$ & 769.50 & 16.4 & 1.50 & 11.6 & 0.4 & 4.9 & 4 \\
\hline $2 / 6 / 2008$ & 603.25 & 16.3 & 3.25 & 12.4 & 0.4 & 4.9 & 4 \\
\hline $3 / 5 / 2008$ & 356.25 & 9.1 & 1.00 & 11.8 & 0.4 & 4.9 & 4 \\
\hline $4 / 2 / 2008$ & 598.50 & 15.6 & 2.25 & 11.8 & 0.8 & 4.9 & 4 \\
\hline $5 / 20 / 2008$ & 864.50 & 23.3 & 8.50 & 10.1 & 1.4 & 4.9 & 4 \\
\hline $6 / 17 / 2008$ & 669.75 & 21.5 & 2.50 & 12.5 & 1.6 & 4.9 & 4 \\
\hline $7 / 14 / 2008$ & 527.25 & 27.0 & 0.75 & 13.4 & 2.6 & 4.9 & 4 \\
\hline $8 / 13 / 2008$ & 365.75 & 7.8 & 1.00 & 11.2 & 0.7 & 4.9 & 4 \\
\hline $9 / 15 / 2008$ & 541.50 & 17.3 & 2.50 & 12.6 & 1.7 & 4.9 & 4 \\
\hline $10 / 28 / 2008$ & 2598.25 & 20.8 & 100.50 & 4.5 & 1.7 & 4.9 & 4 \\
\hline $11 / 18 / 2008$ & 460.75 & 13.5 & 0.75 & 13.5 & 0.7 & 4.9 & 4 \\
\hline $12 / 10 / 2008$ & 294.50 & 9.1 & 2.25 & 12.0 & 0.3 & 4.9 & 4 \\
\hline $1 / 12 / 2009$ & 403.75 & 11.9 & 1.25 & 12.8 & 0.3 & 4.9 & 4 \\
\hline $2 / 9 / 2009$ & 399.00 & 10.8 & 1.00 & 12.9 & 0.3 & 4.9 & 4 \\
\hline $3 / 11 / 2009$ & 361.00 & 14.6 & 1.00 & 13.2 & 0.6 & 4.9 & 4 \\
\hline $4 / 6 / 2009$ & 228.00 & 8.8 & 2.00 & 12.2 & 0.4 & 4.9 & 4 \\
\hline $5 / 5 / 2009$ & 703.00 & 27.7 & 1.50 & 12.8 & 2.1 & 4.9 & 4 \\
\hline $6 / 23 / 2009$ & 399.00 & 14.5 & 1.00 & 13.1 & 1.1 & 4.9 & 4 \\
\hline $7 / 21 / 2009$ & 289.75 & 11.4 & 0.50 & 13.6 & 1.2 & 4.9 & 4 \\
\hline $8 / 18 / 2009$ & 380.00 & 10.1 & 3.50 & 11.7 & 1.0 & 4.9 & 4 \\
\hline $9 / 16 / 2009$ & 237.50 & 8.5 & 1.25 & 13.8 & 0.9 & 4.9 & 4 \\
\hline $10 / 19 / 2009$ & 171.00 & 6.2 & 0.25 & 14.3 & 0.4 & 4.9 & 4 \\
\hline $11 / 16 / 2009$ & 475.00 & 8.7 & 9.25 & 9.4 & 0.5 & 4.9 & 4 \\
\hline $12 / 15 / 2009$ & 313.50 & 7.8 & 2.75 & 12.2 & 0.2 & 4.9 & 4 \\
\hline $1 / 13 / 2010$ & 456.00 & 8.4 & 6.75 & 9.6 & 0.2 & 4.9 & 4 \\
\hline $2 / 17 / 2010$ & 237.50 & 4.3 & 3.25 & 10.1 & 0.1 & 4.9 & 4 \\
\hline $3 / 15 / 2010$ & 270.75 & 6.1 & 4.50 & 8.7 & 0.2 & 4.9 & 4 \\
\hline $4 / 12 / 2010$ & 332.50 & 7.8 & 5.50 & 8.7 & 0.4 & 4.9 & 4 \\
\hline $5 / 19 / 2010$ & 859.75 & 15.4 & 14.25 & 7.5 & 0.9 & 4.9 & 4 \\
\hline
\end{tabular}




\begin{tabular}{|c|c|c|c|c|c|c|c|}
\hline \multicolumn{8}{|c|}{ Appendix 4. Station D4L Corbicula Data } \\
\hline Date & $\begin{array}{l}\text { Total \# of } \\
\text { clams in } \\
\text { sample } \\
\left(\# / \mathrm{m}^{2}\right)\end{array}$ & $\begin{array}{c}\text { Biomass } \\
\left(\mathrm{g} / \mathrm{m}^{2}\right)\end{array}$ & $\begin{array}{l}\text { recruit/0.05 } \\
\mathrm{m}^{2}\end{array}$ & $\begin{array}{l}\text { mean } \\
\text { size } \\
(\mathrm{mm})\end{array}$ & $\begin{array}{c}\text { GR } \\
\left(\mathrm{m}^{3} / \mathrm{m}^{2} / \mathrm{d}\right)\end{array}$ & $\begin{array}{l}\text { Depth } \\
\text { (m) }\end{array}$ & \# Grabs \\
\hline $6 / 9 / 2010$ & 527.25 & 15.4 & 7.75 & 8.7 & 1.1 & 4.9 & 4 \\
\hline $7 / 6 / 2010$ & 517.75 & 14.6 & 5.25 & 9.7 & 1.3 & 4.9 & 4 \\
\hline $8 / 16 / 2010$ & 399.00 & 10.9 & 5.75 & 9.6 & 0.9 & 4.9 & 4 \\
\hline $9 / 7 / 2010$ & 660.25 & 10.9 & 18.00 & 6.9 & 0.9 & 4.9 & 4 \\
\hline $10 / 26 / 2010$ & 237.50 & 5.2 & 1.75 & 10.1 & 0.4 & 4.9 & 4 \\
\hline $11 / 22 / 2010$ & 327.75 & 6.6 & 2.75 & 9.2 & 0.4 & 4.9 & 4 \\
\hline $12 / 20 / 2010$ & 270.75 & 7.9 & 2.00 & 10.4 & 0.3 & 4.9 & 4 \\
\hline $1 / 18 / 2011$ & 342.00 & 6.9 & 3.00 & 9.0 & 0.2 & 4.9 & 4 \\
\hline $2 / 1 / 2011$ & 375.25 & 8.1 & 6.00 & 8.1 & 0.2 & 4.9 & 4 \\
\hline $3 / 7 / 2011$ & 508.25 & 16.9 & 6.25 & 9.7 & 0.6 & 4.9 & 4 \\
\hline $4 / 5 / 2011$ & 1220.75 & 17.0 & 38.50 & 5.0 & 0.7 & 4.9 & 4 \\
\hline $5 / 3 / 2011$ & 1211.25 & 20.0 & 38.75 & 5.3 & 1.2 & 4.9 & 4 \\
\hline $6 / 13 / 2011$ & 1581.75 & 13.1 & 60.25 & 4.1 & 0.8 & 4.9 & 4 \\
\hline $7 / 12 / 2011$ & 1083.00 & 27.7 & 18.50 & 7.1 & 3.1 & 4.9 & 4 \\
\hline $8 / 9 / 2011$ & 489.25 & 13.1 & 8.75 & 7.7 & 1.2 & 4.9 & 4 \\
\hline $9 / 7 / 2011$ & 750.50 & 24.6 & 6.25 & 11.1 & 2.3 & 4.9 & 4 \\
\hline $10 / 3 / 2011$ & 337.25 & 6.2 & 3.75 & 8.3 & 0.5 & 4.9 & 4 \\
\hline $11 / 8 / 2011$ & 484.50 & 14.4 & 2.25 & 11.5 & 1.0 & 4.9 & 4 \\
\hline $12 / 7 / 2011$ & 565.25 & 13.1 & 3.25 & 10.9 & 0.9 & 4.9 & 4 \\
\hline $1 / 9 / 2012$ & 688.75 & 12.8 & 7.25 & 8.7 & 0.3 & 4.9 & 4 \\
\hline $2 / 8 / 2012$ & 389.50 & 11.9 & 1.00 & 11.6 & 0.4 & 4.9 & 4 \\
\hline $3 / 6 / 2012$ & 926.25 & 19.0 & 14.00 & 8.6 & 0.6 & 4.9 & 4 \\
\hline $4 / 5 / 2012$ & 413.25 & 13.8 & 2.75 & 11.4 & 0.6 & 4.9 & 4 \\
\hline $5 / 21 / 2012$ & 394.25 & 11.2 & 1.50 & 11.0 & 0.8 & 4.9 & 4 \\
\hline $6 / 20 / 2012$ & 289.75 & 8.4 & 1.00 & 12.2 & 0.6 & 4.9 & 4 \\
\hline $7 / 17 / 2012$ & 190.00 & 4.4 & 0.50 & 10.6 & 0.5 & 4.9 & 4 \\
\hline $8 / 15 / 2012$ & 299.25 & 10.5 & 0.50 & 13.6 & 1.1 & 4.9 & 4 \\
\hline $9 / 25 / 2012$ & 308.75 & 10.6 & 0.25 & 13.3 & 0.9 & 4.9 & 4 \\
\hline $10 / 24 / 2012$ & 313.50 & 12.8 & 0.75 & 13.1 & 0.9 & 4.9 & 4 \\
\hline $11 / 14 / 2012$ & 237.50 & 7.3 & 0.50 & 12.8 & 0.5 & 4.9 & 4 \\
\hline $12 / 18 / 2012$ & 470.25 & 13.4 & 1.25 & 11.9 & 0.5 & 4.9 & 4 \\
\hline 09-Jan-13 & 275.50 & 9.7 & 2.00 & 12.2 & 0.3 & 4.9 & 4 \\
\hline 05-Feb-13 & 327.75 & 9.6 & 0.75 & 12.3 & 0.3 & 4.9 & 4 \\
\hline 13-Mar-13 & 456.00 & 16.9 & 2.75 & 11.7 & 0.8 & 4.9 & 4 \\
\hline 10-Apr-13 & 726.75 & 17.7 & 16.25 & 8.2 & 1.0 & 4.9 & 4 \\
\hline $5 / 7 / 2013$ & 437.00 & 14.3 & 2.50 & 11.2 & 1.1 & 4.9 & 4 \\
\hline $6 / 4 / 2013$ & 342.00 & 10.4 & 2.00 & 11.5 & 0.9 & 4.9 & 4 \\
\hline $7 / 8 / 2013$ & 346.75 & 15.3 & 1.50 & 12.4 & 1.4 & 4.9 & 4 \\
\hline
\end{tabular}




\begin{tabular}{lrrrrrrr}
\hline \multicolumn{7}{c}{ Appendix 4. Station D4L Corbicula Data } \\
\hline Date & $\begin{array}{c}\text { Total \# of } \\
\text { clams in } \\
\text { sample } \\
\left(\# / \mathbf{m}^{2}\right)\end{array}$ & $\begin{array}{c}\text { Biomass } \\
\left(\mathbf{g} / \mathrm{m}^{2}\right)\end{array}$ & $\begin{array}{c}\text { recruit/0.05 } \\
\mathbf{m}^{2}\end{array}$ & $\begin{array}{c}\text { mean } \\
\text { size } \\
(\mathbf{m m})\end{array}$ & $\begin{array}{c}\text { GR } \\
\left(\mathbf{m}^{3} / \mathbf{m}^{2} / \mathbf{d}\right)\end{array}$ & $\begin{array}{c}\text { Depth } \\
(\mathbf{m})\end{array}$ & \# Grabs \\
\hline $\mathbf{8 / 8 / 2 0 1 3}$ & $\mathrm{N} / \mathrm{D}$ & $\mathrm{N} / \mathrm{D}$ & $\mathrm{N} / \mathrm{D}$ & $\mathrm{N} / \mathrm{D}$ & $\mathrm{N} / \mathrm{D}$ & 4.9 & N/D \\
\hline $\mathbf{9 / 4 / 2 0 1 3}$ & 470.25 & 13.8 & 0.25 & 13.6 & 1.1 & 4.9 & 4 \\
\hline $\mathbf{1 0 / 1 5 / 2 0 1 3}$ & 821.75 & 17.2 & 4.25 & 11.0 & 1.0 & 4.9 & 4 \\
\hline $\mathbf{1 1 / 1 9 / 2 0 1 3}$ & 327.75 & 10.6 & 0.50 & 13.1 & 0.5 & 4.9 & 4 \\
\hline $\mathbf{1 2 / 1 6 / 2 0 1 3}$ & 180.50 & 5.1 & 1.00 & 12.4 & 0.1 & 4.9 & 4 \\
\hline
\end{tabular}

\begin{tabular}{|c|c|c|c|c|c|c|c|}
\hline \multicolumn{8}{|c|}{ Appendix 5. Station D4L Potamocorbula Data } \\
\hline Date & $\begin{array}{l}\text { Total \# of } \\
\text { clams in } \\
\text { sample } \\
\left(\# / \mathrm{m}^{2}\right)\end{array}$ & $\begin{array}{c}\text { biomass } \\
\left(\mathrm{g} / \mathrm{m}^{2}\right)\end{array}$ & $\mathrm{rec} / 0.05 \mathrm{~m}^{2}$ & $\begin{array}{c}\text { mean size } \\
(\mathrm{mm})\end{array}$ & $\begin{array}{c}\text { GR } \\
\left(\mathrm{m}^{3} / \mathrm{m}^{2} / \mathrm{d}\right)\end{array}$ & Depth(M) & \# Grabs \\
\hline $7 / 30 / 1987$ & 3078.0 & 0.17 & 159.00 & 1.5 & 0.06 & 4.9 & 1 \\
\hline $8 / 20 / 1987$ & 4864.0 & 0.55 & 237.00 & 1.9 & 0.19 & 4.9 & 1 \\
\hline 9/18/1987 & 1425.0 & 0.18 & 72.00 & 2.2 & 0.07 & 4.9 & 1 \\
\hline $10 / 30 / 1987$ & 1368.0 & 0.14 & 64.00 & 2.0 & 0.08 & 4.9 & 1 \\
\hline $11 / 9 / 1987$ & 836.0 & 0.48 & 30.00 & 3.0 & 0.13 & 4.9 & 1 \\
\hline $12 / 17 / 1987$ & 1881.0 & 2.64 & 45.00 & 4.1 & 0.54 & 4.9 & 1 \\
\hline $1 / 15 / 1988$ & 836.0 & 2.00 & 14.00 & 4.6 & 0.31 & 4.9 & 1 \\
\hline 2/11/1988 & 2451.0 & 11.56 & 21.00 & 5.5 & 1.47 & 4.9 & 1 \\
\hline 4/1/1988 & 171.0 & 0.72 & 0.00 & 6.2 & 0.12 & 4.9 & 1 \\
\hline $5 / 27 / 1988$ & 76.0 & 0.56 & 2.00 & 5.0 & 0.08 & 4.9 & 1 \\
\hline $6 / 24 / 1988$ & 133.0 & 4.41 & 0.00 & 12.5 & 0.49 & 4.9 & 1 \\
\hline $7 / 22 / 1988$ & 570.0 & 0.17 & 21.00 & 2.3 & 0.04 & 4.9 & 1 \\
\hline $8 / 22 / 1988$ & 418.0 & 0.11 & 16.00 & 2.6 & 0.04 & 4.9 & 1 \\
\hline 9/22/1988 & 304.0 & 0.20 & 9.00 & 3.1 & 0.05 & 4.9 & 1 \\
\hline $10 / 21 / 1988$ & 133.0 & 0.04 & 3.00 & 3.2 & 0.02 & 4.9 & 1 \\
\hline $11 / 17 / 1988$ & 988.0 & 2.22 & 13.00 & 5.1 & 0.53 & 4.9 & 1 \\
\hline $12 / 8 / 1988$ & 76.0 & 0.10 & 2.00 & 4.0 & 0.02 & 4.9 & 1 \\
\hline $1 / 20 / 1989$ & 152.0 & 0.34 & 5.00 & 3.6 & 0.05 & 4.9 & 1 \\
\hline 2/6/1989 & 304.0 & 0.16 & 9.50 & 2.8 & 0.04 & 4.9 & 1 \\
\hline 2/28/1989 & $\mathrm{N} / \mathrm{D}$ & $\mathrm{N} / \mathrm{D}$ & $\mathrm{N} / \mathrm{D}$ & N/D & 0.00 & 4.9 & 1 \\
\hline 3/21/1989 & $\mathrm{N} / \mathrm{D}$ & N/D & N/D & N/D & 0.00 & 4.9 & 1 \\
\hline 5/4/1989 & 142.5 & 0.24 & 1.50 & 4.4 & 0.04 & 4.9 & 1 \\
\hline $6 / 26 / 1989$ & N/D & N/D & N/D & N/D & 0.19 & 4.9 & 1 \\
\hline 7/24/1989 & 19.0 & 1.50 & 0.00 & 16.0 & 0.01 & 4.9 & 1 \\
\hline 8/21/1989 & 47.5 & 0.01 & 1.50 & 2.9 & 0.01 & 4.9 & 1 \\
\hline 9/19/1989 & 19.0 & 0.03 & 0.00 & 5.5 & 0.16 & 4.9 & 1 \\
\hline 10/17/1989 & 57.0 & 1.35 & 1.00 & 10.2 & N/D & 4.9 & 1 \\
\hline
\end{tabular}




\begin{tabular}{|c|c|c|c|c|c|c|c|}
\hline \multicolumn{8}{|c|}{ Appendix 5. Station D4L Potamocorbula Data } \\
\hline Date & $\begin{array}{l}\text { Total \# of } \\
\text { clams in } \\
\text { sample } \\
\left(\# / \mathrm{m}^{2}\right)\end{array}$ & $\begin{array}{c}\text { biomass } \\
\left(\mathrm{g} / \mathrm{m}^{2}\right)\end{array}$ & $\mathrm{rec} / 0.05 \mathrm{~m}^{2}$ & $\begin{array}{c}\text { mean size } \\
(\mathrm{mm})\end{array}$ & $\begin{array}{c}\text { GR } \\
\left(\mathrm{m}^{3} / \mathrm{m}^{2} / \mathrm{d}\right)\end{array}$ & Depth(M) & \# Grabs \\
\hline 11/13/1989 & 62.7 & $N / D$ & $\mathrm{~N} / \mathrm{D}$ & $\mathrm{N} / \mathrm{D}$ & 0.00 & 4.9 & 1 \\
\hline $12 / 12 / 1989$ & 234.3 & N/D & $\mathrm{N} / \mathrm{D}$ & $\mathrm{N} / \mathrm{D}$ & N/D & 4.9 & 1 \\
\hline $1 / 17 / 1990$ & 0.0 & 0.00 & 0.00 & $\mathrm{~N} / \mathrm{D}$ & 0.08 & 4.9 & 3 \\
\hline $2 / 27 / 1990$ & 95.0 & 0.32 & 2.00 & 4.4 & 0.00 & 4.9 & 3 \\
\hline $3 / 18 / 1990$ & 0.0 & 0.00 & 0.00 & $N / D$ & 0.00 & 4.9 & 3 \\
\hline $4 / 20 / 1990$ & 44.3 & 2.07 & 0.00 & 11.4 & 0.00 & 4.9 & 3 \\
\hline $5 / 14 / 1990$ & 62.7 & $\mathrm{~N} / \mathrm{D}$ & $N / D$ & N/D & 0.00 & 4.9 & 3 \\
\hline $6 / 26 / 1990$ & 133.0 & 0.01 & 7.00 & 1.6 & 0.00 & 4.9 & 3 \\
\hline $7 / 12 / 1990$ & 25.3 & 0.00 & 1.33 & 2.0 & 0.00 & 4.9 & 3 \\
\hline $8 / 8 / 1990$ & 437.0 & 0.09 & 20.33 & 1.7 & 0.00 & 4.9 & 3 \\
\hline 9/24/1990 & 1140.0 & 1.66 & 25.67 & 3.7 & 0.02 & 4.9 & 3 \\
\hline $10 / 22 / 1990$ & 82.3 & 0.02 & 4.00 & 2.1 & 0.54 & 4.9 & 3 \\
\hline $11 / 6 / 1990$ & 791.7 & 2.32 & 10.67 & 5.4 & 0.00 & 4.9 & 3 \\
\hline $12 / 13 / 1990$ & 133.0 & 0.90 & 5.33 & 3.2 & 0.17 & 4.9 & 3 \\
\hline 1/7/1991 & 456.0 & 0.11 & 18.00 & 2.3 & 0.27 & 4.9 & 3 \\
\hline 2/19/1991 & 95.0 & 0.04 & 3.00 & 2.9 & 0.03 & 4.9 & 3 \\
\hline 3/5/1991 & 114.0 & 0.06 & 4.00 & 2.8 & 0.01 & 4.9 & 3 \\
\hline 4/11/1991 & 3565.7 & 28.31 & 38.33 & 5.7 & 0.02 & 4.9 & 3 \\
\hline $5 / 23 / 1991$ & 348.3 & 1.73 & 0.67 & 6.0 & 3.50 & 4.9 & 3 \\
\hline $6 / 4 / 1991$ & 57.0 & 1.04 & 1.67 & 5.9 & 0.00 & 4.9 & 3 \\
\hline 7/16/1991 & 1159.0 & 0.26 & 55.67 & 1.7 & 0.06 & 4.9 & 3 \\
\hline $8 / 30 / 1991$ & 728.3 & 0.40 & 16.67 & 3.2 & 0.01 & 4.9 & 3 \\
\hline 9/12/1991 & 342.0 & 0.16 & 6.67 & 3.4 & 0.11 & 4.9 & 3 \\
\hline 10/8/1991 & 133.0 & 0.02 & 6.50 & 2.5 & 0.01 & 4.9 & 3 \\
\hline 11/12/1991 & 209.0 & 0.10 & 7.33 & 2.6 & 0.00 & 4.9 & 3 \\
\hline $12 / 10 / 1991$ & 114.0 & 0.01 & 5.00 & 2.0 & 0.00 & 4.9 & 3 \\
\hline 1/17/1992 & 1165.3 & 4.88 & 7.33 & 6.4 & 0.44 & 4.9 & 3 \\
\hline $2 / 25 / 1992$ & 69.7 & 0.12 & 1.33 & 3.6 & 0.05 & 4.9 & 3 \\
\hline $3 / 24 / 1992$ & 25.3 & 0.01 & 0.67 & 3.0 & 0.00 & 4.9 & 3 \\
\hline 4/6/1992 & 31.7 & 0.09 & 0.00 & 5.3 & 0.04 & 4.9 & 3 \\
\hline 5/14/1992 & 88.7 & 0.78 & 0.00 & 7.9 & 0.16 & 4.9 & 3 \\
\hline $6 / 17 / 1992$ & 772.7 & 2.89 & 31.67 & 3.3 & 0.25 & 4.9 & 3 \\
\hline $7 / 10 / 1992$ & 1425.0 & 2.40 & 52.50 & 2.8 & 0.82 & 4.9 & 3 \\
\hline $8 / 4 / 1992$ & 145.7 & 0.27 & 5.67 & 3.0 & 0.01 & 4.9 & 3 \\
\hline 9/1/1992 & 164.7 & 1.13 & 6.00 & 4.1 & 0.09 & 4.9 & 3 \\
\hline $10 / 23 / 1992$ & 563.7 & 0.49 & 27.33 & 2.0 & 0.30 & 4.9 & 3 \\
\hline 11/5/1992 & 627.0 & 0.18 & 32.33 & 1.5 & 0.08 & 4.9 & 3 \\
\hline $12 / 28 / 1992$ & 152.0 & 1.29 & 6.00 & 4.0 & 0.12 & 4.9 & 3 \\
\hline
\end{tabular}




\begin{tabular}{|c|c|c|c|c|c|c|c|}
\hline \multicolumn{8}{|c|}{ Appendix 5. Station D4L Potamocorbula Data } \\
\hline Date & $\begin{array}{l}\text { Total \# of } \\
\text { clams in } \\
\text { sample } \\
\left(\# / \mathrm{m}^{2}\right)\end{array}$ & $\begin{array}{c}\text { biomass } \\
\left(\mathrm{g} / \mathrm{m}^{2}\right)\end{array}$ & $\mathrm{rec} / 0.05 \mathrm{~m}^{2}$ & $\begin{array}{c}\text { mean size } \\
(\mathrm{mm})\end{array}$ & $\begin{array}{c}G R \\
\left(\mathrm{~m}^{3} / \mathrm{m}^{2} / \mathrm{d}\right)\end{array}$ & Depth(M) & \# Grabs \\
\hline 1/14/1993 & 1260.3 & 33.85 & 16.33 & 10.9 & 4.23 & 4.9 & 3 \\
\hline 2/9/1993 & 57.0 & 1.01 & 1.00 & 7.5 & 0.01 & 4.9 & 3 \\
\hline $3 / 11 / 1993$ & 1570.7 & 90.41 & 10.33 & 11.6 & 0.28 & 4.9 & 3 \\
\hline $4 / 19 / 1993$ & 126.7 & 4.26 & 1.00 & 8.3 & 0.12 & 4.9 & 3 \\
\hline $5 / 20 / 1993$ & 114.0 & 2.97 & 0.00 & 8.2 & 0.12 & 4.9 & 3 \\
\hline $6 / 16 / 1993$ & 50.7 & 0.29 & 0.33 & 6.9 & 0.00 & 4.9 & 3 \\
\hline $7 / 19 / 1993$ & 595.3 & 45.79 & 0.00 & 14.8 & 17.18 & 4.9 & 3 \\
\hline $8 / 19 / 1993$ & 2166.0 & 151.72 & 0.00 & 15.1 & 10.41 & 4.9 & 3 \\
\hline 9/16/1993 & 12.7 & 0.53 & 0.00 & 12.5 & 0.00 & 4.9 & 3 \\
\hline $10 / 8 / 1993$ & 6.3 & 0.31 & 0.00 & 18.5 & 0.19 & 4.9 & 3 \\
\hline $11 / 16 / 1993$ & 25.3 & 0.98 & 0.33 & 11.3 & 0.00 & 4.9 & 3 \\
\hline $12 / 9 / 1993$ & 6.3 & 0.74 & 0.00 & 19.5 & 0.22 & 4.9 & 3 \\
\hline 1/18/1994 & 3800.0 & 209.90 & 0.00 & 16.6 & 21.43 & 4.9 & 3 \\
\hline 2/8/1994 & 19.0 & 1.38 & 0.00 & 18.2 & 0.39 & 4.9 & 3 \\
\hline 3/9/1994 & 0.0 & 0.00 & 0.00 & $\mathrm{~N} / \mathrm{D}$ & 0.00 & 4.9 & 3 \\
\hline 4/12/1994 & 6.3 & 1.12 & 0.00 & 20.5 & 0.00 & 4.9 & 3 \\
\hline $5 / 23 / 1994$ & 0.0 & 0.00 & 0.00 & $N / D$ & 0.22 & 4.9 & 3 \\
\hline 6/9/1994 & 196.3 & 15.52 & 0.00 & 16.1 & 0.48 & 4.9 & 3 \\
\hline $7 / 20 / 1994$ & 0.0 & 0.00 & 0.00 & N/D & 0.00 & 4.9 & 3 \\
\hline 8/9/1994 & 82.3 & 0.82 & 3.67 & 3.5 & 0.19 & 4.9 & 3 \\
\hline 9/21/1994 & 38.0 & 0.39 & 1.67 & 3.7 & 0.00 & 4.9 & 3 \\
\hline $10 / 19 / 1994$ & 101.3 & 0.02 & 4.33 & 2.4 & 0.00 & 4.9 & 3 \\
\hline $11 / 21 / 1994$ & 57.0 & 0.51 & 2.33 & 3.8 & 0.00 & 4.9 & 3 \\
\hline $12 / 16 / 1994$ & 101.3 & 0.00 & 5.33 & 1.6 & 0.00 & 4.9 & 3 \\
\hline 1/17/1995 & 209.0 & 1.73 & 6.33 & 5.1 & 0.06 & 4.9 & 3 \\
\hline 2/15/1995 & 82.3 & 0.07 & 2.00 & 3.3 & 0.03 & 4.9 & 3 \\
\hline 3/15/1995 & 152.0 & 2.92 & 3.00 & 5.3 & 0.31 & 4.9 & 3 \\
\hline 4/27/1995 & 50.7 & 1.59 & 0.00 & 6.6 & 0.00 & 4.9 & 3 \\
\hline 5/17/1995 & 12.7 & 0.03 & 0.00 & 5.0 & 0.01 & 4.9 & 3 \\
\hline $6 / 27 / 1995$ & 221.7 & 2.62 & 0.00 & 7.6 & 0.25 & 4.9 & 3 \\
\hline $7 / 13 / 1995$ & 114.0 & 0.77 & 0.00 & 7.6 & 0.02 & 4.9 & 3 \\
\hline $8 / 24 / 1995$ & 424.3 & 8.16 & 0.00 & 10.1 & 0.91 & 4.9 & 3 \\
\hline 9/26/1995 & 335.7 & 6.96 & 0.33 & 10.7 & 1.88 & 4.9 & 3 \\
\hline $10 / 25 / 1995$ & 202.7 & 2.59 & 0.33 & 11.4 & 0.33 & 4.9 & 3 \\
\hline $11 / 27 / 1995$ & 19.0 & 1.21 & 0.00 & 14.2 & 0.61 & 4.9 & 3 \\
\hline $12 / 27 / 1995$ & 38.0 & $N / D$ & $\mathrm{~N} / \mathrm{D}$ & N/D & N/D & 4.9 & 3 \\
\hline 1/23/1996 & 57.0 & 1.17 & 0.00 & 12.4 & $N / D$ & 4.9 & 4 \\
\hline $2 / 23 / 1996$ & 9.5 & 0.28 & 0.00 & 13.5 & 0.16 & 4.9 & 4 \\
\hline
\end{tabular}




\begin{tabular}{|c|c|c|c|c|c|c|c|}
\hline \multicolumn{8}{|c|}{ Appendix 5. Station D4L Potamocorbula Data } \\
\hline Date & $\begin{array}{l}\text { Total \# of } \\
\text { clams in } \\
\text { sample } \\
\left(\# / \mathrm{m}^{2}\right)\end{array}$ & $\begin{array}{c}\text { biomass } \\
\left(\mathrm{g} / \mathrm{m}^{2}\right)\end{array}$ & $\mathrm{rec} / 0.05 \mathrm{~m}^{2}$ & $\begin{array}{c}\text { mean size } \\
(\mathrm{mm})\end{array}$ & $\begin{array}{c}G R \\
\left(\mathrm{~m}^{3} / \mathrm{m}^{2} / \mathrm{d}\right)\end{array}$ & Depth(M) & \# Grabs \\
\hline 3/21/1996 & 194.8 & 0.42 & 8.25 & 2.5 & 0.07 & 4.9 & 4 \\
\hline $4 / 29 / 1996$ & 4.8 & 0.21 & 0.00 & 13.5 & 0.00 & 4.9 & 4 \\
\hline $5 / 17 / 1996$ & 4.8 & 0.21 & 0.00 & 13.5 & 0.00 & 4.9 & 4 \\
\hline $7 / 18 / 1996$ & 9.5 & 0.43 & 35184.00 & 13.0 & 0.00 & 4.9 & 4 \\
\hline $8 / 30 / 1996$ & 28.5 & 1.48 & 35202.00 & 14.7 & 0.10 & 4.9 & 4 \\
\hline 9/13/1996 & 23.8 & 1.74 & 0.00 & 16.3 & 0.00 & 4.9 & 4 \\
\hline 10/9/1996 & 6.3 & 0.22 & 0.00 & 16.5 & 0.14 & 4.9 & 4 \\
\hline $11 / 15 / 1996$ & 23.8 & 1.35 & 0.50 & 11.5 & 0.00 & 4.9 & 4 \\
\hline 12/12/1996 & 14.3 & 0.84 & 0.00 & 15.5 & 0.00 & 4.9 & 4 \\
\hline $1 / 22 / 1997$ & 14.3 & 1.34 & 0.00 & 17.5 & 0.10 & 4.9 & 4 \\
\hline 2/21/1997 & 14.3 & 1.34 & 0.00 & 17.5 & 0.00 & 4.9 & 4 \\
\hline $3 / 26 / 1997$ & 0.0 & 0.00 & 0.00 & N/D & 0.00 & 4.9 & 4 \\
\hline 4/24/1997 & 19.0 & 0.85 & 0.00 & 11.0 & 0.38 & 4.9 & 4 \\
\hline $5 / 23 / 1997$ & 4.8 & 0.40 & 0.00 & 17.5 & 0.00 & 4.9 & 4 \\
\hline 6/20/1997 & 0.0 & 0.00 & 0.00 & $N / D$ & 0.00 & 4.9 & 4 \\
\hline $7 / 24 / 1997$ & 4.8 & 0.57 & 0.00 & 19.5 & 0.00 & 4.9 & 4 \\
\hline $8 / 21 / 1997$ & 14.3 & 0.85 & 0.00 & 13.8 & 0.22 & 4.9 & 4 \\
\hline 9/18/1997 & 223.3 & 1.31 & 9.75 & 2.5 & 0.00 & 4.9 & 4 \\
\hline 10/29/1997 & 1002.3 & 0.08 & 44.50 & 2.4 & 0.28 & 4.9 & 4 \\
\hline $11 / 20 / 1997$ & 228.0 & 0.05 & 10.00 & 2.4 & 0.00 & 4.9 & 4 \\
\hline 12/18/1997 & 0.0 & 0.00 & 0.00 & $N / D$ & $N / D$ & 4.9 & 4 \\
\hline 1/15/1998 & 114.0 & 0.03 & 4.67 & 2.6 & 0.01 & 4.9 & 4 \\
\hline 2/19/1998 & 418.0 & 0.46 & 13.33 & 3.2 & 0.00 & 4.9 & 4 \\
\hline $3 / 17 / 1998$ & 544.7 & 0.22 & 17.00 & 2.9 & 0.20 & 4.9 & 4 \\
\hline 4/16/1998 & 690.3 & 2.58 & 4.67 & 4.6 & 0.08 & 4.9 & 4 \\
\hline $5 / 13 / 1998$ & 12.7 & 0.00 & 0.67 & 2.5 & 0.16 & 4.9 & 4 \\
\hline 6/8/1998 & 247.0 & 0.26 & 2.67 & 4.3 & 0.07 & 4.9 & 4 \\
\hline $7 / 9 / 1998$ & 190.0 & 5.49 & 0.00 & 7.6 & 0.07 & 4.9 & 4 \\
\hline 8/4/1998 & 0.0 & 0.00 & 0.00 & 0.0 & 0.07 & 4.9 & 4 \\
\hline 9/16/1998 & 0.0 & 0.00 & 0.00 & 0.0 & 0.00 & 4.9 & 4 \\
\hline $10 / 6 / 1998$ & 12.7 & 0.03 & 0.00 & 6.5 & 0.00 & 4.9 & 4 \\
\hline $11 / 4 / 1998$ & 0.0 & 0.00 & 0.00 & 0.0 & 0.01 & 4.9 & 4 \\
\hline $12 / 21 / 1998$ & 0.0 & 0.00 & 0.00 & 0.0 & 0.00 & 4.9 & 4 \\
\hline 1/13/1999 & 0.0 & 0.00 & 0.00 & 0.0 & 0.00 & 4.9 & 4 \\
\hline 2/17/1999 & 0.0 & 0.00 & 0.00 & 0.0 & 0.00 & 4.9 & 4 \\
\hline 3/16/1999 & 0.0 & 0.00 & 0.00 & 0.0 & 0.00 & 4.9 & 4 \\
\hline 4/14/1999 & 0.0 & 0.00 & 0.00 & 0.0 & 0.00 & 4.9 & 4 \\
\hline 5/18/1999 & 0.0 & 0.00 & 0.00 & 0.0 & 0.00 & 4.9 & 4 \\
\hline
\end{tabular}




\begin{tabular}{|c|c|c|c|c|c|c|c|}
\hline \multicolumn{8}{|c|}{ Appendix 5. Station D4L Potamocorbula Data } \\
\hline Date & $\begin{array}{l}\text { Total \# of } \\
\text { clams in } \\
\text { sample } \\
\left(\# / \mathrm{m}^{2}\right)\end{array}$ & $\begin{array}{c}\text { biomass } \\
\left(\mathrm{g} / \mathrm{m}^{2}\right)\end{array}$ & $\mathrm{rec} / 0.05 \mathrm{~m}^{2}$ & $\begin{array}{c}\text { mean size } \\
(\mathrm{mm})\end{array}$ & $\begin{array}{c}G R \\
\left(\mathrm{~m}^{3} / \mathrm{m}^{2} / \mathrm{d}\right)\end{array}$ & Depth(M) & \# Grabs \\
\hline 6/14/1999 & 0.0 & 0.00 & 0.00 & 0.0 & 0.00 & 4.9 & 4 \\
\hline $7 / 13 / 1999$ & 0.0 & 0.00 & 0.00 & 0.0 & 0.00 & 4.9 & 4 \\
\hline 8/11/1999 & 0.0 & 0.00 & 0.00 & 0.0 & 0.00 & 4.9 & 4 \\
\hline 9/22/1999 & 19.0 & 0.03 & 0.00 & 5.0 & 0.00 & 4.9 & 4 \\
\hline 10/27/1999 & 484.5 & 0.08 & 19.75 & 2.4 & 0.00 & 4.9 & 4 \\
\hline 11/9/1999 & 375.3 & 0.06 & 15.50 & 2.5 & 0.03 & 4.9 & 4 \\
\hline 12/8/1999 & 166.3 & 0.05 & 5.00 & 3.0 & 0.02 & 4.9 & 4 \\
\hline $1 / 7 / 2000$ & 50.7 & 0.00 & 2.67 & 1.9 & 0.01 & 4.9 & 4 \\
\hline $2 / 24 / 2000$ & 639.7 & 0.29 & 20.33 & 2.8 & 0.00 & 4.9 & 4 \\
\hline $3 / 24 / 2000$ & 114.0 & 0.15 & 1.67 & 4.1 & 0.00 & 4.9 & 4 \\
\hline $4 / 20 / 2000$ & 658.7 & 1.40 & 6.67 & 4.6 & 0.03 & 4.9 & 4 \\
\hline $5 / 17 / 2000$ & 82.3 & 0.23 & 0.33 & 5.1 & 0.43 & 4.9 & 4 \\
\hline $6 / 15 / 2000$ & 4.8 & $N / D$ & $\mathrm{~N} / \mathrm{D}$ & N/D & 0.02 & 4.9 & 4 \\
\hline $7 / 19 / 2000$ & 4.8 & $N / D$ & $N / D$ & N/D & 0.01 & 4.9 & 4 \\
\hline $8 / 15 / 2000$ & 4.8 & $N / D$ & $\mathrm{~N} / \mathrm{D}$ & $N / D$ & 0.00 & 4.9 & 4 \\
\hline $9 / 13 / 2000$ & 6.3 & 0.05 & 0.00 & 9.5 & 0.00 & 4.9 & 4 \\
\hline $10 / 12 / 2000$ & 19.0 & 0.00 & 1.00 & 1.5 & 0.02 & 4.9 & 4 \\
\hline $11 / 17 / 2000$ & 443.3 & 0.02 & 22.00 & 1.5 & 0.00 & 4.9 & 4 \\
\hline $12 / 13 / 2000$ & 620.7 & 0.05 & 30.00 & 1.8 & 0.00 & 4.9 & 4 \\
\hline $1 / 12 / 2001$ & 361.0 & 0.05 & 16.00 & 2.1 & 0.02 & 4.9 & 4 \\
\hline $2 / 7 / 2001$ & 337.3 & 0.21 & 12.50 & 2.7 & 0.01 & 4.9 & 4 \\
\hline $3 / 8 / 2001$ & 80.8 & 0.02 & 3.75 & 2.1 & 0.03 & 4.9 & 4 \\
\hline $4 / 5 / 2001$ & 185.3 & 0.06 & 7.00 & 2.7 & 0.00 & 4.9 & 4 \\
\hline $5 / 9 / 2001$ & 104.5 & 0.15 & 1.00 & 4.3 & 0.02 & 4.9 & 4 \\
\hline $6 / 19 / 2001$ & 9.5 & 0.02 & 0.00 & 6.0 & 0.08 & 4.9 & 4 \\
\hline $7 / 24 / 2001$ & 95.0 & 0.03 & 3.25 & 2.7 & 0.01 & 4.9 & 4 \\
\hline $8 / 22 / 2001$ & 665.0 & 0.05 & 34.50 & 1.7 & 0.01 & 4.9 & 4 \\
\hline $9 / 20 / 2001$ & 1225.5 & 0.12 & 62.50 & 1.8 & 0.01 & 4.9 & 4 \\
\hline $10 / 19 / 2001$ & 346.8 & 0.02 & 18.00 & 1.8 & 0.05 & 4.9 & 4 \\
\hline $11 / 21 / 2001$ & 85.5 & 0.01 & 3.75 & 2.1 & 0.02 & 4.9 & 4 \\
\hline $12 / 14 / 2001$ & 80.8 & 0.01 & 4.00 & 2.0 & 0.01 & 4.9 & 4 \\
\hline $1 / 17 / 2002$ & 57.0 & 0.02 & 2.00 & 3.1 & 0.00 & 4.9 & 4 \\
\hline $2 / 14 / 2002$ & 33.3 & 0.01 & 1.25 & 2.6 & 0.01 & 4.9 & 4 \\
\hline $3 / 12 / 2002$ & N/D & N/D & N/D & $N / D$ & 0.01 & 4.9 & 4 \\
\hline $4 / 16 / 2002$ & 101.3 & 0.00 & 5.33 & 1.4 & 0.00 & 4.9 & 4 \\
\hline $5 / 15 / 2002$ & 12.7 & 0.06 & 0.00 & 6.5 & 0.00 & 4.9 & 4 \\
\hline $6 / 11 / 2002$ & 9.5 & $N / D$ & $\mathrm{~N} / \mathrm{D}$ & N/D & 0.00 & 4.9 & 4 \\
\hline $7 / 9 / 2002$ & 28.5 & 0.44 & 0.00 & 9.7 & 0.00 & 4.9 & 4 \\
\hline
\end{tabular}




\begin{tabular}{|c|c|c|c|c|c|c|c|}
\hline \multicolumn{8}{|c|}{ Appendix 5. Station D4L Potamocorbula Data } \\
\hline Date & $\begin{array}{l}\text { Total \# of } \\
\text { clams in } \\
\text { sample } \\
\left(\# / \mathrm{m}^{2}\right)\end{array}$ & $\begin{array}{c}\text { biomass } \\
\left(\mathrm{g} / \mathrm{m}^{2}\right)\end{array}$ & $\mathrm{rec} / 0.05 \mathrm{~m}^{2}$ & $\begin{array}{c}\text { mean size } \\
(\mathrm{mm})\end{array}$ & $\begin{array}{c}\text { GR } \\
\left(\mathrm{m}^{3} / \mathrm{m}^{2} / \mathrm{d}\right)\end{array}$ & Depth(M) & \# Grabs \\
\hline $8 / 8 / 2002$ & 0.0 & 0.00 & 0.00 & $\mathrm{~N} / \mathrm{D}$ & 0.00 & 4.9 & 4 \\
\hline $9 / 11 / 2002$ & 484.5 & 0.31 & 23.50 & 2.1 & 0.00 & 4.9 & 4 \\
\hline $10 / 24 / 2002$ & 403.8 & 0.04 & 19.75 & 2.1 & 0.00 & 4.9 & 4 \\
\hline $11 / 6 / 2002$ & 753.7 & 0.06 & 36.33 & 2.0 & 0.02 & 4.9 & 4 \\
\hline $12 / 6 / 2002$ & 275.5 & 0.03 & 13.25 & 2.1 & 0.04 & 4.9 & 4 \\
\hline $1 / 21 / 2003$ & $N / D$ & $N / D$ & $\mathrm{~N} / \mathrm{D}$ & $\mathrm{N} / \mathrm{D}$ & 0.01 & 4.9 & 4 \\
\hline $2 / 18 / 2003$ & $N / D$ & $N / D$ & $\mathrm{~N} / \mathrm{D}$ & $\mathrm{N} / \mathrm{D}$ & $N / D$ & 4.9 & 4 \\
\hline $3 / 18 / 2003$ & $N / D$ & N/D & $\mathrm{N} / \mathrm{D}$ & N/D & $N / D$ & 4.9 & 4 \\
\hline $4 / 16 / 2003$ & $N / D$ & $N / D$ & $N / D$ & $N / D$ & $N / D$ & 4.9 & 4 \\
\hline $5 / 14 / 2003$ & N/D & N/D & N/D & $N / D$ & $N / D$ & 4.9 & 4 \\
\hline $6 / 1 / 2003$ & $N / D$ & $N / D$ & $\mathrm{~N} / \mathrm{D}$ & $\mathrm{N} / \mathrm{D}$ & $N / D$ & 4.9 & 4 \\
\hline $7 / 14 / 2003$ & $N / D$ & N/D & $\mathrm{N} / \mathrm{D}$ & $\mathrm{N} / \mathrm{D}$ & $N / D$ & 4.9 & 4 \\
\hline $8 / 13 / 2003$ & $N / D$ & $N / D$ & $\mathrm{~N} / \mathrm{D}$ & $\mathrm{N} / \mathrm{D}$ & $\mathrm{N} / \mathrm{D}$ & 4.9 & 4 \\
\hline $9 / 18 / 2003$ & $N / D$ & $N / D$ & $N / D$ & $N / D$ & $N / D$ & 4.9 & 4 \\
\hline $10 / 23 / 2003$ & $N / D$ & $N / D$ & $\mathrm{~N} / \mathrm{D}$ & $\mathrm{N} / \mathrm{D}$ & $\mathrm{N} / \mathrm{D}$ & 4.9 & 4 \\
\hline $1 / 8 / 2004$ & 270.8 & $N / D$ & $N / D$ & N/D & $N / D$ & 4.9 & 4 \\
\hline $4 / 7 / 2004$ & 0.0 & $N / D$ & $N / D$ & $N / D$ & $N / D$ & 4.9 & 4 \\
\hline $7 / 15 / 2004$ & 120.3 & 1.19 & 1.67 & 7.4 & $N / D$ & 4.9 & 4 \\
\hline $10 / 26 / 2004$ & 1418.7 & 7.66 & 52.33 & 4.5 & $N / D$ & 4.9 & 4 \\
\hline $1 / 12 / 2005$ & 1102.0 & 14.56 & 30.33 & 6.9 & 1.15 & 4.9 & 4 \\
\hline $4 / 8 / 2005$ & 183.7 & 0.06 & 6.67 & 2.8 & $N / D$ & 4.9 & 4 \\
\hline $7 / 25 / 2005$ & 19.0 & 0.39 & 0.00 & 10.2 & 0.04 & 4.9 & 4 \\
\hline $10 / 14 / 2005$ & 171.0 & 0.01 & 9.00 & 1.5 & 0.09 & 4.9 & 4 \\
\hline $11 / 9 / 2005$ & 266.0 & 0.29 & 13.00 & 2.4 & 0.00 & 4.9 & 4 \\
\hline $12 / 7 / 2005$ & 437.0 & 0.59 & 19.00 & 2.7 & 0.01 & 4.9 & 4 \\
\hline $1 / 12 / 2006$ & 259.7 & 1.92 & 5.00 & 5.3 & 0.00 & 4.9 & 4 \\
\hline 2/9/2006 & 164.7 & 0.19 & 5.00 & 3.4 & 0.27 & 4.9 & 4 \\
\hline $3 / 15 / 2006$ & 202.7 & 1.30 & 5.67 & 3.9 & $N / D$ & 4.9 & 4 \\
\hline $4 / 26 / 2006$ & 57.0 & 0.34 & 0.67 & 5.1 & $N / D$ & 4.9 & 4 \\
\hline $5 / 25 / 2006$ & 95.0 & 0.25 & 0.00 & 5.4 & 0.03 & 4.9 & 4 \\
\hline $6 / 5 / 2006$ & 76.0 & 0.19 & 0.00 & 5.7 & 0.00 & 4.9 & 4 \\
\hline $7 / 10 / 2006$ & 44.3 & 0.53 & 0.00 & 8.8 & 0.13 & 4.9 & 4 \\
\hline $8 / 10 / 2006$ & 4.5 & $N / D$ & $N / D$ & $\mathrm{~N} / \mathrm{D}$ & 0.00 & 4.9 & 4 \\
\hline $9 / 20 / 2006$ & 0.0 & 0.00 & 0.00 & $\mathrm{~N} / \mathrm{D}$ & 0.00 & 4.9 & 4 \\
\hline $10 / 25 / 2006$ & 38.0 & 0.15 & 1.33 & 5.0 & 0.16 & 4.9 & 4 \\
\hline $11 / 20 / 2006$ & 44.3 & 0.33 & 1.67 & 5.1 & 0.00 & 4.9 & 4 \\
\hline $12 / 20 / 2006$ & 31.7 & 0.59 & 0.00 & 10.3 & 1.39 & 4.9 & 4 \\
\hline $1 / 23 / 2007$ & 14.3 & 0.00 & 0.75 & 1.8 & 0.10 & 4.9 & 4 \\
\hline
\end{tabular}




\begin{tabular}{|c|c|c|c|c|c|c|c|}
\hline \multicolumn{8}{|c|}{ Appendix 5. Station D4L Potamocorbula Data } \\
\hline Date & $\begin{array}{l}\text { Total \# of } \\
\text { clams in } \\
\text { sample } \\
\left(\# / \mathrm{m}^{2}\right)\end{array}$ & $\begin{array}{c}\text { biomass } \\
\left(\mathrm{g} / \mathrm{m}^{2}\right)\end{array}$ & $\mathrm{rec} / 0.05 \mathrm{~m}^{2}$ & $\begin{array}{c}\text { mean size } \\
(\mathrm{mm})\end{array}$ & $\begin{array}{c}G R \\
\left(\mathrm{~m}^{3} / \mathrm{m}^{2} / \mathrm{d}\right)\end{array}$ & Depth(M) & \# Grabs \\
\hline $2 / 20 / 2007$ & 52.3 & 0.25 & 1.25 & 4.7 & 0.16 & 4.9 & 4 \\
\hline $3 / 20 / 2007$ & 0.0 & 0.00 & 0.00 & 0.0 & 0.00 & 4.9 & 4 \\
\hline $4 / 16 / 2007$ & 31.7 & 0.48 & 0.00 & 7.7 & 0.00 & 4.9 & 4 \\
\hline $5 / 16 / 2007$ & 47.5 & 0.97 & 0.50 & 7.7 & 0.00 & 4.9 & 4 \\
\hline $6 / 20 / 2007$ & 19.0 & 0.84 & 0.00 & 13.2 & 0.00 & 4.9 & 4 \\
\hline $7 / 16 / 2007$ & 12.7 & 0.23 & 0.00 & 10.0 & 0.27 & 4.9 & 4 \\
\hline $8 / 15 / 2007$ & 14.3 & 0.29 & 0.00 & 11.2 & 0.09 & 4.9 & 4 \\
\hline $9 / 11 / 2007$ & 147.3 & 0.29 & 7.00 & 2.6 & 0.00 & 4.9 & 4 \\
\hline $10 / 3 / 2007$ & 190.0 & 0.01 & 10.00 & 1.6 & 0.27 & 4.9 & 4 \\
\hline $11 / 6 / 2007$ & 42.8 & 0.00 & 2.00 & 1.9 & 0.00 & 4.9 & 4 \\
\hline $12 / 10 / 2007$ & 926.3 & 0.32 & 46.00 & 2.1 & 0.10 & 4.9 & 4 \\
\hline $1 / 8 / 2008$ & 574.8 & 0.45 & 26.50 & 2.5 & 0.00 & 4.9 & 4 \\
\hline $2 / 6 / 2008$ & 574.8 & 0.29 & 27.75 & 2.3 & 0.00 & 4.9 & 4 \\
\hline $3 / 5 / 2008$ & 285.0 & 0.35 & 12.00 & 2.9 & 0.03 & 4.9 & 4 \\
\hline $4 / 2 / 2008$ & 185.3 & 0.29 & 6.25 & 3.1 & 0.14 & 4.9 & 4 \\
\hline $5 / 20 / 2008$ & 209.0 & 1.65 & 0.00 & 7.0 & 0.05 & 4.9 & 4 \\
\hline $6 / 17 / 2008$ & 61.8 & 0.57 & 0.25 & 7.1 & 0.05 & 4.9 & 4 \\
\hline $7 / 14 / 2008$ & 57.0 & 0.30 & 1.25 & 5.6 & 0.03 & 4.9 & 4 \\
\hline $8 / 13 / 2008$ & 14.3 & 0.22 & 0.25 & 8.2 & 0.07 & 4.9 & 4 \\
\hline $9 / 15 / 2008$ & 532.0 & 0.52 & 27.25 & 1.9 & 0.15 & 4.9 & 4 \\
\hline $10 / 28 / 2008$ & 1040.3 & 1.41 & 42.75 & 2.9 & 0.17 & 4.9 & 4 \\
\hline $11 / 18 / 2008$ & 446.5 & 0.80 & 21.75 & 2.4 & 0.02 & 4.9 & 4 \\
\hline $12 / 10 / 2008$ & 527.3 & 0.63 & 25.75 & 2.2 & 0.45 & 4.9 & 4 \\
\hline $1 / 12 / 2009$ & 484.5 & 0.87 & 21.75 & 2.8 & 0.08 & 4.9 & 4 \\
\hline 2/9/2009 & 631.8 & 0.49 & 30.00 & 2.2 & 0.12 & 4.9 & 4 \\
\hline $3 / 11 / 2009$ & 190.0 & 0.13 & 6.50 & 3.1 & 0.01 & 4.9 & 4 \\
\hline $4 / 6 / 2009$ & 285.0 & 0.12 & 10.25 & 2.8 & 0.02 & 4.9 & 4 \\
\hline $5 / 5 / 2009$ & 156.8 & 0.40 & 1.00 & 4.7 & 0.09 & 4.9 & 4 \\
\hline $6 / 23 / 2009$ & 47.5 & 0.11 & 0.00 & 5.5 & 0.10 & 4.9 & 4 \\
\hline $7 / 21 / 2009$ & 42.8 & 0.63 & 0.25 & 7.9 & 0.08 & 4.9 & 4 \\
\hline $8 / 18 / 2009$ & 23.8 & 0.02 & 0.75 & 3.3 & 0.03 & 4.9 & 4 \\
\hline $9 / 16 / 2009$ & 28.5 & 0.00 & 1.50 & 1.8 & 0.00 & 4.9 & 4 \\
\hline $10 / 19 / 2009$ & 342.0 & 0.02 & 17.00 & 1.6 & 0.00 & 4.9 & 4 \\
\hline $11 / 16 / 2009$ & 375.3 & 0.02 & 19.50 & 1.8 & 0.00 & 4.9 & 4 \\
\hline $12 / 15 / 2009$ & 232.8 & 0.01 & 12.25 & 1.7 & 0.01 & 4.9 & 4 \\
\hline $1 / 13 / 2010$ & 318.3 & 0.11 & 15.75 & 2.0 & 0.00 & 4.9 & 4 \\
\hline $2 / 17 / 2010$ & 80.8 & 0.01 & 4.25 & 2.0 & 0.00 & 4.9 & 4 \\
\hline $3 / 15 / 2010$ & 57.0 & 0.01 & 2.25 & 2.4 & 0.01 & 4.9 & 4 \\
\hline
\end{tabular}




\begin{tabular}{|c|c|c|c|c|c|c|c|}
\hline \multicolumn{8}{|c|}{ Appendix 5. Station D4L Potamocorbula Data } \\
\hline Date & $\begin{array}{l}\text { Total \# of } \\
\text { clams in } \\
\text { sample } \\
\left(\# / \mathrm{m}^{2}\right)\end{array}$ & $\begin{array}{c}\text { biomass } \\
\left(\mathrm{g} / \mathrm{m}^{2}\right)\end{array}$ & $\mathrm{rec} / 0.05 \mathrm{~m}^{2}$ & $\begin{array}{c}\text { mean size } \\
(\mathrm{mm})\end{array}$ & $\begin{array}{c}\text { GR } \\
\left(\mathrm{m}^{3} / \mathrm{m}^{2} / \mathrm{d}\right)\end{array}$ & Depth(M) & \# Grabs \\
\hline $4 / 12 / 2010$ & 85.5 & 0.03 & 2.25 & 2.9 & 0.01 & 4.9 & 4 \\
\hline $5 / 19 / 2010$ & 204.3 & 0.81 & 0.00 & 6.2 & 0.00 & 4.9 & 4 \\
\hline 6/9/2010 & 123.5 & 0.41 & 0.25 & 6.1 & 0.09 & 4.9 & 4 \\
\hline $7 / 6 / 2010$ & 61.8 & 0.42 & 0.00 & 7.5 & 0.17 & 4.9 & 4 \\
\hline $8 / 16 / 2010$ & 19.0 & 0.12 & 0.00 & 8.0 & 0.04 & 4.9 & 4 \\
\hline $9 / 7 / 2010$ & 19.0 & 0.10 & 0.25 & 5.8 & 0.04 & 4.9 & 4 \\
\hline $10 / 26 / 2010$ & 612.8 & 0.41 & 31.25 & 1.8 & 0.00 & 4.9 & 4 \\
\hline $11 / 22 / 2010$ & 1087.8 & 0.29 & 57.00 & 1.7 & 0.07 & 4.9 & 4 \\
\hline $12 / 20 / 2010$ & 850.3 & 0.05 & 43.25 & 1.8 & 0.13 & 4.9 & 4 \\
\hline $1 / 18 / 2011$ & 370.5 & 0.16 & 19.00 & 2.1 & 0.08 & 4.9 & 4 \\
\hline $2 / 1 / 2011$ & 494.0 & 0.26 & 25.50 & 1.5 & 0.00 & 4.9 & 4 \\
\hline $3 / 7 / 2011$ & 242.3 & 0.05 & 11.00 & 2.5 & 0.03 & 4.9 & 4 \\
\hline $4 / 5 / 2011$ & 365.8 & 0.19 & 15.25 & 2.7 & 0.06 & 4.9 & 4 \\
\hline $5 / 3 / 2011$ & 261.3 & 0.23 & 4.00 & 3.7 & 0.02 & 4.9 & 4 \\
\hline $6 / 13 / 2011$ & 52.3 & 0.12 & 0.75 & 4.7 & 0.05 & 4.9 & 4 \\
\hline $7 / 12 / 2011$ & 28.5 & 0.02 & 0.50 & 3.5 & 0.06 & 4.9 & 4 \\
\hline $8 / 9 / 2011$ & 38.0 & 0.51 & 0.00 & 9.5 & 0.03 & 4.9 & 4 \\
\hline $9 / 7 / 2011$ & 0.0 & 0.00 & 0.00 & $N / D$ & 0.00 & 4.9 & 4 \\
\hline $10 / 3 / 2011$ & 0.0 & 0.00 & 0.00 & $\mathrm{~N} / \mathrm{D}$ & 0.02 & 4.9 & 4 \\
\hline $11 / 8 / 2011$ & 19.0 & 0.28 & 0.00 & 10.5 & 0.00 & 4.9 & 4 \\
\hline $12 / 7 / 2011$ & 19.0 & 0.63 & 0.00 & 13.5 & 0.00 & 4.9 & 4 \\
\hline $1 / 9 / 2012$ & 6.3 & 0.20 & 0.00 & 14.5 & 0.03 & 4.9 & 4 \\
\hline $2 / 7 / 2012$ & 0.0 & 0.00 & 0.00 & $\mathrm{~N} / \mathrm{D}$ & 0.03 & 4.9 & 4 \\
\hline $3 / 6 / 2012$ & 9.5 & 0.48 & 0.00 & 14.0 & 0.00 & 4.9 & 4 \\
\hline $4 / 4 / 2012$ & 0.0 & 0.00 & 0.00 & 11.4 & 0.00 & 4.9 & 4 \\
\hline $5 / 23 / 2012$ & 0.0 & 0.00 & 0.00 & 0.0 & 0.19 & 4.9 & 4 \\
\hline $6 / 19 / 2012$ & 0.0 & 0.00 & 0.00 & 0.0 & 8.10 & 4.9 & 4 \\
\hline $7 / 17 / 2012$ & 0.0 & 0.00 & 0.00 & 0.0 & N/D & 4.9 & 4 \\
\hline $8 / 14 / 2012$ & 0.0 & 0.00 & 0.00 & 0.0 & $\mathrm{~N} / \mathrm{D}$ & 4.9 & 4 \\
\hline $9 / 25 / 2012$ & 80.8 & 0.01 & 3.75 & 1.7 & N/D & 4.9 & 4 \\
\hline $10 / 25 / 2012$ & 275.5 & 0.02 & 13.75 & 1.9 & N/D & 4.9 & 4 \\
\hline $11 / 13 / 2012$ & 579.5 & 0.04 & 28.00 & 1.7 & 0.00 & 4.9 & 4 \\
\hline $12 / 17 / 2012$ & 323.0 & 0.06 & 13.75 & 2.5 & 0.01 & 4.9 & 4 \\
\hline $1 / 9 / 2013$ & 237.5 & 0.05 & 8.50 & 2.5 & 0.02 & 4.9 & 4 \\
\hline $2 / 5 / 2013$ & 156.8 & 0.12 & 4.00 & 3.3 & 0.02 & 4.9 & 4 \\
\hline $3 / 13 / 2013$ & 446.5 & 0.21 & 14.75 & 3.0 & 0.01 & 4.9 & 4 \\
\hline $4 / 10 / 2013$ & 313.5 & 0.45 & 4.25 & 4.2 & 0.05 & 4.9 & 4 \\
\hline $5 / 7 / 2013$ & 251.8 & 0.51 & 0.75 & 4.8 & 0.08 & 4.9 & 4 \\
\hline
\end{tabular}




\begin{tabular}{|c|c|c|c|c|c|c|c|}
\hline \multicolumn{8}{|c|}{ Appendix 5. Station D4L Potamocorbula Data } \\
\hline Date & $\begin{array}{l}\text { Total \# of } \\
\text { clams in } \\
\text { sample } \\
\left(\# / \mathrm{m}^{2}\right)\end{array}$ & $\begin{array}{c}\text { biomass } \\
\left(\mathrm{g} / \mathrm{m}^{2}\right)\end{array}$ & $\mathrm{rec} / 0.05 \mathrm{~m}^{2}$ & $\begin{array}{c}\text { mean size } \\
(\mathrm{mm})\end{array}$ & $\begin{array}{c}\text { GR } \\
\left(\mathrm{m}^{3} / \mathrm{m}^{2} / \mathrm{d}\right)\end{array}$ & Depth(M) & \# Grabs \\
\hline $6 / 4 / 2013$ & 99.8 & 0.44 & 0.00 & 6.9 & 0.18 & 4.9 & 4 \\
\hline $7 / 8 / 2013$ & 76.0 & 0.57 & 0.25 & 7.8 & 0.20 & 4.9 & 4 \\
\hline $8 / 8 / 2013$ & 0.0 & 0.00 & 0.00 & $\mathrm{~N} / \mathrm{D}$ & 0.17 & 4.9 & 4 \\
\hline 9/4/2013 & 422.8 & 2.11 & 15.00 & 4.5 & 0.22 & 4.9 & 4 \\
\hline $10 / 15 / 2013$ & 2104.3 & 2.18 & 102.00 & 2.3 & $\mathrm{~N} / \mathrm{D}$ & 4.9 & 4 \\
\hline $11 / 19 / 2013$ & 261.3 & 0.74 & 11.25 & 3.3 & 0.81 & 4.9 & 4 \\
\hline $12 / 16 / 2013$ & 555.8 & 0.13 & 27.50 & 2.1 & 0.81 & 4.9 & 4 \\
\hline
\end{tabular}

\begin{tabular}{|c|c|c|c|c|c|c|c|}
\hline \multicolumn{8}{|c|}{ Appendix 6. Station D4R Corbicula Data } \\
\hline Date & $\begin{array}{l}\text { Total \# of } \\
\text { clams in } \\
\text { sample } \\
\left(\# / \mathrm{m}^{2}\right)\end{array}$ & $\begin{array}{c}\text { Biomass } \\
\left(\mathrm{g} / \mathrm{m}^{2}\right)\end{array}$ & $\begin{array}{l}\text { recruit/ } \\
0.05 \mathrm{~m}^{2}\end{array}$ & $\begin{array}{c}\text { mean size } \\
(\mathrm{mm})\end{array}$ & $\begin{array}{c}\text { GR } \\
\left(\mathrm{m}^{3} / \mathrm{m}^{2} / \mathrm{d}\right)\end{array}$ & Depth (M) & \# Grabs \\
\hline $6 / 1 / 1977$ & 323.00 & 0.10 & 12.00 & 2.6 & 0.00 & 4.5 & 1 \\
\hline 10/13/1977 & 19.00 & 0.00 & 0.00 & 5.5 & 0.00 & 4.5 & 1 \\
\hline $6 / 8 / 1978$ & 133.00 & 0.10 & 2.00 & 3.5 & 0.00 & 4.5 & 1 \\
\hline $10 / 4 / 1978$ & 152.00 & 0.00 & 7.00 & 1.9 & 0.00 & 4.5 & 1 \\
\hline $5 / 30 / 1979$ & 456.00 & 0.20 & 12.00 & 2.9 & 0.00 & 4.5 & 1 \\
\hline 9/17/1979 & 912.00 & 0.00 & 47.00 & 0.7 & 0.00 & 4.5 & 1 \\
\hline $6 / 11 / 1980$ & 76.00 & 0.00 & 2.00 & 3.5 & 0.00 & 4.5 & 1 \\
\hline $7 / 18 / 1980$ & 247.00 & 0.50 & 4.00 & 4.6 & 0.00 & 4.5 & 1 \\
\hline $8 / 22 / 1980$ & 133.00 & 0.00 & 5.00 & 2.4 & 0.00 & 4.5 & 1 \\
\hline 9/19/1980 & 266.00 & 0.00 & 11.00 & 2.0 & 0.00 & 4.5 & 1 \\
\hline $10 / 23 / 1980$ & 874.00 & 0.40 & 38.00 & 2.5 & 0.00 & 4.5 & 1 \\
\hline $11 / 20 / 1980$ & 304.00 & 0.10 & 8.00 & 2.5 & 0.00 & 4.5 & 1 \\
\hline $12 / 22 / 1980$ & 494.00 & 0.10 & 23.00 & 1.4 & 0.00 & 4.5 & 1 \\
\hline 1/14/1981 & 361.00 & 0.10 & 17.00 & 1.9 & 0.00 & 4.5 & 1 \\
\hline 2/19/1981 & 1368.00 & 0.40 & 67.00 & 1.3 & 0.00 & 4.5 & 1 \\
\hline $3 / 30 / 1981$ & 361.00 & 5.40 & 16.00 & 3.8 & 0.20 & 4.5 & 1 \\
\hline 4/16/1981 & 2109.00 & 0.10 & 106.00 & 1.5 & 0.00 & 4.5 & 1 \\
\hline $5 / 15 / 1981$ & 3515.00 & 0.60 & 125.00 & 2.5 & 0.00 & 4.5 & 1 \\
\hline $6 / 12 / 1981$ & 2546.00 & 1.40 & 58.00 & 3.1 & 0.10 & 4.5 & 1 \\
\hline $7 / 10 / 1981$ & 1862.00 & 1.50 & 23.00 & 4.0 & 0.20 & 4.5 & 1 \\
\hline $8 / 26 / 1981$ & 209.00 & 0.40 & 3.00 & 4.0 & 0.00 & 4.5 & 1 \\
\hline 9/24/1981 & 741.00 & 1.00 & 27.00 & 2.7 & 0.10 & 4.5 & 1 \\
\hline $10 / 13 / 1981$ & 646.00 & 11.00 & 15.00 & 6.5 & 0.90 & 4.5 & 1 \\
\hline $11 / 20 / 1981$ & 760.00 & 0.90 & 21.00 & 3.1 & 0.00 & 4.5 & 1 \\
\hline $12 / 11 / 1981$ & 570.00 & 0.40 & 17.00 & 2.8 & 0.00 & 4.5 & 1 \\
\hline
\end{tabular}




\begin{tabular}{|c|c|c|c|c|c|c|c|}
\hline \multicolumn{8}{|c|}{ Appendix 6. Station D4R Corbicula Data } \\
\hline Date & $\begin{array}{c}\text { Total \# of } \\
\text { clams in } \\
\text { sample } \\
\left(\# / \mathrm{m}^{2}\right)\end{array}$ & $\begin{array}{c}\text { Biomass } \\
\left(\mathrm{g} / \mathrm{m}^{2}\right)\end{array}$ & $\begin{array}{l}\text { recruit/ } \\
0.05 \mathrm{~m}^{2}\end{array}$ & $\begin{array}{c}\text { mean size } \\
(\mathrm{mm})\end{array}$ & $\begin{array}{c}\text { GR } \\
\left(\mathrm{m}^{3} / \mathrm{m}^{2} / \mathrm{d}\right)\end{array}$ & Depth (M) & \# Grabs \\
\hline 1/21/1982 & 152.00 & 0.10 & 3.00 & 3.1 & 0.00 & 4.5 & 1 \\
\hline $2 / 22 / 1982$ & 57.00 & 0.50 & 0.00 & 8.5 & 0.00 & 4.5 & 1 \\
\hline $3 / 30 / 1982$ & 1558.00 & 1.10 & 79.00 & 1.5 & 0.00 & 4.5 & 1 \\
\hline $4 / 28 / 1982$ & 1216.00 & 0.50 & 57.00 & 2.0 & 0.00 & 4.5 & 1 \\
\hline $5 / 20 / 1982$ & 494.00 & 0.60 & 16.00 & 3.5 & 0.10 & 4.5 & 1 \\
\hline $6 / 25 / 1982$ & 380.00 & 0.20 & 8.00 & 3.4 & 0.00 & 4.5 & 1 \\
\hline $7 / 22 / 1982$ & 418.00 & 3.30 & 8.00 & 5.3 & 0.30 & 4.5 & 1 \\
\hline $8 / 30 / 1982$ & 285.00 & 0.10 & 12.00 & 1.8 & 0.00 & 4.5 & 1 \\
\hline $9 / 20 / 1982$ & 437.00 & 3.10 & 20.00 & 2.9 & 0.40 & 4.5 & 1 \\
\hline $10 / 28 / 1982$ & 437.00 & 0.00 & 23.00 & 1 & 0.00 & 4.5 & 1 \\
\hline $11 / 24 / 1982$ & 722.00 & 0.10 & 37.00 & 1.4 & 0.00 & 4.5 & 1 \\
\hline $12 / 15 / 1982$ & 551.00 & 0.10 & 27.00 & 1.7 & 0.00 & 4.5 & 1 \\
\hline 1/31/1983 & 323.00 & 1.40 & 12.00 & 3.2 & 0.00 & 4.5 & 1 \\
\hline $2 / 8 / 1983$ & 950.00 & 1.40 & 46.00 & 1.3 & 0.10 & 4.5 & 1 \\
\hline $3 / 8 / 1983$ & 3686.00 & 1.00 & 0.00 & 0.0 & 0.00 & 4.5 & 1 \\
\hline $4 / 21 / 1983$ & 1197.00 & 1.00 & 0.00 & 0.0 & 0.00 & 4.5 & 1 \\
\hline $5 / 19 / 1983$ & 665.00 & 0.70 & 25.00 & 2.8 & 0.00 & 4.5 & 1 \\
\hline 6/6/1983 & 1273.00 & 0.20 & 0.00 & 0.0 & 0.00 & 4.5 & 1 \\
\hline $7 / 5 / 1983$ & 408.50 & 2.40 & 0.00 & 0.0 & 0.20 & 4.5 & 1 \\
\hline $9 / 15 / 1983$ & 1311.00 & 0.20 & 0.00 & 0.0 & 0.00 & 4.5 & 1 \\
\hline $11 / 1 / 1983$ & 494.00 & 0.70 & 23.00 & 2.2 & 0.10 & 4.5 & 1 \\
\hline $11 / 30 / 1983$ & 351.50 & 0.50 & 0.00 & 0.0 & 0.00 & 4.5 & 1 \\
\hline $12 / 13 / 1983$ & 418.00 & 0.10 & 0.00 & 0.0 & 0.00 & 4.5 & 1 \\
\hline 1/31/1984 & 2565.00 & 0.10 & 133.00 & 0.6 & 0.00 & 4.5 & 1 \\
\hline $2 / 27 / 1984$ & 589.00 & 0.00 & 30.00 & 0.7 & 0.00 & 4.5 & 1 \\
\hline $3 / 26 / 1984$ & 1615.00 & 6.90 & 79.00 & 1.4 & 0.30 & 4.5 & 1 \\
\hline $4 / 24 / 1984$ & 3496.00 & 0.10 & 182.00 & 0.6 & 0.00 & 4.5 & 1 \\
\hline $5 / 24 / 1984$ & 1254.00 & 1.20 & 64.00 & 1.0 & 0.10 & 4.5 & 1 \\
\hline $6 / 22 / 1984$ & 551.00 & 0.70 & 27.00 & 1.6 & 0.10 & 4.5 & 1 \\
\hline $7 / 23 / 1984$ & 703.00 & 0.10 & 33.00 & 1.3 & 0.00 & 4.5 & 1 \\
\hline $8 / 22 / 1984$ & 684.00 & 0.10 & 30.00 & 1.4 & 0.00 & 4.5 & 1 \\
\hline $9 / 18 / 1984$ & 931.00 & 4.90 & 42.00 & 2.2 & 0.60 & 4.5 & 1 \\
\hline $10 / 30 / 1984$ & 266.00 & 0.00 & 14.00 & 0.6 & 0.00 & 4.5 & 1 \\
\hline $11 / 29 / 1984$ & 247.00 & 0.70 & 11.00 & 2.2 & 0.00 & 4.5 & 1 \\
\hline $12 / 14 / 1984$ & 1634.00 & 2.90 & 78.00 & 1.5 & 0.10 & 4.5 & 1 \\
\hline $1 / 15 / 1985$ & 266.00 & 6.00 & 9.00 & 6.8 & 0.20 & 4.5 & 1 \\
\hline $2 / 26 / 1985$ & 2128.00 & 0.10 & 106.00 & 1.0 & 0.00 & 4.5 & 1 \\
\hline $3 / 18 / 1985$ & 1748.00 & 2.10 & 88.00 & 1.3 & 0.10 & 4.5 & 1 \\
\hline
\end{tabular}




\begin{tabular}{|c|c|c|c|c|c|c|c|}
\hline \multicolumn{8}{|c|}{ Appendix 6. Station D4R Corbicula Data } \\
\hline Date & $\begin{array}{c}\text { Total \# of } \\
\text { clams in } \\
\text { sample } \\
\left(\# / \mathrm{m}^{2}\right)\end{array}$ & $\begin{array}{c}\text { Biomass } \\
\left(\mathrm{g} / \mathrm{m}^{2}\right)\end{array}$ & $\begin{array}{l}\text { recruit/ } \\
0.05 \mathrm{~m}^{2}\end{array}$ & $\begin{array}{c}\text { mean size } \\
(\mathrm{mm})\end{array}$ & $\begin{array}{c}\text { GR } \\
\left(\mathrm{m}^{3} / \mathrm{m}^{2} / \mathrm{d}\right)\end{array}$ & Depth (M) & \# Grabs \\
\hline 4/10/1985 & 6080.00 & 0.50 & 316.00 & 0.7 & 0.00 & 4.5 & 1 \\
\hline $5 / 31 / 1985$ & 4921.00 & 2.90 & 241.00 & 1.7 & 0.20 & 4.5 & 1 \\
\hline $6 / 14 / 1985$ & 3952.00 & 0.90 & 178.00 & 1.8 & 0.10 & 4.5 & 1 \\
\hline $8 / 30 / 1985$ & 665.00 & 0.30 & 23.00 & 2.4 & 0.00 & 4.5 & 1 \\
\hline 10/2/1985 & 304.00 & 2.90 & 14.00 & 2.4 & 0.30 & 4.5 & 1 \\
\hline $10 / 24 / 1985$ & 513.00 & 0.40 & 21.00 & 1.7 & 0.00 & 4.5 & 1 \\
\hline 12/3/1985 & 1083.00 & 3.10 & 47.00 & 2.2 & 0.10 & 4.5 & 1 \\
\hline $12 / 30 / 1985$ & 665.00 & 4.70 & 28.00 & 3.0 & 0.10 & 4.5 & 1 \\
\hline 1/16/1986 & 1064.00 & 2.30 & 50.00 & 1.9 & 0.10 & 4.5 & 1 \\
\hline 2/6/1986 & 665.00 & 3.40 & 23.00 & 3.9 & 0.10 & 4.5 & 1 \\
\hline 3/31/1986 & 3059.00 & 0.10 & 161.00 & 1.1 & 0.00 & 4.5 & 1 \\
\hline $4 / 21 / 1986$ & 1881.00 & 0.10 & 99.00 & 1.6 & 0.00 & 4.5 & 1 \\
\hline $5 / 21 / 1986$ & 209.00 & 0.10 & 4.00 & 3.4 & 0.00 & 4.5 & 1 \\
\hline $6 / 30 / 1986$ & 57.00 & 3.80 & 0.00 & 0.0 & 0.50 & 4.5 & 1 \\
\hline $7 / 25 / 1986$ & 304.00 & 3.20 & 10.00 & 4.3 & 0.30 & 4.5 & 1 \\
\hline $8 / 29 / 1986$ & 475.00 & 3.40 & 20.00 & 2.9 & 0.30 & 4.5 & 1 \\
\hline 9/12/1986 & 1900.00 & 4.60 & 96.00 & 1.8 & 0.40 & 4.5 & 1 \\
\hline $10 / 29 / 1986$ & 608.00 & 2.20 & 28.00 & 2.5 & 0.10 & 4.5 & 1 \\
\hline $11 / 14 / 1986$ & 323.00 & 11.80 & 8.00 & 7.5 & 0.50 & 4.5 & 1 \\
\hline $1 / 23 / 1987$ & 38.00 & 3.10 & 4.00 & 4.8 & 0.10 & 4.5 & 1 \\
\hline $2 / 26 / 1987$ & 348.00 & $N / D$ & $N / D$ & $N / D$ & $\mathrm{~N} / \mathrm{D}$ & 4.5 & 1 \\
\hline $3 / 26 / 1987$ & 513.00 & 1.80 & 26.00 & 1.9 & 0.10 & 4.5 & 1 \\
\hline $4 / 24 / 1987$ & 6745.00 & 2.30 & 349.00 & 1.4 & 0.20 & 4.5 & 1 \\
\hline $5 / 22 / 1987$ & 2426.00 & $N / D$ & N/D & $N / D$ & $\mathrm{~N} / \mathrm{D}$ & 4.5 & 1 \\
\hline 6/9/1987 & 931.00 & 0.40 & 34.00 & 2.7 & 0.00 & 4.5 & 1 \\
\hline $7 / 30 / 1987$ & 171.00 & 5.70 & 5.00 & 7.5 & 0.60 & 4.5 & 1 \\
\hline $8 / 20 / 1987$ & 114.00 & 1.70 & 0.00 & 8.2 & 0.20 & 4.5 & 1 \\
\hline $9 / 18 / 1987$ & 38.00 & 2.00 & 0.00 & 12.5 & 0.20 & 4.5 & 1 \\
\hline $10 / 30 / 1987$ & 57.00 & 3.40 & 0.00 & 15.8 & 0.30 & 4.5 & 1 \\
\hline $11 / 9 / 1987$ & 57.00 & 0.20 & 2.00 & 4.5 & 0.00 & 4.5 & 1 \\
\hline $12 / 17 / 1987$ & 57.00 & 1.90 & 2.00 & 8.2 & 0.10 & 4.5 & 1 \\
\hline $1 / 15 / 1988$ & 1463.00 & 0.00 & 77.00 & 0.7 & 0.00 & 4.5 & 1 \\
\hline 2/11/1988 & 57.00 & 5.70 & 0.00 & 22.5 & 0.20 & 4.5 & 1 \\
\hline $3 / 1 / 1988$ & 171.00 & 4.20 & 7.00 & 5.9 & 0.20 & 4.5 & 1 \\
\hline 4/1/1988 & 6688.00 & 1.50 & 349.00 & 1.4 & 0.10 & 4.5 & 1 \\
\hline $5 / 27 / 1988$ & 6327.00 & 2.20 & 327.00 & 1.7 & 0.20 & 4.5 & 1 \\
\hline $6 / 24 / 1988$ & 817.00 & 5.80 & 19.00 & 4.1 & 0.50 & 4.5 & 1 \\
\hline $7 / 22 / 1988$ & 76.00 & 0.10 & 3.00 & 3.3 & 0.00 & 4.5 & 1 \\
\hline
\end{tabular}




\begin{tabular}{|c|c|c|c|c|c|c|c|}
\hline \multicolumn{8}{|c|}{ Appendix 6. Station D4R Corbicula Data } \\
\hline Date & $\begin{array}{c}\text { Total \# of } \\
\text { clams in } \\
\text { sample } \\
\left(\# / \mathrm{m}^{2}\right)\end{array}$ & $\begin{array}{c}\text { Biomass } \\
\left(\mathrm{g} / \mathrm{m}^{2}\right)\end{array}$ & $\begin{array}{l}\text { recruit// } \\
0.05 \mathrm{~m}^{2}\end{array}$ & $\begin{array}{c}\text { mean size } \\
(\mathrm{mm})\end{array}$ & $\begin{array}{c}\text { GR } \\
\left(\mathrm{m}^{3} / \mathrm{m}^{2} / \mathrm{d}\right)\end{array}$ & Depth (M) & \# Grabs \\
\hline $8 / 22 / 1988$ & 76.00 & 3.60 & 1.00 & 12.0 & 0.40 & 4.5 & 1 \\
\hline $9 / 22 / 1988$ & 76.00 & 5.40 & 1.00 & 17.5 & 0.50 & 4.5 & 1 \\
\hline $10 / 21 / 1988$ & 95.00 & 0.20 & 2.00 & 4.7 & 0.00 & 4.5 & 1 \\
\hline $11 / 17 / 1988$ & 38.00 & 2.00 & 0.00 & 16.5 & 0.10 & 4.5 & 1 \\
\hline $12 / 8 / 1988$ & 133.00 & 8.00 & 0.00 & 15.6 & 0.30 & 4.5 & 1 \\
\hline $1 / 20 / 1989$ & 95.00 & 12.90 & 0.00 & 23.9 & 0.30 & 4.5 & 1 \\
\hline 2/6/1989 & 38.00 & 4.30 & 0.00 & 23 & 0.10 & 4.5 & 1 \\
\hline 5/4/1989 & 5.70 & N/D & N/D & N/D & $\mathrm{N} / \mathrm{D}$ & 4.5 & 1 \\
\hline 6/26/1989 & 95.00 & 3.80 & 1.00 & 8.0 & 0.30 & 4.5 & 1 \\
\hline $7 / 24 / 1989$ & 76.00 & 2.10 & 2.00 & 7.8 & 0.20 & 4.5 & 1 \\
\hline $8 / 21 / 1989$ & 114.00 & 9.70 & 3.00 & 10.7 & 1.10 & 4.5 & 1 \\
\hline 9/19/1989 & 47.50 & 2.60 & 1.00 & 11.7 & 0.20 & 4.5 & 1 \\
\hline $10 / 17 / 1989$ & 19.00 & 0.10 & 0.00 & 9.5 & 0.00 & 4.5 & 1 \\
\hline $11 / 13 / 1989$ & 171.00 & $N / D$ & N/D & $N / D$ & $N / D$ & 4.5 & $N / D$ \\
\hline 12/4/1989 & 285.00 & $\mathrm{~N} / \mathrm{D}$ & N/D & N/D & $\mathrm{N} / \mathrm{D}$ & 4.5 & $N / D$ \\
\hline 1/16/1990 & 76.00 & 5.28 & 2.33 & 12 & 0.20 & 4.5 & 3 \\
\hline $2 / 27 / 1990$ & 1076.67 & 1.80 & 52.67 & 1.6 & 0.10 & 4.5 & 3 \\
\hline 3/19/1990 & 196.33 & 1.37 & 7.67 & 3.4 & 0.10 & 4.5 & 3 \\
\hline $4 / 20 / 1990$ & 931.00 & 9.70 & 44.00 & 2. & 0.60 & 4.5 & 3 \\
\hline $5 / 14 / 1990$ & 1368.00 & 19.09 & 63.67 & 2.4 & 1.50 & 4.5 & 3 \\
\hline $6 / 26 / 1990$ & 2337.00 & 0.43 & 112.67 & 1.6 & 0.00 & 4.5 & 3 \\
\hline $7 / 12 / 1990$ & 1311.00 & 9.66 & 59.00 & 2.3 & 1.10 & 4.5 & 3 \\
\hline 8/8/1990 & 620.67 & 5.03 & 24.00 & 3.4 & 0.60 & 4.5 & 3 \\
\hline 9/24/1990 & 259.67 & 6.28 & 4.00 & 6.6 & 0.60 & 4.5 & 3 \\
\hline 10/22/1990 & 392.67 & 9.66 & 7.67 & 6.2 & 0.70 & 4.5 & 3 \\
\hline $11 / 6 / 1990$ & 342.00 & 2.60 & 5.00 & 4.7 & 0.10 & 4.5 & 3 \\
\hline 12/13/1990 & 456.00 & 4.82 & 11.33 & 4.7 & 0.20 & 4.5 & 3 \\
\hline 1/7/1991 & 278.70 & 7.70 & 2.30 & 8.2 & 0.20 & 4.5 & 3 \\
\hline 2/21/1991 & 240.70 & 7.80 & 0.70 & 9.9 & 0.30 & 4.5 & 3 \\
\hline 3/5/1991 & 44.30 & 4.70 & 0.30 & 13.4 & 0.20 & 4.5 & 3 \\
\hline 4/11/1991 & 183.70 & 7.80 & 2.30 & 8.2 & 0.40 & 4.5 & 3 \\
\hline $5 / 23 / 1991$ & 76.00 & 1.90 & 1.00 & 7.3 & 0.10 & 4.5 & 3 \\
\hline 6/4/1991 & 114.00 & 4.30 & 2.00 & 8.8 & 0.30 & 4.5 & 3 \\
\hline 7/16/1991 & 114.00 & 5.40 & 2.70 & 7.1 & 0.50 & 4.5 & 3 \\
\hline $8 / 30 / 1991$ & 95.00 & 1.70 & 3.70 & 4.0 & 0.20 & 4.5 & 3 \\
\hline 9/12/1991 & 101.30 & 5.90 & 1.30 & 11.4 & 0.60 & 4.5 & 3 \\
\hline 10/8/1991 & 25.30 & 4.20 & 0.70 & 14.5 & 0.40 & 4.5 & 3 \\
\hline $11 / 12 / 1991$ & 44.30 & 4.50 & 0.30 & 16.1 & 0.30 & 4.5 & 3 \\
\hline
\end{tabular}




\begin{tabular}{|c|c|c|c|c|c|c|c|}
\hline \multicolumn{8}{|c|}{ Appendix 6. Station D4R Corbicula Data } \\
\hline Date & $\begin{array}{c}\text { Total \# of } \\
\text { clams in } \\
\text { sample } \\
\left(\# / \mathrm{m}^{2}\right)\end{array}$ & $\begin{array}{c}\text { Biomass } \\
\left(\mathrm{g} / \mathrm{m}^{2}\right)\end{array}$ & $\begin{array}{l}\text { recruit/ } \\
0.05 \mathrm{~m}^{2}\end{array}$ & $\begin{array}{c}\text { mean size } \\
(\mathrm{mm})\end{array}$ & $\begin{array}{c}\text { GR } \\
\left(\mathrm{m}^{3} / \mathrm{m}^{2} / \mathrm{d}\right)\end{array}$ & Depth (M) & \# Grabs \\
\hline $12 / 10 / 1991$ & 31.70 & 0.80 & 1.00 & 7.1 & 0.00 & 4.5 & 3 \\
\hline $1 / 17 / 1992$ & 12.70 & $\mathrm{~N} / \mathrm{D}$ & N/D & $\mathrm{N} / \mathrm{D}$ & $\mathrm{N} / \mathrm{D}$ & $\mathrm{N} / \mathrm{D}$ & $\mathrm{N} / \mathrm{D}$ \\
\hline $2 / 25 / 1992$ & 50.70 & 5.90 & 0.30 & 20.4 & 0.30 & 4.5 & 3 \\
\hline $3 / 24 / 1992$ & 88.70 & 3.70 & 2.00 & 8.0 & 0.20 & 4.5 & 3 \\
\hline 4/6/1992 & 19.00 & 6.10 & 0.00 & 27.8 & 0.40 & 4.5 & 3 \\
\hline $5 / 14 / 1992$ & 19.00 & 0.00 & 0.00 & 6.0 & 0.00 & 4.5 & 3 \\
\hline 6/17/1992 & 44.30 & 1.50 & 1.00 & 6.6 & 0.20 & 4.5 & 3 \\
\hline $7 / 10 / 1992$ & 12.70 & 0.00 & 0.30 & 4.0 & 0.00 & 4.5 & 3 \\
\hline $8 / 4 / 1992$ & 25.30 & 3.00 & 0.30 & 18.8 & 0.30 & 4.5 & 3 \\
\hline 9/1/1992 & 76.00 & 2.10 & 0.70 & 8.0 & 0.20 & 4.5 & 3 \\
\hline $10 / 23 / 1992$ & 44.30 & 0.00 & 0.00 & 4.8 & 0.00 & 4.5 & 3 \\
\hline $11 / 5 / 1992$ & 12.70 & 0.00 & 0.30 & 4.0 & 0.00 & 4.5 & 3 \\
\hline 12/28/1992 & 12.70 & 0.40 & 0.00 & 14.0 & 0.00 & 4.5 & 3 \\
\hline $1 / 14 / 1993$ & 19.00 & 0.65 & 0.00 & 11.0 & 0.00 & 4.5 & 3 \\
\hline 2/9/1993 & 19.00 & 0.50 & 0.33 & 9.2 & 0.00 & 4.5 & 3 \\
\hline $3 / 11 / 1993$ & 57.00 & 8.76 & 0.33 & 17.4 & 0.60 & 4.5 & 3 \\
\hline 4/19/1993 & 25.33 & 0.02 & 0.33 & 4.0 & 0.00 & 4.5 & 3 \\
\hline $5 / 20 / 1993$ & 19.00 & 2.14 & 0.00 & 15.2 & 0.20 & 4.5 & 3 \\
\hline $6 / 16 / 1993$ & 6.27 & $\mathrm{~N} / \mathrm{D}$ & N/D & $N / D$ & $N / D$ & 4.5 & 3 \\
\hline $7 / 19 / 1993$ & 12.67 & 0.29 & 0.00 & 12 & 0.00 & 4.5 & 3 \\
\hline $8 / 19 / 1993$ & 19.00 & 0.23 & 0.00 & 10.5 & 0.00 & 4.5 & 3 \\
\hline 9/16/1993 & 63.33 & 4.46 & 0.33 & 11.2 & 0.50 & 4.5 & 3 \\
\hline $10 / 8 / 1993$ & 25.33 & 0.12 & 0.00 & 7.0 & 0.00 & 4.5 & 3 \\
\hline $11 / 16 / 1993$ & 0.00 & 0.00 & 0.00 & 0.00 & 0.00 & 4.5 & 3 \\
\hline $12 / 9 / 1993$ & 6.33 & 0.00 & 0.00 & 3.5 & 0.00 & 4.5 & 3 \\
\hline 1/18/1994 & 6.30 & 0.00 & 0.00 & 3.5 & 0.00 & 4.5 & 3 \\
\hline 2/8/1994 & 6.30 & 0.10 & 0.00 & 9.5 & 0.00 & 4.5 & 3 \\
\hline $3 / 9 / 1994$ & 0.00 & 0.00 & 0.00 & 0.0 & 0.00 & 4.5 & 3 \\
\hline 4/12/1994 & 19.00 & 0.10 & 0.30 & 6.2 & 0.00 & 4.5 & 3 \\
\hline $5 / 23 / 1994$ & 44.30 & 6.90 & 0.00 & 18.5 & 0.50 & 4.5 & 3 \\
\hline 6/9/1994 & 6.30 & 0.00 & 0.00 & 4.5 & 0.00 & 4.5 & 3 \\
\hline $7 / 20 / 1994$ & 12.70 & 0.10 & 0.00 & 7.5 & 0.00 & 4.5 & 3 \\
\hline 8/9/1994 & 38.00 & 0.10 & 1.30 & 3.5 & 0.00 & 4.5 & 3 \\
\hline 9/21/1994 & 31.70 & 0.10 & 0.00 & 5.9 & 0.00 & 4.5 & 3 \\
\hline $10 / 19 / 1994$ & 12.70 & 0.00 & 0.00 & 3.5 & 0.00 & 4.5 & 3 \\
\hline $11 / 21 / 1994$ & 12.70 & 0.20 & 0.30 & 8.5 & 0.00 & 4.5 & 3 \\
\hline $12 / 16 / 1994$ & 25.30 & 0.90 & 0.30 & 9.5 & 0.00 & 4.5 & 3 \\
\hline 1/17/1995 & 19.00 & 0.00 & 0.00 & 3.8 & 0.00 & 4.5 & 3 \\
\hline
\end{tabular}




\begin{tabular}{lccccccc}
\hline \multicolumn{7}{c}{ Appendix 6. Station D4R Corbicula Data } \\
\hline Date & $\begin{array}{c}\text { Total \# of } \\
\text { clams in } \\
\text { sample } \\
\left(\# / \mathbf{m}^{2}\right)\end{array}$ & $\begin{array}{c}\text { Biomass } \\
\left(\mathrm{g} / \mathbf{m}^{2}\right)\end{array}$ & $\begin{array}{c}\text { recruit/ } \\
\mathbf{0 . 0 5} \mathbf{~ m}^{\mathbf{2}}\end{array}$ & $\begin{array}{c}\text { mean size } \\
(\mathbf{m m})\end{array}$ & $\begin{array}{c}\text { GR } \\
\left(\mathbf{m}^{3} / \mathbf{m}^{2} / \mathbf{d}\right)\end{array}$ & Depth (M) & \# Grabs \\
\hline $\mathbf{2 / 1 5 / 1 9 9 5}$ & 38.00 & 0.20 & 0.70 & 6.2 & 0.00 & 4.5 & 3 \\
\hline $\mathbf{3 / 1 5 / 1 9 9 5}$ & 6.30 & 0.00 & 0.00 & 3.5 & 0.00 & 4.5 & 3 \\
\hline $\mathbf{4 / 2 7 / 1 9 9 5}$ & 658.70 & 1.80 & 30.70 & 2.1 & 0.10 & 4.5 & 3 \\
\hline $\mathbf{5 / 1 7 / 1 9 9 5}$ & 899.30 & 0.20 & 41.70 & 1.9 & 0.00 & 4.5 & 3 \\
\hline $\mathbf{6 / 2 7 / 1 9 9 5}$ & 310.30 & 0.20 & 9.30 & 3.0 & 0.00 & 4.5 & 3 \\
\hline $\mathbf{7 / 1 3 / 1 9 9 5}$ & 202.70 & 0.10 & 2.00 & 3.8 & 0.00 & 4.5 & 3 \\
\hline $\mathbf{8 / 2 4 / 1 9 9 5}$ & 418.00 & 2.20 & 0.70 & 7.1 & 0.30 & 4.5 & 3 \\
\hline $\mathbf{9 / 2 6 / 1 9 9 5}$ & 190.00 & 0.90 & 3.30 & 6.1 & 0.10 & 4.5 & 3 \\
\hline $\mathbf{1 0 / 2 5 / 1 9 9 5}$ & 734.70 & 7.00 & 16.30 & 5.8 & 0.50 & 4.5 & 3 \\
\hline $\mathbf{1 1 / 2 7 / 1 9 9 5}$ & 82.30 & 0.40 & 0.00 & 6.9 & 0.00 & 4.5 & 3 \\
\hline
\end{tabular}

Appendix 7. Station D4R Potamocorbula Data

\begin{tabular}{|c|c|c|c|c|c|c|c|}
\hline \multicolumn{8}{|c|}{ Appendix 7. Station D4R Potamocorbula Data } \\
\hline Date & $\begin{array}{c}\text { Total \# of } \\
\text { clams in } \\
\text { sample } \\
\left(\# / \mathrm{m}^{2}\right)\end{array}$ & $\begin{array}{c}\text { Biomass } \\
\left(\mathrm{g} / \mathrm{m}^{2}\right)\end{array}$ & $\mathrm{rec} / 0.05 \mathrm{~m}^{2}$ & $\begin{array}{c}\text { mean size } \\
(\mathrm{mm})\end{array}$ & $\begin{array}{c}\text { GR } \\
\left(\mathrm{m}^{3} / \mathrm{m}^{2} / \mathrm{d}\right)\end{array}$ & $\begin{array}{l}\text { Depth } \\
\text { (M) }\end{array}$ & $\begin{array}{r}\# \\
\text { Grabs }\end{array}$ \\
\hline 6/9/1987 & 418 & 0.26 & 12.00 & 3.14 & 0.1 & 4.5 & 1 \\
\hline $7 / 30 / 1987$ & 1672 & 0.18 & 85.00 & 1.70 & 0.07 & 4.5 & 1 \\
\hline $8 / 20 / 1987$ & 1767 & 0.44 & 77.00 & 2.56 & 0.16 & 4.5 & 1 \\
\hline 9/18/1987 & 2242 & 0.44 & 105.00 & 2.35 & 0.16 & 4.5 & 1 \\
\hline $10 / 30 / 1987$ & 1615 & 0.54 & 63.00 & 2.63 & 0.20 & 4.5 & 1 \\
\hline 11/9/1987 & 2622 & 1.06 & 72.00 & 3.04 & 0.39 & 4.5 & 1 \\
\hline $12 / 17 / 1987$ & 1026 & 0.60 & 13.00 & 3.67 & 0.23 & 4.5 & 1 \\
\hline 1/15/1988 & 931 & 1.61 & 6.00 & 4.40 & 0.41 & 4.5 & 1 \\
\hline 2/11/1988 & 1235 & 3.49 & 6.00 & 4.82 & 1.30 & 4.5 & 1 \\
\hline 4/1/1988 & 741 & 3.49 & 0.00 & 6.35 & 1.31 & 4.5 & 1 \\
\hline $5 / 27 / 1988$ & 133 & 0.98 & 0.00 & 8.50 & 0.38 & 4.5 & 1 \\
\hline $6 / 24 / 1988$ & 114 & 0.89 & 1.00 & 6.67 & 0.35 & 4.5 & 1 \\
\hline $7 / 22 / 1988$ & 95 & 0.14 & 0.00 & 4.50 & 0.05 & 4.5 & 1 \\
\hline $8 / 22 / 1988$ & 494 & 0.05 & 22.00 & 2.12 & 0.02 & 4.5 & 1 \\
\hline $9 / 22 / 1988$ & 2356 & 1.30 & 63.00 & 3.04 & 0.48 & 4.5 & 1 \\
\hline $10 / 21 / 1988$ & 2546 & 2.26 & 67.00 & 3.44 & 0.83 & 4.5 & 1 \\
\hline $11 / 17 / 1988$ & 1729 & 2.58 & 23.00 & 4.27 & 0.95 & 4.5 & 1 \\
\hline $12 / 8 / 1988$ & 4655 & 14.38 & 29.00 & 5.36 & 4.92 & 4.5 & 1 \\
\hline 1/20/1989 & 684 & 1.18 & 9.00 & 4.61 & 0.30 & 4.5 & 1 \\
\hline 2/6/1989 & 1938 & 6.77 & 5.50 & 5.59 & 1.66 & 4.5 & 1 \\
\hline 2/28/1989 & $\mathrm{N} / \mathrm{D}$ & $\mathrm{N} / \mathrm{D}$ & $N / D$ & N/D & N/D & 4.5 & 1 \\
\hline 3/21/1989 & $\mathrm{N} / \mathrm{D}$ & $N / D$ & N/D & N/D & $\mathrm{N} / \mathrm{D}$ & 4.5 & 1 \\
\hline
\end{tabular}




\begin{tabular}{|c|c|c|c|c|c|c|c|}
\hline \multicolumn{8}{|c|}{ Appendix 7. Station D4R Potamocorbula Data } \\
\hline Date & $\begin{array}{c}\text { Total \# of } \\
\text { clams in } \\
\text { sample } \\
\left(\# / \mathrm{m}^{2}\right)\end{array}$ & $\begin{array}{c}\text { Biomass } \\
\left(\mathrm{g} / \mathrm{m}^{2}\right)\end{array}$ & $\mathrm{rec} / 0.05 \mathrm{~m}^{2}$ & $\begin{array}{l}\text { mean size } \\
(\mathrm{mm})\end{array}$ & $\begin{array}{c}\text { GR } \\
\left(\mathrm{m}^{3} / \mathrm{m}^{2} / \mathrm{d}\right)\end{array}$ & $\begin{array}{l}\text { Depth } \\
\text { (M) }\end{array}$ & $\begin{array}{r}\# \\
\text { Grabs }\end{array}$ \\
\hline $5 / 4 / 1989$ & 133 & 0.84 & 0.50 & 6.93 & 0.33 & 4.5 & 1 \\
\hline 6/26/1989 & 28.5 & 0.15 & 0.00 & 7.17 & 0.06 & 4.5 & 1 \\
\hline $7 / 24 / 1989$ & 104.5 & 2.12 & 0.00 & 10.23 & 0.82 & 4.5 & 1 \\
\hline $8 / 21 / 1989$ & 19 & 0.63 & 0.00 & 12.83 & 0.25 & 4.5 & 1 \\
\hline 9/19/1989 & 76 & 0.38 & 0.00 & 6.63 & 0.15 & 4.5 & 1 \\
\hline 10/17/1989 & 19 & 0.03 & 0.00 & 5.50 & 0.01 & 4.5 & 1 \\
\hline 11/13/1989 & 43.7 & 0.00 & 0.00 & $N / D$ & N/D & 4.5 & 1 \\
\hline 12/12/1989 & 126.67 & 0.00 & 0.00 & $N / D$ & N/D & 4.5 & 1 \\
\hline 1/16/1990 & 57 & 3.96 & 0.00 & 14.50 & 1.04 & 4.5 & 3 \\
\hline 2/27/1990 & 88.67 & 1.24 & 2.00 & 6.79 & 0.49 & 4.5 & 3 \\
\hline $3 / 19 / 1990$ & 82.33 & 0.59 & 1.33 & 5.19 & 0.23 & 4.5 & 3 \\
\hline $4 / 20 / 1990$ & 25.33 & 0.39 & 0.00 & 8.00 & 0.16 & 4.5 & 3 \\
\hline $5 / 14 / 1990$ & 12.67 & 0.69 & 0.00 & 12.00 & 0.27 & 4.5 & 3 \\
\hline $6 / 26 / 1990$ & 817 & 1.85 & 30.67 & 3.03 & 0.70 & 4.5 & 3 \\
\hline $7 / 12 / 1990$ & 291.33 & 0.24 & 8.00 & 3.33 & 0.09 & 4.5 & 3 \\
\hline $8 / 8 / 1990$ & 158.33 & 0.15 & 2.33 & 3.82 & 0.06 & 4.5 & 3 \\
\hline 9/24/1990 & 582.67 & 1.02 & 3.33 & 4.45 & 0.39 & 4.5 & 3 \\
\hline 10/22/1990 & 1811.33 & 5.33 & 5.67 & 6.40 & 1.92 & 4.5 & 3 \\
\hline $11 / 6 / 1990$ & 2159.67 & 17.76 & 6.00 & 7.60 & 6.24 & 4.5 & 3 \\
\hline 12/13/1990 & 3350.33 & 18.37 & 68.67 & 5.56 & 6.44 & 4.5 & 3 \\
\hline 1/7/1991 & 1754.33 & 14.39 & 33.67 & 6.78 & 3.51 & 4.5 & 3 \\
\hline 2/19/1991 & 3369.33 & 22.63 & 62.67 & 6.10 & 7.85 & 4.5 & 3 \\
\hline 3/5/1991 & 880.33 & 7.52 & 11.33 & 5.33 & 2.82 & 4.5 & 3 \\
\hline 4/11/1991 & 3616.33 & 49.72 & 24.00 & 6.94 & 17.15 & 4.5 & 3 \\
\hline $5 / 23 / 1991$ & 1463.00 & 14.18 & 1.00 & 7.22 & 0.00 & 4.5 & 3 \\
\hline 6/4/1991 & 2090.00 & 29.03 & 0.33 & 8.49 & 10.13 & 4.5 & 3 \\
\hline 7/16/1991 & 1589.67 & 17.41 & 26.33 & 6.70 & 6.33 & 4.5 & 3 \\
\hline $8 / 30 / 1991$ & 2476.33 & 31.73 & 23.67 & 7.12 & 11.04 & 4.5 & 3 \\
\hline 9/12/1991 & 3926.67 & 109.38 & 30.00 & 9.94 & 35.23 & 4.5 & 3 \\
\hline 10/8/1991 & 456.00 & 2.19 & 2.00 & 6.75 & 0.83 & 4.5 & 3 \\
\hline 11/12/1991 & 582.67 & 2.65 & 5.33 & 5.46 & 1.01 & 4.5 & 3 \\
\hline 12/10/1991 & 969.00 & 10.11 & 2.00 & 7.60 & 2.51 & 4.5 & 3 \\
\hline 1/17/1992 & 2685.33 & 35.35 & 10.67 & 8.86 & 8.17 & 4.5 & 3 \\
\hline 2/25/1992 & 329.33 & 5.67 & 1.00 & 9.38 & 2.14 & 4.5 & 3 \\
\hline $3 / 24 / 1992$ & 2888.00 & 99.71 & 0.00 & 10.69 & 32.87 & 4.5 & 3 \\
\hline 4/6/1992 & 405.33 & 11.31 & 0.33 & 10.23 & 4.22 & 4.5 & 3 \\
\hline $5 / 14 / 1992$ & 1513.67 & 54.90 & 0.00 & 11.45 & 18.88 & 4.5 & 3 \\
\hline $6 / 17 / 1992$ & 1152.67 & 43.57 & 9.00 & 11.49 & 15.3 & 4.5 & 3 \\
\hline
\end{tabular}




\begin{tabular}{|c|c|c|c|c|c|c|c|}
\hline \multicolumn{8}{|c|}{ Appendix 7. Station D4R Potamocorbula Data } \\
\hline Date & $\begin{array}{l}\text { Total \# of } \\
\text { clams in } \\
\text { sample } \\
\left(\# / \mathrm{m}^{2}\right)\end{array}$ & $\begin{array}{c}\text { Biomass } \\
\left(\mathrm{g} / \mathrm{m}^{2}\right)\end{array}$ & $\mathrm{rec} / 0.05 \mathrm{~m}^{2}$ & $\begin{array}{l}\text { mean size } \\
(\mathrm{mm})\end{array}$ & $\begin{array}{c}\text { GR } \\
\left(\mathrm{m}^{3} / \mathrm{m}^{2} / \mathrm{d}\right)\end{array}$ & $\begin{array}{l}\text { Depth } \\
\text { (M) }\end{array}$ & $\begin{array}{r}\# \\
\text { Grabs }\end{array}$ \\
\hline $7 / 10 / 1992$ & 804.33 & 24.41 & 19.00 & 8.11 & 9.00 & 4.5 & 3 \\
\hline 8/4/1992 & 563.67 & 16.59 & 9.67 & 9.16 & 6.14 & 4.5 & 3 \\
\hline 9/1/1992 & 456.00 & 11.59 & 6.67 & 8.19 & 4.36 & 4.5 & 3 \\
\hline 10/23/1992 & 3274.33 & 51.95 & 33.67 & 9.75 & 17.08 & 4.5 & 3 \\
\hline 11/5/1992 & 633.33 & 22.78 & 5.00 & 11.58 & 8.28 & 4.5 & 3 \\
\hline 12/28/1992 & 2704.33 & 97.46 & 20.33 & 11.34 & 31.68 & 4.5 & 3 \\
\hline 1/14/1993 & 1304.67 & 32.89 & 10.00 & 10.54 & 7.83 & 4.5 & 3 \\
\hline 2/9/1993 & 380.00 & 7.19 & 7.67 & 7.88 & 2.73 & 4.5 & 3 \\
\hline $3 / 11 / 1993$ & 95.00 & 5.32 & 1.00 & 11.7 & 2.05 & 4.5 & 3 \\
\hline 4/19/1993 & 1532.67 & 79.96 & 0.67 & 12.01 & 27.27 & 4.5 & 3 \\
\hline $5 / 20 / 1993$ & 1235.00 & 68.84 & 0.67 & 12.86 & 23.89 & 4.5 & 3 \\
\hline $6 / 16 / 1993$ & 2229.33 & 126.62 & 0.33 & 14.52 & 0.00 & 4.5 & 3 \\
\hline $7 / 19 / 1993$ & 1336.33 & 103.29 & 0.00 & 15.52 & 34.39 & 4.5 & 3 \\
\hline $8 / 19 / 1993$ & 994.33 & 62.90 & 0.00 & 14.93 & 21.78 & 4.5 & 3 \\
\hline $9 / 16 / 1993$ & 278.67 & 19.71 & 0.00 & 15.18 & 0.00 & 4.5 & 3 \\
\hline $10 / 8 / 1993$ & 544.67 & 16.96 & 0.00 & 15.03 & 6.06 & 4.5 & 3 \\
\hline 11/16/1993 & 1874.67 & 113.66 & 0.00 & 15.71 & 0.00 & 4.5 & 3 \\
\hline 12/9/1993 & 1399.67 & 77.32 & 0.00 & 15.32 & 25.62 & 4.5 & 3 \\
\hline 1/18/1994 & 842.33 & 31.40 & 0.00 & 14.75 & 7.43 & 4.5 & 3 \\
\hline 2/8/1994 & 1285.67 & 58.98 & 0.00 & 15.56 & 13.31 & 4.5 & 3 \\
\hline 3/9/1994 & 1513.67 & 96.22 & 0.00 & 14.12 & 0.00 & 4.5 & 3 \\
\hline 4/12/1994 & 1697.33 & 129.29 & 0.00 & 15.51 & 0.00 & 4.5 & 3 \\
\hline $5 / 23 / 1994$ & 1627.67 & 127.89 & 0.00 & 15.60 & 41.7 & 4.5 & 3 \\
\hline 6/9/1994 & 627.00 & 43.97 & 0.00 & 15.77 & 15.57 & 4.5 & 3 \\
\hline $7 / 20 / 1994$ & 418.00 & 31.22 & 0.00 & 15.38 & 0.00 & 4.5 & 3 \\
\hline 8/9/1994 & 804.33 & 59.98 & 0.00 & 15.89 & 20.87 & 4.5 & 3 \\
\hline 9/21/1994 & 1450.33 & 94.78 & 3.67 & 15.09 & 31.29 & 4.5 & 3 \\
\hline 10/19/1994 & 354.67 & 7.47 & 2.33 & 10.39 & 2.80 & 4.5 & 3 \\
\hline $11 / 21 / 1994$ & 215.33 & 7.76 & 1.00 & 10.21 & 2.95 & 4.5 & 3 \\
\hline 12/16/1994 & 690.33 & 35.81 & 3.33 & 13.30 & 8.63 & 4.5 & 3 \\
\hline 1/17/1995 & 563.67 & 21.84 & 2.33 & 13.46 & 7.89 & 4.5 & 3 \\
\hline 2/15/1995 & 665.00 & 27.43 & 0.00 & 13.79 & 9.82 & 4.5 & 3 \\
\hline 3/15/1995 & 25.33 & 0.56 & 0.33 & 8.50 & 0.22 & 4.5 & 3 \\
\hline 4/27/1995 & 101.33 & 6.56 & 0.00 & 13.5 & 2.52 & 4.5 & 3 \\
\hline 5/17/1995 & 107.67 & 3.41 & 0.00 & 9.79 & 1.32 & 4.5 & 3 \\
\hline $6 / 27 / 1995$ & 44.33 & 1.74 & 0.00 & 12.64 & 0.68 & 4.5 & 3 \\
\hline 7/13/1995 & 12.67 & 1.22 & 0.00 & 17.00 & 0.48 & 4.5 & 3 \\
\hline 8/24/1995 & 82.33 & 6.72 & 0.00 & 16.19 & 2.57 & 4.5 & 3 \\
\hline
\end{tabular}




\begin{tabular}{|c|c|c|c|c|c|c|c|}
\hline \multicolumn{8}{|c|}{ Appendix 7. Station D4R Potamocorbula Data } \\
\hline Date & $\begin{array}{l}\text { Total \# of } \\
\text { clams in } \\
\text { sample } \\
\left(\# / \mathrm{m}^{2}\right)\end{array}$ & $\begin{array}{c}\text { Biomass } \\
\left(\mathrm{g} / \mathrm{m}^{2}\right)\end{array}$ & $\mathrm{rec} / 0.05 \mathrm{~m}^{2}$ & $\begin{array}{l}\text { mean size } \\
(\mathrm{mm})\end{array}$ & $\begin{array}{c}\text { GR } \\
\left(\mathrm{m}^{3} / \mathrm{m}^{2} / \mathrm{d}\right)\end{array}$ & $\begin{array}{l}\text { Depth } \\
\text { (M) }\end{array}$ & $\begin{array}{r}\# \\
\text { Grabs }\end{array}$ \\
\hline 9/26/1995 & 25.33 & 1.01 & 0.00 & 13.50 & 0.40 & 4.5 & 3 \\
\hline 10/25/1995 & 95.00 & 4.43 & 0.00 & 17.90 & 1.68 & 4.5 & 3 \\
\hline 11/27/1995 & 19.00 & 1.14 & 0.00 & 15.83 & 0.45 & 4.5 & 3 \\
\hline 12/27/1995 & 19.00 & 1.40 & .000 & 15.83 & 0.37 & 4.5 & 3 \\
\hline
\end{tabular}

\begin{tabular}{|c|c|c|c|c|c|c|c|}
\hline \multicolumn{8}{|c|}{ Appendix 8. Station D6 Potamocorbula Data } \\
\hline Date & $\begin{array}{l}\text { Total \# of } \\
\text { clams in } \\
\text { sample } \\
\left(\# / \mathrm{m}^{2}\right)\end{array}$ & $\begin{array}{c}\text { biomass } \\
\left(\mathrm{g} / \mathrm{m}^{2}\right)\end{array}$ & $\begin{array}{c}\mathrm{rec} / \\
0.05 \mathrm{~m}^{2}\end{array}$ & $\begin{array}{c}\text { mean size } \\
(\mathrm{mm})\end{array}$ & $\begin{array}{c}\text { GR } \\
\left(\mathrm{m}^{3} / \mathrm{m}^{2} / \mathrm{d}\right)\end{array}$ & Depth (M) & \# Grabs \\
\hline $1 / 23 / 2007$ & 15931.50 & 7.80 & 365.30 & 3.30 & 1.67 & 7 & 4 \\
\hline $2 / 20 / 2007$ & 10236.30 & 9.80 & 205.00 & 3.50 & 3.27 & 7 & 4 \\
\hline $3 / 20 / 2007$ & 8911.00 & 14.30 & 74.80 & 4.30 & 4.67 & 7 & 4 \\
\hline $4 / 16 / 2007$ & 8768.50 & 21.20 & 15.80 & 5.10 & 6.80 & 7 & 4 \\
\hline $5 / 16 / 2007$ & 8524.70 & 20.50 & 18.70 & 5.10 & 6.58 & 7 & 4 \\
\hline $6 / 20 / 2007$ & 6555.00 & 13.00 & 7.80 & 5.30 & 4.31 & 7 & 4 \\
\hline $7 / 16 / 2007$ & 11461.80 & 38.90 & 2.30 & 5.70 & 12.01 & 7 & 4 \\
\hline $8 / 13 / 2007$ & 5491.00 & 15.70 & 2.00 & 5.80 & 5.27 & 7 & 4 \\
\hline 9/11/2007 & 5453.00 & 6.80 & 49.80 & 4.40 & 2.32 & 7 & 4 \\
\hline $10 / 2 / 2007$ & 2166.00 & 2.20 & 24.00 & 4.40 & 0.81 & 7 & 4 \\
\hline $11 / 7 / 2007$ & 9181.80 & 8.20 & 39.00 & 4.30 & 2.65 & 7 & 4 \\
\hline $12 / 10 / 2007$ & 2883.30 & 3.80 & 20.50 & 4.70 & 1.35 & 7 & 4 \\
\hline $1 / 8 / 2008$ & 1035.50 & 0.80 & 19.00 & 3.80 & 0.21 & 7 & 4 \\
\hline $2 / 6 / 2008$ & 6759.25 & 12.90 & 29.80 & 4.80 & 4.32 & 7 & 4 \\
\hline $3 / 5 / 2008$ & 551.00 & 1.10 & 4.00 & 4.60 & 0.42 & 7 & 4 \\
\hline $4 / 2 / 2008$ & 798.00 & 2.20 & 8.00 & 5.00 & 0.82 & 7 & 4 \\
\hline $5 / 21 / 2008$ & 1021.25 & 3.30 & 4.50 & 5.40 & 1.22 & 7 & 4 \\
\hline $6 / 18 / 2008$ & 10036.75 & 16.30 & 273.50 & 3.80 & 5.45 & 7 & 4 \\
\hline $7 / 15 / 2008$ & 12886.75 & 34.10 & 213.00 & 4.30 & 10.59 & 7 & 4 \\
\hline $8 / 14 / 2008$ & 21517.50 & 11.30 & 633.00 & 3.20 & 3.44 & 7 & 4 \\
\hline $9 / 16 / 2008$ & 16287.75 & 21.60 & 228.00 & 4.00 & 6.47 & 7 & 4 \\
\hline $10 / 27 / 2008$ & 28922.75 & 15.30 & 431.30 & 3.60 & 4.42 & 7 & 4 \\
\hline $11 / 18 / 2008$ & 15266.50 & 26.60 & 71.00 & 4.70 & 8.05 & 7 & 4 \\
\hline $12 / 10 / 2008$ & 19038.00 & 19.80 & 147.80 & 4.20 & 5.78 & 7 & 4 \\
\hline $1 / 12 / 2009$ & 13846.25 & 12.80 & 116.80 & 4.10 & 2.65 & 7 & 4 \\
\hline 2/9/2009 & 5643.00 & 8.50 & 13.00 & 4.50 & 2.90 & 7 & 4 \\
\hline $3 / 11 / 2009$ & 4921.00 & 4.60 & 47.00 & 3.80 & 1.65 & 7 & 4 \\
\hline $4 / 6 / 2009$ & 5947.00 & 14.10 & 4.50 & 5.10 & 4.72 & 7 & 4 \\
\hline
\end{tabular}




\begin{tabular}{|c|c|c|c|c|c|c|c|}
\hline \multicolumn{8}{|c|}{ Appendix 8. Station D6 Potamocorbula Data } \\
\hline Date & $\begin{array}{l}\text { Total \# of } \\
\text { clams in } \\
\text { sample } \\
\left(\# / \mathrm{m}^{2}\right)\end{array}$ & $\begin{array}{c}\text { biomass } \\
\left(\mathrm{g} / \mathrm{m}^{2}\right)\end{array}$ & $\begin{array}{c}\mathrm{rec} / \\
0.05 \mathrm{~m}^{2}\end{array}$ & $\begin{array}{c}\text { mean size } \\
(\mathrm{mm})\end{array}$ & $\begin{array}{c}\text { GR } \\
\left(\mathrm{m}^{3} / \mathrm{m}^{2} / \mathrm{d}\right)\end{array}$ & Depth (M) & \# Grabs \\
\hline $5 / 4 / 2009$ & 4104.00 & 16.80 & 1.30 & 6.20 & 5.72 & 7 & 4 \\
\hline $6 / 24 / 2009$ & 4455.50 & 21.80 & 13.30 & 6.90 & 7.39 & 7 & 4 \\
\hline $7 / 21 / 2009$ & 5842.50 & 20.40 & 128.50 & 4.90 & 6.95 & 7 & 4 \\
\hline $8 / 18 / 2009$ & 25654.75 & 16.10 & 945.50 & 3.10 & 4.74 & 7 & 4 \\
\hline $9 / 16 / 2009$ & 30143.50 & 22.40 & 886.50 & 3.30 & 6.43 & 7 & 4 \\
\hline $10 / 19 / 2009$ & 18914.50 & 8.40 & 717.30 & 2.80 & 2.66 & 7 & 4 \\
\hline $11 / 16 / 2009$ & 6464.75 & 14.50 & 116.00 & 4.60 & 4.87 & 7 & 4 \\
\hline $12 / 16 / 2009$ & 12516.25 & 13.60 & 212.50 & 3.90 & 2.99 & 7 & 4 \\
\hline $1 / 14 / 2010$ & 2864.25 & 1.90 & 44.00 & 3.60 & 0.46 & 7 & 4 \\
\hline $2 / 18 / 2010$ & 2702.75 & 3.70 & 37.50 & 4.00 & 1.31 & 7 & 4 \\
\hline $3 / 15 / 2010$ & 4579.00 & 5.20 & 48.50 & 4.00 & 1.79 & 7 & 4 \\
\hline $4 / 12 / 2010$ & 6797.25 & 12.90 & 11.30 & 4.80 & 4.33 & 7 & 4 \\
\hline $5 / 18 / 2010$ & 5153.75 & 25.00 & 23.80 & 6.10 & 8.35 & 7 & 4 \\
\hline 6/9/2010 & 4588.50 & 13.40 & 53.50 & 5.30 & 4.59 & 7 & 4 \\
\hline $7 / 6 / 2010$ & 8649.75 & 31.50 & 85.30 & 5.30 & 10.11 & 7 & 4 \\
\hline $8 / 17 / 2010$ & 7519.25 & 27.40 & 50.30 & 5.70 & 8.94 & 7 & 4 \\
\hline $9 / 7 / 2010$ & 9775.50 & 10.20 & 144.50 & 4.00 & 3.28 & 7 & 4 \\
\hline $10 / 25 / 2010$ & 12449.75 & 19.20 & 88.50 & 4.90 & 5.99 & 7 & 4 \\
\hline $11 / 22 / 2010$ & 10245.75 & 13.00 & 45.50 & 4.60 & 4.15 & 7 & 4 \\
\hline $12 / 20 / 2010$ & 2018.75 & 4.50 & 10.80 & 5.10 & 1.61 & 7 & 4 \\
\hline $1 / 19 / 2011$ & 3966.25 & 5.20 & 32.80 & 4.30 & 1.23 & 7 & 4 \\
\hline $2 / 2 / 2011$ & 5448.25 & 11.20 & 31.00 & 4.70 & 3.82 & 7 & 4 \\
\hline $3 / 8 / 2011$ & 7590.50 & 21.40 & 17.00 & 5.20 & 6.96 & 7 & 4 \\
\hline $4 / 6 / 2011$ & 5315.25 & 15.60 & 11.30 & 5.20 & 5.26 & 7 & 4 \\
\hline $5 / 2 / 2011$ & 2731.25 & 5.20 & 17.30 & 4.70 & 1.87 & 7 & 4 \\
\hline $6 / 14 / 2011$ & 1102.00 & 6.70 & 0.00 & 7.60 & 2.45 & 7 & 4 \\
\hline $7 / 13 / 2011$ & 2071.00 & 20.50 & 11.80 & 7.90 & 7.21 & 7 & 4 \\
\hline $8 / 9 / 2011$ & 1382.25 & 14.40 & 1.30 & 8.90 & 5.16 & 7 & 4 \\
\hline $9 / 7 / 2011$ & 3866.50 & 29.90 & 57.30 & 6.50 & 10.27 & 7 & 4 \\
\hline $10 / 3 / 2011$ & 4075.50 & 13.60 & 44.50 & 5.70 & 4.69 & 7 & 4 \\
\hline $11 / 8 / 2011$ & 8958.50 & 41.90 & 45.80 & 5.60 & 13.39 & 7 & 4 \\
\hline $12 / 7 / 2011$ & 8811.25 & 29.50 & 81.00 & 5.00 & 6.37 & 7 & 4 \\
\hline $1 / 9 / 2012$ & 6692.75 & 12.40 & 47.50 & 4.60 & 2.80 & 7 & 4 \\
\hline $2 / 8 / 2012$ & 7823.25 & 18.80 & 39.80 & 4.80 & 6.22 & 7 & 4 \\
\hline $3 / 6 / 2012$ & 18225.75 & 61.50 & 53.80 & 5.30 & 17.53 & 7 & 4 \\
\hline $4 / 5 / 2012$ & 6873.25 & 36.60 & 27.50 & 5.80 & 12.07 & 7 & 4 \\
\hline $5 / 21 / 2012$ & 10374.00 & 41.30 & 39.80 & 5.50 & 12.93 & 7 & 4 \\
\hline $6 / 20 / 2012$ & 8464.50 & 28.70 & 29.50 & 5.70 & 9.24 & 7 & 4 \\
\hline
\end{tabular}




\begin{tabular}{|c|c|c|c|c|c|c|c|}
\hline \multicolumn{8}{|c|}{ Appendix 8. Station D6 Potamocorbula Data } \\
\hline Date & $\begin{array}{l}\text { Total \# of } \\
\text { clams in } \\
\text { sample } \\
\left(\# / \mathrm{m}^{2}\right)\end{array}$ & $\begin{array}{c}\text { biomass } \\
\left(\mathrm{g} / \mathrm{m}^{2}\right)\end{array}$ & $\begin{array}{c}\text { rec/ } \\
0.05 \mathrm{~m}^{2}\end{array}$ & $\begin{array}{c}\text { mean size } \\
(\mathrm{mm})\end{array}$ & $\begin{array}{c}\text { GR } \\
\left(\mathrm{m}^{3} / \mathrm{m}^{2} / \mathrm{d}\right)\end{array}$ & Depth (M) & \# Grabs \\
\hline $7 / 17 / 2012$ & 5723.75 & 16.80 & 37.50 & 5.20 & 5.63 & 7 & 4 \\
\hline $8 / 15 / 2012$ & 5685.75 & 16.00 & 47.30 & 5.30 & 5.38 & 7 & 4 \\
\hline $9 / 25 / 2012$ & 4612.25 & 5.50 & 65.00 & 4.20 & 1.92 & 7 & 4 \\
\hline $10 / 24 / 2012$ & 4735.75 & 6.80 & 42.00 & 4.90 & 2.36 & 7 & 4 \\
\hline $11 / 14 / 2012$ & 845.50 & 2.40 & 4.80 & 5.50 & 0.91 & 7 & 4 \\
\hline $12 / 18 / 2012$ & 5966.00 & 9.90 & 25.30 & 4.90 & 3.36 & 7 & 4 \\
\hline $1 / 9 / 2013$ & 2688.50 & 5.10 & 9.80 & 5.10 & 1.22 & 7 & 4 \\
\hline $2 / 5 / 2013$ & 1486.75 & 4.10 & 4.30 & 5.30 & 1.49 & 7 & 4 \\
\hline $3 / 13 / 2013$ & 2840.50 & 9.00 & 9.30 & 5.50 & 3.18 & 7 & 4 \\
\hline $4 / 10 / 2013$ & 2869.00 & 14.10 & 18.00 & 6.10 & 4.96 & 7 & 4 \\
\hline $5 / 7 / 2013$ & 4108.75 & 17.90 & 23.00 & 6.00 & 6.09 & 7 & 4 \\
\hline $6 / 4 / 2013$ & 6127.50 & 11.80 & 190.30 & 3.80 & 4.13 & 7 & 4 \\
\hline $7 / 8 / 2013$ & 13190.75 & 23.50 & 493.50 & 3.40 & 7.64 & 7 & 4 \\
\hline $8 / 8 / 2013$ & $\mathrm{~N} / \mathrm{D}$ & $\mathrm{N} / \mathrm{D}$ & $N / D$ & $N / D$ & $\mathrm{~N} / \mathrm{D}$ & 7 & 4 \\
\hline $9 / 4 / 2013$ & 21479.50 & 16.50 & 886.00 & 3.00 & 5.01 & 7 & 4 \\
\hline $10 / 15 / 2013$ & 22106.50 & 6.80 & 845.50 & 2.80 & 2.12 & 7 & 4 \\
\hline $11 / 19 / 2013$ & 7894.50 & 5.90 & 179.30 & 3.50 & 2.01 & 7 & 4 \\
\hline $12 / 16 / 2013$ & 8991.75 & 5.60 & 213.80 & 3.40 & 1.28 & 7 & 4 \\
\hline
\end{tabular}

Appendix 9. Station D7 Corbicula Data

\begin{tabular}{|c|c|c|c|c|c|c|c|}
\hline Date & $\begin{array}{c}\text { Total \# of } \\
\text { clams in } \\
\text { sample } \\
\left(\# / \mathrm{m}^{2}\right)\end{array}$ & $\begin{array}{c}\text { Biomass } \\
\left(\mathrm{g} / \mathrm{m}^{2}\right)\end{array}$ & $\begin{array}{l}\text { recruit/ } \\
0.05 \mathrm{~m}^{2}\end{array}$ & $\begin{array}{c}\text { mean size } \\
(\mathrm{mm})\end{array}$ & $\begin{array}{c}\text { GR } \\
\left(\mathrm{m}^{3} / \mathrm{m}^{2} / \mathrm{d}\right)\end{array}$ & Depth (M) & \# Grabs \\
\hline $1 / 21 / 1981$ & 38.00 & 0.00 & 2.00 & 1.50 & 0.00 & 1.7 & 1 \\
\hline 2/19/1981 & 5.70 & $N / D$ & $\mathrm{~N} / \mathrm{D}$ & $N / D$ & N/D & $N / D$ & $N / D$ \\
\hline $3 / 30 / 1981$ & N/D & N/D & $\mathrm{N} / \mathrm{D}$ & N/D & $N / D$ & $\mathrm{~N} / \mathrm{D}$ & $N / D$ \\
\hline $4 / 16 / 1981$ & 38.00 & 0.02 & 1.00 & 3.00 & 0.00 & 1.7 & 1 \\
\hline $5 / 15 / 1981$ & N/D & N/D & $\mathrm{N} / \mathrm{D}$ & $\mathrm{N} / \mathrm{D}$ & $N / D$ & $N / D$ & $\mathrm{~N} / \mathrm{D}$ \\
\hline $6 / 12 / 1981$ & N/D & $N / D$ & $\mathrm{~N} / \mathrm{D}$ & $N / D$ & $\mathrm{~N} / \mathrm{D}$ & $N / D$ & $N / D$ \\
\hline $7 / 10 / 1981$ & N/D & N/D & N/D & $\mathrm{N} / \mathrm{D}$ & N/D & N/D & N/D \\
\hline $8 / 26 / 1981$ & 5.70 & $N / D$ & $\mathrm{~N} / \mathrm{D}$ & $\mathrm{N} / \mathrm{D}$ & $\mathrm{N} / \mathrm{D}$ & $N / D$ & $N / D$ \\
\hline 9/24/1981 & N/D & $N / D$ & $\mathrm{~N} / \mathrm{D}$ & $\mathrm{N} / \mathrm{D}$ & $N / D$ & $N / D$ & $N / D$ \\
\hline 10/13/1981 & N/D & $N / D$ & $\mathrm{~N} / \mathrm{D}$ & $\mathrm{N} / \mathrm{D}$ & $\mathrm{N} / \mathrm{D}$ & $N / D$ & $N / D$ \\
\hline $11 / 20 / 1981$ & $\mathrm{~N} / \mathrm{D}$ & N/D & N/D & N/D & N/D & N/D & $\mathrm{N} / \mathrm{D}$ \\
\hline 12/11/1981 & 57.00 & 0.01 & 3.00 & 1.83 & 0.00 & 1.7 & 1 \\
\hline 1/21/1982 & $\mathrm{N} / \mathrm{D}$ & $N / D$ & $\mathrm{~N} / \mathrm{D}$ & $\mathrm{N} / \mathrm{D}$ & $N / D$ & $N / D$ & $\mathrm{~N} / \mathrm{D}$ \\
\hline $2 / 22 / 1982$ & N/D & N/D & $\mathrm{N} / \mathrm{D}$ & $\mathrm{N} / \mathrm{D}$ & $\mathrm{N} / \mathrm{D}$ & $N / D$ & $\mathrm{~N} / \mathrm{D}$ \\
\hline
\end{tabular}


Appendix 9. Station D7 Corbicula Data

\begin{tabular}{|c|c|c|c|c|c|c|c|}
\hline Date & $\begin{array}{l}\text { Total \# of } \\
\text { clams in } \\
\text { sample } \\
\left(\# / \mathrm{m}^{2}\right)\end{array}$ & $\begin{array}{c}\text { Biomass } \\
\left(\mathrm{g} / \mathrm{m}^{2}\right)\end{array}$ & $\begin{array}{l}\text { recruit/ } \\
0.05 \mathrm{~m}^{2}\end{array}$ & $\begin{array}{c}\text { mean size } \\
(\mathrm{mm})\end{array}$ & $\begin{array}{c}\text { GR } \\
\left(\mathrm{m}^{3} / \mathrm{m}^{2} / \mathrm{d}\right)\end{array}$ & Depth (M) & \# Grabs \\
\hline $3 / 30 / 1982$ & $N / D$ & N/D & N/D & $N / D$ & $N / D$ & N/D & $\mathrm{N} / \mathrm{D}$ \\
\hline $4 / 28 / 1982$ & 5.70 & N/D & N/D & $N / D$ & N/D & 1.7 & 1 \\
\hline $5 / 20 / 1982$ & $N / D$ & $\mathrm{~N} / \mathrm{D}$ & N/D & $N / D$ & $N / D$ & $\mathrm{~N} / \mathrm{D}$ & $\mathrm{N} / \mathrm{D}$ \\
\hline $6 / 25 / 1982$ & 38.00 & 0.04 & 0.00 & 4.50 & 0.00 & 1.7 & 1 \\
\hline $7 / 22 / 1982$ & $N / D$ & $\mathrm{~N} / \mathrm{D}$ & N/D & $N / D$ & $N / D$ & $\mathrm{~N} / \mathrm{D}$ & $\mathrm{N} / \mathrm{D}$ \\
\hline $8 / 30 / 1982$ & $\mathrm{~N} / \mathrm{D}$ & N/D & N/D & $N / D$ & $N / D$ & $N / D$ & $N / D$ \\
\hline 9/20/1982 & 38.00 & 0.61 & 0.00 & 11.00 & 0.06 & 1.7 & 1 \\
\hline 10/28/1982 & 5.70 & N/D & N/D & $N / D$ & $N / D$ & 1.7 & 1 \\
\hline $11 / 24 / 1982$ & 19.00 & 0.05 & 0.00 & 6.50 & 0.00 & 1.7 & 1 \\
\hline 12/15/1982 & 38.00 & 0.35 & 0.00 & 9.50 & 0.01 & 1.7 & 1 \\
\hline $1 / 31 / 1983$ & 57.00 & 0.00 & 3.00 & 1.17 & 0.00 & 1.7 & 1 \\
\hline 2/8/1983 & 57.00 & 0.00 & 3.00 & 1.17 & 0.00 & 1.7 & 1 \\
\hline $3 / 8 / 1983$ & 57.00 & 0.01 & 3.00 & 2.17 & 0.00 & 1.7 & 1 \\
\hline 4/26/1983 & 1007.00 & 0.25 & 48.00 & 2.07 & 0.01 & 1.7 & 1 \\
\hline $5 / 19 / 1983$ & 589.00 & 0.45 & 13.00 & 3.37 & 0.02 & 1.7 & 1 \\
\hline 6/6/1983 & 437.00 & 0.38 & 9.00 & 3.67 & 0.03 & 1.7 & 1 \\
\hline $7 / 5 / 1983$ & 171.00 & 0.52 & 0.00 & 5.50 & 0.06 & 1.7 & 1 \\
\hline 9/15/1983 & 969.00 & 0.53 & 48.00 & 1.93 & 0.05 & 1.7 & 1 \\
\hline 11/1/1983 & $\mathrm{N} / \mathrm{D}$ & N/D & N/D & $N / D$ & N/D & $\mathrm{N} / \mathrm{D}$ & $N / D$ \\
\hline $11 / 30 / 1983$ & 874.00 & 3.57 & 28.00 & 3.99 & 0.20 & 1.7 & 1 \\
\hline $12 / 13 / 1983$ & 1197.00 & 5.00 & 53.00 & 3.18 & 0.16 & 1.7 & 1 \\
\hline $1 / 31 / 1984$ & $\mathrm{~N} / \mathrm{D}$ & N/D & $N / D$ & $N / D$ & N/D & $N / D$ & $N / D$ \\
\hline 2/27/1984 & 7581.00 & 3.86 & 391.00 & 1.26 & 0.12 & 1.7 & 1 \\
\hline $3 / 26 / 1984$ & 6061.00 & 2.59 & 315.00 & 1.25 & 0.11 & 1.7 & 1 \\
\hline $4 / 24 / 1984$ & 4294.00 & 5.70 & 208.00 & 2.22 & 0.27 & 1.7 & 1 \\
\hline $5 / 24 / 1984$ & 3648.00 & 3.48 & 158.00 & 2.29 & 0.23 & 1.7 & 1 \\
\hline $6 / 22 / 1984$ & 3306.00 & 1.43 & 93.00 & 2.98 & 0.11 & 1.7 & 1 \\
\hline $7 / 23 / 1984$ & 1710.00 & 10.01 & 4.00 & 5.64 & 1.01 & 1.7 & 1 \\
\hline $8 / 22 / 1984$ & 722.00 & 22.63 & 0.00 & 10.79 & 2.19 & 1.7 & 1 \\
\hline 9/18/1984 & 380.00 & 16.06 & 1.00 & 13.50 & 1.77 & 1.7 & 1 \\
\hline $10 / 30 / 1984$ & 171.00 & 7.55 & 3.00 & 10.83 & 0.59 & 1.7 & 1 \\
\hline 11/29/1984 & 228.00 & 4.72 & 4.00 & 9.17 & 0.23 & 1.7 & 1 \\
\hline 12/13/1984 & 399.00 & 8.08 & 11.00 & 8.21 & 0.22 & 1.7 & 1 \\
\hline $1 / 15 / 1985$ & 437.00 & 11.51 & 9.00 & 9.37 & 0.31 & 1.7 & 1 \\
\hline 2/13/1985 & 399.00 & 12.46 & 6.00 & 10.98 & 0.33 & 1.7 & 1 \\
\hline 3/13/1985 & 532.00 & 7.44 & 19.00 & 5.36 & 0.30 & 1.7 & 1 \\
\hline 4/10/1985 & 475.00 & 6.82 & 20.00 & 4.54 & 0.39 & 1.7 & 1 \\
\hline $5 / 31 / 1985$ & 532.00 & 7.09 & 20.00 & 4.82 & 0.50 & 1.7 & 1 \\
\hline
\end{tabular}


Appendix 9. Station D7 Corbicula Data

\begin{tabular}{|c|c|c|c|c|c|c|c|}
\hline Date & $\begin{array}{c}\text { Total \# of } \\
\text { clams in } \\
\text { sample } \\
\left(\# / \mathrm{m}^{2}\right)\end{array}$ & $\begin{array}{c}\text { Biomass } \\
\left(\mathrm{g} / \mathrm{m}^{2}\right)\end{array}$ & $\begin{array}{l}\text { recruit/ } \\
0.05 \mathrm{~m}^{2}\end{array}$ & $\begin{array}{c}\text { mean size } \\
(\mathrm{mm})\end{array}$ & $\begin{array}{c}\text { GR } \\
\left(\mathrm{m}^{3} / \mathrm{m}^{2} / \mathrm{d}\right)\end{array}$ & Depth (M) & \# Grabs \\
\hline $6 / 11 / 1985$ & 171.00 & 4.91 & 1.00 & 11.39 & 0.47 & 1.7 & 1 \\
\hline $8 / 30 / 1985$ & 114.00 & 5.95 & 0.00 & 15.83 & 0.57 & 1.7 & 1 \\
\hline $10 / 2 / 1985$ & 133.00 & 7.57 & 0.00 & 16.64 & 0.40 & 1.7 & 1 \\
\hline 10/22/1985 & 171.00 & 12.62 & 0.00 & 18.17 & 0.39 & 1.7 & 1 \\
\hline $12 / 4 / 1985$ & 190.00 & 14.56 & 0.00 & 19.50 & 0.36 & 1.7 & 1 \\
\hline 12/30/1985 & 19.00 & 1.44 & 0.00 & 19.50 & 0.48 & 1.7 & 1 \\
\hline $1 / 15 / 1986$ & 152.00 & 8.55 & 0.00 & 17.38 & 0.04 & 1.7 & 1 \\
\hline $2 / 12 / 1986$ & 38.00 & 2.12 & 0.00 & 19.00 & 0.07 & 1.7 & 1 \\
\hline $3 / 31 / 1986$ & 38.00 & 4.27 & 0.00 & 20.00 & 0.15 & 1.7 & 1 \\
\hline $4 / 21 / 1986$ & 76.00 & 7.89 & 0.00 & 19.50 & 0.43 & 1.7 & 1 \\
\hline $5 / 20 / 1986$ & 57.00 & 7.68 & 0.00 & 21.50 & 0.53 & 1.7 & 1 \\
\hline $6 / 30 / 1986$ & 95.00 & 18.28 & 0.00 & 21.70 & 1.36 & 1.7 & 1 \\
\hline $7 / 25 / 1986$ & 76.00 & 9.03 & 0.00 & 20.25 & 0.76 & 1.7 & 1 \\
\hline $8 / 26 / 1986$ & 57.00 & 7.95 & 0.00 & 21.17 & 0.68 & 1.7 & 1 \\
\hline 9/9/1986 & 12.73 & $N / D$ & N/D & $N / D$ & $N / D$ & $\mathrm{~N} / \mathrm{D}$ & $\mathrm{N} / \mathrm{D}$ \\
\hline 10/29/1986 & 19.00 & 3.33 & 0.00 & 25.50 & 0.19 & 1.7 & 1 \\
\hline $11 / 14 / 1986$ & 19.00 & 1.43 & 0.00 & 19.50 & 0.07 & 1.7 & 1 \\
\hline 12/15/1986 & 57.00 & 10.09 & 0.00 & 23.83 & 0.28 & 1.7 & 1 \\
\hline $1 / 23 / 1987$ & 38.00 & 5.23 & 0.00 & 21.00 & 0.15 & 1.7 & 1 \\
\hline $2 / 26 / 1987$ & 12.70 & 0.00 & 0.00 & 0.00 & 0.00 & 1.7 & 1 \\
\hline $3 / 26 / 1987$ & 12.70 & 0.00 & 0.00 & 0.00 & 0.00 & 1.7 & 1 \\
\hline 4/24/1987 & 418.00 & 0.07 & 19.00 & 2.05 & 0.00 & 1.7 & 1 \\
\hline $5 / 19 / 1987$ & 12.70 & 0.00 & 0.00 & 0.00 & 0.00 & 1.7 & 1 \\
\hline 6/9/1987 & 0.00 & 0.00 & 0.00 & 0.00 & 0.00 & 1.7 & 1 \\
\hline $7 / 30 / 1987$ & 19.00 & 0.01 & 0.00 & 3.50 & 0.00 & 1.7 & 1 \\
\hline $8 / 20 / 1987$ & 0.00 & 0.00 & 0.00 & 0.00 & 0.00 & 1.7 & 1 \\
\hline 9/15/1987 & 5.70 & 0.00 & 0.00 & 0.00 & 0.00 & 1.7 & 1 \\
\hline 10/27/1987 & 19.00 & 0.03 & 0.00 & 3.50 & 0.00 & 1.7 & 1 \\
\hline $11 / 9 / 1987$ & 19.00 & 0.02 & 0.00 & 4.50 & 0.00 & 1.7 & 1 \\
\hline 12/16/1987 & 0.00 & 0.00 & 0.00 & 0.00 & 0.00 & 1.7 & 1 \\
\hline $1 / 12 / 1988$ & 0.00 & 0.00 & 0.00 & 0.00 & 0.00 & 1.7 & 1 \\
\hline $2 / 10 / 1988$ & 0.00 & 0.00 & 0.00 & 0.00 & 0.00 & 1.7 & 1 \\
\hline 4/1/1988 & 0.00 & 0.00 & 0.00 & 0.00 & 0.00 & 1.7 & 1 \\
\hline 4/25/1988 & 0.00 & 0.00 & 0.00 & 0.00 & 0.00 & 1.7 & 1 \\
\hline $5 / 27 / 1988$ & 0.00 & 0.00 & 0.00 & 0.00 & 0.00 & 1.7 & 1 \\
\hline $6 / 21 / 1988$ & 0.00 & 0.00 & 0.00 & 0.00 & 0.00 & 1.7 & 1 \\
\hline $7 / 22 / 1988$ & 0.00 & 0.00 & 0.00 & 0.00 & 0.00 & 1.7 & 1 \\
\hline $8 / 17 / 1988$ & 0.00 & 0.00 & 0.00 & 0.00 & 0.00 & 1.7 & 1 \\
\hline
\end{tabular}


Appendix 9. Station D7 Corbicula Data

\begin{tabular}{|c|c|c|c|c|c|c|c|}
\hline Date & $\begin{array}{l}\text { Total \# of } \\
\text { clams in } \\
\text { sample } \\
\left(\# / \mathrm{m}^{2}\right)\end{array}$ & $\begin{array}{c}\text { Biomass } \\
\left(\mathrm{g} / \mathrm{m}^{2}\right)\end{array}$ & $\begin{array}{l}\text { recruit/ } \\
0.05 \mathrm{~m}^{2}\end{array}$ & $\begin{array}{c}\text { mean size } \\
(\mathrm{mm})\end{array}$ & $\begin{array}{c}\text { GR } \\
\left(\mathrm{m}^{3} / \mathrm{m}^{2} / \mathrm{d}\right)\end{array}$ & Depth (M) & \# Grabs \\
\hline 9/19/1988 & 0.00 & 0.00 & 0.00 & 0.00 & 0.00 & 1.7 & 1 \\
\hline 10/18/1988 & 0.00 & 0.00 & 0.00 & 0.00 & 0.00 & 1.7 & 1 \\
\hline $11 / 18 / 1988$ & 0.00 & 0.00 & 0.00 & 0.00 & 0.00 & 1.7 & 1 \\
\hline $12 / 5 / 1988$ & 0.00 & 0.00 & 0.00 & 0.00 & 0.00 & 1.7 & 1 \\
\hline 1/17/1989 & 0.00 & 0.00 & 0.00 & 0.00 & 0.00 & 1.7 & 1 \\
\hline 2/1/1989 & 0.00 & 0.00 & 0.00 & 0.00 & 0.00 & 1.7 & 1 \\
\hline 5/5/1989 & 0.00 & 0.00 & 0.00 & 0.00 & 0.00 & 1.7 & 1 \\
\hline $7 / 25 / 1989$ & 0.00 & 0.00 & 0.00 & 0.00 & 0.00 & 1.7 & 1 \\
\hline $8 / 22 / 1989$ & 0.00 & 0.00 & 0.00 & 0.00 & 0.00 & 1.7 & 1 \\
\hline 9/20/1989 & 0.00 & 0.00 & 0.00 & 0.00 & 0.00 & 1.7 & 1 \\
\hline 10/18/1989 & 0.00 & 0.00 & 0.00 & 0.00 & 0.00 & 1.7 & 1 \\
\hline 11/7/1989 & 0.00 & 0.00 & 0.00 & 0.00 & 0.00 & 1.7 & 1 \\
\hline 12/5/1989 & 0.00 & 0.00 & 0.00 & 0.00 & 0.00 & 1.7 & 1 \\
\hline 1/17/1990 & 0.00 & 0.00 & 0.00 & 0.00 & 0.00 & 1.7 & 3 \\
\hline 2/27/1990 & 0.00 & 0.00 & 0.00 & 0.00 & 0.00 & 1.7 & 3 \\
\hline 3/19/1990 & 0.00 & 0.00 & 0.00 & 0.00 & 0.00 & 1.7 & 3 \\
\hline 4/20/1990 & 0.00 & 0.00 & 0.00 & 0.00 & 0.00 & 1.7 & 3 \\
\hline $5 / 14 / 1990$ & 0.00 & 0.00 & 0.00 & 0.00 & 0.00 & 1.7 & 3 \\
\hline $6 / 27 / 1990$ & 0.00 & 0.00 & 0.00 & 0.00 & 0.00 & 1.7 & 3 \\
\hline $7 / 27 / 1990$ & 0.00 & 0.00 & 0.00 & 0.00 & 0.00 & 1.7 & 3 \\
\hline $8 / 13 / 1990$ & 0.00 & 0.00 & 0.00 & 0.00 & 0.00 & 1.7 & 3 \\
\hline 9/25/1990 & 0.00 & 0.00 & 0.00 & 0.00 & 0.00 & 1.7 & 3 \\
\hline 10/23/1990 & 0.00 & 0.00 & 0.00 & 0.00 & 0.00 & 1.7 & 3 \\
\hline 11/7/1990 & 0.00 & 0.00 & 0.00 & 0.00 & 0.00 & 1.7 & 3 \\
\hline 12/10/1990 & 0.00 & 0.00 & 0.00 & 0.00 & 0.00 & 1.7 & 3 \\
\hline 1/8/1991 & 0.00 & 0.00 & 0.00 & 0.00 & 0.00 & 1.7 & 3 \\
\hline 2/20/1991 & 0.00 & 0.00 & 0.00 & 0.00 & 0.00 & 1.7 & 3 \\
\hline 3/6/1991 & 0.00 & 0.00 & 0.00 & 0.00 & 0.00 & 1.7 & 3 \\
\hline 4/8/1991 & 0.00 & 0.00 & 0.00 & 0.00 & 0.00 & 1.7 & 3 \\
\hline $5 / 20 / 1991$ & 0.00 & 0.00 & 0.00 & 0.00 & 0.00 & 1.7 & 3 \\
\hline 6/5/1991 & 0.00 & 0.00 & 0.00 & 0.00 & 0.00 & 1.7 & 3 \\
\hline $8 / 20 / 1991$ & 0.00 & 0.00 & 0.00 & 0.00 & 0.00 & 1.7 & 3 \\
\hline 9/16/1991 & 0.00 & 0.00 & 0.00 & 0.00 & 0.00 & 1.7 & 3 \\
\hline 10/1/1991 & 5.70 & 0.00 & 0.00 & 0.00 & 0.00 & 1.7 & 3 \\
\hline 11/13/1991 & 0.00 & 0.00 & 0.00 & 0.00 & 0.00 & 1.7 & 3 \\
\hline 12/11/1991 & 0.00 & 0.00 & 0.00 & 0.00 & 0.00 & 1.7 & 3 \\
\hline $1 / 14 / 1992$ & 0.00 & 0.00 & 0.00 & 0.00 & 0.00 & 1.7 & 3 \\
\hline 2/26/1992 & 0.00 & 0.00 & 0.00 & 0.00 & 0.00 & 1.7 & 3 \\
\hline
\end{tabular}


Appendix 9. Station D7 Corbicula Data

\begin{tabular}{|c|c|c|c|c|c|c|c|}
\hline Date & $\begin{array}{c}\text { Total \# of } \\
\text { clams in } \\
\text { sample } \\
\left(\# / \mathrm{m}^{2}\right)\end{array}$ & $\begin{array}{c}\text { Biomass } \\
\left(\mathrm{g} / \mathrm{m}^{2}\right)\end{array}$ & $\begin{array}{l}\text { recruit/ } \\
0.05 \mathrm{~m}^{2}\end{array}$ & $\begin{array}{c}\text { mean size } \\
(\mathrm{mm})\end{array}$ & $\begin{array}{c}G R \\
\left(\mathrm{~m}^{3} / \mathrm{m}^{2} / \mathrm{d}\right)\end{array}$ & Depth (M) & \# Grabs \\
\hline $3 / 25 / 1992$ & 0.00 & 0.00 & 0.00 & 0.00 & 0.00 & 1.7 & 3 \\
\hline 4/7/1992 & 0.00 & 0.00 & 0.00 & 0.00 & 0.00 & 1.7 & 3 \\
\hline $5 / 8 / 1992$ & 0.00 & 0.00 & 0.00 & 0.00 & 0.00 & 1.7 & 3 \\
\hline $6 / 22 / 1992$ & 0.00 & 0.00 & 0.00 & 0.00 & 0.00 & 1.7 & 3 \\
\hline $7 / 7 / 1992$ & 0.00 & 0.00 & 0.00 & 0.00 & 0.00 & 1.7 & 3 \\
\hline 8/5/1992 & 0.00 & 0.00 & 0.00 & 0.00 & 0.00 & 1.7 & 3 \\
\hline 9/2/1992 & 0.00 & 0.00 & 0.00 & 0.00 & 0.00 & 1.7 & 3 \\
\hline 10/2/1992 & 0.00 & 0.00 & 0.00 & 0.00 & 0.00 & 1.7 & 3 \\
\hline 11/2/1992 & 0.00 & 0.00 & 0.00 & 0.00 & 0.00 & 1.7 & 3 \\
\hline $12 / 28 / 1992$ & 0.00 & 0.00 & 0.00 & 0.00 & 0.00 & 1.7 & 3 \\
\hline $1 / 14 / 1993$ & 0.00 & 0.00 & 0.00 & 0.00 & 0.00 & 1.7 & 3 \\
\hline 2/9/1993 & 0.00 & 0.00 & 0.00 & 0.00 & 0.00 & 1.7 & 3 \\
\hline $3 / 11 / 1993$ & 0.00 & 0.00 & 0.00 & 0.00 & 0.00 & 1.7 & 3 \\
\hline 4/19/1993 & 0.00 & 0.00 & 0.00 & 0.00 & 0.00 & 1.7 & 3 \\
\hline $5 / 20 / 1993$ & 0.00 & 0.00 & 0.00 & 0.00 & 0.00 & 1.7 & 3 \\
\hline $6 / 16 / 1993$ & 0.00 & 0.00 & 0.00 & 0.00 & 0.00 & 1.7 & 3 \\
\hline $7 / 19 / 1993$ & 0.00 & 0.00 & 0.00 & 0.00 & 0.00 & 1.7 & 3 \\
\hline $8 / 19 / 1993$ & 0.00 & 0.00 & 0.00 & 0.00 & 0.00 & 1.7 & 3 \\
\hline 9/16/1993 & 0.00 & 0.00 & 0.00 & 0.00 & 0.00 & 1.7 & 3 \\
\hline $10 / 8 / 1993$ & 0.00 & 0.00 & 0.00 & 0.00 & 0.00 & 1.7 & 3 \\
\hline $11 / 16 / 1993$ & 0.00 & 0.00 & 0.00 & 0.00 & 0.00 & 1.7 & 3 \\
\hline $12 / 9 / 1993$ & 0.00 & 0.00 & 0.00 & 0.00 & 0.00 & 1.7 & 3 \\
\hline 1/18/1994 & 0.00 & 0.00 & 0.00 & 0.00 & 0.00 & 1.7 & 3 \\
\hline 2/8/1994 & 0.00 & 0.00 & 0.00 & 0.00 & 0.00 & 1.7 & 3 \\
\hline $3 / 9 / 1994$ & 0.00 & 0.00 & 0.00 & 0.00 & 0.00 & 1.7 & 3 \\
\hline 4/12/1994 & 0.00 & 0.00 & 0.00 & 0.00 & 0.00 & 1.7 & 3 \\
\hline $5 / 23 / 1994$ & 0.00 & 0.00 & 0.00 & 0.00 & 0.00 & 1.7 & 3 \\
\hline $6 / 9 / 1994$ & 0.00 & 0.00 & 0.00 & 0.00 & 0.00 & 1.7 & 3 \\
\hline $7 / 20 / 1994$ & 0.00 & 0.00 & 0.00 & 0.00 & 0.00 & 1.7 & 3 \\
\hline 8/9/1994 & 0.00 & 0.00 & 0.00 & 0.00 & 0.00 & 1.7 & 3 \\
\hline 9/21/1994 & 0.00 & 0.00 & 0.00 & 0.00 & 0.00 & 1.7 & 3 \\
\hline $10 / 19 / 1994$ & 0.00 & 0.00 & 0.00 & 0.00 & 0.00 & 1.7 & 3 \\
\hline $11 / 21 / 1994$ & 0.00 & 0.00 & 0.00 & 0.00 & 0.00 & 1.7 & 3 \\
\hline $12 / 16 / 1994$ & 0.00 & 0.00 & 0.00 & 0.00 & 0.00 & 1.7 & 3 \\
\hline $1 / 17 / 1995$ & 0.00 & 0.00 & 0.00 & 0.00 & 0.00 & 1.7 & 3 \\
\hline 2/15/1995 & 0.00 & 0.00 & 0.00 & 0.00 & 0.00 & 1.7 & 3 \\
\hline 3/15/1995 & 0.00 & 0.00 & 0.00 & 0.00 & 0.00 & 1.7 & 3 \\
\hline 4/27/1995 & 0.00 & 0.00 & 0.00 & 0.00 & 0.00 & 1.7 & 3 \\
\hline
\end{tabular}


Appendix 9. Station D7 Corbicula Data

\begin{tabular}{|c|c|c|c|c|c|c|c|}
\hline Date & $\begin{array}{l}\text { Total \# of } \\
\text { clams in } \\
\text { sample } \\
\left(\# / \mathrm{m}^{2}\right)\end{array}$ & $\begin{array}{c}\text { Biomass } \\
\left(\mathrm{g} / \mathrm{m}^{2}\right)\end{array}$ & $\begin{array}{l}\text { recruit/ } \\
0.05 \mathrm{~m}^{2}\end{array}$ & $\begin{array}{c}\text { mean size } \\
(\mathrm{mm})\end{array}$ & $\begin{array}{c}\text { GR } \\
\left(\mathrm{m}^{3} / \mathrm{m}^{2} / \mathrm{d}\right)\end{array}$ & Depth (M) & \# Grabs \\
\hline 5/17/1995 & 0.00 & 0.00 & 0.00 & 0.00 & 0.00 & 1.7 & 3 \\
\hline $6 / 27 / 1995$ & 4.75 & 0.00 & 0.00 & 0.00 & 0.00 & 1.7 & 3 \\
\hline 7/13/1995 & 0.00 & 0.00 & 0.00 & 0.00 & 0.00 & 1.7 & 3 \\
\hline $8 / 24 / 1995$ & 0.00 & 0.00 & 0.00 & 0.00 & 0.00 & 1.7 & 3 \\
\hline 9/26/1995 & 4.75 & 0.00 & 0.00 & 0.00 & 0.00 & 1.7 & 3 \\
\hline 10/25/1995 & 0.00 & 0.00 & 0.00 & 0.00 & 0.00 & 1.7 & 3 \\
\hline $11 / 27 / 1995$ & 0.00 & 0.00 & 0.00 & 0.00 & 0.00 & 1.7 & 3 \\
\hline 12/27/1995 & 0.00 & 0.00 & 0.00 & 0.00 & 0.00 & 1.7 & 3 \\
\hline 1/22/1996 & 0.00 & 0.00 & 0.00 & 0.00 & 0.00 & 1.7 & 4 \\
\hline 2/21/1996 & 0.00 & 0.00 & 0.00 & 0.00 & 0.00 & 1.7 & 4 \\
\hline $3 / 20 / 1996$ & 0.00 & 0.00 & 0.00 & 0.00 & 0.00 & 1.7 & 4 \\
\hline 4/29/1996 & 4.75 & 0.00 & 0.00 & 0.00 & 0.00 & 1.7 & 4 \\
\hline $5 / 16 / 1996$ & 0.00 & 0.00 & 0.00 & 0.00 & 0.00 & 1.7 & 4 \\
\hline $6 / 18 / 1996$ & 0.00 & 0.00 & 0.00 & 0.00 & 0.00 & 1.7 & 4 \\
\hline $7 / 16 / 1996$ & 4.75 & 0.00 & 0.00 & 0.00 & 0.00 & 1.7 & 4 \\
\hline 8/28/1996 & 9.50 & 0.00 & 0.00 & 0.00 & 0.00 & 1.7 & 4 \\
\hline 9/11/1996 & 4.75 & 0.00 & 0.00 & 0.00 & 0.00 & 1.7 & 4 \\
\hline 10/8/1996 & 0.00 & 0.00 & 0.00 & 0.00 & 0.00 & 1.7 & 4 \\
\hline 11/14/1996 & 0.00 & 0.00 & 0.00 & 0.00 & 0.00 & 1.7 & 4 \\
\hline 12/11/1996 & 0.00 & 0.00 & 0.00 & 0.00 & 0.00 & 1.7 & 4 \\
\hline $1 / 23 / 1997$ & 4.75 & 0.00 & 0.00 & 0.00 & 0.00 & 1.7 & 4 \\
\hline 2/20/1997 & 0.00 & 0.00 & 0.00 & 0.00 & 0.00 & 1.7 & 4 \\
\hline $3 / 24 / 1997$ & 0.00 & 0.00 & 0.00 & 0.00 & 0.00 & 1.7 & 4 \\
\hline 4/22/1997 & 0.00 & 0.00 & 0.00 & 0.00 & 0.00 & 1.7 & 4 \\
\hline $5 / 21 / 1997$ & 0.00 & 0.00 & 0.00 & 0.00 & 0.00 & 1.7 & 4 \\
\hline $6 / 18 / 1997$ & 0.00 & 0.00 & 0.00 & 0.00 & 0.00 & 1.7 & 4 \\
\hline $7 / 22 / 1997$ & 0.00 & 0.00 & 0.00 & 0.00 & 0.00 & 1.7 & 4 \\
\hline 8/19/1997 & 0.00 & 0.00 & 0.00 & 0.00 & 0.00 & 1.7 & 4 \\
\hline 9/16/1997 & 0.00 & 0.00 & 0.00 & 0.00 & 0.00 & 1.7 & 4 \\
\hline 10/28/1997 & 0.00 & 0.00 & 0.00 & 0.00 & 0.00 & 1.7 & 4 \\
\hline 11/18/1997 & 0.00 & 0.00 & 0.00 & 0.00 & 0.00 & 1.7 & 4 \\
\hline 12/16/1997 & 551.00 & 0.00 & 0.00 & 0.00 & 0.00 & 1.7 & 4 \\
\hline 1/15/1998 & 0.00 & 0.00 & 0.00 & 0.00 & 0.00 & 1.7 & 4 \\
\hline 2/19/1998 & 0.00 & 0.00 & 0.00 & 0.00 & 0.00 & 1.7 & 4 \\
\hline $3 / 16 / 1998$ & 0.00 & 0.00 & 0.00 & 0.00 & 0.00 & 1.7 & 4 \\
\hline 4/15/1998 & 0.00 & 0.00 & 0.00 & 0.00 & 0.00 & 1.7 & 4 \\
\hline $5 / 12 / 1998$ & 9.50 & 0.00 & 0.00 & 0.00 & 0.00 & 1.7 & 4 \\
\hline 6/8/1998 & 0.00 & 0.00 & 0.00 & 0.00 & 0.00 & 1.7 & 4 \\
\hline
\end{tabular}


Appendix 9. Station D7 Corbicula Data

\begin{tabular}{|c|c|c|c|c|c|c|c|}
\hline Date & $\begin{array}{l}\text { Total \# of } \\
\text { clams in } \\
\text { sample } \\
\left(\# / \mathrm{m}^{2}\right)\end{array}$ & $\begin{array}{c}\text { Biomass } \\
\left(\mathrm{g} / \mathrm{m}^{2}\right)\end{array}$ & $\begin{array}{l}\text { recruit/ } \\
0.05 \mathrm{~m}^{2}\end{array}$ & $\begin{array}{c}\text { mean size } \\
(\mathrm{mm})\end{array}$ & $\begin{array}{c}\text { GR } \\
\left(\mathrm{m}^{3} / \mathrm{m}^{2} / \mathrm{d}\right)\end{array}$ & Depth (M) & \# Grabs \\
\hline 7/9/1998 & 0.00 & 0.00 & 0.00 & 0.00 & 0.00 & 1.7 & 4 \\
\hline 8/5/1998 & 23.75 & 0.00 & 0.00 & 0.00 & 0.00 & 1.7 & 4 \\
\hline 9/16/1998 & 14.25 & 0.00 & 0.00 & 0.00 & 0.00 & 1.7 & 4 \\
\hline $10 / 6 / 1998$ & 4.75 & 0.00 & 0.00 & 0.00 & 0.00 & 1.7 & 4 \\
\hline 11/5/1998 & 4.75 & 0.00 & 0.00 & 0.00 & 0.00 & 1.7 & 4 \\
\hline 12/21/1998 & 4.75 & 0.00 & 0.00 & 0.00 & 0.00 & 1.7 & 4 \\
\hline 1/13/1999 & 0.00 & 0.00 & 0.00 & 0.00 & 0.00 & 1.7 & 4 \\
\hline 2/17/1999 & 0.00 & 0.00 & 0.00 & 0.00 & 0.00 & 1.7 & 4 \\
\hline 3/16/1999 & 4.75 & 0.00 & 0.00 & 0.00 & 0.00 & 1.7 & 4 \\
\hline 4/14/1999 & 0.00 & 0.00 & 0.00 & 0.00 & 0.00 & 1.7 & 4 \\
\hline 5/18/1999 & 0.00 & 0.00 & 0.00 & 0.00 & 0.00 & 1.7 & 4 \\
\hline $6 / 14 / 1999$ & 0.00 & 0.00 & 0.00 & 0.00 & 0.00 & 1.7 & 4 \\
\hline 7/13/1999 & 14.25 & 0.00 & 0.00 & 0.00 & 0.00 & 1.7 & 4 \\
\hline 8/11/1999 & 0.00 & 0.00 & 0.00 & 0.00 & 0.00 & 1.7 & 4 \\
\hline 9/22/1999 & 4.75 & 0.00 & 0.00 & 0.00 & 0.00 & 1.7 & 4 \\
\hline 10/26/1999 & 0.00 & 0.00 & 0.00 & 0.00 & 0.00 & 1.7 & 4 \\
\hline 11/10/1999 & 0.00 & 0.00 & 0.00 & 0.00 & 0.00 & 1.7 & 4 \\
\hline 12/8/1999 & 0.00 & 0.00 & 0.00 & 0.00 & 0.00 & 1.7 & 4 \\
\hline $1 / 5 / 2000$ & 4.75 & 0.00 & 0.00 & 0.00 & 0.00 & 1.7 & 4 \\
\hline $2 / 23 / 2000$ & 0.00 & 0.00 & 0.00 & 0.00 & 0.00 & 1.7 & 4 \\
\hline $3 / 22 / 2000$ & 0.00 & 0.00 & 0.00 & 0.00 & 0.00 & 1.7 & 4 \\
\hline $4 / 19 / 2000$ & 0.00 & 0.00 & 0.00 & 0.00 & 0.00 & 1.7 & 4 \\
\hline $5 / 18 / 2000$ & 0.00 & 0.00 & 0.00 & 0.00 & 0.00 & 1.7 & 4 \\
\hline $6 / 14 / 2000$ & 0.00 & 0.00 & 0.00 & 0.00 & 0.00 & 1.7 & 4 \\
\hline $7 / 17 / 2000$ & 0.00 & 0.00 & 0.00 & 0.00 & 0.00 & 1.7 & 4 \\
\hline $8 / 15 / 2000$ & 0.00 & 0.00 & 0.00 & 0.00 & 0.00 & 1.7 & 4 \\
\hline $9 / 11 / 2000$ & 0.00 & 0.00 & 0.00 & 0.00 & 0.00 & 1.7 & 4 \\
\hline $10 / 10 / 2000$ & 0.00 & 0.00 & 0.00 & 0.00 & 0.00 & 1.7 & 4 \\
\hline $11 / 15 / 2000$ & 0.00 & 0.00 & 0.00 & 0.00 & 0.00 & 1.7 & 4 \\
\hline $12 / 12 / 2000$ & 0.00 & 0.00 & 0.00 & 0.00 & 0.00 & 1.7 & 4 \\
\hline
\end{tabular}




\begin{tabular}{|c|c|c|c|c|c|c|c|}
\hline \multicolumn{8}{|c|}{ Appendix 10. Station D7 Potamocorbula Data } \\
\hline Date & $\begin{array}{l}\text { Total \# of } \\
\text { clams in } \\
\text { sample } \\
\left(\# / \mathrm{m}^{2}\right)\end{array}$ & $\begin{array}{c}\text { biomass } \\
\left(\mathrm{g} / \mathrm{m}^{2}\right)\end{array}$ & $\begin{array}{c}\mathrm{rec} / \\
0.05 \mathrm{~m}^{2}\end{array}$ & $\begin{array}{l}\text { mean size } \\
(\mathrm{mm})\end{array}$ & $\begin{array}{c}\text { GR } \\
\left(\mathrm{m}^{3} / \mathrm{m}^{2} / \mathrm{d}\right)\end{array}$ & Depth (M) & \# Grabs \\
\hline $5 / 20 / 1987$ & 2166.00 & 0.40 & 103.00 & 1.80 & 0.14 & 1.7 & 1 \\
\hline 6/9/1987 & 5339.00 & 0.50 & 267.00 & 1.90 & 0.18 & 1.7 & 1 \\
\hline $7 / 30 / 1987$ & 4370.00 & 5.60 & 45.00 & 4.40 & 1.94 & 1.7 & 1 \\
\hline $8 / 18 / 1987$ & 5529.00 & 8.00 & 34.00 & 5.00 & 2.70 & 1.7 & 1 \\
\hline 9/16/1987 & 4579.00 & 8.50 & 9.00 & 5.50 & 2.91 & 1.7 & 1 \\
\hline $10 / 28 / 1987$ & 4047.00 & 9.20 & 9.00 & 6.10 & 3.16 & 1.7 & 1 \\
\hline $11 / 19 / 1987$ & 4199.00 & 10.00 & 10.00 & 5.90 & 2.33 & 1.7 & 1 \\
\hline $12 / 14 / 1987$ & 3249.00 & 9.30 & 8.00 & 6.40 & 2.19 & 1.7 & 1 \\
\hline $1 / 13 / 1988$ & 3059.00 & 10.70 & 7.00 & 6.40 & 2.51 & 1.7 & 1 \\
\hline 2/11/1988 & 3344.00 & 4.50 & 105.00 & 3.40 & 1.10 & 1.7 & 1 \\
\hline 4/1/1988 & 3819.00 & 3.40 & 150.00 & 3.30 & 1.21 & 1.7 & 1 \\
\hline $4 / 26 / 1988$ & 5586.00 & 6.00 & 142.00 & 3.60 & 2.12 & 1.7 & 1 \\
\hline $5 / 25 / 1988$ & 6593.00 & 9.80 & 40.00 & 4.40 & 3.28 & 1.7 & 1 \\
\hline $6 / 22 / 1988$ & 3268.00 & 6.20 & 1.00 & 5.50 & 2.18 & 1.7 & 1 \\
\hline $7 / 20 / 1988$ & 4161.00 & 9.10 & 19.00 & 5.60 & 3.13 & 1.7 & 1 \\
\hline $8 / 18 / 1988$ & 4921.00 & 10.00 & 38.00 & 5.70 & 3.39 & 1.7 & 1 \\
\hline $9 / 20 / 1988$ & 5434.00 & 13.90 & 31.00 & 6.20 & 4.63 & 1.7 & 1 \\
\hline $10 / 19 / 1988$ & 4921.00 & 13.20 & 35.00 & 6.00 & 4.42 & 1.7 & 1 \\
\hline $11 / 17 / 1988$ & 3534.00 & 10.10 & 20.00 & 6.20 & 2.36 & 1.7 & 1 \\
\hline $12 / 6 / 1988$ & 2964.00 & 11.50 & 19.00 & 6.40 & 2.72 & 1.7 & 1 \\
\hline 1/18/1989 & 2071.00 & 3.00 & 53.00 & 3.80 & 0.75 & 1.7 & 1 \\
\hline 2/2/1989 & 3344.00 & 5.90 & 105.00 & 3.50 & 1.44 & 1.7 & 1 \\
\hline $5 / 4 / 1989$ & 722.00 & 1.10 & 5.00 & 4.60 & 0.43 & 1.7 & 1 \\
\hline $6 / 30 / 1989$ & 1387.00 & 1.70 & 21.00 & 4.50 & 0.62 & 1.7 & 1 \\
\hline $7 / 26 / 1989$ & 2318.00 & 4.90 & 25.00 & 5.40 & 1.74 & 1.7 & 1 \\
\hline $8 / 23 / 1989$ & 3173.00 & 5.20 & 52.00 & 4.90 & 1.87 & 1.7 & 1 \\
\hline 9/21/1989 & 4028.00 & 6.60 & 104.00 & 4.20 & 2.30 & 1.7 & 1 \\
\hline 10/19/1989 & 3743.00 & 10.60 & 40.00 & 6.00 & 3.64 & 1.7 & 1 \\
\hline 11/8/1989 & 2527.00 & 7.70 & 28.00 & 5.90 & 1.86 & 1.7 & 1 \\
\hline 12/6/1989 & 2603.00 & 6.90 & 23.00 & 5.60 & 1.65 & 1.7 & 1 \\
\hline 1/17/1989 & 2342.70 & 10.50 & 31.00 & 6.40 & 2.52 & 1.7 & 3 \\
\hline $2 / 27 / 1990$ & 1019.70 & 3.60 & 36.30 & 6.30 & 0.91 & 1.7 & 3 \\
\hline $3 / 19 / 1990$ & 1374.30 & 2.60 & 10.30 & 4.20 & 0.95 & 1.7 & 3 \\
\hline 4/20/1990 & 1463.00 & 5.80 & 5.70 & 6.60 & 2.11 & 1.7 & 3 \\
\hline $5 / 14 / 1990$ & 1887.30 & 4.70 & 5.70 & 4.80 & 1.73 & 1.7 & 3 \\
\hline $6 / 28 / 1990$ & 1615.00 & 5.40 & 0.00 & 6.70 & 1.94 & 1.7 & 3 \\
\hline $8 / 16 / 1990$ & 1064.00 & 4.20 & 0.70 & 7.70 & 1.54 & 1.7 & 3 \\
\hline 9/26/1990 & 1007.00 & 4.50 & 59.30 & 8.10 & 1.65 & 1.7 & 3 \\
\hline
\end{tabular}




\begin{tabular}{|c|c|c|c|c|c|c|c|}
\hline \multicolumn{8}{|c|}{ Appendix 10. Station D7 Potamocorbula Data } \\
\hline Date & $\begin{array}{l}\text { Total \# of } \\
\text { clams in } \\
\text { sample } \\
\left(\# / \mathrm{m}^{2}\right)\end{array}$ & $\begin{array}{c}\text { biomass } \\
\left(\mathrm{g} / \mathrm{m}^{2}\right)\end{array}$ & $\begin{array}{c}\mathrm{rec} / \\
0.05 \mathrm{~m}^{2}\end{array}$ & $\begin{array}{l}\text { mean size } \\
(\mathrm{mm})\end{array}$ & $\begin{array}{c}\text { GR } \\
\left(\mathrm{m}^{3} / \mathrm{m}^{2} / \mathrm{d}\right)\end{array}$ & Depth (M) & \# Grabs \\
\hline $10 / 24 / 1990$ & 2406.70 & 6.60 & 131.00 & 5.40 & 2.37 & 1.7 & 3 \\
\hline $11 / 8 / 1990$ & 3622.70 & 7.60 & 11.30 & 4.20 & 1.82 & 1.7 & 3 \\
\hline $12 / 11 / 1990$ & 4249.70 & 8.50 & 159.00 & 4.00 & 2.00 & 1.7 & 3 \\
\hline 1/7/1991 & 1811.30 & 6.20 & 50.00 & 5.00 & 1.53 & 1.7 & 3 \\
\hline 2/6/1991 & 1092.50 & 4.40 & 33.00 & 4.60 & 1.10 & 1.7 & 3 \\
\hline 3/6/1991 & 1722.70 & 1.90 & 47.70 & 3.50 & 0.73 & 1.7 & 3 \\
\hline 4/8/1991 & 1399.70 & 1.60 & 50.30 & 3.10 & 0.60 & 1.7 & 3 \\
\hline $5 / 20 / 1991$ & 2267.30 & 1.90 & 61.70 & 3.30 & 0.68 & 1.7 & 3 \\
\hline 6/5/1991 & 2102.70 & 2.10 & 33.70 & 3.90 & 0.77 & 1.7 & 3 \\
\hline $8 / 20 / 1991$ & 1475.70 & 2.00 & 31.00 & 4.30 & 0.73 & 1.7 & 3 \\
\hline 9/16/1991 & 1615.00 & 3.60 & 20.70 & 5.50 & 1.32 & 1.7 & 3 \\
\hline 10/1/1991 & 2039.30 & 5.00 & 33.30 & 5.60 & 1.81 & 1.7 & 3 \\
\hline $11 / 13 / 1991$ & 2546.00 & 7.50 & 37.70 & 5.60 & 2.33 & 1.7 & 3 \\
\hline 12/11/1991 & 2197.70 & 6.70 & 28.00 & 5.90 & 1.48 & 1.7 & 3 \\
\hline 1/14/1992 & 2463.70 & 6.80 & 48.70 & 4.80 & 1.61 & 1.7 & 3 \\
\hline $2 / 26 / 1992$ & 2517.50 & 6.50 & 68.70 & 3.70 & 2.30 & 1.7 & 3 \\
\hline $3 / 25 / 1992$ & 2679.00 & 5.10 & 72.30 & 4.10 & 1.81 & 1.7 & 3 \\
\hline 4/8/1992 & 2134.30 & 3.00 & 59.30 & 3.80 & 1.10 & 1.7 & 3 \\
\hline $5 / 10 / 1992$ & 2527.00 & 5.90 & 18.30 & 5.20 & 2.05 & 1.7 & 3 \\
\hline $6 / 22 / 1992$ & 2539.70 & 4.60 & 43.30 & 4.60 & 1.60 & 1.7 & 3 \\
\hline 7/7/1992 & 2318.00 & 4.20 & 49.00 & 4.60 & 1.48 & 1.7 & 3 \\
\hline 8/5/1992 & 2400.30 & 4.90 & 36.30 & 5.30 & 1.73 & 1.7 & 3 \\
\hline 9/2/1992 & 3135.00 & 8.30 & 48.30 & 5.80 & 2.80 & 1.7 & 3 \\
\hline $10 / 4 / 1992$ & 2926.00 & 8.40 & 35.70 & 6.10 & 2.88 & 1.7 & 3 \\
\hline 11/2/1992 & 3078.00 & 12.20 & 36.30 & 6.40 & 3.75 & 1.7 & 3 \\
\hline $12 / 28 / 1992$ & 2292.70 & 11.10 & 19.70 & 7.40 & 3.61 & 1.7 & 3 \\
\hline $1 / 27 / 1993$ & 551.00 & 0.50 & 13.30 & 3.40 & 0.12 & 1.7 & 3 \\
\hline 2/9/1993 & 427.50 & 0.20 & 12.30 & 2.80 & 0.09 & 1.7 & 3 \\
\hline $3 / 17 / 1993$ & 475.00 & 1.90 & 5.30 & 5.70 & 0.72 & 1.7 & 3 \\
\hline 4/15/1993 & 88.70 & 0.90 & 0.00 & 8.40 & 0.35 & 1.7 & 3 \\
\hline $5 / 20 / 1993$ & 215.30 & 1.70 & 0.70 & 7.80 & 0.66 & 1.7 & 3 \\
\hline $6 / 17 / 1993$ & 240.70 & 1.10 & 2.00 & 7.10 & 0.42 & 1.7 & 3 \\
\hline $7 / 19 / 1993$ & 126.70 & 0.30 & 0.70 & 6.30 & 0.13 & 1.7 & 3 \\
\hline $8 / 25 / 1993$ & 107.70 & 1.20 & 0.00 & 12.40 & 0.47 & 1.7 & 3 \\
\hline 9/15/1993 & 177.30 & 2.00 & 0.00 & 11.10 & 0.74 & 1.7 & 3 \\
\hline 10/12/1993 & 164.70 & 4.40 & 0.00 & 13.50 & 1.63 & 1.7 & 3 \\
\hline $11 / 16 / 1993$ & 424.30 & 3.10 & 15.70 & 5.30 & 1.08 & 1.7 & 3 \\
\hline 12/9/1993 & 665.00 & 4.40 & 25.70 & 4.90 & 1.45 & 1.7 & 3 \\
\hline
\end{tabular}




\begin{tabular}{|c|c|c|c|c|c|c|c|}
\hline \multicolumn{8}{|c|}{ Appendix 10. Station D7 Potamocorbula Data } \\
\hline Date & $\begin{array}{l}\text { Total \# of } \\
\text { clams in } \\
\text { sample } \\
\left(\# / \mathrm{m}^{2}\right)\end{array}$ & $\begin{array}{c}\text { biomass } \\
\left(\mathrm{g} / \mathrm{m}^{2}\right)\end{array}$ & $\begin{array}{c}\mathrm{rec} / \\
0.05 \mathrm{~m}^{2}\end{array}$ & $\begin{array}{l}\text { mean size } \\
(\mathrm{mm})\end{array}$ & $\begin{array}{c}\text { GR } \\
\left(\mathrm{m}^{3} / \mathrm{m}^{2} / \mathrm{d}\right)\end{array}$ & Depth (M) & \# Grabs \\
\hline 1/18/1994 & 500.30 & 4.20 & 15.70 & 6.70 & 1.07 & 1.7 & 3 \\
\hline 2/8/1994 & 1016.50 & 2.20 & 26.70 & 3.10 & 0.57 & 1.7 & 3 \\
\hline 3/9/1994 & 842.30 & 0.80 & 22.00 & 3.20 & 0.32 & 1.7 & 3 \\
\hline 4/13/1994 & 753.70 & 0.80 & 13.70 & 3.70 & 0.30 & 1.7 & 3 \\
\hline $5 / 23 / 1994$ & 956.30 & 1.40 & 9.00 & 4.30 & 0.53 & 1.7 & 3 \\
\hline 6/9/1994 & 867.70 & 1.10 & 10.30 & 4.40 & 0.43 & 1.7 & 3 \\
\hline $7 / 20 / 1994$ & 2267.30 & 3.10 & 72.70 & 3.70 & 1.14 & 1.7 & 3 \\
\hline 8/9/1994 & 950.00 & 0.70 & 38.00 & 2.80 & 0.27 & 1.7 & 3 \\
\hline 9/21/1994 & 4104.00 & 4.80 & 137.30 & 3.60 & 1.71 & 1.7 & 3 \\
\hline 10/19/1994 & 4325.70 & 4.30 & 153.30 & 3.30 & 1.55 & 1.7 & 3 \\
\hline $11 / 28 / 1994$ & 2052.00 & 3.10 & 63.70 & 3.90 & 0.92 & 1.7 & 3 \\
\hline $12 / 12 / 1994$ & 1931.70 & 3.60 & 46.70 & 4.40 & 0.74 & 1.7 & 3 \\
\hline 1/17/1995 & 1608.70 & 2.00 & 45.30 & 3.80 & 0.75 & 1.7 & 3 \\
\hline 2/15/1995 & 256.50 & 0.50 & 6.00 & 4.40 & 0.19 & 1.7 & 3 \\
\hline $3 / 15 / 1995$ & 196.30 & 0.10 & 7.00 & 3.80 & 0.06 & 1.7 & 3 \\
\hline 4/27/1995 & 202.70 & 0.30 & 0.70 & 5.20 & 0.11 & 1.7 & 3 \\
\hline 5/17/1995 & 183.70 & 0.40 & 0.00 & 7.40 & 0.15 & 1.7 & 3 \\
\hline 6/27/1995 & 139.30 & 0.90 & 0.00 & 9.00 & 0.34 & 1.7 & 3 \\
\hline 7/13/1995 & 145.70 & 1.50 & 1.30 & 9.70 & 0.56 & 1.7 & 3 \\
\hline $8 / 24 / 1995$ & 139.30 & 1.30 & 1.30 & 9.00 & 0.51 & 1.7 & 3 \\
\hline 9/27/1995 & 576.30 & 0.30 & 25.00 & 2.60 & 0.13 & 1.7 & 3 \\
\hline 10/26/1995 & 462.30 & 1.50 & 8.30 & 4.90 & 0.58 & 1.7 & 3 \\
\hline 11/27/1995 & 196.30 & 0.90 & 3.00 & 5.70 & 0.33 & 1.7 & 3 \\
\hline 1/23/1996 & 351.50 & 0.80 & 10.80 & 4.40 & 0.22 & 1.7 & 4 \\
\hline 2/22/1996 & 432.30 & 1.20 & 12.00 & 5.60 & 0.45 & 1.7 & 4 \\
\hline 3/21/1996 & 318.30 & 0.40 & 6.00 & 4.80 & 0.15 & 1.7 & 4 \\
\hline $4 / 30 / 1996$ & 266.00 & 0.40 & 0.50 & 5.90 & 0.16 & 1.7 & 4 \\
\hline 5/17/1996 & 209.00 & 0.70 & 0.00 & 8.50 & 0.25 & 1.7 & 4 \\
\hline 7/17/1996 & 190.00 & 1.60 & 0.00 & 10.00 & 0.59 & 1.7 & 4 \\
\hline $8 / 29 / 1996$ & 228.00 & 2.10 & 4.50 & 8.10 & 0.81 & 1.7 & 4 \\
\hline 9/12/1996 & 793.30 & 3.40 & 24.50 & 5.30 & 1.28 & 1.7 & 4 \\
\hline 10/10/1996 & 223.30 & 1.60 & 5.80 & 6.90 & 0.63 & 1.7 & 4 \\
\hline 11/15/1996 & 1752.80 & 1.50 & 81.50 & 2.80 & 0.83 & 1.7 & 4 \\
\hline 12/11/1996 & 1434.50 & 2.60 & 57.80 & 3.30 & 0.66 & 1.7 & 4 \\
\hline 1/21/1997 & 37.06 & 0.27 & 79.00 & 1.95 & 0.07 & 1.7 & 4 \\
\hline 2/23/1997 & 48.01 & 0.50 & 63.00 & 2.53 & 0.19 & 1.7 & 4 \\
\hline $3 / 25 / 1997$ & 53.66 & 0.37 & 37.50 & 2.82 & 0.14 & 1.7 & 4 \\
\hline 4/22/1997 & 83.06 & 0.34 & 6.00 & 4.37 & 0.13 & 1.7 & 4 \\
\hline
\end{tabular}




\begin{tabular}{|c|c|c|c|c|c|c|c|}
\hline \multicolumn{8}{|c|}{ Appendix 10. Station D7 Potamocorbula Data } \\
\hline Date & $\begin{array}{l}\text { Total \# of } \\
\text { clams in } \\
\text { sample } \\
\left(\# / \mathrm{m}^{2}\right)\end{array}$ & $\begin{array}{c}\text { biomass } \\
\left(\mathrm{g} / \mathrm{m}^{2}\right)\end{array}$ & $\begin{array}{c}\mathrm{rec} / \\
0.05 \mathrm{~m}^{2}\end{array}$ & $\begin{array}{l}\text { mean size } \\
(\mathrm{mm})\end{array}$ & $\begin{array}{c}\text { GR } \\
\left(\mathrm{m}^{3} / \mathrm{m}^{2} / \mathrm{d}\right)\end{array}$ & Depth (M) & \# Grabs \\
\hline $5 / 21 / 1997$ & 87.77 & 0.89 & 14.50 & 4.62 & 0.33 & 1.7 & 4 \\
\hline 6/18/1997 & 94.40 & 2.77 & 21.25 & 4.97 & 1.00 & 1.7 & 4 \\
\hline $7 / 22 / 1997$ & 126.33 & 3.13 & 1.00 & 6.65 & 1.14 & 1.7 & 4 \\
\hline $8 / 19 / 1997$ & 141.79 & 4.72 & 4.75 & 7.46 & 1.69 & 1.7 & 4 \\
\hline 9/16/1997 & 124.60 & 6.06 & 17.00 & 6.56 & 2.16 & 1.7 & 4 \\
\hline 10/28/1997 & 93.84 & 10.72 & 99.00 & 4.94 & 3.34 & 1.7 & 4 \\
\hline 11/18/1997 & 98.61 & 7.15 & 48.33 & 5.19 & 1.72 & 1.7 & 4 \\
\hline 12/14/1997 & 105.64 & 9.73 & 77.00 & 5.56 & 3.32 & 1.7 & 4 \\
\hline 1/12/1998 & 1187.50 & 1.67 & 36.25 & 3.72 & 0.42 & 1.7 & 4 \\
\hline 2/17/1998 & 907.25 & 0.52 & 33.00 & 3.05 & 0.19 & 1.7 & 4 \\
\hline $3 / 16 / 1998$ & 593.75 & 0.27 & 18.00 & 3.16 & 0.10 & 1.7 & 4 \\
\hline 4/13/1998 & 532.00 & 0.27 & 11.25 & 3.58 & 0.10 & 1.7 & 4 \\
\hline $5 / 12 / 1998$ & 356.25 & 0.28 & 1.75 & 5.07 & 0.11 & 1.7 & 4 \\
\hline 6/8/1998 & 342.00 & 0.61 & 0.75 & 2.86 & 0.23 & 1.7 & 4 \\
\hline $7 / 8 / 1998$ & 335.67 & 1.35 & 0.00 & 6.52 & 0.51 & 1.7 & 4 \\
\hline $8 / 3 / 1998$ & 152.00 & 1.05 & 0.00 & 9.34 & 0.40 & 1.7 & 4 \\
\hline 9/16/1998 & 323.00 & 1.87 & 8.50 & 6.54 & 0.71 & 1.7 & 4 \\
\hline 10/6/1998 & 175.75 & 1.22 & 1.75 & 7.61 & 0.42 & 1.7 & 4 \\
\hline $11 / 3 / 1998$ & 266.00 & 0.93 & 9.25 & 4.57 & 0.36 & 1.7 & 4 \\
\hline 12/21/1998 & 304.00 & 0.38 & 12.00 & 3.38 & 0.10 & 1.7 & 4 \\
\hline 1/13/1999 & 812.30 & 0.20 & 32.50 & 2.40 & 0.06 & 1.7 & 4 \\
\hline 2/17/1999 & 266.00 & 0.30 & 9.50 & 3.00 & 0.07 & 1.7 & 4 \\
\hline 3/16/1999 & 166.30 & 0.00 & 4.50 & 3.00 & 0.01 & 1.7 & 4 \\
\hline 4/14/1999 & 204.30 & 0.10 & 4.00 & 3.80 & 0.05 & 1.7 & 4 \\
\hline 5/18/1999 & 95.00 & 0.50 & 0.00 & 6.50 & 0.20 & 1.7 & 4 \\
\hline 6/14/1999 & 76.00 & 0.30 & 1.30 & 6.10 & 0.11 & 1.7 & 4 \\
\hline 7/13/1999 & 522.50 & 1.60 & 16.00 & 4.50 & 0.60 & 1.7 & 4 \\
\hline 8/11/1999 & 5353.30 & 3.30 & 160.50 & 3.20 & 1.14 & 1.7 & 4 \\
\hline 9/22/1999 & 3562.50 & 3.70 & 97.80 & 3.70 & 1.29 & 1.7 & 4 \\
\hline 10/27/1999 & 6517.00 & 8.12 & 159.80 & 3.80 & 2.25 & 1.7 & 4 \\
\hline 11/9/1999 & 3819.00 & 5.30 & 84.80 & 4.10 & 1.84 & 1.7 & 4 \\
\hline 12/8/1999 & 1334.80 & 1.30 & 10.00 & 4.40 & 0.33 & 1.7 & 4 \\
\hline $1 / 5 / 2000$ & 3147.70 & 2.80 & 70.00 & 3.70 & 0.68 & 1.7 & 4 \\
\hline $2 / 23 / 2000$ & 1190.70 & 0.40 & 45.30 & 2.60 & 0.17 & 1.7 & 4 \\
\hline $3 / 22 / 2000$ & 1000.70 & 0.70 & 36.70 & 2.90 & 0.25 & 1.7 & 4 \\
\hline $4 / 19 / 2000$ & 525.70 & 1.10 & 3.00 & 4.70 & 0.41 & 1.7 & 4 \\
\hline $5 / 16 / 2000$ & 690.30 & 1.30 & 14.70 & 4.10 & 0.48 & 1.7 & 4 \\
\hline $6 / 14 / 2000$ & 918.30 & 1.90 & 8.30 & 5.30 & 0.72 & 1.7 & 4 \\
\hline
\end{tabular}




\begin{tabular}{|c|c|c|c|c|c|c|c|}
\hline \multicolumn{8}{|c|}{ Appendix 10. Station D7 Potamocorbula Data } \\
\hline Date & $\begin{array}{l}\text { Total \# of } \\
\text { clams in } \\
\text { sample } \\
\left(\# / \mathrm{m}^{2}\right)\end{array}$ & $\begin{array}{c}\text { biomass } \\
\left(\mathrm{g} / \mathrm{m}^{2}\right)\end{array}$ & $\begin{array}{c}\mathrm{rec} / \\
0.05 \mathrm{~m}^{2}\end{array}$ & $\begin{array}{l}\text { mean size } \\
(\mathrm{mm})\end{array}$ & $\begin{array}{c}\text { GR } \\
\left(\mathrm{m}^{3} / \mathrm{m}^{2} / \mathrm{d}\right)\end{array}$ & Depth (M) & \# Grabs \\
\hline $7 / 17 / 2000$ & 836.00 & 1.40 & 6.30 & 5.40 & 0.53 & 1.7 & 4 \\
\hline $8 / 16 / 2000$ & 1184.30 & 2.90 & 4.00 & 6.30 & 1.05 & 1.7 & 4 \\
\hline $9 / 13 / 2000$ & 1171.70 & 3.60 & 4.00 & 6.60 & 1.31 & 1.7 & 4 \\
\hline $10 / 10 / 2000$ & 532.00 & 3.20 & 1.30 & 7.90 & 0.88 & 1.7 & 4 \\
\hline $11 / 15 / 2000$ & 969.00 & 5.40 & 6.70 & 7.10 & 1.98 & 1.7 & 4 \\
\hline $12 / 13 / 2000$ & 1057.70 & 3.40 & 26.30 & 4.70 & 0.86 & 1.7 & 4 \\
\hline $1 / 11 / 2001$ & 1469.30 & 1.90 & 57.00 & 3.20 & 0.48 & 1.7 & 4 \\
\hline 2/7/2001 & 2166.00 & 2.60 & 91.70 & 3.10 & 0.65 & 1.7 & 4 \\
\hline $3 / 7 / 2001$ & 1190.70 & 0.80 & 45.70 & 3.00 & 0.32 & 1.7 & 4 \\
\hline 4/4/2001 & 734.70 & 0.80 & 19.00 & 3.70 & 0.31 & 1.7 & 4 \\
\hline $5 / 9 / 2001$ & 2413.00 & 1.20 & 93.00 & 2.40 & 0.43 & 1.7 & 4 \\
\hline $6 / 5 / 2001$ & 5054.00 & 2.40 & 204.70 & 2.80 & 0.86 & 1.7 & 4 \\
\hline $7 / 24 / 2001$ & 2653.70 & 8.40 & 2.30 & 7.00 & 2.92 & 1.7 & 4 \\
\hline $8 / 22 / 2001$ & 3014.70 & 5.90 & 10.70 & 5.60 & 2.08 & 1.7 & 4 \\
\hline $9 / 18 / 2001$ & 3578.30 & 8.10 & 13.70 & 5.90 & 2.80 & 1.7 & 4 \\
\hline $10 / 16 / 2001$ & 3382.00 & 8.45 & 11.00 & 6.20 & 2.98 & 1.7 & 4 \\
\hline $11 / 19 / 2001$ & 3458.00 & 10.90 & 25.00 & 6.30 & 3.73 & 1.7 & 4 \\
\hline $12 / 11 / 2001$ & 2058.30 & 0.80 & 72.00 & 2.70 & 0.31 & 1.7 & 4 \\
\hline $1 / 15 / 2002$ & 1722.70 & 1.40 & 62.00 & 2.80 & 0.51 & 1.7 & 4 \\
\hline $2 / 14 / 2002$ & 912.00 & 0.80 & 32.30 & 3.00 & 0.21 & 1.7 & 4 \\
\hline $3 / 2 / 2002$ & 373.70 & 0.40 & 7.70 & 3.70 & 0.14 & 1.7 & 4 \\
\hline $4 / 15 / 2002$ & 614.30 & 0.60 & 6.70 & 3.80 & 0.23 & 1.7 & 4 \\
\hline $5 / 13 / 2002$ & 2539.70 & 0.60 & 121.70 & 2.10 & 0.24 & 1.7 & 4 \\
\hline $6 / 10 / 2002$ & 5301.00 & 1.90 & 199.00 & 2.70 & 0.69 & 1.7 & 4 \\
\hline $7 / 7 / 2002$ & 3920.30 & 3.50 & 100.30 & 3.50 & 1.24 & 1.7 & 4 \\
\hline $8 / 8 / 2002$ & 5871.00 & 6.60 & 104.30 & 4.20 & 2.25 & 1.7 & 4 \\
\hline 9/9/2002 & 4819.70 & 9.40 & 43.70 & 5.40 & 3.17 & 1.7 & 4 \\
\hline $10 / 23 / 2002$ & 4876.70 & 10.45 & 59.70 & 5.40 & 3.60 & 1.7 & 4 \\
\hline $11 / 5 / 2002$ & 5060.30 & 11.50 & 69.30 & 5.30 & 3.90 & 1.7 & 4 \\
\hline $12 / 4 / 2002$ & 3508.70 & 3.30 & 104.00 & 3.40 & 1.19 & 1.7 & 4 \\
\hline $1 / 21 / 2003$ & 1615.00 & 2.10 & $N / D$ & N/D & 0.54 & 1.7 & 4 \\
\hline $2 / 18 / 2003$ & 1410.80 & 1.10 & $N / D$ & N/D & 0.43 & 1.7 & 4 \\
\hline $3 / 18 / 2003$ & 937.30 & 0.80 & $\mathrm{~N} / \mathrm{D}$ & N/D & 0.31 & 1.7 & 4 \\
\hline $4 / 16 / 2003$ & 883.50 & 0.90 & $N / D$ & N/D & 0.32 & 1.7 & 4 \\
\hline $5 / 14 / 2003$ & 5543.30 & 2.60 & N/D & N/D & 0.79 & 1.7 & 4 \\
\hline $6 / 1 / 2003$ & 10521.30 & 3.40 & $N / D$ & N/D & 0.84 & 1.7 & 4 \\
\hline $7 / 14 / 2003$ & 3405.00 & 4.00 & $N / D$ & N/D & 1.44 & 1.7 & 4 \\
\hline $8 / 13 / 2003$ & 3400.00 & 4.80 & $N / D$ & $N / D$ & 1.72 & 1.7 & 4 \\
\hline
\end{tabular}




\begin{tabular}{|c|c|c|c|c|c|c|c|}
\hline \multicolumn{8}{|c|}{ Appendix 10. Station D7 Potamocorbula Data } \\
\hline Date & $\begin{array}{l}\text { Total \# of } \\
\text { clams in } \\
\text { sample } \\
\left(\# / \mathrm{m}^{2}\right)\end{array}$ & $\begin{array}{c}\text { biomass } \\
\left(\mathrm{g} / \mathrm{m}^{2}\right)\end{array}$ & $\begin{array}{c}\mathrm{rec} / \\
0.05 \mathrm{~m}^{2}\end{array}$ & $\begin{array}{l}\text { mean size } \\
(\mathrm{mm})\end{array}$ & $\begin{array}{c}\text { GR } \\
\left(\mathrm{m}^{3} / \mathrm{m}^{2} / \mathrm{d}\right)\end{array}$ & Depth (M) & \# Grabs \\
\hline $9 / 18 / 2003$ & 3395.00 & 6.60 & $\mathrm{~N} / \mathrm{D}$ & N/D & 2.35 & 1.7 & 4 \\
\hline $10 / 23 / 2003$ & 6530.00 & 11.80 & $\mathrm{~N} / \mathrm{D}$ & N/D & 3.95 & 1.7 & 4 \\
\hline $1 / 8 / 2004$ & 2147.00 & 2.90 & $\mathrm{~N} / \mathrm{D}$ & N/D & 0.69 & 1.7 & 4 \\
\hline $4 / 7 / 2004$ & 868.00 & 0.70 & $N / D$ & $N / D$ & 0.26 & 1.7 & 4 \\
\hline $7 / 14 / 2004$ & 4294.00 & 3.70 & 90.00 & 4.00 & 1.30 & 1.7 & 4 \\
\hline 10/25/2002 & 3420.00 & 11.10 & 41.00 & 5.70 & 3.85 & 1.7 & 4 \\
\hline $1 / 10 / 2005$ & 1615.00 & 1.80 & 29.70 & 4.60 & 0.55 & 1.7 & 4 \\
\hline $4 / 5 / 2005$ & 950.00 & 0.40 & 35.70 & 2.80 & 0.23 & 1.7 & 4 \\
\hline $7 / 19 / 2005$ & 956.30 & 2.20 & 0.70 & 6.90 & 0.96 & 1.7 & 4 \\
\hline $10 / 12 / 2005$ & 5408.70 & 8.90 & 144.30 & 4.00 & 3.78 & 1.7 & 4 \\
\hline $11 / 6 / 2005$ & 4883.00 & 7.70 & 126.30 & 4.10 & 3.93 & 1.7 & 4 \\
\hline $12 / 4 / 2005$ & 3489.70 & 9.30 & 60.30 & 5.20 & 4.52 & 1.7 & 4 \\
\hline $1 / 11 / 2006$ & 1583.30 & 0.40 & 67.70 & 2.40 & 0.11 & 1.7 & 4 \\
\hline $2 / 8 / 2006$ & 291.30 & 0.10 & 13.00 & 2.70 & 0.02 & 1.7 & 4 \\
\hline $4 / 26 / 2006$ & 544.70 & 0.40 & 9.00 & 4.20 & 0.15 & 1.7 & 4 \\
\hline $5 / 25 / 2006$ & 266.00 & 0.90 & 0.00 & 7.00 & 0.36 & 1.7 & 4 \\
\hline $6 / 6 / 2006$ & 240.70 & 0.70 & 0.30 & 7.40 & 0.27 & 1.7 & 4 \\
\hline $7 / 10 / 2006$ & 367.30 & 2.90 & 0.00 & 9.50 & 1.09 & 1.7 & 4 \\
\hline $8 / 10 / 2006$ & 13439.30 & 3.30 & 656.00 & 1.90 & 1.08 & 1.7 & 4 \\
\hline $9 / 20 / 2006$ & 14427.30 & 4.20 & 631.70 & 2.40 & 1.33 & 1.7 & 4 \\
\hline $10 / 25 / 2006$ & 13091.00 & 5.30 & 364.70 & 3.20 & 1.65 & 1.7 & 4 \\
\hline $11 / 20 / 2006$ & 8752.70 & 7.10 & 233.70 & 3.40 & 2.31 & 1.7 & 4 \\
\hline $12 / 20 / 2006$ & 7156.70 & 8.10 & 173.30 & 3.80 & 2.63 & 1.7 & 4 \\
\hline $1 / 23 / 2007$ & 2786.70 & 1.40 & 78.00 & 3.40 & 0.35 & 1.7 & 4 \\
\hline $2 / 20 / 2007$ & 1969.70 & 0.80 & 55.70 & 3.40 & 0.30 & 1.7 & 4 \\
\hline $3 / 20 / 2007$ & 1254.00 & 0.50 & 33.70 & 3.50 & 0.18 & 1.7 & 4 \\
\hline $4 / 16 / 2007$ & 1241.30 & 0.90 & 17.00 & 4.20 & 0.34 & 1.7 & 4 \\
\hline $5 / 16 / 2007$ & 1672.00 & 0.60 & 45.00 & 3.20 & 0.24 & 1.7 & 4 \\
\hline $6 / 1 / 2007$ & 3863.30 & 1.30 & 141.30 & 2.70 & 0.47 & 1.7 & 4 \\
\hline $7 / 16 / 2007$ & 3914.00 & 2.30 & 137.30 & 3.40 & 0.80 & 1.7 & 4 \\
\hline $8 / 13 / 2007$ & 7954.70 & 3.50 & 282.70 & 2.80 & 1.16 & 1.7 & 4 \\
\hline $9 / 11 / 2007$ & 7137.70 & 5.80 & 200.70 & 3.60 & 1.93 & 1.7 & 4 \\
\hline $10 / 2 / 2007$ & 7530.30 & 7.02 & 170.70 & 3.90 & 2.63 & 1.7 & 4 \\
\hline $11 / 7 / 2007$ & 4477.70 & 4.40 & 84.30 & 4.10 & 1.52 & 1.7 & 4 \\
\hline $12 / 10 / 2007$ & 3356.70 & 1.60 & 91.00 & 3.30 & 0.38 & 1.7 & 4 \\
\hline $1 / 8 / 2008$ & 3002.00 & 1.20 & 95.00 & 3.00 & 0.28 & 1.7 & 4 \\
\hline $2 / 6 / 2008$ & 3576.80 & 0.90 & 129.30 & 2.60 & 0.33 & 1.7 & 4 \\
\hline $3 / 5 / 2008$ & 1551.70 & 0.30 & 61.00 & 2.30 & 0.10 & 1.7 & 4 \\
\hline
\end{tabular}




\begin{tabular}{|c|c|c|c|c|c|c|c|}
\hline \multicolumn{8}{|c|}{ Appendix 10. Station D7 Potamocorbula Data } \\
\hline Date & $\begin{array}{l}\text { Total \# of } \\
\text { clams in } \\
\text { sample } \\
\left(\# / \mathrm{m}^{2}\right)\end{array}$ & $\begin{array}{c}\text { biomass } \\
\left(\mathrm{g} / \mathrm{m}^{2}\right)\end{array}$ & $\begin{array}{c}\mathrm{rec} / \\
0.05 \mathrm{~m}^{2}\end{array}$ & $\begin{array}{l}\text { mean size } \\
(\mathrm{mm})\end{array}$ & $\begin{array}{c}\text { GR } \\
\left(\mathrm{m}^{3} / \mathrm{m}^{2} / \mathrm{d}\right)\end{array}$ & Depth (M) & \# Grabs \\
\hline $4 / 2 / 2008$ & 1019.70 & 0.30 & 41.70 & 2.80 & 0.13 & 1.7 & 4 \\
\hline $5 / 19 / 2008$ & 9354.30 & 1.20 & 407.70 & 2.20 & 0.39 & 1.7 & 4 \\
\hline $6 / 17 / 2008$ & 17917.00 & 5.00 & 660.70 & 2.60 & 1.53 & 1.7 & 4 \\
\hline $7 / 14 / 2008$ & 15231.70 & 9.70 & 354.00 & 3.60 & 2.92 & 1.7 & 4 \\
\hline $8 / 13 / 2008$ & 13426.70 & 16.20 & 163.70 & 4.50 & 4.67 & 1.7 & 4 \\
\hline $9 / 15 / 2008$ & 14465.30 & 22.50 & 118.30 & 4.90 & 6.29 & 1.7 & 4 \\
\hline $10 / 27 / 2008$ & 14547.70 & 23.63 & 102.70 & 5.20 & 6.60 & 1.7 & 4 \\
\hline $11 / 18 / 2008$ & 9139.00 & 14.00 & 66.70 & 5.20 & 4.25 & 1.7 & 4 \\
\hline $12 / 10 / 2008$ & 4648.70 & 3.20 & 58.00 & 4.30 & 1.07 & 1.7 & 4 \\
\hline $1 / 12 / 2009$ & 2831.00 & 2.00 & 30.70 & 4.30 & 0.47 & 1.7 & 4 \\
\hline 2/9/2009 & 3078.00 & 2.20 & 66.30 & 3.60 & 0.79 & 1.7 & 4 \\
\hline $3 / 11 / 2009$ & 1665.70 & 0.50 & 50.00 & 3.10 & 0.17 & 1.7 & 4 \\
\hline $4 / 6 / 2009$ & 1602.30 & 1.40 & 39.00 & 3.50 & 0.52 & 1.7 & 4 \\
\hline $5 / 4 / 2009$ & 717.30 & 0.40 & 8.80 & 4.10 & 0.14 & 1.7 & 4 \\
\hline $6 / 24 / 2009$ & 26568.30 & 4.50 & 1301.70 & 2.00 & 1.33 & 1.7 & 4 \\
\hline $7 / 21 / 2009$ & 24345.30 & 5.90 & 991.70 & 2.50 & 1.70 & 1.7 & 4 \\
\hline $8 / 18 / 2009$ & 15067.00 & 7.80 & 350.00 & 3.30 & 2.37 & 1.7 & 4 \\
\hline $9 / 16 / 2009$ & 17530.70 & 11.70 & 343.00 & 3.70 & 3.31 & 1.7 & 4 \\
\hline $10 / 19 / 2009$ & 13675.30 & 5.89 & 356.80 & 3.50 & 1.87 & 1.7 & 4 \\
\hline $11 / 16 / 2009$ & 7517.70 & 3.40 & 209.00 & 3.20 & 1.14 & 1.7 & 4 \\
\hline $12 / 16 / 2009$ & 4085.00 & 1.40 & 103.70 & 3.40 & 0.33 & 1.7 & 4 \\
\hline $1 / 14 / 2010$ & 4370.00 & 1.60 & 110.30 & 3.50 & 0.38 & 1.7 & 4 \\
\hline $2 / 18 / 2010$ & 1159.00 & 0.30 & 24.70 & 3.70 & 0.13 & 1.7 & 4 \\
\hline $3 / 15 / 2010$ & 760.00 & 0.30 & 19.70 & 3.40 & 0.11 & 1.7 & 4 \\
\hline $4 / 12 / 2010$ & 500.30 & 0.40 & 10.70 & 3.90 & 0.16 & 1.7 & 4 \\
\hline $5 / 18 / 2010$ & 6694.30 & 1.20 & 320.00 & 2.30 & 0.43 & 1.7 & 4 \\
\hline $6 / 9 / 2010$ & 7967.30 & 3.40 & 237.30 & 3.00 & 1.12 & 1.7 & 4 \\
\hline $7 / 6 / 2010$ & 9082.00 & 4.40 & 238.00 & 3.40 & 1.41 & 1.7 & 4 \\
\hline $8 / 17 / 2010$ & 7695.00 & 6.10 & 114.00 & 4.30 & 1.94 & 1.7 & 4 \\
\hline 9/7/2010 & 7821.70 & 8.10 & 91.30 & 4.70 & 2.55 & 1.7 & 4 \\
\hline $10 / 25 / 2010$ & 6184.50 & 19.11 & 27.00 & 6.50 & 4.81 & 1.7 & 4 \\
\hline $11 / 22 / 2010$ & 6225.70 & 18.10 & 41.30 & 6.40 & 5.63 & 1.7 & 4 \\
\hline $12 / 20 / 2010$ & 2894.30 & 3.40 & 35.00 & 5.00 & 1.17 & 1.7 & 4 \\
\hline $1 / 19 / 2011$ & 962.70 & 0.90 & 11.70 & 4.80 & 0.23 & 1.7 & 4 \\
\hline $2 / 2 / 2011$ & 931.00 & 0.50 & 18.50 & 4.00 & 0.19 & 1.7 & 4 \\
\hline $3 / 8 / 2011$ & 487.70 & 0.40 & 4.70 & 4.40 & 0.14 & 1.7 & 4 \\
\hline $4 / 6 / 2011$ & 266.00 & 0.30 & 1.70 & 4.60 & 0.12 & 1.7 & 4 \\
\hline $5 / 2 / 2011$ & 313.50 & 0.40 & 0.50 & 5.50 & 0.15 & 1.7 & 4 \\
\hline
\end{tabular}




\begin{tabular}{|c|c|c|c|c|c|c|c|}
\hline \multicolumn{8}{|c|}{ Appendix 10. Station D7 Potamocorbula Data } \\
\hline Date & $\begin{array}{c}\text { Total \# of } \\
\text { clams in } \\
\text { sample } \\
\left(\# / \mathrm{m}^{2}\right)\end{array}$ & $\begin{array}{c}\text { biomass } \\
\left(\mathrm{g} / \mathrm{m}^{2}\right)\end{array}$ & $\begin{array}{c}\mathrm{rec} / \\
0.05 \mathrm{~m}^{2}\end{array}$ & $\begin{array}{c}\text { mean size } \\
(\mathrm{mm})\end{array}$ & $\begin{array}{c}\text { GR } \\
\left(\mathrm{m}^{3} / \mathrm{m}^{2} / \mathrm{d}\right)\end{array}$ & Depth (M) & \# Grabs \\
\hline $6 / 14 / 2011$ & 166.30 & 1.00 & 0.00 & 8.60 & 0.40 & 1.7 & 4 \\
\hline $7 / 13 / 2011$ & 137.80 & 1.20 & 0.00 & 10.50 & 0.46 & 1.7 & 4 \\
\hline $8 / 9 / 2011$ & 161.50 & 1.60 & 0.80 & 10.00 & 0.62 & 1.7 & 4 \\
\hline $9 / 7 / 2011$ & 3287.00 & 2.40 & 130.00 & 2.70 & 0.86 & 1.7 & 4 \\
\hline $10 / 3 / 2011$ & 5529.00 & 4.65 & 197.00 & 2.90 & 1.72 & 1.7 & 4 \\
\hline $11 / 8 / 2011$ & 3443.80 & 5.10 & 86.50 & 4.20 & 1.74 & 1.7 & 4 \\
\hline $12 / 7 / 2011$ & 1814.50 & 4.90 & 21.00 & 6.10 & 1.18 & 1.7 & 4 \\
\hline $1 / 9 / 2012$ & 3135.00 & 3.20 & 110.50 & 3.40 & 0.78 & 1.7 & 4 \\
\hline $2 / 8 / 2012$ & 4170.50 & 2.10 & 183.00 & 2.40 & 0.73 & 1.7 & 4 \\
\hline $3 / 6 / 2012$ & 3695.50 & 1.10 & 163.80 & 2.60 & 0.38 & 1.7 & 4 \\
\hline $4 / 5 / 2012$ & 2085.30 & 0.80 & 88.80 & 2.60 & 0.29 & 1.7 & 4 \\
\hline $5 / 21 / 2012$ & 869.30 & 0.70 & 12.80 & 4.10 & 0.27 & 1.7 & 4 \\
\hline $6 / 20 / 2012$ & 3771.50 & 2.20 & 159.30 & 2.60 & 0.77 & 1.7 & 4 \\
\hline $7 / 17 / 2012$ & 5353.30 & 4.10 & 196.00 & 3.10 & 1.39 & 1.7 & 4 \\
\hline $8 / 15 / 2012$ & 4659.80 & 4.60 & 107.50 & 3.80 & 1.58 & 1.7 & 4 \\
\hline $9 / 25 / 2012$ & 4545.80 & 6.10 & 67.00 & 4.60 & 2.03 & 1.7 & 4 \\
\hline $10 / 24 / 2012$ & 3310.80 & 4.74 & 38.00 & 5.10 & 1.60 & 1.7 & 4 \\
\hline $11 / 14 / 2012$ & 4227.50 & 7.10 & 27.00 & 5.50 & 2.37 & 1.7 & 4 \\
\hline $12 / 18 / 2012$ & 1581.80 & 1.60 & 20.00 & 4.40 & 0.58 & 1.7 & 4 \\
\hline $1 / 9 / 2013$ & 916.80 & 0.40 & 18.50 & 3.60 & 0.09 & 1.7 & 4 \\
\hline $2 / 5 / 2013$ & 584.30 & 0.20 & 16.00 & 3.30 & 0.08 & 1.7 & 4 \\
\hline $3 / 13 / 2013$ & 261.30 & 0.10 & 6.30 & 3.40 & 0.06 & 1.7 & 4 \\
\hline $4 / 10 / 2013$ & 161.50 & 0.20 & 0.30 & 5.10 & 0.09 & 1.7 & 4 \\
\hline $5 / 7 / 2013$ & 20011.80 & 1.10 & 1037.00 & 1.40 & 0.30 & 1.7 & 4 \\
\hline $6 / 4 / 2013$ & 16648.80 & 2.80 & 758.00 & 2.30 & 0.86 & 1.7 & 4 \\
\hline $7 / 8 / 2013$ & 11514.00 & 2.60 & 494.00 & 2.50 & 0.82 & 1.7 & 4 \\
\hline $9 / 4 / 2013$ & 12853.50 & 6.80 & 207.00 & 3.70 & 1.33 & 1.7 & 4 \\
\hline $10 / 15 / 2013$ & 12706.30 & 10.69 & 179.50 & 4.00 & 2.03 & 1.7 & 4 \\
\hline $11 / 19 / 2013$ & 4954.30 & 3.20 & 69.30 & 3.80 & 0.70 & 1.7 & 4 \\
\hline $12 / 16 / 2013$ & 3434.30 & 2.30 & 88.00 & 3.60 & 0.35 & 1.7 & 4 \\
\hline
\end{tabular}




\begin{tabular}{|c|c|c|c|c|c|c|c|}
\hline \multicolumn{8}{|c|}{ Appendix 11. Station D11 Corbicula Data } \\
\hline Date & $\begin{array}{l}\text { Total \# of } \\
\text { clams in } \\
\text { sample } \\
\left(\# / \mathrm{m}^{2}\right)\end{array}$ & $\begin{array}{c}\text { biomass } \\
\left(\mathrm{g} / \mathrm{m}^{2}\right)\end{array}$ & $\begin{array}{l}\text { recruit/ } \\
0.05 \mathrm{~m}^{2}\end{array}$ & $\begin{array}{c}\text { mean size } \\
(\mathrm{mm})\end{array}$ & $\begin{array}{c}\text { GR } \\
\left(\mathrm{m}^{3} / \mathrm{m}^{2} / \mathrm{d}\right)\end{array}$ & Depth (M) & \# Grabs \\
\hline $6 / 2 / 1977$ & 19.00 & 0.00 & 1.00 & 0.50 & 0.00 & 3 & 1 \\
\hline 10/11/1977 & 361.00 & 0.00 & 19.00 & 0.58 & 0.00 & 3 & 1 \\
\hline $6 / 8 / 1978$ & 95.00 & 0.01 & 5.00 & 1.90 & 0.00 & 3 & 1 \\
\hline $10 / 4 / 1978$ & 1957.00 & 0.01 & 103.00 & 0.62 & 0.00 & 3 & 1 \\
\hline $5 / 30 / 1979$ & 76.00 & 0.01 & 4.00 & 2.50 & 0.00 & 3 & 1 \\
\hline 9/17/1979 & 95.00 & 0.00 & 5.00 & 0.70 & 0.00 & 3 & 1 \\
\hline $6 / 11 / 1980$ & 152.00 & 0.02 & 7.00 & 2.50 & 0.00 & 3 & 1 \\
\hline $7 / 18 / 1980$ & 380.00 & 0.08 & 17.00 & 1.45 & 0.01 & 3 & 1 \\
\hline $8 / 22 / 1980$ & 57.00 & 0.05 & 1.00 & 4.17 & 0.01 & 3 & 1 \\
\hline 9/19/1980 & 342.00 & 0.02 & 17.00 & 0.94 & 0.00 & 3 & 1 \\
\hline $10 / 23 / 1980$ & 912.00 & 0.01 & 48.00 & 0.79 & 0.00 & 3 & 1 \\
\hline $11 / 20 / 1980$ & 570.00 & 0.01 & 30.00 & 0.80 & 0.00 & 3 & 1 \\
\hline $12 / 22 / 1980$ & 418.00 & 0.01 & 22.00 & 0.82 & 0.00 & 3 & 1 \\
\hline $1 / 14 / 1981$ & 1292.00 & 0.02 & 67.00 & 1.03 & 0.00 & 3 & 1 \\
\hline 2/19/1981 & 1273.00 & 0.03 & 67.00 & 1.22 & 0.00 & 3 & 1 \\
\hline $3 / 30 / 1981$ & 1862.00 & 0.06 & 97.00 & 1.36 & 0.00 & 3 & 1 \\
\hline $4 / 16 / 1981$ & 1026.00 & 0.07 & 51.00 & 1.61 & 0.00 & 3 & 1 \\
\hline $5 / 15 / 1981$ & 1539.00 & 0.64 & 38.00 & 3.27 & 0.05 & 3 & 1 \\
\hline $6 / 12 / 1981$ & 209.00 & 0.08 & 6.00 & 2.59 & 0.01 & 3 & 1 \\
\hline $7 / 10 / 1981$ & 399.00 & 0.08 & 18.00 & 2.07 & 0.01 & 3 & 1 \\
\hline $8 / 26 / 1981$ & 798.00 & 0.03 & 41.00 & 1.45 & 0.00 & 3 & 1 \\
\hline $9 / 24 / 1981$ & 779.00 & 0.03 & 40.00 & 1.30 & 0.00 & 3 & 1 \\
\hline $10 / 13 / 1981$ & 608.00 & 0.07 & 29.00 & 1.59 & 0.01 & 3 & 1 \\
\hline $11 / 20 / 1981$ & 874.00 & 0.03 & 46.00 & 1.37 & 0.00 & 3 & 1 \\
\hline $12 / 11 / 1981$ & 1691.00 & 0.09 & 87.00 & 1.15 & 0.00 & 3 & 1 \\
\hline $1 / 21 / 1982$ & 836.00 & 0.06 & 44.00 & 1.61 & 0.00 & 3 & 1 \\
\hline $2 / 22 / 1982$ & 1995.00 & 0.08 & 105.00 & 1.32 & 0.00 & 3 & 1 \\
\hline $3 / 30 / 1982$ & 475.00 & 0.06 & 22.00 & 2.06 & 0.00 & 3 & 1 \\
\hline $4 / 28 / 1982$ & 532.00 & 0.14 & 25.00 & 2.11 & 0.01 & 3 & 1 \\
\hline $5 / 20 / 1982$ & 760.00 & 0.18 & 32.00 & 2.33 & 0.01 & 3 & 1 \\
\hline $6 / 25 / 1982$ & 114.00 & 0.09 & 2.00 & 3.67 & 0.01 & 3 & 1 \\
\hline $7 / 22 / 1982$ & 133.00 & 0.02 & 5.00 & 2.36 & 0.00 & 3 & 1 \\
\hline $8 / 30 / 1982$ & 494.00 & 0.00 & 26.00 & 0.65 & 0.00 & 3 & 1 \\
\hline $9 / 20 / 1982$ & 741.00 & 0.02 & 39.00 & 0.76 & 0.00 & 3 & 1 \\
\hline $10 / 28 / 1982$ & 285.00 & 0.00 & 15.00 & 1.03 & 0.00 & 3 & 1 \\
\hline $11 / 24 / 1982$ & 1330.00 & 0.03 & 70.00 & 1.23 & 0.00 & 3 & 1 \\
\hline $12 / 15 / 1982$ & 494.00 & 0.01 & 26.00 & 1.08 & 0.00 & 3 & 1 \\
\hline 1/31/1983 & 1615.00 & 0.05 & 85.00 & 1.14 & 0.00 & 3 & 1 \\
\hline
\end{tabular}




\begin{tabular}{|c|c|c|c|c|c|c|c|}
\hline \multicolumn{8}{|c|}{ Appendix 11. Station D11 Corbicula Data } \\
\hline Date & $\begin{array}{l}\text { Total \# of } \\
\text { clams in } \\
\text { sample } \\
\left(\# / \mathrm{m}^{2}\right)\end{array}$ & $\begin{array}{c}\text { biomass } \\
\left(\mathrm{g} / \mathrm{m}^{2}\right)\end{array}$ & $\begin{array}{l}\text { recruit/ } \\
0.05 \mathrm{~m}^{2}\end{array}$ & $\begin{array}{c}\text { mean size } \\
(\mathrm{mm})\end{array}$ & $\begin{array}{c}\text { GR } \\
\left(\mathrm{m}^{3} / \mathrm{m}^{2} / \mathrm{d}\right)\end{array}$ & Depth (M) & \# Grabs \\
\hline $2 / 8 / 1983$ & 817.00 & 0.02 & 43.00 & 1.29 & 0.00 & 3 & 1 \\
\hline $3 / 8 / 1983$ & 722.00 & 0.04 & 38.00 & 1.42 & 0.00 & 3 & 1 \\
\hline $4 / 21 / 1983$ & 1729.00 & 0.54 & 74.00 & 1.97 & 0.02 & 3 & 1 \\
\hline $5 / 19 / 1983$ & 1425.00 & 0.34 & 61.00 & 2.31 & 0.02 & 3 & 1 \\
\hline $6 / 6 / 1983$ & 722.00 & 0.36 & 21.00 & 2.92 & 0.04 & 3 & 1 \\
\hline $7 / 5 / 1983$ & 323.00 & 0.11 & 9.00 & 3.03 & 0.01 & 3 & 1 \\
\hline 9/15/1983 & 399.00 & 0.11 & 18.00 & 1.69 & 0.01 & 3 & 1 \\
\hline $11 / 1 / 1983$ & 323.00 & 0.01 & 17.00 & 1.50 & 0.00 & 3 & 1 \\
\hline $11 / 30 / 1983$ & 1387.00 & 0.03 & 73.00 & 1.13 & 0.00 & 3 & 1 \\
\hline $12 / 13 / 1983$ & 817.00 & 0.02 & 43.00 & 1.34 & 0.00 & 3 & 1 \\
\hline $1 / 31 / 1984$ & 152.00 & 0.01 & 8.00 & 1.50 & 0.00 & 3 & 1 \\
\hline $2 / 27 / 1984$ & 1615.00 & 0.05 & 85.00 & 1.21 & 0.00 & 3 & 1 \\
\hline $3 / 26 / 1984$ & 2660.00 & 0.08 & 140.00 & 1.13 & 0.00 & 3 & 1 \\
\hline $4 / 24 / 1984$ & 1995.00 & 0.29 & 100.00 & 1.52 & 0.02 & 3 & 1 \\
\hline $5 / 24 / 1984$ & 589.00 & 0.13 & 24.00 & 2.27 & 0.01 & 3 & 1 \\
\hline $6 / 22 / 1984$ & 247.00 & 0.02 & 12.00 & 1.50 & 0.00 & 3 & 1 \\
\hline $7 / 23 / 1984$ & 228.00 & 0.02 & 11.00 & 1.67 & 0.00 & 3 & 1 \\
\hline $8 / 22 / 1984$ & 228.00 & 0.03 & 10.00 & 1.92 & 0.00 & 3 & 1 \\
\hline 9/18/1984 & 1729.00 & 0.12 & 91.00 & 1.18 & 0.01 & 3 & 1 \\
\hline $10 / 30 / 1984$ & 513.00 & 0.07 & 23.00 & 1.57 & 0.01 & 3 & 1 \\
\hline $11 / 29 / 1984$ & 266.00 & 0.01 & 14.00 & 1.07 & 0.00 & 3 & 1 \\
\hline $12 / 14 / 1984$ & 1178.00 & 0.03 & 62.00 & 1.10 & 0.00 & 3 & 1 \\
\hline $1 / 15 / 1985$ & 608.00 & 0.02 & 31.00 & 1.19 & 0.00 & 3 & 1 \\
\hline 2/26/1985 & 2071.00 & 0.07 & 108.00 & 1.20 & 0.00 & 3 & 1 \\
\hline $3 / 18 / 1985$ & 2603.00 & 0.07 & 136.00 & 1.09 & 0.00 & 3 & 1 \\
\hline 4/10/1985 & 2204.00 & 0.10 & 112.00 & 1.40 & 0.00 & 3 & 1 \\
\hline $5 / 31 / 1985$ & 475.00 & 0.03 & 23.00 & 1.66 & 0.00 & 3 & 1 \\
\hline $6 / 14 / 1985$ & 912.00 & 0.09 & 47.00 & 1.50 & 0.01 & 3 & 1 \\
\hline $8 / 30 / 1985$ & 722.00 & 0.07 & 36.00 & 1.37 & 0.01 & 3 & 1 \\
\hline $10 / 2 / 1985$ & 3971.00 & 0.07 & 207.00 & 0.73 & 0.01 & 3 & 1 \\
\hline $10 / 24 / 1985$ & 3287.00 & 0.44 & 172.00 & 0.89 & 0.03 & 3 & 1 \\
\hline $12 / 3 / 1985$ & 4142.00 & 0.14 & 214.00 & 0.79 & 0.01 & 3 & 1 \\
\hline $12 / 30 / 1985$ & 3420.00 & 0.12 & 178.00 & 0.91 & 0.00 & 3 & 1 \\
\hline 1/16/1986 & 1938.00 & 0.11 & 101.00 & 1.10 & 0.00 & 3 & 1 \\
\hline $2 / 6 / 1986$ & 1273.00 & 0.07 & 65.00 & 0.99 & 0.00 & 3 & 1 \\
\hline $3 / 31 / 1986$ & 817.00 & 0.12 & 38.00 & 1.87 & 0.01 & 3 & 1 \\
\hline 4/21/1986 & 361.00 & 0.03 & 18.00 & 1.82 & 0.00 & 3 & 1 \\
\hline $5 / 21 / 1986$ & 494.00 & 0.14 & 22.00 & 2.42 & 0.01 & 3 & 1 \\
\hline
\end{tabular}




\begin{tabular}{|c|c|c|c|c|c|c|c|}
\hline \multicolumn{8}{|c|}{ Appendix 11. Station D11 Corbicula Data } \\
\hline Date & $\begin{array}{l}\text { Total \# of } \\
\text { clams in } \\
\text { sample } \\
\left(\# / \mathrm{m}^{2}\right)\end{array}$ & $\begin{array}{c}\text { biomass } \\
\left(\mathrm{g} / \mathrm{m}^{2}\right)\end{array}$ & $\begin{array}{l}\text { recruit/ } \\
0.05 \mathrm{~m}^{2}\end{array}$ & $\begin{array}{c}\text { mean size } \\
(\mathrm{mm})\end{array}$ & $\begin{array}{c}\text { GR } \\
\left(\mathrm{m}^{3} / \mathrm{m}^{2} / \mathrm{d}\right)\end{array}$ & Depth (M) & \# Grabs \\
\hline $6 / 30 / 1986$ & 57.00 & 0.00 & 3.00 & 1.17 & 0.00 & 3 & 1 \\
\hline $7 / 25 / 1986$ & 342.00 & 0.01 & 18.00 & 1.44 & 0.00 & 3 & 1 \\
\hline $8 / 29 / 1986$ & 456.00 & 0.00 & 24.00 & 1.29 & 0.00 & 3 & 1 \\
\hline 9/12/1986 & 342.00 & 0.00 & 18.00 & 1.17 & 0.00 & 3 & 1 \\
\hline 10/29/1986 & 380.00 & 0.03 & 20.00 & 1.50 & 0.00 & 3 & 1 \\
\hline $11 / 14 / 1986$ & 266.00 & 0.01 & 14.00 & 1.29 & 0.00 & 3 & 1 \\
\hline $12 / 11 / 1986$ & 608.00 & 0.02 & 31.00 & 1.22 & 0.00 & 3 & 1 \\
\hline $1 / 23 / 1987$ & 228.00 & 0.01 & 12.00 & 1.67 & 0.00 & 3 & 1 \\
\hline 2/26/1987 & 304.00 & 0.02 & 15.00 & 1.69 & 0.00 & 3 & 1 \\
\hline $3 / 26 / 1987$ & 532.00 & 0.04 & 26.00 & 1.68 & 0.00 & 3 & 1 \\
\hline $4 / 24 / 1987$ & 893.00 & 0.10 & 41.00 & 1.84 & 0.01 & 3 & 1 \\
\hline $5 / 22 / 1987$ & 361.00 & 0.04 & 14.00 & 2.24 & 0.00 & 3 & 1 \\
\hline $6 / 9 / 1987$ & $\mathrm{~N} / \mathrm{D}$ & $\mathrm{N} / \mathrm{D}$ & $\mathrm{N} / \mathrm{D}$ & N/D & $N / D$ & $\mathrm{~N} / \mathrm{D}$ & $N / D$ \\
\hline $7 / 30 / 1987$ & 2109.00 & 0.02 & 111.00 & 1.09 & 0.00 & 3 & 1 \\
\hline $8 / 20 / 1987$ & 2109.00 & 0.08 & 111.00 & 1.11 & 0.01 & 3 & 1 \\
\hline 9/18/1987 & 2470.00 & 2.34 & 128.00 & 1.40 & 0.23 & 3 & 1 \\
\hline $10 / 30 / 1987$ & 2033.00 & 0.61 & 106.00 & 1.43 & 0.05 & 3 & 1 \\
\hline $11 / 9 / 1987$ & 1292.00 & 0.14 & 67.00 & 1.72 & 0.01 & 3 & 1 \\
\hline $12 / 17 / 1987$ & 1197.00 & 0.08 & 63.00 & 1.40 & 0.00 & 3 & 1 \\
\hline 1/15/1988 & 1330.00 & 0.06 & 70.00 & 1.40 & 0.00 & 3 & 1 \\
\hline 2/11/1988 & 456.00 & 0.03 & 24.00 & 1.42 & 0.00 & 3 & 1 \\
\hline 4/1/1988 & 462.00 & $\mathrm{~N} / \mathrm{D}$ & $N / D$ & $N / D$ & $N / D$ & N/D & $N / D$ \\
\hline $5 / 27 / 1988$ & 418.00 & 0.15 & 9.00 & 3.14 & 0.01 & 3 & 1 \\
\hline $6 / 24 / 1988$ & 342.00 & 0.10 & 11.00 & 2.67 & 0.01 & 3 & 1 \\
\hline $7 / 22 / 1988$ & 133.00 & 0.02 & 6.00 & 1.93 & 0.00 & 3 & 1 \\
\hline $8 / 22 / 1988$ & 1273.00 & 0.06 & 67.00 & 1.31 & 0.01 & 3 & 1 \\
\hline $9 / 22 / 1988$ & 304.00 & 0.11 & 16.00 & 1.50 & 0.01 & 3 & 1 \\
\hline $10 / 21 / 1988$ & 152.00 & 0.03 & 7.00 & 1.88 & 0.00 & 3 & 1 \\
\hline $11 / 17 / 1988$ & 399.00 & 0.05 & 21.00 & 1.40 & 0.00 & 3 & 1 \\
\hline $12 / 8 / 1988$ & 475.00 & 2.37 & 24.00 & 2.30 & 0.09 & 3 & 1 \\
\hline 1/20/1989 & 171.00 & 0.02 & 8.00 & 1.72 & 0.00 & 3 & 1 \\
\hline 2/6/1989 & 551.00 & 0.03 & 29.00 & 1.29 & 0.00 & 3 & 1 \\
\hline $5 / 4 / 1989$ & 266.00 & 0.05 & 9.00 & 2.43 & 0.00 & 3 & 1 \\
\hline 6/26/1989 & 89.00 & $\mathrm{~N} / \mathrm{D}$ & $N / D$ & $N / D$ & $\mathrm{~N} / \mathrm{D}$ & $\mathrm{N} / \mathrm{D}$ & $\mathrm{N} / \mathrm{D}$ \\
\hline $7 / 24 / 1989$ & 266.00 & N/D & $N / D$ & N/D & $N / D$ & N/D & $N / D$ \\
\hline $8 / 21 / 1989$ & 475.00 & $\mathrm{~N} / \mathrm{D}$ & $\mathrm{N} / \mathrm{D}$ & $N / D$ & $\mathrm{~N} / \mathrm{D}$ & $\mathrm{N} / \mathrm{D}$ & $\mathrm{N} / \mathrm{D}$ \\
\hline 9/19/1989 & 2166.00 & $\mathrm{~N} / \mathrm{D}$ & $N / D$ & N/D & $N / D$ & $N / D$ & $N / D$ \\
\hline 10/17/1989 & 3648.00 & 0.02 & 192.00 & 1.38 & 0.00 & 3 & 1 \\
\hline
\end{tabular}




\begin{tabular}{|c|c|c|c|c|c|c|c|}
\hline \multicolumn{8}{|c|}{ Appendix 11. Station D11 Corbicula Data } \\
\hline Date & $\begin{array}{l}\text { Total \# of } \\
\text { clams in } \\
\text { sample } \\
\left(\# / \mathrm{m}^{2}\right)\end{array}$ & $\begin{array}{c}\text { biomass } \\
\left(\mathrm{g} / \mathrm{m}^{2}\right)\end{array}$ & $\begin{array}{l}\text { recruit/ } \\
0.05 \mathrm{~m}^{2}\end{array}$ & $\begin{array}{c}\text { mean size } \\
(\mathrm{mm})\end{array}$ & $\begin{array}{c}\text { GR } \\
\left(\mathrm{m}^{3} / \mathrm{m}^{2} / \mathrm{d}\right)\end{array}$ & Depth (M) & \# Grabs \\
\hline 11/13/1989 & 513.00 & 1.22 & 24.00 & 2.91 & 0.08 & 3 & 1 \\
\hline 12/4/1989 & 4655.00 & 0.95 & 243.50 & 1.45 & 0.04 & 3 & 1 \\
\hline $1 / 16 / 1990$ & 4129.33 & 1.27 & 211.00 & 1.35 & 0.04 & 3 & 3 \\
\hline $2 / 27 / 1990$ & 1748.00 & 0.19 & 88.00 & 1.38 & 0.01 & 3 & 3 \\
\hline $3 / 19 / 1990$ & 2014.00 & 2.15 & 102.67 & 1.33 & 0.11 & 3 & 3 \\
\hline $4 / 20 / 1990$ & 2831.00 & 6.99 & 141.00 & 1.34 & 0.44 & 3 & 3 \\
\hline $5 / 14 / 1990$ & 3426.33 & 1.63 & 170.00 & 1.38 & 0.13 & 3 & 3 \\
\hline $6 / 26 / 1990$ & 1235.00 & 4.47 & 59.00 & 1.98 & 0.50 & 3 & 3 \\
\hline $7 / 12 / 1990$ & 1412.33 & 3.14 & 58.67 & 2.64 & 0.39 & 3 & 3 \\
\hline 8/8/1990 & 525.67 & 0.12 & 20.67 & 2.38 & 0.02 & 3 & 3 \\
\hline 9/24/1990 & 1570.67 & 0.95 & 79.33 & 1.41 & 0.11 & 3 & 3 \\
\hline 10/22/1990 & 4104.00 & 1.44 & 213.33 & 0.96 & 0.11 & 3 & 3 \\
\hline $11 / 6 / 1990$ & 3071.67 & 0.30 & 160.33 & 0.91 & 0.02 & 3 & 3 \\
\hline 12/13/1990 & 7498.67 & 2.31 & 387.33 & 1.29 & 0.07 & 3 & 3 \\
\hline 1/7/1991 & 7840.67 & 0.82 & 396.00 & 1.71 & 0.02 & 3 & 3 \\
\hline 2/21/1991 & 6878.00 & 1.30 & 358.67 & 1.36 & 0.05 & 3 & 3 \\
\hline 3/5/1991 & 5079.33 & 1.04 & 262.00 & 1.49 & 0.04 & 3 & 3 \\
\hline 4/11/1991 & 5883.67 & 0.54 & 301.33 & 1.41 & 0.03 & 3 & 3 \\
\hline $5 / 23 / 1991$ & 2805.67 & 5.52 & 129.00 & 2.36 & 0.38 & 3 & 3 \\
\hline 6/4/1991 & 2799.33 & 1.82 & 123.33 & 2.42 & 0.17 & 3 & 3 \\
\hline $7 / 16 / 1991$ & 1089.33 & 1.85 & 39.67 & 2.80 & 0.18 & 3 & 3 \\
\hline $8 / 30 / 1991$ & 411.67 & 2.83 & 8.00 & 4.32 & 0.28 & 3 & 3 \\
\hline 9/12/1991 & 532.00 & 1.02 & 22.67 & 2.11 & 0.12 & 3 & 3 \\
\hline 10/8/1991 & 829.67 & 1.91 & 37.00 & 2.55 & 0.19 & 3 & 3 \\
\hline 11/12/1991 & 139.33 & 1.52 & 3.00 & 6.59 & 0.07 & 3 & 3 \\
\hline 12/10/1991 & 1051.33 & 5.44 & 49.33 & 2.86 & 0.16 & 3 & 3 \\
\hline 1/17/1992 & 1482.00 & 3.68 & 70.33 & 2.06 & 0.10 & 3 & 3 \\
\hline $2 / 25 / 1992$ & 1475.67 & 3.10 & 75.00 & 1.92 & 0.14 & 3 & 3 \\
\hline $3 / 24 / 1992$ & 1254.00 & 3.94 & 61.00 & 2.01 & 0.22 & 3 & 3 \\
\hline 4/6/1992 & 1007.00 & 1.38 & 49.67 & 2.01 & 0.11 & 3 & 3 \\
\hline $5 / 14 / 1992$ & 557.33 & 4.36 & 19.67 & 3.73 & 0.44 & 3 & 3 \\
\hline $6 / 17 / 1992$ & 240.67 & 3.83 & 8.67 & 4.11 & 0.44 & 3 & 3 \\
\hline $7 / 10 / 1992$ & 196.33 & 1.25 & 8.67 & 3.05 & 0.16 & 3 & 3 \\
\hline $8 / 4 / 1992$ & 399.00 & 2.29 & 18.67 & 2.63 & 0.29 & 3 & 3 \\
\hline 9/1/1992 & 259.67 & 6.20 & 7.00 & 8.40 & 0.75 & 3 & 3 \\
\hline $10 / 23 / 1992$ & 133.00 & 7.79 & 0.67 & 15.88 & 0.66 & 3 & 3 \\
\hline 11/5/1992 & 76.00 & 2.64 & 0.67 & 13.50 & 0.21 & 3 & 3 \\
\hline $12 / 28 / 1992$ & 44.33 & 1.98 & 0.67 & 14.36 & 0.08 & 3 & 3 \\
\hline
\end{tabular}




\begin{tabular}{|c|c|c|c|c|c|c|c|}
\hline \multicolumn{8}{|c|}{ Appendix 11. Station D11 Corbicula Data } \\
\hline Date & $\begin{array}{l}\text { Total \# of } \\
\text { clams in } \\
\text { sample } \\
\left(\# / \mathrm{m}^{2}\right)\end{array}$ & $\begin{array}{c}\text { biomass } \\
\left(\mathrm{g} / \mathrm{m}^{2}\right)\end{array}$ & $\begin{array}{l}\text { recruit/ } \\
0.05 \mathrm{~m}^{2}\end{array}$ & $\begin{array}{l}\text { mean size } \\
(\mathrm{mm})\end{array}$ & $\begin{array}{c}\text { GR } \\
\left(\mathrm{m}^{3} / \mathrm{m}^{2} / \mathrm{d}\right)\end{array}$ & Depth (M) & \# Grabs \\
\hline 1/14/1993 & 63.33 & 2.12 & 0.67 & 13.20 & 0.06 & 3 & 3 \\
\hline 2/9/1993 & 107.67 & 4.03 & 2.00 & 12.79 & 0.13 & 3 & 3 \\
\hline 3/11/1993 & 82.33 & 1.87 & 3.00 & 6.58 & 0.12 & 3 & 3 \\
\hline 4/19/1993 & 76.00 & 5.83 & 0.67 & 15.58 & 0.29 & 3 & 3 \\
\hline $5 / 20 / 1993$ & 114.00 & 9.88 & 1.33 & 15.00 & 0.76 & 3 & 3 \\
\hline $6 / 16 / 1993$ & 114.00 & 4.78 & 2.00 & 8.67 & 0.48 & 3 & 3 \\
\hline $7 / 19 / 1993$ & 126.67 & 7.51 & 2.00 & 11.80 & 0.82 & 3 & 3 \\
\hline $8 / 19 / 1993$ & 601.67 & 6.31 & 28.67 & 2.98 & 0.71 & 3 & 3 \\
\hline 9/16/1993 & 164.67 & 8.39 & 4.33 & 10.00 & 0.91 & 3 & 3 \\
\hline 10/8/1993 & 126.67 & 2.88 & 4.33 & 6.55 & 0.26 & 3 & 3 \\
\hline $11 / 16 / 1993$ & 101.33 & 3.58 & 3.00 & 9.44 & 0.23 & 3 & 3 \\
\hline 12/9/1993 & 126.67 & 10.27 & 1.67 & 15.65 & 0.32 & 3 & 3 \\
\hline 1/18/1994 & 88.67 & 4.07 & 3.67 & 6.50 & 0.12 & 3 & 3 \\
\hline 2/8/1994 & 145.67 & 11.36 & 2.33 & 14.20 & 0.35 & 3 & 3 \\
\hline 3/9/1994 & 145.67 & 4.37 & 5.00 & 7.41 & 0.25 & 3 & 3 \\
\hline $4 / 12 / 1994$ & 823.33 & 7.14 & 39.67 & 3.04 & 0.20 & 3 & 3 \\
\hline $5 / 23 / 1994$ & 1437.67 & 9.32 & 66.67 & 2.61 & 0.66 & 3 & 3 \\
\hline 6/9/1994 & 3489.67 & 3.75 & 174.33 & 1.57 & 0.37 & 3 & 3 \\
\hline $7 / 20 / 1994$ & 1608.67 & 8.72 & 76.67 & 2.36 & 0.85 & 3 & 3 \\
\hline 8/9/1994 & 437.00 & 5.19 & 18.00 & 4.25 & 0.72 & 3 & 3 \\
\hline 9/21/1994 & 817.00 & 2.05 & 35.33 & 2.47 & 0.23 & 3 & 3 \\
\hline 10/19/1994 & 2609.33 & 5.30 & 115.67 & 2.05 & 0.36 & 3 & 3 \\
\hline $11 / 21 / 1994$ & 1906.33 & 5.72 & 86.67 & 2.44 & 0.20 & 3 & 3 \\
\hline 12/16/1994 & 4313.00 & 6.91 & 207.00 & 1.96 & 0.18 & 3 & 3 \\
\hline 1/17/1995 & 1513.67 & 6.81 & 66.33 & 2.44 & 0.22 & 3 & 3 \\
\hline 2/15/1995 & 1418.67 & 1.29 & 63.67 & 1.89 & 0.05 & 3 & 3 \\
\hline $3 / 15 / 1995$ & 760.00 & 5.99 & 36.67 & 2.78 & 0.25 & 3 & 3 \\
\hline 4/27/1995 & 1463.00 & 12.69 & 47.00 & 3.64 & 0.63 & 3 & 3 \\
\hline $5 / 17 / 1995$ & 1235.00 & 21.08 & 25.67 & 5.04 & 1.00 & 3 & 3 \\
\hline 6/27/1995 & 924.67 & 15.16 & 1.33 & 6.99 & 1.36 & 3 & 3 \\
\hline $7 / 13 / 1995$ & 804.33 & 9.25 & 0.67 & 7.54 & 0.84 & 3 & 3 \\
\hline $8 / 24 / 1995$ & 905.67 & 16.48 & 11.33 & 7.84 & 2.06 & 3 & 3 \\
\hline 9/26/1995 & 1083.00 & 13.18 & 25.33 & 6.72 & 1.33 & 3 & 3 \\
\hline 10/25/1995 & 1102.00 & 13.84 & 22.67 & 7.21 & 0.98 & 3 & 3 \\
\hline 11/27/1995 & 956.33 & 13.71 & 8.33 & 9.29 & 0.75 & 3 & 3 \\
\hline 12/27/1995 & 829.67 & 12.65 & 12.67 & 8.35 & 0.41 & 3 & 3 \\
\hline
\end{tabular}




\begin{tabular}{|c|c|c|c|c|c|c|c|}
\hline \multicolumn{8}{|c|}{ Appendix 12. Station D11 Potamocorbula Data } \\
\hline Date & $\begin{array}{l}\text { Total \# of } \\
\text { clams in } \\
\text { sample } \\
\left(\# / \mathrm{m}^{2}\right)\end{array}$ & $\begin{array}{c}\text { biomass } \\
\left(\mathrm{g} / \mathrm{m}^{2}\right)\end{array}$ & $\begin{array}{c}\mathrm{rec} / \\
0.05 \mathrm{~m}^{2}\end{array}$ & $\begin{array}{c}\text { mean size } \\
(\mathrm{mm})\end{array}$ & $\begin{array}{c}\text { GR } \\
\left(\mathrm{m}^{3} / \mathrm{m}^{2} / \mathrm{d}\right)\end{array}$ & Depth (M) & \# Grabs \\
\hline 6/9/1987 & $\mathrm{N} / \mathrm{D}$ & $\mathrm{N} / \mathrm{D}$ & N/D & $\mathrm{N} / \mathrm{D}$ & $\mathrm{N} / \mathrm{D}$ & $\mathrm{N} / \mathrm{D}$ & $\mathrm{N} / \mathrm{D}$ \\
\hline $7 / 30 / 1987$ & 38.00 & 0.01 & 0.00 & 2.50 & 0.00 & 3 & 1 \\
\hline $8 / 20 / 1987$ & 0.00 & 0.00 & 0.00 & $\mathrm{~N} / \mathrm{D}$ & 0.00 & 3 & 1 \\
\hline 9/18/1987 & 114.00 & 0.01 & 0.00 & 2.30 & 0.00 & 3 & 1 \\
\hline $10 / 30 / 1987$ & 19.00 & 0.00 & 0.00 & 1.50 & 0.00 & 3 & 1 \\
\hline $11 / 9 / 1987$ & 171.00 & 0.05 & 0.00 & 2.90 & 0.02 & 3 & 1 \\
\hline $12 / 17 / 1987$ & 19.00 & 0.00 & 0.00 & 2.50 & 0.00 & 3 & 1 \\
\hline 1/15/1988 & 19.00 & 0.00 & 0.00 & 2.00 & 0.00 & 3 & 1 \\
\hline 2/11/1988 & 19.00 & 0.00 & 0.00 & 2.50 & 0.00 & 3 & 1 \\
\hline 4/1/1988 & 0.00 & 0.00 & 0.00 & 0.00 & 0.00 & 3 & 1 \\
\hline $5 / 27 / 1988$ & 0.00 & 0.00 & 0.00 & 0.00 & 0.00 & 3 & 1 \\
\hline $6 / 24 / 1988$ & 0.00 & 0.00 & 0.00 & 0.00 & 0.00 & 3 & 1 \\
\hline $7 / 22 / 1988$ & 0.00 & 0.00 & 0.00 & 0.00 & 0.00 & 3 & 1 \\
\hline $8 / 22 / 1988$ & 19.00 & 0.00 & 0.00 & 1.50 & 0.00 & 3 & 1 \\
\hline $9 / 22 / 1988$ & 0.00 & 0.00 & 0.00 & 0.00 & 0.00 & 3 & 1 \\
\hline $10 / 21 / 1988$ & 19.00 & 0.00 & 0.00 & 1.50 & 0.00 & 3 & 1 \\
\hline $11 / 17 / 1988$ & 0.00 & 0.00 & 0.00 & 0.00 & 0.00 & 3 & 1 \\
\hline $12 / 8 / 1988$ & 0.00 & 0.00 & 0.00 & 0.00 & 0.00 & 3 & 1 \\
\hline $1 / 20 / 1989$ & 0.00 & 0.00 & 0.00 & 0.00 & 0.00 & 3 & 1 \\
\hline 2/6/1989 & 0.00 & 0.00 & 0.00 & 0.00 & 0.00 & 3 & 1 \\
\hline 2/28/1989 & 0.00 & 0.00 & 0.00 & 0.00 & 0.00 & 3 & 1 \\
\hline 3/21/1989 & 0.00 & 0.00 & 0.00 & 0.00 & 0.00 & 3 & 1 \\
\hline 5/4/1989 & 19.00 & 0.02 & 0.00 & 4.50 & 0.01 & 3 & 1 \\
\hline $6 / 26 / 1989$ & 0.00 & 0.00 & 0.00 & 0.00 & 0.00 & 3 & 1 \\
\hline $7 / 24 / 1989$ & 0.00 & 0.00 & 0.00 & 0.00 & 0.00 & 3 & 1 \\
\hline $8 / 21 / 1989$ & 0.00 & 0.00 & 0.00 & 0.00 & 0.00 & 3 & 1 \\
\hline 9/19/1989 & 0.00 & 0.00 & 0.00 & 0.00 & 0.00 & 3 & 1 \\
\hline 10/17/1989 & 0.00 & 0.00 & 0.00 & 0.00 & 0.00 & 3 & 1 \\
\hline $11 / 13 / 1989$ & 0.00 & 0.00 & 0.00 & 0.00 & 0.00 & 3 & 1 \\
\hline 12/12/1989 & 0.00 & 0.00 & 0.00 & 0.00 & 0.00 & 3 & 1 \\
\hline $1 / 16 / 1990$ & 0.00 & 0.00 & 0.00 & 0.00 & 0.00 & 3 & 3 \\
\hline $2 / 27 / 1990$ & 0.00 & 0.00 & 0.00 & 0.00 & 0.00 & 3 & 3 \\
\hline $3 / 19 / 1990$ & 0.00 & 0.00 & 0.00 & 0.00 & 0.00 & 3 & 3 \\
\hline 4/20/1990 & 0.00 & 0.00 & 0.00 & 0.00 & 0.00 & 3 & 3 \\
\hline $5 / 14 / 1990$ & 0.00 & 0.00 & 0.00 & 0.00 & 0.00 & 3 & 3 \\
\hline $6 / 26 / 1990$ & 0.00 & 0.00 & 0.00 & 0.00 & 0.00 & 3 & 3 \\
\hline $7 / 12 / 1990$ & 0.00 & 0.00 & 0.00 & 0.00 & 0.00 & 3 & 3 \\
\hline $8 / 8 / 1990$ & 0.00 & 0.00 & 0.00 & 0.00 & 0.00 & 3 & 3 \\
\hline
\end{tabular}




\begin{tabular}{|c|c|c|c|c|c|c|c|}
\hline \multicolumn{8}{|c|}{ Appendix 12. Station D11 Potamocorbula Data } \\
\hline Date & $\begin{array}{l}\text { Total \# of } \\
\text { clams in } \\
\text { sample } \\
\left(\# / \mathrm{m}^{2}\right)\end{array}$ & $\begin{array}{c}\text { biomass } \\
\left(\mathrm{g} / \mathrm{m}^{2}\right)\end{array}$ & $\begin{array}{c}\mathrm{rec} / \\
0.05 \mathrm{~m}^{2}\end{array}$ & $\begin{array}{c}\text { mean size } \\
(\mathrm{mm})\end{array}$ & $\begin{array}{c}\text { GR } \\
\left(\mathrm{m}^{3} / \mathrm{m}^{2} / \mathrm{d}\right)\end{array}$ & Depth (M) & \# Grabs \\
\hline $9 / 24 / 1990$ & 0.00 & 0.00 & 0.00 & 0.00 & 0.00 & 3 & 3 \\
\hline 10/22/1990 & 0.00 & 0.00 & 0.00 & 0.00 & 0.00 & 3 & 3 \\
\hline $11 / 6 / 1990$ & 57.00 & 0.01 & 0.00 & 2.50 & 0.00 & 3 & 3 \\
\hline $12 / 13 / 1990$ & 44.33 & 0.00 & 0.00 & 2.20 & 0.00 & 3 & 3 \\
\hline 1/7/1991 & 82.33 & 0.01 & 0.00 & 2.00 & 0.00 & 3 & 3 \\
\hline 2/19/1991 & 19.00 & 0.02 & 0.00 & 4.20 & 0.01 & 3 & 3 \\
\hline 3/5/1991 & 19.00 & 0.01 & 0.00 & 2.80 & 0.00 & 3 & 3 \\
\hline 4/11/1991 & 6.33 & 0.00 & 0.00 & 2.50 & 0.00 & 3 & 3 \\
\hline $5 / 23 / 1991$ & 0.00 & 0.00 & 0.00 & 0.00 & 0.00 & 3 & 3 \\
\hline 6/4/1991 & 0.00 & 0.00 & 0.00 & 0.00 & 0.00 & 3 & 3 \\
\hline $7 / 16 / 1991$ & 0.00 & 0.00 & 0.00 & 0.00 & 0.00 & 3 & 3 \\
\hline $8 / 30 / 1991$ & 19.00 & 0.00 & 0.00 & 2.20 & 0.00 & 3 & 3 \\
\hline 9/12/1991 & 12.67 & 0.24 & 0.00 & 7.50 & 0.10 & 3 & 3 \\
\hline 10/8/1991 & 0.00 & 0.00 & 0.00 & 0.00 & 0.00 & 3 & 3 \\
\hline $11 / 12 / 1991$ & 0.00 & 0.00 & 0.00 & 0.00 & 0.00 & 3 & 3 \\
\hline 12/10/1991 & 0.00 & 0.00 & 0.00 & 0.00 & 0.00 & 3 & 3 \\
\hline 1/17/1992 & 0.00 & 0.00 & 0.00 & 0.00 & 0.00 & 3 & 3 \\
\hline 2/25/1992 & 0.00 & 0.00 & 0.00 & 0.00 & 0.00 & 3 & 3 \\
\hline $3 / 24 / 1992$ & 0.00 & 0.00 & 0.00 & 0.00 & 0.00 & 3 & 3 \\
\hline 4/6/1992 & 0.00 & 0.00 & 0.00 & 0.00 & 0.00 & 3 & 3 \\
\hline $5 / 14 / 1992$ & 0.00 & 0.00 & 0.00 & 0.00 & 0.00 & 3 & 3 \\
\hline $6 / 17 / 1992$ & 0.00 & 0.00 & 0.00 & 0.00 & 0.00 & 3 & 3 \\
\hline $7 / 10 / 1992$ & 0.00 & 0.00 & 0.00 & 0.00 & 0.00 & 3 & 3 \\
\hline 8/4/1992 & 6.33 & 1.20 & 0.00 & 21.50 & 0.47 & 3 & 3 \\
\hline 9/1/1992 & 31.67 & 0.00 & 0.00 & 1.30 & 0.00 & 3 & 3 \\
\hline 10/23/1992 & 0.00 & 0.00 & 0.00 & 0.00 & 0.00 & 3 & 3 \\
\hline 11/5/1992 & 0.00 & 0.00 & 0.00 & 0.00 & 0.00 & 3 & 3 \\
\hline $12 / 28 / 1992$ & 0.00 & 0.00 & 0.00 & 0.00 & 0.00 & 3 & 3 \\
\hline $1 / 14 / 1993$ & 6.33 & 0.01 & 0.00 & 6.00 & 0.00 & 3 & 3 \\
\hline 2/9/1993 & 0.00 & 0.00 & 0.00 & 0.00 & 0.00 & 3 & 3 \\
\hline $3 / 11 / 1993$ & 0.00 & 0.00 & 0.00 & 0.00 & 0.00 & 3 & 3 \\
\hline 4/19/1993 & 0.00 & 0.00 & 0.00 & 0.00 & 0.00 & 3 & 3 \\
\hline $5 / 20 / 1993$ & 0.00 & 0.00 & 0.00 & 0.00 & 0.00 & 3 & 3 \\
\hline 6/16/1993 & 0.00 & 0.00 & 0.00 & 0.00 & 0.00 & 3 & 3 \\
\hline $7 / 19 / 1993$ & 0.00 & 0.00 & 0.00 & 0.00 & 0.00 & 3 & 3 \\
\hline $8 / 19 / 1993$ & 0.00 & 0.00 & 0.00 & 0.00 & 0.00 & 3 & 3 \\
\hline 9/16/1993 & 0.00 & 0.00 & 0.00 & 0.00 & 0.00 & 3 & 3 \\
\hline 10/8/1993 & 0.00 & 0.00 & 0.00 & 0.00 & 0.00 & 3 & 3 \\
\hline
\end{tabular}




\begin{tabular}{|c|c|c|c|c|c|c|c|}
\hline \multicolumn{8}{|c|}{ Appendix 12. Station D11 Potamocorbula Data } \\
\hline Date & $\begin{array}{l}\text { Total \# of } \\
\text { clams in } \\
\text { sample } \\
\left(\# / \mathrm{m}^{2}\right)\end{array}$ & $\begin{array}{c}\text { biomass } \\
\left(\mathrm{g} / \mathrm{m}^{2}\right)\end{array}$ & $\begin{array}{c}\mathrm{rec} / \\
0.05 \mathrm{~m}^{2}\end{array}$ & $\begin{array}{c}\text { mean size } \\
(\mathrm{mm})\end{array}$ & $\begin{array}{c}\text { GR } \\
\left(\mathrm{m}^{3} / \mathrm{m}^{2} / \mathrm{d}\right)\end{array}$ & Depth (M) & \# Grabs \\
\hline $11 / 16 / 1993$ & 0.00 & 0.00 & 0.00 & 0.00 & 0.00 & 3 & 3 \\
\hline 12/9/1993 & 0.00 & 0.00 & 0.00 & 0.00 & 0.00 & 3 & 3 \\
\hline $1 / 18 / 1994$ & 0.00 & 0.00 & 0.00 & 0.00 & 0.00 & 3 & 3 \\
\hline 2/8/1994 & 0.00 & 0.00 & 0.00 & 0.00 & 0.00 & 3 & 3 \\
\hline 3/9/1994 & 0.00 & 0.00 & 0.00 & 0.00 & 0.00 & 3 & 3 \\
\hline 4/12/1994 & 0.00 & 0.00 & 0.00 & 0.00 & 0.00 & 3 & 3 \\
\hline $5 / 23 / 1994$ & 0.00 & 0.00 & 0.00 & 0.00 & 0.00 & 3 & 3 \\
\hline 6/9/1994 & 0.00 & 0.00 & 0.00 & 0.00 & 0.00 & 3 & 3 \\
\hline $7 / 20 / 1994$ & 0.00 & 0.00 & 0.00 & 0.00 & 0.00 & 3 & 3 \\
\hline 8/9/1994 & 0.00 & 0.00 & 0.00 & 0.00 & 0.00 & 3 & 3 \\
\hline 9/21/1994 & 0.00 & 0.00 & 0.00 & 0.00 & 0.00 & 3 & 3 \\
\hline $10 / 19 / 1994$ & 6.33 & 0.00 & 0.00 & 8.50 & 0.01 & 3 & 3 \\
\hline $11 / 21 / 1994$ & 0.00 & 0.00 & 0.00 & 0.00 & 0.00 & 3 & 3 \\
\hline $12 / 16 / 1994$ & 0.00 & 0.00 & 0.00 & 0.00 & 0.00 & 3 & 3 \\
\hline 1/17/1995 & 0.00 & 0.00 & 0.00 & 0.00 & 0.00 & 3 & 3 \\
\hline 2/15/1995 & 0.00 & 0.00 & 0.00 & 0.00 & 0.00 & 3 & 3 \\
\hline 3/15/1995 & 0.00 & 0.00 & 0.00 & 0.00 & 0.00 & 3 & 3 \\
\hline 4/27/1995 & 0.00 & 0.00 & 0.00 & 0.00 & 0.00 & 3 & 3 \\
\hline 5/17/1995 & 0.00 & 0.00 & 0.00 & 0.00 & 0.00 & 3 & 3 \\
\hline 6/27/1995 & 0.00 & 0.00 & 0.00 & 0.00 & 0.00 & 3 & 3 \\
\hline 7/13/1995 & 0.00 & 0.00 & 0.00 & 0.00 & 0.00 & 3 & 3 \\
\hline $8 / 24 / 1995$ & 0.00 & 0.00 & 0.00 & 0.00 & 0.00 & 3 & 3 \\
\hline 9/26/1995 & 0.00 & 0.00 & 0.00 & 0.00 & 0.00 & 3 & 3 \\
\hline 10/25/1995 & 0.00 & 0.00 & 0.00 & 0.00 & 0.00 & 3 & 3 \\
\hline $11 / 27 / 1995$ & 0.00 & 0.00 & 0.00 & 0.00 & 0.00 & 3 & 3 \\
\hline
\end{tabular}




\begin{tabular}{|c|c|c|c|c|c|c|c|}
\hline \multicolumn{8}{|c|}{ Appendix 13. Station D16 Corbicula Data } \\
\hline Date & $\begin{array}{c}\text { Total \# of } \\
\text { clams in } \\
\text { sample } \\
\left(\# / \mathrm{m}^{2)}\right.\end{array}$ & $\begin{array}{c}\text { biomass } \\
\left(\mathrm{g} / \mathrm{m}^{2}\right)\end{array}$ & $\mathrm{rec} / 0.05 \mathrm{~m}^{2}$ & $\begin{array}{c}\text { mean size } \\
(\mathrm{mm})\end{array}$ & $\begin{array}{c}\text { GR } \\
\left(\mathrm{m}^{3} / \mathrm{m}^{2} / \mathrm{d}\right)\end{array}$ & Depth (M) & \# Grabs \\
\hline 1/23/1996 & 23.75 & 0.32 & 1.00 & 4.70 & 0.01 & 3.38 & 4 \\
\hline 2/22/1996 & 47.50 & 0.05 & 2.25 & 1.90 & 0.00 & 3.38 & 4 \\
\hline 3/21/1996 & 237.50 & 2.07 & 11.00 & 3.46 & 0.09 & 3.38 & 4 \\
\hline $4 / 30 / 1996$ & 76.00 & 1.54 & 2.00 & 7.38 & 0.10 & 3.38 & 4 \\
\hline 5/17/1996 & 574.75 & 18.08 & 13.50 & 9.79 & 1.17 & 3.38 & 4 \\
\hline $6 / 15 / 1996$ & N/D & $\mathrm{N} / \mathrm{D}$ & N/D & N/D & $\mathrm{N} / \mathrm{D}$ & $\mathrm{N} / \mathrm{D}$ & $N / D$ \\
\hline 7/17/1996 & 133.00 & 2.93 & 3.00 & 8.61 & 0.37 & 3.38 & 4 \\
\hline $8 / 29 / 1996$ & 218.50 & 4.19 & 8.00 & 6.41 & 0.37 & 3.38 & 4 \\
\hline 9/12/1996 & 180.50 & 8.29 & 1.25 & 15.24 & 0.55 & 3.38 & 4 \\
\hline 10/10/1996 & 161.50 & 7.62 & 1.75 & 14.68 & 0.32 & 3.38 & 4 \\
\hline 11/15/1996 & 399.00 & 19.94 & 4.75 & 14.38 & 0.63 & 3.38 & 4 \\
\hline 12/11/1996 & 950.00 & 35.35 & 17.75 & 11.82 & 1.02 & 3.38 & 4 \\
\hline 1/21/1997 & 584.25 & 33.56 & 4.00 & 15.56 & 0.88 & 3.38 & 4 \\
\hline 2/23/1997 & 394.25 & 21.89 & 4.25 & 14.75 & 0.77 & 3.38 & 4 \\
\hline $3 / 25 / 1997$ & 2085.25 & 95.26 & 49.50 & 11.29 & 3.37 & 3.38 & 4 \\
\hline 4/22/1997 & 256.50 & 0.48 & 13.00 & 1.80 & 0.04 & 3.38 & 4 \\
\hline $5 / 21 / 1997$ & 848.67 & 34.81 & 21.00 & 10.75 & 2.94 & 3.38 & 4 \\
\hline $6 / 18 / 1997$ & 1292.00 & 27.44 & 44.67 & 0.00 & 3.40 & 3.38 & 4 \\
\hline $7 / 22 / 1997$ & 1665.67 & 82.54 & 37.67 & 12.06 & 9.06 & 3.38 & 4 \\
\hline 8/19/1997 & 190.00 & 3.95 & 6.00 & 7.67 & 0.44 & 3.38 & 4 \\
\hline 9/16/1997 & 715.67 & 29.40 & 10.33 & 13.00 & 1.92 & 3.38 & 4 \\
\hline 10/28/1997 & 437.00 & 14.14 & 10.33 & 10.08 & 0.83 & 3.38 & 4 \\
\hline 11/18/1997 & 329.33 & 13.60 & 5.67 & 12.77 & 0.45 & 3.38 & 4 \\
\hline 12/14/1997 & 316.67 & 12.27 & 6.00 & 12.20 & 0.32 & 3.38 & 4 \\
\hline 1/12/1998 & 422.75 & 13.31 & 14.25 & 8.11 & 0.41 & 3.38 & 4 \\
\hline 2/17/1998 & 278.67 & 12.91 & 4.67 & 12.89 & 0.43 & 3.38 & 4 \\
\hline $3 / 16 / 1998$ & 696.67 & 49.75 & 5.33 & 17.33 & 1.91 & 3.38 & 4 \\
\hline 4/13/1998 & $N / D$ & $\mathrm{~N} / \mathrm{D}$ & N/D & $\mathrm{N} / \mathrm{D}$ & $N / D$ & $N / D$ & $N / D$ \\
\hline $5 / 12 / 1998$ & 405.33 & 25.70 & 6.33 & 14.53 & 1.99 & 3.38 & 4 \\
\hline 6/8/1998 & 1494.67 & 40.38 & 54.00 & 7.09 & 4.28 & 3.38 & 4 \\
\hline $7 / 8 / 1998$ & 760.00 & 25.03 & 23.67 & 8.67 & 2.80 & 3.38 & 4 \\
\hline 8/3/1998 & 272.33 & 7.74 & 8.00 & 8.48 & 0.00 & 3.38 & 4 \\
\hline 9/16/1998 & 1640.33 & 88.43 & 31.33 & 13.69 & 3.88 & 3.38 & 4 \\
\hline $10 / 6 / 1998$ & 2634.67 & 89.63 & 77.33 & 9.08 & 2.61 & 3.38 & 4 \\
\hline $11 / 3 / 1998$ & 1222.33 & 41.21 & 33.33 & 9.59 & 0.98 & 3.38 & 4 \\
\hline 12/21/1998 & 1045.00 & 19.26 & 34.33 & 6.42 & 0.50 & 3.38 & 4 \\
\hline 1/13/1999 & 1045.00 & 63.33 & 15.67 & 14.15 & 1.35 & 3.38 & 4 \\
\hline 2/17/1999 & 1798.67 & 75.22 & 47.00 & 9.83 & 1.68 & 3.38 & 4 \\
\hline
\end{tabular}




\begin{tabular}{|c|c|c|c|c|c|c|c|}
\hline \multicolumn{8}{|c|}{ Appendix 13. Station D16 Corbicula Data } \\
\hline Date & $\begin{array}{c}\text { Total \# of } \\
\text { clams in } \\
\text { sample } \\
\left(\# / \mathrm{m}^{2)}\right.\end{array}$ & $\begin{array}{l}\text { biomass } \\
\left(\mathrm{g} / \mathrm{m}^{2}\right)\end{array}$ & $\mathrm{rec} / 0.05 \mathrm{~m}^{2}$ & $\begin{array}{c}\text { mean size } \\
(\mathrm{mm})\end{array}$ & $\begin{array}{c}\text { GR } \\
\left(\mathrm{m}^{3} / \mathrm{m}^{2} / \mathrm{d}\right)\end{array}$ & Depth (M) & \# Grabs \\
\hline 3/16/1999 & 722.00 & 26.12 & 19.33 & 8.34 & 0.85 & 3.38 & 4 \\
\hline 4/14/1999 & 2666.33 & 58.54 & 106.33 & 5.74 & 3.23 & 3.38 & 4 \\
\hline 5/18/1999 & 3907.67 & 80.01 & 149.00 & 5.58 & 5.20 & 3.38 & 4 \\
\hline 6/14/1999 & 2565.00 & 38.46 & 97.33 & 4.94 & 3.84 & 3.38 & 4 \\
\hline 7/13/1999 & 1697.33 & 48.25 & 46.33 & 7.81 & 3.60 & 3.38 & 4 \\
\hline 8/11/1999 & 728.33 & 22.89 & 14.33 & 9.80 & 1.81 & 3.38 & 4 \\
\hline 9/22/1999 & 753.67 & 29.86 & 13.33 & 11.01 & 2.25 & 3.38 & 4 \\
\hline 10/27/1999 & 848.67 & 56.91 & 8.00 & 15.93 & 2.44 & 3.38 & 4 \\
\hline 11/9/1999 & 551.00 & 33.89 & 6.67 & 15.18 & 0.80 & 3.38 & 4 \\
\hline 12/8/1999 & 557.33 & 36.61 & 5.67 & 15.48 & 0.86 & 3.38 & 4 \\
\hline $1 / 5 / 2000$ & 427.50 & 22.79 & 6.00 & 11.59 & 0.67 & 3.38 & 4 \\
\hline $2 / 23 / 2000$ & 565.25 & 45.92 & 2.75 & 17.10 & 1.31 & 3.38 & 4 \\
\hline $3 / 22 / 2000$ & 152.00 & 12.20 & 0.75 & 17.38 & 0.72 & 3.38 & 4 \\
\hline $4 / 19 / 2000$ & 722.00 & 36.72 & 9.00 & 11.80 & 2.00 & 3.38 & 4 \\
\hline $5 / 16 / 2000$ & 437.00 & 26.60 & 5.00 & 14.11 & 2.04 & 3.38 & 4 \\
\hline $6 / 14 / 2000$ & 665.00 & 31.47 & 10.75 & 11.84 & 3.02 & 3.38 & 4 \\
\hline $7 / 17 / 2000$ & 959.50 & 41.96 & 20.50 & 10.71 & 4.37 & 3.38 & 4 \\
\hline $8 / 16 / 2000$ & 760.00 & 27.38 & 18.75 & 9.68 & 2.11 & 3.38 & 4 \\
\hline $9 / 13 / 2000$ & 807.50 & 65.77 & 0.25 & 19.85 & 4.00 & 3.38 & 4 \\
\hline $10 / 10 / 2000$ & 503.50 & 38.67 & 4.25 & 16.62 & 1.61 & 3.38 & 4 \\
\hline $11 / 15 / 2000$ & 1168.50 & 56.56 & 20.50 & 12.35 & 1.25 & 3.38 & 4 \\
\hline $12 / 13 / 2000$ & 650.75 & 57.94 & 0.00 & 20.76 & 1.18 & 3.38 & 4 \\
\hline $1 / 11 / 2001$ & 23.75 & 3.72 & 0.00 & 24.30 & 0.11 & 3.38 & 4 \\
\hline $2 / 7 / 2001$ & 28.50 & 0.51 & 0.50 & 6.50 & 0.02 & 3.38 & 4 \\
\hline $3 / 7 / 2001$ & 278.67 & 20.33 & 1.67 & 16.59 & 0.92 & 3.38 & 4 \\
\hline $4 / 4 / 2001$ & 924.67 & 57.51 & 6.67 & 15.02 & 3.81 & 3.38 & 4 \\
\hline $5 / 9 / 2001$ & 253.33 & 19.46 & 1.33 & 16.83 & 1.72 & 3.38 & 4 \\
\hline $6 / 5 / 2001$ & 147.25 & 13.81 & 1.00 & 19.40 & 1.25 & 3.38 & 4 \\
\hline $7 / 24 / 2001$ & 418.00 & 31.12 & 3.33 & 16.83 & 2.91 & 3.38 & 4 \\
\hline $8 / 22 / 2001$ & 1323.67 & 45.80 & 47.67 & 7.99 & 3.83 & 3.38 & 4 \\
\hline $9 / 18 / 2001$ & 1469.33 & 48.57 & 48.00 & 8.26 & 3.22 & 3.38 & 4 \\
\hline $10 / 16 / 2001$ & 874.00 & 21.70 & 31.00 & 7.45 & 1.26 & 3.38 & 4 \\
\hline $11 / 19 / 2001$ & 47.50 & 2.88 & 0.25 & 16.30 & 0.08 & 3.38 & 4 \\
\hline $12 / 11 / 2001$ & 76.00 & 0.39 & 3.50 & 2.94 & 0.01 & 3.38 & 4 \\
\hline $1 / 15 / 2002$ & 475.00 & 15.30 & 11.00 & 8.62 & 0.41 & 3.38 & 4 \\
\hline $2 / 14 / 2002$ & 85.50 & 1.37 & 3.50 & 3.94 & 0.08 & 3.38 & 4 \\
\hline $3 / 12 / 2002$ & 570.00 & 14.80 & 17.75 & 7.23 & 0.79 & 3.38 & 4 \\
\hline $4 / 15 / 2002$ & 1102.00 & 23.72 & 32.00 & 6.31 & 2.13 & 3.38 & 4 \\
\hline
\end{tabular}


Appendix 13. Station D16 Corbicula Data

\begin{tabular}{|c|c|c|c|c|c|c|c|}
\hline Date & $\begin{array}{c}\text { Total \# of } \\
\text { clams in } \\
\text { sample } \\
\left(\# / \mathrm{m}^{2)}\right.\end{array}$ & $\begin{array}{c}\text { biomass } \\
\left(\mathrm{g} / \mathrm{m}^{2}\right)\end{array}$ & $\mathrm{rec} / 0.05 \mathrm{~m}^{2}$ & $\begin{array}{c}\text { mean size } \\
(\mathrm{mm})\end{array}$ & $\begin{array}{c}\text { GR } \\
\left(\mathrm{m}^{3} / \mathrm{m}^{2} / \mathrm{d}\right)\end{array}$ & Depth (M) & \# Grabs \\
\hline $5 / 13 / 2002$ & 1097.25 & 29.87 & 31.25 & 7.34 & 3.29 & 3.38 & 4 \\
\hline $6 / 10 / 2002$ & 484.50 & 20.18 & 5.50 & 11.37 & 2.01 & 3.38 & 4 \\
\hline $7 / 7 / 2002$ & 399.00 & 12.12 & 11.25 & 7.64 & 1.30 & 3.38 & 4 \\
\hline $8 / 8 / 2002$ & 399.00 & 9.23 & 10.75 & 6.90 & 0.80 & 3.38 & 4 \\
\hline $9 / 9 / 2002$ & 950.00 & 22.96 & 33.50 & 6.69 & 1.08 & 3.38 & 4 \\
\hline $10 / 23 / 2002$ & 399.00 & 5.55 & 15.00 & 5.21 & 0.20 & 3.38 & 4 \\
\hline $11 / 5 / 2002$ & 475.00 & 9.42 & 13.00 & 7.02 & 0.26 & 3.38 & 4 \\
\hline $12 / 4 / 2002$ & 237.50 & 11.67 & 4.25 & 12.98 & 0.31 & 3.38 & 4 \\
\hline $1 / 21 / 2003$ & N/D & N/D & $\mathrm{N} / \mathrm{D}$ & $\mathrm{N} / \mathrm{D}$ & N/D & N/D & N/D \\
\hline $2 / 18 / 2003$ & N/D & N/D & $\mathrm{N} / \mathrm{D}$ & $N / D$ & $N / D$ & $N / D$ & $N / D$ \\
\hline $3 / 18 / 2003$ & N/D & N/D & $\mathrm{N} / \mathrm{D}$ & $N / D$ & N/D & N/D & N/D \\
\hline $4 / 16 / 2003$ & N/D & N/D & $\mathrm{N} / \mathrm{D}$ & $N / D$ & $\mathrm{~N} / \mathrm{D}$ & $\mathrm{N} / \mathrm{D}$ & N/D \\
\hline $5 / 14 / 2003$ & N/D & N/D & $\mathrm{N} / \mathrm{D}$ & $N / D$ & N/D & N/D & N/D \\
\hline $6 / 1 / 2003$ & N/D & N/D & $\mathrm{N} / \mathrm{D}$ & $N / D$ & $N / D$ & $N / D$ & $N / D$ \\
\hline $7 / 14 / 2003$ & N/D & N/D & $\mathrm{N} / \mathrm{D}$ & $N / D$ & N/D & N/D & N/D \\
\hline $8 / 13 / 2003$ & N/D & N/D & $\mathrm{N} / \mathrm{D}$ & $N / D$ & $\mathrm{~N} / \mathrm{D}$ & $\mathrm{N} / \mathrm{D}$ & N/D \\
\hline $9 / 18 / 2003$ & N/D & N/D & $\mathrm{N} / \mathrm{D}$ & $N / D$ & $\mathrm{~N} / \mathrm{D}$ & $N / D$ & $N / D$ \\
\hline $10 / 23 / 2003$ & N/D & N/D & $\mathrm{N} / \mathrm{D}$ & $N / D$ & $\mathrm{~N} / \mathrm{D}$ & $\mathrm{N} / \mathrm{D}$ & $N / D$ \\
\hline $7 / 15 / 2004$ & 23.75 & 0.02 & 1.00 & 3.10 & 0.00 & 3.38 & 4 \\
\hline $10 / 26 / 2004$ & 76.00 & 2.98 & 1.75 & 10.44 & 0.22 & 3.38 & 4 \\
\hline $1 / 11 / 2005$ & 33.25 & 2.13 & 0.00 & 15.79 & 0.06 & 3.38 & 4 \\
\hline $4 / 6 / 2005$ & 19.00 & 0.02 & 0.00 & 3.50 & 0.00 & 3.38 & 4 \\
\hline $7 / 20 / 2005$ & 33.25 & 0.90 & 0.00 & 9.79 & 0.12 & 3.38 & 4 \\
\hline $10 / 13 / 2005$ & 57.00 & 1.10 & 0.00 & 6.33 & 0.08 & 3.38 & 4 \\
\hline $11 / 7 / 2005$ & 19.00 & 0.01 & 0.00 & 2.50 & 0.00 & 3.38 & 4 \\
\hline $12 / 5 / 2005$ & 118.75 & 0.63 & 0.00 & 4.90 & 0.02 & 3.38 & 4 \\
\hline $1 / 12 / 2006$ & 33.25 & 0.02 & 1.25 & 2.79 & 0.00 & 3.38 & 4 \\
\hline $2 / 8 / 2006$ & 42.75 & 0.74 & 1.00 & 5.50 & 0.03 & 3.38 & 4 \\
\hline $3 / 15 / 2006$ & 104.50 & 1.37 & 3.00 & 6.00 & 0.05 & 3.38 & 4 \\
\hline $4 / 26 / 2006$ & 38.00 & 1.55 & 0.00 & 13.38 & 0.07 & 3.38 & 4 \\
\hline $5 / 25 / 2006$ & 9.50 & 0.03 & 0.00 & 7.00 & 0.00 & 3.38 & 4 \\
\hline $6 / 6 / 2006$ & 9.50 & 0.00 & 0.50 & 1.50 & 0.00 & 3.38 & 4 \\
\hline $7 / 10 / 2006$ & 19.00 & 0.44 & 0.00 & 12.50 & 0.06 & 3.38 & 4 \\
\hline $8 / 10 / 2006$ & 47.50 & 0.23 & 1.25 & 5.00 & 0.03 & 3.38 & 4 \\
\hline $9 / 20 / 2006$ & 19.00 & 0.06 & 0.25 & 5.75 & 0.01 & 3.38 & 4 \\
\hline $10 / 25 / 2006$ & 14.25 & 0.00 & 0.75 & 2.17 & 0.00 & 3.38 & 4 \\
\hline $11 / 20 / 2006$ & 61.75 & 1.34 & 2.00 & 6.19 & 0.08 & 3.38 & 4 \\
\hline $12 / 20 / 2006$ & 38.00 & 0.01 & 1.00 & 3.00 & 0.00 & 3.38 & 4 \\
\hline
\end{tabular}


Appendix 13. Station D16 Corbicula Data

\begin{tabular}{|c|c|c|c|c|c|c|c|}
\hline Date & $\begin{array}{c}\text { Total \# of } \\
\text { clams in } \\
\text { sample } \\
\left(\# / \mathrm{m}^{2)}\right.\end{array}$ & $\begin{array}{c}\text { biomass } \\
\left(\mathrm{g} / \mathrm{m}^{2}\right)\end{array}$ & $\mathrm{rec} / 0.05 \mathrm{~m}^{2}$ & $\begin{array}{c}\text { mean size } \\
(\mathrm{mm})\end{array}$ & $\begin{array}{c}\text { GR } \\
\left(\mathrm{m}^{3} / \mathrm{m}^{2} / \mathrm{d}\right)\end{array}$ & Depth (M) & \# Grabs \\
\hline $1 / 23 / 2007$ & 66.50 & 3.02 & 0.75 & 10.86 & 0.09 & 3.38 & 4 \\
\hline $2 / 20 / 2007$ & 95.00 & 0.40 & 2.75 & 5.00 & 0.01 & 3.38 & 4 \\
\hline $3 / 20 / 2007$ & 28.50 & 0.05 & 0.75 & 3.83 & 0.00 & 3.38 & 4 \\
\hline $4 / 16 / 2007$ & 66.50 & 0.20 & 2.00 & 4.21 & 0.01 & 3.38 & 4 \\
\hline $5 / 16 / 2007$ & 9.50 & 0.21 & 0.25 & 8.50 & 0.02 & 3.38 & 4 \\
\hline $6 / 20 / 2007$ & 28.50 & 1.90 & 0.25 & 14.33 & 0.15 & 3.38 & 4 \\
\hline $7 / 16 / 2007$ & 14.25 & 0.03 & 0.25 & 5.50 & 0.00 & 3.38 & 4 \\
\hline $8 / 13 / 2007$ & 0.00 & 0.00 & 0.00 & 0.00 & 0.00 & 3.38 & 4 \\
\hline 9/11/2007 & 9.50 & 0.01 & 0.25 & 3.50 & 0.00 & 3.38 & 4 \\
\hline $10 / 2 / 2007$ & 23.75 & 0.04 & 0.75 & 4.50 & 0.00 & 3.38 & 4 \\
\hline $11 / 7 / 2007$ & 660.25 & 13.89 & 10.50 & 9.65 & 0.70 & 3.38 & 4 \\
\hline $12 / 10 / 2007$ & 213.75 & 1.76 & 6.75 & 4.28 & 0.05 & 3.38 & 4 \\
\hline $1 / 8 / 2008$ & 9.50 & 0.01 & 0.00 & 3.50 & 0.00 & 3.38 & 4 \\
\hline $2 / 6 / 2008$ & 19.00 & 0.50 & 0.00 & 10.00 & 0.01 & 3.38 & 4 \\
\hline $3 / 5 / 2008$ & 14.25 & 0.26 & 0.50 & 6.50 & 0.01 & 3.38 & 4 \\
\hline $4 / 2 / 2008$ & 28.50 & 1.84 & 0.00 & 16.83 & 0.10 & 3.38 & 4 \\
\hline $5 / 21 / 2008$ & 9.50 & 0.02 & 0.25 & 4.50 & 0.00 & 3.38 & 4 \\
\hline $6 / 18 / 2008$ & 23.75 & 1.37 & 0.25 & 14.50 & 0.13 & 3.38 & 4 \\
\hline $7 / 15 / 2008$ & 14.25 & 0.00 & 0.50 & 2.83 & 0.00 & 3.38 & 4 \\
\hline $8 / 14 / 2008$ & 498.75 & 7.67 & 5.75 & 7.87 & 0.81 & 3.38 & 4 \\
\hline $9 / 16 / 2008$ & 52.25 & 0.00 & 2.75 & 1.23 & 0.00 & 3.38 & 4 \\
\hline $10 / 27 / 2008$ & 38.00 & 0.04 & 1.75 & 3.00 & 0.00 & 3.38 & 4 \\
\hline $11 / 18 / 2008$ & 38.00 & 0.05 & 1.25 & 3.38 & 0.00 & 3.38 & 4 \\
\hline $12 / 10 / 2008$ & 66.50 & 0.76 & 1.50 & 6.21 & 0.03 & 3.38 & 4 \\
\hline $1 / 12 / 2009$ & 57.00 & 2.05 & 1.00 & 8.17 & 0.06 & 3.38 & 4 \\
\hline 2/9/2009 & 19.00 & 0.21 & 0.67 & 5.50 & 0.01 & 3.38 & 4 \\
\hline $3 / 11 / 2009$ & 31.67 & 1.10 & 0.33 & 11.50 & 0.05 & 3.38 & 4 \\
\hline $4 / 6 / 2009$ & 47.50 & 1.32 & 0.50 & 11.10 & 0.07 & 3.38 & 4 \\
\hline $5 / 4 / 2009$ & 38.00 & 2.49 & 0.33 & 14.67 & 0.20 & 3.38 & 4 \\
\hline $6 / 24 / 2009$ & 85.50 & 1.49 & 2.00 & 7.22 & 0.14 & 3.38 & 4 \\
\hline $7 / 21 / 2009$ & 12.67 & 1.07 & 0.00 & 19.00 & 0.12 & 3.38 & 4 \\
\hline $8 / 18 / 2009$ & 133.00 & 0.00 & 7.00 & 1.50 & 0.00 & 3.38 & 4 \\
\hline $9 / 16 / 2009$ & 71.25 & 0.07 & 3.50 & 2.57 & 0.01 & 3.38 & 4 \\
\hline $10 / 19 / 2009$ & 1401.25 & 2.06 & 58.50 & 2.66 & 0.16 & 3.38 & 4 \\
\hline $11 / 16 / 2009$ & 52.25 & 0.07 & 1.50 & 3.68 & 0.00 & 3.38 & 4 \\
\hline $12 / 16 / 2009$ & 655.50 & 1.53 & 12.25 & 4.25 & 0.04 & 3.38 & 4 \\
\hline $1 / 14 / 2010$ & 23.75 & 0.04 & 0.50 & 4.10 & 0.00 & 3.38 & 4 \\
\hline $2 / 18 / 2010$ & 479.75 & 5.46 & 1.75 & 7.10 & 0.15 & 3.38 & 4 \\
\hline
\end{tabular}




\begin{tabular}{|c|c|c|c|c|c|c|c|}
\hline \multicolumn{8}{|c|}{ Appendix 13. Station D16 Corbicula Data } \\
\hline Date & $\begin{array}{c}\text { Total \# of } \\
\text { clams in } \\
\text { sample } \\
\left(\# / \mathrm{m}^{2)}\right.\end{array}$ & $\begin{array}{l}\text { biomass } \\
\left(\mathrm{g} / \mathrm{m}^{2}\right)\end{array}$ & $\mathrm{rec} / 0.05 \mathrm{~m}^{2}$ & $\begin{array}{c}\text { mean size } \\
(\mathrm{mm})\end{array}$ & $\begin{array}{c}\text { GR } \\
\left(\mathrm{m}^{3} / \mathrm{m}^{2} / \mathrm{d}\right)\end{array}$ & Depth (M) & \# Grabs \\
\hline $3 / 15 / 2010$ & 494.00 & 3.05 & 1.75 & 6.73 & 0.11 & 3.38 & 4 \\
\hline $4 / 12 / 2010$ & 19.00 & 0.01 & 0.50 & 3.00 & 0.00 & 3.38 & 4 \\
\hline $5 / 18 / 2010$ & 351.50 & 3.53 & 1.75 & 7.49 & 0.22 & 3.38 & 4 \\
\hline $6 / 9 / 2010$ & 4.75 & 0.03 & 0.00 & 7.50 & 0.00 & 3.38 & 4 \\
\hline $7 / 6 / 2010$ & 19.00 & 0.61 & 0.00 & 11.75 & 0.07 & 3.38 & 4 \\
\hline $8 / 17 / 2010$ & 893.00 & 2.76 & 33.00 & 3.96 & 0.27 & 3.38 & 4 \\
\hline 9/7/2010 & 38.00 & 0.08 & 1.25 & 4.13 & 0.01 & 3.38 & 4 \\
\hline $10 / 25 / 2010$ & 66.50 & 0.37 & 3.00 & 3.50 & 0.03 & 3.38 & 4 \\
\hline $11 / 22 / 2010$ & 636.50 & 1.08 & 9.50 & 4.30 & 0.06 & 3.38 & 4 \\
\hline $12 / 20 / 2010$ & 76.00 & 0.83 & 1.25 & 6.50 & 0.03 & 3.38 & 4 \\
\hline $1 / 19 / 2011$ & 612.75 & 4.74 & 8.00 & 6.03 & 0.13 & 3.38 & 4 \\
\hline $2 / 2 / 2011$ & 14.25 & 0.37 & 0.25 & 8.17 & 0.01 & 3.38 & 4 \\
\hline $3 / 8 / 2011$ & 19.00 & 0.01 & 0.25 & 3.25 & 0.00 & 3.38 & 4 \\
\hline $4 / 6 / 2011$ & 346.75 & 1.18 & 4.25 & 4.93 & 0.06 & 3.38 & 4 \\
\hline $5 / 2 / 2011$ & 551.00 & 3.74 & 6.25 & 6.34 & 0.26 & 3.38 & 4 \\
\hline $6 / 14 / 2011$ & 261.25 & 1.56 & 2.75 & 6.10 & 0.10 & 3.38 & 4 \\
\hline $7 / 13 / 2011$ & 19.00 & 0.02 & 0.75 & 3.25 & 0.00 & 3.38 & 4 \\
\hline $8 / 9 / 2011$ & 47.50 & 0.18 & 1.50 & 4.10 & 0.02 & 3.38 & 4 \\
\hline 9/7/2011 & 223.25 & 0.10 & 10.50 & 1.93 & 0.01 & 3.38 & 4 \\
\hline $10 / 3 / 2011$ & 945.25 & 1.29 & 39.50 & 2.65 & 0.10 & 3.38 & 4 \\
\hline $11 / 8 / 11$ & 332.50 & 1.64 & 8.50 & 4.80 & 0.08 & 3.38 & 4 \\
\hline $12 / 7 / 11$ & 456.00 & 2.69 & 3.75 & 6.88 & 0.07 & 3.38 & 4 \\
\hline $1 / 9 / 2012$ & 622.25 & 5.00 & 7.00 & 6.28 & 0.14 & 3.38 & 4 \\
\hline $2 / 8 / 2012$ & 118.75 & 0.40 & 3.50 & 3.70 & 0.01 & 3.38 & 4 \\
\hline $3 / 15 / 2012$ & 285.00 & 2.55 & 5.00 & 6.32 & 0.10 & 3.38 & 4 \\
\hline $4 / 5 / 2012$ & 498.75 & 2.24 & 9.75 & 4.50 & 0.11 & 3.38 & 4 \\
\hline $5 / 23 / 2012$ & 152.00 & 1.68 & 1.50 & 6.81 & 0.14 & 3.38 & 4 \\
\hline $6 / 18 / 2012$ & 80.75 & 0.30 & 1.25 & 5.50 & 0.03 & 3.38 & 4 \\
\hline $7 / 17 / 2012$ & 166.25 & 0.75 & 4.25 & 4.70 & 0.10 & 3.38 & 4 \\
\hline $8 / 15 / 2012$ & 152.00 & 0.33 & 4.25 & 3.97 & 0.04 & 3.38 & 4 \\
\hline $9 / 25 / 2012$ & 318.25 & 1.67 & 3.75 & 6.23 & 0.18 & 3.38 & 4 \\
\hline $10 / 25 / 2012$ & 323.00 & 2.16 & 10.75 & 4.34 & 0.22 & 3.38 & 4 \\
\hline $11 / 14 / 2012$ & 251.75 & 0.43 & 10.00 & 3.05 & 0.03 & 3.38 & 4 \\
\hline $12 / 17 / 2012$ & 137.75 & 1.40 & 0.50 & 8.67 & 0.06 & 3.38 & 4 \\
\hline $1 / 10 / 2013$ & 351.50 & 4.12 & 3.00 & 8.26 & 0.11 & 3.38 & 4 \\
\hline $2 / 5 / 2013$ & 57.00 & 0.58 & 0.25 & 8.08 & 0.02 & 3.38 & 4 \\
\hline $3 / 13 / 2013$ & 161.50 & 3.49 & 0.50 & 10.47 & 0.17 & 3.38 & 4 \\
\hline $4 / 10 / 2013$ & 61.75 & 1.06 & 1.50 & 7.35 & 0.06 & 3.38 & 4 \\
\hline
\end{tabular}


Appendix 13. Station D16 Corbicula Data

\begin{tabular}{|c|c|c|c|c|c|c|c|}
\hline Date & $\begin{array}{l}\text { Total \# of } \\
\text { clams in } \\
\text { sample } \\
\left(\# / \mathrm{m}^{2)}\right.\end{array}$ & $\begin{array}{c}\text { biomass } \\
\left(\mathrm{g} / \mathrm{m}^{2}\right)\end{array}$ & $\mathrm{rec} / 0.05 \mathrm{~m}^{2}$ & $\begin{array}{l}\text { mean size } \\
(\mathrm{mm})\end{array}$ & $\begin{array}{c}\text { GR } \\
\left(\mathrm{m}^{3} / \mathrm{m}^{2} / \mathrm{d}\right)\end{array}$ & Depth (M) & \# Grabs \\
\hline $5 / 7 / 2013$ & 28.50 & 0.18 & 0.50 & 6.67 & 0.02 & 3.38 & 4 \\
\hline $6 / 4 / 2013$ & 76.00 & 0.56 & 1.75 & 5.75 & 0.06 & 3.38 & 4 \\
\hline $7 / 9 / 2013$ & 85.50 & 0.35 & 2.00 & 5.06 & 0.05 & 3.38 & 4 \\
\hline $8 / 7 / 2013$ & $\mathrm{~N} / \mathrm{D}$ & $\mathrm{N} / \mathrm{D}$ & $\mathrm{N} / \mathrm{D}$ & $N / D$ & $\mathrm{~N} / \mathrm{D}$ & $\mathrm{N} / \mathrm{D}$ & $\mathrm{N} / \mathrm{D}$ \\
\hline $9 / 4 / 2013$ & 289.75 & 0.37 & 11.75 & 2.93 & 0.04 & 3.38 & 4 \\
\hline $10 / 16 / 2013$ & 527.25 & 0.97 & 22.25 & 2.93 & 0.07 & 3.38 & 4 \\
\hline $11 / 19 / 2013$ & 313.50 & 2.69 & 5.00 & 7.09 & 0.13 & 3.38 & 4 \\
\hline $12 / 16 / 2013$ & 90.25 & 1.02 & 1.50 & 7.55 & 0.03 & 3.38 & 4 \\
\hline
\end{tabular}

\begin{tabular}{|c|c|c|c|c|c|c|c|}
\hline \multicolumn{8}{|c|}{ Appendix 14. Station D19C Corbicula Data } \\
\hline Date & $\begin{array}{c}\text { Total \# of } \\
\text { clams in } \\
\text { sample } \\
\left(\# / \mathrm{m}^{2}\right)\end{array}$ & $\begin{array}{c}\text { biomass } \\
\left(\mathrm{g} / \mathrm{m}^{2}\right)\end{array}$ & $\begin{array}{l}\text { recruit/ } \\
0.05 \mathrm{~m}^{2}\end{array}$ & $\begin{array}{c}\text { mean size } \\
(\mathrm{mm})\end{array}$ & $\begin{array}{c}\text { GR } \\
\left(\mathrm{m}^{3} / \mathrm{m}^{2} / \mathrm{d}\right)\end{array}$ & Depth (M) & \# Grabs \\
\hline $3 / 3 / 1977$ & 10988.00 & $\mathrm{~N} / \mathrm{D}$ & $\mathrm{N} / \mathrm{D}$ & $N / D$ & $\mathrm{~N} / \mathrm{D}$ & N/D & $\mathrm{N} / \mathrm{D}$ \\
\hline $6 / 2 / 1977$ & 3521.00 & $\mathrm{~N} / \mathrm{D}$ & $\mathrm{N} / \mathrm{D}$ & $N / D$ & $\mathrm{~N} / \mathrm{D}$ & $N / D$ & $\mathrm{~N} / \mathrm{D}$ \\
\hline 10/11/1977 & 1501.00 & N/D & $\mathrm{N} / \mathrm{D}$ & $N / D$ & $\mathrm{~N} / \mathrm{D}$ & N/D & $\mathrm{N} / \mathrm{D}$ \\
\hline $6 / 8 / 1978$ & 760.00 & 7.10 & 34.00 & 2.80 & 0.70 & 3 & 1 \\
\hline $10 / 4 / 1978$ & 57.00 & 2.30 & 2.00 & 7.20 & 0.30 & 3 & 1 \\
\hline $5 / 30 / 1979$ & 2926.00 & 4.60 & 153.00 & 1.10 & 0.30 & 3 & 1 \\
\hline 9/17/1979 & 1767.00 & 12.00 & 90.00 & 1.40 & 1.70 & 3 & 1 \\
\hline $6 / 11 / 1980$ & 2552.00 & N/D & $N / D$ & $N / D$ & $\mathrm{~N} / \mathrm{D}$ & $N / D$ & $N / D$ \\
\hline $7 / 18 / 1980$ & 5586.00 & N/D & $N / D$ & $N / D$ & $\mathrm{~N} / \mathrm{D}$ & N/D & $\mathrm{N} / \mathrm{D}$ \\
\hline $8 / 22 / 1980$ & 361.00 & 12.20 & 14.00 & 6.10 & 1.30 & 3 & 1 \\
\hline 9/19/1980 & 342.00 & 17.70 & 14.00 & 6.30 & 1.90 & 3 & 1 \\
\hline $10 / 23 / 1980$ & 1127.00 & N/D & $N / D$ & $N / D$ & $N / D$ & $N / D$ & $N / D$ \\
\hline $11 / 20 / 1980$ & 2394.00 & N/D & $N / D$ & $N / D$ & $\mathrm{~N} / \mathrm{D}$ & N/D & $\mathrm{N} / \mathrm{D}$ \\
\hline $12 / 22 / 1980$ & 1045.00 & 47.60 & 34.00 & 8.40 & 1.20 & 3 & 1 \\
\hline 1/14/1981 & 931.00 & 4.00 & 47.00 & 1.80 & 0.10 & 3 & 1 \\
\hline 2/19/1981 & 3724.00 & 16.20 & 193.00 & 1.50 & 0.60 & 3 & 1 \\
\hline $3 / 30 / 1981$ & 3724.00 & 11.60 & 191.00 & 1.70 & 0.50 & 3 & 1 \\
\hline 4/16/1981 & 4560.00 & 7.50 & 230.00 & 1.90 & 0.70 & 3 & 1 \\
\hline $5 / 15 / 1981$ & 2109.00 & 52.70 & 85.00 & 4.20 & 4.30 & 3 & 1 \\
\hline $6 / 12 / 1981$ & 2945.00 & 40.20 & 131.00 & 3.00 & 5.70 & 3 & 1 \\
\hline $7 / 10 / 1981$ & 2375.00 & 36.10 & 95.00 & 3.50 & 4.20 & 3 & 1 \\
\hline $8 / 26 / 1981$ & 4237.00 & 39.40 & 194.00 & 2.70 & 5.10 & 3 & 1 \\
\hline 9/24/1981 & 1976.00 & 36.20 & 92.00 & 3.40 & 3.40 & 3 & 1 \\
\hline $10 / 13 / 1981$ & 1653.00 & 16.20 & 78.00 & 2.90 & 1.40 & 3 & 1 \\
\hline
\end{tabular}




\begin{tabular}{|c|c|c|c|c|c|c|c|}
\hline \multicolumn{8}{|c|}{ Appendix 14. Station D19C Corbicula Data } \\
\hline Date & $\begin{array}{l}\text { Total \# of } \\
\text { clams in } \\
\text { sample } \\
\left(\# / \mathrm{m}^{2}\right)\end{array}$ & $\begin{array}{c}\text { biomass } \\
\left(\mathrm{g} / \mathrm{m}^{2}\right)\end{array}$ & $\begin{array}{l}\text { recruit/ } \\
0.05 \mathrm{~m}^{2}\end{array}$ & $\begin{array}{c}\text { mean size } \\
(\mathrm{mm})\end{array}$ & $\begin{array}{c}\text { GR } \\
\left(\mathrm{m}^{3} / \mathrm{m}^{2} / \mathrm{d}\right)\end{array}$ & Depth (M) & \# Grabs \\
\hline $11 / 20 / 1981$ & 1805.00 & 11.80 & 87.00 & 2.20 & 0.60 & 3 & 1 \\
\hline $12 / 11 / 1981$ & 475.00 & 12.10 & 16.00 & 5.30 & 0.40 & 3 & 1 \\
\hline $1 / 21 / 1982$ & 1064.00 & 18.20 & 44.00 & 3.60 & 0.50 & 3 & 1 \\
\hline $2 / 22 / 1982$ & 152.00 & 0.00 & 4.00 & 2.90 & 0.00 & 3 & 1 \\
\hline $3 / 30 / 1982$ & 2318.00 & 7.40 & 114.00 & 1.40 & 0.30 & 3 & 1 \\
\hline $4 / 28 / 1982$ & 7543.00 & 0.50 & 382.00 & 1.40 & 0.00 & 3 & 1 \\
\hline $5 / 20 / 1982$ & 10431.00 & 9.20 & 497.00 & 1.90 & 0.40 & 3 & 1 \\
\hline $6 / 25 / 1982$ & 4389.00 & 17.00 & 162.00 & 2.80 & 1.80 & 3 & 1 \\
\hline $7 / 22 / 1982$ & 5491.00 & 17.80 & 253.00 & 2.20 & 2.00 & 3 & 1 \\
\hline $8 / 30 / 1982$ & 1729.00 & 7.20 & 84.00 & 2.00 & 0.90 & 3 & 1 \\
\hline 9/20/1982 & 1900.00 & 13.80 & 98.00 & 1.90 & 1.60 & 3 & 1 \\
\hline $10 / 28 / 1982$ & 1235.00 & 0.90 & 61.00 & 1.70 & 0.10 & 3 & 1 \\
\hline $11 / 24 / 1982$ & 684.00 & 16.60 & 32.00 & 3.50 & 0.70 & 3 & 1 \\
\hline $12 / 15 / 1982$ & 2508.00 & 11.60 & 123.00 & 2.20 & 0.40 & 3 & 1 \\
\hline $1 / 31 / 1983$ & 741.00 & 40.60 & 31.00 & 5.20 & 1.10 & 3 & 1 \\
\hline $2 / 8 / 1983$ & 2964.00 & 17.80 & 140.00 & 1.90 & 0.70 & 3 & 1 \\
\hline $3 / 8 / 1983$ & 2907.00 & 11.90 & 143.00 & 1.40 & 0.50 & 3 & 1 \\
\hline $4 / 21 / 1983$ & 2945.00 & 9.70 & 149.00 & 1.20 & 0.50 & 3 & 1 \\
\hline $5 / 19 / 1983$ & 2565.00 & 9.80 & 116.00 & 2.40 & 0.50 & 3 & 1 \\
\hline 6/6/1983 & 5358.00 & 4.20 & 259.00 & 1.60 & 0.40 & 3 & 1 \\
\hline $7 / 5 / 1983$ & 3059.00 & 5.20 & 112.00 & 2.70 & 0.60 & 3 & 1 \\
\hline 9/15/1983 & 2109.00 & 24.90 & 51.00 & 4.40 & 2.30 & 3 & 1 \\
\hline $11 / 1 / 1983$ & 2765.00 & 5.50 & 108.00 & 2.50 & 0.50 & 3 & 1 \\
\hline $11 / 30 / 1983$ & 2223.00 & 24.70 & 35.00 & 4.90 & 1.10 & 3 & 1 \\
\hline $12 / 13 / 1983$ & 779.00 & 3.10 & 13.50 & 4.90 & 0.10 & 3 & 1 \\
\hline $1 / 31 / 1984$ & 1558.00 & 5.50 & 54.00 & 3.30 & 0.20 & 3 & 1 \\
\hline $2 / 27 / 1984$ & 1378.00 & 7.50 & 32.00 & 4.80 & 0.30 & 3 & 1 \\
\hline $3 / 26 / 1984$ & 2565.00 & 5.00 & 111.50 & 2.10 & 0.20 & 3 & 1 \\
\hline $4 / 24 / 1984$ & 2632.00 & 33.30 & 23.00 & 6.60 & 1.40 & 3 & 1 \\
\hline $5 / 24 / 1984$ & 3325.00 & 19.70 & 148.50 & 2.50 & 1.50 & 3 & 1 \\
\hline $6 / 22 / 1984$ & 3002.00 & 9.20 & 127.00 & 3.00 & 0.80 & 3 & 1 \\
\hline $7 / 23 / 1984$ & 2575.00 & 3.50 & 122.50 & 1.90 & 0.50 & 3 & 1 \\
\hline $8 / 22 / 1984$ & 1216.00 & 12.10 & 33.00 & 5.30 & 1.80 & 3 & 1 \\
\hline $9 / 18 / 1984$ & 380.00 & 12.00 & 5.00 & 10.50 & 1.40 & 3 & 1 \\
\hline $10 / 30 / 1984$ & 1216.00 & 51.30 & 29.00 & 9.30 & 3.80 & 3 & 1 \\
\hline $11 / 29 / 1984$ & 1463.00 & 33.90 & 51.00 & 5.90 & 1.60 & 3 & 1 \\
\hline $12 / 14 / 1984$ & 1121.00 & 3.10 & 52.00 & 2.50 & 0.10 & 3 & 1 \\
\hline $1 / 15 / 1985$ & 1140.00 & 36.20 & 39.00 & 6.40 & 0.90 & 3 & 1 \\
\hline
\end{tabular}




\begin{tabular}{|c|c|c|c|c|c|c|c|}
\hline \multicolumn{8}{|c|}{ Appendix 14. Station D19C Corbicula Data } \\
\hline Date & $\begin{array}{l}\text { Total \# of } \\
\text { clams in } \\
\text { sample } \\
\left(\# / \mathrm{m}^{2}\right)\end{array}$ & $\begin{array}{c}\text { biomass } \\
\left(\mathrm{g} / \mathrm{m}^{2}\right)\end{array}$ & $\begin{array}{l}\text { recruit/ } \\
0.05 \mathrm{~m}^{2}\end{array}$ & $\begin{array}{c}\text { mean size } \\
(\mathrm{mm})\end{array}$ & $\begin{array}{c}\text { GR } \\
\left(\mathrm{m}^{3} / \mathrm{m}^{2} / \mathrm{d}\right)\end{array}$ & Depth (M) & \# Grabs \\
\hline $2 / 26 / 1985$ & 1786.00 & 19.90 & 69.00 & 4.80 & 0.50 & 3 & 1 \\
\hline $3 / 18 / 1985$ & 1121.00 & 27.70 & 34.00 & 6.90 & 1.00 & 3 & 1 \\
\hline $4 / 10 / 1985$ & 399.00 & 39.60 & 11.00 & 10.60 & 1.90 & 3 & 1 \\
\hline $5 / 31 / 1985$ & 874.00 & 37.10 & 30.00 & 7.40 & 3.00 & 3 & 1 \\
\hline $6 / 14 / 1985$ & 855.00 & 11.50 & 28.00 & 5.90 & 1.40 & 3 & 1 \\
\hline $8 / 30 / 1985$ & 836.00 & 42.20 & 30.00 & 6.80 & 4.40 & 3 & 1 \\
\hline $10 / 2 / 1985$ & 1121.00 & 45.20 & 26.00 & 9.60 & 3.80 & 3 & 1 \\
\hline $10 / 24 / 1985$ & 722.00 & 31.50 & 16.00 & 9.90 & 1.80 & 3 & 1 \\
\hline $12 / 3 / 1985$ & 393.00 & $\mathrm{~N} / \mathrm{D}$ & N/D & N/D & $N / D$ & N/D & $N / D$ \\
\hline $12 / 30 / 1985$ & 690.00 & $\mathrm{~N} / \mathrm{D}$ & $N / D$ & $N / D$ & $\mathrm{~N} / \mathrm{D}$ & $\mathrm{N} / \mathrm{D}$ & $N / D$ \\
\hline 1/16/1986 & 722.00 & 45.90 & 5.00 & 14.80 & 1.10 & 3 & 1 \\
\hline 2/6/1986 & 551.00 & 65.00 & 9.00 & 14.40 & 2.00 & 3 & 1 \\
\hline $3 / 31 / 1986$ & 532.00 & 40.70 & 2.00 & 15.80 & 2.10 & 3 & 1 \\
\hline 4/21/1986 & 247.00 & 9.80 & 5.00 & 10.00 & 0.60 & 3 & 1 \\
\hline $5 / 21 / 1986$ & 1349.00 & 45.50 & 3.00 & 13.20 & 2.60 & 3 & 1 \\
\hline 6/30/1986 & 684.00 & 54.60 & 0.00 & 16.90 & 4.70 & 3 & 1 \\
\hline $7 / 25 / 1986$ & 285.00 & 20.00 & 0.00 & 17.20 & 2.40 & 3 & 1 \\
\hline $8 / 29 / 1986$ & 4389.00 & 185.30 & 5.00 & 14.00 & 9.00 & 3 & 1 \\
\hline 9/12/1986 & 418.00 & 36.10 & 2.00 & 16.70 & 3.40 & 3 & 1 \\
\hline $10 / 29 / 1986$ & 589.00 & 59.50 & 1.00 & 17.20 & 3.00 & 3 & 1 \\
\hline $11 / 14 / 1986$ & 798.00 & 45.20 & 1.00 & 15.90 & 1.60 & 3 & 1 \\
\hline $12 / 9 / 1986$ & 475.00 & 30.00 & 5.00 & 14.50 & $N / D$ & 3 & 1 \\
\hline $1 / 23 / 1987$ & 722.00 & 42.20 & 5.00 & 14.80 & 1.00 & 3 & 1 \\
\hline $2 / 26 / 1987$ & 798.00 & 36.80 & 2.00 & 14.80 & 0.90 & 3 & 1 \\
\hline $3 / 26 / 1987$ & 627.00 & 29.20 & 18.00 & 9.00 & 1.10 & 3 & 1 \\
\hline $4 / 24 / 1987$ & 475.00 & 25.10 & 9.00 & 12.10 & 1.60 & 3 & 1 \\
\hline $5 / 22 / 1987$ & 874.00 & 29.70 & 24.00 & 9.10 & 2.90 & 3 & 1 \\
\hline 6/9/1987 & $\mathrm{N} / \mathrm{D}$ & $\mathrm{N} / \mathrm{D}$ & N/D & $\mathrm{N} / \mathrm{D}$ & $N / D$ & $N / D$ & $N / D$ \\
\hline $7 / 30 / 1987$ & 570.00 & 17.60 & 18.00 & 7.70 & 2.00 & 3 & 1 \\
\hline $8 / 20 / 1987$ & 513.00 & 19.00 & 12.00 & 9.20 & 2.40 & 3 & 1 \\
\hline $9 / 18 / 1987$ & 1273.00 & 15.40 & 53.00 & 3.90 & 2.10 & 3 & 1 \\
\hline $10 / 30 / 1987$ & 1368.00 & 35.70 & 56.00 & 5.00 & 2.90 & 3 & 1 \\
\hline $11 / 9 / 1987$ & 1387.00 & 14.80 & 61.00 & 3.50 & 0.70 & 3 & 1 \\
\hline $12 / 17 / 1987$ & 2052.00 & 16.50 & 94.00 & 2.80 & 0.60 & 3 & 1 \\
\hline $1 / 15 / 1988$ & 836.00 & 32.10 & 28.00 & 7.40 & 0.80 & 3 & 1 \\
\hline 2/11/1988 & 798.00 & 22.20 & 25.00 & 7.30 & 0.70 & 3 & 1 \\
\hline 4/1/1988 & 627.00 & 15.40 & 24.00 & 5.90 & 1.20 & 3 & 1 \\
\hline $5 / 27 / 1988$ & 456.00 & 19.00 & 11.00 & 10.10 & 1.70 & 3 & 1 \\
\hline
\end{tabular}




\begin{tabular}{|c|c|c|c|c|c|c|c|}
\hline \multicolumn{8}{|c|}{ Appendix 14. Station D19C Corbicula Data } \\
\hline Date & $\begin{array}{l}\text { Total \# of } \\
\text { clams in } \\
\text { sample } \\
\left(\# / \mathrm{m}^{2}\right)\end{array}$ & $\begin{array}{c}\text { biomass } \\
\left(\mathrm{g} / \mathrm{m}^{2}\right)\end{array}$ & $\begin{array}{l}\text { recruit/ } \\
0.05 \mathrm{~m}^{2}\end{array}$ & $\begin{array}{c}\text { mean size } \\
(\mathrm{mm})\end{array}$ & $\begin{array}{c}\text { GR } \\
\left(\mathrm{m}^{3} / \mathrm{m}^{2} / \mathrm{d}\right)\end{array}$ & Depth (M) & \# Grabs \\
\hline $6 / 24 / 1988$ & 1672.00 & 32.40 & 71.00 & 4.40 & 3.80 & 3 & 1 \\
\hline $7 / 22 / 1988$ & 931.00 & 41.60 & 10.00 & 9.70 & 4.90 & 3 & 1 \\
\hline $8 / 22 / 1988$ & 456.00 & 27.30 & 7.00 & 12.50 & 2.70 & 3 & 1 \\
\hline 9/22/1988 & 418.00 & 38.10 & 5.00 & 14.60 & 2.90 & 3 & 1 \\
\hline $10 / 21 / 1988$ & 2147.00 & 20.40 & 103.00 & 2.70 & 1.80 & 3 & 1 \\
\hline $11 / 17 / 1988$ & 2033.00 & 36.60 & 86.00 & 4.40 & 2.10 & 3 & 1 \\
\hline $12 / 8 / 1988$ & 3097.00 & 25.10 & 147.00 & 2.50 & 0.80 & 3 & 1 \\
\hline $1 / 20 / 1989$ & 5700.00 & 51.60 & 274.00 & 2.40 & 1.30 & 3 & 1 \\
\hline 2/6/1989 & 2109.00 & 26.20 & 97.00 & 3.40 & 0.70 & 3 & 1 \\
\hline 5/4/1989 & 2527.00 & 20.80 & 120.00 & 2.80 & 1.60 & 3 & 1 \\
\hline $6 / 26 / 1989$ & $\mathrm{~N} / \mathrm{D}$ & $\mathrm{N} / \mathrm{D}$ & $N / D$ & N/D & $N / D$ & $N / D$ & $\mathrm{~N} / \mathrm{D}$ \\
\hline $7 / 24 / 1989$ & $\mathrm{~N} / \mathrm{D}$ & $\mathrm{N} / \mathrm{D}$ & $N / D$ & $N / D$ & $N / D$ & $\mathrm{~N} / \mathrm{D}$ & $\mathrm{N} / \mathrm{D}$ \\
\hline $8 / 21 / 1989$ & 969.00 & 25.40 & 36.00 & 6.00 & 2.60 & 3 & 1 \\
\hline 9/19/1989 & 2147.00 & 6.20 & 105.00 & 1.60 & 0.60 & 3 & 1 \\
\hline $10 / 17 / 1989$ & 1501.00 & 39.80 & 65.00 & 4.70 & 3.30 & 3 & 1 \\
\hline 11/13/1989 & 665.00 & 47.10 & 8.70 & 14.20 & 2.20 & 3 & 1 \\
\hline 12/4/1989 & 4376.00 & 10.20 & 223.70 & 1.40 & 0.40 & 3 & 1 \\
\hline 1/16/1990 & 2084.00 & 16.80 & 103.00 & 2.30 & 0.50 & 3 & 3 \\
\hline $2 / 27 / 1990$ & 2907.00 & 26.70 & 140.30 & 2.80 & 0.70 & 3 & 3 \\
\hline 3/19/1990 & 2723.00 & 28.90 & 128.00 & 3.20 & 1.50 & 3 & 3 \\
\hline 4/20/1990 & 1393.00 & 67.30 & 25.70 & 11.80 & 3.70 & 3 & 3 \\
\hline $5 / 14 / 1990$ & 2027.00 & 10.50 & 101.70 & 1.80 & 0.90 & 3 & 3 \\
\hline $6 / 26 / 1990$ & 513.00 & 14.20 & 15.30 & 6.20 & 1.90 & 3 & 3 \\
\hline 7/12/1990 & 760.00 & 19.70 & 23.00 & 6.30 & 2.50 & 3 & 3 \\
\hline $8 / 8 / 1990$ & 399.00 & 24.00 & 6.00 & 11.10 & 2.70 & 3 & 3 \\
\hline 9/24/1990 & 906.00 & 43.90 & 27.30 & 8.90 & 4.30 & 3 & 3 \\
\hline $10 / 22 / 1990$ & 456.00 & 8.70 & 20.30 & 4.00 & 0.70 & 3 & 3 \\
\hline 11/6/1990 & 1545.00 & 79.60 & 22.70 & 12.70 & 2.60 & 3 & 3 \\
\hline $12 / 13 / 1990$ & 754.00 & N/D & N/D & $\mathrm{N} / \mathrm{D}$ & $N / D$ & N/D & $N / D$ \\
\hline 1/7/1991 & 513.00 & 26.40 & 13.30 & 10.10 & 0.70 & 3 & 3 \\
\hline 2/21/1991 & 874.00 & 44.10 & 27.00 & 9.00 & 1.60 & 3 & 3 \\
\hline 3/5/1991 & 817.00 & 10.80 & 39.00 & 3.00 & 0.40 & 3 & 3 \\
\hline 4/11/1991 & 722.00 & 36.00 & 20.70 & 9.50 & 1.80 & 3 & 3 \\
\hline $5 / 23 / 1991$ & 1393.00 & 19.40 & 63.30 & 3.80 & 1.30 & 3 & 3 \\
\hline 6/4/1991 & 2166.00 & $\mathrm{~N} / \mathrm{D}$ & $N / D$ & N/D & $N / D$ & N/D & $N / D$ \\
\hline $7 / 16 / 1991$ & 1900.00 & 36.90 & 77.70 & 4.70 & 4.20 & 3 & 3 \\
\hline $8 / 30 / 1991$ & 956.00 & 30.50 & 32.00 & 6.90 & 3.10 & 3 & 3 \\
\hline 9/12/1991 & 1146.00 & 17.20 & 49.00 & 4.20 & 2.00 & 3 & 3 \\
\hline
\end{tabular}




\begin{tabular}{|c|c|c|c|c|c|c|c|}
\hline \multicolumn{8}{|c|}{ Appendix 14. Station D19C Corbicula Data } \\
\hline Date & $\begin{array}{l}\text { Total \# of } \\
\text { clams in } \\
\text { sample } \\
\left(\# / \mathrm{m}^{2}\right)\end{array}$ & $\begin{array}{c}\text { biomass } \\
\left(\mathrm{g} / \mathrm{m}^{2}\right)\end{array}$ & $\begin{array}{l}\text { recruit/ } \\
0.05 \mathrm{~m}^{2}\end{array}$ & $\begin{array}{c}\text { mean size } \\
(\mathrm{mm})\end{array}$ & $\begin{array}{c}\text { GR } \\
\left(\mathrm{m}^{3} / \mathrm{m}^{2} / \mathrm{d}\right)\end{array}$ & Depth (M) & \# Grabs \\
\hline 10/8/1991 & 431.00 & 23.00 & 11.00 & 10.30 & 2.60 & 3 & 3 \\
\hline 11/12/1991 & 785.00 & 24.00 & 28.30 & 6.50 & 1.10 & 3 & 3 \\
\hline $12 / 10 / 1991$ & 906.00 & 38.00 & 25.30 & 9.30 & 0.90 & 3 & 3 \\
\hline 1/17/1992 & 652.00 & 25.30 & 21.70 & 7.20 & 0.70 & 3 & 3 \\
\hline 2/25/1992 & 792.00 & 30.00 & 27.30 & 7.10 & 1.20 & 3 & 3 \\
\hline $3 / 24 / 1992$ & 855.00 & 14.80 & 33.30 & 4.00 & 0.70 & 3 & 3 \\
\hline 4/6/1992 & 1305.00 & 41.40 & 46.30 & 6.10 & 2.60 & 3 & 3 \\
\hline $5 / 14 / 1992$ & 1406.00 & 21.80 & 58.30 & 4.00 & 2.30 & 3 & 3 \\
\hline 6/17/1992 & 2001.00 & 35.30 & 53.30 & 5.10 & 3.90 & 3 & 3 \\
\hline $7 / 10 / 1992$ & 621.00 & 9.10 & 18.30 & 5.00 & 1.20 & 3 & 3 \\
\hline $8 / 4 / 1992$ & 697.00 & 35.00 & 12.00 & 9.80 & 4.30 & 3 & 3 \\
\hline 9/1/1992 & 722.00 & 16.10 & 16.00 & 5.90 & 1.70 & 3 & 3 \\
\hline $10 / 23 / 1992$ & 944.00 & 39.70 & 15.70 & 9.80 & 2.70 & 3 & 3 \\
\hline 11/5/1992 & 918.00 & 48.80 & 16.70 & 11.80 & 2.90 & 3 & 3 \\
\hline $12 / 28 / 1992$ & 690.00 & 23.40 & 18.30 & 8.10 & 0.80 & 3 & 3 \\
\hline 1/14/1993 & 716.00 & 19.30 & 23.00 & 5.90 & 0.50 & 3 & 3 \\
\hline 2/9/1993 & 684.00 & 34.20 & 13.30 & 11.10 & 1.00 & 3 & 3 \\
\hline 3/11/1993 & 1026.00 & 23.70 & 36.70 & 5.50 & 1.30 & 3 & 3 \\
\hline 4/19/1993 & 519.00 & 20.00 & 13.00 & 8.60 & 1.10 & 3 & 3 \\
\hline $5 / 20 / 1993$ & 513.00 & 9.40 & 17.70 & 4.90 & 0.70 & 3 & 3 \\
\hline 6/16/1993 & 773.00 & 14.00 & 29.70 & 4.80 & 1.50 & 3 & 3 \\
\hline $7 / 19 / 1993$ & 1039.00 & 12.40 & 40.30 & 4.10 & 1.50 & 3 & 3 \\
\hline $8 / 19 / 1993$ & 735.00 & 25.30 & 18.30 & 7.70 & 2.60 & 3 & 3 \\
\hline 9/16/1993 & 500.00 & 16.10 & 16.30 & 6.90 & 2.10 & 3 & 3 \\
\hline $10 / 8 / 1993$ & 450.00 & 16.10 & 14.30 & 7.50 & 1.40 & 3 & 3 \\
\hline $11 / 16 / 1993$ & 659.00 & 15.00 & 23.00 & 6.10 & 0.90 & 3 & 3 \\
\hline $12 / 9 / 1993$ & 665.00 & 18.40 & 18.70 & 7.00 & 0.50 & 3 & 3 \\
\hline 1/18/1994 & 1102.00 & 32.70 & 36.00 & 6.40 & 0.90 & 3 & 3 \\
\hline 2/8/1994 & 836.00 & 58.60 & 7.00 & 15.10 & 1.40 & 3 & 3 \\
\hline 3/9/1994 & 817.00 & 61.50 & 6.30 & 15.80 & 2.40 & 3 & 3 \\
\hline $4 / 12 / 1994$ & 804.00 & 47.10 & 14.30 & 11.60 & 2.20 & 3 & 3 \\
\hline $5 / 23 / 1994$ & 1989.00 & 25.00 & 75.70 & 4.10 & 2.00 & 3 & 3 \\
\hline 6/9/1994 & 2527.00 & 28.30 & 107.30 & 3.50 & 2.90 & 3 & 3 \\
\hline $7 / 20 / 1994$ & 1191.00 & 21.00 & 38.00 & 5.20 & 2.40 & 3 & 3 \\
\hline 8/9/1994 & 703.00 & 17.50 & 16.30 & 6.40 & 3.20 & 3 & 3 \\
\hline 9/21/1994 & 576.00 & 13.80 & 14.00 & 6.70 & 1.50 & 3 & 3 \\
\hline $10 / 19 / 1994$ & 1184.00 & 29.70 & 32.70 & 6.40 & 1.90 & 3 & 3 \\
\hline $11 / 21 / 1994$ & 1172.00 & 37.30 & 38.70 & 6.40 & 1.10 & 3 & 3 \\
\hline
\end{tabular}




\begin{tabular}{|c|c|c|c|c|c|c|c|}
\hline \multicolumn{8}{|c|}{ Appendix 14. Station D19C Corbicula Data } \\
\hline Date & $\begin{array}{l}\text { Total \# of } \\
\text { clams in } \\
\text { sample } \\
\left(\# / \mathrm{m}^{2}\right)\end{array}$ & $\begin{array}{c}\text { biomass } \\
\left(\mathrm{g} / \mathrm{m}^{2}\right)\end{array}$ & $\begin{array}{l}\text { recruit/ } \\
0.05 \mathrm{~m}^{2}\end{array}$ & $\begin{array}{c}\text { mean size } \\
(\mathrm{mm})\end{array}$ & $\begin{array}{c}\text { GR } \\
\left(\mathrm{m}^{3} / \mathrm{m}^{2} / \mathrm{d}\right)\end{array}$ & Depth (M) & \# Grabs \\
\hline $12 / 16 / 1994$ & 336.00 & 9.60 & 4.30 & 8.30 & 0.30 & 3 & 3 \\
\hline 1/17/1995 & 1507.00 & 8.40 & 66.00 & 2.40 & 0.30 & 3 & 3 \\
\hline 2/15/1995 & 481.00 & 31.60 & 2.70 & 13.20 & 1.00 & 3 & 3 \\
\hline 3/15/1995 & 412.00 & 30.00 & 7.30 & 13.10 & 1.10 & 3 & 3 \\
\hline 4/27/1995 & 513.00 & 19.00 & 10.00 & 9.00 & 0.80 & 3 & 3 \\
\hline 5/17/1995 & 2350.00 & 29.00 & 103.30 & 3.80 & 2.20 & 3 & 3 \\
\hline $6 / 27 / 1995$ & 969.00 & 11.90 & 35.70 & 4.80 & 0.90 & 3 & 3 \\
\hline 7/13/1995 & 1349.00 & 21.40 & 33.30 & 5.50 & 2.00 & 3 & 3 \\
\hline 8/24/1995 & 1267.00 & 14.10 & 47.70 & 4.00 & 1.90 & 3 & 3 \\
\hline 9/26/1995 & 5333.00 & 20.50 & 253.00 & 2.00 & 1.90 & 3 & 3 \\
\hline $10 / 25 / 1995$ & 4414.00 & 37.20 & 194.30 & 3.20 & 2.60 & 3 & 3 \\
\hline $11 / 27 / 1995$ & 1577.00 & 16.30 & 56.30 & 3.80 & 0.90 & 3 & 3 \\
\hline $12 / 27 / 1995$ & 6251.00 & 17.40 & 302.70 & 2.30 & 0.60 & 3 & 3 \\
\hline
\end{tabular}

\section{Appendix 15. Station D24 Corbicula Data}

\begin{tabular}{|c|c|c|c|c|c|c|c|}
\hline Date & $\begin{array}{l}\text { Total \# of } \\
\text { clams in } \\
\text { sample } \\
\left(\# / \mathrm{m}^{2}\right)\end{array}$ & $\begin{array}{c}\text { biomass } \\
\left(\mathrm{g} / \mathrm{m}^{2}\right)\end{array}$ & $\mathrm{rec} / 0.05 \mathrm{~m}^{2}$ & $\begin{array}{l}\text { mean size } \\
(\mathrm{mm})\end{array}$ & $\begin{array}{c}\text { GR } \\
\left(\mathrm{m}^{3} / \mathrm{m}^{2} / \mathrm{d}\right)\end{array}$ & Depth (M) & \# Grabs \\
\hline 1/23/1996 & 1811.33 & 34.77 & 70.00 & 5.30 & 0.90 & 8.26 & 4 \\
\hline 2/23/1996 & 95.00 & 3.58 & 2.70 & 9.60 & 0.10 & 8.26 & 4 \\
\hline $3 / 22 / 1996$ & 867.67 & 15.84 & 32.70 & 5.10 & 0.50 & 8.26 & 4 \\
\hline 4/29/1996 & 1608.67 & 58.10 & 47.30 & 7.60 & 2.00 & 8.26 & 4 \\
\hline $5 / 17 / 1996$ & 722.00 & 73.74 & 10.30 & 11.30 & 4.00 & 8.26 & 4 \\
\hline 7/18/1996 & 392.67 & 23.12 & 0.30 & 11.60 & 2.30 & 8.26 & 4 \\
\hline $8 / 30 / 1996$ & 1368.00 & 46.55 & 35.70 & 7.70 & 5.00 & 8.26 & 4 \\
\hline 9/13/1996 & 1564.33 & 27.29 & 57.70 & 5.00 & 2.20 & 8.26 & 4 \\
\hline 10/9/1996 & 823.33 & 24.85 & 31.00 & 5.50 & 1.70 & 8.26 & 4 \\
\hline 11/15/1996 & 1203.33 & 42.45 & 37.30 & 7.60 & 1.50 & 8.26 & 4 \\
\hline 12/12/1996 & 1684.67 & 51.62 & 52.70 & 7.00 & 1.80 & 8.26 & 4 \\
\hline 1/22/1997 & 532.00 & 51.00 & 0.30 & 18.30 & 1.30 & 8.26 & 4 \\
\hline 2/21/1997 & 342.00 & 21.08 & 1.00 & 15.60 & 0.50 & 8.26 & 4 \\
\hline $3 / 26 / 1997$ & 475.00 & 30.68 & 10.70 & 11.30 & 1.40 & 8.26 & 4 \\
\hline 4/24/1997 & 256.50 & 0.08 & 11.30 & 2.10 & 0.00 & 8.26 & 4 \\
\hline 5/23/1997 & 2356.00 & 39.19 & 107.00 & 3.00 & 3.30 & 8.26 & 4 \\
\hline 6/20/1997 & 690.33 & 22.84 & 21.70 & 5.80 & 2.20 & 8.26 & 4 \\
\hline $7 / 24 / 1997$ & 3192.00 & 12.06 & 159.70 & 1.90 & 1.30 & 8.26 & 4 \\
\hline $8 / 21 / 1997$ & 2178.67 & 34.17 & 91.00 & 3.80 & 3.60 & 8.26 & 4 \\
\hline
\end{tabular}




\begin{tabular}{|c|c|c|c|c|c|c|c|}
\hline \multicolumn{8}{|c|}{ Appendix 15. Station D24 Corbicula Data } \\
\hline Date & $\begin{array}{l}\text { Total \# of } \\
\text { clams in } \\
\text { sample } \\
\left(\# / \mathrm{m}^{2}\right)\end{array}$ & $\begin{array}{c}\text { biomass } \\
\left(\mathrm{g} / \mathrm{m}^{2}\right)\end{array}$ & $\mathrm{rec} / 0.05 \mathrm{~m}^{2}$ & $\begin{array}{c}\text { mean size } \\
(\mathrm{mm})\end{array}$ & $\begin{array}{c}\text { GR } \\
\left(\mathrm{m}^{3} / \mathrm{m}^{2} / \mathrm{d}\right)\end{array}$ & Depth (M) & \# Grabs \\
\hline 9/18/1997 & 2178.67 & 29.96 & 106.00 & 2.70 & 3.20 & 8.26 & 4 \\
\hline 10/29/1997 & 2204.00 & 2.58 & 109.00 & 1.90 & 0.20 & 8.26 & 4 \\
\hline 11/20/1997 & 943.67 & 21.56 & 40.70 & 4.20 & 1.20 & 8.26 & 4 \\
\hline 12/18/1997 & 874.00 & 25.75 & 29.30 & 5.50 & 1.00 & 8.26 & 4 \\
\hline $1 / 15 / 1998$ & 1450.33 & 43.50 & 57.30 & 5.40 & 1.10 & 8.26 & 4 \\
\hline 2/19/1998 & 335.67 & 13.58 & 11.30 & 7.70 & 0.40 & 8.26 & 4 \\
\hline $3 / 17 / 1998$ & 475.00 & 57.98 & 5.30 & 16.00 & 2.20 & 8.26 & 4 \\
\hline 4/16/1998 & 741.00 & 50.46 & 10.00 & 11.50 & 1.60 & 8.26 & 4 \\
\hline $5 / 13 / 1998$ & 874.00 & 56.19 & 32.70 & 6.20 & 2.70 & 8.26 & 4 \\
\hline 6/8/1998 & 1235.00 & 47.11 & 49.80 & 5.20 & 2.80 & 8.26 & 4 \\
\hline 7/9/1998 & 291.33 & 3.08 & 12.70 & 3.10 & 0.40 & 8.26 & 4 \\
\hline $8 / 4 / 1998$ & 888.25 & 0.35 & 35.00 & 1.80 & 0.00 & 8.26 & 4 \\
\hline 9/16/1998 & 1456.67 & 15.01 & 64.70 & 2.60 & 1.70 & 8.26 & 4 \\
\hline $10 / 6 / 1998$ & 2273.67 & 65.49 & 102.00 & 3.60 & 1.80 & 8.26 & 4 \\
\hline $11 / 4 / 1998$ & 1059.25 & 11.91 & 49.80 & 2.70 & 0.40 & 8.26 & 4 \\
\hline $12 / 21 / 1998$ & 5408.67 & 27.21 & 274.70 & 2.00 & 0.70 & 8.26 & 4 \\
\hline 1/15/1999 & 6498.00 & 15.34 & 321.30 & 1.80 & 0.40 & 8.26 & 4 \\
\hline 2/19/1999 & 5668.33 & 9.54 & 280.00 & 1.90 & 0.30 & 8.26 & 4 \\
\hline 3/17/1999 & 2736.00 & 6.69 & 137.00 & 1.90 & 0.20 & 8.26 & 4 \\
\hline 4/16/1999 & 6035.67 & 20.57 & 289.00 & 2.10 & 0.70 & 8.26 & 4 \\
\hline 5/20/1999 & 1311.00 & 23.89 & 59.00 & 2.80 & 1.20 & 8.26 & 4 \\
\hline $6 / 15 / 1999$ & 601.67 & 16.44 & 23.30 & 3.70 & 1.20 & 8.26 & 4 \\
\hline 7/15/1999 & 639.67 & 0.81 & 31.30 & 2.00 & 0.10 & 8.26 & 4 \\
\hline 8/13/1999 & 544.67 & 0.51 & 27.00 & 2.00 & 0.10 & 8.26 & 4 \\
\hline 9/24/1999 & 1045.00 & 45.29 & 37.30 & 6.60 & 3.70 & 8.26 & 4 \\
\hline 10/27/1999 & 826.50 & 20.99 & 37.50 & 3.20 & 1.30 & 8.26 & 4 \\
\hline 11/9/1999 & 570.00 & 0.40 & 21.70 & 2.70 & 0.00 & 8.26 & 4 \\
\hline 12/9/1999 & 943.67 & 12.74 & 34.00 & 3.30 & 0.40 & 8.26 & 4 \\
\hline $1 / 7 / 2000$ & 456.00 & 3.73 & 14.50 & 3.60 & 0.10 & 8.26 & 4 \\
\hline $2 / 24 / 2000$ & 2527.00 & 16.26 & 119.80 & 2.10 & 0.50 & 8.26 & 4 \\
\hline $3 / 24 / 2000$ & 1429.75 & 6.92 & 67.80 & 2.30 & 0.20 & 8.26 & 4 \\
\hline $4 / 20 / 2000$ & 1776.50 & 45.05 & 81.50 & 3.00 & 2.20 & 8.26 & 4 \\
\hline $5 / 17 / 2000$ & 1201.75 & 164.07 & 42.50 & 7.50 & 9.20 & 8.26 & 4 \\
\hline $6 / 15 / 2000$ & 2398.75 & 48.71 & 115.50 & 5.50 & 4.20 & 8.26 & 4 \\
\hline $7 / 19 / 2000$ & 570.00 & 27.50 & 25.80 & 2.40 & 2.50 & 8.26 & 4 \\
\hline $8 / 15 / 2000$ & 2213.50 & 24.63 & 109.50 & 1.50 & 2.40 & 8.26 & 4 \\
\hline $9 / 13 / 2000$ & 1358.50 & 6.88 & 63.30 & 2.10 & 0.50 & 8.26 & 4 \\
\hline $10 / 12 / 2000$ & 1083.00 & 10.89 & 49.30 & 2.00 & 0.80 & 8.26 & 4 \\
\hline
\end{tabular}


Appendix 15. Station D24 Corbicula Data

\begin{tabular}{|c|c|c|c|c|c|c|c|}
\hline Date & $\begin{array}{l}\text { Total \# of } \\
\text { clams in } \\
\text { sample } \\
\left(\# / \mathrm{m}^{2}\right)\end{array}$ & $\begin{array}{c}\text { biomass } \\
\left(\mathrm{g} / \mathrm{m}^{2}\right)\end{array}$ & $\mathrm{rec} / 0.05 \mathrm{~m}^{2}$ & $\begin{array}{c}\text { mean size } \\
(\mathrm{mm})\end{array}$ & $\begin{array}{c}\text { GR } \\
\left(\mathrm{m}^{3} / \mathrm{m}^{2} / \mathrm{d}\right)\end{array}$ & Depth (M) & \# Grabs \\
\hline $11 / 17 / 2000$ & 945.25 & 2.29 & 41.30 & 2.10 & 0.10 & 8.26 & 4 \\
\hline $12 / 13 / 2000$ & 1021.25 & 18.43 & 46.00 & 2.60 & 0.50 & 8.26 & 4 \\
\hline $1 / 12 / 2001$ & 513.00 & 11.87 & 17.30 & 4.00 & 0.30 & 8.26 & 4 \\
\hline $2 / 7 / 2001$ & 1786.00 & 3.41 & 86.30 & 1.80 & 0.10 & 8.26 & 4 \\
\hline $3 / 8 / 2001$ & 1241.33 & 4.80 & 57.00 & 2.20 & 0.10 & 8.26 & 4 \\
\hline $4 / 5 / 2001$ & 1790.75 & 34.25 & 86.00 & 2.70 & 2.20 & 8.26 & 4 \\
\hline $5 / 9 / 2001$ & 449.67 & 3.23 & 22.70 & 2.40 & 0.20 & 8.26 & 4 \\
\hline $6 / 19 / 2001$ & 2365.50 & 14.78 & 121.50 & 1.80 & 1.50 & 8.26 & 4 \\
\hline $7 / 24 / 2001$ & 2854.75 & 31.20 & 144.80 & 1.90 & 3.80 & 8.26 & 4 \\
\hline $8 / 22 / 2001$ & 1729.00 & 22.52 & 87.50 & 2.20 & 2.50 & 8.26 & 4 \\
\hline $9 / 20 / 2001$ & 1982.33 & 19.37 & 101.30 & 2.10 & 1.90 & 8.26 & 4 \\
\hline $10 / 19 / 2001$ & 1127.33 & 5.90 & 56.00 & 2.20 & 0.50 & 8.26 & 4 \\
\hline $11 / 21 / 2001$ & 1564.33 & 4.25 & 76.70 & 2.20 & 0.20 & 8.26 & 4 \\
\hline $12 / 14 / 2001$ & 190.00 & 2.81 & 7.80 & 4.20 & 0.10 & 8.26 & 4 \\
\hline $1 / 17 / 2002$ & 1710.00 & 27.39 & 80.00 & 5.90 & 0.70 & 8.26 & 4 \\
\hline $2 / 14 / 2002$ & 902.50 & 2.42 & 45.00 & 1.00 & 0.10 & 8.26 & 4 \\
\hline $3 / 12 / 2002$ & 2066.25 & 12.92 & 101.30 & 1.10 & 0.40 & 8.26 & 4 \\
\hline $4 / 16 / 2002$ & 1667.25 & 8.88 & 78.80 & 2.40 & 0.50 & 8.26 & 4 \\
\hline $5 / 15 / 2002$ & 1909.50 & 25.46 & 77.80 & 1.60 & 1.60 & 8.26 & 4 \\
\hline $6 / 11 / 2002$ & 921.50 & 14.82 & 34.30 & 1.90 & 1.50 & 8.26 & 4 \\
\hline $7 / 9 / 2002$ & 970.92 & 27.08 & 45.80 & 2.40 & 2.70 & 8.26 & 4 \\
\hline $8 / 8 / 2002$ & 7215.00 & 6.15 & 377.80 & 1.20 & 0.60 & 8.26 & 4 \\
\hline $9 / 11 / 2002$ & 2689.00 & 6.33 & 135.50 & 2.00 & 0.50 & 8.26 & 4 \\
\hline $10 / 24 / 2002$ & 2385.00 & 3.06 & 119.00 & 1.60 & 0.20 & 8.26 & 4 \\
\hline $11 / 6 / 2002$ & 1302.00 & 2.81 & 57.30 & 2.60 & 0.10 & 8.26 & 4 \\
\hline $12 / 6 / 2002$ & 2280.00 & 1.73 & 111.80 & 1.70 & 0.10 & 8.26 & 4 \\
\hline $1 / 21 / 2003$ & $\mathrm{~N} / \mathrm{D}$ & $\mathrm{N} / \mathrm{D}$ & $\mathrm{N} / \mathrm{D}$ & $N / D$ & $N / D$ & $N / D$ & $N / D$ \\
\hline $2 / 18 / 2003$ & N/D & $N / D$ & $\mathrm{~N} / \mathrm{D}$ & $\mathrm{N} / \mathrm{D}$ & $N / D$ & $N / D$ & $\mathrm{~N} / \mathrm{D}$ \\
\hline $3 / 18 / 2003$ & $\mathrm{~N} / \mathrm{D}$ & $\mathrm{N} / \mathrm{D}$ & $\mathrm{N} / \mathrm{D}$ & $N / D$ & $N / D$ & $N / D$ & $N / D$ \\
\hline $4 / 16 / 2003$ & N/D & $N / D$ & $\mathrm{~N} / \mathrm{D}$ & $\mathrm{N} / \mathrm{D}$ & $\mathrm{N} / \mathrm{D}$ & $\mathrm{N} / \mathrm{D}$ & $\mathrm{N} / \mathrm{D}$ \\
\hline $5 / 14 / 2003$ & $N / D$ & N/D & $\mathrm{N} / \mathrm{D}$ & $N / D$ & $N / D$ & $N / D$ & $N / D$ \\
\hline $6 / 1 / 2003$ & N/D & $N / D$ & $\mathrm{~N} / \mathrm{D}$ & $\mathrm{N} / \mathrm{D}$ & $\mathrm{N} / \mathrm{D}$ & $N / D$ & $N / D$ \\
\hline $7 / 14 / 2003$ & $\mathrm{~N} / \mathrm{D}$ & N/D & $\mathrm{N} / \mathrm{D}$ & $\mathrm{N} / \mathrm{D}$ & N/D & N/D & $N / D$ \\
\hline $8 / 13 / 2003$ & N/D & $N / D$ & $\mathrm{~N} / \mathrm{D}$ & N/D & $\mathrm{N} / \mathrm{D}$ & $N / D$ & $N / D$ \\
\hline $9 / 18 / 2003$ & $\mathrm{~N} / \mathrm{D}$ & N/D & $\mathrm{N} / \mathrm{D}$ & N/D & N/D & N/D & $N / D$ \\
\hline $10 / 23 / 2003$ & N/D & $N / D$ & $\mathrm{~N} / \mathrm{D}$ & N/D & N/D & $N / D$ & $N / D$ \\
\hline $1 / 8 / 2004$ & $\mathrm{~N} / \mathrm{D}$ & $\mathrm{N} / \mathrm{D}$ & $\mathrm{N} / \mathrm{D}$ & $\mathrm{N} / \mathrm{D}$ & $\mathrm{N} / \mathrm{D}$ & N/D & $N / D$ \\
\hline $4 / 7 / 2004$ & $N / D$ & $\mathrm{~N} / \mathrm{D}$ & $\mathrm{N} / \mathrm{D}$ & N/D & N/D & N/D & $N / D$ \\
\hline
\end{tabular}




\begin{tabular}{|c|c|c|c|c|c|c|c|}
\hline \multicolumn{8}{|c|}{ Appendix 15. Station D24 Corbicula Data } \\
\hline Date & $\begin{array}{l}\text { Total \# of } \\
\text { clams in } \\
\text { sample } \\
\left(\# / \mathrm{m}^{2}\right)\end{array}$ & $\begin{array}{c}\text { biomass } \\
\left(\mathrm{g} / \mathrm{m}^{2}\right)\end{array}$ & $\mathrm{rec} / 0.05 \mathrm{~m}^{2}$ & $\begin{array}{c}\text { mean size } \\
(\mathrm{mm})\end{array}$ & $\begin{array}{c}\text { GR } \\
\left(\mathrm{m}^{3} / \mathrm{m}^{2} / \mathrm{d}\right)\end{array}$ & Depth (M) & \# Grabs \\
\hline $7 / 15 / 2004$ & 1222.00 & 7.88 & 59.70 & 2.50 & 0.90 & 8.26 & 4 \\
\hline $10 / 26 / 2004$ & 1172.00 & 9.63 & 19.00 & 4.90 & 0.90 & 8.26 & 4 \\
\hline $1 / 12 / 2005$ & 251.75 & 1.39 & 7.80 & 3.70 & 0.00 & 8.26 & 4 \\
\hline $4 / 8 / 2005$ & 2007.67 & 9.01 & 63.70 & 4.00 & 0.40 & 8.26 & 4 \\
\hline $7 / 25 / 2005$ & 2267.33 & 16.43 & 107.00 & 2.50 & 1.10 & 8.26 & 4 \\
\hline $10 / 14 / 2005$ & 1336.33 & 8.63 & 33.30 & 4.20 & 0.50 & 8.26 & 4 \\
\hline $11 / 9 / 2005$ & 1089.33 & 6.06 & 22.30 & 4.90 & 0.30 & 8.26 & 4 \\
\hline $12 / 7 / 2005$ & 595.33 & 6.29 & 7.70 & 5.30 & 0.20 & 8.26 & 4 \\
\hline $1 / 12 / 2006$ & 251.75 & 3.00 & 3.00 & 6.80 & 0.10 & 8.26 & 4 \\
\hline $2 / 9 / 2006$ & 413.25 & 11.11 & 4.80 & 3.70 & 0.40 & 8.26 & 4 \\
\hline $3 / 15 / 2006$ & 498.75 & 1.95 & 17.80 & 1.50 & 0.10 & 8.26 & 4 \\
\hline $4 / 26 / 2006$ & 285.00 & 4.39 & 5.70 & 3.10 & 0.10 & 8.26 & 4 \\
\hline $5 / 25 / 2006$ & 840.75 & 36.89 & 10.80 & 8.30 & 2.10 & 8.26 & 4 \\
\hline $6 / 5 / 2006$ & 1130.50 & 10.34 & 19.80 & 2.60 & 0.80 & 8.26 & 4 \\
\hline $7 / 10 / 2006$ & 532.00 & 15.36 & 14.30 & 5.70 & 1.30 & 8.26 & 4 \\
\hline $8 / 10 / 2006$ & 1724.25 & 37.57 & 58.50 & 2.80 & 3.70 & 8.26 & 4 \\
\hline $9 / 25 / 2006$ & 2099.50 & 9.27 & 71.00 & 3.60 & 0.80 & 8.26 & 4 \\
\hline $10 / 25 / 2006$ & 1738.50 & 17.06 & 52.30 & 0.30 & 1.00 & 8.26 & 4 \\
\hline $11 / 20 / 2006$ & 1406.00 & 11.98 & 42.80 & 4.80 & 0.50 & 8.26 & 4 \\
\hline $12 / 20 / 2006$ & 1472.50 & 57.44 & 30.30 & 0.30 & 1.70 & 8.26 & 4 \\
\hline $1 / 23 / 2007$ & 2322.75 & 46.51 & 73.00 & 5.80 & 1.20 & 8.26 & 4 \\
\hline $2 / 20 / 2007$ & 665.00 & 8.19 & 20.70 & 2.20 & 0.20 & 8.26 & 4 \\
\hline $3 / 20 / 2007$ & 1178.00 & 34.52 & 29.70 & 3.30 & 1.10 & 8.26 & 4 \\
\hline $4 / 16 / 2007$ & 2242.00 & 96.11 & 56.50 & 7.50 & 3.90 & 8.26 & 4 \\
\hline $5 / 16 / 2007$ & 845.50 & 21.68 & 13.80 & 3.20 & 1.40 & 8.26 & 4 \\
\hline $6 / 20 / 2007$ & 646.00 & 43.50 & 1.80 & 5.40 & 3.20 & 8.26 & 4 \\
\hline $7 / 16 / 2007$ & 779.00 & 48.18 & 0.00 & 6.50 & 4.00 & 8.26 & 4 \\
\hline $8 / 15 / 2007$ & 1230.25 & 46.50 & 26.30 & 4.10 & 4.40 & 8.26 & 4 \\
\hline $9 / 11 / 2007$ & 603.25 & 22.87 & 5.50 & 11.10 & 1.80 & 8.26 & 4 \\
\hline $10 / 3 / 2007$ & 945.25 & 42.87 & 8.80 & 11.90 & 2.00 & 8.26 & 4 \\
\hline $11 / 6 / 2007$ & 228.00 & 7.70 & 2.00 & 9.40 & 0.40 & 8.26 & 4 \\
\hline $12 / 10 / 2007$ & 1235.00 & 59.82 & 5.30 & 13.10 & 1.30 & 8.26 & 4 \\
\hline $1 / 8 / 2008$ & 308.75 & 5.42 & 4.30 & 8.50 & 0.20 & 8.26 & 4 \\
\hline $2 / 6 / 2008$ & 489.25 & 9.85 & 10.30 & 3.50 & 0.30 & 8.26 & 4 \\
\hline $3 / 5 / 2008$ & 821.75 & 50.11 & 2.50 & 7.10 & 1.90 & 8.26 & 4 \\
\hline $4 / 2 / 2008$ & 931.00 & 52.93 & 1.80 & 6.90 & 2.60 & 8.26 & 4 \\
\hline $5 / 20 / 2008$ & 669.75 & 38.48 & 0.50 & 7.30 & 2.50 & 8.26 & 4 \\
\hline $6 / 17 / 2008$ & 608.00 & 25.85 & 0.50 & 6.70 & 2.40 & 8.26 & 4 \\
\hline
\end{tabular}




\begin{tabular}{|c|c|c|c|c|c|c|c|}
\hline \multicolumn{8}{|c|}{ Appendix 15. Station D24 Corbicula Data } \\
\hline Date & $\begin{array}{l}\text { Total \# of } \\
\text { clams in } \\
\text { sample } \\
\left(\# / \mathrm{m}^{2}\right)\end{array}$ & $\begin{array}{c}\text { biomass } \\
\left(\mathrm{g} / \mathrm{m}^{2}\right)\end{array}$ & $\mathrm{rec} / 0.05 \mathrm{~m}^{2}$ & $\begin{array}{c}\text { mean size } \\
(\mathrm{mm})\end{array}$ & $\begin{array}{c}\text { GR } \\
\left(\mathrm{m}^{3} / \mathrm{m}^{2} / \mathrm{d}\right)\end{array}$ & Depth (M) & \# Grabs \\
\hline $7 / 14 / 2008$ & 1111.50 & 71.90 & 1.00 & 15.50 & 5.70 & 8.26 & 4 \\
\hline $8 / 13 / 2008$ & 2968.75 & 36.99 & 118.50 & 2.30 & 3.90 & 8.26 & 4 \\
\hline $9 / 15 / 2008$ & 755.25 & 19.50 & 8.80 & 5.20 & 1.70 & 8.26 & 4 \\
\hline $10 / 28 / 2008$ & 916.75 & 21.76 & 16.30 & 8.60 & 1.10 & 8.26 & 4 \\
\hline $11 / 18 / 2008$ & 988.00 & 40.10 & 4.50 & 13.10 & 1.60 & 8.26 & 4 \\
\hline $12 / 10 / 2008$ & 513.00 & 10.18 & 4.30 & 10.00 & 0.30 & 8.26 & 4 \\
\hline $1 / 12 / 2009$ & 1154.25 & 54.88 & 1.80 & 14.70 & 1.10 & 8.26 & 4 \\
\hline 2/9/2009 & 674.50 & 28.74 & 2.30 & 5.50 & 0.80 & 8.26 & 4 \\
\hline 3/11/2009 & 703.00 & 36.87 & 1.00 & 7.10 & 1.20 & 8.26 & 4 \\
\hline $4 / 6 / 2009$ & 1021.25 & 61.56 & 1.50 & 7.00 & 2.50 & 8.26 & 4 \\
\hline $5 / 5 / 2009$ & 1073.50 & 53.86 & 2.30 & 7.10 & 4.30 & 8.26 & 4 \\
\hline $6 / 23 / 2009$ & 788.50 & 33.13 & 1.80 & 7.00 & 3.00 & 8.26 & 4 \\
\hline $7 / 21 / 2009$ & 745.75 & 29.77 & 0.50 & 13.60 & 2.70 & 8.26 & 4 \\
\hline $8 / 18 / 2009$ & 1302.00 & 69.43 & 7.50 & 7.00 & 6.00 & 8.26 & 4 \\
\hline $9 / 16 / 2009$ & 936.00 & 30.04 & 8.00 & 6.00 & 3.10 & 8.26 & 4 \\
\hline $10 / 19 / 2009$ & 922.00 & 17.03 & 7.00 & 11.00 & 0.70 & 8.26 & 4 \\
\hline $11 / 16 / 2009$ & 1126.00 & 36.29 & 6.30 & 12.10 & 1.10 & 8.26 & 4 \\
\hline $12 / 15 / 2009$ & 846.00 & 16.05 & 8.50 & 8.80 & 0.40 & 8.26 & 4 \\
\hline $1 / 13 / 2010$ & 1040.00 & 35.33 & 3.80 & 12.30 & 0.80 & 8.26 & 4 \\
\hline $2 / 17 / 2010$ & 855.00 & 17.44 & 4.80 & 10.10 & 0.50 & 8.26 & 4 \\
\hline $3 / 15 / 2010$ & 1020.00 & 32.31 & 8.70 & 10.90 & 1.40 & 8.26 & 4 \\
\hline $4 / 12 / 2010$ & 1226.00 & 51.16 & 5.80 & 13.20 & 1.70 & 8.26 & 4 \\
\hline $5 / 19 / 2010$ & 1112.00 & 43.28 & 4.80 & 12.20 & 2.10 & 8.26 & 4 \\
\hline $6 / 9 / 2010$ & 865.00 & 25.46 & 4.80 & 11.30 & 1.70 & 8.26 & 4 \\
\hline $7 / 6 / 2010$ & 1406.00 & 60.92 & 5.00 & 13.20 & 4.30 & 8.26 & 4 \\
\hline $8 / 16 / 2010$ & 1411.00 & 46.26 & 8.00 & 12.20 & 3.40 & 8.26 & 4 \\
\hline $9 / 7 / 2010$ & 1268.00 & 38.25 & 15.80 & 10.90 & 2.40 & 8.26 & 4 \\
\hline $10 / 26 / 2010$ & 1244.50 & 22.16 & 14.30 & 8.90 & 1.10 & 8.26 & 4 \\
\hline $11 / 22 / 2010$ & 1539.00 & 50.14 & 12.30 & 10.50 & 1.70 & 8.26 & 4 \\
\hline $12 / 20 / 2010$ & 2337.00 & 90.06 & 22.80 & 9.90 & 2.10 & 8.26 & 4 \\
\hline $1 / 18 / 2011$ & 1543.75 & 51.21 & 9.00 & 11.70 & 1.10 & 8.26 & 4 \\
\hline $2 / 1 / 2011$ & 1458.25 & 40.60 & 10.50 & 10.50 & 0.90 & 8.26 & 4 \\
\hline $3 / 7 / 2011$ & 1724.25 & 58.18 & 15.00 & 5.10 & 1.70 & 8.26 & 4 \\
\hline $4 / 5 / 2011$ & 1334.75 & 56.02 & 4.50 & 6.10 & 2.50 & 8.26 & 4 \\
\hline $5 / 3 / 2011$ & 1847.75 & 92.88 & 16.80 & 5.30 & 5.00 & 8.26 & 4 \\
\hline $6 / 13 / 2011$ & 1653.00 & 92.04 & 10.50 & 5.90 & 6.00 & 8.26 & 4 \\
\hline $7 / 12 / 2011$ & 1505.75 & 117.17 & 3.00 & 13.40 & 7.30 & 8.26 & 4 \\
\hline $8 / 9 / 2011$ & 1040.25 & 61.02 & 0.80 & 6.90 & 6.20 & 8.26 & 4 \\
\hline
\end{tabular}




\begin{tabular}{|c|c|c|c|c|c|c|c|}
\hline \multicolumn{8}{|c|}{ Appendix 15. Station D24 Corbicula Data } \\
\hline Date & $\begin{array}{l}\text { Total \# of } \\
\text { clams in } \\
\text { sample } \\
\left(\# / \mathrm{m}^{2}\right)\end{array}$ & $\begin{array}{c}\text { biomass } \\
\left(\mathrm{g} / \mathrm{m}^{2}\right)\end{array}$ & $\mathrm{rec} / 0.05 \mathrm{~m}^{2}$ & $\begin{array}{c}\text { mean size } \\
(\mathrm{mm})\end{array}$ & $\begin{array}{c}\text { GR } \\
\left(\mathrm{m}^{3} / \mathrm{m}^{2} / \mathrm{d}\right)\end{array}$ & Depth (M) & \# Grabs \\
\hline 9/7/2011 & 1762.25 & 84.27 & 20.30 & 11.70 & 5.40 & 8.26 & 4 \\
\hline $10 / 3 / 2011$ & 1952.25 & 108.55 & 18.30 & 12.40 & 5.30 & 8.26 & 4 \\
\hline $11 / 8 / 2011$ & 2337.00 & 71.72 & 27.80 & 10.10 & 1.80 & 8.26 & 4 \\
\hline $12 / 7 / 2011$ & 1638.75 & 95.86 & 12.50 & 13.30 & 1.90 & 8.26 & 4 \\
\hline $1 / 9 / 2012$ & 1833.50 & 91.58 & 10.30 & 12.30 & 1.80 & 8.26 & 4 \\
\hline $2 / 8 / 2012$ & 1976.00 & 108.47 & 20.30 & 12.00 & 2.10 & 8.26 & 4 \\
\hline $3 / 6 / 2012$ & 2075.75 & 90.61 & 26.80 & 5.20 & 2.60 & 8.26 & 4 \\
\hline $4 / 5 / 2012$ & 3268.00 & 132.45 & 66.50 & 4.50 & 5.30 & 8.26 & 4 \\
\hline $5 / 21 / 2012$ & 3439.00 & 144.46 & 33.50 & 5.10 & 9.60 & 8.26 & 4 \\
\hline $6 / 20 / 2012$ & 3301.25 & 173.06 & 17.50 & 5.60 & 16.10 & 8.26 & 4 \\
\hline $7 / 17 / 2012$ & 2394.00 & 144.80 & 0.80 & 13.20 & 8.70 & 8.26 & 4 \\
\hline $8 / 15 / 2012$ & 2189.75 & 111.65 & 1.30 & 6.30 & 8.30 & 8.26 & 4 \\
\hline $9 / 25 / 2012$ & 1648.25 & 116.83 & 5.30 & 13.70 & 7.10 & 8.26 & 4 \\
\hline $10 / 24 / 2012$ & 2337.00 & 129.36 & 3.80 & 13.90 & 7.00 & 8.26 & 4 \\
\hline $11 / 14 / 2012$ & 731.50 & 31.74 & 4.30 & 12.10 & 1.30 & 8.26 & 4 \\
\hline $12 / 18 / 2012$ & 2199.25 & 114.06 & 4.30 & 13.80 & 3.20 & 8.26 & 4 \\
\hline $1 / 9 / 2013$ & 1515.25 & 98.95 & 1.80 & 15.00 & 1.80 & 8.26 & 4 \\
\hline $2 / 5 / 2013$ & 1686.25 & 118.44 & 1.50 & 15.40 & 2.10 & 8.26 & 4 \\
\hline $3 / 13 / 2013$ & 1672.00 & 158.32 & 2.50 & 15.50 & 3.20 & 8.26 & 4 \\
\hline $4 / 10 / 2013$ & 1752.75 & 169.32 & 0.50 & 15.90 & 3.40 & 8.26 & 4 \\
\hline $5 / 7 / 2013$ & 1211.25 & 73.65 & 0.80 & 14.00 & 2.10 & 8.26 & 4 \\
\hline $6 / 4 / 2013$ & 1482.00 & 103.53 & 1.30 & 14.10 & 3.20 & 8.26 & 4 \\
\hline $7 / 8 / 2013$ & 1268.25 & 117.89 & 0.80 & 15.80 & 4.60 & 8.26 & 4 \\
\hline $9 / 4 / 2013$ & 1068.75 & 84.70 & 0.30 & 15.80 & 4.90 & 8.26 & 4 \\
\hline $10 / 15 / 2013$ & 1159.00 & 35.63 & 17.50 & 10.70 & 1.30 & 8.26 & 4 \\
\hline $11 / 19 / 2013$ & 1244.50 & 75.89 & 3.50 & 15.80 & 1.90 & 8.26 & 4 \\
\hline $12 / 16 / 2013$ & 1805.00 & 122.75 & 1.00 & 16.60 & 2.60 & 8.26 & 4 \\
\hline
\end{tabular}




\begin{tabular}{|c|c|c|c|c|c|c|c|}
\hline \multicolumn{8}{|c|}{ Appendix 16. Station D28 Corbicula Data } \\
\hline Date & $\begin{array}{l}\text { Total \# of } \\
\text { clams in } \\
\text { sample } \\
\left(\# / \mathrm{m}^{2}\right)\end{array}$ & $\begin{array}{c}\text { biomass } \\
\left(\mathrm{g} / \mathrm{m}^{2}\right)\end{array}$ & $\begin{array}{l}\text { recruit/ } \\
0.05 \mathrm{~m}^{2}\end{array}$ & $\begin{array}{c}\text { mean size } \\
(\mathrm{mm})\end{array}$ & $\begin{array}{c}\text { GR } \\
\left(\mathrm{m}^{3} / \mathrm{m}^{2} / \mathrm{d}\right)\end{array}$ & Depth (M) & \# Grabs \\
\hline $6 / 8 / 1976$ & 2318.00 & 0.63 & 105.00 & 2.40 & 0.05 & 3.78 & 1 \\
\hline 6/2/1977 & 627.00 & 0.00 & 32.00 & 1.30 & 0.01 & 3.78 & 1 \\
\hline $10 / 11 / 1977$ & 342.00 & 1.80 & 16.00 & 2.90 & 0.19 & 3.78 & 1 \\
\hline $5 / 30 / 1979$ & 2736.00 & 0.20 & 138.00 & 1.70 & 0.01 & 3.78 & 1 \\
\hline 9/18/1979 & 361.00 & 0.10 & 17.00 & 2.30 & 0.01 & 3.78 & 1 \\
\hline $6 / 11 / 1980$ & 2983.00 & 9.60 & 141.00 & 2.40 & 1.14 & 3.78 & 1 \\
\hline $7 / 18 / 1980$ & 4199.00 & 12.10 & 208.00 & 1.90 & 1.46 & 3.78 & 1 \\
\hline $8 / 22 / 1980$ & 3040.00 & 0.30 & 149.00 & 1.60 & 0.04 & 3.78 & 1 \\
\hline 9/19/1980 & 3135.00 & 0.20 & 162.00 & 1.40 & 0.02 & 3.78 & 1 \\
\hline $10 / 23 / 1980$ & 5871.00 & 4.00 & 301.00 & 1.20 & 0.31 & 3.78 & 1 \\
\hline $11 / 20 / 1980$ & 1805.00 & 4.80 & 83.00 & 2.50 & 0.24 & 3.78 & 1 \\
\hline $12 / 22 / 1980$ & 4047.00 & 0.60 & 211.00 & 1.40 & 0.02 & 3.78 & 1 \\
\hline $1 / 21 / 1981$ & 1672.00 & 4.20 & 75.00 & 2.20 & 0.12 & 3.78 & 1 \\
\hline 2/19/1981 & 665.00 & 44.20 & 21.00 & 8.60 & 1.64 & 3.78 & 1 \\
\hline $3 / 30 / 1981$ & 931.00 & 53.20 & 33.00 & 5.70 & 2.30 & 3.78 & 1 \\
\hline 4/16/1981 & 798.00 & 0.10 & 38.00 & 1.60 & 0.01 & 3.78 & 1 \\
\hline $5 / 15 / 1981$ & 950.00 & 3.00 & 42.00 & 2.70 & 0.30 & 3.78 & 1 \\
\hline $6 / 12 / 1981$ & 1045.00 & 29.00 & 46.00 & 4.10 & 5.42 & 3.78 & 1 \\
\hline $7 / 10 / 1981$ & 3724.00 & 1.50 & 171.00 & 2.20 & 0.20 & 3.78 & 1 \\
\hline $8 / 26 / 1981$ & 2147.00 & 5.90 & 83.00 & 2.80 & 0.80 & 3.78 & 1 \\
\hline $9 / 24 / 1981$ & 684.00 & 39.90 & 26.00 & 6.10 & 5.83 & 3.78 & 1 \\
\hline $10 / 13 / 1981$ & 2375.00 & 6.30 & 117.00 & 2.20 & 0.49 & 3.78 & 1 \\
\hline $11 / 20 / 1981$ & 1634.00 & 65.40 & 69.00 & 5.00 & 3.36 & 3.78 & 1 \\
\hline $12 / 11 / 1981$ & 3192.00 & 7.90 & 147.00 & 2.30 & 0.24 & 3.78 & 1 \\
\hline $1 / 21 / 1982$ & 513.00 & 4.40 & 21.00 & 3.30 & 0.13 & 3.78 & 1 \\
\hline $2 / 22 / 1982$ & 4617.00 & 8.60 & 213.00 & 2.20 & 0.33 & 3.78 & 1 \\
\hline $3 / 30 / 1982$ & 950.00 & 0.70 & 35.00 & 2.60 & 0.03 & 3.78 & 1 \\
\hline $4 / 28 / 1982$ & 5947.00 & 21.80 & 296.00 & 2.00 & 1.01 & 3.78 & 1 \\
\hline $5 / 20 / 1982$ & 26942.00 & 10.90 & 1221.00 & 2.30 & 0.69 & 3.78 & 1 \\
\hline $6 / 25 / 1982$ & 5890.00 & 5.50 & 244.00 & 2.70 & 0.62 & 3.78 & 1 \\
\hline $7 / 22 / 1982$ & 5890.00 & 7.50 & 255.00 & 2.40 & 0.93 & 3.78 & 1 \\
\hline $8 / 30 / 1982$ & 1862.00 & 4.50 & 85.00 & 2.50 & 0.76 & 3.78 & 1 \\
\hline $9 / 20 / 1982$ & 1577.00 & 16.70 & 68.00 & 4.00 & 1.55 & 3.78 & 1 \\
\hline $10 / 28 / 1982$ & 1463.00 & 7.30 & 65.00 & 3.40 & 0.57 & 3.78 & 1 \\
\hline $11 / 24 / 1982$ & 361.00 & 14.40 & 10.00 & 12.60 & 0.83 & 3.78 & 1 \\
\hline $12 / 15 / 1982$ & 2660.00 & 23.10 & 122.00 & 3.50 & 0.70 & 3.78 & 1 \\
\hline $1 / 31 / 1983$ & 418.00 & 8.50 & 13.00 & 6.70 & 0.24 & 3.78 & 1 \\
\hline $2 / 8 / 1983$ & 817.00 & 4.10 & 34.00 & 3.50 & 0.13 & 3.78 & 1 \\
\hline
\end{tabular}




\begin{tabular}{|c|c|c|c|c|c|c|c|}
\hline \multicolumn{8}{|c|}{ Appendix 16. Station D28 Corbicula Data } \\
\hline Date & $\begin{array}{l}\text { Total \# of } \\
\text { clams in } \\
\text { sample } \\
\left(\# / \mathrm{m}^{2}\right)\end{array}$ & $\begin{array}{c}\text { biomass } \\
\left(\mathrm{g} / \mathrm{m}^{2}\right)\end{array}$ & $\begin{array}{l}\text { recruit/ } \\
0.05 \mathrm{~m}^{2}\end{array}$ & $\begin{array}{c}\text { mean size } \\
(\mathrm{mm})\end{array}$ & $\begin{array}{c}\text { GR } \\
\left(\mathrm{m}^{3} / \mathrm{m}^{2} / \mathrm{d}\right)\end{array}$ & Depth (M) & \# Grabs \\
\hline $3 / 8 / 1983$ & 741.00 & 5.50 & 32.00 & 3.60 & 0.22 & 3.78 & 1 \\
\hline $4 / 26 / 1983$ & 9006.00 & 10.80 & 440.00 & 1.90 & 0.45 & 3.78 & 1 \\
\hline $5 / 19 / 1983$ & 9595.00 & 1.50 & 446.00 & 2.20 & 0.07 & 3.78 & 1 \\
\hline $6 / 6 / 1983$ & 5776.00 & 33.90 & 187.00 & 3.50 & 3.23 & 3.78 & 1 \\
\hline $7 / 5 / 1983$ & 1919.00 & 10.90 & 18.00 & 5.30 & 1.21 & 3.78 & 1 \\
\hline 9/15/1983 & 304.00 & 15.90 & 3.00 & 10.40 & 1.66 & 3.78 & 1 \\
\hline $11 / 1 / 1983$ & 323.00 & 0.90 & 9.00 & 4.70 & 0.09 & 3.78 & 1 \\
\hline $11 / 30 / 1983$ & 228.00 & 2.10 & 4.00 & 6.80 & 0.12 & 3.78 & 1 \\
\hline $12 / 13 / 1983$ & 1254.00 & 14.30 & 46.00 & 4.50 & 0.44 & 3.78 & 1 \\
\hline $1 / 31 / 1984$ & 1444.00 & 44.40 & 56.00 & 4.60 & 1.20 & 3.78 & 1 \\
\hline $2 / 27 / 1984$ & 1558.00 & 6.60 & 67.00 & 3.00 & 0.23 & 3.78 & 1 \\
\hline $3 / 26 / 1984$ & 1539.00 & 42.90 & 53.00 & 5.50 & 1.78 & 3.78 & 1 \\
\hline $4 / 24 / 1984$ & 323.00 & 13.80 & 4.00 & 11.20 & 0.65 & 3.78 & 1 \\
\hline $5 / 24 / 1984$ & 589.00 & 23.90 & 15.00 & 6.80 & 2.03 & 3.78 & 1 \\
\hline $6 / 22 / 1984$ & 570.00 & 38.90 & 6.00 & 12.20 & 3.73 & 3.78 & 1 \\
\hline $7 / 23 / 1984$ & 1748.00 & 34.50 & 31.00 & 9.10 & 4.65 & 3.78 & 1 \\
\hline $8 / 22 / 1984$ & 589.00 & 33.50 & 10.80 & 10.80 & 4.12 & 3.78 & 1 \\
\hline 9/18/1984 & 285.00 & 20.10 & 16.40 & 16.40 & 2.74 & 3.78 & 1 \\
\hline $10 / 30 / 1984$ & 114.00 & 0.90 & 5.30 & 5.30 & 0.05 & 3.78 & 1 \\
\hline $11 / 29 / 1984$ & 1292.00 & 58.40 & 12.90 & 12.90 & 1.43 & 3.78 & 1 \\
\hline $12 / 13 / 1984$ & 627.00 & 23.70 & 10.20 & 10.20 & 0.60 & 3.78 & 1 \\
\hline $1 / 15 / 1985$ & 190.00 & 6.20 & 6.00 & 8.00 & 0.18 & 3.78 & 1 \\
\hline $2 / 13 / 1985$ & 513.00 & 29.10 & 7.00 & 11.40 & 0.74 & 3.78 & 1 \\
\hline 3/13/1985 & 627.00 & 53.90 & 7.00 & 14.00 & 1.80 & 3.78 & 1 \\
\hline $4 / 10 / 1985$ & 798.00 & 28.30 & 15.00 & 9.40 & 2.21 & 3.78 & 1 \\
\hline $5 / 31 / 1985$ & 171.00 & 0.00 & 8.00 & 2.10 & 0.00 & 3.78 & 1 \\
\hline $6 / 11 / 1985$ & 171.00 & 10.30 & 0.00 & 15.70 & 1.49 & 3.78 & 1 \\
\hline $8 / 30 / 1985$ & 551.00 & 18.70 & 11.00 & 10.10 & 2.59 & 3.78 & 1 \\
\hline 9/18/1985 & 1178.00 & 69.90 & 17.00 & 12.10 & 5.32 & 3.78 & 1 \\
\hline $10 / 21 / 1985$ & 152.00 & 7.20 & 1.00 & 11.10 & 0.45 & 3.78 & 1 \\
\hline $12 / 4 / 1985$ & 171.00 & 9.00 & 3.00 & 12.60 & 0.28 & 3.78 & 1 \\
\hline $12 / 30 / 1985$ & 228.00 & 17.30 & 5.00 & 11.80 & 0.53 & 3.78 & 1 \\
\hline 1/15/1986 & 133.00 & 18.80 & 1.00 & 18.60 & 0.50 & 3.78 & 1 \\
\hline 2/12/1986 & 2698.00 & 86.10 & 78.00 & 8.20 & 1.84 & 3.78 & 1 \\
\hline $3 / 31 / 1986$ & 190.00 & 12.10 & 0.00 & 17.80 & 0.62 & 3.78 & 1 \\
\hline 4/21/1986 & 76.00 & 6.50 & 0.00 & 11.80 & 0.13 & 3.78 & 1 \\
\hline $5 / 20 / 1986$ & 304.00 & 11.70 & 9.00 & 7.30 & 1.02 & 3.78 & 1 \\
\hline $6 / 30 / 1986$ & 950.00 & 75.50 & 17.00 & 13.70 & 7.31 & 3.78 & 1 \\
\hline
\end{tabular}




\begin{tabular}{|c|c|c|c|c|c|c|c|}
\hline \multicolumn{8}{|c|}{ Appendix 16. Station D28 Corbicula Data } \\
\hline Date & $\begin{array}{l}\text { Total \# of } \\
\text { clams in } \\
\text { sample } \\
\left(\# / \mathrm{m}^{2}\right)\end{array}$ & $\begin{array}{c}\text { biomass } \\
\left(\mathrm{g} / \mathrm{m}^{2}\right)\end{array}$ & $\begin{array}{l}\text { recruit/ } \\
0.05 \mathrm{~m}^{2}\end{array}$ & $\begin{array}{c}\text { mean size } \\
(\mathrm{mm})\end{array}$ & $\begin{array}{c}\text { GR } \\
\left(\mathrm{m}^{3} / \mathrm{m}^{2} / \mathrm{d}\right)\end{array}$ & Depth (M) & \# Grabs \\
\hline $7 / 25 / 1986$ & 475.00 & 73.00 & 0.00 & 17.80 & 9.16 & 3.78 & 1 \\
\hline $8 / 26 / 1986$ & 342.00 & 35.20 & 0.00 & 19.60 & 3.59 & 3.78 & 1 \\
\hline 9/9/1986 & 665.00 & 63.40 & 3.00 & 18.00 & 5.26 & 3.78 & 1 \\
\hline 10/29/1986 & 57.00 & 4.50 & 0.00 & 15.80 & 0.32 & 3.78 & 1 \\
\hline $11 / 14 / 1986$ & 95.00 & 10.40 & 0.00 & 20.90 & 0.62 & 3.78 & 1 \\
\hline $1 / 23 / 1987$ & 1691.00 & 70.30 & 41.00 & 10.30 & 1.53 & 3.78 & 1 \\
\hline $2 / 26 / 1987$ & 133.00 & 9.20 & 1.00 & 15.20 & 0.25 & 3.78 & 1 \\
\hline $3 / 26 / 1987$ & 95.00 & 12.20 & 0.00 & 20.30 & 0.52 & 3.78 & 1 \\
\hline $4 / 24 / 1987$ & 209.00 & 19.40 & 1.00 & 15.30 & 1.59 & 3.78 & 1 \\
\hline $5 / 19 / 1987$ & 171.00 & 17.40 & 0.00 & 18.50 & 1.76 & 3.78 & 1 \\
\hline 6/9/1987 & 285.00 & 16.20 & 4.00 & 11.90 & 1.69 & 3.78 & 1 \\
\hline $7 / 30 / 1987$ & 532.00 & 0.00 & 28.00 & 1.30 & 0.00 & 3.78 & 1 \\
\hline $8 / 20 / 1987$ & 3876.00 & 42.20 & 172.00 & 3.50 & 5.23 & 3.78 & 1 \\
\hline 9/15/1987 & 1349.00 & 45.30 & 45.00 & 7.90 & 5.41 & 3.78 & 1 \\
\hline $10 / 27 / 1987$ & 779.00 & 32.10 & 27.00 & 7.80 & 2.62 & 3.78 & 1 \\
\hline $11 / 9 / 1987$ & 589.00 & 8.30 & 26.00 & 4.40 & 0.59 & 3.78 & 1 \\
\hline $12 / 16 / 1987$ & 589.00 & 13.90 & 23.00 & 5.80 & 0.49 & 3.78 & 1 \\
\hline $1 / 12 / 1988$ & 1976.00 & 81.20 & 70.00 & 7.50 & 1.91 & 3.78 & 1 \\
\hline $2 / 10 / 1988$ & 1387.00 & 26.60 & 50.00 & 6.10 & 0.96 & 3.78 & 1 \\
\hline $4 / 1 / 1988$ & 1558.00 & 30.40 & 44.00 & 7.50 & 1.17 & 3.78 & 1 \\
\hline $4 / 25 / 1988$ & 3287.00 & 70.70 & 110.00 & 7.30 & 3.76 & 3.78 & 1 \\
\hline $5 / 27 / 1988$ & 5358.00 & 64.10 & 238.00 & 3.40 & 5.51 & 3.78 & 1 \\
\hline $6 / 21 / 1988$ & 6137.00 & 84.40 & 242.00 & 4.90 & 9.32 & 3.78 & 1 \\
\hline $7 / 22 / 1988$ & 95.00 & 0.00 & 5.00 & 2.10 & 0.00 & 3.78 & 1 \\
\hline $8 / 17 / 1988$ & 874.00 & 25.90 & 22.00 & 6.90 & 3.31 & 3.78 & 1 \\
\hline 9/19/1988 & 38.00 & 0.00 & 2.00 & 0.50 & 0.00 & 3.78 & 1 \\
\hline $10 / 18 / 1988$ & 95.00 & 5.60 & 1.00 & 13.70 & 0.49 & 3.78 & 1 \\
\hline $11 / 18 / 1988$ & 456.00 & 7.10 & 19.00 & 4.30 & 0.46 & 3.78 & 1 \\
\hline $12 / 5 / 1988$ & 57.00 & 1.30 & 1.00 & 9.80 & 0.04 & 3.78 & 1 \\
\hline 1/17/1989 & 114.00 & 2.30 & 4.00 & 7.70 & 0.07 & 3.78 & 1 \\
\hline 2/1/1989 & 722.00 & 2.20 & 30.00 & 2.60 & 0.07 & 3.78 & 1 \\
\hline 5/5/1989 & 20463.00 & 60.90 & 1035.00 & 1.80 & 4.59 & 3.78 & 1 \\
\hline $7 / 25 / 1989$ & 190.00 & 10.10 & 4.00 & 11.50 & 1.51 & 3.78 & 1 \\
\hline 8/22/1989 & 779.00 & 30.20 & 17.00 & 9.10 & 3.67 & 3.78 & 1 \\
\hline 9/20/1989 & 3287.00 & 30.00 & 159.00 & 2.70 & 3.17 & 3.78 & 1 \\
\hline 10/18/1989 & 190.00 & 15.60 & 4.00 & 14.30 & 1.30 & 3.78 & 1 \\
\hline $11 / 7 / 1989$ & 285.00 & 29.60 & 6.00 & 12.90 & 1.40 & 3.78 & 1 \\
\hline 12/5/1989 & 418.00 & 14.30 & 13.00 & 8.40 & 0.49 & 3.78 & 1 \\
\hline
\end{tabular}




\begin{tabular}{|c|c|c|c|c|c|c|c|}
\hline \multicolumn{8}{|c|}{ Appendix 16. Station D28 Corbicula Data } \\
\hline Date & $\begin{array}{l}\text { Total \# of } \\
\text { clams in } \\
\text { sample } \\
\left(\# / \mathrm{m}^{2}\right)\end{array}$ & $\begin{array}{c}\text { biomass } \\
\left(\mathrm{g} / \mathrm{m}^{2}\right)\end{array}$ & $\begin{array}{l}\text { recruit/ } \\
0.05 \mathrm{~m}^{2}\end{array}$ & $\begin{array}{c}\text { mean size } \\
(\mathrm{mm})\end{array}$ & $\begin{array}{c}\text { GR } \\
\left(\mathrm{m}^{3} / \mathrm{m}^{2} / \mathrm{d}\right)\end{array}$ & Depth (M) & \# Grabs \\
\hline $1 / 17 / 1990$ & 3895.00 & 10.70 & 192.00 & 2.10 & 0.29 & 3.78 & 3 \\
\hline $2 / 27 / 1990$ & 6555.00 & 53.80 & 312.00 & 3.20 & 1.30 & 3.78 & 3 \\
\hline $3 / 19 / 1990$ & 12217.00 & 30.40 & 623.00 & 1.80 & 1.55 & 3.78 & 3 \\
\hline $4 / 20 / 1990$ & 171.00 & 11.50 & 0.00 & 19.40 & 0.82 & 3.78 & 3 \\
\hline $5 / 14 / 1990$ & 9709.00 & 39.30 & 465.00 & 2.40 & 3.00 & 3.78 & 3 \\
\hline $6 / 27 / 1990$ & 2793.00 & 20.30 & 119.00 & 3.70 & 2.59 & 3.78 & 3 \\
\hline $7 / 27 / 1990$ & 228.00 & 9.30 & 4.00 & 9.30 & 1.57 & 3.78 & 3 \\
\hline $8 / 13 / 1990$ & 1045.00 & 14.20 & 35.00 & 4.80 & 2.11 & 3.78 & 3 \\
\hline 9/25/1990 & 114.00 & 2.40 & 5.00 & 5.20 & 0.31 & 3.78 & 3 \\
\hline 10/23/1990 & 342.00 & 7.10 & 9.00 & 6.20 & 0.50 & 3.78 & 3 \\
\hline 11/7/1990 & 2223.00 & 46.30 & 98.00 & 4.20 & 1.92 & 3.78 & 3 \\
\hline $12 / 10 / 1990$ & 1273.00 & 5.30 & 58.00 & 2.70 & 0.15 & 3.78 & 3 \\
\hline 1/8/1991 & 1146.33 & 12.60 & 40.00 & 5.60 & 0.34 & 3.78 & 3 \\
\hline 2/20/1991 & 6206.67 & 5.90 & 317.33 & 1.10 & 0.23 & 3.78 & 3 \\
\hline 3/6/1991 & 3204.67 & 19.40 & 149.00 & 2.50 & 0.75 & 3.78 & 3 \\
\hline 4/8/1991 & 1906.33 & 11.80 & 85.00 & 2.90 & 0.65 & 3.78 & 3 \\
\hline $5 / 20 / 1991$ & 1836.67 & 12.20 & 80.67 & 2.50 & 0.95 & 3.78 & 3 \\
\hline 6/5/1991 & 3097.00 & 27.90 & 111.33 & 4.20 & 2.73 & 3.78 & 3 \\
\hline $8 / 20 / 1991$ & 703.00 & 6.60 & 25.33 & 4.10 & 0.90 & 3.78 & 3 \\
\hline 9/16/1991 & 367.33 & 3.10 & 12.67 & 3.50 & 0.40 & 3.78 & 3 \\
\hline 10/1/1991 & 475.00 & 6.10 & 18.33 & 4.00 & 0.68 & 3.78 & 3 \\
\hline 11/13/1991 & 671.33 & 10.20 & 27.67 & 3.90 & 0.58 & 3.78 & 3 \\
\hline 12/11/1991 & 646.00 & 10.80 & 24.00 & 5.40 & 0.30 & 3.78 & 3 \\
\hline 1/14/1992 & 988.00 & 20.90 & 29.00 & 8.50 & 0.52 & 3.78 & 3 \\
\hline 2/26/1992 & 551.00 & 13.80 & 16.00 & 7.30 & 0.73 & 3.78 & 3 \\
\hline $3 / 25 / 1992$ & 234.33 & 5.30 & 5.33 & 7.00 & 0.30 & 3.78 & 3 \\
\hline 4/7/1992 & 202.67 & 3.00 & 5.00 & 5.30 & 0.24 & 3.78 & 3 \\
\hline 5/8/1992 & 1621.33 & 6.40 & 64.67 & 2.80 & 0.79 & 3.78 & 3 \\
\hline $6 / 22 / 1992$ & 1076.67 & 18.30 & 18.00 & 7.60 & 2.52 & 3.78 & 3 \\
\hline 7/7/1992 & 1722.67 & 85.40 & 23.67 & 10.70 & 10.00 & 3.78 & 3 \\
\hline 8/5/1992 & 652.33 & 13.80 & 16.67 & 6.60 & 1.80 & 3.78 & 3 \\
\hline 9/2/1992 & 3318.67 & 21.10 & 150.67 & 2.90 & 2.49 & 3.78 & 3 \\
\hline 10/2/1992 & 1026.00 & 8.80 & 34.33 & 4.00 & 0.85 & 3.78 & 3 \\
\hline 11/2/1992 & 1456.67 & 26.40 & 53.67 & 4.40 & 1.98 & 3.78 & 3 \\
\hline $12 / 28 / 1992$ & 2938.67 & 45.00 & 113.00 & 4.90 & 1.29 & 3.78 & 3 \\
\hline 1/14/1993 & 3812.67 & 42.90 & 166.33 & 3.60 & 1.11 & 3.78 & 3 \\
\hline 2/9/1993 & 1418.67 & 34.80 & 38.00 & 7.50 & 1.08 & 3.78 & 3 \\
\hline 3/11/1993 & 5567.00 & 35.50 & 261.33 & 2.70 & 2.07 & 3.78 & 3 \\
\hline
\end{tabular}




\begin{tabular}{|c|c|c|c|c|c|c|c|}
\hline \multicolumn{8}{|c|}{ Appendix 16. Station D28 Corbicula Data } \\
\hline Date & $\begin{array}{l}\text { Total \# of } \\
\text { clams in } \\
\text { sample } \\
\left(\# / \mathrm{m}^{2}\right)\end{array}$ & $\begin{array}{c}\text { biomass } \\
\left(\mathrm{g} / \mathrm{m}^{2}\right)\end{array}$ & $\begin{array}{l}\text { recruit/ } \\
0.05 \mathrm{~m}^{2}\end{array}$ & $\begin{array}{c}\text { mean size } \\
(\mathrm{mm})\end{array}$ & $\begin{array}{c}\text { GR } \\
\left(\mathrm{m}^{3} / \mathrm{m}^{2} / \mathrm{d}\right)\end{array}$ & Depth (M) & \# Grabs \\
\hline $4 / 19 / 1993$ & 4382.67 & 59.70 & 176.00 & 4.70 & 2.85 & 3.78 & 3 \\
\hline $5 / 20 / 1993$ & 4161.00 & 54.60 & 185.67 & 3.50 & 4.33 & 3.78 & 3 \\
\hline $6 / 16 / 1993$ & 8379.00 & 65.80 & 383.00 & 3.30 & 5.94 & 3.78 & 3 \\
\hline $7 / 19 / 1993$ & 2356.00 & 67.50 & 71.67 & 6.20 & 7.72 & 3.78 & 3 \\
\hline $8 / 19 / 1993$ & 937.33 & 53.20 & 12.33 & 11.70 & 6.76 & 3.78 & 3 \\
\hline 9/16/1993 & 481.33 & 20.70 & 7.33 & 10.20 & 2.59 & 3.78 & 3 \\
\hline $10 / 8 / 1993$ & 2191.33 & 79.00 & 74.00 & 7.60 & 5.67 & 3.78 & 3 \\
\hline $11 / 16 / 1993$ & 525.67 & 12.90 & 12.00 & 7.10 & 0.78 & 3.78 & 3 \\
\hline 12/9/1993 & 183.67 & 15.10 & 4.33 & 12.20 & 0.41 & 3.78 & 3 \\
\hline 1/18/1994 & 969.00 & 47.40 & 16.00 & 10.90 & 1.14 & 3.78 & 3 \\
\hline 2/8/1994 & 145.67 & 5.50 & 1.67 & 9.80 & 0.16 & 3.78 & 3 \\
\hline 3/9/1994 & 715.67 & 14.50 & 25.33 & 4.70 & 1.02 & 3.78 & 3 \\
\hline 4/12/1994 & 665.00 & 46.90 & 10.67 & 11.70 & 2.58 & 3.78 & 3 \\
\hline $5 / 23 / 1994$ & 1133.67 & 39.40 & 31.00 & 7.10 & 3.10 & 3.78 & 3 \\
\hline 6/9/1994 & 1450.33 & 62.40 & 30.67 & 9.10 & 8.74 & 3.78 & 3 \\
\hline $7 / 20 / 1994$ & 1412.33 & 5.60 & 54.00 & 2.90 & 0.86 & 3.78 & 3 \\
\hline $8 / 9 / 1994$ & 576.33 & 15.50 & 16.67 & 7.00 & 2.25 & 3.78 & 3 \\
\hline 9/21/1994 & 506.67 & 3.40 & 19.33 & 3.50 & 0.42 & 3.78 & 3 \\
\hline $10 / 19 / 1994$ & 785.33 & 18.50 & 21.33 & 6.30 & 1.23 & 3.78 & 3 \\
\hline $11 / 21 / 1994$ & 798.00 & 16.10 & 28.33 & 5.10 & 0.44 & 3.78 & 3 \\
\hline $12 / 16 / 1994$ & 297.67 & 8.90 & 9.00 & 6.90 & 0.25 & 3.78 & 3 \\
\hline 1/17/1995 & 139.33 & 1.00 & 4.33 & 3.50 & 0.03 & 3.78 & 3 \\
\hline 2/15/1995 & 31.67 & 1.00 & 0.67 & 9.10 & 0.04 & 3.78 & 3 \\
\hline 3/15/1995 & 728.33 & 36.30 & 12.67 & 9.40 & 1.31 & 3.78 & 3 \\
\hline 4/27/1995 & 1114.67 & 26.60 & 29.00 & 5.80 & 1.27 & 3.78 & 3 \\
\hline 5/17/1995 & 3128.67 & 50.10 & 115.67 & 4.60 & 2.82 & 3.78 & 3 \\
\hline $6 / 27 / 1995$ & 1095.67 & 30.90 & 8.00 & 8.30 & 2.65 & 3.78 & 3 \\
\hline 7/13/1995 & 1906.33 & 67.30 & 34.00 & 8.30 & 6.66 & 3.78 & 3 \\
\hline $8 / 24 / 1995$ & 1912.67 & 35.10 & 68.33 & 5.00 & 4.86 & 3.78 & 3 \\
\hline 9/26/1995 & 335.67 & 2.90 & 13.33 & 3.50 & 0.36 & 3.78 & 3 \\
\hline $10 / 25 / 1995$ & 665.00 & 26.00 & 12.33 & 10.10 & 1.82 & 3.78 & 3 \\
\hline 11/27/1995 & 272.33 & 18.30 & 3.00 & 13.60 & 0.95 & 3.78 & 3 \\
\hline $12 / 27 / 1995$ & 791.67 & 14.60 & 32.00 & 4.50 & 0.58 & 3.78 & 3 \\
\hline 1/22/1996 & 318.25 & 0.70 & 16.25 & 1.60 & 0.02 & 3.78 & 4 \\
\hline 2/21/1996 & 874.00 & 1.30 & 43.25 & 1.50 & 0.06 & 3.78 & 4 \\
\hline $3 / 20 / 1996$ & 280.25 & 4.80 & 10.00 & 4.00 & 0.22 & 3.78 & 4 \\
\hline 4/29/1996 & 1928.50 & 16.70 & 91.00 & 2.30 & 1.30 & 3.78 & 4 \\
\hline 5/16/1996 & 223.25 & 5.70 & 8.00 & 5.80 & 0.58 & 3.78 & 4 \\
\hline
\end{tabular}




\begin{tabular}{|c|c|c|c|c|c|c|c|}
\hline \multicolumn{8}{|c|}{ Appendix 16. Station D28 Corbicula Data } \\
\hline Date & $\begin{array}{l}\text { Total \# of } \\
\text { clams in } \\
\text { sample } \\
\left(\# / \mathrm{m}^{2}\right)\end{array}$ & $\begin{array}{c}\text { biomass } \\
\left(\mathrm{g} / \mathrm{m}^{2}\right)\end{array}$ & $\begin{array}{l}\text { recruit/ } \\
0.05 \mathrm{~m}^{2}\end{array}$ & $\begin{array}{l}\text { mean size } \\
(\mathrm{mm})\end{array}$ & $\begin{array}{c}\text { GR } \\
\left(\mathrm{m}^{3} / \mathrm{m}^{2} / \mathrm{d}\right)\end{array}$ & Depth (M) & \# Grabs \\
\hline $6 / 18 / 1996$ & 313.50 & 11.50 & 10.00 & 6.80 & 1.75 & 3.78 & 4 \\
\hline 7/16/1996 & 1529.50 & 60.50 & 48.75 & 7.80 & 7.97 & 3.78 & 4 \\
\hline $8 / 28 / 1996$ & 1410.75 & 60.20 & 41.75 & 8.20 & 7.79 & 3.78 & 4 \\
\hline 9/11/1996 & 665.00 & 41.30 & 13.25 & 11.20 & 3.53 & 3.78 & 4 \\
\hline 10/8/1996 & 1045.00 & 39.60 & 34.25 & 8.10 & 2.74 & 3.78 & 4 \\
\hline 11/14/1996 & 90.25 & 8.30 & 1.75 & 14.70 & 0.37 & 3.78 & 4 \\
\hline 12/11/1996 & 232.75 & 3.60 & 9.25 & 4.50 & 0.13 & 3.78 & 4 \\
\hline 1/23/1997 & 660.25 & 20.70 & 28.50 & 4.90 & 0.83 & 3.78 & 4 \\
\hline 2/20/1997 & 1225.50 & 25.80 & 38.00 & 6.10 & 0.84 & 3.78 & 4 \\
\hline $3 / 24 / 1997$ & 456.00 & 18.00 & 11.25 & 7.30 & 0.87 & 3.78 & 4 \\
\hline 4/22/1997 & 204.25 & 19.00 & 4.00 & 12.20 & 1.16 & 3.78 & 4 \\
\hline $5 / 21 / 1997$ & 28.50 & 0.00 & 1.25 & 2.50 & 0.00 & 3.78 & 4 \\
\hline $6 / 18 / 1997$ & 437.00 & 33.80 & 3.25 & 14.60 & 3.62 & 3.78 & 4 \\
\hline $7 / 22 / 1997$ & 14.25 & 1.60 & 0.00 & 16.80 & 0.00 & 3.78 & 4 \\
\hline 8/19/1997 & 1876.25 & 58.30 & 65.75 & 6.90 & 7.72 & 3.78 & 4 \\
\hline 9/16/1997 & 2926.00 & 43.90 & 135.25 & 3.40 & 5.59 & 3.78 & 4 \\
\hline 10/28/1997 & 964.25 & 51.00 & 26.75 & 10.20 & 3.05 & 3.78 & 4 \\
\hline 11/18/1997 & 118.75 & 7.60 & 3.25 & 11.00 & 0.48 & 3.78 & 4 \\
\hline 12/16/1997 & 356.25 & 3.00 & 17.25 & 2.30 & 0.10 & 3.78 & 4 \\
\hline 1/15/1998 & 342.00 & 35.05 & 7.67 & 14.00 & 0.91 & 3.78 & 4 \\
\hline 2/19/1998 & 456.00 & 16.21 & 17.00 & 6.30 & 0.51 & 3.78 & 4 \\
\hline 3/16/1998 & 1108.33 & 18.19 & 44.00 & 4.30 & 0.71 & 3.78 & 4 \\
\hline $4 / 15 / 1998$ & 399.00 & 1.26 & 15.00 & 2.90 & 0.08 & 3.78 & 4 \\
\hline $5 / 12 / 1998$ & 734.67 & 4.74 & 29.67 & 3.30 & 0.27 & 3.78 & 4 \\
\hline 6/8/1998 & 2723.33 & 90.88 & 52.70 & 7.30 & 7.83 & 3.78 & 4 \\
\hline $7 / 9 / 1998$ & 665.00 & 39.40 & 4.33 & 10.50 & 6.00 & 3.78 & 4 \\
\hline $8 / 5 / 1998$ & 443.33 & 26.52 & 12.00 & 9.70 & 3.81 & 3.78 & 4 \\
\hline 9/16/1998 & 1748.00 & 80.31 & 71.00 & 6.30 & 9.57 & 3.78 & 4 \\
\hline $10 / 6 / 1998$ & 1279.33 & 26.18 & 59.00 & 4.20 & 1.78 & 3.78 & 4 \\
\hline $11 / 5 / 1998$ & 3065.33 & 67.03 & 126.67 & 5.10 & 2.31 & 3.78 & 4 \\
\hline 12/21/1998 & 2907.00 & 70.04 & 121.00 & 4.80 & 1.78 & 3.78 & 4 \\
\hline 1/13/1999 & 1268.25 & 17.60 & 55.00 & 3.30 & 0.49 & 3.78 & 4 \\
\hline 2/17/1999 & 1425.00 & 20.90 & 63.75 & 3.70 & 0.58 & 3.78 & 4 \\
\hline 3/16/1999 & 1581.75 & 24.30 & 74.00 & 2.80 & 0.87 & 3.78 & 4 \\
\hline 4/14/1999 & 2118.50 & 39.70 & 92.50 & 3.50 & 1.36 & 3.78 & 4 \\
\hline 5/18/1999 & 1154.25 & 33.90 & 51.00 & 4.60 & 2.89 & 3.78 & 4 \\
\hline $6 / 14 / 1999$ & 2911.75 & 42.80 & 122.50 & 3.80 & 3.91 & 3.78 & 4 \\
\hline 7/13/1999 & 817.00 & 6.10 & 28.00 & 4.00 & 0.92 & 3.78 & 4 \\
\hline
\end{tabular}




\begin{tabular}{|c|c|c|c|c|c|c|c|}
\hline \multicolumn{8}{|c|}{ Appendix 16. Station D28 Corbicula Data } \\
\hline Date & $\begin{array}{l}\text { Total \# of } \\
\text { clams in } \\
\text { sample } \\
\left(\# / \mathrm{m}^{2}\right)\end{array}$ & $\begin{array}{c}\text { biomass } \\
\left(\mathrm{g} / \mathrm{m}^{2}\right)\end{array}$ & $\begin{array}{l}\text { recruit/ } \\
0.05 \mathrm{~m}^{2}\end{array}$ & $\begin{array}{l}\text { mean size } \\
(\mathrm{mm})\end{array}$ & $\begin{array}{c}\text { GR } \\
\left(\mathrm{m}^{3} / \mathrm{m}^{2} / \mathrm{d}\right)\end{array}$ & Depth (M) & \# Grabs \\
\hline 8/11/1999 & 1192.25 & 5.50 & 47.25 & 2.90 & 0.62 & 3.78 & 4 \\
\hline 9/22/1999 & 399.00 & 47.80 & 5.50 & 16.90 & 3.60 & 3.78 & 4 \\
\hline 10/26/1999 & 1301.50 & 38.10 & 53.50 & 5.60 & 3.14 & 3.78 & 4 \\
\hline 11/10/1999 & 622.25 & 37.00 & 13.75 & 10.60 & 1.85 & 3.78 & 4 \\
\hline 12/8/1999 & 945.25 & 62.30 & 19.50 & 11.50 & 1.47 & 3.78 & 4 \\
\hline $1 / 5 / 2000$ & 798.00 & 76.00 & 8.67 & 14.20 & 1.72 & 3.78 & 4 \\
\hline $2 / 23 / 2000$ & 658.67 & 13.70 & 21.33 & 6.10 & 0.47 & 3.78 & 4 \\
\hline $3 / 22 / 2000$ & 709.33 & 59.90 & 9.67 & 11.50 & 2.32 & 3.78 & 4 \\
\hline $4 / 19 / 2000$ & 278.67 & 13.00 & 2.33 & 10.60 & 0.88 & 3.78 & 4 \\
\hline $5 / 18 / 2000$ & 101.33 & 6.40 & 1.67 & 11.40 & 0.50 & 3.78 & 4 \\
\hline $6 / 14 / 2000$ & 791.67 & 70.70 & 9.00 & 13.80 & 5.65 & 3.78 & 4 \\
\hline $7 / 17 / 2000$ & 494.00 & 35.90 & 4.67 & 13.30 & 3.85 & 3.78 & 4 \\
\hline $8 / 15 / 2000$ & 589.00 & 4.30 & 24.00 & 3.40 & 0.67 & 3.78 & 4 \\
\hline $9 / 11 / 2000$ & 475.00 & 35.10 & 11.00 & 11.10 & 2.80 & 3.78 & 4 \\
\hline $10 / 10 / 2000$ & 1577.00 & 62.10 & 48.00 & 7.80 & 5.85 & 3.78 & 4 \\
\hline $11 / 15 / 2000$ & 380.00 & 31.40 & 5.67 & 13.50 & 1.42 & 3.78 & 4 \\
\hline $12 / 12 / 2000$ & 867.67 & 24.10 & 29.67 & 6.60 & 0.64 & 3.78 & 4 \\
\hline $1 / 10 / 2001$ & 351.50 & 32.80 & 5.00 & 13.90 & 0.84 & 3.78 & 4 \\
\hline $2 / 9 / 2001$ & 498.75 & 16.50 & 16.75 & 6.70 & 0.46 & 3.78 & 4 \\
\hline $3 / 7 / 2001$ & 175.75 & 9.90 & 3.75 & 9.00 & 0.44 & 3.78 & 4 \\
\hline $4 / 6 / 2001$ & 484.50 & 31.10 & 9.25 & 10.20 & 1.44 & 3.78 & 4 \\
\hline $5 / 9 / 2001$ & 308.75 & 20.90 & 5.00 & 9.00 & 2.22 & 3.78 & 4 \\
\hline $6 / 7 / 2001$ & 304.00 & 19.70 & 2.50 & 10.10 & 2.31 & 3.78 & 4 \\
\hline $7 / 23 / 2001$ & 147.25 & 0.00 & 7.00 & 1.40 & 0.00 & 3.78 & 4 \\
\hline $8 / 21 / 2001$ & 636.50 & 4.70 & 30.00 & 3.10 & 0.65 & 3.78 & 4 \\
\hline $9 / 18 / 2001$ & 356.25 & 5.70 & 14.25 & 4.40 & 0.64 & 3.78 & 4 \\
\hline $10 / 18 / 2001$ & 484.50 & 0.60 & 19.25 & 2.60 & 0.05 & 3.78 & 4 \\
\hline $11 / 19 / 2001$ & 931.00 & 0.90 & 46.25 & 1.60 & 0.06 & 3.78 & 4 \\
\hline $12 / 13 / 2001$ & 1121.00 & 9.80 & 52.75 & 2.90 & 0.32 & 3.78 & 4 \\
\hline $1 / 15 / 2002$ & 1230.25 & 7.90 & 54.00 & 2.30 & 0.23 & 3.78 & 4 \\
\hline $2 / 13 / 2002$ & 973.75 & 0.30 & 42.75 & 2.10 & 0.01 & 3.78 & 4 \\
\hline $3 / 12 / 2002$ & 769.50 & 8.60 & 25.00 & 4.90 & 0.38 & 3.78 & 4 \\
\hline $4 / 15 / 2002$ & 156.75 & 0.70 & 3.75 & 4.53 & 0.05 & 3.78 & 4 \\
\hline $5 / 13 / 2002$ & 907.25 & 10.60 & 32.50 & 4.20 & 0.66 & 3.78 & 4 \\
\hline $6 / 10 / 2002$ & 437.00 & 8.50 & 12.50 & 6.36 & 1.14 & 3.78 & 4 \\
\hline $7 / 9 / 2002$ & 460.75 & 11.50 & 11.00 & 7.13 & 1.69 & 3.78 & 4 \\
\hline $8 / 7 / 2002$ & 1710.00 & 36.10 & 55.75 & 5.89 & 4.51 & 3.78 & 4 \\
\hline 9/9/2002 & 470.25 & 4.50 & 15.75 & 5.07 & 0.55 & 3.78 & 4 \\
\hline
\end{tabular}




\begin{tabular}{|c|c|c|c|c|c|c|c|}
\hline \multicolumn{8}{|c|}{ Appendix 16. Station D28 Corbicula Data } \\
\hline Date & $\begin{array}{l}\text { Total \# of } \\
\text { clams in } \\
\text { sample } \\
\left(\# / \mathrm{m}^{2}\right)\end{array}$ & $\begin{array}{c}\text { biomass } \\
\left(\mathrm{g} / \mathrm{m}^{2}\right)\end{array}$ & $\begin{array}{l}\text { recruit/ } \\
0.05 \mathrm{~m}^{2}\end{array}$ & $\begin{array}{l}\text { mean size } \\
(\mathrm{mm})\end{array}$ & $\begin{array}{c}\text { GR } \\
\left(\mathrm{m}^{3} / \mathrm{m}^{2} / \mathrm{d}\right)\end{array}$ & Depth (M) & \# Grabs \\
\hline $10 / 23 / 2002$ & 783.75 & 3.40 & 35.50 & 2.68 & 0.31 & 3.78 & 4 \\
\hline 11/19/2002 & 465.50 & 9.30 & 14.75 & 5.90 & 0.33 & 3.78 & 4 \\
\hline $12 / 4 / 2002$ & 361.00 & 1.40 & 16.00 & 3.18 & 0.05 & 3.78 & 4 \\
\hline $1 / 21 / 2003$ & $N / D$ & $N / D$ & $\mathrm{~N} / \mathrm{D}$ & $N / D$ & $\mathrm{~N} / \mathrm{D}$ & $N / D$ & $N / D$ \\
\hline $2 / 21 / 2003$ & $\mathrm{~N} / \mathrm{D}$ & $N / D$ & $N / D$ & $N / D$ & $N / D$ & N/D & $N / D$ \\
\hline $3 / 18 / 2003$ & N/D & $N / D$ & $\mathrm{~N} / \mathrm{D}$ & $N / D$ & $\mathrm{~N} / \mathrm{D}$ & $N / D$ & $\mathrm{~N} / \mathrm{D}$ \\
\hline $4 / 16 / 2003$ & N/D & N/D & $N / D$ & $N / D$ & $N / D$ & N/D & $\mathrm{N} / \mathrm{D}$ \\
\hline $5 / 14 / 2003$ & N/D & $\mathrm{N} / \mathrm{D}$ & $N / D$ & $N / D$ & $N / D$ & N/D & $N / D$ \\
\hline $6 / 3 / 2003$ & N/D & N/D & $N / D$ & $N / D$ & $N / D$ & N/D & $\mathrm{N} / \mathrm{D}$ \\
\hline $7 / 15 / 2003$ & $N / D$ & $N / D$ & $\mathrm{~N} / \mathrm{D}$ & $N / D$ & $N / D$ & $N / D$ & $\mathrm{~N} / \mathrm{D}$ \\
\hline $8 / 12 / 2003$ & N/D & N/D & $N / D$ & $N / D$ & $N / D$ & N/D & $N / D$ \\
\hline $9 / 25 / 2003$ & $N / D$ & $\mathrm{~N} / \mathrm{D}$ & $N / D$ & $N / D$ & $N / D$ & $N / D$ & $N / D$ \\
\hline $10 / 22 / 2003$ & N/D & N/D & $N / D$ & N/D & $N / D$ & N/D & $\mathrm{N} / \mathrm{D}$ \\
\hline $1 / 7 / 2004$ & N/D & $N / D$ & $\mathrm{~N} / \mathrm{D}$ & $N / D$ & $\mathrm{~N} / \mathrm{D}$ & N/D & $\mathrm{N} / \mathrm{D}$ \\
\hline $4 / 6 / 2004$ & $N / D$ & $\mathrm{~N} / \mathrm{D}$ & $N / D$ & $N / D$ & $N / D$ & N/D & $N / D$ \\
\hline $7 / 14 / 2004$ & 270.75 & 1.30 & 11.50 & 3.10 & 0.19 & 3.78 & 4 \\
\hline $10 / 25 / 2004$ & 346.75 & 8.80 & 13.00 & 4.90 & 0.63 & 3.78 & 4 \\
\hline $1 / 10 / 2005$ & 498.75 & 6.70 & 20.00 & 3.80 & 0.19 & 3.78 & 4 \\
\hline $4 / 7 / 2005$ & 346.75 & 1.00 & 12.50 & 2.90 & 0.05 & 3.78 & 4 \\
\hline $7 / 21 / 2005$ & 764.75 & 3.00 & 39.00 & 2.00 & 0.48 & 3.78 & 4 \\
\hline $10 / 12 / 2005$ & 251.75 & 2.10 & 11.25 & 3.10 & 0.15 & 3.78 & 4 \\
\hline $11 / 8 / 2005$ & 441.75 & 0.30 & 22.75 & 1.80 & 0.02 & 3.78 & 4 \\
\hline $12 / 6 / 2005$ & 494.00 & 3.00 & 25.00 & 2.20 & 0.09 & 3.78 & 4 \\
\hline $1 / 11 / 2006$ & 498.75 & 0.50 & 23.25 & 2.10 & 0.02 & 3.78 & 4 \\
\hline $2 / 7 / 2006$ & 199.50 & 2.80 & 6.75 & 3.98 & 0.09 & 3.78 & 4 \\
\hline $3 / 14 / 2006$ & 1102.00 & 0.31 & 43.00 & 2.42 & 0.01 & 3.78 & 4 \\
\hline $4 / 27 / 2006$ & 1439.25 & 0.41 & 62.50 & 2.26 & 0.02 & 3.78 & 4 \\
\hline $5 / 24 / 2006$ & 1966.50 & 0.80 & 87.50 & 2.30 & 0.07 & 3.78 & 4 \\
\hline $6 / 7 / 2006$ & 4883.00 & 9.10 & 139.33 & 3.40 & 1.10 & 3.78 & 4 \\
\hline $7 / 11 / 2006$ & 294.50 & 1.10 & 9.75 & 3.60 & 0.17 & 3.78 & 4 \\
\hline $8 / 11 / 2006$ & 1178.00 & 0.60 & 58.25 & 1.80 & 0.08 & 3.78 & 4 \\
\hline $9 / 21 / 2006$ & 2189.75 & 28.40 & 86.00 & 4.70 & 2.88 & 3.78 & 4 \\
\hline $10 / 26 / 2006$ & 465.50 & 0.70 & 23.75 & 1.90 & 0.05 & 3.78 & 4 \\
\hline $11 / 21 / 2006$ & 1444.00 & 11.30 & 62.50 & 3.50 & 0.70 & 3.78 & 4 \\
\hline $12 / 21 / 2006$ & 522.50 & 1.40 & 25.25 & 2.20 & 0.04 & 3.78 & 4 \\
\hline $1 / 22 / 2007$ & 1311.00 & 0.40 & 66.75 & 1.60 & 0.01 & 3.78 & 4 \\
\hline $2 / 21 / 2007$ & 954.75 & 2.30 & 37.25 & 2.90 & 0.07 & 3.78 & 4 \\
\hline $3 / 19 / 2007$ & 734.67 & 10.30 & 27.67 & 4.80 & 0.37 & 3.78 & 4 \\
\hline
\end{tabular}




\begin{tabular}{|c|c|c|c|c|c|c|c|}
\hline \multicolumn{8}{|c|}{ Appendix 16. Station D28 Corbicula Data } \\
\hline Date & $\begin{array}{l}\text { Total \# of } \\
\text { clams in } \\
\text { sample } \\
\left(\# / \mathrm{m}^{2}\right)\end{array}$ & $\begin{array}{c}\text { biomass } \\
\left(\mathrm{g} / \mathrm{m}^{2}\right)\end{array}$ & $\begin{array}{l}\text { recruit/ } \\
0.05 \mathrm{~m}^{2}\end{array}$ & $\begin{array}{l}\text { mean size } \\
(\mathrm{mm})\end{array}$ & $\begin{array}{c}\text { GR } \\
\left(\mathrm{m}^{3} / \mathrm{m}^{2} / \mathrm{d}\right)\end{array}$ & Depth (M) & \# Grabs \\
\hline $4 / 17 / 2007$ & 1396.50 & 6.00 & 57.50 & 2.80 & 0.38 & 3.78 & 4 \\
\hline $5 / 15 / 2007$ & 693.50 & 13.90 & 15.75 & 7.50 & 1.03 & 3.78 & 4 \\
\hline $6 / 19 / 2007$ & 152.00 & 2.10 & 6.75 & 3.80 & 0.20 & 3.78 & 4 \\
\hline $7 / 17 / 2007$ & 259.67 & 3.10 & 9.00 & 5.30 & 0.34 & 3.78 & 4 \\
\hline $8 / 14 / 2007$ & 1102.00 & 8.50 & 37.75 & 4.40 & 1.01 & 3.78 & 4 \\
\hline $9 / 12 / 2007$ & 375.25 & 3.00 & 17.75 & 3.10 & 0.30 & 3.78 & 4 \\
\hline $10 / 4 / 2007$ & 574.75 & 14.70 & 16.75 & 7.50 & 0.99 & 3.78 & 4 \\
\hline $11 / 6 / 2007$ & 608.00 & 1.70 & 29.50 & 2.20 & 0.09 & 3.78 & 4 \\
\hline $12 / 11 / 2007$ & 247.00 & 1.80 & 11.00 & 3.10 & 0.05 & 3.78 & 4 \\
\hline $1 / 9 / 2008$ & 2142.25 & 20.80 & 88.50 & 3.50 & 0.56 & 3.78 & 4 \\
\hline $2 / 7 / 2008$ & 1078.25 & 15.70 & 29.50 & 7.00 & 0.40 & 3.78 & 4 \\
\hline $3 / 6 / 2008$ & 712.50 & 11.50 & 15.75 & 8.20 & 0.48 & 3.78 & 4 \\
\hline $4 / 3 / 2008$ & 318.25 & 2.30 & 10.75 & 4.70 & 0.12 & 3.78 & 4 \\
\hline $5 / 27 / 2008$ & 750.50 & 10.00 & 15.75 & 5.60 & 0.77 & 3.78 & 4 \\
\hline $6 / 18 / 2008$ & 722.00 & 11.10 & 13.75 & 7.10 & 1.01 & 3.78 & 4 \\
\hline $7 / 15 / 2008$ & 137.75 & 2.20 & 1.50 & 7.70 & 0.31 & 3.78 & 4 \\
\hline $8 / 14 / 2008$ & 413.25 & 4.10 & 16.25 & 4.20 & 0.51 & 3.78 & 4 \\
\hline $9 / 16 / 2008$ & 166.25 & 0.40 & 6.75 & 3.40 & 0.06 & 3.78 & 4 \\
\hline $10 / 29 / 2008$ & 1097.25 & 4.60 & 31.75 & 3.90 & 0.45 & 3.78 & 4 \\
\hline $11 / 19 / 2008$ & 603.25 & 0.20 & 26.75 & 2.30 & 0.01 & 3.78 & 4 \\
\hline $12 / 11 / 2008$ & 299.25 & 0.50 & 9.75 & 3.40 & 0.02 & 3.78 & 4 \\
\hline $1 / 13 / 2009$ & 380.00 & 0.50 & 17.50 & 2.40 & 0.01 & 3.78 & 4 \\
\hline $2 / 10 / 2009$ & 793.25 & 14.50 & 17.50 & 7.10 & 0.38 & 3.78 & 4 \\
\hline $3 / 12 / 2009$ & 517.75 & 4.90 & 17.50 & 4.40 & 0.22 & 3.78 & 4 \\
\hline 4/7/2009 & 475.00 & 11.90 & 5.25 & 8.60 & 0.57 & 3.78 & 4 \\
\hline $5 / 6 / 2009$ & 484.50 & 4.30 & 7.25 & 5.50 & 0.38 & 3.78 & 4 \\
\hline $6 / 23 / 2009$ & 90.25 & 2.00 & 1.25 & 7.60 & 0.23 & 3.78 & 4 \\
\hline $7 / 22 / 2009$ & 893.00 & 3.40 & 32.25 & 3.10 & 0.38 & 3.78 & 4 \\
\hline $8 / 19 / 2009$ & 1919.00 & 9.60 & 86.50 & 2.80 & 1.17 & 3.78 & 4 \\
\hline 9/17/2009 & 1643.50 & 3.70 & 73.50 & 3.00 & 0.39 & 3.78 & 4 \\
\hline $10 / 22 / 2009$ & 1249.25 & 9.00 & 40.25 & 4.30 & 0.61 & 3.78 & 4 \\
\hline $11 / 17 / 2009$ & 1482.00 & 7.40 & 55.50 & 3.70 & 0.41 & 3.78 & 4 \\
\hline $12 / 15 / 2009$ & 2546.00 & 14.40 & 96.00 & 3.90 & 0.39 & 3.78 & 4 \\
\hline $1 / 13 / 2010$ & 152.00 & 0.50 & 4.50 & 3.60 & 0.01 & 3.78 & 4 \\
\hline $2 / 18 / 2010$ & 1534.25 & 1.30 & 66.75 & 2.40 & 0.04 & 3.78 & 4 \\
\hline $3 / 16 / 2010$ & 536.75 & 2.10 & 12.50 & 4.20 & 0.08 & 3.78 & 4 \\
\hline $4 / 13 / 2010$ & 1505.75 & 2.90 & 38.50 & 3.50 & 0.13 & 3.78 & 4 \\
\hline $5 / 17 / 2010$ & 1239.75 & 11.90 & 5.25 & 7.00 & 0.74 & 3.78 & 4 \\
\hline
\end{tabular}




\begin{tabular}{|c|c|c|c|c|c|c|c|}
\hline \multicolumn{8}{|c|}{ Appendix 16. Station D28 Corbicula Data } \\
\hline Date & $\begin{array}{l}\text { Total \# of } \\
\text { clams in } \\
\text { sample } \\
\left(\# / \mathrm{m}^{2}\right)\end{array}$ & $\begin{array}{c}\text { biomass } \\
\left(\mathrm{g} / \mathrm{m}^{2}\right)\end{array}$ & $\begin{array}{l}\text { recruit/ } \\
0.05 \mathrm{~m}^{2}\end{array}$ & $\begin{array}{l}\text { mean size } \\
(\mathrm{mm})\end{array}$ & $\begin{array}{c}\text { GR } \\
\left(\mathrm{m}^{3} / \mathrm{m}^{2} / \mathrm{d}\right)\end{array}$ & Depth (M) & \# Grabs \\
\hline $6 / 10 / 2010$ & 722.00 & 11.90 & 3.00 & 8.60 & 0.96 & 3.78 & 4 \\
\hline $7 / 7 / 2010$ & 631.75 & 6.90 & 7.50 & 6.90 & 0.90 & 3.78 & 4 \\
\hline $8 / 16 / 2010$ & 304.00 & 2.20 & 14.75 & 2.50 & 0.26 & 3.78 & 4 \\
\hline $9 / 8 / 2010$ & 4759.50 & 18.70 & 205.25 & 3.30 & 1.83 & 3.78 & 4 \\
\hline $10 / 28 / 2010$ & 209.00 & 0.30 & 10.25 & 2.10 & 0.02 & 3.78 & 4 \\
\hline $11 / 23 / 2010$ & 52.25 & 0.50 & 1.75 & 4.60 & 0.03 & 3.78 & 4 \\
\hline $12 / 21 / 2010$ & 1045.00 & 4.60 & 48.50 & 3.00 & 0.16 & 3.78 & 4 \\
\hline 1/19/2011 & 736.25 & 5.30 & 26.75 & 4.50 & 0.15 & 3.78 & 4 \\
\hline $2 / 2 / 2011$ & 608.00 & 2.30 & 26.00 & 3.20 & 0.07 & 3.78 & 4 \\
\hline $3 / 8 / 2011$ & 413.25 & 3.80 & 9.50 & 5.90 & 0.15 & 3.78 & 4 \\
\hline $4 / 6 / 2011$ & 237.50 & 2.00 & 4.75 & 6.00 & 0.10 & 3.78 & 4 \\
\hline $5 / 5 / 2011$ & 631.75 & 3.90 & 11.25 & 5.30 & 0.27 & 3.78 & 4 \\
\hline $6 / 14 / 2011$ & 133.00 & 2.10 & 2.00 & 7.40 & 0.15 & 3.78 & 4 \\
\hline $7 / 13 / 2011$ & 104.50 & 2.60 & 3.25 & 7.90 & 0.41 & 3.78 & 4 \\
\hline $8 / 8 / 2011$ & 1339.50 & 5.70 & 58.25 & 3.00 & 0.77 & 3.78 & 4 \\
\hline 9/8/2011 & 142.50 & 1.30 & 6.25 & 3.90 & 0.17 & 3.78 & 4 \\
\hline $10 / 5 / 2011$ & 1738.50 & 13.10 & 68.00 & 4.30 & 1.09 & 3.78 & 4 \\
\hline $11 / 8 / 2011$ & 90.25 & 1.20 & 3.00 & 5.90 & 0.06 & 3.78 & 4 \\
\hline $12 / 7 / 2011$ & 204.25 & 1.70 & 6.75 & 4.90 & 0.05 & 3.78 & 4 \\
\hline $1 / 10 / 2012$ & 821.75 & 11.70 & 22.50 & 6.70 & 0.31 & 3.78 & 4 \\
\hline $2 / 8 / 2012$ & 874.00 & 3.10 & 37.75 & 3.20 & 0.10 & 3.78 & 4 \\
\hline $3 / 7 / 2012$ & 33.25 & 0.70 & 0.75 & 7.60 & 0.03 & 3.78 & 4 \\
\hline $4 / 4 / 2012$ & 641.25 & 4.70 & 24.25 & 4.10 & 0.24 & 3.78 & 4 \\
\hline $5 / 21 / 2012$ & 755.25 & 5.90 & 13.75 & 5.30 & 0.56 & 3.78 & 4 \\
\hline $6 / 19 / 2012$ & 33.25 & 1.00 & 0.75 & 9.40 & 0.09 & 3.78 & 4 \\
\hline $7 / 17 / 2012$ & 19.00 & 0.00 & 1.00 & 0.80 & 0.00 & 3.78 & 4 \\
\hline $8 / 15 / 2012$ & 33.25 & 0.20 & 1.50 & 3.20 & 0.02 & 3.78 & 4 \\
\hline $9 / 26 / 2012$ & 161.50 & 0.70 & 7.50 & 2.80 & 0.10 & 3.78 & 4 \\
\hline $10 / 24 / 2012$ & 223.25 & 2.50 & 8.25 & 5.10 & 0.25 & 3.78 & 4 \\
\hline $11 / 14 / 2012$ & 294.50 & 2.90 & 10.75 & 4.80 & 0.21 & 3.78 & 4 \\
\hline $12 / 18 / 2012$ & 432.25 & 1.50 & 19.75 & 3.20 & 0.06 & 3.78 & 4 \\
\hline $1 / 10 / 2013$ & 175.75 & 0.00 & 9.00 & 1.60 & 0.00 & 3.78 & 4 \\
\hline $2 / 5 / 2013$ & 346.75 & 0.10 & 15.75 & 2.10 & 0.00 & 3.78 & 4 \\
\hline $3 / 13 / 2013$ & 38.00 & 0.00 & 2.00 & 1.60 & 0.00 & 3.78 & 4 \\
\hline $4 / 11 / 2013$ & 574.75 & 10.60 & 10.50 & 7.20 & 0.56 & 3.78 & 4 \\
\hline $5 / 8 / 2013$ & 1192.25 & 2.30 & 54.50 & 2.30 & 0.25 & 3.78 & 4 \\
\hline $6 / 1 / 2013$ & 560.50 & 4.00 & 16.25 & 4.30 & 0.45 & 3.78 & 4 \\
\hline $7 / 8 / 2013$ & 848.67 & 0.00 & 44.67 & 1.30 & 0.00 & 3.78 & 4 \\
\hline
\end{tabular}




\begin{tabular}{|c|c|c|c|c|c|c|c|}
\hline \multicolumn{8}{|c|}{ Appendix 16. Station D28 Corbicula Data } \\
\hline Date & $\begin{array}{l}\text { Total \# of } \\
\text { clams in } \\
\text { sample } \\
\left(\# / \mathrm{m}^{2}\right)\end{array}$ & $\begin{array}{c}\text { biomass } \\
\left(\mathrm{g} / \mathrm{m}^{2}\right)\end{array}$ & $\begin{array}{l}\text { recruit/ } \\
0.05 \mathrm{~m}^{2}\end{array}$ & $\begin{array}{c}\text { mean size } \\
(\mathrm{mm})\end{array}$ & $\begin{array}{c}G R \\
\left(\mathrm{~m}^{3} / \mathrm{m}^{2} / \mathrm{d}\right)\end{array}$ & Depth (M) & \# Grabs \\
\hline $8 / 8 / 2013$ & $\mathrm{~N} / \mathrm{D}$ & $\mathrm{N} / \mathrm{D}$ & $\mathrm{N} / \mathrm{D}$ & $\mathrm{N} / \mathrm{D}$ & $\mathrm{N} / \mathrm{D}$ & $\mathrm{N} / \mathrm{D}$ & $\mathrm{N} / \mathrm{D}$ \\
\hline 9/4/2013 & 228.00 & 0.00 & 10.75 & 2.00 & 0.00 & 3.78 & 4 \\
\hline $10 / 15 / 2013$ & 33.25 & 0.00 & 1.75 & 1.50 & 0.00 & 3.78 & 4 \\
\hline $11 / 19 / 2013$ & 1586.50 & 9.90 & 67.00 & 4.00 & 0.42 & 3.78 & 4 \\
\hline $12 / 16 / 2013$ & 133.00 & 0.00 & 5.75 & 2.10 & 0.00 & 3.78 & 4 \\
\hline
\end{tabular}

\begin{tabular}{|c|c|c|c|c|c|c|c|}
\hline \multicolumn{8}{|c|}{ Appendix 17. Station D41A Potamocorbula Data } \\
\hline Date & $\begin{array}{c}\text { Total \# of } \\
\text { clams in } \\
\text { sample } \\
\left(\# / \mathrm{m}^{2}\right)\end{array}$ & $\begin{array}{c}\text { biomass } \\
\left(\mathrm{g} / \mathrm{m}^{2}\right)\end{array}$ & $\mathrm{rec} / 0.05 \mathrm{~m}^{2}$ & $\begin{array}{c}\text { mean size } \\
(\mathrm{mm})\end{array}$ & $\begin{array}{c}\text { GR } \\
\left(\mathrm{m}^{3} / \mathrm{m}^{2} / \mathrm{d}\right)\end{array}$ & Depth (M) & \# Grabs \\
\hline $6 / 8 / 1987$ & 76.00 & 0.00 & 2.30 & 2.30 & 0.01 & 2.5 & 4 \\
\hline $7 / 23 / 1987$ & 210.00 & 0.20 & 6.00 & 3.40 & 0.07 & 2.5 & 4 \\
\hline 9/28/1987 & 628.00 & 0.70 & 24.80 & 3.00 & 0.26 & 2.5 & 4 \\
\hline 11/10/1987 & 1060.00 & 2.50 & 15.40 & 4.90 & 0.93 & 2.5 & 4 \\
\hline $1 / 12 / 1988$ & 1212.20 & 1.70 & 32.40 & 3.70 & 0.44 & 2.5 & 4 \\
\hline $3 / 14 / 1988$ & 817.00 & 1.90 & 14.40 & 4.10 & 0.73 & 2.5 & 4 \\
\hline $5 / 31 / 1988$ & 9747.00 & 11.50 & 297.00 & 3.00 & 3.84 & 2.5 & 4 \\
\hline $7 / 25 / 1988$ & 7007.20 & 11.50 & 74.00 & 4.90 & 3.83 & 2.5 & 4 \\
\hline $9 / 13 / 1988$ & 7463.20 & 22.60 & 39.00 & 6.00 & 7.26 & 2.5 & 4 \\
\hline $11 / 1 / 1988$ & 3120.00 & 13.60 & 9.20 & 6.90 & 4.71 & 2.5 & 4 \\
\hline 1/31/1989 & 576.33 & 0.70 & 11.00 & 4.10 & 0.18 & 2.5 & 3 \\
\hline 3/21/1989 & 551.00 & 1.40 & 9.70 & 3.90 & 0.54 & 2.5 & 3 \\
\hline $7 / 13 / 1989$ & 23759.50 & 21.80 & 411.50 & 3.80 & 6.53 & 2.5 & 3 \\
\hline 9/8/1989 & 27265.00 & 38.00 & 288.00 & 4.20 & 10.67 & 2.5 & 3 \\
\hline 11/9/1989 & 14433.67 & 27.40 & 95.30 & 4.90 & 8.59 & 2.5 & 3 \\
\hline 1/19/1990 & 5660.00 & 12.00 & 31.00 & 5.10 & 2.75 & 2.5 & 3 \\
\hline $3 / 22 / 1990$ & 3400.00 & 10.10 & 21.30 & 4.90 & 3.58 & 2.5 & 3 \\
\hline 5/31/1990 & 947.00 & 4.30 & 0.00 & 7.70 & 1.57 & 2.5 & 3 \\
\hline $8 / 29 / 1990$ & 1280.00 & 6.50 & 0.30 & 7.70 & 2.35 & 2.5 & 3 \\
\hline $10 / 25 / 1990$ & 1046.67 & 10.20 & 7.30 & 9.80 & 3.63 & 2.5 & 3 \\
\hline $2 / 22 / 1991$ & 2786.67 & 1.30 & 116.30 & 2.20 & 0.48 & 2.5 & 3 \\
\hline 4/24/1991 & 2020.00 & 1.30 & 78.30 & 1.80 & 0.50 & 2.5 & 3 \\
\hline $6 / 7 / 1991$ & 6240.00 & 2.50 & 215.00 & 2.50 & 0.89 & 2.5 & 3 \\
\hline $8 / 19 / 1991$ & 4080.00 & 21.70 & 0.70 & 8.00 & 7.13 & 2.5 & 3 \\
\hline 10/3/1991 & 3973.33 & 24.70 & 0.30 & 8.70 & 8.14 & 2.5 & 3 \\
\hline $11 / 20 / 1991$ & 1720.00 & 11.10 & 0.70 & 8.30 & 3.92 & 2.5 & 3 \\
\hline 12/13/1991 & 973.33 & 3.60 & 3.70 & 6.50 & 1.34 & 2.5 & 3 \\
\hline
\end{tabular}




\begin{tabular}{|c|c|c|c|c|c|c|c|}
\hline \multicolumn{8}{|c|}{ Appendix 17. Station D41A Potamocorbula Data } \\
\hline Date & $\begin{array}{l}\text { Total \# of } \\
\text { clams in } \\
\text { sample } \\
\left(\# / \mathrm{m}^{2}\right)\end{array}$ & $\begin{array}{c}\text { biomass } \\
\left(\mathrm{g} / \mathrm{m}^{2}\right)\end{array}$ & $\mathrm{rec} / 0.05 \mathrm{~m}^{2}$ & $\begin{array}{c}\text { mean size } \\
(\mathrm{mm})\end{array}$ & $\begin{array}{c}G R \\
\left(\mathrm{~m}^{3} / \mathrm{m}^{2} / \mathrm{d}\right)\end{array}$ & Depth (M) & \# Grabs \\
\hline 1/16/1992 & 506.67 & 2.40 & 2.30 & 6.90 & 0.61 & 2.5 & 3 \\
\hline $2 / 28 / 1992$ & 418.00 & 1.20 & 7.00 & 5.10 & 0.45 & 2.5 & 3 \\
\hline 3/27/1992 & 202.67 & 1.10 & 1.00 & 5.80 & 0.44 & 2.5 & 3 \\
\hline 4/10/1992 & 5054.00 & 0.80 & 257.30 & 1.60 & 0.31 & 2.5 & 3 \\
\hline $5 / 12 / 1992$ & 2628.33 & 4.10 & 82.30 & 3.10 & 1.51 & 2.5 & 3 \\
\hline $6 / 24 / 1992$ & 2856.33 & 4.10 & 54.70 & 4.30 & 1.47 & 2.5 & 3 \\
\hline 7/9/1992 & 1127.33 & 2.40 & 9.70 & 5.30 & 0.89 & 2.5 & 3 \\
\hline 8/7/1992 & 703.00 & 1.70 & 8.00 & 5.50 & 0.66 & 2.5 & 3 \\
\hline 9/8/1992 & 969.00 & 3.20 & 2.30 & 6.20 & 1.18 & 2.5 & 3 \\
\hline $10 / 6 / 1992$ & 1741.67 & 6.00 & 2.70 & 6.50 & 2.15 & 2.5 & 3 \\
\hline 11/4/1992 & 798.00 & 2.50 & 5.70 & 6.00 & 0.94 & 2.5 & 3 \\
\hline 2/10/1993 & 304.00 & 0.70 & 3.30 & 5.10 & 0.26 & 2.5 & 3 \\
\hline $3 / 18 / 1993$ & 481.33 & 1.00 & 9.70 & 3.90 & 0.38 & 2.5 & 3 \\
\hline $4 / 16 / 1993$ & 28633.00 & 5.90 & 1447.70 & 1.70 & 1.96 & 2.5 & 3 \\
\hline $5 / 21 / 1993$ & 5364.33 & 1.80 & 67.00 & 4.20 & 0.64 & 2.5 & 3 \\
\hline $6 / 18 / 1993$ & 11001.00 & 10.30 & 124.70 & 4.10 & 3.33 & 2.5 & 3 \\
\hline $7 / 20 / 1993$ & 2077.33 & 5.80 & 12.00 & 5.90 & 2.08 & 2.5 & 3 \\
\hline $8 / 23 / 1993$ & 8258.67 & 17.00 & 15.30 & 6.00 & 5.38 & 2.5 & 3 \\
\hline 9/17/1993 & 10291.67 & 32.20 & 16.30 & 5.90 & 10.10 & 2.5 & 3 \\
\hline 10/13/1993 & 5478.33 & 21.40 & 8.70 & 6.30 & 7.11 & 2.5 & 3 \\
\hline 11/17/1993 & 1786.00 & 4.70 & 0.70 & 5.80 & 1.71 & 2.5 & 3 \\
\hline 12/10/1993 & 1323.67 & 4.40 & 1.30 & 6.00 & 1.62 & 2.5 & 3 \\
\hline 1/19/1994 & 722.00 & 1.70 & 3.70 & 5.20 & 0.62 & 2.5 & 3 \\
\hline 2/9/1994 & 513.00 & 1.20 & 0.70 & 5.30 & 0.47 & 2.5 & 3 \\
\hline $3 / 10 / 1994$ & 367.46 & 1.30 & 1.70 & 5.10 & 0.48 & 2.5 & 3 \\
\hline $4 / 14 / 1994$ & 228.19 & 0.80 & 2.70 & 4.60 & 0.30 & 2.5 & 3 \\
\hline $5 / 24 / 1994$ & 817.00 & 2.70 & 28.30 & 3.60 & 1.05 & 2.5 & 3 \\
\hline $6 / 10 / 1994$ & 373.73 & 0.70 & 11.30 & 4.00 & 0.26 & 2.5 & 3 \\
\hline $7 / 21 / 1994$ & 741.00 & 2.00 & 16.30 & 5.00 & 0.74 & 2.5 & 3 \\
\hline $8 / 10 / 1994$ & 658.73 & 1.60 & 14.00 & 4.90 & 0.62 & 2.5 & 3 \\
\hline 9/22/1994 & 918.46 & 2.40 & 21.70 & 4.70 & 0.89 & 2.5 & 3 \\
\hline $10 / 20 / 1994$ & 962.73 & 2.00 & 24.00 & 4.40 & 0.74 & 2.5 & 3 \\
\hline $11 / 30 / 1994$ & 886.54 & 1.10 & 17.70 & 4.00 & 0.43 & 2.5 & 3 \\
\hline 12/14/1994 & 519.08 & 0.90 & 9.30 & 4.20 & 0.33 & 2.5 & 3 \\
\hline 1/18/1995 & 380.00 & 0.30 & 6.00 & 4.00 & 0.13 & 2.5 & 3 \\
\hline 2/16/1995 & 246.81 & 0.20 & 3.70 & 4.20 & 0.08 & 2.5 & 3 \\
\hline 3/16/1995 & 126.35 & 0.10 & 0.30 & 4.30 & 0.04 & 2.5 & 3 \\
\hline 4/28/1995 & 633.08 & 0.50 & 17.70 & 3.30 & 0.19 & 2.5 & 3 \\
\hline
\end{tabular}




\begin{tabular}{|c|c|c|c|c|c|c|c|}
\hline \multicolumn{8}{|c|}{ Appendix 17. Station D41A Potamocorbula Data } \\
\hline Date & $\begin{array}{l}\text { Total \# of } \\
\text { clams in } \\
\text { sample } \\
\left(\# / \mathrm{m}^{2}\right)\end{array}$ & $\begin{array}{c}\text { biomass } \\
\left(\mathrm{g} / \mathrm{m}^{2}\right)\end{array}$ & $\mathrm{rec} / 0.05 \mathrm{~m}^{2}$ & $\begin{array}{c}\text { mean size } \\
(\mathrm{mm})\end{array}$ & $\begin{array}{c}\text { GR } \\
\left(\mathrm{m}^{3} / \mathrm{m}^{2} / \mathrm{d}\right)\end{array}$ & Depth (M) & \# Grabs \\
\hline 5/19/1995 & 1931.54 & 3.40 & 27.30 & 4.90 & 1.25 & 2.5 & 3 \\
\hline $6 / 28 / 1995$ & 1152.92 & 6.40 & 3.70 & 7.50 & 2.34 & 2.5 & 3 \\
\hline 7/14/1995 & 937.08 & 6.30 & 1.70 & 9.50 & 2.28 & 2.5 & 3 \\
\hline $8 / 25 / 1995$ & 1729.00 & 11.10 & 19.70 & 8.80 & 3.94 & 2.5 & 3 \\
\hline 9/28/1995 & 1222.46 & 10.80 & 19.30 & 8.70 & 3.89 & 2.5 & 3 \\
\hline 10/27/1995 & 949.81 & 11.90 & 3.00 & 12.00 & 4.21 & 2.5 & 3 \\
\hline 11/28/1995 & 285.00 & 3.20 & 0.00 & 11.70 & 1.19 & 2.5 & 3 \\
\hline 12/28/1995 & 798.00 & 2.90 & 19.30 & 5.60 & 1.08 & 2.5 & 3 \\
\hline 1/23/1996 & 593.75 & 0.60 & 17.80 & 3.70 & 0.24 & 2.5 & 4 \\
\hline 2/22/1996 & 760.00 & 1.40 & 11.00 & 4.60 & 0.52 & 2.5 & 4 \\
\hline 3/21/1996 & 978.50 & 0.70 & 20.30 & 3.50 & 0.26 & 2.5 & 4 \\
\hline 4/30/1996 & 2897.50 & 0.90 & 114.00 & 2.60 & 0.34 & 2.5 & 4 \\
\hline 5/17/1996 & 2588.75 & 4.50 & 16.50 & 5.10 & 1.60 & 2.5 & 4 \\
\hline 7/17/1996 & 3971.00 & 7.10 & 44.30 & 5.40 & 2.46 & 2.5 & 4 \\
\hline 8/29/1996 & 4360.50 & 11.30 & 23.50 & 6.10 & 3.84 & 2.5 & 4 \\
\hline 9/12/1996 & 3168.25 & 9.30 & 11.00 & 6.50 & 3.24 & 2.5 & 4 \\
\hline 10/10/1996 & 1491.50 & 4.20 & 11.30 & 6.40 & 1.53 & 2.5 & 4 \\
\hline 11/14/1996 & 755.25 & 1.70 & 8.50 & 5.70 & 0.63 & 2.5 & 4 \\
\hline 12/12/1996 & 1244.50 & 1.30 & 30.30 & 4.00 & 0.48 & 2.5 & 4 \\
\hline 2/24/1997 & 646.00 & 0.30 & 18.50 & 3.30 & 0.13 & 2.5 & 4 \\
\hline 3/26/1997 & 1011.75 & 0.20 & 43.30 & 2.20 & 0.08 & 2.5 & 4 \\
\hline 4/23/1997 & 7144.00 & 1.70 & 347.30 & 1.80 & 0.62 & 2.5 & 4 \\
\hline 5/22/1997 & 4621.75 & 1.70 & 151.00 & 3.30 & 0.60 & 2.5 & 4 \\
\hline $6 / 19 / 1997$ & 5476.75 & 7.60 & 164.80 & 3.80 & 2.67 & 2.5 & 4 \\
\hline 7/23/1997 & 4517.25 & 6.90 & 83.80 & 4.70 & 2.40 & 2.5 & 4 \\
\hline $8 / 20 / 1997$ & 5761.75 & 14.60 & 57.30 & 6.00 & 4.81 & 2.5 & 4 \\
\hline 9/17/1997 & 3496.00 & 9.90 & 25.00 & 6.20 & 3.44 & 2.5 & 4 \\
\hline 10/29/1997 & 1534.25 & 2.40 & 13.00 & 5.20 & 0.86 & 2.5 & 4 \\
\hline 11/19/1997 & 688.75 & 2.10 & 1.50 & 6.70 & 0.79 & 2.5 & 4 \\
\hline 12/15/1997 & 888.25 & 1.20 & 5.30 & 4.80 & 0.44 & 2.5 & 4 \\
\hline 1/13/1998 & 261.25 & 0.20 & 3.30 & 4.10 & 0.08 & 2.5 & 4 \\
\hline 2/18/1998 & 270.75 & 0.30 & 2.00 & 4.90 & 0.13 & 2.5 & 4 \\
\hline 3/17/1998 & 351.50 & 0.30 & 8.00 & 4.00 & 0.12 & 2.5 & 4 \\
\hline 4/14/1998 & 821.75 & 0.10 & 40.00 & 1.80 & 0.05 & 2.5 & 4 \\
\hline $5 / 13 / 1998$ & 1249.25 & 1.00 & 42.30 & 3.20 & 0.37 & 2.5 & 4 \\
\hline 6/9/1998 & 8901.50 & 4.80 & 343.30 & 2.90 & 1.65 & 2.5 & 4 \\
\hline 7/9/1998 & 4526.75 & 6.40 & 16.80 & 5.10 & 2.21 & 2.5 & 4 \\
\hline $8 / 4 / 1998$ & 1767.00 & 5.00 & 12.00 & 6.40 & 1.82 & 2.5 & 4 \\
\hline
\end{tabular}




\begin{tabular}{|c|c|c|c|c|c|c|c|}
\hline \multicolumn{8}{|c|}{ Appendix 17. Station D41A Potamocorbula Data } \\
\hline Date & $\begin{array}{l}\text { Total \# of } \\
\text { clams in } \\
\text { sample } \\
\left(\# / \mathrm{m}^{2}\right)\end{array}$ & $\begin{array}{c}\text { biomass } \\
\left(\mathrm{g} / \mathrm{m}^{2}\right)\end{array}$ & $\mathrm{rec} / 0.05 \mathrm{~m}^{2}$ & $\begin{array}{c}\text { mean size } \\
(\mathrm{mm})\end{array}$ & $\begin{array}{c}\text { GR } \\
\left(\mathrm{m}^{3} / \mathrm{m}^{2} / \mathrm{d}\right)\end{array}$ & Depth (M) & \# Grabs \\
\hline 9/17/1998 & 4042.25 & 13.10 & 2.30 & 7.20 & 4.35 & 2.5 & 4 \\
\hline 10/7/1998 & 6137.00 & 20.30 & 1.80 & 7.60 & 6.45 & 2.5 & 4 \\
\hline 11/4/1998 & 2983.00 & 8.70 & 15.00 & 6.60 & 3.05 & 2.5 & 4 \\
\hline 12/22/1998 & 731.50 & 1.50 & 6.00 & 5.70 & 0.56 & 2.5 & 4 \\
\hline 1/14/1999 & 1909.50 & 1.10 & 75.50 & 2.90 & 0.27 & 2.5 & 4 \\
\hline 2/18/1999 & 836.00 & 0.40 & 31.50 & 2.90 & 0.10 & 2.5 & 4 \\
\hline 3/17/1999 & 475.00 & 0.40 & 9.80 & 3.70 & 0.15 & 2.5 & 4 \\
\hline 4/15/1999 & 522.50 & 0.30 & 9.30 & 3.60 & 0.10 & 2.5 & 4 \\
\hline 5/19/1999 & 745.75 & 0.50 & 22.30 & 3.10 & 0.19 & 2.5 & 4 \\
\hline 6/15/1999 & 2968.75 & 3.40 & 67.30 & 3.90 & 1.23 & 2.5 & 4 \\
\hline 7/14/1999 & 5837.75 & 5.50 & 113.30 & 4.20 & 1.88 & 2.5 & 4 \\
\hline $8 / 12 / 1999$ & 1757.50 & 4.50 & 17.50 & 6.20 & 1.64 & 2.5 & 4 \\
\hline 9/23/1999 & 4764.25 & 10.60 & 24.50 & 6.10 & 3.56 & 2.5 & 4 \\
\hline 10/27/1999 & 2451.00 & 5.60 & 9.30 & 5.80 & 2.01 & 2.5 & 4 \\
\hline 11/9/1999 & 1814.50 & 5.30 & 2.30 & 6.50 & 1.93 & 2.5 & 4 \\
\hline 12/9/1999 & 579.50 & 2.00 & 0.30 & 7.00 & 0.75 & 2.5 & 4 \\
\hline $1 / 6 / 2000$ & 253.33 & 0.40 & 0.67 & 5.70 & 0.16 & 2.5 & 4 \\
\hline $2 / 24 / 2000$ & 171.00 & 0.30 & 1.67 & 4.70 & 0.11 & 2.5 & 4 \\
\hline $3 / 23 / 2000$ & 177.33 & 0.30 & 1.00 & 4.10 & 0.10 & 2.5 & 4 \\
\hline $4 / 20 / 2000$ & 7378.33 & 0.50 & 376.67 & 1.60 & 0.20 & 2.5 & 4 \\
\hline $5 / 17 / 2000$ & 38836.00 & 2.80 & 1984.00 & 1.80 & 0.87 & 2.5 & 4 \\
\hline $6 / 15 / 2000$ & 17727.00 & 13.40 & 464.67 & 3.50 & 4.20 & 2.5 & 4 \\
\hline $7 / 18 / 2000$ & 13927.00 & 14.40 & 258.67 & 4.10 & 4.43 & 2.5 & 4 \\
\hline $8 / 17 / 2000$ & 13661.00 & 16.10 & 217.33 & 4.50 & 4.96 & 2.5 & 4 \\
\hline $9 / 14 / 2000$ & 12888.33 & 24.20 & 141.67 & 4.70 & 7.52 & 2.5 & 4 \\
\hline $10 / 11 / 2000$ & 7701.33 & 28.80 & 24.00 & 6.00 & 9.20 & 2.5 & 4 \\
\hline $11 / 16 / 2000$ & 1741.67 & 2.50 & 21.33 & 4.20 & 0.92 & 2.5 & 4 \\
\hline $12 / 14 / 2000$ & 969.00 & 1.40 & 17.00 & 4.00 & 0.51 & 2.5 & 4 \\
\hline $1 / 11 / 2001$ & 519.33 & 0.40 & 13.00 & 3.10 & 0.14 & 2.5 & 4 \\
\hline $2 / 8 / 2001$ & 234.33 & 0.20 & 6.33 & 3.40 & 0.09 & 2.5 & 4 \\
\hline $3 / 8 / 2011$ & 266.00 & 0.20 & 7.33 & 3.10 & 0.09 & 2.5 & 4 \\
\hline $4 / 5 / 2001$ & 69.67 & 0.00 & 1.00 & 4.00 & 0.02 & 2.5 & 4 \\
\hline $5 / 10 / 2001$ & 380.00 & 0.40 & 12.67 & 3.00 & 0.17 & 2.5 & 4 \\
\hline $6 / 6 / 2001$ & 4902.00 & 4.30 & 161.33 & 3.30 & 1.54 & 2.5 & 4 \\
\hline $7 / 25 / 2001$ & 1425.00 & 5.80 & 12.67 & 6.60 & 2.11 & 2.5 & 4 \\
\hline $8 / 23 / 2001$ & 1260.33 & 5.60 & 8.67 & 7.10 & 2.05 & 2.5 & 4 \\
\hline 9/19/2001 & 2052.00 & 10.50 & 8.00 & 7.40 & 3.71 & 2.5 & 4 \\
\hline $10 / 17 / 2001$ & 1697.33 & 10.90 & 6.00 & 7.10 & 3.89 & 2.5 & 4 \\
\hline
\end{tabular}




\begin{tabular}{|c|c|c|c|c|c|c|c|}
\hline \multicolumn{8}{|c|}{ Appendix 17. Station D41A Potamocorbula Data } \\
\hline Date & $\begin{array}{l}\text { Total \# of } \\
\text { clams in } \\
\text { sample } \\
\left(\# / \mathrm{m}^{2}\right)\end{array}$ & $\begin{array}{c}\text { biomass } \\
\left(\mathrm{g} / \mathrm{m}^{2}\right)\end{array}$ & $\mathrm{rec} / 0.05 \mathrm{~m}^{2}$ & $\begin{array}{c}\text { mean size } \\
(\mathrm{mm})\end{array}$ & $\begin{array}{c}\text { GR } \\
\left(\mathrm{m}^{3} / \mathrm{m}^{2} / \mathrm{d}\right)\end{array}$ & Depth (M) & \# Grabs \\
\hline $11 / 20 / 2001$ & 424.33 & 0.90 & 3.33 & 5.10 & 0.35 & 2.5 & 4 \\
\hline $12 / 12 / 2001$ & 209.00 & 0.70 & 2.00 & 5.80 & 0.27 & 2.5 & 4 \\
\hline $1 / 16 / 2002$ & 164.67 & 0.30 & 3.00 & 4.30 & 0.12 & 2.5 & 4 \\
\hline $3 / 13 / 2002$ & 82.33 & 0.20 & 1.33 & 3.90 & 0.06 & 2.5 & 4 \\
\hline $5 / 14 / 2002$ & 1589.67 & 1.00 & 64.67 & 2.50 & 0.38 & 2.5 & 4 \\
\hline $6 / 11 / 2002$ & 4135.67 & 4.90 & 81.67 & 4.20 & 1.71 & 2.5 & 4 \\
\hline $7 / 8 / 2002$ & 3983.67 & 9.80 & 41.33 & 5.60 & 3.40 & 2.5 & 4 \\
\hline $8 / 8 / 2002$ & 2197.67 & 8.10 & 8.67 & 6.90 & 2.91 & 2.5 & 4 \\
\hline $9 / 10 / 2002$ & 2729.67 & 20.70 & 1.00 & 9.60 & 6.94 & 2.5 & 4 \\
\hline $10 / 24 / 2002$ & 240.67 & 3.20 & 0.00 & 10.60 & 1.21 & 2.5 & 4 \\
\hline $11 / 6 / 2002$ & 69.67 & 1.10 & 0.00 & 12.20 & 0.44 & 2.5 & 4 \\
\hline $12 / 5 / 2002$ & 6.33 & 0.00 & 0.00 & 3.50 & 0.00 & 2.5 & 4 \\
\hline $1 / 22 / 2003$ & 0.00 & 0.00 & 0.00 & 0.00 & 0.00 & 2.5 & 4 \\
\hline $2 / 19 / 2003$ & 5.00 & 0.00 & 0.00 & 0.00 & 0.00 & 2.5 & 4 \\
\hline $3 / 19 / 2003$ & 80.00 & 0.07 & 0.00 & 0.00 & 0.03 & 2.5 & 4 \\
\hline $4 / 17 / 2003$ & 920.00 & 0.20 & 0.00 & 0.00 & 0.08 & 2.5 & 4 \\
\hline $5 / 15 / 2003$ & 4115.00 & 4.40 & $\mathrm{~N} / \mathrm{D}$ & $\mathrm{N} / \mathrm{D}$ & 1.48 & 2.5 & 4 \\
\hline $6 / 2 / 2003$ & 5875.00 & 5.40 & $N / D$ & $N / D$ & 1.70 & 2.5 & 4 \\
\hline $7 / 14 / 2003$ & 5740.00 & 5.60 & $\mathrm{~N} / \mathrm{D}$ & $\mathrm{N} / \mathrm{D}$ & 1.77 & 2.5 & 4 \\
\hline $8 / 13 / 2003$ & 5210.00 & 14.00 & $N / D$ & $\mathrm{~N} / \mathrm{D}$ & 4.41 & 2.5 & 4 \\
\hline $9 / 18 / 2003$ & 4600.00 & 13.00 & $\mathrm{~N} / \mathrm{D}$ & $\mathrm{N} / \mathrm{D}$ & 4.33 & 2.5 & 4 \\
\hline $10 / 23 / 2003$ & 3520.00 & 7.00 & $N / D$ & $\mathrm{~N} / \mathrm{D}$ & 2.39 & 2.5 & 4 \\
\hline $1 / 8 / 2004$ & 195.00 & 0.40 & $\mathrm{~N} / \mathrm{D}$ & $N / D$ & 0.16 & 2.5 & 4 \\
\hline $4 / 7 / 2004$ & 2130.00 & 0.10 & $N / D$ & $N / D$ & 0.04 & 2.5 & 4 \\
\hline $7 / 15 / 2004$ & 720.00 & 1.13 & 17.00 & 4.10 & 0.43 & 2.5 & 4 \\
\hline $10 / 26 / 2004$ & 633.30 & 2.94 & 0.70 & 6.90 & 1.11 & 2.5 & 4 \\
\hline $1 / 11 / 2005$ & 82.33 & 0.20 & 0.33 & 6.50 & 0.07 & 2.5 & 4 \\
\hline $4 / 5 / 2005$ & 988.00 & 0.10 & 51.00 & 1.70 & 0.05 & 2.5 & 4 \\
\hline $7 / 19 / 2005$ & 956.33 & 1.80 & 17.33 & 4.00 & 0.67 & 2.5 & 4 \\
\hline $10 / 13 / 2005$ & 620.67 & 0.90 & 2.00 & 5.70 & 0.34 & 2.5 & 4 \\
\hline $9 / 7 / 2005$ & 468.67 & 1.10 & 2.00 & 5.60 & 0.40 & 2.5 & 4 \\
\hline $12 / 5 / 2005$ & 304.00 & 0.60 & 0.67 & 5.80 & 0.23 & 2.5 & 4 \\
\hline $1 / 12 / 2006$ & 133.00 & 0.20 & 0.67 & 5.70 & 0.09 & 2.5 & 4 \\
\hline $2 / 8 / 2006$ & 171.00 & 0.20 & 2.30 & 4.20 & 0.07 & 2.5 & 4 \\
\hline $3 / 15 / 2006$ & $N / D$ & $N / D$ & $N / D$ & N/D & N/D & N/D & $N / D$ \\
\hline $4 / 25 / 2006$ & 487.67 & 0.40 & 7.67 & 3.80 & 0.14 & 2.5 & 4 \\
\hline $5 / 25 / 2006$ & 563.67 & 1.30 & 0.33 & 6.40 & 0.51 & 2.5 & 4 \\
\hline $6 / 6 / 2006$ & 399.00 & 1.50 & 0.00 & 7.90 & 0.56 & 2.5 & 4 \\
\hline
\end{tabular}




\begin{tabular}{|c|c|c|c|c|c|c|c|}
\hline \multicolumn{8}{|c|}{ Appendix 17. Station D41A Potamocorbula Data } \\
\hline Date & $\begin{array}{l}\text { Total \# of } \\
\text { clams in } \\
\text { sample } \\
\left(\# / \mathrm{m}^{2}\right)\end{array}$ & $\begin{array}{c}\text { biomass } \\
\left(\mathrm{g} / \mathrm{m}^{2}\right)\end{array}$ & $\mathrm{rec} / 0.05 \mathrm{~m}^{2}$ & $\begin{array}{c}\text { mean size } \\
(\mathrm{mm})\end{array}$ & $\begin{array}{c}\text { GR } \\
\left(\mathrm{m}^{3} / \mathrm{m}^{2} / \mathrm{d}\right)\end{array}$ & Depth (M) & \# Grabs \\
\hline $7 / 10 / 2006$ & 633.33 & 3.40 & 4.33 & 8.60 & 1.26 & 2.5 & 4 \\
\hline $8 / 10 / 2006$ & 544.67 & 3.90 & 2.33 & 9.70 & 1.45 & 2.5 & 4 \\
\hline $9 / 20 / 2006$ & 943.67 & 3.90 & 17.00 & 6.50 & 1.45 & 2.5 & 4 \\
\hline $10 / 25 / 2006$ & 1545.33 & 6.80 & 21.00 & 6.80 & 2.46 & 2.5 & 4 \\
\hline $11 / 20 / 2006$ & 2033.33 & 3.30 & 60.00 & 4.10 & 1.20 & 2.5 & 4 \\
\hline $12 / 20 / 2006$ & 1006.67 & 0.80 & 28.33 & 3.60 & 0.30 & 2.5 & 4 \\
\hline $1 / 23 / 2007$ & 1051.33 & 0.60 & 35.00 & 3.20 & 0.16 & 2.5 & 4 \\
\hline $2 / 20 / 2007$ & 468.67 & 0.20 & 12.33 & 3.30 & 0.09 & 2.5 & 4 \\
\hline $3 / 20 / 2007$ & 266.00 & 0.20 & 1.33 & 4.20 & 0.09 & 2.5 & 4 \\
\hline $4 / 16 / 2007$ & 202.67 & 0.10 & 2.33 & 4.50 & 0.04 & 2.5 & 4 \\
\hline $5 / 17 / 2007$ & 1773.33 & 1.40 & 48.33 & 3.40 & 0.52 & 2.5 & 4 \\
\hline $6 / 20 / 2007$ & 1064.00 & 3.20 & 11.67 & 6.30 & 1.18 & 2.5 & 4 \\
\hline $7 / 16 / 2007$ & 386.33 & 3.50 & 0.00 & 10.50 & 1.33 & 2.5 & 4 \\
\hline $8 / 13 / 2007$ & 12.67 & 0.30 & 0.00 & 15.00 & 0.12 & 2.5 & 4 \\
\hline $9 / 11 / 2007$ & 31.67 & 0.00 & 1.00 & 2.50 & 0.00 & 2.5 & 4 \\
\hline $10 / 2 / 2007$ & 0.00 & 0.00 & 0.00 & 0.00 & 0.00 & 2.5 & 4 \\
\hline $11 / 7 / 2007$ & 0.00 & 0.00 & 0.00 & 0.00 & 0.00 & 2.5 & 4 \\
\hline $12 / 10 / 2007$ & 0.00 & 0.00 & 0.00 & 0.00 & 0.00 & 2.5 & 4 \\
\hline $1 / 8 / 2007$ & 0.00 & 0.00 & 0.00 & 0.00 & 0.00 & 2.5 & 4 \\
\hline $2 / 6 / 2008$ & 6.33 & 0.00 & 0.30 & 1.50 & 0.00 & 2.5 & 4 \\
\hline $3 / 5 / 2008$ & 6.33 & 0.00 & 0.00 & 4.50 & 0.00 & 2.5 & 4 \\
\hline $4 / 2 / 2008$ & 12.67 & 0.00 & 0.00 & 5.00 & 0.00 & 2.5 & 4 \\
\hline $5 / 19 / 2008$ & 6.33 & 0.00 & 0.00 & 7.50 & 0.01 & 2.5 & 4 \\
\hline $6 / 17 / 2008$ & 6.33 & 0.00 & 0.00 & 3.50 & 0.00 & 2.5 & 4 \\
\hline $7 / 14 / 2008$ & 19.00 & 0.00 & 1.00 & 2.20 & 0.00 & 2.5 & 4 \\
\hline $8 / 13 / 2008$ & 0.00 & 0.00 & 0.00 & 0.00 & 0.00 & 2.5 & 4 \\
\hline $9 / 15 / 2008$ & 19.00 & 0.00 & 1.00 & 2.20 & 0.00 & 2.5 & 4 \\
\hline $10 / 27 / 2008$ & 6.33 & 0.00 & 0.00 & 4.50 & 0.00 & 2.5 & 4 \\
\hline $11 / 18 / 2008$ & 6.33 & 0.10 & 0.00 & 12.50 & 0.03 & 2.5 & 4 \\
\hline $12 / 10 / 2008$ & 0.00 & 0.00 & 0.00 & 0.00 & 0.00 & 2.5 & 4 \\
\hline $1 / 12 / 2009$ & 0.00 & 0.00 & 0.00 & 0.00 & 0.00 & 2.5 & 4 \\
\hline $2 / 9 / 2009$ & 0.00 & 0.00 & 0.00 & 0.00 & 0.00 & 2.5 & 4 \\
\hline $3 / 11 / 2009$ & 0.00 & 0.00 & 0.00 & 0.00 & 0.00 & 2.5 & 4 \\
\hline $4 / 6 / 2009$ & 0.00 & 0.00 & 0.00 & 0.00 & 0.00 & 2.5 & 4 \\
\hline $5 / 4 / 2009$ & 31.67 & 0.00 & 0.30 & 6.70 & 0.01 & 2.5 & 4 \\
\hline $6 / 24 / 2009$ & 0.00 & 0.00 & 0.00 & 0.00 & 0.00 & 2.5 & 4 \\
\hline $7 / 21 / 2009$ & 6.33 & 0.10 & 0.00 & 14.50 & 0.05 & 2.5 & 4 \\
\hline $8 / 18 / 2009$ & 0.00 & 0.00 & 0.00 & 0.00 & 0.00 & 2.5 & 4 \\
\hline
\end{tabular}




\begin{tabular}{|c|c|c|c|c|c|c|c|}
\hline \multicolumn{8}{|c|}{ Appendix 17. Station D41A Potamocorbula Data } \\
\hline Date & $\begin{array}{l}\text { Total \# of } \\
\text { clams in } \\
\text { sample } \\
\left(\# / \mathrm{m}^{2}\right)\end{array}$ & $\begin{array}{c}\text { biomass } \\
\left(\mathrm{g} / \mathrm{m}^{2}\right)\end{array}$ & $\mathrm{rec} / 0.05 \mathrm{~m}^{2}$ & $\begin{array}{c}\text { mean size } \\
(\mathrm{mm})\end{array}$ & $\begin{array}{c}\text { GR } \\
\left(\mathrm{m}^{3} / \mathrm{m}^{2} / \mathrm{d}\right)\end{array}$ & Depth (M) & \# Grabs \\
\hline $9 / 16 / 2009$ & 0.00 & 0.00 & 0.00 & 0.00 & 0.00 & 2.5 & 4 \\
\hline $10 / 19 / 2009$ & 6.33 & 0.00 & 0.30 & 2.50 & 0.00 & 2.5 & 4 \\
\hline $11 / 16 / 2009$ & 0.00 & 0.00 & 0.00 & 0.00 & 0.00 & 2.5 & 4 \\
\hline 12/16/2009 & 0.00 & 0.00 & 0.00 & 0.00 & 0.00 & 2.5 & 4 \\
\hline $1 / 14 / 2010$ & 0.00 & 0.00 & 0.00 & 0.00 & 0.00 & 2.5 & 4 \\
\hline $2 / 18 / 2010$ & 0.00 & 0.00 & 0.00 & 0.00 & 0.00 & 2.5 & 4 \\
\hline $3 / 15 / 2010$ & 0.00 & 0.00 & 0.00 & 0.00 & 0.00 & 2.5 & 4 \\
\hline $4 / 12 / 2010$ & 202.67 & 0.00 & 11.00 & 1.30 & 0.00 & 2.5 & 4 \\
\hline $5 / 18 / 2010$ & 2085.25 & 0.40 & 91.30 & 2.20 & 0.13 & 2.5 & 4 \\
\hline $6 / 9 / 2010$ & 6529.67 & 2.80 & 239.00 & 2.70 & 0.98 & 2.5 & 4 \\
\hline $7 / 6 / 2010$ & 7498.67 & 9.50 & 128.00 & 4.40 & 3.14 & 2.5 & 4 \\
\hline $8 / 17 / 2010$ & 6656.33 & 12.20 & 68.00 & 5.20 & 4.02 & 2.5 & 4 \\
\hline 9/7/2010 & 8195.33 & 14.70 & 55.00 & 5.30 & 4.76 & 2.5 & 4 \\
\hline $10 / 25 / 2010$ & 4161.00 & 13.50 & 4.80 & 7.00 & 4.50 & 2.5 & 4 \\
\hline $11 / 22 / 2010$ & 709.33 & 2.90 & 0.00 & 7.70 & 1.06 & 2.5 & 4 \\
\hline $12 / 20 / 2010$ & 348.33 & 1.50 & 0.30 & 7.90 & 0.59 & 2.5 & 4 \\
\hline $1 / 19 / 2011$ & 367.33 & 0.80 & 7.30 & 5.20 & 0.30 & 2.5 & 4 \\
\hline $2 / 2 / 2011$ & 215.33 & 0.40 & 9.70 & 5.90 & 0.16 & 2.5 & 4 \\
\hline $3 / 8 / 2011$ & 544.67 & 0.30 & 21.30 & 2.70 & 0.13 & 2.5 & 4 \\
\hline $4 / 6 / 2011$ & 361.00 & 0.10 & 8.00 & 3.60 & 0.02 & 2.5 & 4 \\
\hline $5 / 2 / 2011$ & 1049.75 & 0.20 & 45.30 & 2.30 & 0.08 & 2.5 & 4 \\
\hline $6 / 14 / 2011$ & 5771.25 & 1.80 & 252.80 & 2.40 & 0.66 & 2.5 & 4 \\
\hline $7 / 13 / 2011$ & 14425.75 & 8.60 & 407.00 & 3.40 & 2.76 & 2.5 & 4 \\
\hline $8 / 9 / 2011$ & 9338.50 & 6.80 & 140.30 & 4.00 & 2.20 & 2.5 & 4 \\
\hline 9/7/2011 & 13855.75 & 17.40 & 1085.30 & 4.50 & 5.35 & 2.5 & 4 \\
\hline $10 / 3 / 2011$ & 12117.25 & 14.90 & 85.00 & 4.60 & 4.67 & 2.5 & 4 \\
\hline $11 / 8 / 2011$ & 7310.25 & 11.90 & 27.30 & 5.20 & 3.90 & 2.5 & 4 \\
\hline $12 / 7 / 2011$ & 6374.50 & 8.80 & 40.80 & 4.80 & 2.01 & 2.5 & 4 \\
\hline $1 / 9 / 2012$ & 2968.75 & 3.70 & 22.00 & 4.60 & 0.89 & 2.5 & 4 \\
\hline $2 / 8 / 2012$ & 2441.50 & 2.20 & 40.30 & 3.90 & 0.80 & 2.5 & 4 \\
\hline $3 / 6 / 2012$ & 912.00 & 0.80 & 10.00 & 4.10 & 0.31 & 2.5 & 4 \\
\hline $4 / 5 / 2012$ & 888.25 & 0.30 & 22.50 & 3.10 & 0.11 & 2.5 & 4 \\
\hline $5 / 21 / 2012$ & 12145.75 & 7.30 & 317.50 & 3.30 & 2.39 & 2.5 & 4 \\
\hline $6 / 20 / 2012$ & 9395.50 & 10.00 & 168.00 & 4.20 & 3.25 & 2.5 & 4 \\
\hline $7 / 17 / 2012$ & 6797.25 & 13.00 & 44.75 & 5.60 & 4.30 & 2.5 & 4 \\
\hline $8 / 15 / 2012$ & 6422.00 & 23.10 & 20.50 & 6.70 & 7.55 & 2.5 & 4 \\
\hline $9 / 25 / 2012$ & 1976.00 & 13.20 & 1.80 & 8.70 & 4.64 & 2.5 & 4 \\
\hline 10/24/2012 & 579.50 & 3.80 & 1.30 & 8.90 & 1.41 & 2.5 & 4 \\
\hline
\end{tabular}




\begin{tabular}{|c|c|c|c|c|c|c|c|}
\hline \multicolumn{8}{|c|}{ Appendix 17. Station D41A Potamocorbula Data } \\
\hline Date & $\begin{array}{l}\text { Total \# of } \\
\text { clams in } \\
\text { sample } \\
\left(\# / \mathrm{m}^{2}\right)\end{array}$ & $\begin{array}{c}\text { biomass } \\
\left(\mathrm{g} / \mathrm{m}^{2}\right)\end{array}$ & $\mathrm{rec} / 0.05 \mathrm{~m}^{2}$ & $\begin{array}{c}\text { mean size } \\
(\mathrm{mm})\end{array}$ & $\begin{array}{c}\text { GR } \\
\left(\mathrm{m}^{3} / \mathrm{m}^{2} / \mathrm{d}\right)\end{array}$ & Depth (M) & \# Grabs \\
\hline 11/14/2012 & 460.75 & 1.70 & 9.80 & 6.10 & 0.66 & 2.5 & 4 \\
\hline $12 / 18 / 2012$ & 555.75 & 0.50 & 23.80 & 2.70 & 0.21 & 2.5 & 4 \\
\hline $1 / 9 / 2013$ & 688.75 & 0.30 & 34.30 & 2.10 & 0.08 & 2.5 & 4 \\
\hline $2 / 5 / 2013$ & 760.00 & 0.20 & 36.80 & 2.20 & 0.07 & 2.5 & 4 \\
\hline $3 / 13 / 2013$ & 722.00 & 0.30 & 24.00 & 2.70 & 0.13 & 2.5 & 4 \\
\hline $4 / 10 / 2013$ & 451.25 & 0.10 & 17.00 & 2.80 & 0.04 & 2.5 & 4 \\
\hline $5 / 7 / 2013$ & 460.75 & 0.10 & 21.80 & 1.80 & 0.03 & 2.5 & 4 \\
\hline $6 / 4 / 2013$ & 171.00 & 0.10 & 5.80 & 2.90 & 0.03 & 2.5 & 4 \\
\hline $7 / 8 / 2013$ & 2090.00 & 6.70 & 14.00 & 6.20 & 2.40 & 2.5 & 4 \\
\hline $8 / 8 / 2013$ & $N / D$ & $N / D$ & $N / D$ & $N / D$ & $N / D$ & $N / D$ & $N / D$ \\
\hline $9 / 4 / 2013$ & 489.25 & 5.20 & 0.80 & 10.00 & 1.93 & 2.5 & 4 \\
\hline $10 / 15 / 2013$ & 232.75 & 0.10 & 11.00 & 2.40 & 0.02 & 2.5 & 4 \\
\hline $11 / 19 / 2013$ & 28.50 & 0.00 & 1.50 & 1.70 & 0.00 & 2.5 & 4 \\
\hline $12 / 16 / 2013$ & 57.00 & 0.00 & 2.30 & 2.70 & 0.00 & 2.5 & 4 \\
\hline
\end{tabular}

Appendix 18. Station D41C Potamocorbula Data

\begin{tabular}{|c|c|c|c|c|c|c|c|}
\hline Date & $\begin{array}{l}\text { Total \# of } \\
\text { clams in } \\
\text { sample } \\
\left(\# / \mathrm{m}^{2)}\right.\end{array}$ & $\begin{array}{c}\text { biomass } \\
\left(\mathrm{g} / \mathrm{m}^{2)}\right.\end{array}$ & $\begin{array}{l}\text { recruit/0.05 } \\
\mathrm{m}^{2}\end{array}$ & $\begin{array}{c}\text { mean size } \\
(\mathrm{mm})\end{array}$ & $\begin{array}{c}\text { GR } \\
\left(\mathrm{m}^{3} / \mathrm{m}^{2} / \mathrm{d}\right)\end{array}$ & Depth (M) & \# Grabs \\
\hline 1/23/1996 & 2888.00 & 20.42 & 3.75 & 11.23 & 6.59 & 4.9 & 4 \\
\hline 2/22/1996 & 2626.75 & 14.28 & 2.75 & 8.86 & 4.90 & 4.9 & 4 \\
\hline 3/21/1996 & 4436.50 & 23.94 & 3.25 & 8.61 & 7.80 & 4.9 & 4 \\
\hline 4/30/1996 & 4232.25 & 14.00 & 13.25 & 9.38 & 4.47 & 4.9 & 4 \\
\hline $5 / 17 / 1996$ & 3705.00 & 21.16 & 27.50 & 8.92 & 7.03 & 4.9 & 4 \\
\hline 7/17/1996 & 2997.25 & 23.29 & 8.75 & 10.04 & 7.64 & 4.9 & 4 \\
\hline $8 / 29 / 1996$ & 6792.50 & 31.03 & 58.25 & 7.51 & 9.73 & 4.9 & 4 \\
\hline 9/12/1996 & 4089.75 & 26.38 & 1.75 & 8.70 & 8.67 & 4.9 & 4 \\
\hline 10/10/1996 & 1876.25 & 8.95 & 0.75 & 8.18 & 3.15 & 4.9 & 4 \\
\hline 11/14/1996 & 3652.75 & 13.88 & 0.00 & 9.95 & 4.51 & 4.9 & 4 \\
\hline 12/12/1996 & 4821.25 & 21.77 & 0.00 & 7.97 & 7.03 & 4.9 & 4 \\
\hline 2/24/1997 & 769.50 & 1.60 & 0.25 & 6.02 & 0.60 & 4.9 & 4 \\
\hline $3 / 26 / 1997$ & 375.25 & 1.28 & 0.00 & 7.18 & 0.49 & 4.9 & 4 \\
\hline 4/23/1997 & 437.00 & 0.67 & 9.75 & 4.40 & 0.26 & 4.9 & 4 \\
\hline $5 / 22 / 1997$ & 627.00 & 0.67 & 5.50 & 5.57 & 0.25 & 4.9 & 4 \\
\hline 6/19/1997 & 9058.25 & 10.84 & 220.75 & 3.84 & 3.66 & 4.9 & 4 \\
\hline $7 / 23 / 1997$ & 2626.75 & 5.62 & 22.50 & 5.59 & 2.00 & 4.9 & 4 \\
\hline $8 / 20 / 1997$ & 6564.50 & 32.91 & 28.33 & 11.25 & 9.32 & 4.9 & 4 \\
\hline
\end{tabular}




\begin{tabular}{|c|c|c|c|c|c|c|c|}
\hline \multicolumn{8}{|c|}{ Appendix 18. Station D41C Potamocorbula Data } \\
\hline Date & $\begin{array}{l}\text { Total \# of } \\
\text { clams in } \\
\text { sample } \\
\left(\# / \mathrm{m}^{2)}\right.\end{array}$ & $\begin{array}{l}\text { biomass } \\
\left(\mathrm{g} / \mathrm{m}^{2)}\right.\end{array}$ & $\begin{array}{c}\text { recruit/0.05 } \\
\mathrm{m}^{2}\end{array}$ & $\begin{array}{l}\text { mean size } \\
(\mathrm{mm})\end{array}$ & $\begin{array}{c}\text { GR } \\
\left(\mathrm{m}^{3} / \mathrm{m}^{2} / \mathrm{d}\right)\end{array}$ & Depth (M) & \# Grabs \\
\hline 9/17/1997 & 2280.00 & 12.39 & 2.25 & 8.43 & 4.30 & 4.9 & 4 \\
\hline 10/29/1997 & 2109.00 & 17.10 & 0.25 & 10.77 & 5.81 & 4.9 & 4 \\
\hline 11/19/1997 & 109.25 & 1.37 & 1.25 & 11.11 & 0.53 & 4.9 & 4 \\
\hline 12/15/1997 & 38.00 & 0.45 & 0.25 & 12.00 & 0.18 & 4.9 & 4 \\
\hline $1 / 13 / 1998$ & 0.00 & 0.00 & 0.00 & 0.00 & 0.00 & 4.9 & 4 \\
\hline 2/18/1998 & 0.00 & 0.00 & 0.00 & 0.00 & 0.00 & 4.9 & 4 \\
\hline 3/17/1998 & 0.00 & 0.00 & 0.00 & 0.00 & 0.00 & 4.9 & 4 \\
\hline 4/14/1998 & 313.50 & 0.08 & 14.25 & 2.21 & 0.03 & 4.9 & 4 \\
\hline $5 / 13 / 1998$ & 8151.00 & 6.91 & 193.75 & 3.47 & 2.36 & 4.9 & 4 \\
\hline 6/9/1998 & 1306.25 & 0.99 & 40.50 & 3.50 & 0.37 & 4.9 & 4 \\
\hline 7/9/1998 & 1754.33 & 1.81 & 34.67 & 4.60 & 0.67 & 4.9 & 4 \\
\hline 8/4/1998 & 8550.00 & 35.40 & 4.00 & 9.02 & 10.09 & 4.9 & 4 \\
\hline 9/17/1998 & 3749.33 & 8.41 & 7.33 & 6.71 & 2.89 & 4.9 & 4 \\
\hline 10/7/1998 & 5674.67 & 9.25 & 9.33 & 6.32 & 3.06 & 4.9 & 4 \\
\hline $11 / 4 / 1998$ & 3667.00 & 11.04 & 6.00 & 7.71 & 3.72 & 4.9 & 4 \\
\hline 12/22/1998 & 365.75 & 1.58 & 2.00 & 7.62 & 0.60 & 4.9 & 4 \\
\hline 1/14/1999 & 361.00 & 0.85 & 3.25 & 6.28 & 0.22 & 4.9 & 4 \\
\hline 2/18/1999 & 171.00 & 0.33 & 2.00 & 5.61 & 0.09 & 4.9 & 4 \\
\hline 3/17/1999 & 555.75 & 0.59 & 11.75 & 4.17 & 0.22 & 4.9 & 4 \\
\hline 4/15/1999 & 128.25 & 0.11 & 1.25 & 5.57 & 0.04 & 4.9 & 4 \\
\hline 5/19/1999 & 584.25 & 0.48 & 18.50 & 2.99 & 0.18 & 4.9 & 4 \\
\hline 6/15/1999 & 1315.75 & 1.55 & 30.00 & 4.00 & 0.57 & 4.9 & 4 \\
\hline 7/14/1999 & 1325.25 & 0.97 & 48.00 & 3.21 & 0.37 & 4.9 & 4 \\
\hline $8 / 12 / 1999$ & 4.75 & 0.00 & 0.00 & 3.50 & 0.00 & 4.9 & 4 \\
\hline 9/23/1999 & 90.25 & 0.27 & 1.00 & 5.50 & 0.11 & 4.9 & 4 \\
\hline 10/27/1999 & 47.50 & 0.24 & 0.00 & 7.90 & 0.09 & 4.9 & 4 \\
\hline 11/9/1999 & 57.00 & 0.25 & 0.50 & 7.25 & 0.10 & 4.9 & 4 \\
\hline 12/9/1999 & 0.00 & 0.00 & 0.00 & 0.00 & 0.00 & 4.9 & 4 \\
\hline $1 / 6 / 2000$ & 0.00 & 0.00 & 0.00 & 0.00 & 0.00 & 4.9 & 4 \\
\hline $2 / 24 / 2000$ & 0.00 & 0.00 & 0.00 & 0.00 & 0.00 & 4.9 & 4 \\
\hline $3 / 23 / 2000$ & 0.00 & 0.00 & 0.00 & 0.00 & 0.00 & 4.9 & 4 \\
\hline $4 / 20 / 2000$ & 161.50 & 0.06 & 5.75 & 2.79 & 0.02 & 4.9 & 4 \\
\hline $5 / 17 / 2000$ & 12345.25 & 3.55 & 375.25 & 2.95 & 1.16 & 4.9 & 4 \\
\hline $6 / 15 / 2000$ & 1173.25 & 1.28 & 29.50 & 3.82 & 0.48 & 4.9 & 4 \\
\hline $7 / 18 / 2000$ & 2816.75 & 4.46 & 24.00 & 4.76 & 1.60 & 4.9 & 4 \\
\hline $8 / 17 / 2000$ & 13249.33 & 22.72 & 113.00 & 5.27 & 6.86 & 4.9 & 4 \\
\hline $9 / 14 / 2000$ & 21945.00 & 38.31 & 333.00 & 5.20 & 10.49 & 4.9 & 4 \\
\hline $10 / 11 / 2000$ & 39779.67 & 81.91 & 287.00 & 5.78 & 18.86 & 4.9 & 4 \\
\hline
\end{tabular}


Appendix 18. Station D41C Potamocorbula Data

\begin{tabular}{|c|c|c|c|c|c|c|c|}
\hline Date & $\begin{array}{l}\text { Total \# of } \\
\text { clams in } \\
\text { sample } \\
\left(\# / \mathrm{m}^{2)}\right.\end{array}$ & $\begin{array}{l}\text { biomass } \\
\left(\mathrm{g} / \mathrm{m}^{2)}\right.\end{array}$ & $\begin{array}{l}\text { recruit/0.05 } \\
\mathrm{m}^{2}\end{array}$ & $\begin{array}{c}\text { mean size } \\
(\mathrm{mm})\end{array}$ & $\begin{array}{c}\text { GR } \\
\left(\mathrm{m}^{3} / \mathrm{m}^{2} / \mathrm{d}\right)\end{array}$ & Depth (M) & \# Grabs \\
\hline $11 / 16 / 2000$ & 2489.00 & 8.24 & 2.00 & 7.33 & 2.87 & 4.9 & 4 \\
\hline $12 / 14 / 2000$ & 1486.75 & 4.39 & 3.50 & 7.12 & 1.58 & 4.9 & 4 \\
\hline $1 / 11 / 2001$ & 0.00 & 0.00 & 0.00 & 0.00 & 0.00 & 4.9 & 4 \\
\hline $2 / 7 / 2001$ & 0.00 & 0.00 & 0.00 & 0.00 & 0.00 & 4.9 & 4 \\
\hline $3 / 7 / 2001$ & 61.75 & 0.02 & 1.00 & 3.27 & 0.01 & 4.9 & 4 \\
\hline $4 / 4 / 2001$ & 0.00 & 0.00 & 0.00 & 0.00 & 0.00 & 4.9 & 4 \\
\hline $5 / 9 / 2001$ & 164.67 & 0.02 & 7.50 & 2.29 & 0.01 & 4.9 & 4 \\
\hline $6 / 5 / 2001$ & 0.00 & 0.00 & 0.00 & 0.00 & 0.00 & 4.9 & 4 \\
\hline $7 / 24 / 2001$ & 0.00 & 0.00 & 0.00 & 0.00 & 0.00 & 4.9 & 4 \\
\hline $8 / 22 / 2001$ & 14.25 & 0.05 & 0.00 & 7.17 & 0.02 & 4.9 & 4 \\
\hline $9 / 18 / 2001$ & 0.00 & 0.00 & 0.00 & 0.00 & 0.00 & 4.9 & 4 \\
\hline $10 / 16 / 2001$ & 0.00 & 0.00 & 0.00 & 0.00 & 0.00 & 4.9 & 4 \\
\hline $11 / 19 / 2001$ & 0.00 & 0.00 & 0.00 & 0.00 & 0.00 & 4.9 & 4 \\
\hline $12 / 11 / 2001$ & 0.00 & 0.00 & 0.00 & 0.00 & 0.00 & 4.9 & 4 \\
\hline $1 / 15 / 2002$ & 0.00 & 0.00 & 0.00 & 0.00 & 0.00 & 4.9 & 4 \\
\hline $2 / 14 / 2002$ & 223.25 & 0.21 & 5.00 & 3.67 & 0.08 & 4.9 & 4 \\
\hline $3 / 12 / 2002$ & 0.00 & 0.00 & 0.00 & 0.00 & 0.00 & 4.9 & 4 \\
\hline $4 / 15 / 2002$ & 137.75 & 0.01 & 5.25 & 2.67 & 0.01 & 4.9 & 4 \\
\hline $5 / 13 / 2002$ & 0.00 & 0.00 & 0.00 & 0.00 & 0.00 & 4.9 & 4 \\
\hline $6 / 10 / 2002$ & 0.00 & 0.00 & 0.00 & 0.00 & 0.00 & 4.9 & 4 \\
\hline $7 / 7 / 2002$ & 0.00 & 0.00 & 0.00 & 0.00 & 0.00 & 4.9 & 4 \\
\hline $8 / 8 / 2002$ & 0.00 & 0.00 & 0.00 & 0.00 & 0.00 & 4.9 & 4 \\
\hline 9/9/2002 & 0.00 & 0.00 & 0.00 & 0.00 & 0.00 & 4.9 & 4 \\
\hline $10 / 23 / 2002$ & 0.00 & 0.00 & 0.00 & 0.00 & 0.00 & 4.9 & 4 \\
\hline $11 / 5 / 2002$ & 0.00 & 0.00 & 0.00 & 0.00 & 0.00 & 4.9 & 4 \\
\hline $12 / 4 / 2002$ & 0.00 & 0.00 & 0.00 & 0.00 & 0.00 & 4.9 & 4 \\
\hline $1 / 21 / 2003$ & $\mathrm{~N} / \mathrm{D}$ & $N / D$ & $N / D$ & $N / D$ & N/D & N/D & N/D \\
\hline $2 / 18 / 2003$ & $\mathrm{~N} / \mathrm{D}$ & $N / D$ & $N / D$ & $N / D$ & N/D & $\mathrm{N} / \mathrm{D}$ & N/D \\
\hline $3 / 18 / 2003$ & $\mathrm{~N} / \mathrm{D}$ & $N / D$ & $N / D$ & $N / D$ & $N / D$ & $N / D$ & N/D \\
\hline $4 / 16 / 2003$ & $\mathrm{~N} / \mathrm{D}$ & $N / D$ & $N / D$ & $N / D$ & N/D & $\mathrm{N} / \mathrm{D}$ & N/D \\
\hline $5 / 14 / 2003$ & $N / D$ & $N / D$ & $N / D$ & $N / D$ & N/D & $N / D$ & N/D \\
\hline $6 / 1 / 2003$ & $\mathrm{~N} / \mathrm{D}$ & $N / D$ & $N / D$ & $N / D$ & $\mathrm{~N} / \mathrm{D}$ & $\mathrm{N} / \mathrm{D}$ & N/D \\
\hline $7 / 14 / 2003$ & N/D & $N / D$ & $N / D$ & $N / D$ & N/D & $\mathrm{N} / \mathrm{D}$ & N/D \\
\hline $8 / 13 / 2003$ & N/D & $N / D$ & $N / D$ & $N / D$ & $\mathrm{~N} / \mathrm{D}$ & $\mathrm{N} / \mathrm{D}$ & N/D \\
\hline $9 / 18 / 2003$ & N/D & $N / D$ & $N / D$ & $N / D$ & N/D & $N / D$ & N/D \\
\hline $10 / 23 / 2003$ & N/D & $N / D$ & $N / D$ & $N / D$ & $\mathrm{~N} / \mathrm{D}$ & $\mathrm{N} / \mathrm{D}$ & N/D \\
\hline $1 / 8 / 2004$ & $\mathrm{~N} / \mathrm{D}$ & $N / D$ & $N / D$ & $N / D$ & N/D & $\mathrm{N} / \mathrm{D}$ & N/D \\
\hline $4 / 7 / 2004$ & $\mathrm{~N} / \mathrm{D}$ & $N / D$ & $N / D$ & $N / D$ & $\mathrm{~N} / \mathrm{D}$ & $N / D$ & $N / D$ \\
\hline
\end{tabular}


Appendix 18. Station D41C Potamocorbula Data

\begin{tabular}{|c|c|c|c|c|c|c|c|}
\hline Date & $\begin{array}{l}\text { Total \# of } \\
\text { clams in } \\
\text { sample } \\
\left(\# / \mathrm{m}^{2)}\right.\end{array}$ & $\begin{array}{c}\text { biomass } \\
\left(\mathrm{g} / \mathrm{m}^{2}\right)\end{array}$ & $\begin{array}{c}\text { recruit/0.05 } \\
\mathrm{m}^{2}\end{array}$ & $\begin{array}{c}\text { mean size } \\
(\mathrm{mm})\end{array}$ & $\begin{array}{c}\text { GR } \\
\left(\mathrm{m}^{3} / \mathrm{m}^{2} / \mathrm{d}\right)\end{array}$ & Depth (M) & \# Grabs \\
\hline $7 / 15 / 2004$ & 0.00 & 0.00 & 0.00 & 0.00 & 0.00 & 4.9 & 4 \\
\hline $10 / 26 / 2004$ & 0.00 & 0.00 & 0.00 & 0.00 & 0.00 & 4.9 & 4 \\
\hline $1 / 11 / 2005$ & 0.00 & 0.00 & 0.00 & 0.00 & 0.00 & 4.9 & 4 \\
\hline $4 / 6 / 2005$ & 0.00 & 0.00 & 0.00 & 0.00 & 0.00 & 4.9 & 4 \\
\hline $7 / 20 / 2005$ & 19.00 & 0.19 & 0.00 & 11.17 & 0.08 & 4.9 & 4 \\
\hline $10 / 13 / 2005$ & 12.67 & 0.10 & 0.00 & 12.00 & 0.04 & 4.9 & 4 \\
\hline $11 / 7 / 2005$ & 0.00 & 0.00 & 0.00 & 0.00 & 0.00 & 4.9 & 4 \\
\hline $12 / 5 / 2005$ & 0.00 & 0.00 & 0.00 & 0.00 & 0.00 & 4.9 & 4 \\
\hline $1 / 12 / 2006$ & 0.00 & 0.00 & 0.00 & 0.00 & 0.00 & 4.9 & 4 \\
\hline $2 / 8 / 2006$ & 0.00 & 0.00 & 0.00 & 0.00 & 0.00 & 4.9 & 4 \\
\hline $3 / 15 / 2006$ & 0.00 & 0.00 & 0.00 & 0.00 & 0.00 & 4.9 & 4 \\
\hline $4 / 26 / 2006$ & 4275.00 & 1.83 & 113.00 & 3.19 & 0.66 & 4.9 & 4 \\
\hline $5 / 25 / 2006$ & 4129.33 & 8.79 & 18.33 & 5.73 & 3.04 & 4.9 & 4 \\
\hline $6 / 6 / 2006$ & 4306.67 & 20.49 & 1.33 & 8.04 & 6.70 & 4.9 & 4 \\
\hline $7 / 10 / 2006$ & 6175.00 & 42.69 & 1.00 & 9.50 & 12.90 & 4.9 & 4 \\
\hline $8 / 10 / 2006$ & 5364.33 & 39.24 & 0.00 & 9.82 & 12.12 & 4.9 & 4 \\
\hline $9 / 20 / 2006$ & 2926.00 & 25.53 & 0.00 & 10.47 & 8.40 & 4.9 & 4 \\
\hline $10 / 25 / 2006$ & 1108.33 & 10.75 & 0.00 & 11.01 & 3.79 & 4.9 & 4 \\
\hline $11 / 20 / 2006$ & 1120.00 & 9.05 & 0.00 & 10.47 & 2.18 & 4.9 & 4 \\
\hline $12 / 20 / 2006$ & 1020.00 & 9.15 & 0.33 & 10.89 & 3.28 & 4.9 & 4 \\
\hline $1 / 23 / 2007$ & 80.75 & 0.46 & 0.00 & 8.91 & 0.18 & 4.9 & 4 \\
\hline $2 / 20 / 2007$ & 133.00 & 1.26 & 0.00 & 11.00 & 0.48 & 4.9 & 4 \\
\hline $3 / 20 / 2007$ & 52.25 & 0.42 & 0.00 & 10.23 & 0.16 & 4.9 & 4 \\
\hline $4 / 16 / 2007$ & 4.75 & 0.00 & 0.25 & 2.50 & 0.00 & 4.9 & 4 \\
\hline $5 / 16 / 2007$ & 9.50 & 0.02 & 0.25 & 4.50 & 0.01 & 4.9 & 4 \\
\hline $6 / 20 / 2007$ & 9.50 & 0.08 & 0.00 & 10.50 & 0.03 & 4.9 & 4 \\
\hline $7 / 16 / 2007$ & 14.25 & 0.12 & 0.00 & 10.50 & 0.05 & 4.9 & 4 \\
\hline $8 / 13 / 2007$ & 4.75 & 0.11 & 0.00 & 15.50 & 0.04 & 4.9 & 4 \\
\hline $9 / 11 / 2007$ & 0.00 & 0.00 & 0.00 & 0.00 & 0.00 & 4.9 & 4 \\
\hline $10 / 2 / 2007$ & 0.00 & 0.00 & 0.00 & 0.00 & 0.00 & 4.9 & 4 \\
\hline $11 / 7 / 2007$ & 0.00 & 0.00 & 0.00 & 0.00 & 0.00 & 4.9 & 4 \\
\hline $12 / 10 / 2007$ & 0.00 & 0.00 & 0.00 & 0.00 & 0.00 & 4.9 & 4 \\
\hline $1 / 8 / 2008$ & 0.00 & 0.00 & 0.00 & 0.00 & 0.00 & 4.9 & 4 \\
\hline $2 / 6 / 2008$ & 0.00 & 0.00 & 0.00 & 0.00 & 0.00 & 4.9 & 4 \\
\hline $3 / 5 / 2008$ & 0.00 & 0.00 & 0.00 & 0.00 & 0.00 & 4.9 & 4 \\
\hline $4 / 2 / 2008$ & 0.00 & 0.00 & 0.00 & 0.00 & 0.00 & 4.9 & 4 \\
\hline $5 / 21 / 2008$ & 0.00 & 0.00 & 0.00 & 0.00 & 0.00 & 4.9 & 4 \\
\hline $6 / 18 / 2008$ & 0.00 & 0.00 & 0.00 & 0.00 & 0.00 & 4.9 & 4 \\
\hline
\end{tabular}


Appendix 18. Station D41C Potamocorbula Data

\begin{tabular}{|c|c|c|c|c|c|c|c|}
\hline Date & $\begin{array}{l}\text { Total \# of } \\
\text { clams in } \\
\text { sample } \\
\left(\# / \mathrm{m}^{2)}\right.\end{array}$ & $\begin{array}{c}\text { biomass } \\
\left(\mathrm{g} / \mathrm{m}^{2)}\right.\end{array}$ & $\begin{array}{c}\text { recruit/0.05 } \\
\mathrm{m}^{2}\end{array}$ & $\begin{array}{c}\text { mean size } \\
(\mathrm{mm})\end{array}$ & $\begin{array}{c}\text { GR } \\
\left(\mathrm{m}^{3} / \mathrm{m}^{2} / \mathrm{d}\right)\end{array}$ & Depth (M) & \# Grabs \\
\hline $7 / 15 / 2008$ & 0.00 & 0.00 & 0.00 & 0.00 & 0.00 & 4.9 & 4 \\
\hline $8 / 14 / 2008$ & 0.00 & 0.00 & 0.00 & 0.00 & 0.00 & 4.9 & 4 \\
\hline $9 / 16 / 2008$ & 0.00 & 0.00 & 0.00 & 0.00 & 0.00 & 4.9 & 4 \\
\hline $10 / 27 / 2008$ & 0.00 & 0.00 & 0.00 & 0.00 & 0.00 & 4.9 & 4 \\
\hline $11 / 18 / 2008$ & 0.00 & 0.00 & 0.00 & 0.00 & 0.00 & 4.9 & 4 \\
\hline $12 / 10 / 2008$ & 0.00 & 0.00 & 0.00 & 0.00 & 0.00 & 4.9 & 4 \\
\hline $1 / 12 / 2009$ & 0.00 & 0.00 & 0.00 & 0.00 & 0.00 & 4.9 & 4 \\
\hline 2/9/2009 & 0.00 & 0.00 & 0.00 & 0.00 & 0.00 & 4.9 & 4 \\
\hline $3 / 11 / 2009$ & 361.00 & 0.50 & 1.33 & 4.83 & 0.19 & 4.9 & 4 \\
\hline $4 / 6 / 2009$ & 0.00 & 0.00 & 0.00 & 0.00 & 0.00 & 4.9 & 4 \\
\hline $5 / 4 / 2009$ & 0.00 & 0.00 & 0.00 & 0.00 & 0.00 & 4.9 & 4 \\
\hline $6 / 24 / 2009$ & 0.00 & 0.00 & 0.00 & 0.00 & 0.00 & 4.9 & 4 \\
\hline $7 / 21 / 2009$ & 0.00 & 0.00 & 0.00 & 0.00 & 0.00 & 4.9 & 4 \\
\hline $8 / 18 / 2009$ & 0.00 & 0.00 & 0.00 & 0.00 & 0.00 & 4.9 & 4 \\
\hline $9 / 16 / 2009$ & 0.00 & 0.00 & 0.00 & 0.00 & 0.00 & 4.9 & 4 \\
\hline $10 / 19 / 2009$ & 0.00 & 0.00 & 0.00 & 0.00 & 0.00 & 4.9 & 4 \\
\hline $11 / 16 / 2009$ & 0.00 & 0.00 & 0.00 & 0.00 & 0.00 & 4.9 & 4 \\
\hline $12 / 16 / 2009$ & 0.00 & 0.00 & 0.00 & 0.00 & 0.00 & 4.9 & 4 \\
\hline $1 / 14 / 2010$ & 0.00 & 0.00 & 0.00 & 0.00 & 0.00 & 4.9 & 4 \\
\hline $2 / 18 / 2010$ & 0.00 & 0.00 & 0.00 & 0.00 & 0.00 & 4.9 & 4 \\
\hline $3 / 15 / 2010$ & 0.00 & 0.00 & 0.00 & 0.00 & 0.00 & 4.9 & 4 \\
\hline $4 / 12 / 2010$ & 0.00 & 0.00 & 0.00 & 0.00 & 0.00 & 4.9 & 4 \\
\hline $5 / 18 / 2010$ & 0.00 & 0.00 & 0.00 & 0.00 & 0.00 & 4.9 & 4 \\
\hline $6 / 9 / 2010$ & 0.00 & 0.00 & 0.00 & 0.00 & 0.00 & 4.9 & 4 \\
\hline $7 / 6 / 2010$ & 0.00 & 0.00 & 0.00 & 0.00 & 0.00 & 4.9 & 4 \\
\hline $8 / 17 / 2010$ & 0.00 & 0.00 & 0.00 & 0.00 & 0.00 & 4.9 & 4 \\
\hline $9 / 7 / 2010$ & 0.00 & 0.00 & 0.00 & 0.00 & 0.00 & 4.9 & 4 \\
\hline $10 / 25 / 2010$ & 0.00 & 0.00 & 0.00 & 0.00 & 0.00 & 4.9 & 4 \\
\hline $11 / 22 / 2010$ & 0.00 & 0.00 & 0.00 & 0.00 & 0.00 & 4.9 & 4 \\
\hline $12 / 20 / 2010$ & 0.00 & 0.00 & 0.00 & 0.00 & 0.00 & 4.9 & 4 \\
\hline $1 / 19 / 2011$ & 0.00 & 0.00 & 0.00 & 0.00 & 0.00 & 4.9 & 4 \\
\hline $2 / 2 / 2011$ & 0.00 & 0.00 & 0.00 & 0.00 & 0.00 & 4.9 & 4 \\
\hline $3 / 8 / 2011$ & 0.00 & 0.00 & 0.00 & 0.00 & 0.00 & 4.9 & 4 \\
\hline $4 / 6 / 2011$ & 6.33 & 0.04 & 0.00 & 9.50 & 0.02 & 4.9 & 4 \\
\hline $5 / 2 / 2011$ & 0.00 & 0.00 & 0.00 & 0.00 & 0.00 & 4.9 & 4 \\
\hline $6 / 14 / 2011$ & 0.00 & 0.00 & 0.00 & 0.00 & 0.00 & 4.9 & 4 \\
\hline $7 / 13 / 2011$ & 0.00 & 0.00 & 0.00 & 0.00 & 0.00 & 4.9 & 4 \\
\hline $8 / 9 / 2011$ & 0.00 & 0.00 & 0.00 & 0.00 & 0.00 & 4.9 & 4 \\
\hline
\end{tabular}




\begin{tabular}{|c|c|c|c|c|c|c|c|}
\hline \multicolumn{8}{|c|}{ Appendix 18. Station D41C Potamocorbula Data } \\
\hline Date & $\begin{array}{l}\text { Total \# of } \\
\text { clams in } \\
\text { sample } \\
\left(\# / \mathrm{m}^{2)}\right.\end{array}$ & $\begin{array}{c}\text { biomass } \\
\left(\mathrm{g} / \mathrm{m}^{2)}\right.\end{array}$ & $\begin{array}{c}\text { recruit/0.05 } \\
\mathrm{m}^{2}\end{array}$ & $\begin{array}{c}\text { mean size } \\
(\mathrm{mm})\end{array}$ & $\begin{array}{c}\text { GR } \\
\left(\mathrm{m}^{3} / \mathrm{m}^{2} / \mathrm{d}\right)\end{array}$ & Depth (M) & \# Grabs \\
\hline 9/7/2011 & 147.25 & 0.05 & 5.00 & 2.73 & 0.02 & 4.9 & 4 \\
\hline $10 / 3 / 2011$ & 0.00 & 0.00 & 0.00 & 0.00 & 0.00 & 4.9 & 4 \\
\hline $11 / 8 / 2011$ & 9.50 & 0.02 & 0.00 & 6.00 & 0.00 & 4.9 & 4 \\
\hline $12 / 7 / 2011$ & 0.00 & 0.00 & 0.00 & 0.00 & 0.00 & 4.9 & 4 \\
\hline $1 / 9 / 2012$ & 10.00 & 0.05 & 0.00 & 9.00 & 0.02 & 4.9 & 4 \\
\hline $2 / 8 / 2012$ & 0.00 & 0.00 & 0.00 & 0.00 & 0.00 & 4.9 & 4 \\
\hline $3 / 6 / 2012$ & 0.00 & 0.00 & 0.00 & 0.00 & 0.00 & 4.9 & 4 \\
\hline $4 / 5 / 2012$ & 0.00 & 0.00 & 0.00 & 0.00 & 0.00 & 4.9 & 4 \\
\hline $5 / 21 / 2012$ & 0.00 & 0.00 & 0.00 & 0.00 & 0.00 & 4.9 & 4 \\
\hline $6 / 20 / 2012$ & 0.00 & 0.00 & 0.00 & 0.00 & 0.00 & 4.9 & 4 \\
\hline $7 / 17 / 2012$ & 0.00 & 0.00 & 0.00 & 0.00 & 0.00 & 4.9 & 4 \\
\hline $8 / 15 / 2012$ & 0.00 & 0.00 & 0.00 & 0.00 & 0.00 & 4.9 & 4 \\
\hline $9 / 25 / 2012$ & 0.00 & 0.00 & 0.00 & 0.00 & 0.00 & 4.9 & 4 \\
\hline $10 / 24 / 2012$ & 0.00 & 0.00 & 0.00 & 0.00 & 0.00 & 4.9 & 4 \\
\hline $11 / 14 / 2012$ & 0.00 & 0.00 & 0.00 & 0.00 & 0.00 & 4.9 & 4 \\
\hline $12 / 18 / 2012$ & 0.00 & 0.00 & 0.00 & 0.00 & 0.00 & 4.9 & 4 \\
\hline $1 / 9 / 2013$ & 0.00 & 0.00 & 0.00 & 0.00 & 0.00 & 4.9 & 4 \\
\hline $2 / 5 / 2013$ & 0.00 & 0.00 & 0.00 & 0.00 & 0.00 & 4.9 & 4 \\
\hline $3 / 13 / 2013$ & 5.00 & 0.00 & 0.00 & 3.50 & 0.00 & 4.9 & 4 \\
\hline $4 / 10 / 2013$ & 0.00 & 0.00 & 0.00 & 0.00 & 0.00 & 4.9 & 4 \\
\hline $5 / 7 / 2013$ & 0.00 & 0.00 & 0.00 & 0.00 & 0.00 & 4.9 & 4 \\
\hline $6 / 4 / 2013$ & 0.00 & 0.00 & 0.00 & 0.00 & 0.00 & 4.9 & 4 \\
\hline $7 / 8 / 2013$ & 0.00 & 0.00 & 0.00 & 0.00 & 0.00 & 4.9 & 4 \\
\hline $8 / 8 / 2013$ & 0.00 & 0.00 & 0.00 & 0.00 & 0.00 & 4.9 & 4 \\
\hline $9 / 4 / 2013$ & 0.00 & 0.00 & 0.00 & 0.00 & 0.00 & 4.9 & 4 \\
\hline $10 / 15 / 2013$ & 0.00 & 0.00 & 0.00 & 0.00 & 0.00 & 4.9 & 4 \\
\hline $11 / 19 / 2013$ & 0.00 & 0.00 & 0.00 & 0.00 & 0.00 & 4.9 & 4 \\
\hline $12 / 16 / 2013$ & 0.00 & 0.00 & 0.00 & 0.00 & 0.00 & 4.9 & 4 \\
\hline
\end{tabular}




\begin{tabular}{|c|c|c|c|c|c|c|c|}
\hline \multicolumn{8}{|c|}{ Appendix 19. Station P8 Corbicula Data } \\
\hline Date & $\begin{array}{l}\text { Total \# of } \\
\text { clams in } \\
\text { sample } \\
\left(\# / \mathrm{m}^{2}\right)\end{array}$ & $\begin{array}{c}\text { biomass } \\
\left(\mathrm{g} / \mathrm{m}^{2}\right)\end{array}$ & $\mathrm{rec} / 0.05 \mathrm{~m}^{2}$ & $\begin{array}{c}\text { mean size } \\
(\mathrm{mm})\end{array}$ & $\begin{array}{c}\text { GR } \\
\left(\mathrm{m}^{3} / \mathrm{m}^{2} / \mathrm{d}\right)\end{array}$ & Depth (M) & \# Grabs \\
\hline 1/23/1996 & 973.75 & 7.63 & 46.75 & 2.28 & 0.22 & 3.3 & 4 \\
\hline 2/23/1996 & $N / D$ & $\mathrm{~N} / \mathrm{D}$ & $N / D$ & $\mathrm{~N} / \mathrm{D}$ & $\mathrm{N} / \mathrm{D}$ & $\mathrm{N} / \mathrm{D}$ & $\mathrm{N} / \mathrm{D}$ \\
\hline $3 / 22 / 1996$ & 926.25 & 5.53 & 41.50 & 2.40 & 0.25 & 3.3 & 4 \\
\hline $4 / 29 / 1996$ & 622.25 & 14.53 & 27.00 & 3.23 & 1.04 & 3.3 & 4 \\
\hline 5/17/1996 & 356.25 & 12.34 & 14.25 & 3.71 & 1.12 & 3.3 & 4 \\
\hline 6/15/1996 & 323.00 & 8.53 & 12.25 & 3.47 & 1.52 & 3.3 & 4 \\
\hline 7/18/1996 & 2118.50 & 5.78 & 109.00 & 1.50 & 1.01 & 3.3 & 4 \\
\hline $8 / 30 / 1996$ & 2242.00 & 7.23 & 112.50 & 1.71 & 1.26 & 3.3 & 4 \\
\hline 9/13/1996 & 2308.50 & 1.72 & 118.50 & 1.37 & 0.19 & 3.3 & 4 \\
\hline 10/9/1996 & 845.50 & 0.42 & 43.50 & 1.38 & 0.03 & 3.3 & 4 \\
\hline 11/15/1996 & 1178.00 & 5.50 & 59.75 & 1.70 & 0.26 & 3.3 & 4 \\
\hline 12/12/1996 & 356.25 & 6.92 & 16.75 & 3.38 & 0.26 & 3.3 & 4 \\
\hline 1/22/1997 & 1833.50 & 1.00 & 93.75 & 1.48 & 0.04 & 3.3 & 4 \\
\hline 2/21/1997 & 1710.00 & 0.20 & 86.75 & 1.61 & 0.01 & 3.3 & 4 \\
\hline $3 / 26 / 1997$ & 451.25 & 26.16 & 19.75 & 4.30 & 1.34 & 3.3 & 4 \\
\hline 4/24/1997 & 228.00 & 1.01 & 11.00 & 2.50 & 0.08 & 3.3 & 4 \\
\hline 5/23/1997 & 90.25 & 5.31 & 1.75 & 5.45 & 0.55 & 3.3 & 4 \\
\hline 6/20/1997 & 532.00 & 9.82 & 25.25 & 2.74 & 1.39 & 3.3 & 4 \\
\hline $7 / 24 / 1997$ & 1140.00 & 9.49 & 50.50 & 2.29 & 1.47 & 3.3 & 4 \\
\hline $8 / 21 / 1997$ & 1738.50 & 110.60 & 67.50 & 6.93 & 16.54 & 3.3 & 4 \\
\hline 9/18/1997 & 289.75 & 4.24 & 13.00 & 3.29 & 0.68 & 3.3 & 4 \\
\hline 10/29/1997 & 574.75 & 2.98 & 27.50 & 2.38 & 0.27 & 3.3 & 4 \\
\hline $11 / 20 / 1997$ & 456.00 & 0.02 & 23.75 & 1.38 & 0.00 & 3.3 & 4 \\
\hline 12/18/1997 & 275.50 & 3.71 & 13.00 & 2.91 & 0.14 & 3.3 & 4 \\
\hline 1/15/1998 & 323.00 & 6.81 & 15.00 & 2.75 & 0.20 & 3.3 & 4 \\
\hline 2/19/1998 & 373.67 & 2.40 & 18.33 & 2.33 & 0.08 & 3.3 & 4 \\
\hline $3 / 17 / 1998$ & 190.00 & 0.34 & 6.00 & 3.30 & 0.00 & 3.3 & 4 \\
\hline 4/16/1998 & 133.00 & 0.08 & 5.33 & 2.60 & 0.01 & 3.3 & 4 \\
\hline $5 / 13 / 1998$ & 177.33 & 3.32 & 6.33 & 5.00 & 0.22 & 3.3 & 4 \\
\hline 6/8/1998 & 76.00 & 10.01 & 1.00 & 11.75 & 1.00 & 3.3 & 4 \\
\hline $7 / 9 / 1998$ & 291.33 & 4.86 & 13.33 & 2.89 & 0.70 & 3.3 & 4 \\
\hline 8/4/1998 & 1095.67 & 3.23 & 53.33 & 2.08 & 0.45 & 3.3 & 4 \\
\hline 9/16/1998 & 753.67 & 3.20 & 36.00 & 2.39 & 0.36 & 3.3 & 4 \\
\hline $10 / 6 / 1998$ & 741.00 & 3.40 & 36.33 & 2.24 & 0.20 & 3.3 & 4 \\
\hline $11 / 4 / 1998$ & 310.33 & 2.30 & 14.33 & 2.64 & 0.09 & 3.3 & 4 \\
\hline 12/21/1998 & 506.67 & 4.15 & 25.33 & 2.49 & 0.12 & 3.3 & 4 \\
\hline 1/15/1999 & 1007.00 & 10.29 & 51.25 & 1.95 & 0.30 & 3.3 & 4 \\
\hline 2/19/1999 & 608.00 & 7.59 & 31.25 & 2.28 & 0.25 & 3.3 & 4 \\
\hline
\end{tabular}




\begin{tabular}{|c|c|c|c|c|c|c|c|}
\hline \multicolumn{8}{|c|}{ Appendix 19. Station P8 Corbicula Data } \\
\hline Date & $\begin{array}{l}\text { Total \# of } \\
\text { clams in } \\
\text { sample } \\
\left(\# / \mathrm{m}^{2}\right)\end{array}$ & $\begin{array}{c}\text { biomass } \\
\left(\mathrm{g} / \mathrm{m}^{2}\right)\end{array}$ & $\mathrm{rec} / 0.05 \mathrm{~m}^{2}$ & $\begin{array}{c}\text { mean size } \\
(\mathrm{mm})\end{array}$ & $\begin{array}{c}\text { GR } \\
\left(\mathrm{m}^{3} / \mathrm{m}^{2} / \mathrm{d}\right)\end{array}$ & Depth (M) & \# Grabs \\
\hline 3/17/1999 & 180.50 & 4.83 & 9.00 & 3.18 & 0.16 & 3.3 & 4 \\
\hline 4/16/1999 & 223.25 & 15.13 & 9.00 & 4.27 & 0.56 & 3.3 & 4 \\
\hline 5/20/1999 & 266.00 & 2.83 & 11.75 & 2.61 & 0.08 & 3.3 & 4 \\
\hline 6/15/1999 & 147.25 & 4.47 & 7.25 & 3.37 & 0.58 & 3.3 & 4 \\
\hline 7/15/1999 & 1553.25 & 5.03 & 80.00 & 1.37 & 0.79 & 3.3 & 4 \\
\hline 8/13/1999 & 1135.25 & 6.46 & 57.25 & 1.78 & 0.91 & 3.3 & 4 \\
\hline 9/24/1999 & 983.25 & 7.51 & 47.25 & 2.32 & 0.94 & 3.3 & 4 \\
\hline 10/27/1999 & 503.50 & 1.89 & 24.00 & 2.03 & 0.19 & 3.3 & 4 \\
\hline 11/9/1999 & 266.00 & 1.72 & 12.50 & 2.36 & 0.11 & 3.3 & 4 \\
\hline 12/9/1999 & 270.75 & 2.02 & 12.25 & 2.61 & 0.06 & 3.3 & 4 \\
\hline $1 / 7 / 2000$ & 202.67 & 3.21 & 10.33 & 2.34 & 0.10 & 3.3 & 4 \\
\hline $2 / 24 / 2000$ & 418.00 & 0.08 & 20.67 & 1.74 & 0.00 & 3.3 & 4 \\
\hline $3 / 24 / 2000$ & 266.00 & 0.07 & 12.33 & 2.17 & 0.00 & 3.3 & 4 \\
\hline $4 / 20 / 2000$ & 392.67 & 0.06 & 20.33 & 1.85 & 0.01 & 3.3 & 4 \\
\hline $5 / 17 / 2000$ & 196.33 & 2.60 & 8.67 & 3.21 & 0.17 & 3.3 & 4 \\
\hline $6 / 15 / 2000$ & 342.00 & 0.11 & 15.67 & 2.11 & 0.01 & 3.3 & 4 \\
\hline $7 / 19 / 2000$ & 456.00 & 3.88 & 14.00 & 3.21 & 0.61 & 3.3 & 4 \\
\hline $8 / 15 / 2000$ & 633.33 & 0.12 & 26.33 & 2.28 & 0.03 & 3.3 & 4 \\
\hline $9 / 13 / 2000$ & 361.00 & 0.03 & 17.33 & 1.97 & 0.00 & 3.3 & 4 \\
\hline $10 / 12 / 2000$ & 221.67 & 0.06 & 7.33 & 2.73 & 0.01 & 3.3 & 4 \\
\hline $11 / 17 / 2000$ & 291.33 & 0.37 & 13.00 & 2.48 & 0.02 & 3.3 & 4 \\
\hline $12 / 13 / 2000$ & 386.33 & 0.17 & 14.67 & 2.60 & 0.00 & 3.3 & 4 \\
\hline $1 / 12 / 2001$ & 707.75 & 2.24 & 35.75 & 1.65 & 0.07 & 3.3 & 4 \\
\hline $2 / 7 / 2001$ & 361.00 & $N / D$ & $N / D$ & N/D & $N / D$ & $\mathrm{~N} / \mathrm{D}$ & $N / D$ \\
\hline $3 / 8 / 2001$ & 541.00 & $N / D$ & $N / D$ & $N / D$ & $N / D$ & N/D & $N / D$ \\
\hline $4 / 5 / 2001$ & 427.50 & 0.08 & 19.00 & 2.04 & 0.00 & 3.3 & 4 \\
\hline $5 / 9 / 2001$ & 365.75 & 0.06 & 15.00 & 2.06 & 0.01 & 3.3 & 4 \\
\hline $6 / 19 / 2001$ & 560.50 & 6.60 & 26.25 & 2.02 & 0.93 & 3.3 & 4 \\
\hline $7 / 24 / 2001$ & 684.00 & 1.55 & 27.50 & 2.44 & 0.27 & 3.3 & 4 \\
\hline $8 / 22 / 2001$ & 470.25 & 0.17 & 19.25 & 2.26 & 0.03 & 3.3 & 4 \\
\hline $9 / 20 / 2001$ & 437.00 & 0.09 & 19.00 & 2.18 & 0.01 & 3.3 & 4 \\
\hline $10 / 19 / 2001$ & 346.75 & 0.07 & 14.25 & 2.09 & 0.01 & 3.3 & 4 \\
\hline $11 / 21 / 2001$ & 978.50 & 0.06 & 50.00 & 1.40 & 0.00 & 3.3 & 4 \\
\hline $12 / 14 / 2001$ & 707.75 & 0.08 & 34.00 & 1.92 & 0.00 & 3.3 & 4 \\
\hline $1 / 17 / 2002$ & 1697.33 & 0.34 & 83.67 & 1.92 & 0.01 & 3.3 & 4 \\
\hline $2 / 14 / 2002$ & 1121.00 & 0.27 & 54.33 & 2.01 & 0.01 & 3.3 & 4 \\
\hline $3 / 12 / 2002$ & 988.00 & 0.16 & 47.75 & 2.05 & $N / D$ & 3.3 & 4 \\
\hline $4 / 16 / 2002$ & 318.25 & 0.12 & 10.75 & 2.65 & $\mathrm{~N} / \mathrm{D}$ & 3.3 & 4 \\
\hline
\end{tabular}




\begin{tabular}{|c|c|c|c|c|c|c|c|}
\hline \multicolumn{8}{|c|}{ Appendix 19. Station P8 Corbicula Data } \\
\hline Date & $\begin{array}{l}\text { Total \# of } \\
\text { clams in } \\
\text { sample } \\
\left(\# / \mathrm{m}^{2}\right)\end{array}$ & $\begin{array}{c}\text { biomass } \\
\left(\mathrm{g} / \mathrm{m}^{2}\right)\end{array}$ & $\mathrm{rec} / 0.05 \mathrm{~m}^{2}$ & $\begin{array}{c}\text { mean size } \\
(\mathrm{mm})\end{array}$ & $\begin{array}{c}\text { GR } \\
\left(\mathrm{m}^{3} / \mathrm{m}^{2} / \mathrm{d}\right)\end{array}$ & Depth (M) & \# Grabs \\
\hline $5 / 15 / 2002$ & 399.00 & 0.12 & 16.25 & 2.30 & 0.01 & 3.3 & 4 \\
\hline $6 / 11 / 2002$ & 660.25 & 1.94 & 33.50 & 2.03 & 0.01 & 3.3 & 4 \\
\hline $7 / 9 / 2002$ & 595.33 & 0.14 & 25.33 & 2.27 & 0.27 & 3.3 & 4 \\
\hline $8 / 8 / 2002$ & 867.67 & 0.62 & 43.67 & 1.15 & 0.03 & 3.3 & 4 \\
\hline $9 / 11 / 2002$ & 373.67 & 0.13 & 14.00 & 2.57 & 0.11 & 3.3 & 4 \\
\hline 10/24/2002 & 332.50 & 0.06 & 15.75 & 2.13 & 0.02 & 3.3 & 4 \\
\hline $11 / 6 / 2002$ & 373.67 & 0.10 & 17.00 & 2.09 & 0.01 & 3.3 & 4 \\
\hline $12 / 6 / 2002$ & 1249.25 & 0.06 & 63.75 & 1.62 & 0.01 & 3.3 & 4 \\
\hline $1 / 21 / 2003$ & $N / D$ & $N / D$ & $N / D$ & $N / D$ & $N / D$ & $\mathrm{~N} / \mathrm{D}$ & $\mathrm{N} / \mathrm{D}$ \\
\hline $2 / 18 / 2003$ & $\mathrm{~N} / \mathrm{D}$ & $N / D$ & $N / D$ & $N / D$ & $\mathrm{~N} / \mathrm{D}$ & $\mathrm{N} / \mathrm{D}$ & $\mathrm{N} / \mathrm{D}$ \\
\hline $3 / 18 / 2003$ & $N / D$ & $N / D$ & $N / D$ & $N / D$ & $N / D$ & $\mathrm{~N} / \mathrm{D}$ & $N / D$ \\
\hline $4 / 16 / 2003$ & $N / D$ & $N / D$ & $N / D$ & $N / D$ & $N / D$ & $\mathrm{~N} / \mathrm{D}$ & $N / D$ \\
\hline $5 / 14 / 2003$ & $N / D$ & $N / D$ & $N / D$ & N/D & $\mathrm{N} / \mathrm{D}$ & $\mathrm{N} / \mathrm{D}$ & $\mathrm{N} / \mathrm{D}$ \\
\hline $6 / 1 / 2003$ & $N / D$ & $N / D$ & $N / D$ & $N / D$ & $N / D$ & $N / D$ & $N / D$ \\
\hline $7 / 14 / 2003$ & $N / D$ & $N / D$ & $N / D$ & N/D & $N / D$ & $\mathrm{~N} / \mathrm{D}$ & $N / D$ \\
\hline $8 / 13 / 2003$ & $N / D$ & $N / D$ & $N / D$ & $N / D$ & $N / D$ & $N / D$ & $N / D$ \\
\hline $9 / 18 / 2003$ & $N / D$ & $N / D$ & N/D & N/D & $N / D$ & $\mathrm{~N} / \mathrm{D}$ & $\mathrm{N} / \mathrm{D}$ \\
\hline $10 / 23 / 2003$ & $N / D$ & $N / D$ & $N / D$ & $N / D$ & $N / D$ & $\mathrm{~N} / \mathrm{D}$ & $N / D$ \\
\hline $1 / 8 / 2004$ & $N / D$ & $N / D$ & N/D & N/D & $N / D$ & $\mathrm{~N} / \mathrm{D}$ & $\mathrm{N} / \mathrm{D}$ \\
\hline $4 / 7 / 2004$ & N/D & $N / D$ & $N / D$ & $N / D$ & $N / D$ & $\mathrm{~N} / \mathrm{D}$ & $N / D$ \\
\hline $7 / 15 / 2004$ & 753.67 & 0.21 & 30.67 & 2.29 & 0.04 & 3.3 & 4 \\
\hline $10 / 26 / 2004$ & 627.00 & 0.08 & 30.33 & 1.93 & 0.01 & 3.3 & 4 \\
\hline $1 / 12 / 2005$ & 1292.00 & 0.09 & 66.33 & 1.27 & 0.00 & 3.3 & 4 \\
\hline $4 / 8 / 2005$ & 361.00 & 0.61 & 14.33 & 2.82 & 0.03 & 3.3 & 4 \\
\hline $7 / 25 / 2005$ & 361.00 & 1.88 & 16.67 & 2.54 & 0.27 & 3.3 & 4 \\
\hline $10 / 14 / 2005$ & 145.67 & 0.08 & 5.67 & 2.50 & 0.01 & 3.3 & 4 \\
\hline $11 / 9 / 2005$ & 291.33 & 3.47 & 12.33 & 3.37 & 0.16 & 3.3 & 4 \\
\hline $12 / 7 / 2005$ & 703.00 & 1.48 & 34.00 & 2.13 & 0.04 & 3.3 & 4 \\
\hline $1 / 12 / 2006$ & 1089.33 & 0.19 & 54.00 & 1.69 & 0.01 & 3.3 & 4 \\
\hline $2 / 9 / 2006$ & 690.33 & 0.18 & 31.67 & 1.99 & 0.01 & 3.3 & 4 \\
\hline $3 / 15 / 2006$ & 798.00 & 0.32 & 34.50 & 2.30 & 0.01 & 3.3 & 4 \\
\hline $4 / 26 / 2006$ & 855.00 & 5.26 & 38.33 & 2.56 & 0.27 & 3.3 & 4 \\
\hline $5 / 25 / 2006$ & 361.00 & 0.06 & 16.67 & 2.04 & 0.01 & 3.3 & 4 \\
\hline $6 / 5 / 2006$ & 164.67 & 0.05 & 6.00 & 2.69 & 0.01 & 3.3 & 4 \\
\hline $7 / 10 / 2006$ & 304.00 & 1.58 & 14.00 & 2.69 & 0.23 & 3.3 & 4 \\
\hline $8 / 10 / 2006$ & 1152.67 & 1.04 & 45.67 & 2.88 & 0.13 & 3.3 & 4 \\
\hline $9 / 25 / 2006$ & 95.00 & 0.03 & 3.00 & 2.70 & 0.00 & 3.3 & 4 \\
\hline $10 / 25 / 2006$ & 164.67 & 0.31 & 7.00 & 2.81 & 0.03 & 3.3 & 4 \\
\hline
\end{tabular}




\begin{tabular}{|c|c|c|c|c|c|c|c|}
\hline \multicolumn{8}{|c|}{ Appendix 19. Station P8 Corbicula Data } \\
\hline Date & $\begin{array}{l}\text { Total \# of } \\
\text { clams in } \\
\text { sample } \\
\left(\# / \mathrm{m}^{2}\right)\end{array}$ & $\begin{array}{c}\text { biomass } \\
\left(\mathrm{g} / \mathrm{m}^{2}\right)\end{array}$ & $\mathrm{rec} / 0.05 \mathrm{~m}^{2}$ & $\begin{array}{c}\text { mean size } \\
(\mathrm{mm})\end{array}$ & $\begin{array}{c}\text { GR } \\
\left(\mathrm{m}^{3} / \mathrm{m}^{2} / \mathrm{d}\right)\end{array}$ & Depth (M) & \# Grabs \\
\hline $11 / 20 / 2006$ & 443.33 & 0.07 & 20.67 & 2.19 & 0.00 & 3.3 & 4 \\
\hline $12 / 20 / 2006$ & 867.67 & 0.33 & 44.00 & 1.76 & 0.01 & 3.3 & 4 \\
\hline $1 / 23 / 2007$ & 731.50 & 3.82 & 33.25 & 2.79 & 0.11 & 3.3 & 4 \\
\hline $2 / 20 / 2007$ & 897.75 & 0.10 & 45.25 & 1.52 & 0.00 & 3.3 & 4 \\
\hline $3 / 20 / 2007$ & 232.75 & 0.06 & 11.00 & 2.32 & 0.00 & 3.3 & 4 \\
\hline $4 / 16 / 2007$ & 204.25 & 6.34 & 7.50 & 3.85 & 0.47 & 3.3 & 4 \\
\hline $5 / 16 / 2007$ & 118.75 & 1.89 & 3.00 & 4.54 & 0.13 & 3.3 & 4 \\
\hline $6 / 20 / 2007$ & 1743.25 & 2.01 & 86.75 & 1.79 & 0.20 & 3.3 & 4 \\
\hline $7 / 16 / 2007$ & 679.25 & 2.29 & 26.25 & 2.59 & 0.36 & 3.3 & 4 \\
\hline $8 / 15 / 2007$ & 318.25 & 1.36 & 13.25 & 2.43 & 0.19 & 3.3 & 4 \\
\hline $9 / 11 / 2007$ & 546.25 & 1.03 & 27.75 & 2.13 & 0.15 & 3.3 & 4 \\
\hline $10 / 3 / 2007$ & 66.50 & 1.99 & 2.50 & 6.21 & 0.15 & 3.3 & 4 \\
\hline $11 / 6 / 2007$ & 451.25 & 1.88 & 21.25 & 2.57 & 0.11 & 3.3 & 4 \\
\hline $12 / 10 / 2007$ & 712.50 & 0.09 & 37.25 & 1.51 & 0.00 & 3.3 & 4 \\
\hline $1 / 8 / 2008$ & 798.00 & 1.59 & 37.75 & 2.19 & 0.05 & 3.3 & 4 \\
\hline $2 / 6 / 2008$ & 1790.75 & 0.38 & 87.25 & 1.99 & 0.01 & 3.3 & 4 \\
\hline $3 / 5 / 2008$ & 560.50 & 0.65 & 27.25 & 2.60 & 0.03 & 3.3 & 4 \\
\hline $4 / 2 / 2008$ & 655.50 & 1.29 & 27.75 & 2.70 & 0.07 & 3.3 & 4 \\
\hline $5 / 20 / 2008$ & 323.00 & 0.92 & 10.00 & 3.54 & 0.07 & 3.3 & 4 \\
\hline $6 / 17 / 2008$ & 247.00 & 0.81 & 10.25 & 3.35 & 0.08 & 3.3 & 4 \\
\hline $7 / 14 / 2008$ & 247.00 & 2.78 & 9.50 & 5.00 & 0.44 & 3.3 & 4 \\
\hline $8 / 13 / 2008$ & 869.25 & 1.36 & 45.00 & 1.89 & 0.24 & 3.3 & 4 \\
\hline $9 / 15 / 2008$ & 1002.25 & 0.90 & 49.25 & 2.09 & 0.14 & 3.3 & 4 \\
\hline $10 / 28 / 2008$ & 175.75 & 1.41 & 8.00 & 2.91 & 0.16 & 3.3 & 4 \\
\hline $11 / 18 / 2008$ & 598.50 & 5.48 & 28.00 & 2.49 & 0.32 & 3.3 & 4 \\
\hline $12 / 10 / 2008$ & 408.50 & 0.56 & 18.00 & 2.37 & 0.02 & 3.3 & 4 \\
\hline $1 / 12 / 2009$ & 1168.50 & 9.18 & 54.00 & 2.64 & 0.26 & 3.3 & 4 \\
\hline 2/9/2009 & 503.50 & 3.75 & 23.00 & 2.53 & 0.13 & 3.3 & 4 \\
\hline 3/11/2009 & 1173.25 & 0.57 & 60.75 & 1.69 & 0.03 & 3.3 & 4 \\
\hline $4 / 6 / 2009$ & 270.75 & 0.67 & 12.00 & 2.80 & 0.04 & 3.3 & 4 \\
\hline $5 / 5 / 2009$ & 779.00 & 0.43 & 33.25 & 2.50 & 0.04 & 3.3 & 4 \\
\hline $6 / 23 / 2009$ & 247.00 & 13.23 & 5.75 & 8.21 & 1.61 & 3.3 & 4 \\
\hline $7 / 21 / 2009$ & 1040.25 & 0.60 & 52.25 & 2.08 & 0.09 & 3.3 & 4 \\
\hline $8 / 18 / 2009$ & 1463.00 & 3.43 & 74.00 & 2.13 & 0.59 & 3.3 & 4 \\
\hline $9 / 16 / 2009$ & 123.50 & 0.69 & 5.50 & 2.96 & 0.10 & 3.3 & 4 \\
\hline $10 / 19 / 2009$ & 304.00 & 17.59 & 11.00 & 8.59 & 1.35 & 3.3 & 4 \\
\hline $11 / 16 / 2009$ & 57.00 & 0.03 & 1.50 & 2.92 & 0.00 & 3.3 & 4 \\
\hline $12 / 15 / 2009$ & 61.75 & 0.01 & 2.50 & 2.12 & 0.00 & 3.3 & 4 \\
\hline
\end{tabular}




\begin{tabular}{|c|c|c|c|c|c|c|c|}
\hline \multicolumn{8}{|c|}{ Appendix 19. Station P8 Corbicula Data } \\
\hline Date & $\begin{array}{l}\text { Total \# of } \\
\text { clams in } \\
\text { sample } \\
\left(\# / \mathrm{m}^{2}\right)\end{array}$ & $\begin{array}{c}\text { biomass } \\
\left(\mathrm{g} / \mathrm{m}^{2}\right)\end{array}$ & $\mathrm{rec} / 0.05 \mathrm{~m}^{2}$ & $\begin{array}{c}\text { mean size } \\
(\mathrm{mm})\end{array}$ & $\begin{array}{c}\text { GR } \\
\left(\mathrm{m}^{3} / \mathrm{m}^{2} / \mathrm{d}\right)\end{array}$ & Depth (M) & \# Grabs \\
\hline $1 / 13 / 2010$ & 80.75 & 0.07 & 3.25 & 2.50 & 0.00 & 3.3 & 4 \\
\hline $2 / 17 / 2010$ & 204.25 & 6.97 & 10.25 & 2.69 & 0.21 & 3.3 & 4 \\
\hline $3 / 15 / 2010$ & 247.00 & 0.09 & 11.50 & 2.12 & 0.00 & 3.3 & 4 \\
\hline $4 / 12 / 2010$ & 441.75 & 0.06 & 21.75 & 1.79 & 0.00 & 3.3 & 4 \\
\hline $5 / 19 / 2010$ & 237.50 & 0.03 & 12.00 & 1.82 & 0.00 & 3.3 & 4 \\
\hline $6 / 9 / 2010$ & 218.50 & 0.23 & 10.50 & 2.52 & 0.02 & 3.3 & 4 \\
\hline $7 / 6 / 2010$ & 152.00 & 0.04 & 6.50 & 2.31 & 0.01 & 3.3 & 4 \\
\hline $8 / 16 / 2010$ & 1567.50 & 0.18 & 79.75 & 1.81 & 0.03 & 3.3 & 4 \\
\hline 9/7/2010 & 788.50 & 0.15 & 37.00 & 2.33 & 0.02 & 3.3 & 4 \\
\hline $10 / 26 / 2010$ & 123.50 & 0.03 & 5.25 & 2.04 & 0.00 & 3.3 & 4 \\
\hline $11 / 22 / 2010$ & 52.25 & 0.01 & 2.25 & 1.77 & 0.00 & 3.3 & 4 \\
\hline $12 / 20 / 2010$ & 85.50 & 0.64 & 4.00 & 3.06 & 0.02 & 3.3 & 4 \\
\hline $1 / 18 / 2011$ & 123.50 & 1.76 & 6.25 & 2.23 & 0.05 & 3.3 & 4 \\
\hline $2 / 1 / 2011$ & 133.00 & 4.18 & 5.25 & 3.64 & 0.14 & 3.3 & 4 \\
\hline $3 / 7 / 2011$ & 289.75 & 5.12 & 13.00 & 3.09 & 0.22 & 3.3 & 4 \\
\hline $4 / 5 / 2011$ & 356.25 & 0.11 & 16.75 & 1.93 & 0.01 & 3.3 & 4 \\
\hline $5 / 3 / 2011$ & 508.25 & 0.04 & 25.75 & 1.65 & 0.00 & 3.3 & 4 \\
\hline $6 / 13 / 2011$ & 142.50 & 2.78 & 3.25 & 5.17 & 0.16 & 3.3 & 4 \\
\hline $7 / 12 / 2011$ & 251.75 & 2.48 & 9.50 & 3.27 & 0.35 & 3.3 & 4 \\
\hline $8 / 9 / 2011$ & 517.75 & 0.54 & 26.00 & 1.85 & 0.06 & 3.3 & 4 \\
\hline $9 / 7 / 2011$ & 745.75 & 0.07 & 36.50 & 1.84 & 0.01 & 3.3 & 4 \\
\hline $10 / 3 / 2011$ & 688.75 & 0.07 & 32.25 & 1.78 & 0.01 & 3.3 & 4 \\
\hline $11 / 8 / 2011$ & 479.75 & 1.75 & 8.00 & 3.91 & 0.08 & 3.3 & 4 \\
\hline $12 / 7 / 2011$ & 228.00 & 1.04 & 8.50 & 3.31 & 0.03 & 3.3 & 4 \\
\hline $1 / 9 / 2012$ & 313.50 & 0.58 & 5.75 & 3.58 & 0.02 & 3.3 & 4 \\
\hline $2 / 8 / 2012$ & 128.25 & 1.57 & 2.25 & 4.31 & 0.06 & 3.3 & 4 \\
\hline $3 / 6 / 2012$ & 242.25 & 5.85 & 2.75 & 5.26 & 0.24 & 3.3 & 4 \\
\hline $4 / 5 / 2012$ & 342.00 & 0.74 & 8.75 & 3.75 & 0.04 & 3.3 & 4 \\
\hline $5 / 21 / 2012$ & 285.00 & 2.63 & 10.50 & 3.27 & 0.24 & 3.3 & 4 \\
\hline $6 / 20 / 2012$ & 261.25 & 0.31 & 12.75 & 2.28 & 0.04 & 3.3 & 4 \\
\hline $7 / 17 / 2012$ & 128.25 & 0.43 & 3.75 & 4.09 & 0.07 & 3.3 & 4 \\
\hline $8 / 15 / 2012$ & 128.25 & 4.31 & 5.25 & 4.35 & 0.69 & 3.3 & 4 \\
\hline $9 / 25 / 2012$ & 42.75 & 0.92 & 0.25 & 10.50 & 0.13 & 3.3 & 4 \\
\hline $10 / 24 / 2012$ & 104.50 & 3.33 & 0.25 & 10.68 & 0.41 & 3.3 & 4 \\
\hline $11 / 14 / 2012$ & 23.75 & 1.37 & 0.25 & 11.10 & 0.10 & 3.3 & 4 \\
\hline $12 / 18 / 2012$ & 33.25 & 1.04 & 0.00 & 12.79 & 0.05 & 3.3 & 4 \\
\hline $1 / 9 / 2013$ & 28.50 & 0.50 & 0.00 & 9.67 & 0.01 & 3.3 & 4 \\
\hline $2 / 5 / 2013$ & 38.00 & 1.50 & 0.00 & 13.25 & 0.05 & 3.3 & 4 \\
\hline
\end{tabular}




\begin{tabular}{|c|c|c|c|c|c|c|c|}
\hline \multicolumn{8}{|c|}{ Appendix 19. Station P8 Corbicula Data } \\
\hline Date & $\begin{array}{l}\text { Total \# of } \\
\text { clams in } \\
\text { sample } \\
\left(\# / \mathrm{m}^{2}\right)\end{array}$ & $\begin{array}{c}\text { biomass } \\
\left(\mathrm{g} / \mathrm{m}^{2}\right)\end{array}$ & $\mathrm{rec} / 0.05 \mathrm{~m}^{2}$ & $\begin{array}{c}\text { mean size } \\
(\mathrm{mm})\end{array}$ & $\begin{array}{c}\text { GR } \\
\left(\mathrm{m}^{3} / \mathrm{m}^{2} / \mathrm{d}\right)\end{array}$ & Depth (M) & \# Grabs \\
\hline $3 / 13 / 2013$ & 28.50 & 0.42 & 0.25 & 9.00 & 0.02 & 3.3 & 4 \\
\hline $4 / 10 / 2013$ & 247.00 & 4.69 & 10.25 & 4.77 & 0.31 & 3.3 & 4 \\
\hline $5 / 7 / 2013$ & 133.00 & 0.24 & 6.00 & 2.46 & 0.02 & 3.3 & 4 \\
\hline 6/4/2013 & 85.50 & 1.94 & 2.75 & 4.44 & 0.28 & 3.3 & 4 \\
\hline $7 / 8 / 2013$ & 171.00 & 2.51 & 7.25 & 3.78 & 0.45 & 3.3 & 4 \\
\hline $8 / 8 / 2013$ & $\mathrm{~N} / \mathrm{D}$ & $\mathrm{N} / \mathrm{D}$ & $\mathrm{N} / \mathrm{D}$ & $\mathrm{N} / \mathrm{D}$ & $N / D$ & $N / D$ & $N / D$ \\
\hline $9 / 4 / 2013$ & 536.75 & 0.81 & 25.50 & 2.29 & 0.10 & 3.3 & 4 \\
\hline $10 / 15 / 2013$ & 61.75 & 0.02 & 2.50 & 2.50 & 0.00 & 3.3 & 4 \\
\hline $11 / 19 / 2013$ & 128.25 & 1.36 & 5.00 & 4.69 & 0.07 & 3.3 & 4 \\
\hline $12 / 16 / 2013$ & 61.75 & 1.64 & 1.75 & 5.96 & 0.05 & 3.3 & 4 \\
\hline
\end{tabular}

Appendix 20. Station C9 Corbicula Data

\begin{tabular}{|c|c|c|c|c|c|c|c|}
\hline Date & $\begin{array}{l}\text { Total \# of } \\
\text { clams in } \\
\text { sample } \\
\left(\# / \mathrm{m}^{2}\right)\end{array}$ & $\begin{array}{c}\text { biomass } \\
\left(\mathrm{g} / \mathrm{m}^{2}\right)\end{array}$ & $\begin{array}{c}\text { rec/ } \\
0.05 \mathrm{~m}^{2}\end{array}$ & $\begin{array}{c}\text { mean size } \\
(\mathrm{mm})\end{array}$ & $\begin{array}{c}\text { GR } \\
\left(\mathrm{m}^{3} / \mathrm{m}^{2} / \mathrm{d}\right)\end{array}$ & Depth (M) & \# Grabs \\
\hline 1/23/1996 & 728.33 & 4.92 & 32.33 & 2.61 & 0.14 & 3.16 & 4 \\
\hline 2/23/1996 & 1567.50 & 4.18 & 74.75 & 2.30 & 0.17 & 3.16 & 4 \\
\hline 3/22/1996 & 3928.25 & 0.44 & 192.25 & 1.38 & 0.02 & 3.16 & 4 \\
\hline 4/29/1996 & 403.75 & 2.27 & 16.25 & 2.70 & 0.19 & 3.16 & 4 \\
\hline 5/17/1996 & 164.67 & 7.07 & 1.33 & 7.65 & 0.70 & 3.16 & 4 \\
\hline $6 / 15 / 1996$ & 299.25 & 22.39 & 6.75 & 8.60 & 3.35 & 3.16 & 4 \\
\hline 7/18/1996 & 147.25 & 34.81 & 3.50 & 16.44 & 5.05 & 3.16 & 4 \\
\hline $8 / 30 / 1996$ & 242.25 & 29.20 & 7.50 & 7.26 & 4.47 & 3.16 & 4 \\
\hline 9/13/1996 & 175.75 & 60.74 & 1.75 & 16.26 & 5.57 & 3.16 & 4 \\
\hline 10/9/1996 & 52.25 & 32.28 & 0.50 & 26.77 & 2.43 & 3.16 & 4 \\
\hline 11/15/1996 & 228.00 & 43.51 & 6.00 & 16.21 & 1.78 & 3.16 & 4 \\
\hline 12/12/1996 & 256.50 & 33.40 & 7.75 & 11.65 & 1.14 & 3.16 & 4 \\
\hline $1 / 22 / 1997$ & N/D & N/D & $\mathrm{N} / \mathrm{D}$ & N/D & N/D & $N / D$ & N/D \\
\hline 2/21/1997 & 118.75 & 7.37 & 5.50 & 4.94 & 0.28 & 3.16 & 4 \\
\hline $3 / 26 / 1997$ & 560.50 & 25.81 & 19.50 & 5.06 & 1.29 & 3.16 & 4 \\
\hline 4/24/1997 & 532.00 & 33.70 & 18.25 & 4.33 & 2.15 & 3.16 & 4 \\
\hline $5 / 23 / 1997$ & 185.25 & 27.54 & 3.75 & 10.96 & 3.30 & 3.16 & 4 \\
\hline $6 / 20 / 1997$ & 1306.25 & 45.36 & 60.50 & 3.30 & 5.49 & 3.16 & 4 \\
\hline $7 / 24 / 1997$ & 1178.00 & 18.39 & 58.00 & 2.77 & 0.00 & 3.16 & 4 \\
\hline $8 / 21 / 1997$ & 380.00 & 0.87 & 14.25 & 2.96 & 0.14 & 3.16 & 4 \\
\hline 9/18/1997 & 114.00 & 78.20 & 0.75 & 28.71 & 9.38 & 3.16 & 4 \\
\hline 10/29/1997 & 237.50 & 84.25 & 5.75 & 16.58 & 5.41 & 3.16 & 4 \\
\hline
\end{tabular}




\begin{tabular}{|c|c|c|c|c|c|c|c|}
\hline \multicolumn{8}{|c|}{ Appendix 20. Station C9 Corbicula Data } \\
\hline Date & $\begin{array}{c}\text { Total \# of } \\
\text { clams in } \\
\text { sample } \\
\left(\# / \mathrm{m}^{2}\right)\end{array}$ & $\begin{array}{c}\text { biomass } \\
\left(\mathrm{g} / \mathrm{m}^{2}\right)\end{array}$ & $\begin{array}{c}\mathrm{rec} / \\
0.05 \mathrm{~m}^{2}\end{array}$ & $\begin{array}{c}\text { mean size } \\
(\mathrm{mm})\end{array}$ & $\begin{array}{c}G R \\
\left(\mathrm{~m}^{3} / \mathrm{m}^{2} / \mathrm{d}\right)\end{array}$ & Depth (M) & \# Grabs \\
\hline $11 / 20 / 1997$ & 403.75 & 5.44 & 18.00 & 3.11 & 0.35 & 3.16 & 4 \\
\hline 12/18/1997 & 147.25 & 5.33 & 4.25 & 5.60 & 0.18 & 3.16 & 4 \\
\hline 1/15/1998 & 327.75 & 0.57 & 16.25 & 1.80 & 0.02 & 3.16 & 4 \\
\hline 2/19/1998 & $N / D$ & N/D & $\mathrm{N} / \mathrm{D}$ & $N / D$ & $\mathrm{~N} / \mathrm{D}$ & $\mathrm{N} / \mathrm{D}$ & $\mathrm{N} / \mathrm{D}$ \\
\hline $3 / 17 / 1998$ & 897.75 & 32.35 & 36.25 & 4.44 & 1.28 & 3.16 & 4 \\
\hline $4 / 16 / 1998$ & 736.25 & 122.60 & 23.25 & 8.07 & 7.08 & 3.16 & 4 \\
\hline $5 / 13 / 1998$ & 443.33 & 72.98 & 11.67 & 12.17 & 3.66 & 3.16 & 4 \\
\hline 6/8/1998 & 394.25 & 15.61 & 10.50 & 6.05 & 1.69 & 3.16 & 4 \\
\hline 7/9/1998 & 517.75 & 109.73 & 10.00 & 15.13 & 15.76 & 3.16 & 4 \\
\hline 8/4/1998 & 323.00 & 17.03 & 14.25 & 4.96 & 2.64 & 3.16 & 4 \\
\hline $9 / 16 / 1998$ & 707.75 & 81.63 & 25.25 & 7.32 & 10.42 & 3.16 & 4 \\
\hline $10 / 6 / 1998$ & 266.00 & 16.45 & 10.75 & 4.93 & 1.20 & 3.16 & 4 \\
\hline $11 / 4 / 1998$ & 367.33 & 16.18 & 12.33 & 6.55 & 0.65 & 3.16 & 4 \\
\hline 12/21/1998 & 266.00 & 12.39 & 11.00 & 5.02 & 0.36 & 3.16 & 4 \\
\hline 1/15/1999 & 541.50 & 0.07 & 25.75 & 1.75 & 0.00 & 3.16 & 4 \\
\hline 2/19/1999 & 650.75 & 26.97 & 29.00 & 4.40 & 0.77 & 3.16 & 4 \\
\hline 3/17/1999 & 655.50 & 14.72 & 31.50 & 3.07 & 0.53 & 3.16 & 4 \\
\hline 4/16/1999 & 888.25 & 72.54 & 39.25 & 4.52 & 2.55 & 3.16 & 4 \\
\hline $5 / 20 / 1999$ & 413.25 & 0.09 & 18.75 & 2.19 & 0.01 & 3.16 & 4 \\
\hline 6/15/1999 & 114.00 & 0.02 & 4.75 & 2.08 & 0.00 & 3.16 & 4 \\
\hline 7/15/1999 & 38.00 & 0.01 & 1.50 & 2.00 & 0.00 & 3.16 & 4 \\
\hline 8/13/1999 & 152.00 & 21.82 & 5.75 & 8.31 & 2.43 & 3.16 & 4 \\
\hline 9/24/1999 & 4.75 & 0.00 & 0.25 & 2.50 & 0.00 & 3.16 & 4 \\
\hline 10/27/1999 & $N / D$ & $\mathrm{~N} / \mathrm{D}$ & $\mathrm{N} / \mathrm{D}$ & N/D & $\mathrm{N} / \mathrm{D}$ & $N / D$ & $N / D$ \\
\hline 11/9/1999 & 128.25 & 0.07 & 3.75 & 2.76 & 0.00 & 3.16 & 4 \\
\hline 12/9/1999 & 104.50 & 0.02 & 5.00 & 1.86 & 0.00 & 3.16 & 4 \\
\hline $1 / 7 / 2000$ & 76.00 & 4.68 & 1.75 & 7.25 & 0.14 & 3.16 & 4 \\
\hline $2 / 24 / 2000$ & 223.25 & 6.80 & 9.75 & 3.88 & 0.25 & 3.16 & 4 \\
\hline $3 / 24 / 2000$ & 541.50 & 0.15 & 22.00 & 2.25 & 0.01 & 3.16 & 4 \\
\hline $4 / 20 / 2000$ & 741.00 & 23.70 & 28.75 & 4.13 & 1.66 & 3.16 & 4 \\
\hline $5 / 17 / 2000$ & 171.00 & 0.07 & 6.25 & 2.64 & 0.01 & 3.16 & 4 \\
\hline $6 / 15 / 2000$ & 95.00 & 0.01 & 5.00 & 1.95 & 0.00 & 3.16 & 4 \\
\hline $7 / 19 / 2000$ & 137.75 & 3.90 & 5.75 & 3.53 & 0.51 & 3.16 & 4 \\
\hline $8 / 15 / 2000$ & 437.00 & 0.69 & 10.00 & 3.77 & 0.11 & 3.16 & 4 \\
\hline $9 / 13 / 2000$ & 85.50 & 0.02 & 3.75 & 2.11 & 0.00 & 3.16 & 4 \\
\hline $10 / 12 / 2000$ & 247.00 & 17.73 & 10.75 & 4.42 & 2.02 & 3.16 & 4 \\
\hline $11 / 17 / 2000$ & 90.25 & 0.01 & 4.50 & 1.66 & 0.00 & 3.16 & 4 \\
\hline $12 / 13 / 2000$ & 109.25 & 0.05 & 4.50 & 2.33 & 0.00 & 3.16 & 4 \\
\hline
\end{tabular}




\begin{tabular}{|c|c|c|c|c|c|c|c|}
\hline \multicolumn{8}{|c|}{ Appendix 20. Station C9 Corbicula Data } \\
\hline Date & $\begin{array}{l}\text { Total \# of } \\
\text { clams in } \\
\text { sample } \\
\left(\# / \mathrm{m}^{2}\right)\end{array}$ & $\begin{array}{c}\text { biomass } \\
\left(\mathrm{g} / \mathrm{m}^{2}\right)\end{array}$ & $\begin{array}{c}\text { rec/ } \\
0.05 \mathrm{~m}^{2}\end{array}$ & $\begin{array}{c}\text { mean size } \\
(\mathrm{mm})\end{array}$ & $\begin{array}{c}\text { GR } \\
\left(\mathrm{m}^{3} / \mathrm{m}^{2} / \mathrm{d}\right)\end{array}$ & Depth (M) & \# Grabs \\
\hline $1 / 12 / 2001$ & 1121.00 & 46.07 & 45.00 & 3.53 & 1.30 & 3.16 & 4 \\
\hline $2 / 7 / 2001$ & 161.50 & 4.03 & 6.25 & 3.21 & 0.12 & 3.16 & 4 \\
\hline $3 / 8 / 2001$ & 180.50 & 2.94 & 8.25 & 2.87 & 0.14 & 3.16 & 4 \\
\hline $4 / 5 / 2001$ & 145.67 & 8.75 & 6.33 & 4.20 & 0.46 & 3.16 & 4 \\
\hline $5 / 9 / 2001$ & 147.25 & 12.10 & 2.75 & 6.76 & 1.37 & 3.16 & 4 \\
\hline $6 / 19 / 2001$ & 342.00 & 144.63 & 10.50 & 7.67 & 17.45 & 3.16 & 4 \\
\hline $7 / 24 / 2001$ & 612.75 & 0.11 & 27.75 & 2.09 & 0.01 & 3.16 & 4 \\
\hline $8 / 22 / 2001$ & 133.00 & 2.09 & 3.50 & 4.61 & 0.30 & 3.16 & 4 \\
\hline $9 / 20 / 2001$ & 185.25 & 1.85 & 6.50 & 3.99 & 0.21 & 3.16 & 4 \\
\hline 10/19/2001 & 137.75 & 0.02 & 6.00 & 2.16 & 0.00 & 3.16 & 4 \\
\hline $11 / 21 / 2001$ & 769.50 & 15.45 & 33.25 & 3.14 & 0.99 & 3.16 & 4 \\
\hline $12 / 14 / 2001$ & 194.75 & 0.07 & 7.75 & 2.16 & 0.00 & 3.16 & 4 \\
\hline $1 / 17 / 2002$ & 126.67 & 0.11 & 4.00 & 3.20 & 0.00 & 3.16 & 4 \\
\hline $2 / 14 / 2002$ & 50.67 & 0.01 & 2.00 & 2.38 & 0.00 & 3.16 & 4 \\
\hline $3 / 12 / 2002$ & 291.33 & 0.15 & 11.00 & 2.37 & 0.01 & 3.16 & 4 \\
\hline $4 / 16 / 2002$ & 166.25 & 0.57 & 7.25 & 2.67 & 0.02 & 3.16 & 4 \\
\hline $5 / 15 / 2002$ & 63.33 & 0.02 & 2.33 & 2.40 & 0.00 & 3.16 & 4 \\
\hline $6 / 11 / 2002$ & 3413.67 & 16.61 & 175.67 & 1.66 & 1.05 & 3.16 & 4 \\
\hline $7 / 9 / 2002$ & 665.00 & 44.17 & 33.75 & 2.99 & 5.51 & 3.16 & 4 \\
\hline 8/8/2002 & 346.75 & 1.61 & 13.00 & 2.99 & 0.26 & 3.16 & 4 \\
\hline $9 / 11 / 2002$ & 456.00 & 14.57 & 15.75 & 4.35 & 2.02 & 3.16 & 4 \\
\hline $10 / 24 / 2002$ & 275.50 & 0.26 & 12.25 & 2.55 & 0.03 & 3.16 & 4 \\
\hline $11 / 6 / 2002$ & 126.67 & 0.01 & 5.67 & 2.05 & 0.00 & 3.16 & 4 \\
\hline $12 / 6 / 2002$ & N/D & N/D & $\mathrm{N} / \mathrm{D}$ & N/D & $N / D$ & $\mathrm{~N} / \mathrm{D}$ & $N / D$ \\
\hline $1 / 21 / 2003$ & $N / D$ & $\mathrm{~N} / \mathrm{D}$ & $\mathrm{N} / \mathrm{D}$ & N/D & $N / D$ & $N / D$ & $\mathrm{~N} / \mathrm{D}$ \\
\hline $2 / 18 / 2003$ & $\mathrm{~N} / \mathrm{D}$ & $\mathrm{N} / \mathrm{D}$ & $\mathrm{N} / \mathrm{D}$ & $N / D$ & $N / D$ & $\mathrm{~N} / \mathrm{D}$ & $N / D$ \\
\hline $3 / 18 / 2003$ & N/D & N/D & $\mathrm{N} / \mathrm{D}$ & N/D & $N / D$ & $N / D$ & $\mathrm{~N} / \mathrm{D}$ \\
\hline $4 / 16 / 2003$ & $N / D$ & $\mathrm{~N} / \mathrm{D}$ & $\mathrm{N} / \mathrm{D}$ & N/D & $N / D$ & $\mathrm{~N} / \mathrm{D}$ & $N / D$ \\
\hline $5 / 14 / 2003$ & N/D & N/D & $\mathrm{N} / \mathrm{D}$ & N/D & $N / D$ & $N / D$ & $\mathrm{~N} / \mathrm{D}$ \\
\hline $6 / 1 / 2003$ & $N / D$ & $\mathrm{~N} / \mathrm{D}$ & $\mathrm{N} / \mathrm{D}$ & $N / D$ & $\mathrm{~N} / \mathrm{D}$ & $N / D$ & $N / D$ \\
\hline $7 / 14 / 2003$ & $N / D$ & $\mathrm{~N} / \mathrm{D}$ & $\mathrm{N} / \mathrm{D}$ & $N / D$ & $N / D$ & $N / D$ & $N / D$ \\
\hline $8 / 13 / 2003$ & $N / D$ & $\mathrm{~N} / \mathrm{D}$ & $\mathrm{N} / \mathrm{D}$ & $\mathrm{N} / \mathrm{D}$ & $\mathrm{N} / \mathrm{D}$ & $\mathrm{N} / \mathrm{D}$ & $N / D$ \\
\hline $9 / 18 / 2003$ & $N / D$ & $\mathrm{~N} / \mathrm{D}$ & $\mathrm{N} / \mathrm{D}$ & $N / D$ & $N / D$ & $N / D$ & $N / D$ \\
\hline $10 / 23 / 2003$ & $N / D$ & $N / D$ & $\mathrm{~N} / \mathrm{D}$ & $N / D$ & $\mathrm{~N} / \mathrm{D}$ & $\mathrm{N} / \mathrm{D}$ & $N / D$ \\
\hline $1 / 8 / 2004$ & $N / D$ & $\mathrm{~N} / \mathrm{D}$ & $\mathrm{N} / \mathrm{D}$ & N/D & $\mathrm{N} / \mathrm{D}$ & $\mathrm{N} / \mathrm{D}$ & $N / D$ \\
\hline $4 / 7 / 2004$ & $N / D$ & $N / D$ & $\mathrm{~N} / \mathrm{D}$ & $N / D$ & $\mathrm{~N} / \mathrm{D}$ & $\mathrm{N} / \mathrm{D}$ & $N / D$ \\
\hline $7 / 15 / 2004$ & 1862.00 & 1.08 & 86.00 & 2.20 & 0.15 & 3.16 & 4 \\
\hline $10 / 26 / 2004$ & 76.00 & 9.30 & 2.25 & 8.25 & 0.68 & 3.16 & 4 \\
\hline
\end{tabular}




\begin{tabular}{|c|c|c|c|c|c|c|c|}
\hline \multicolumn{8}{|c|}{ Appendix 20. Station C9 Corbicula Data } \\
\hline Date & $\begin{array}{l}\text { Total \# of } \\
\text { clams in } \\
\text { sample } \\
\left(\# / \mathrm{m}^{2}\right)\end{array}$ & $\begin{array}{c}\text { biomass } \\
\left(\mathrm{g} / \mathrm{m}^{2}\right)\end{array}$ & $\begin{array}{c}\text { rec/ } \\
0.05 \mathrm{~m}^{2}\end{array}$ & $\begin{array}{c}\text { mean size } \\
(\mathrm{mm})\end{array}$ & $\begin{array}{c}\text { GR } \\
\left(\mathrm{m}^{3} / \mathrm{m}^{2} / \mathrm{d}\right)\end{array}$ & Depth (M) & \# Grabs \\
\hline $1 / 12 / 2005$ & 57.00 & 0.02 & 2.25 & 2.50 & 0.00 & 3.16 & 4 \\
\hline $4 / 8 / 2005$ & $N / D$ & N/D & $\mathrm{N} / \mathrm{D}$ & $N / D$ & $N / D$ & $N / D$ & $N / D$ \\
\hline $7 / 25 / 2005$ & 166.25 & 0.67 & 6.50 & 2.99 & 0.11 & 3.16 & 4 \\
\hline $10 / 14 / 2005$ & 128.25 & 13.74 & 4.50 & 6.43 & 1.00 & 3.16 & 4 \\
\hline $11 / 9 / 2005$ & 323.00 & 0.10 & 14.33 & 2.34 & 0.01 & 3.16 & 4 \\
\hline $12 / 7 / 2005$ & 508.25 & 1.57 & 19.50 & 2.72 & 0.05 & 3.16 & 4 \\
\hline $1 / 12 / 2006$ & 460.75 & 2.04 & 19.00 & 2.80 & 0.06 & 3.16 & 4 \\
\hline $2 / 9 / 2006$ & 869.25 & 1.17 & 37.00 & 2.29 & 0.04 & 3.16 & 4 \\
\hline $3 / 15 / 2006$ & 1225.50 & 12.10 & 45.50 & 3.14 & 0.43 & 3.16 & 4 \\
\hline $4 / 26 / 2006$ & 565.25 & 4.80 & 9.25 & 4.47 & 0.27 & 3.16 & 4 \\
\hline $5 / 25 / 2006$ & 356.25 & 12.20 & 3.75 & 5.86 & 1.09 & 3.16 & 4 \\
\hline $6 / 5 / 2006$ & 574.75 & 2.82 & 8.50 & 4.94 & 0.39 & 3.16 & 4 \\
\hline $7 / 10 / 2006$ & 156.75 & 5.52 & 2.00 & 7.62 & 0.86 & 3.16 & 4 \\
\hline $8 / 10 / 2006$ & 33.25 & 0.02 & 1.50 & 2.21 & 0.00 & 3.16 & 4 \\
\hline $9 / 25 / 2006$ & 66.50 & 0.23 & 3.25 & 2.29 & 0.03 & 3.16 & 4 \\
\hline $10 / 25 / 2006$ & 109.25 & 0.01 & 5.50 & 1.63 & 0.00 & 3.16 & 4 \\
\hline $11 / 20 / 2006$ & 14.25 & 0.00 & 0.75 & 1.50 & 0.00 & 3.16 & 4 \\
\hline $12 / 20 / 2006$ & 47.50 & 0.01 & 2.50 & 1.80 & 0.00 & 3.16 & 4 \\
\hline $1 / 23 / 2007$ & 42.75 & 6.35 & 1.50 & 9.72 & 0.19 & 3.16 & 4 \\
\hline $2 / 20 / 2007$ & 1130.50 & 0.05 & 59.50 & 1.44 & 0.00 & 3.16 & 4 \\
\hline $3 / 20 / 2007$ & 551.00 & 0.31 & 25.25 & 2.18 & 0.01 & 3.16 & 4 \\
\hline $4 / 16 / 2007$ & 280.25 & 2.32 & 9.75 & 3.14 & 0.15 & 3.16 & 4 \\
\hline $5 / 16 / 2007$ & 175.75 & 1.11 & 3.75 & 4.77 & 0.09 & 3.16 & 4 \\
\hline $6 / 20 / 2007$ & 90.25 & 0.14 & 2.00 & 4.50 & 0.01 & 3.16 & 4 \\
\hline $7 / 16 / 2007$ & 175.75 & 5.54 & 6.75 & 4.01 & 0.64 & 3.16 & 4 \\
\hline $8 / 15 / 2007$ & 152.00 & 0.59 & 4.00 & 4.13 & 0.08 & 3.16 & 4 \\
\hline $9 / 11 / 2007$ & 123.50 & 0.26 & 3.00 & 4.04 & 0.03 & 3.16 & 4 \\
\hline $10 / 3 / 2007$ & 137.75 & 2.94 & 4.00 & 4.57 & 0.22 & 3.16 & 4 \\
\hline $11 / 6 / 2007$ & 199.50 & 0.14 & 9.50 & 1.98 & 0.01 & 3.16 & 4 \\
\hline $12 / 10 / 2007$ & 408.50 & 0.27 & 18.50 & 2.17 & 0.01 & 3.16 & 4 \\
\hline $1 / 8 / 2008$ & 285.00 & 0.49 & 9.00 & 3.43 & 0.01 & 3.16 & 4 \\
\hline $2 / 6 / 2008$ & 85.50 & 2.93 & 2.25 & 6.50 & 0.09 & 3.16 & 4 \\
\hline $3 / 5 / 2008$ & 465.50 & 3.64 & 16.50 & 3.22 & 0.17 & 3.16 & 4 \\
\hline $4 / 2 / 2008$ & 270.75 & 0.45 & 6.25 & 3.34 & 0.02 & 3.16 & 4 \\
\hline $5 / 20 / 2008$ & 1007.00 & 40.67 & 17.00 & 6.42 & 2.96 & 3.16 & 4 \\
\hline $6 / 17 / 2008$ & 299.25 & 11.02 & 2.75 & 6.99 & 1.07 & 3.16 & 4 \\
\hline $7 / 14 / 2008$ & 403.75 & 23.24 & 4.50 & 7.70 & 3.09 & 3.16 & 4 \\
\hline $8 / 13 / 2008$ & 133.00 & 3.82 & 4.50 & 5.36 & 0.49 & 3.16 & 4 \\
\hline
\end{tabular}




\begin{tabular}{|c|c|c|c|c|c|c|c|}
\hline \multicolumn{8}{|c|}{ Appendix 20. Station C9 Corbicula Data } \\
\hline Date & $\begin{array}{c}\text { Total \# of } \\
\text { clams in } \\
\text { sample } \\
\left(\# / \mathrm{m}^{2}\right)\end{array}$ & $\begin{array}{c}\text { biomass } \\
\left(\mathrm{g} / \mathrm{m}^{2}\right)\end{array}$ & $\begin{array}{c}\mathrm{rec} / \\
0.05 \mathrm{~m}^{2}\end{array}$ & $\begin{array}{c}\text { mean size } \\
(\mathrm{mm})\end{array}$ & $\begin{array}{c}\text { GR } \\
\left(\mathrm{m}^{3} / \mathrm{m}^{2} / \mathrm{d}\right)\end{array}$ & Depth (M) & \# Grabs \\
\hline $9 / 15 / 2008$ & 156.75 & 0.35 & 6.75 & 3.32 & 0.04 & 3.16 & 4 \\
\hline $10 / 28 / 2008$ & 161.50 & 5.13 & 5.75 & 5.15 & 0.52 & 3.16 & 4 \\
\hline $11 / 18 / 2008$ & 38.00 & 5.07 & 0.75 & 14.38 & 0.26 & 3.16 & 4 \\
\hline $12 / 10 / 2008$ & 128.25 & 3.23 & 3.50 & 5.20 & 0.14 & 3.16 & 4 \\
\hline $1 / 12 / 2009$ & 52.25 & 6.66 & 1.50 & 9.50 & 0.20 & 3.16 & 4 \\
\hline $2 / 9 / 2009$ & 71.25 & 0.03 & 1.75 & 2.90 & 0.00 & 3.16 & 4 \\
\hline $3 / 11 / 2009$ & 261.25 & 5.92 & 8.50 & 5.17 & 0.27 & 3.16 & 4 \\
\hline $4 / 6 / 2009$ & 261.25 & 1.42 & 10.75 & 3.25 & 0.07 & 3.16 & 4 \\
\hline $5 / 5 / 2009$ & 71.25 & 3.61 & 1.25 & 9.83 & 0.33 & 3.16 & 4 \\
\hline $6 / 23 / 2009$ & 769.50 & 38.47 & 8.25 & 7.52 & 3.92 & 3.16 & 4 \\
\hline $7 / 21 / 2009$ & 194.75 & 9.36 & 5.00 & 6.38 & 1.05 & 3.16 & 4 \\
\hline $8 / 18 / 2009$ & 218.50 & 4.30 & 9.25 & 3.87 & 0.55 & 3.16 & 4 \\
\hline $9 / 16 / 2009$ & 261.25 & 14.01 & 9.50 & 6.50 & 1.55 & 3.16 & 4 \\
\hline $10 / 19 / 2009$ & 215.33 & 10.62 & 9.00 & 5.76 & 0.77 & 3.16 & 4 \\
\hline $11 / 16 / 2009$ & 460.75 & 0.37 & 15.50 & 2.80 & 0.02 & 3.16 & 4 \\
\hline $12 / 15 / 2009$ & 142.50 & 6.89 & 4.25 & 7.80 & 0.20 & 3.16 & 4 \\
\hline $1 / 13 / 2010$ & 247.00 & 5.91 & 7.75 & 4.73 & 0.03 & 3.16 & 4 \\
\hline $2 / 17 / 2010$ & 52.25 & 7.60 & 1.25 & 10.05 & 0.02 & 3.16 & 4 \\
\hline $3 / 15 / 2010$ & 665.00 & 10.89 & 21.75 & 3.79 & 0.07 & 3.16 & 4 \\
\hline $4 / 12 / 2010$ & 114.00 & 2.81 & 0.75 & 8.46 & 0.11 & 3.16 & 4 \\
\hline $5 / 19 / 2010$ & 142.50 & 10.91 & 0.75 & 7.80 & 0.22 & 3.16 & 4 \\
\hline $6 / 9 / 2010$ & 142.50 & 10.95 & 0.75 & 7.80 & 0.20 & 3.16 & 4 \\
\hline $7 / 6 / 2010$ & 90.25 & 4.91 & 0.75 & 10.76 & 0.90 & 3.16 & 4 \\
\hline $8 / 16 / 2010$ & 389.50 & 1.64 & 17.75 & 2.73 & 0.57 & 3.16 & 4 \\
\hline $9 / 7 / 2010$ & 907.25 & 7.93 & 45.25 & 2.38 & 0.37 & 3.16 & 4 \\
\hline $10 / 26 / 2010$ & 294.50 & 10.88 & 13.50 & 4.15 & 0.12 & 3.16 & 4 \\
\hline $11 / 22 / 2010$ & 289.75 & 4.58 & 11.25 & 4.60 & 0.12 & 3.16 & 4 \\
\hline $12 / 20 / 2010$ & 166.25 & 2.32 & 7.50 & 3.79 & 0.12 & 3.16 & 4 \\
\hline $1 / 18 / 2011$ & 422.75 & 6.93 & 14.25 & 4.68 & 0.05 & 3.16 & 4 \\
\hline $2 / 1 / 2011$ & 142.50 & 1.83 & 5.00 & 5.17 & 0.04 & 3.16 & 4 \\
\hline $3 / 7 / 2011$ & 109.25 & 3.29 & 0.25 & 9.33 & 0.09 & 3.16 & 4 \\
\hline $4 / 5 / 2011$ & 299.25 & 16.06 & 2.50 & 8.23 & 0.17 & 3.16 & 4 \\
\hline $5 / 3 / 2011$ & 256.50 & 5.79 & 7.75 & 6.17 & 0.46 & 3.16 & 4 \\
\hline $6 / 13 / 2011$ & 209.00 & 7.04 & 4.50 & 7.75 & 0.54 & 3.16 & 4 \\
\hline $7 / 12 / 2011$ & 52.25 & 5.26 & 0.00 & 14.95 & 1.83 & 3.16 & 4 \\
\hline $8 / 9 / 2011$ & 351.50 & 7.50 & 13.00 & 5.41 & 1.08 & 3.16 & 4 \\
\hline $9 / 7 / 2011$ & 109.25 & 24.10 & 1.50 & 17.28 & 1.02 & 3.16 & 4 \\
\hline $10 / 3 / 2011$ & 261.25 & 12.64 & 9.25 & 7.34 & 0.79 & 3.16 & 4 \\
\hline
\end{tabular}




\begin{tabular}{|c|c|c|c|c|c|c|c|}
\hline \multicolumn{8}{|c|}{ Appendix 20. Station C9 Corbicula Data } \\
\hline Date & $\begin{array}{l}\text { Total \# of } \\
\text { clams in } \\
\text { sample } \\
\left(\# / \mathrm{m}^{2}\right)\end{array}$ & $\begin{array}{c}\text { biomass } \\
\left(\mathrm{g} / \mathrm{m}^{2}\right)\end{array}$ & $\begin{array}{c}\mathrm{rec} / \\
0.05 \mathrm{~m}^{2}\end{array}$ & $\begin{array}{c}\text { mean size } \\
(\mathrm{mm})\end{array}$ & $\begin{array}{c}\text { GR } \\
\left(\mathrm{m}^{3} / \mathrm{m}^{2} / \mathrm{d}\right)\end{array}$ & Depth (M) & \# Grabs \\
\hline $11 / 8 / 2011$ & 99.75 & 5.63 & 3.00 & 9.21 & 0.13 & 3.16 & 4 \\
\hline $12 / 7 / 2011$ & 33.25 & 8.06 & 0.00 & 26.36 & 0.09 & 3.16 & 4 \\
\hline $1 / 9 / 2012$ & 47.50 & 12.08 & 0.25 & 18.20 & 0.34 & 3.16 & 4 \\
\hline $2 / 8 / 2012$ & 33.25 & 3.25 & 0.50 & 14.50 & 0.11 & 3.16 & 4 \\
\hline $3 / 6 / 2012$ & 1121.00 & 9.85 & 46.25 & 3.44 & 0.39 & 3.16 & 4 \\
\hline $4 / 5 / 2012$ & 1121.00 & 9.74 & 42.75 & 3.38 & 0.49 & 3.16 & 4 \\
\hline $5 / 21 / 2012$ & 308.75 & 17.64 & 8.50 & 7.65 & 1.71 & 3.16 & 4 \\
\hline $6 / 20 / 2012$ & 137.75 & 68.05 & 0.25 & 21.71 & 5.45 & 3.16 & 4 \\
\hline $7 / 17 / 2012$ & 85.50 & 25.93 & 0.00 & 21.61 & 3.36 & 3.16 & 4 \\
\hline $8 / 15 / 2012$ & 194.75 & 3.73 & 7.00 & 7.33 & 0.41 & 3.16 & 4 \\
\hline $9 / 25 / 2012$ & 47.50 & 5.14 & 0.25 & 23.00 & 0.62 & 3.16 & 4 \\
\hline $10 / 24 / 2012$ & 19.00 & 0.81 & 0.25 & 15.00 & 0.08 & 3.16 & 4 \\
\hline $11 / 14 / 2012$ & 52.25 & 9.29 & 0.00 & 20.77 & 0.65 & 3.16 & 4 \\
\hline $12 / 18 / 2012$ & 14.25 & 2.22 & 0.00 & 21.83 & 0.09 & 3.16 & 4 \\
\hline $1 / 9 / 2013$ & $N / D$ & $N / D$ & $N / D$ & $N / D$ & N/D & $N / D$ & N/D \\
\hline $2 / 5 / 2013$ & 66.50 & 17.36 & 0.00 & 23.43 & 0.53 & 3.16 & 4 \\
\hline $3 / 13 / 2013$ & 85.50 & 12.84 & 0.25 & 21.17 & 0.68 & 3.16 & 4 \\
\hline $4 / 10 / 2013$ & 66.50 & 3.57 & 1.25 & 10.86 & 0.21 & 3.16 & 4 \\
\hline $5 / 7 / 2013$ & 133.00 & 7.52 & 3.25 & 11.68 & 0.82 & 3.16 & 4 \\
\hline $6 / 4 / 2013$ & 228.00 & 23.32 & 7.25 & 7.54 & 2.57 & 3.16 & 4 \\
\hline $7 / 8 / 2013$ & 133.00 & 2.11 & 6.00 & 3.86 & 0.31 & 3.16 & 4 \\
\hline $8 / 8 / 2013$ & N/D & N/D & N/D & $N / D$ & $\mathrm{~N} / \mathrm{D}$ & $\mathrm{N} / \mathrm{D}$ & N/D \\
\hline $9 / 4 / 2013$ & 80.75 & 1.34 & 2.50 & 6.62 & 0.14 & 3.16 & 4 \\
\hline $10 / 15 / 2013$ & 52.25 & 0.01 & 2.00 & 2.59 & 0.00 & 3.16 & 4 \\
\hline $11 / 19 / 2013$ & 118.75 & 2.84 & 3.75 & 6.74 & 0.13 & 3.16 & 4 \\
\hline $12 / 16 / 2013$ & 323.00 & 1.99 & 12.50 & 3.85 & 0.06 & 3.16 & 4 \\
\hline
\end{tabular}

